Miocene Marine

Mollusks from the

Astoria Formation

in Oregon

GEOLOGIGAL SURVEY PROFESIONAL PAPER 419

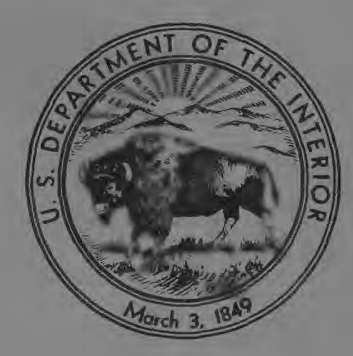




\section{Miocene Marine}

\section{Mollusks from the}

Astoria Formation

in Oregon

By ELLEN JAMES MOORE

GEOLOGICAL SURVEY PROFESSIONAL PAPER 419

Systematics and relationships of the mollusks of the Astoria formation in Oregon: 97 species representing 45 families are described; 11 species are new

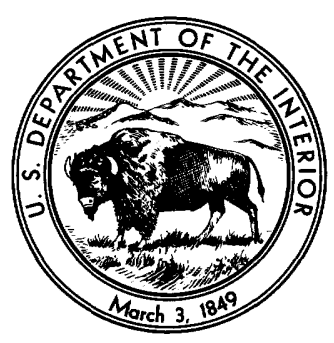




\section{UNITED STATES DEPARTMENT OF THE INTERIOR \\ STEWART L. UDALL, Secretary}

\section{GEOLOGICAL SURVEY}

Thomas B. Nolan, Director

For sale by the Superintendent of Documents, U.S. Government Printing Office Washington, D.C., 20402 


\section{CON T EN T S}

Abstract.

Introduction

istorical background

Conrad's types

Purpose and scope

Acknowledgments.

Annotated list of reports dealing with the Astoria formation and its fossils

Astoria formation

Stratigraphy

General features and geographic distribution.-.

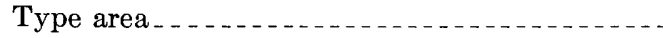

Coastal outcrop area $\ldots \ldots \ldots$

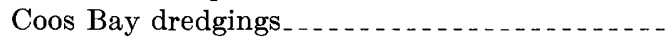

Occurrences in Washington................

Faunal composition .......................

Paleoecology .........

Age and correlation California

Washington ...........

Kamchatka ...........

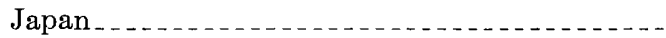

Description of species ............

Mollusks .

Gastropods . . . . . . . . .

Family Trochidae.......................

Family Turbinidae.

Family Vitrinellidae......................

Family Turritellidae................

Family Epitoniidae.

Family Calyptraeidae..............

Family Naticidae.......................

Family Cassididae. .................

Family Cymatiidae.................

Family Ficidae

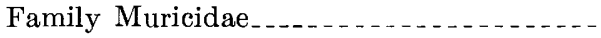

Family Thaidiidae...................

Family Neptuneidae.

Family Buccinidae.
Paleontology _...

\begin{tabular}{|c|c|c|}
\hline Page & of species-Continued & \\
\hline 1 & ollusks-Continued & \\
\hline 1 & Gastropods-Continued & Page \\
\hline 1 & Family Nassariidae $\ldots \ldots$ & 38 \\
\hline 2 & Family Fusinidae & 39 \\
\hline 4 & Family Volutidae. & 42 \\
\hline 5 & Family Cancellariidae $\ldots$ & 44 \\
\hline & Family Olividae & 46 \\
\hline 5 & Family Turridae & 46 \\
\hline 10 & Family Scaphandridae & 49 \\
\hline 10 & Family Acteocinidae & 50 \\
\hline 10 & Scaphopods & 50 \\
\hline 10 & Family Dentaliidae & 50 \\
\hline 12 & Pelecypods & 51 \\
\hline 13 & Family Solemyacidae & 51 \\
\hline 15 & Family Nuculidae & 52 \\
\hline 16 & Family Nuculanidae & 55 \\
\hline 16 & Family Glycymerididae & 58 \\
\hline 17 & Family Arcidae & 59 \\
\hline 20 & Family Limopsidae & 61 \\
\hline 20 & Family Mytilidae & 62 \\
\hline 22 & Family Pectinidae & 63 \\
\hline 22 & Family Propeamussiidae & 68 \\
\hline 22 & Family Carditidae & 69 \\
\hline 23 & Family Lucinidae & 70 \\
\hline 23 & Family Diplodontidae & 71 \\
\hline 23 & Family Thyasiridae & 71 \\
\hline 23 & Family Cardiidae & 72 \\
\hline 24 & Family Veneridae. & 73 \\
\hline 24 & Family Tellinidae & 78 \\
\hline 25 & Family Sanguinolariidae & 81 \\
\hline 25 & Family Solenidae. & 82 \\
\hline 26 & Family Mactridae & 82 \\
\hline 27 & Family Hiatellidae. & 83 \\
\hline 30 & Family Thraciidae & 84 \\
\hline 31 & Cephalopod & 85 \\
\hline 32 & Family Nautilidae & 85 \\
\hline 33 & Fossils other than mollusks & 86 \\
\hline 35 & Fossil localities & 90 \\
\hline 35 & References cited & 95 \\
\hline 37 & Index $\ldots \ldots$ & 101 \\
\hline
\end{tabular}

\section{ILLUSTRATIONS}

[Plates follow index]

Plates 1-10. Gastropods.

11-30. Pelecypods.

31. Pelecypods, scaphopods, and cephalopod.

32. Bryozoa, brachiopods, coral, and echinoids.

33. Outline map of Newport area, Oregon, with measured sections and fossil localities...... In pocket
2. Map of Astoria, Oreg., showing fossilcollecting localities..................

3. Generalized geologic map of Coos Bay,

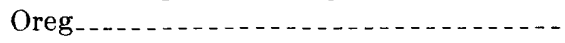

Figure 1. Index to geologic maps of western Oregon 
Page

Figure 4, 5. Collecting locality on dredgings, Coos Bay, Oreg _... 14, 15

6. Beds of Astoria formation exposed in headland north of Wade Creek, Newport area, Oregon

7. Closeup of barren marker and Anadara

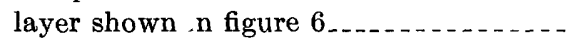

Figure 8. Whorl profiles of Priscofusus discussed in present report .........................

9. Outline map showing location of quadrangles pertinent to locality descrip-

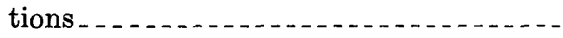

Page

\section{TABLES}

TABLE 1. Stratigraphic names and age assigned to Astoria formation from 1848 to 1931 ...-

TABLE 3. Geographic distribution of Foraminifera in 


\title{
MIOGENE MARINE MOLLUSKS FROM THE ASTORIA FORMATION IN OREGON
}

\author{
By Ellen James Moore
}

\begin{abstract}
The marine Astoria formation of Miocene age occurs in western Oregon. Fossiliferous exposures are limited almost entirely to the sea cliffs along the Pacific Ocean in Tillamook and Lincoln Counties. The Astoria rocks are intermittently exposed; they are faulted and exposures are interrupted by volcanic rocks and slides. The maximum thickness of beds exposed in an uninterrupted section is about 250 feet.

The type area of the Astoria formation is in the city of Astoria, but most of the former exposures are now covered by the buildings of the city and by sand dredged from the Columbia River.

J. K. Townsend made the first recorded collection of Cenozoic fossils from the Pacific coast of North America from the type Astoria, and 14 species from his collection were described by T. A. Conrad in 1848. J. D. Dana collected fossils at the trading post of Astoria and along the south bank of the Columbia River in 1841, while he was with the U.S. Exploring Expedition. The mollusks in this collection were described by Conrad in 1849 and are on deposit in the U.S. National Museum. The types of the Astoria species described by Conrad are here redescribed and illustrated.

Faunas were collected from measured stratigraphic sections of the Astoria formation in the Newport area. In these faunas the concentrations or repeated associations of particular species may aid correlations within the Astoria formation over small areas, but they do not seem to be useful for wider correlations.

A new Miocene fauna from Coos Bay, Oreg., was obtained between 1949 and 1954 from the spoil pile of a dredging operation in the bay. Miocene sedimentary rocks are not exposed in the Coos Bay region, and this is the first record of a Miocene fauna to be obtained there. This fauna is probably the age equivalent of the Astoria fauna in the Newport area and at Astoria.

Ninety-seven species of Miocene mollusks representing 73 genera and 45 families are described. Forty-seven of these species are also known from the Astoria (?) formation in Washington and 20 from the equivalent Barker's Ranch fauna of the Temblor formation, middle Miocene, in California. The biologic affinities of the Astoria species previously-described are reconsidered.
\end{abstract}

\section{INTRODUCTION}

\section{HISTORICAL BACKGROUND}

The first Tertiary fossils to be described from the Pacific coast of North America were collected by J. K. Townsend sometime between 1834 and 1837 (Townsend, 1839) from the Astoria formation in Astoria and were described, illustrated, and correctly assigned to the Miocene by Conrad (1848, p. 432-433). Townsend was an ornithologist at the Academy of Natural
Sciences of Philadelphia (Thwaites, 1905, p. 14-15). J. D. Dana collected additional fossils from Astoria in 1841, when he was with the U.S. Exploring Expedition under the command of Capt. Charles Wilkes. His specimens also were described and illustrated by Conrad (1849, p. 659, append. p. 723-728, atlas, pls. 17-21). No specific localities are given for the specimens in these two collections.

The following information given by Dana (1849, p. $722,729)$, in the section he wrote on systematic paleontology, is all the locality data available for his Astoria collection. In describing vertebrate remains, Dana $(1849$, p. 722$)$ says that in some places they were found in the argillaceous sandstone of Astoria on the south side of the Columbia River, about 13 miles above its mouth and could be picked up along the shores of the river. Dana describes a crustacean that he says was found in the calcareous concretions of the argillaceous rock near Astoria (1849, p. 722) and a fossil plant that he says occurred in a limestone nodule like most of the specimens $(1849$, p. 729$)$. He also mentions Foraminifera which he says were found in the soft argillaceous shale on the shores below Astoria (1849, p. 729). This information indicates that the Dana Astoria collection came from places near and within the old city limits of Astoria from rocks exposed in the south bank of the Columbia River.

Though Conrad originally assigned the fossils from Astoria to the Miocene, in 1865 he correlated the Astoria formation with the London Clay (1865b, p. 70) and referred the entire fauna that had been collected from the formation to the Eocene (1865a, p. 150). He was acting on the basis of his identification of Aturia angustata as Aturia ziczac-an identification which is understood when the knowledge of this group in Conrad's time and its innate complexity are considered. Conrad's referral of the Astoria to the Eocene started a great deal of confusion as to the age of the formation and of its correlatives, and also of the relative ages of other formations in the Pacific Northwest.

In 1909 W. H. Dall (p. 8-11) summarized the observations which he had made during a visit to Astoria in 1890 , and he divided the Astoria formation into Oligocene and Miocene parts. By 1890, however, the 
city of Astoria had expanded and the probable original exposures from which Townsend and Dana had collected were no longer accessible; it was those exposures that Dall referred to the Oligocene. Dall (1909, p. 88, 90) identified a specimen he believed to have been collected at Astoria as an Ampullinopsis (p. 29). It is probable that this identification influenced him in calling the Astoria formation Oligocene (Woodring, 1931, p. 385).

In this same report Dall redescribed many of Conrad's original types. Dall, however, correlated the Empire formation, now considered Pliocene(?), with the Astoria formation (Miocene), and consequently in describing an Astoria species of Conrad's he sometimes includes Empire species in the same discussion, and occasionally he illustrates them as representative of Astoria species.

The Astoria formation was believed to be of Oligocene or Oligocene-Miocene age from the time of Dall's publication (1909) until 1926, when H. V. Howe referred it in its entirety to the middle Miocene.

Since Howe's publication appeared, the Astoria formation has usually been regarded as middle Miocene by paleontologists working on the mollusks. It has been called early Miocene, or even late Oligocene, however, by some paleontologists who have studied the Foraminifera. This discrepancy is primarily due to the difference in opinion between the two groups of specialists as to the placement of the Oligocene-Miocene boundary.

The U.S. Geological Survey published three Oil and Gas Investigations Maps of areas in northwestern Oregon in 1945 and 1949 (fig. 1). These are the first and only geologic maps available for northwestern Oregon, the area in which the Astoria formation is exposed. Allen and Baldwin (1944) published a geologic map of the Coos Bay quadrangle (fig. 1), which includes the area surrounding the bay from which Miocene sediments were dredged.

\section{CONRAD'S TYPES}

The holotypes of the species described by Conrad in 1848 have been listed in most subsequent papers as missing or lost. These types were deposited in the Academy of Natural Sciences of Philadelphia. $C y$ therea oregonensis, Loripes parilis, and Solen curtus were located in 1958; after an intensive search the remaining 11 types are presumed lost.

The identification of some of Conrad's types from Astoria, Oreg., described in 1849 (append. p. 723-728) and on deposit in the U.S. National Museum has been rather difficult. The illustrations were prepared by J. D. Dana, and although they are drawings some of them are accurate representations. Generally, if a small piece of shell is missing from a specimen, the draw- ing shows that it is missing, or if a specimen is broken, it is shown as broken and almost the exact nature of the break is represented. If a specimen is in a concretion, the concretion is often drawn, but if on the other hand a specimen is in rock, the rock may not be shown, or if shown may not be accurately drawn. Usually it has been possible to identify the holotypes beyond reasonable doubt. Some single specimens of certain species in the type collection, however, do not agree exactly with the original illustration or description given for that species. The specimen may not agree with the measurements given in the description, or it may be in a concretion and not so illustrated, or details of sculpture may be slightly different.

If a species in the type collection is represented by a single specimen and is cataloged as collected by Dana, it can be assumed that this specimen was the only one available to Conrad, and therefore it should be accepted as the holotype, even though it differs slightly from the illustration by which it is supposedly represented. Some of the species in the collection are represented by more than one specimen, however, and it is not known which specimen was the type illustrated. When there is any doubt, a lectotype is here designated. Schuchert (1905) and Weaver (1942) have listed specimens in the U.S. National Museum type collection as holotypes of Conrad's, but lectotypes have been designated where necessary for clarification, and these lectotypes may or may not be cited by either Schuchert or Weaver as the holotype.

Only a few of the specimens in Conrad's type collection were originally given individual catalog numbers, and a single catalog number was often assigned to several specimens now thought to be different species, and at least in some cases probably so considered by Conrad, as this cataloging was done after his death. The catalog numbers assigned to this collection run from 3478 to 3686 , excluding the Gibb's Astoria collection-3572 to 3578 , and are entered in the Cenozoic Fossil Catalog as "Copied from old Smithsonian Registers." These old registers were books in which fossils were formerly entered and assigned numbers regardless of age. Later it was considered advisable to keep separate catalogs for the Cenozoic, Mesozoic, and Paleozoic, and for certain biologic groups, and the old entries were copied out into the appropriate catalogs. The catalog numbers were put on the specimens with black ink or red paint.

Conrad's types were originally assigned catalog numbers in 1864 and were copied out of the old register into the Cenozoic Catalog in 1888. It is necessary to go back to the original register to check the entry for an old number, as some numbers were erroneously entered in the new catalog book. When the numbers were 


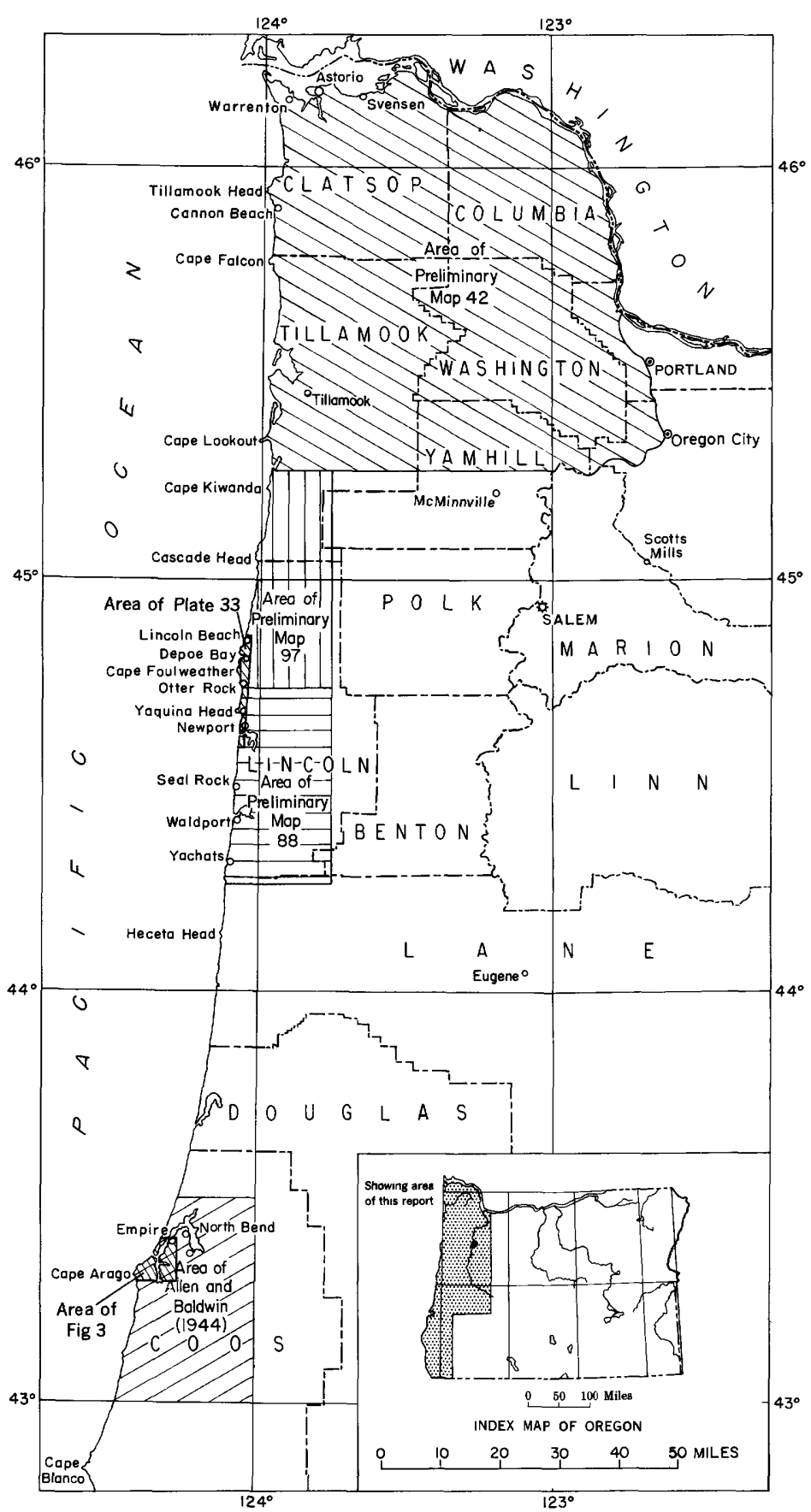

FIGURE 1.--Index map of northwest Oregon showing location of areas for which geologic maps pertinent to this report have been prepared.

copied in the new catalog, blue checks were put beside the number for each specimen that was found in the collections.

It is reasonably certain that Conrad handled all of the specimens in the Dana collection, and there is no doubt about Conrad's identifications of the specimens that he figured. There is, however, no way of invariably ascertaining what Conrad's original paratype material for a particular species may have been. This means that if Conrad described more than one species under a genus, the remaining unfigured specimens, even though they may have the same catalog number as the type of a particular species, may or may not be Conrad's paratypes of that species. The catalog numbers were assigned by J. B. Marcou, who also painted the numbers on the specimens (Marcou, 1885, p. 290).

The holotypes and lectotypes in Conrad's 1849 collection have been left under the old catalog numbers, 
as these are the numbers that have been used in the literature. The remaining specimens have been assigned new catalog numbers so that they can be readily separated.

In Conrad's 1849 type collection there is a set of old numbers in addition to the original catalog numbers. This set of numbers ranges from 5 to 63 and is printed on small square pieces of white paper that are glued to the specimens. These numbers are in a lower numerical series than any of the catalog numbers entered in the U.S. National Museum Cenozoic Catalog. They have been found on some holotypes, but not on all of them, and some are on specimens that are not holotypes. These numbers are attributed to Dana by Dall $(1909$, p. 78,83$)$ and are on other Dana collections in the U.S. National Museum.

Seven specimens entered in the U.S. National Museum Cenozoic Catalog with those collected by Dana are listed as having been collected by George Gibbs. Gibbs' connection with the Smithsonian Institution was as a collaborator in ethnology. He was in charge of the Indian vocabularies collected by the Smithsonian and was preparing them for publication at the time of his death in 1873 . He accompanied the Mounted Rifle Regiment to Oregon where he arrived in early October 1849 (Stevens, 1874, p. 222). Gibbs received the appointment of collector of the Port of Astoria in 1854 and held this post during President Fillmore's administration. It can be presumed that he collected the fossils mentioned sometime later than October 1849, and that these fossils were not handled by Conrad in the preparation of his 1849 report.

Most of Conrad's 1849 types are poorly preserved. A few of these types are too poorly preserved to assign the species to genera. It has seemed best not to use these names and they are regarded as nomina dubia in this paper. It should be borne in mind, however, that this collection was all that Conrad had available to him. What is remarkable is that Conrad, despite the poor material he had and despite the fact that he had no other collections of fossils from the Western United States for comparison, was able to describe these fossils and to assign them correctly to the Miocene.

Dall (1909, p. 126) broke up a rock specimen in Conrad's type collection, because the specimen did not contain a type. He then removed the specimen and assigned it the same number but added a letter-3529a. It is possible to put the pieces of this rock back into position and ascertain which specimens were exposed and therefore seen by Conrad. This is pertinent to the identification of the holotypes and also to subsequent type designations. Dall also removed at least one of Conrad's types (that is, Anadara devincta,
1909 , p. 109) from its matrix for study. This knowledge assists in the identification of the type as originally illustrated. Inasmuch as the matrix was retained with the specimen in the type collection, it can be replaced in its original position.

Small green diamond-shaped or rectangular stickers were glued on most of the specimens in Conrad's type collection that are labeled as types. These stickers were applied by J. B. Marcou (Marcou, 1885, p. 290) to every specimen that he considered to be a Conrad type and on each side figured. Green stickers were also placed by Marcou on other old west coast type collections: those described by Conrad in 1855-57, by White in 1884-85, and by Stanton in 1897. Marcou also painted the catalog numbers on the types. Marcou (1885, p. 290) said that many of the original labels had been lost or misplaced. None of Conrad's labels remain with his 1849 type collection, but some labels written by Dall, presumably in connection with his Coos Bay paper (1909), are present. The lack of original labels may explain discrepancies in the cataloging of specimens. Some specimens were assigned the same number although they had no relation to one another, whereas counterparts of some concretions were given different numbers in addition to different identifications.

It should not be assumed that a specimen in one of the old type collections that bears a green sticker is a holotype identified or separated by the author of the species. Nor should it be assumed that a lot of specimens with the same catalog number were so grouped by the original author. It has been proved beyond doubt that some specimens in Conrad's 1849 collection marked as holotypes by green stickers are not really the holotypes, and that some specimens without stickers are the holotypes. It has also been proved that the cataloging does not always reflect the original author's concept of his species.

The recent additions to the U.S. National Museum type collections by the staff of the Museum may also bear green diamond- or triangular-shaped stickers. The primary types bear the diamond-shaped stickers with: $\mathrm{H}$ for holotype, $\mathrm{L}$ for lectotype, = for paratype, and $\mathrm{S}$ for syntype. The secondary types bear triangular stickers with: $P$ for plesiotype and a blank triangle for hypotype. These stickers need not be confused with the diamond-shaped green stickers on the old type collections which bear no symbols but are blank.

\section{PURPOSE AND SCOPE}

The purpose of this report is to describe and illustrate the mollusks from the Astoria formation of Miocene age in western Oregon and to reconsider their biologic affinities and stratigraphic implications. In 
order to do this, old collections were restudied and new material was obtained from measured stratigraphic sections and from dredgings in Coos Bay.

The U.S. National Museum collections of mollusks from the Astoria formation date back to the collection made by J. D. Dana at Astoria in 1841 and described by Conrad in 1849. The collection made by Townsend and described by Conrad (1848) is in the Academy of Natural Sciences of Philadelphia. Conrad's original descriptions in these papers are brief, are illustrated by drawings, and are based on generally poorly preserved type material-all that was available to Conrad at that time. It has been difficult for west coast paleontologists, to whom the type material has not been readily accessible, to identify Conrad's species. Conrad's types, therefore, are here reillustrated and described, and their generic affinities are reconsidered.

It has ordinarily been possible to identify the holotypes for the species described by Conrad in 1849 (append., p. 723-728). Lectotypes were designated by Woodring (1938) for Venus angustifrons and Lucina acutilineata. Schuchert (1905) and Weaver (1942) have given U.S. National Museum Catalog numbers for the specimens they believed to be Conrad's types, but many of the catalog numbers listed by them were assigned originally to more than one specimen.

Many of the species names proposed by Conrad in 1848 have been used by authors despite the fact that the types have not been available and that the original descriptions were very brief and were illustrated by drawings. In the present report also, Conrad's 1848 specific names have been used when possible, and new names have not been proposed.

Stratigraphic sections of the Astoria formation were measured in the Newport area, Lincoln County, and the faunas collected from them are discussed. A new Miocene marine molluscan fauna obtained between 1949 and 1954 from the spoil pile of a dredging operation in Coos Bay provides the first record of a Miocene fauna from that area.

\section{ACKNOWLEDGMENTS}

I am indebted to Dr. H. V. Howe, Louisiana State University, for permission to describe species in his collections at the California Academy of Sciences and for the use of his doctorate thesis, "The Miocene of Clatsop and Lincoln Counties, Oregon," which is on deposit in the library of Stanford University, California. His work has contributed greatly to our knowledge of the stratigraphy and faunas of the Astoria formation, particularly in the type area.

Mr. A. G. Terry, formerly of the U.S. Army Corps of Engineers at Empire, Oreg., first called attention to the fact that the rock dredged from the channel of Coos Bay,
Oreg., contained fossils. If he had not observed these fossils and appreciated their significance, the fauna revealed by the dredgings might have gone unnoticed and eventually have been redeposited beneath the water of the bay.

The San Francisco Bridge Co. kindly made available their data concerning the dredging at Coos Bay.

Dr. E. M. Baldwin, Professor of Geology at the University of Oregon, supervised the preparation of my 1950 manuscript report, "A new Miocene marine invertebrate fauna from Coos Bay, Oregon," and also loaned collections from Coos Bay and Depoe Bay, Oreg.

I appreciate the help of the following people who made collections available, loaned specimens, furnished photographs, and made pertinent suggestions concerning taxonomy: J. W. Durham and J. H. Peck, University of California; L. G. Hertlein, California Academy of Sciences; Myra Keen, Stanford University; H. G. Richards, Academy of Natural Sciences of Philadelphia; and Courtney Werner, Washington University, St. Louis.

I am indebted to the following paleontologists for identifications: in the U.S. National Museum, G. A. Cooper, brachiopods; D. H. Dunkle, fish remains; H. B. Roberts, crabs; the late R. W. Brown, U.S. Geological Survey, plant remains; J. B. Wells, Cornell University and U.S. Geological Survey, corals; V. Standish Mallory, University of Washington, Foraminifera.

Mr. and Mrs. Rudolph Erickson, Portland, Oreg., gave to the Museum of Paleontology, University of California, an exceptionally well preserved specimen of Liracassis petrosa, which was borrowed for study and figuring.

I am grateful to my mother, Mildred P. James, of Portland, Oreg., who assisted me in collecting and also donated specimens from her personal collections.

I am particularly indebted for valuable assistance concerning the identification, taxonomy, and stratigraphic significance of species to W. P. Woodring and Druid Wilson, U.S. Geological Survey, who have been kind in their encouragement and generous in their bestowal of time to my problems.

P. E. Cloud, Jr., formerly of the U.S. Geological Survey, by his continuous support, enthusiasm, and assistance made the preparation of this report possible.

\section{ANNOTATED LIST OF REPORTS DEALING WITH THE ASTORIA FORMATION AND ITS FOSSILS 1}

1842. Wilkes, Charles. A list of the officers and scientists of the 1838-42 U.S. Exploring Expedition is given.

1 Stratigraphic nomenclature herein used is that of the references cited and does not necessarily accord to that of the U.S. Geol. Survey. 
1845. Wilkes, Charles. A general account of the experiences of the U.S. Exploring Expedition while on the Columbia River, with a drawing of Astoria.

1848. Conrad, T. A. Description of 14 species of mollusks collected near Astoria by J. K. Townsend and assigned to the Miocene (table 1). The descriptions are brief and the illustrations are drawings, but measurements are given.

1849. Dana, J. D. Described the "Tertiary formation" at Astoria, including lithology and structure. It is often difficult in reading Dana's report to ascertain whether a given passage refers to the Astoria formation or to the entire Tertiary sequence of the Pacific coast, as there was no "Astoria formation," of course, in Dana's time. In a letter to W. H. Dall dated July 2, 1890, Dana said that he was in Astoria only a few days after shipwreck on the Columbia bar.

Foraminifera, crustacea, fishes, vertebrates, corals, and plants are described in the appendix and illustrated in the atlas.

1849. Conrad, T. A. Described 33 mollusks and a brachiopod from the Dana Astoria collection and assigned them to the Miocene. The descriptions are brief and the illustrations are drawings; measurements are added in brackets by Dana.

1855. Isbister, A. K. Discussed Dana's 1849 report, cited Conrad's (1849) Miocene age determination of the Astoria formation ["Tertiary formation"], and listed species identified by Conrad from Astoria, Oreg.

1856. Newberry, J. S. The Miocene age of the Astoria formation is questioned (p. 25).

1864. Meek, F. B. Suggested that the beds at Astoria might be older than Tertiary. Lists Miocene mollusks of Oregon and synonymy and discussion is given under "Notes and explanations" (p. 25-32).

1865a. Conrad, T. A. Listed and assigned to the Eocene the mollusks described by Conrad in 1848 and 1849. The generic assignments were revised and the new genus Priscofusus proposed. Specific names were given to mollusks that Conrad illustrated but did not name in his report of 1849 .

1865b. Conrad, T. A. The Astoria formation was assigned to the Eocene and correlated with the London Clay (p. 70). This was done because of Conrad's identification of Aturia angustata (Conrad), from the Astoria formation at Astoria as Aturia ziczac (Sowerby), of the Eocene of England (Miller, 1947, p. 85). The resulting confusion as to the age of the Astoria formation continued until Howe's publication in 1926.

1866c. Conrad, T. A. Divided the Eocene into lower and medial Eocene (Shark River and Claiborne Group), Shell Bluff Group, and upper Eocene of Jackson Group. Assigned most of the mollusks from the Astoria formation at Astoria, Oreg., originally described by Conrad $(1848,1849)$ as Miocene, to the lower and medial Eocene.

1880a. Cope, E. D. Applied the name "Astoria shales" (p. 457) taken from the unpublished notes of Thomas Condon, who filled the office of Oregon State Geologist, created in 1872. Cope believed the rocks of the Coast Range to be not older than Miocene, rather than Archean as previously recorded on the geologic maps of Oregon.

1889. White, C. A. Divided the Astoria formation (p. 31-32) into beds of possible Eocene and Miocene age. Tentatively assigned the species described by Conrad in 1848 to the Eocene, and those described by Conrad in 1849 to the Miocene.
1892. Dall, W. H., and Harris, G. D. Divided what is now called the Astoria formation into three distinct formations (p. 223226) in ascending order, the Aturia bed, the Astoria shales, and the Astoria sandstone.

They included beds of both Eocene and Miocene age in the Astoria formation saying that the Eocene beds were covered by the expansion of the city of Astoria and no longer accessible. They proposed the name "Astoria group," which was to include their Miocene sandstone and shale but not the Aturia bed. They said that the shale and sandstone were part of the same sedimentary series and that the fossils were the same Miocene species in both.

1896. Merriam, J. C. Correlated the fauna of the Carmanah Point beds, which is Miocene, with that of all but the lower part of the Astoria, which Merriam regarded as Eocene.

1896. Diller, J. S. Divided the Astoria formation into beds of Oligocene and Miocene age (p. 464-476), giving Dall (1896) as his authority for calling part of the section Oligocene. He assigned the Aturia bed to the Oligocene; part of the shale he questionably referred to the Miocene, and the overlying sandstone he definitely referred to the Miocene.

Up to this time no formations on the west coast of North America had been assigned to the Oligocene.

Discussed the Astoria formation in the Yaquina Bay region and assigned the rocks exposed from Yaquina Bay north to beyond Otter Rock to the Miocene. Includes lists of fossils identified by Dall from the Astoria formation. Diller also included in the Astoria formation-specifically in his discussion of the Miocene-collections made east of Yaquina Bay, presumably from the Yaquina formation (Oligocene) and possibly also from the Nye formation (Miocene).

Correlated the Astoria formation ("Miocene rocks") at Yaquina Bay, with the Empire formation of Coos Bay (now regarded as Pliocene?), on the basis of fossils identified by Dall.

1898. Dall, W. H. Assigned the Aturia bed to the lower Oligocene, the Astoria shales to the upper Oligocene, and the Astoria sandstones to the Miocene.

1905. Anderson, F. M. Described new species of California Miocene mollusks, some of which are also recognized in the Astoria formation, and uses a few of Conrad's names $(1848,1849)$ for California Miocene forms.

1905. Thwaites, R. G. Incorporated Townsend's "Narrative of a journey across the Rocky Mountains to the Columbia River." Omits the scientific appendix, which does not contain any mention of mollusks.

1906a. Arnold, Ralph. Listed mollusks found in formations in California ranging in age from Eocene through Pleistocene. Included descriptions and illustrations of species of Pecten that occur in the Astoria formation of Oregon.

1906b. Arnold, Ralph. The Clallam formation was considered to include both Oligocene and Miocene rocks and was correlated in part with the Astoria sandstones and shales (p. 461). Gives lists of fossils from the Clallam formation.

1909. Dall, W. H. Divided the Astoria formation at Astoria into Oligocene and Miocene beds and said that there was no proper Eocene exposed there. Explained that his Aturia bed of Oligocene age, in which he believed "Aturia angustata, Miopleiona indurata, Marcia angustifrons, Trophosycon oregonensis, and Scapharca devincta" to be characteristic species, was no longer accessible. 


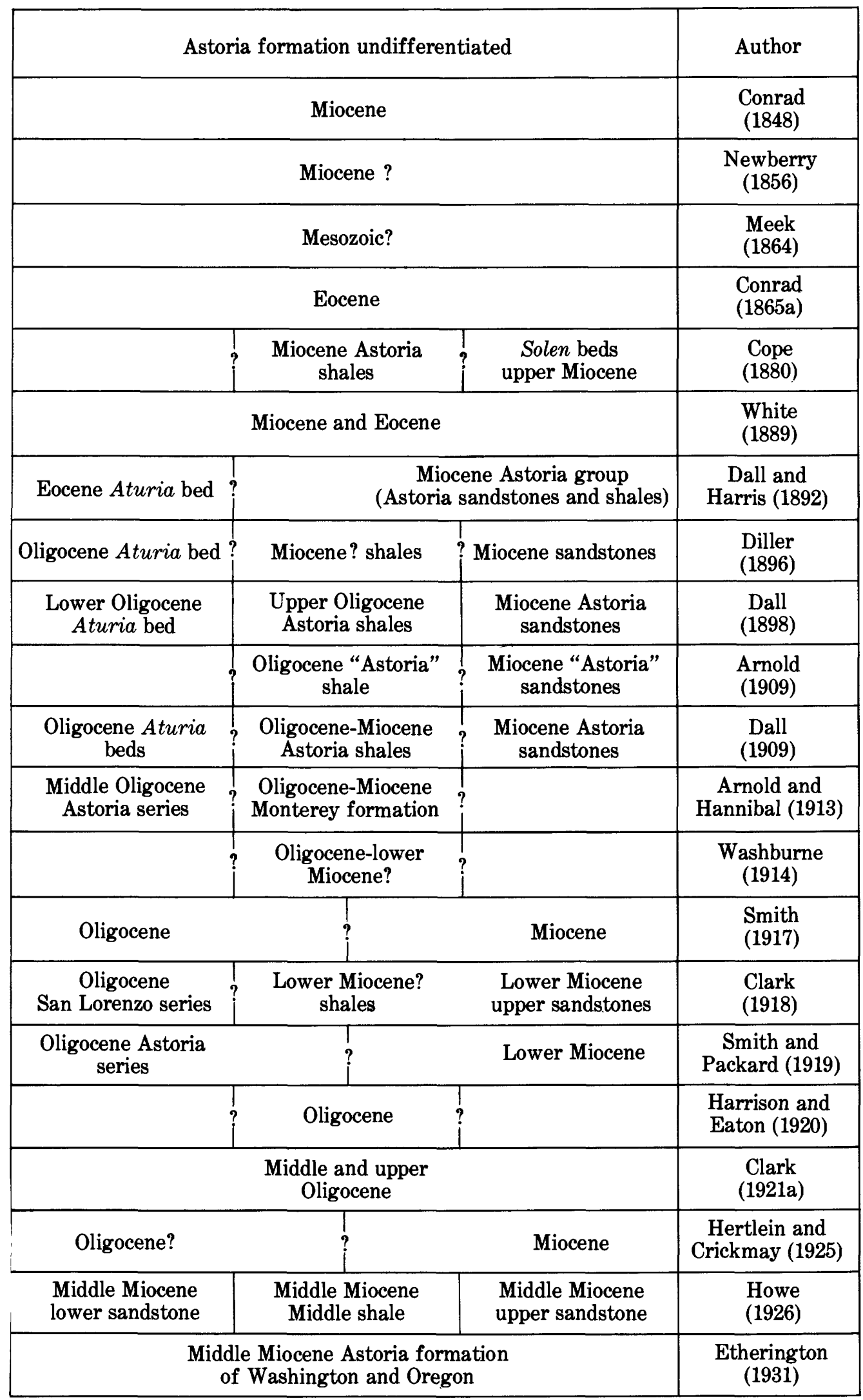

TABLE 1.-Stratigraphic names and age assigned to Astoria formation from 1848 to 1931 
Dall redescribed many of Conrad's original types. He correlated the Empire formation of Coos Bay, now regared as Pliocene?, with the Astoria formation (Miocene), and described the figured specimens from each as Astoria species.

He reprinted the reports of Conrad (1848, 1849), but omitted the illustrations from the reprint of the 1849 report.

Dall said the Eugene formation (now regarded as Oligocene) at Eugene, Oreg., was Miocene and he described and illustrated species from the Eugene in this report. $\mathrm{He}$ also described and illustrated species from the Pittsburg Bluff formation (now regarded as Oligocene) which he assigned to the Eocene.

1909. Reagan, A. B. Included deseriptions and drawings of Miocene mollusks from the Clallam formation of Washington, the age equivalent of the Astoria formation.

1910. Reagan, A. B. Included faunal lists from the Clallam formation, Washington, Carmanah Point and Sooke district, Vancouver Island, and the Astoria formation of Oregon.

1912. Weaver, C. E. Divided rocks he considered lower Miocene into three formations the Blakeley, Wahkiakum, and Chehalis. Deseribed and illustrated a few speeies of mollusks that occur in the Astoria formation in Oregon.

1913. Arnold, Ralph, and Hannibal, Harold. Proposed the name "Astoria Series" for the San Lorenzo, "Seattle," and "Twin River" formations (p. 576-579). Extended the Monterey formation (Oligocene-Miocene of these authors) to include the rocks exposed at the foot of 19th Street in Astoria, along the south shore of Tillamook Bay, and for several miles up and down the coast west of Newport. Includes fossil lists from the Clallam formation of Clallam Bay district and the Astoria formation in Astoria (p. 583, 588).

1914. Anderson, F. M., and Martin, Bruce. Described 10 gastropods from the Astoria formation in Oregon.

1914. Washburne, C. W. The Astoria shale at Astoria is called Oligocene-Miocene-the lower part of the shale Oligocene and the upper part Miocene. Ineludes lists of fossils prepared by W. H. Dall (p. 27-32).

1914. English, W. A. Discussed Ficus modestus (Conrad) and "Trophosycon" oregonensis (Conrad), both of which are Astoria species.

1916. Weaver, C. E. Assigned rocks exposed along the north shore of the Olympic Peninsula betweer Clallam Bay and Pyscht, in Wahkiakum County on the Alockanian River about 12 miles north of Cathlamet, and in parts of the Grays Harbor area to the Wahkiakum Horizon, which he regarded as lower Miocene in age and as closely related to the "Arca" montereyana zone of California. The list of mollusks given for the Wahkiakum Horizon contains species now regarded as characteristic of the Astoria formation. Described and illustrated a few species of mollusks that occur in the Astoria formation in Oregon.

1917. Smith, W. D. P. Assigned the Eugene formation at Smith's quarry, Eugene, Oreg., referred by earlier writers to the Miocene, to the Oligocene and included a list of fossils. Assigned the "Astoria beds," in part to the Miocene.

1918. Clark, B. L. Proposed that the name "San Lorenzo series" be used in place of the "Astoria series" of Arnold and Hannibal (1913) and the "Clallam formation" of Weaver (1916) and that it be applied to all the marine beds of California, Oregon, Washington, and British Columbia referred to the Oligocene (p. 55).
Discarded the term "Astoria" for the marine Oligocene of the West Coast, because he believed that the highly fossiliferous "upper sandstones" were of early Miocene age and that the Oligocene shales were buried.

1919. Smith, W. D. P. and Packard, E. L. Considered rocks of both Oligocene and Miocene age to be present at Astoria, Oreg. (p. 97).

1920. Harrison and Eaton (firm), regarded the Astoria shales of Astoria as Oligocene and suggested that the "Acila shales" of Newport could be called Astoria shales. The fossils listed from the "Acila shales" of Newport (p. 6-7) include only forms now regarded as eharacteristic of the Nye Shale of Newport, and it is this formation that is ealled the "Aeila Shales." Assigned "tuffaceous sandstones and shales" of Newport to the Miocene, giving these beds no formational name. The fossils listed from these rocks include one species now thought to be restricted to the Empire (Pliocene?) formation, but the rest are characteristic of the Astoria.

1921a. Clark, B. L. Referred "Astoria" of Arnold, Hannibal, Packard, and Smith to the San Lorenzo Oligocene. Listed species now considered common in the Astoria formation in "Blakeley" on the correlation chart facing p. 614.

1921b. Clark, B. L. Assigned the Temblor formation of California to the early Miocene and considered it equivalent to the "Wahkiakum" formation and to part of the Blakeley formation. Listed Arca devincta Conrad, Turritella oregonensis Conrad, Miopleiona indurata (Conrad), and Eudolium petrosum (Conrad) as characteristic species.

1922. Dall, W. H. Redeseribed and made numerous changes in Reagan's (1909) identifications of the mollusks from the Clallam formation, the age equivalent of the Astoria formation. Did not reillustrate the specimens described by Reagan.

1922. Howe, H. V. Included historical summary, stratigraphy, structure, and systematic paleontology of the Astoria formation, which he assigned to the middle Miocene. Gave localities for all the fossils collected within the city of Astoria and included a geologic map of the eity.

This report is of particular value for the information it gives concerning the locations of former outerops now concealed, of the Astoria formation in the city of Astoria, and the fossils collected from them.

1925. Hertlein, L. G., and Crickmay, C.H. Tentatively assigned the lower part of the Astoria formation to the Oligocene, correlating it with the Blakeley formation, which was also assigned to the Oligocene. Referred the upper part to the Miocene and correlated it with the Clallam formation in Washington and the Monterey and Temblor formations in California (p. 250-261). Included a list of fossils from the Astoria formation in Oregon.

1926, (1927). Stewart, R. B. Described some species from the Astoria formation in Oregon.

1926. Howe, H. V. Referred the Astoria formation to the middle Miocene and considered it equivalent to the middle Miocene Temblor formation of Kern River, Calif. Howe found the stratigraphie section at Astoria to consist of a lower sandstone, a middle shale, and an upper sandstone. The lower sandstone and the upper had been confused in the past, and he showed that the rocks that had been regarded as the lower part of the Astoria and referred to the Eocene, overlie the part of the section that had been considered to be younger. 
Included discussions of the stratigraphy and structure of the Astoria formation at Astoria, with brief reference to the Newport area, a geologic map of Astoria, and a list of fossils.

1928. Wiedey, L. W. Described "Area procumbens" from the Astoria formation north of Yaquina Head, Oreg.

1928. Schenck, H. G. Lithologic cross sections for Yaquina Bay and Jump Off Joe, Oreg., that include the Astoria formation. Discussed the lithology, ecology, and fauna of the Nye shale.

1930. Stewart, R. B. Discussed species from the Astoria formation in Oregon.

1931. Etherington, T. J. Included stratigraphy and systematic paleontology of the Astoria(?) formation and a geologic map of Grays Harbor County, in southwestern Washington. Extended the name Astoria formation to include the Miocene strata in Washington that had been called the Clallam, Wahkiakum, and Chehalis formations. Considered the Astoria middle Miocene and equivalent to the Temblor formation of California. Described new species, which also occur in the Astoria in Oregon.

1931. Grant, U. S., 4th and Gale, H. R. Described and illustrated a few species that occur in the Astoria formation in Oregon.

1932. Loel, Wayne, and Corey, W. H. Considered that the Astoria formation has a large number of species in common with the Temblor of California, and that it has a few in common with the Vaqueros-all of them forms with long range and wide environmental distribution (p. 156). Included a faunal list (p. 141-153) for the Vaqueros and Temblor formations.

1933. Tegland, N. M. Regarded the Astoria formation as middle Miocene and as having a fauna distinct from that of the Blakeley (p. 89). Figured species occurring in the Astoria for comparison with the Blakeley forms.

1934. Packard, E. L. Discussed the geology of the Newport region and included a list of mollusks from the Astoria of Lincoln County. Correlated the Astoria at Newport with the lower "Astoria Aturia sandstone."

1937. Weaver, C. E. Discussed the stratigraphy, structure, and faunal relations of the Astoria in the Grays Harbor, North River-Dryad Synclinal, and Nasel areas, Washington, and the Columbia County and Yaquina Bay areas, Oregon, and assigned the Astoria to the middle Miocene. Included geologic maps and discussions of the faunas (p. 175-187).

In his summary of the Coos Bay area (p. 182) Weaver accurately predicted the discovery of Miocene strata in Coos Bay.

1938. Woodring, W. P. Discussed Lucina acutilineata Conrad and Venus angustifrons Conrad originally described from Astoria and designated lectotypes.

1938. Kleinpell, R. M. Placed the Foraminifera in the shale at Astoria in the Uvigerinella obesa zone of his upper Saucesian (p. 154), which he assigned to the late Oligocene. Includes a checklist of Foraminifera (p. 77) from the Blakeley formation in Washington.

1941. Packard, E. L. Recorded vertebrate material from the Astoria-a small porpoise, sharks teeth, isolated fish vertebrae, and the skull of a gigantic chelonian (leatherback turtle). Said that the lower beds of the Astoria contain marine mammals wherever they occur between Waldport, Lincoln County, and Astoria, Clatsop County, in Oregon.
1942. Durham, J. W., Harper, Herbert, and Wilder, Beverly Jr. Recognized rocks of early Miocene age in the southern half of the Mollala quadrangle, about 30 miles south of Portland, Oreg. Believed on the basis of the mollusks that the beds were most likely to be equivalent in age to the Vaqueros formation of California and that they contain the first mollusks found north of California that resemble the Vaqueros.

1942 (1943). Weaver, C. E. Described and illustrated the invertebrate fauna (exclusive of Foraminifera) of the Astoria. Proposed two new species, Echinarachinium blancoensis var. etheringtoni and Megasurcula etheringtoni, from the Astoria of Washington. Included a faunal list of the Astoria and an extensive bibliography.

1944. Durham, J. W. Included checklists of Miocene mollusks from the Clallam formation, the age equivalent of the Astoria, and from the Sooke and Blakeley formations of early Miocene age.

1945. Warren, W. C., Grivetti, R. M., and Norbisrath, Hans. The first of three Oil and Gas maps (fig. 1, in present report) that cover all of the known exposures of the Astoria formation in Oregon, with the exception of the exposure at Cape Balnco (Durham, 1953, p. 1504-1505). Included a checklist of mollusks from the Astoria formation.

1945b. Weaver, C. E. Discussed the general geology of Oregon and Washington with a brief section on the Astoria formation.

1947 (1948). Cushman, J. A., Stewart, R. E., and Stewart, K. C. Described, illustrated, and assigned to the middle Miocene Foraminifera from the northwest corner of 10th Street and Harrison Avenue, Astoria, Oreg., and the base of the beach cliff about 700 feet southwest of Yaquina Head, north of Newport, Oreg.

1948. Rau, W. W. Said that Foraminifera from the Astoria formation, Washington, indicate lower to middle Miocene age, and that they show considerable similarity to those of the Temblor formation, California.

1949. Vokes, H. E., Norbisrath, Hans, and Snavely, P. D., Jr. Included a check list of the mollusks collected from the Astoria formation, Lincoln County, Oreg., and a brief discussion of the stratigraphy. Considered the correlation of the Astoria formation with the Temblor to be confirmed.

1949. Snavely, P. D., Jr., and Vokes, H. E. Included a discussion of the stratigraphy and a check.list of the mollusks in the Astoria formation, Oregon.

1951. Rau, W. W. Regarded at least 1,100 feet of dark-gray very slightly indurated carbonaceous siltstone in southwest Washington as probably equivalent to the lower part of the Astoria formation and perhaps to parts of both upper and lower Saucesian of Kleinpell and therefore as being near the top of the lower Miocene (p. 428).

1951. Lutz, G. C. Designated the type section of the Sobrante a definite correlation between the Sobrante sandstone of California, the Astoria formation, and the Temblor formation. He said that the evidence suggested Saucesian, or Relizian, or perhaps even lower Luisian age of Kleinpell in terms of the microfauna sequence and "Temblor" age in the megafaunal sequence and added that indirect evidence based on the Foraminifera shows a greater likelihood that the age is Relizian.

1951. Stewart, R. E., and Stewart, K. C. Reported upper Oligocene Foraminifera from Commercial Street, 100 yards east of 37th Street in Astoria and the occurrence of Oligocene shale on the east limb of the syncline in Astoria, Oreg. 
1953. Durham, J. W. Described sedimentary rocks that may be equivalent to the Astoria formation as occurring in the sea cliff about half a mile southeast of Cape Blanco. This is the most southern reported occurrence of Miocene marine strata in Oregon. Included a check list of mollusks.

1956-57. Stewart, R. E. Tentatively assigned the Astoria foraminiferal fauna to Kleinpell's upper Saucesian Stage, which Stewart believed might be of latest early Miocene age (p. 2). Lists Foraminifera that were collected from the Astoria formation at 10th Street and Harrison Avenue in Astoria, in the vicinity of Depoe Bay, and along the coast between Otter Rock and Newport, Oreg. (p. 4-5).

\section{ASTORIA FORMATION}

\section{STRATIGRAPHY}

\section{GENERAL FEATURES AND GEOGRAPHIC DISTRIBUTION}

The northernmost occurrence of the Astoria formation in Oregon is at the type area in Astoria, and the southernmost reported exposure is just south of Cape Blanco (Durham, 1953, p. 1504-1505).

The most fossiliferous exposed parts of the Astoria formation are in sea cliffs extending intermittently along the coast from Tillamook Bay south to the Newport area, and in a few outcrops and roadcuts near U.S. Highway 101 that are mostly about half a mile to a mile inland from the Pacific Ocean.

\section{TYPE AREA}

The city of Astoria (fig. 2) is built on a peninsula bounded on the north by the Columbia River and on the south by Youngs Bay. It is unfortunate that this is the type area, for the city now covers almost the entire peninsula, so that few of the exposures originally within the city are available for study. To give room for more building, the river banks that once exposed the Astoria formation are now covered with sand dredged from the river and held in place by piling. A few exposures remain within the city limits and in roadcuts near the city, but hardly any of the probable exposures from which fossils were collected as early as the middle 1830's can be restudied.

Townsend, Dana, and the other early explorers made their collections from the cliffs along the Columbia River; according to Howe $(1926$, p. 296), from the present location of Nineteenth Street, west at least as far as the site of the present courthouse. Howe wrote that the cliffs consisted of shale and that the beach was covered with fossiliferous calcareous concretions which had been washed out of the shale. According to Dana $(1849$, p. 722,729$)$ the fossils he collected came from the south bank of the Columbia River near and within Astoria.

The type section of the Astoria formation can be defined faunally and placed in time on the basis of its fauna, but does not now provide an adequate lithologic or stratigraphic basis for definition and extension of the formation. Astoria formation has been used as a name for almost all of the marine middle Miocene sedimentary rocks of Washington and Oregon, but correlations with the type Astoria formation have usually been made on the basis of a characteristic fauna and not on lithology and by mapping into the type area. While this keeps the record from being taxed with many formational names, it also tends to confuse rock-stratigraphic terminology with paleontologic zonation.

Howe (1926, p. 297-301) divided the Astoria formation in Astoria in to three members: a lower sandstone, a shale, and an upper sandstone. These rocks, which form the Astoria peninsula, are part of the northern limb of a syncline, the axis of which is exposed near the mouth of the John Day River east of Astoria. The syncline trends northeastward and plunges to the southwest.

The lower sandstone (Howe, 1926, p. 297-299), the base of which is not exposed, is the oldest unit visible on the northern limb of the syncline. The lowest exposed part of this sandstone occurs at Fifth and Commercial Streets, where it consists of fine-grained sandstone alternating with sandy shale in which coal pebbles, small round concretions the size of marbles, and fossils are abundant. This sandstone was estimated by Howe to be probably more than 150 feet thick. Toward the top, shale alternates with sandstone and finally the unit grades into the overlying shale. Howe estimated the shale to be less than 1,000 feet thick, but because it is involved in slumping a more definite estimate of its thickness could not be made.

A layer of fine-grained greensand containing limy concretions lies about 150 feet above the base of the shale. Howe (1926, p. 300) traced this greensand from

$* * *$ the beach just to the south of the Port of Astoria docks *** with interruptions due to the covering of timber, to the neighborhood of Volstead and Duane Streets, where a fine band of greensand about six inches in thickness, appears in intimate association with the concretions $* * *$. This greensand-limestone-concretionary bed may then be definitely traced in the same relative stratigraphic position to Irving and Fourteenth Streets, in the center of the city, where the greensand increases to six feet thickness.

This greensand may still be observed at 10th and Harrison Streets. A petrographic analysis of the shale and greensand from the road cut at the northwest corner of this street intersection (Cushman, Stewart, and Stewart, 1947, p. 12) revealed that:

The shale is bentonitic and made up predominantly of beidelite(?). The greensand consists largely of a glauconite-like mineral and gypsum with a minor amount of detrital grains of quartz and plagioclase. Spectrographic analysis of the greensand shows the presence of approximately 3 percent potassium. which indicates its glauconite nature. 


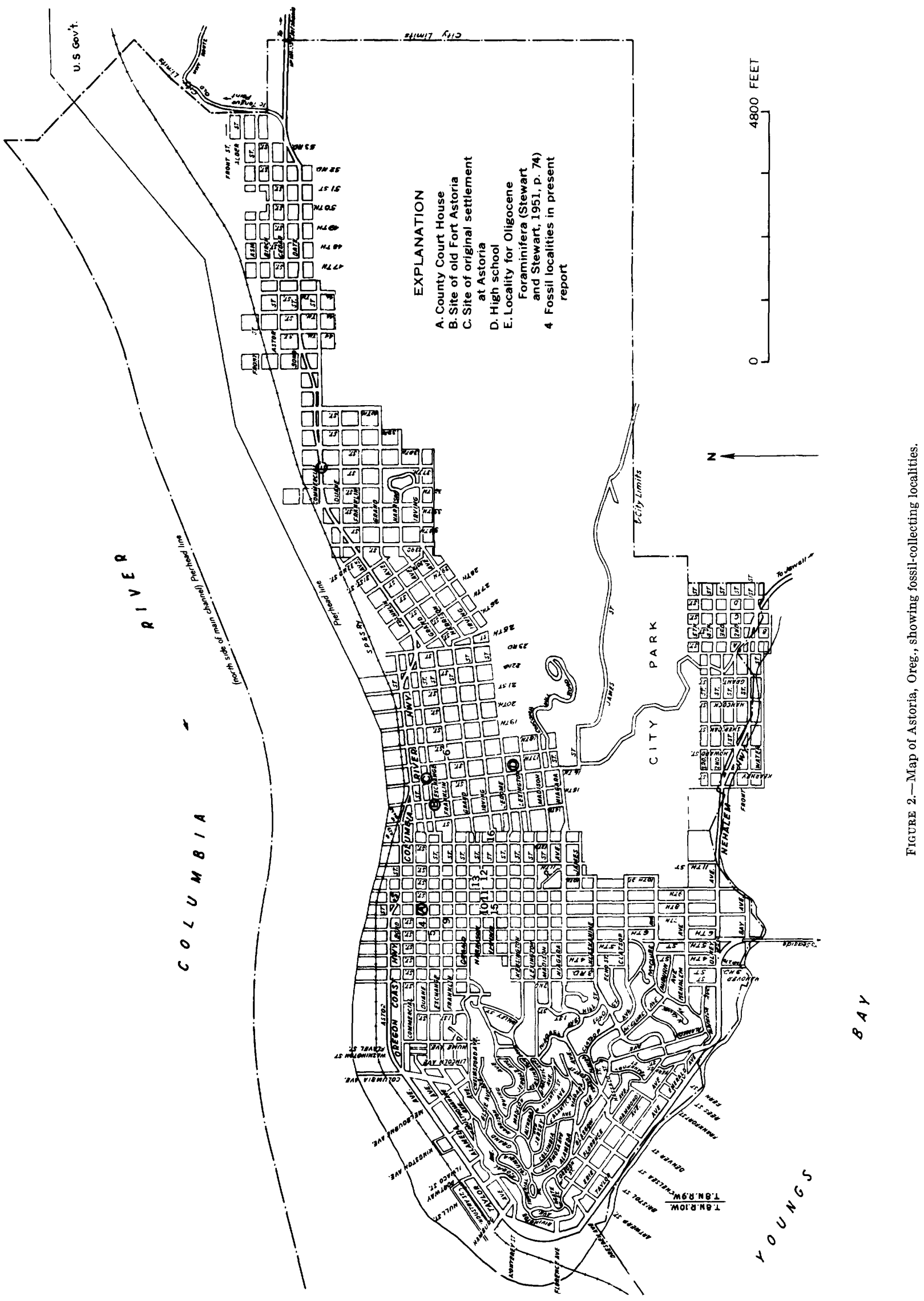


Dana $(1849$, p. 657$)$ noted that the shale in the vicinity of Astoria contained numerous fossils, and that those to the east were embedded in calcareous nodules, whereas those to the west were unprotected in the shale and had been compressed.

Dall $(1909$, p. 9) said that the lower part of the shale lacked fossil remains, but that the fossils appeared to be the same species throughout the sandstone and the greater part of the shale. This agrees with Howe's (1926, p. 302) observation that 54 percent of the species collected by him in shale of the Astoria were also found in the underlying sandstone. Dall also made the interesting observation that some of the shells in the upper part of the shale seemed to have been fossilized in sandstone, reworked, and reembedded in the shale. He found remnants of soft coarse sandstone between the valves or on one side of a single valve of pelecypods that were preserved in the shale.

Howe (1926, p. 301) wrote:

*** it appears that the shales in their upper portion contain several beds of a coarse, arkosic, micaceous sandstone, separated by shale $* * *$ the different beds vary in thickness from ten to more than one hundred feet. They are in places cross-bedded, but there are very few lines of stratification $* * *$. There is no reason to suppose that these sandstones are separated from the Astoria shale by any great stratigraphic break, but as they are unfossiliferous in the Astoria area, it is quite impossible to demonstrate this point.

According to Howe (1926, p. 300-301), the upper sandstone is best exposed in road cuts along the Columbia Highway, on both sides of the John Day River bridge, and in the railroad cuts which parallel the highway, and along the Olney and Waterworks road immediately south of Astoria.

Stewart and Stewart (1951, p. 74) described an exposure of shale on Commercial Street, about 100 yards east of 37th Street, in Astoria. According to their interpretation, the shale is of late Oligocene age and lies on the north flank of a syncline trending east and west.

\section{COASTAL OUTCROP AREA}

The Astoria formation south of the type area at Astoria is composed of marine sedimentary rocks exposed on the western flank of the Coast Range. Fossiliferous exposures are limited almost entirely to the sea cliffs along the Pacific Ocean between Tillamook Bay, in Tillamook County, and Beaver Creek, in Lincoln County. In this distance of about 70 miles, Astoria rocks are only intermittently exposed; they are much faulted and are repeated in fault blocks that form cliffs, and exposures are commonly interrupted by volcanic rocks and slides. The beds usually dip westward, at angles generally less than $25^{\circ}$. The maximum thickness of beds exposed in an uninterrupted section is about 250 feet, measured immediately south of Yaquina Head, north of Newport, Lincoln County, but few exposures, in fact, are more than a few hundred feet long. The total estimated thickness in the Newport area is roughly 550 feet.

The strata exposed consist of shale varying in silt and sand content, siltstone, fine-grained sandstone with varying amounts of silt, coarse-grained sandstone, conglomerate, and tuff. Calcareous silty shale and finegrained silty sandstone generally predominate. The strata are locally in truded by volcanic rocks and in some places contain much volcanic detritus. Concretions as much as a foot and a half in diameter are common in a few places, and carbonized wood and carbonaceous particles are present. Glauconite forms an appreciable part of the rocks in some sections, particularly in the section formerly well exposed in the city of Astoria (Howe, 1926) and still partly exposed at 10th and Harrison Streets. Some glauconite is also in the section exposed at Beaver Creek, south of Tillamook Bay (Snavely and Vokes, 1949). Sections measured in the Newport area, Lincoln County, are shown on plate 33.

The Astoria formation where exposed in the sea cliffs is usually thin bedded, but a few beds of fine-grained silty sandstone attain a maximum thickness of 60 feet.

The sedimentary rocks in the Astoria formation vary considerably in induration. The well-indurated beds form ledges and cliffs along the coast, and the poorly indurated beds are undercut and are often involved in slides. The westerly dip of these beds and the presence of hydroplastic shale in the Astoria and underlying Nye mudstone (lower Miocene) have caused fairly large slides in the Newport area and smaller ones elsewhere, some of which have destroyed buildings and parts of roads. The exposures in the sea cliffs are changed in detail every winter by storms and high tides.

The Astoria formation is in most places unconformable with both the underlying and the overlying formations. It rests unconformably, in different areas, upon the Nye mudstone (early Miocene), the Blakeley formation (late Oligocene or early Miocene), and possibly the Tunnel Point sandstone (middle Oligocene). In the beach cliffs along the coast, the Astoria is usually overlain unconformably by Pleistocene sediments. In the Coos Bay area, it is overlain by the Empire formation (Pliocene?), and in the Beaver Creek area its eroded surface is covered by Columbia River basalt (Miocene). In some areas the Astoria may be overlain by upper Miocene rocks, but as the strata in question are not fossiliferous their age remains in doubt. In the Grays Harbor area in Washington the Astoria (?) formation is probably overlain conformably by the Montesano formation (Weaver, 1912), of upper Miocene age, but in the Montesano area an unconformity is present between the two formations (Etherington, 1931, p. 46). 


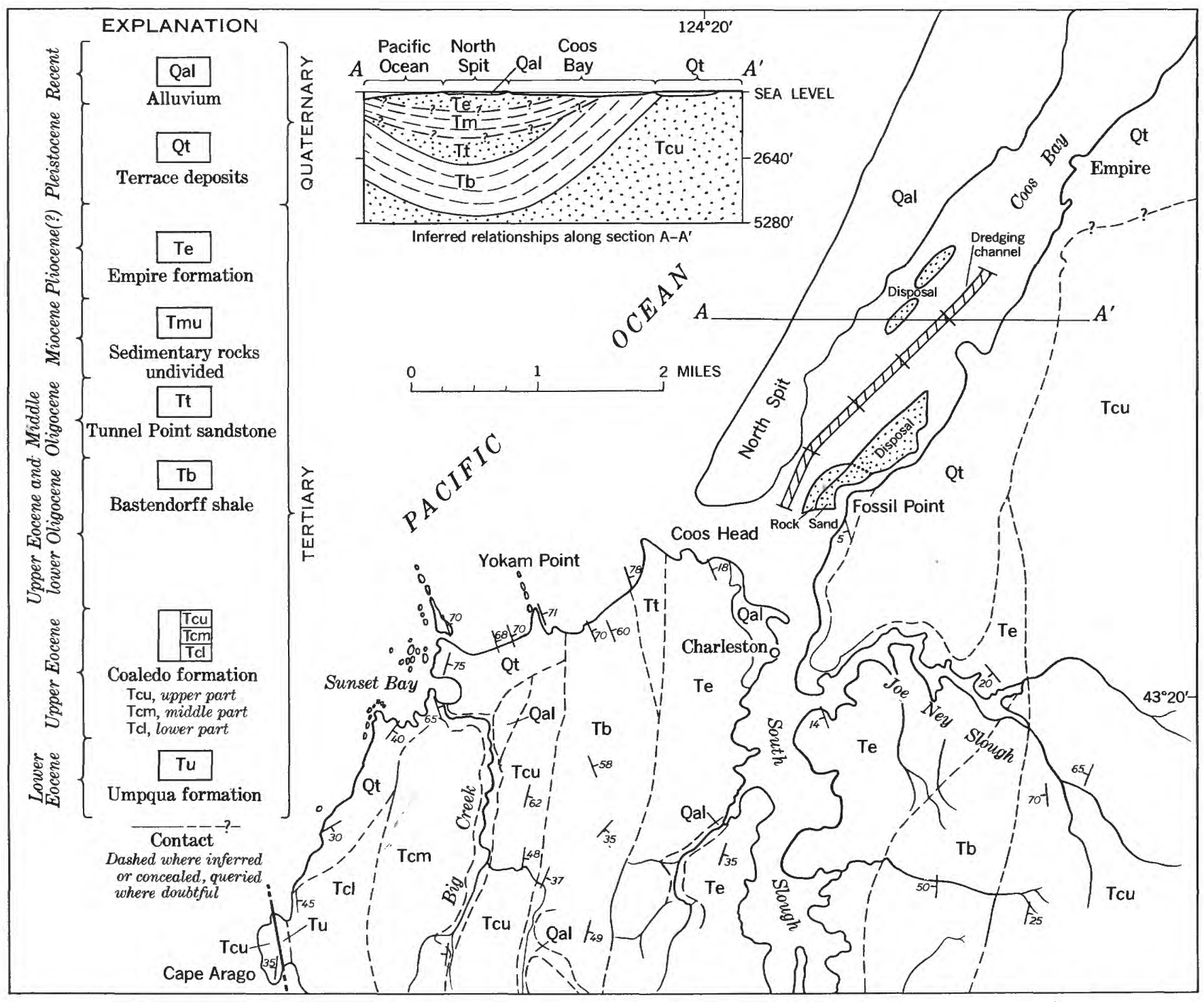

Figure 3.-Generalized geologic map and cross section of the Coos Bay area, Oregon, showing location of dredging. Adapted from Allen and Baldwin, 1944 .

\section{COOS BAY DREDGINGS}

No strata of Miocene age are exposed in the Coos Bay area (fig. 3); the Tunnel Point sandstone (middle Oligocene) is unconformably overlain by the Empire formation (Pliocene (?)) in areas where these beds are exposed. Sedimentary rocks that contain a marine invertebrate fauna of Miocene age, however, were brought to the surface when the channel of Coos Bay was dredged in the spring of 1949 by the San Francisco Bridge Co.

The channel of Coos Bay was dredged to 31 feet below mean lower low water from mile 2.0 to mile 4.5, except for a distance of about 900 feet on each side of mile 3.5, as measured from beginning of dredging. The dredgings were placed in two disposal areas beside the channel. The maximum length of pipeline used was 2,770 feet, but the average length used was less than 2,000 feet. Material in the disposal areas was removed from a point in the channel within this radius, so that the approximate source of the material dredged can be determined.

The location of the dredged channel and the disposal areas are shown in figure 3 . According to the map furnished by the U.S. Army Corps of Engineers, there were originally 2 disposal heaps on the northwest side of the channel, but in the summer of 1954 only 1 projected above the surface of the water.

In the area at Coos Bay pertinent to this discussion, strata of Eocene to Recent age are exposed on the western and eastern flanks of a syncline that plunges to the north in the area of exposure (fig. 3). The formations thus exposed are the Coaledo formation of Eocene age, the Bastendorff shale of Eocene and Oligocene age, the Tunnel Point sandstone of middle Oligocene age, 
the Empire formation of Pliocene (?) age, Pleistocene terrace deposits, and alluvium of Recent age.

A fauna which can probably be correlated with that of the Empire formation occurs in the material dredged from mile 2.0 to the undredged area near mile 3.5 (fig. 3). This fauna is sparse and poorly preserved, except for an occasional Patinopecten coosensis. Fragmental Crepidula and Macoma were recognized, but the species could not be determined. The fossils occur in a poorly cemented sandstone, similar to the sandstone facies of the Empire formation which crops out nearby. These dredgings were dumped southeast of the channel.

The material dredged between approximately mile 3.5 and mile 4.0 contains a fauna of Miocene age and a few isolated fossils that may be of Pliocene age. These dredgings were placed in a disposal heap northwest of the channel alongside North Spit, opposite the Cape Arago Pulp Mill (figs. 3-5). This disposal area is approximately $1 \frac{1 / 4}{1 / 4}$ miles southwest of the town of Empire and can be reached only by boat. From the south end of this disposal area the tall chimney of the Cape Arago Pulp Mill bears S. $32^{\circ}$ E., and the Compass Station on North Spit bears S. $80^{\circ}$ W.

The Miocene rocks are probably unconformable on the Tunnel Point sandstone, assuming rocks of intermediate age are not buried in the center of the syncline. The Empire formation covers the center of the syncline from which the Miocene rocks were dredged and lies unconformably on the Tunnel Point sandstone and the Bastendorff shale in the area where exposures of Miocene strata might be expected. Earlier writers (that is, Allen and Baldwin, 1944, p. 34; Weaver, 1945, p. 50) have speculated on the possibility that Miocene rocks may underlie the Empire formation. The dredging reached these Miocene rocks where they had been exposed in the channel.

It was not necessary, for engineering purposes, to dredge the area extending for 900 feet on each side of mile 3.5. It is possible that the contact between the Empire formation and the Miocene rocks lies within this area and that the contact was more easily eroded than the rocks on either side.

The Miocene rocks in the accessible disposal area consist in part of a well indurated and apparently massive sandstone and in part of a shaly siltstone. Blocks of the indurated sandstone as large as 2 feet in diameter are present in the disposal area, and these contain Miocene fossils. The shaly siltstone, being much more easily broken up in the dredging process, is in pieces rarely larger than 1 or 2 inches in diameter. Some of the larger fragments of siltstone contain Miocene fossils, but most of the fossils were found loose on top of the siltstone, with little or no matrix adhering to them.

The material dredged between the northern end of the channel and mile 4.5 and placed on the north

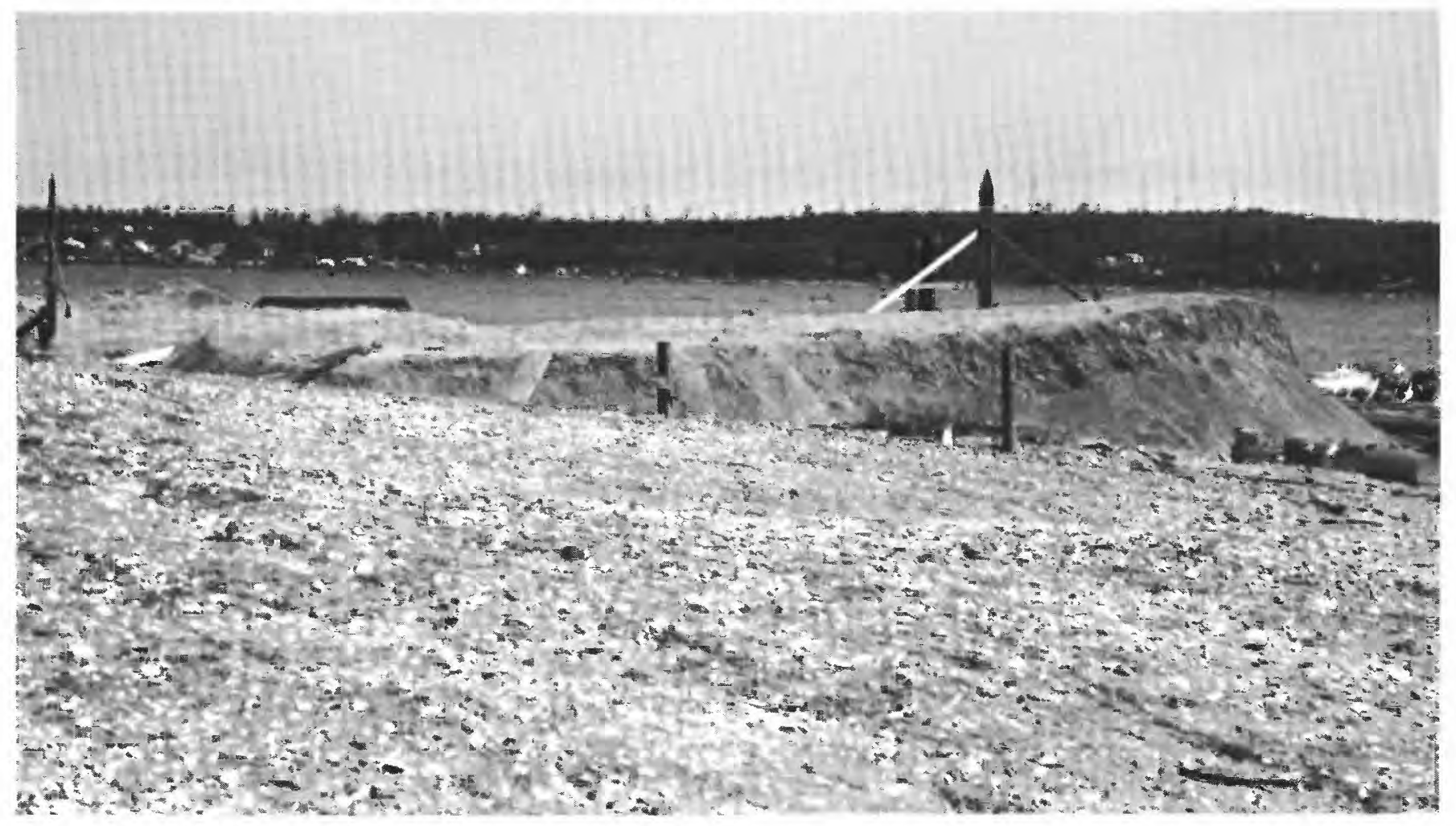

FIGURE 4.-Locality on the dredgings for the collection of Miocene fossils at Coos Bay, Oreg. The view is toward the northeast, and the fosslls were collected in the foreground and to the south and the southwest. (Photograph taken in June 1949.) 


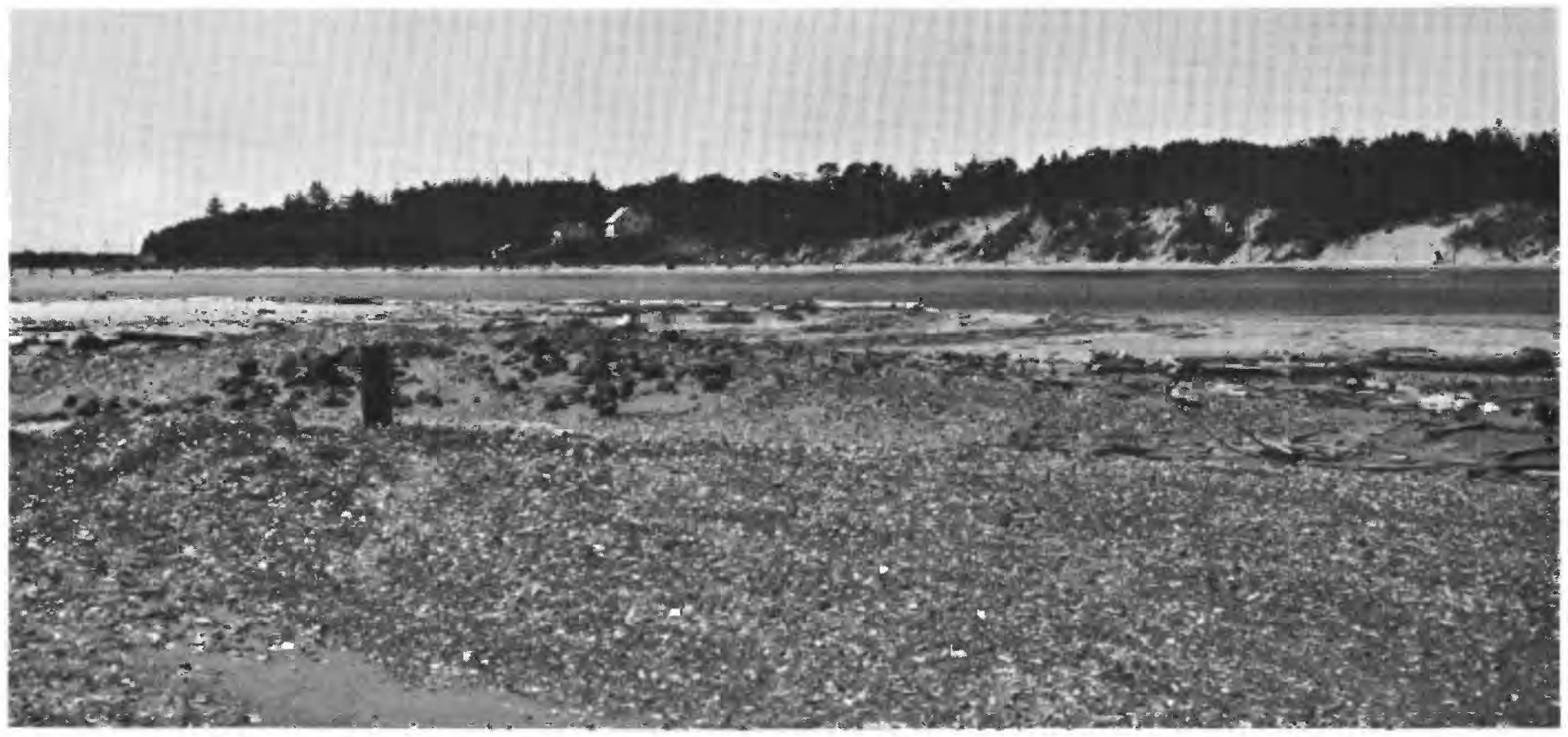

Figure 5.-Locality on the dredgings for tho collection of Miocene fossils at Coos Bay, Oreg. The vlew is toward the southwest, and the fossils were collected in the foreground. (Photograph taken in June 1949.)

end of the disposal pile on which the Miocene fossils were collected, contains Foraminifera which R. E. Stewart (oral communication, 1950) identified and considered characteristic of the upper part of the Bastendorff shale (lower Oligocene). No mollusks were found in these rocks.

\section{OCCURRENCES IN WASHINGTON}

Marine rocks of middle Miocene age are known in three areas in Washington: in northwesternmost Washington along the Strait of Juan De Fuca, in southwestern Washington in the Grays Harbor area, and in southwesternmost Washington in Wahkiakum County.

Arnold (1906b, p. 461) proposed the Clallam formation for all of the pre-Pleistocene rocks, except the volcanic rocks of Eocene age, exposed along the Strait of Jaun De Fuca between Freshwater Bay and Cape Flattery. He correlated the upper part of his Clallam formation with the Astoria formation in Oregon. Subsequent workers (Weaver, 1937; Durham, 1944; Gower, 1960) have restricted the Clallam formation to the middle Miocene rocks exposed in the Clallam BayPillar Point area.

The Clallam formation is intermittently exposed along the Strait of Juan De Fuca in cliffs and in rocks exposed at low tide. Durham (1944, fig. 5) estimated the thickness of the Clallam formation in this area as more than 500 feet and collected fossils at two localities in the Clallam west of Pysht River. He considered the fossils to be Miocene and to correspond approximately with the Barker's Ranch Temblor fauna of California.
Weaver $(1912$, p. 17) divided rocks in Washington that he considered to be early Miocene into three formations: Blakeley, Wahkiakum, and Chehalis. In 1916 he assigned rocks he considered early Miocene to the Wahkiakum horizon (Weaver, p. 6). Etherington $(1931$, p. 56) extended the name Astoria formation to include the Miocene rocks previously called the Wahkiakum Horizon and correlated the Astoria formation with the Clallam formation, assigning them both to the middle Miocene.

In the Montesano area, Etherington (1931, p. 44) measured 2,500 feet of marine sedimentary rocks along the Clemons Logging Railroad and assigned them to the Astoria formation.

Middle Miocene marine strata are reported by Weaver in southwesternmost Washington. According to Weaver (1937, p.178-179),

*** the Astoria sandstones *** occupy a zone about 4 'miles in width and $2 \frac{1}{2}$ miles in length in the valley of the lower half of Nasel River. Excellent exposures of the Astoria sandstone may be observed along the shores of the lower portion of the Nasel River and in the highway cuts as well as along the north shore of the Columbia River from the mouth of Grays River westerly to the town of Frankfort.

The sandstone of the Astoria formation $* * *$ on the north side of Columbia River has a thickness of nearly 3,500 feet * * * An area approximately 3 to 4 miles in width occurs on the north side of Columbia River, from the entrance to Grays Bay easterly through Wahkiakum County, for a distance of about 25 miles and is composed of massive rather coarse-grained grayish-brown marine sandstones with a thickness of 3,000 feet $* * *$.

Astoria(?) formation has been used for middle Miocene rocks in the Centralia-Chehalis district, 
Washington (Snavely and others, 1958, p. 54). This usage reflects the fact that the beds cannot be traced without interruption into the type section of the Astoria formation. They are tentatively correlated on the basis of their fauna, stratigraphic position, and lithologic characteristics, but they may not occupy a stratigraphic position identical to the Astoria formation in Oregon.

Astoria(?) formation is used in this report for all the middle Miocene rocks in the Grays Harbor Montesano area and to the south in Washington that have been correlated with the Astoria formation in Oregon, as they cannot be traced without interruption into the type section of the Astoria formation.

\section{PALEONTOLOGY}

\section{FAUNAL COMPOSITION}

A total of 97 species (table 2) of mollusks have been collected from the Astoria formation in Oregon and are in the U.S. National Museum collections. Of this total, 58 were collected in the city of Astoria-60 percent of the entire fauna. The 97 species represent the faunas from about 550 feet of the Astoria formation which is intermittently exposed for many miles along the Oregon coast. The exposed fossiliferous part of the Astoria formation in Astoria is perhaps no more than 300 feet thick, and the original exposure along the south bank of the Columbia River, although perhaps more than 300 feet thick, may at most have been a mile long. It does not seem surprising therefore, that only 60 percent of the entire fauna has been collected from the type area.

Only 1 species, excluding 2 of doubtful record, is unique to the type site. This species is Paramusium astoriana and is the first fossil record on the Pacific coast of a genus that has been collected in Recent seas from depths of 218 to 1,800 fathoms. Therefore, for all practical purposes, the species collected in Astoria are the same as those from other exposures of the Astoria formation in Oregon.

Delectopecten peckhami, a species that elsewhere generally is rare in the Astoria formation, is common in the shale exposed at 9th and 10th and Harrison Streets in Astoria. This species is, however, common in the few other shale beds in the Astoria formation. Depositional environment, rather than age, determines its presence or absence.

The Miocene fauna recovered from the Coos Bay dredgings was collected from the northern disposal area (figs. 4, 5) mainly on the surface of a few inches beneath the surface of the dredgings. Most of the fossils were free of any matrix and were collected singly.
Some blocks of sandstone contained more than one form.

The fossils are almost all replaced by chalcedony. Most of them are complete or almost complete specimens, generally much better preserved than those collected from the Astoria formation in any of the exposures farther north.

Because the Miocene rocks at Coos Bay are seen only in dredgings, it is sometimes impossible to determine whether or not two species picked up separately on the disposal heap without any matrix both came from the Miocene rocks, and if so whether they were in direct association. So whenever a piece of rock was collected that enclosed more than one species, such association was recorded before the specimens were removed for study. From these observations it is known that the following listed fossils occur in close association in the Miocene strata of Coos Bay.

Fossils from Coos Bay dredgings known to be associated in the Miocene strata

Gastropods

Cryptonatica oregonensis (Conrad)

Bruclarkia oregonensis (Conrad)

Hinia? lincolnensis (Anderson and Martin)

Cylichnina petrosa (Conrad)

\section{Pelecypods}

Litorhadia astoriana (Henderson)

Patinopecten oregonensis cancellosus (Moore)

Katherinella (Katherinella) angustifrons (Conrad)

Dosinia (Dosinia) whitneyi (Gabb)

Chione (Securella) ensifera (Dall)

Macoma arctata (Conrad)

Tellina aff. T. idae Dall

Tellina oregonensis Conrad

Tellina emacerata Conrad

Panope (Panope) abrupta (Conrad)

Thracia trapezoides Conrad

This list is not meant to imply that other forms identified in this fauna but occurring singly were not associated with those listed. It is assumed that they were associated, but this cannot be definitely proved. It may always remain questionable whether some of the Miocene species collected from the dredgings actually occurred together.

The Miocene fauna collected from the rock dredged from Coos Bay differs to some extent from faunas collected elsewhere from the Astoria in Oregon and Washington.

Forty-five species recorded elsewhere in the Astoria in Oregon are not found in the fauna collected from the dredgings at Coos Bay. North of Coos Bay the Astoria formation is exposed for many hundreds of 
feet along the beach cliffs, and fossils have been collected from most of the section. At Coos Bay presumably only a small part of the formation was reached by dredging.

Forms collected from the Coos Bay dredging but not known to occur in the Astoria formation elsewhere in Oregon are as follows: Fossils found in Coos Bay dredgings but not elsewhere in Astoria
formation in Oregon

Cancellaria? n. sp.?

Crawfordina? n. sp.?

Spirotropis calodius Moore, n. sp.

Patinopecten oregonensis cancellosus Moore, $\mathrm{n}$. subsp.

Clinocardium aff. C. nuttallii (Conrad)

Dosinia (Dosinia) whitneyi (Gabb)

Macoma n. sp.?

Gari? aff. G. edentula (Gabb)

Dosinia whitneyi may be present in the section exposed at Cape Kiwanda, but the specimens are too poorly preserved to be identified. The remainder of the fauna with the exception of the species in the above list is conspecific with fossils collected from exposures of the Astoria in Oregon.

It seems reasonable to suppose that the Miocene fauna present in rock dredged between points near mile 3.5 and mile 4.0 is the age equivalent of the fauna in the Astoria formation exposed farther north.

\section{PALEOECOLOGY}

Most of the 73 genera collected from the Astoria formation in Oregon are still living along the Pacific coast of North America, but 7 are now extinct: Liracassis, Trophosycon, Molopophorus, Bruclarkia, Priscofusus, Aturia, and Vertipecten, and probably 5 are locally extinct-Sinum, Turritella, Ficus, Anadara, and Dosinia. Katherinella in the restricted sense is also extinct. One genus, Psephaea, is today restricted to Japanese waters.

The species collected do not represent all of the groups of mollusks that might be expected to have lived in the warm-temperate waters along the Oregon coast during the Miocene. No mollusks representing the rock-dwelling groups, except a few specimens of the Mytilidae, are present, nor are there any rocks of appreciable thickness that might be interpreted as having been deposited at the strand line. Delectopecten, Propeamussium, Paramussium, Solemya, and Dentalium are the only representatives of moderate to deep water, and with the exception of the shale in the section at Astoria, there is no appreciable thickness of shale exposed that is not either silty or sandy. Thus most of the mollusks represented in the fauna are those that lived in shallow to moderate depths and those that were adapted to, if not actually preferring, a bottom sediment ranging from a fine-grained sand to a silty mud.

No brackish- or fresh-water mollusks and no land snails are represented in the fauna, although an occasional leaf fragment is preserved and carbonized wood is fairly common.

The Astoria fauna is remarkable for the preponderance of a few forms that occur in great abundance and, at many places, in concentrated layers that may be continuous through several miles of exposure. The species notable in this respect are Anadara devincta and Katherinella angustifrons and, to a much lesser extent, Patinopecten propatulus and Acila conradi. Both Anadara and Katherinella are concentrated to the virtual exclusion of other forms in parts of the exposures south of Spencer Creek, in the beach cliffs north of Newport. Hundreds of paired and articulated valves of these two species may be collected at such places, and it seems probable that they were not transported any great distance.

The absence of thick stratigraphic units of uniform lithology and the fairly rapid succession and repetition of thin units of siltstone and sandstone indicate that the ocean along the Miocene coast was not of uniform depth for very long periods of time.

In the rocks exposed from Spencer Creek south to Yaquina Head there is a siltstone unit 1 to 2 feet thick in which Anadara is very abundant and the mollusks are so closely packed that they form a traceable layer; the Anadara layer is the most fossiliferous unit seen in the Astoria formation. This layer is made up of well-indurated rock and is overlain with slight irregularity by 6 inches to 2 feet of a darkgreenish-gray fine-grained sandstone that is completely barren of fossils (figs. 6, 7). The bottom contact of the Anadara layer is irregular.

The barren layer that rests upon the Anadara layer, and one other such barren unit 4 to $4 \frac{1}{2}$ feet higher are the only completely unfossiliferous parts of the Astoria formation in this area. Both the Anadara layer and the barren layers are unique, and to explain their existence would be difficult enough without trying to explain why the Anadara layer is overlain by a barren layer. The fossils in the Anadara layer are well preserved. Although they are moderately strong hinged. forms, they were certainly not transported any considerable distance. The shells in this zone are entire; there is no appreciable amount of shell fragments. Perhaps the barren layer represents a sand bar that transgressed rapidly across the Anadara layer.

North of Yaquina Bay Anadara is very common and Chione is rare, but south of Yaquina Bay the reverse is true and Chione is very abundant and Anadara rare. Perhaps the difference in abundance of Anadara 


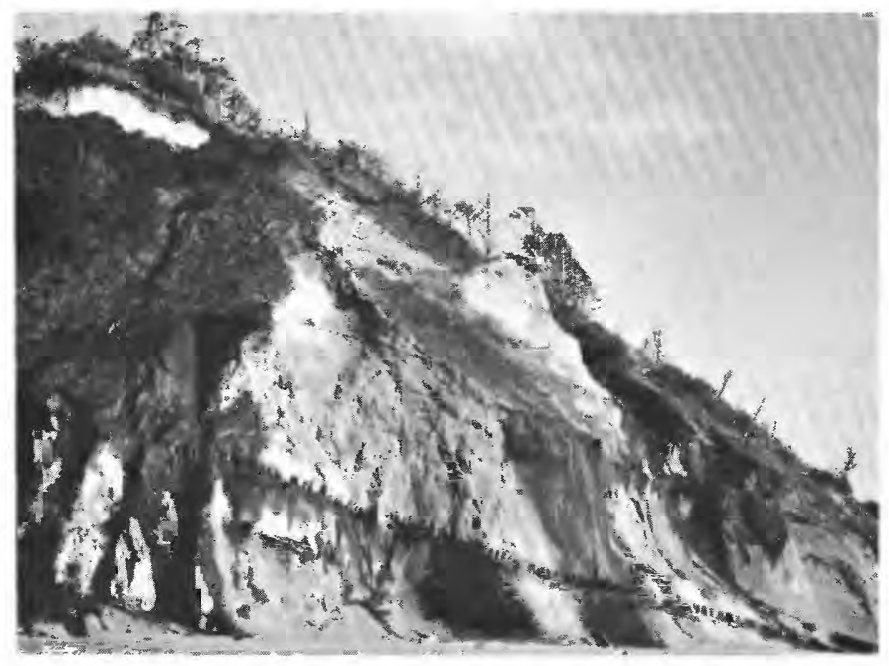

Figure 6-Exposure of the Astoria formation in beach headland north of Wade Creek, Newport area, Oregon. The barren layer is the dark blocky band that slopes upward at an angle of about $17^{\circ}$ from the lower right hand corner. Fossil localities 119-120. (Photographed in 1954.)

and Chione at certain places can be explained by slightly different environmental requirements for the two forms; Chione preferring generally shallower water and a slightly coarser substrate than Anadara.

Dosinia whitneyi is extremely common in the dredgings at Coos Bay. More than 200 specimens were collected, and this total represents only a small precentage of the number that might have been obtained.
Most of the other species collected at that locality are represented by no more than about 20 specimens, though Chione ensifera, Macoma arctata, and Bruclarkia oregonensis are more abundant.

Most of the specimens of Dosinia collected in the dredgings are preserved in an articulated state. Most were collected loose on the dredgings, but a few were collected from rock in which they occurred in dense concentrations, usually to the exclusion of other forms. There was no apparent alinement of the specimens within the rock. Occasionally the gaping valves of one specimen enclosed one or more additional specimens. All sizes were represented from juvenile to adult.

The genus Dosinia has not previously been recorded as occurring in the Astoria formation in Oregon; the species collected from the Coos Bay dredgings is the first reported occurrence. A few specimens referred tentatively to Dosinia whitneyi are in the U.S. National Museum collections from the Astoria formation at Cape Kiwanda, Oreg. An unidentified species of Dosinia (Durham, Harper, and Wilder, 1942) has been found at Scotts Mills, about 40 miles south of Portland, in rocks presumed to be of early Miocene age and probably equivalent to the Vaqueros formation. This is the only other reported occurrence of Dosinia in Oregon.

Etherington (1931, p. 78) said that he collected Dosinia (Dosinidia) cf. mathewsoni (Gabb) from the

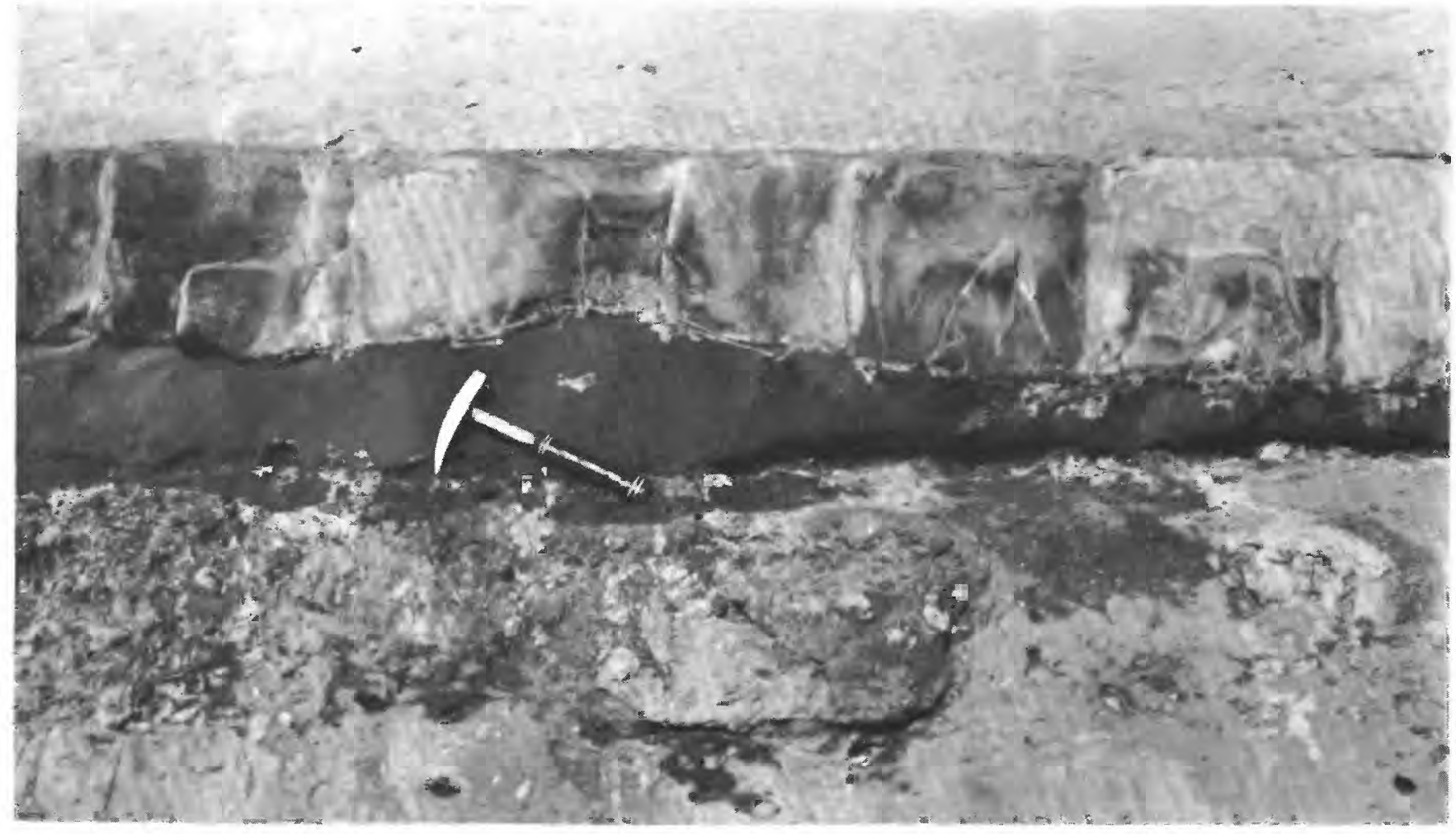

Figure 7.-Closeup of barren layer in figure 6. Shows the concentration of Anadara devincta (Conrad) in the bed below the barren layer. Fossil localities 119-120. (Photographed in 1954.) 
Astoria formation in Washington. Several specimens of Dosinia whitneyi were seen in the collections at Stanford Uuiversity made by Harold Hannibal from the Astoria(?) formation in Washington, but the genus is rare. D. whitneyi has been collected from the San Ramon, Vaqueros, and Temblor formations of California.

It is possible that during Miocene time Coos Bay was a large protected body of water, perhaps in part shallow and rather warm and bordered by extensive mud flats. Under such conditions Dosinia might have taken hold and thrived. The absence of Dosinia elsewhere along the Oregon coast (except for the few specimens from Cape Kiwanda) may be due to lack of a favorable environment. According to Keen (1958, p. 136) the allied recent species $D$. dunkeri is common on mud flats and offshore to depths of 30 fathoms.

Specimens of Solemya (Acharax) ventricosa were collected from the shale at Astoria and at a few other localities. Solemya lives in mud or fine sand and is rare in fossil collections in the U.S. National Museum. According to Vokes $(1955$, p. 536-537), recent species of Acharax occur at depths of 3 to 1,800 fathoms. He (p. 535) said that

Solemya (Acharax) includes species that are predominately of deep water distribution, although there is evidence that the controlling factor is water temperature. Thus $S$. (A.) johnsoni Dall has been reported from 60 fathoms in Puget Sound, 1005 fathoms off Lower California and 1740 fathoms, near the Equator off northern Ecuador.

Solemya is recorded from the Pliocene of the Eel River basin, in northern California, where it is associated with species of cool-water facies (Woodring, 1938, p. 15).

Acila (Truncacila) conradi is abundant in some units of the Astoria formation. According to Schenck (1936, p. 33), the greatest number of Recent species of Acila live in waters having a temperature of between $40^{\circ}$ and $70^{\circ} \mathrm{F}$, Truncacila preferring, but not being restricted to, a cool temperate habitat. Schenck also found that the genus is neritic or bathyal and has not been collected in water deeper than 803 fathoms or in the intertidal zone.

Paramusium, a genus that has not previously been reported as a fossil on the Pacific coast, has been found in the Astoria formation at Astoria. Living representatives of the type species of the genus, Paramusium dalli, have been collected along the East coast of North America from Cape Hatteras to the Antilles at recorded depths of from 218 to 1,591 fathoms. Specimens in the U.S. National Museum were collected at depths of 220 to 966 fathoms from mud and sand at temperatures ranging from $39.6^{\circ}$ to $44.4^{\circ} \mathrm{F}$. P. meridionale was recorded by E. A. Smith (1885, p. 316-317) from the following localities:
Station 158, in the Southern Ocean, south of Australia, at a depth of 1,800 fathoms. Also Station 146, Southern Ocean, east of Marion Island, in 1,375 fathoms. Also Station 302, west of Patagonia, in 1,450 fathoms.

Geoducks (Panope) are most abundant and have their greatest development on the Northwest coast, especially in the Puget Sound area. They live in shallow water buried in muddy sand (Keen, 1958, p. 213). Panope abrupta (Conrad) is a common species in the Astoria formation in Oregon.

The Turritellidae characteristically live buried just below the sediment-water interface, although they are capable of crawling about on the surface of the sediment (Keen, 1958, p. 288). They are gregarious mollusks tending to form large colonies where they do occur (Keen, 1958, p. 289). Turritella oregonensis represents this family in the Astoria and occurs in local concentrations in the section exposed in the first headland north of Spencer Creek.

Scaphopods are represented in the Astoria by two species of Dentalium. According to Keen (1958, p. 237 ), no scaphopods are found in the intertidal zone, a few have been dredged in relatively shallow water, but perhaps a majority of the species inhabit deep water, some forms having been dredged at depths of more than two thousand fathoms.

Delectopecten peckhami (as interpreted by Arnold) is common in the shale at Astoria and has also been collected from other shale units in the Astoria formation. Living species of Delectopecten are usually restricted to depths greater than 10 fathoms and are more common in depths greater than 100 fathoms. This may also have been true of the Miocene forms. Delectopecten randolphi has been recorded from depths greater than 200 fathoms in the Aleutian faunal province and from depths greater than 300 fathoms in the Oregonian faunal province (Woodring, 1938, pl. 3, facing p. 14). Delectopecten randolphi tillamookensis has been recorded from shallow water (less than 100 fathoms) in the Aleutian faunal region, but it has been collected from deep water only (greater than 100 fathoms) in the Oregonian and Californian faunal provinces (Woodring, 1938, pl. 3, facing p. 14). Many of the specimens of D.peckhami, collected in the city of Astoria, occur with fairly large amounts of glauconite. According to Cloud (1955, p. 488) it appears that glauconite in recent marine sediments is commonest at depths of 10-400 fathoms and may originate mainly in the upper part of the 10-400 fathom interval.

Lucinoma annulata, a species comparable to L. acutilineata in the Astoria formation, has an intermediate depth range along the coast of California (10-414 fathoms), but forms of L. annulata are found at California 
localities in Pliocene strata of shallow-water facies (Woodring, 1938, p. 15). According to Keen (1958, p. $97), L$. annulata is mainly a northern species, reaching its southern limit in the Gulf of California, and it is always an offshore species.

Two species of corals have been collected from the shale at Astoria. They are Lophelia and Stephanocyathus, which indicate either deep water or shallow cold water, according to J. W. Wells (oral communication). Lophelia lives today at the edge of the Continental Shelf.

The following data, compiled from Grau (1959), Keen (1937, 1958), Ricketts and Calvin (1952), and Woodring (1938), on the distribution of living species of mollusks bears on the distribution of their allied fossil species:

Ecologic distribution of Recent mollusks allied to Astoria species

\begin{tabular}{|c|c|c|}
\hline Fossil species & Recent species & $\begin{array}{l}\text { Ecologic distribution of Recent } \\
\text { species }\end{array}$ \\
\hline Neverita jamesae (Moore). & $\begin{array}{l}N . \text { reclusiana } \\
\text { (Deshayes). }\end{array}$ & $\begin{array}{l}\text { Matzatlan and Tres Marias } \\
\text { Islands, Mexico, to Crescent } \\
\text { City, Califif, } 21^{\circ} \text { to } 42^{\circ} \text { N. lat. } \\
\text { Muddy sand; common inter- } \\
\text { tidally on sandbars. }\end{array}$ \\
\hline $\begin{array}{l}\text { Sinum scopulosum (Con- } \\
\text { rad) } \\
\text { Saccella calkinsi (Moore) }\end{array}$ & $\begin{array}{l}\text { S. californicum } \\
\text { Oldroyd. } \\
\text { S.taphria (Dall) }\end{array}$ & $\begin{array}{l}\text { San Diego to Monterey, Calif., } \\
32^{\circ} \text { to } 37^{\circ} \mathrm{N} \text {. lat. } \\
\text { Arena Bank, Grif of California, }\end{array}$ \\
\hline Patinopecten propatulus & & $\begin{array}{l}\text { to Bodega Bay, Calif., } 23^{\circ} \text { to } \\
38^{\circ} \mathrm{N} \text {. lat, } 6 \text { to } 45 \text { fathoms. } \\
\text { Point Reyes, Calif., to Channel }\end{array}$ \\
\hline $\begin{array}{l}\text { (Conrad). } \\
\text { (Copatulus }\end{array}$ & P. caurinus (Utould) & $\begin{array}{l}\text { Point Reyes, Calif., to Channel } \\
\text { Inlet, Orca Inlet, Cordova, }\end{array}$ \\
\hline $\begin{array}{l}\text { Delectopecten peckhami } \\
\text { (Gabb). }\end{array}$ & D. randolphi (Dall) & $\begin{array}{l}\text { Cape Blanco, Oreg., to Bering } \\
\text { Sea, } 43^{\circ} \text { to } 59^{\circ} \text { N. lat, } 200 \text { to } \\
\text { lat }\end{array}$ \\
\hline Lucinoma acutilineata & L. annulata (Reeve) & $\begin{array}{l}\text { 1,100 fathoms. } \\
\text { Gulf of California to Alaska, }\end{array}$ \\
\hline $\begin{array}{l}\text { Thyasira bisecta (Con- } \\
\text { rad). }\end{array}$ & T. disjuncta ( $\mathrm{G}$ & $\begin{array}{l}\text { to } 114 \text { fathoms. } \\
\text { Coos Bay, Oreg, to Sitka, } \\
\text { Alaska, } 44^{\circ} \text { to } 56^{\circ} \mathrm{N} \text {. lat. }\end{array}$ \\
\hline Dosinia whitneyi (Gabb) & D. dunkeri (Philippi) & $\begin{array}{l}\text { Zorritos, Peru, to Magdalena } \\
\text { Bay, Lower, Californa, } 4^{\circ} \mathrm{S} \text {. } \\
\text { lat. to } 25^{\circ} \mathrm{N} \text {. lat. Mud flats } \\
\text { and offshore to depths of } 30 \\
\text { fathoms. }\end{array}$ \\
\hline $\begin{array}{l}\text { Katherinella (K.) an- } \\
\text { gustifrons (Conrad). }\end{array}$ & $\begin{array}{l}\text { K. (Compsomyax) } \\
\text { subdiaphana } \\
\text { (Carpenter). }\end{array}$ & $\begin{array}{l}\text { Cedros Islands, Lower Cali- } \\
\text { fornia, to Sannakh Island, } \\
\text { Alaska, } 34^{\circ} \text { to } 56^{\circ} \text { N. lat, } 20 \text { to } \\
300 \quad \text { athoms }\end{array}$ \\
\hline Tellina aff. T. idae Dall_ & T. idae Dall_ & Santa Barbara Islands and S \\
\hline $\begin{array}{l}\text { Panope (Panope) } \\
\text { abrupta (Conrad). } \\
\text { Thracia trapezoides Con- } \\
\text { rad. }\end{array}$ & $\begin{array}{l}P .(P .) \text { abrupta } \\
\text { (Conrad). } \\
\text { T. trapezoides Conrad. }\end{array}$ & $\begin{array}{l}\text { Lower Califormia to Alaska, } 28^{\circ} \\
\text { to } 55^{\circ} \mathrm{N} \text {. lat. Silt or sand. } \\
\text { Monterey, Calif. to Sitka, } \\
\text { Alaska, } 36^{\circ} \text { to } 56^{\circ} \mathrm{N} \text {. lat, } 20 \text { to } \\
35 \text { fathoms. }\end{array}$ \\
\hline
\end{tabular}

In summary, most of the pelecypods collected from the Astoria formation in Oregon are found with their valves articulated and closed. For those forms that have weak hinges this suggests that they were buried near where they lived. For forms with strong hinges, it can be assumed that they were probably not transported great distances. In addition, the fossils are seldom worn, amd spinose forms such as Trophon or Cancellaria commonly have fine details of sculpture preserved

Possible warm-water representatives in the Astoria formation are in the families Turritellidae, Ficidae, Nassariidae, and Veneridae. Turritella is not recorded farther north than Monterey ( $37^{\circ}$ N. lat). Living spe- cies of the Ficidae are tropical in distribution (Keen, 1958 , p. 342) and do not range as far north as California. Species of Nassariidae are more common in tropical water (Keen, 1958, p. 408) and this family is represented in the Astoria by two genera. Dosinia is recorded no farther north than Scammon Lagoon, Baja California $\left(28^{\circ} \mathrm{N}\right.$. lat) according to Hertlein and Strong (1955, p. 188).

Solemya, Patinopecten, and Thyasira are thought to be indicative of cool water. Liracassis is an extinct genus of the Northwestern United States and Japan. It is unknown in the United States south of Oregon and may therefore be indicative of cooler water than is represented by the Miocene of California.

The large turritellids and species of Chionopsis (a subgenus of Chione) in the Temblor formation also indicate warmer water for California than Oregon in the Miocene. The composition of the Astoria fauna suggests warm-temperate water.

Forms indicative of quite shallow water are rare in known occurrences of the Astoria formation and forms indicative of very deep water are not represented. Most of the Astoria species could be expected to have lived in shallow to moderate depths.

The thin lithologic units suggest that depositional environments may not have been constant at one place for long periods of time, although they may have been similar over large areas for brief intervals.

\section{AGE AND CORRELATION}

For at least the last three decades the Astoria formation has been considered to be middle Miocene on the basis of its molluscan faunas. During this same period, however, some specialists on Foraminifera have considered it to be early Miocene or Oligocene. This difference in opinion is the result primarily of conflicting views on the age of the European Aquitanian stage and its American equivalents. For most specialists on mollusks and for most European paleontologists, Dollfus (1909, p. 379-495) satisfactorily established the age of the Aquitanian as early Miocene.

Because the faunas are for the most part generically dissimilar, it is not possible to compare the Astoria fauna closely with those of European Miocene stages. It is possible, however, to correlate the Astoria formation with the Temblor formation (Barker's Ranch Fauna) of California which is considered of middle Miocene age by specialists in mollusks.

\section{CAITFORNLA}

Of the 97 species of mollusks in the Astoria formation 20 also occur in the Temblor formation (California) and 1 more has been tentatively identified. Four species are found in the Astoria formation and also in the 
Vaqueros formation of early Miocene age of California; two additional species have been tentatively identified. One species occurs in the Vaqueros-Temblor transition beds.

The following are the species found in both the Astoria and the Temblor formations, and also in other Miocene rocks in California:

Astoria mollusks that occur in the California Miocene

\begin{tabular}{|c|c|c|c|c|c|}
\hline \multirow{2}{*}{ Species } & \multicolumn{2}{|c|}{ Lower Miocene } & \multicolumn{2}{|c|}{ Middle Miocene } & \multirow{2}{*}{$\begin{array}{c}\begin{array}{c}\text { Upper } \\
\text { Miocene }\end{array} \\
\begin{array}{c}\text { Briones } \\
\text { sandston }\end{array}\end{array}$} \\
\hline & $\mid \begin{array}{l}\text { Vaqueros } \\
\text { formation }\end{array}$ & $\begin{array}{l}\text { Temblor } \\
\text { formation }\end{array}$ & $\begin{array}{l}\text { Sobrante } \\
\text { sandstone }\end{array}$ & $\begin{array}{l}\text { Oursan } \\
\text { sandstone }\end{array}$ & \\
\hline $\begin{array}{l}\text { Gastropods } \\
\text { Crepidula praerupta (Conrad) } \\
\text { Sinum scopulosum (Conrad) }\end{array}$ & $\stackrel{?}{\longrightarrow}$ & $\underset{x}{x}$ & & & $x$ \\
\hline $\begin{array}{l}\text { "icus modesta (Conrad) } \\
\text { "Trophon" kernensis (Ander- } \\
\text { son) }\end{array}$ & & $\hat{x}$ & $\cdots$ & $\cdots$ & $x$ \\
\hline $\begin{array}{l}\text { Bruclarkia oregonensis (Con- } \\
\text { rad) }\end{array}$ & & $x$ & $x$ & $?$ & \\
\hline $\begin{array}{l}\text { Molopophorus anglonana (An- } \\
\text { derson) }\end{array}$ & & $x$ & & & \\
\hline $\begin{array}{l}\text { Uzitag arnoldi (Anderson) } \\
\text { Cancellaria (Euclia) oregonen- }\end{array}$ & & $x$ & & & 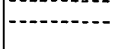 \\
\hline $\begin{array}{l}\text { ancellaria (Euclia) oregonen- } \\
\text { sis (Conrad) } \\
\text { "Thesbia" antiselli (Anderson } \\
\text { and Martin) }\end{array}$ & $x$ & $\begin{array}{l}x \\
x\end{array}$ & & & $x$ \\
\hline $\begin{array}{l}\text { Megasurcula condonana (An- } \\
\text { derson and Martin) }\end{array}$ & & $\times$ & & & \\
\hline $\begin{array}{l}\text { Scaphopod } \\
\text { Dentalium (Dentalium?) pseu- } \\
\text { donyma Pilsbry and Sharp.- }\end{array}$ & & $\times$ & & $?$ & \\
\hline $\begin{array}{c}\text { Pelecypods } \\
\text { Acila } \\
\text { (Meek) }\end{array}$ & & $x$ & & & \\
\hline $\begin{array}{l}\text { Anadara (Anadara) devincta } \\
\text { (Conrad) }\end{array}$ & & $x$ & $x$ & & $x$ \\
\hline $\begin{array}{l}\text { Patinopecten propatulus (Con- } \\
\text { rad) }\end{array}$ & & & $\times$ & & \\
\hline $\begin{array}{l}\text { Delectopecten peckha mi (Gabb) } \\
\text { of Arnold.. }\end{array}$ & & & $x$ & & \\
\hline $\begin{array}{l}\text { Lucinoma acutilineata (Con- } \\
\text { rad) }\end{array}$ & $x$ & X & $x$ & & \\
\hline $\begin{array}{c}\text { Dosinia } \\
\text { (Gabb) }\end{array}$ & $x$ & 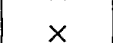 & $x$ & & \\
\hline $\begin{array}{l}\text { Katherinella (Katherinella) an- } \\
\text { gustifrons (Conrad) }\end{array}$ & & & $x$ & & \\
\hline $\begin{array}{l}\text { Macoma aretata (Conrad } \\
\text { Solen conradi (Dall) }\end{array}$ & $x$ & $\stackrel{x}{x}$ & ? & & \\
\hline $\begin{array}{l}\text { Spisula (Mactromeris) albaria } \\
\text { (Conrad) }\end{array}$ & & $x$ & $x$ & & \\
\hline $\begin{array}{l}\text { Panope (Panope) abrupta } \\
\text { (Conrad) }\end{array}$ & ? & 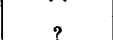 & ก & & 入 \\
\hline $\begin{array}{l}\text { Thracia (Thracia) trapezoides } \\
\text { (Conrad) }\end{array}$ & & $x$ & & & \\
\hline
\end{tabular}

The Temblor fauna is representative of warmer water than the Astoria fauna, with more tropical forms in the Temblor and more northern forms in the Astoria. Therefore, a correlation of the Astoria with the Temblor on the basis of 21 percent similar species in the smaller fauna is reasonable.

Turritella ocoyana occurs in abundance in the Temblor formation. The Turritella ocoyana stock is of wide distribution and particularly valuable for correlation. T. ocoyana occurs in beds of middle Miocene age in the San Ignacio and Purisima regions of Lower California (Merriam, 1941, fig. 7, facing p. 44). According to Merriam (1941, p. 47) Turritella abrupta should probably be regarded as a subspecies of $T$. ocoyana. Woodring $(1957-59$, p. 107,1957$)$ said that T. abrupta might be considered a large strongly and sharply carinate subspecies of $T$. ocoyana but preferred to retain the specific name abrupta until more was known concerning the sculpture of the early whorls of both forms. Woodring records T. abrupta from formations generally of middle Miocene age in Peru, Ecuador, the Darién basin of Panama, the Chiriqui area of Panama, Colombia, and Venezuela, and also noted the occurrence in Peru in the upper Zorritos and Cardalitos formations that have been dated as late early and middle Miocene. $\mathrm{He}$ also stated that $T$. ocoyana has no predecessors in California and might be a migrant from tropical America, where there are closely related species. Merriam (1941, p. 48) says that Turritella subgrundifera Dall from the Chipola formation (lower Miocene) of northwestern Florida shows the same type of growth line as $T$. ocoyana and may represent an ancestral member of the stock, and that Turritella terebralis Lamarck, abundant in the middle Miocene of Europe, was a related form.

Additional information concerning the age of the Astoria formation can be obtained from the vertebrate fauna of the Temblor formation. Merriam (1915, p. 1-44) reported a land-mammal fauna, called the Merychippus fauna, that was obtained from a zone at the upper limit of the Temblor formation about 12 miles north of Coalinga. He considered the Merychippus zone to be equivalent to the Turritella ocoyana zone and not older than the stage of the middle Miocene of the Mascall and Virgin Valley faunas of the Great Basin area and the Pawnee Creek stage of the Great Plains area (Merriam, 1915, p. 20).

Merriam (1915) described four land mammals from the Merychippus zone: Merychippus, Proshtennops, Procamelus, and Tetrabelodon, and he also reported the marine vertebrate, Desmostylus from this zone. Bode (1935, p. 70-71) identified 16 genera of land vertebrates from the Merychippus zone and, in addition to cetacean remains, Desmostylus and selachian teeth of the marine vertebrates. Merychippus californicus was represented in his collection by 2,500 teeth, out of a possible total of more than 5,000 teeth found in the field. Bode estimated that this would mean that a minimum of 250 individuals were represented. Bode $(1935$, p. 69$)$ found the mammals scattered throughout a stratigraphic interval of 100 feet, abundant in the upper 20 feet where they were usually concentrated in conglomerate, and most abundant at the top of the section where the number of horse teeth frequently exceeded the number of other pebbles. Bode collected these fossils 20 feet below Merriam's (1915) stratigraphic locality, which further documents the occurrence of the Merychippus fauna as within the "Temblor" and not the base of the Big Blue. Bode (1935, p. 84) considered that the Merychippus zone north of Coalinga 
was probably equivalent to beds above the type Temblor formation, and that the name Temblor should perhaps not be used for the Merychippus beds on Domengine Creek.

Bode (1935, p. 79) considered the Merychippus zone to be late middle Miocene and said that the Big Blue and the underlying Merychippus zone were within the stratigraphic range of Turritella ocoyana (1935, p. 82).

Kellogg (in Schenck, 1928, p. 6-7) wrote that the Temblor fauna of pelagic mammals represented some stage of the middle Miocene and that porpoises, pinnipeds, a primitive whalebone whale, a sperm whale, and Desmostylus had been obtained from the Temblor. He recorded the first appearance of Desmostylus in the Sooke formation (early Miocene?) of Vancouver and said that it was known to have survived until the close of the late Miocene, being represented by teeth in the San Pablo series of California.

\section{WASHINGTON}

Of the 97 identified species described from the Astoria formation in Oregon, the following 47 also occur in the Astoria(?) formation in Washington.

Fossils that occur in the Astoria formation in Washington and Oregon

Gastropods

Chlorostoma pacificum (Anderson and Martin) Turritella oregonensis (Conrad)

Crepidula praerupta Conrad

Cryptonatica oregonensis (Conrad)

Neverita (Glossaulax) jamesae Moore, n. sp.

Sinum scopulosm (Conrad)

Liracassis petrosa (Conrad), n. gen.

Ficus modesta (Conrad)

Bruclarkia oregonensis (Conrad)

Searlesia? carlsoni (Anderson and Martin)

Antillophos dumbleana chehalisensis (Weaver)

Molopophorus anglonana (Anderson)

Molopophorus anglonana matthewi Etherington

Uzita? arnoldi (Anderson)

Hinia? lincolnensis (Anderson and Martin)

Psephaea (Miopleiona) indurata (Conrad)

"Cancellaria" wynoochensis Weaver

Cancellaria (Euclia) oregonensis Conrad

Spirotropis washingtonensis Etherington

"Thesbia" antiselli (Anderson and Martin)

Megasurcula condonana (Anderson and Martin

Megasurcula wynoocheensis (Weaver)

Cylichnina petrosa (Conrad)

Scaphopod

Dentalium (Rhabdus) schencki Moore, n. sp.

Pelecypods

Nucula (Ennucula?) nuculana (Dall)

Acila (Truncacila) conradi (Meek)

Saccella calkinsi Moore, n. sp.

Portlandia (Portlandella) reagani (Dall)
Modiolus directus Dall

Patinopecten propatulus (Conrad)

Vertipecten fucanus (Dall)

Aequipecten andersoni clemonensis (Etherington)

Propeamussium of. $P$. clallamensis (Arnold)

Cyclocardia subtenta (Conrad)

Lucinoma acutilineata (Conrad)

Thyasira bisecta (Conrad)

Dosinia (Dosinia) whitneyi (Gabb)

Chione (Securella) ensifera (Dall)

Katherinella (Katherinella) angustifrons (Conrad)

Tellina emacerata Conrad

Macoma albaria (Conrad)

Macoma arctata (Conrad)

Solen conradi Dall

Spisula (Mactromeris) albaria (Conrad)

Panope (Panope) abrupta (Conrad)

Thracia (Thracia) trapezoides Conrad

Cephalopod

Aturia angustata (Conrad)

On the basis of 48 percent similar species it is reasonable to assume a close correlation between the Astoria(?) formation in Washington and the Astoria formation in Oregon.

Etherington (1931, p. 42-44) differentiated three faunal zones in the Clemons section in the Montesano area in Washington. He called the lower zone "Arca devincta montereyana," the middle zone "Arca devincta," and the upper zone "Nuculana chehalisensis." These zones are not recognized in Oregon, but this is believed to be indicative of different ecologic environments rather than denoting a difference in age.

\section{KAMCHATKA}

It is possible that on the west coast of Kamchatka there are Miocene rocks that contain a molluscan fauna in some respects similar to and perhaps even conspecific with the Astoria fauna. This observation is based on the paper of Slodkewitsch (1938), in which the Tertiary pelecypods of Kamchatka are described. Slodkewitsch noted similarities between the Tertiary faunas of Kamchatka and the Tertiary faunas of the West Coast of the United States and dated the Tertiary formations in Kamchatka on the basis of North American species which he identified in his fauna. No collections from Kamchatka are available, and Slodkewitsch's illustrations are inadequate for systematic recognition.

\section{JAPAN}

The genus Liracassis, which is described in this report for the first time, is represented in Japan by at least two species: L. yokoyami and L. yabei. According to Hatai and Nisiyama (1952, p. 229-230), L. yabie occurs in the Suenomatsuyama and the Yanagawa formations and L. yokoyami in the Fujina and Sugota formations. The Fujina formation is assigned to the 
early Miocene by Hatai and Nisiyama, but as they consider the Aquitanian to be Oligocene (p. 7) their early Miocene would probably be middle Miocene according to the usage of the present report. The Yanagawa and Sugota formations are considered to be Miocene and the Suenomatsuyama to be Miocene and Pliocene. The presence of Liracassis in Japan at least implies faunal similarities between the Astoria formation and the Miocene of Japan.

A topotype specimen of Anadara watanabei available for study is labeled as being from the Kokozuri formation, but the species was originally described as from the Taga series. A. watanabei is conspecific with $A$. devincta of the Astoria formation. It seems to be reasonably certain that if collections were compared other identical species would be found, but the illustrations in most of the papers published in Japan are too poor for the positive recognition of species.

\section{DESCRIPTION OF SPECIES}

\section{Mollusks \\ Gastropods \\ Family TROCHIDAE \\ Subfamily MONODONTINAE \\ Genus CHLOROSTOMA Swainson}

Chlorostoma Swainson, 1840, A treatise on malacology, London, p. 350 .

Type.-By subsequent designation (Herrmannsen, 1846, Indicis generum malacozoorum, v. 1, p. 231), Trochus argyrostomus Gmelin. Recent, Philippines and China seas.

\section{Chlorostoma pacificum (Anderson and Martin)}

Plate 1, figures 17,18

Calliostoma pacificum Anderson and Martin, 1914, California Acad. Sci. Proc., v. 4, 4th ser., p. 64-65, pl. 8, figs. 2a, 2 b.

Etherington, 1931, California Univ., Dept. Geol. Sci. Bull., v. 20. p, 89, pl. 11, figs. 8, 12 .

Weaver, 1942, Washington Univ. [Seattle] Pub. in Geology, v. 5 , p. $286-287$, pl. 62 , fig. 16 [1943].

Homalopoma pacifica (Anderson and Martin). Weaver, 1942, Washington Univ. [Seattle] Pub. in Geology, v. 5, p. 297298, pl. 63, figs. 16, 19 [1943]

The whorls of Chlorostoma pacificum have 8 to 11 spiral cords, 10 being the average, and interspaces as wide to one-half as wide as the cords; no secondary cords or threads were noted. On the base of the body whorl the spiral cords are finer and more numerous, numbering about 17 , and the interspaces are as wide as the cords or slightly wider. The tooth on the inner lip is blunt; the outer lip seems to be smooth and to have been thickened.
Holotype: California Acad. Sci. 134.

Type locality: One mile north of Yaquina Head, Lincoln County, Oreg. (Astoria formation).

Chlorostoma pacificum resembles $C$. argyrostoma, the type species of Chlorostoma, by having a single sharp riblike tooth on the middle of the inner lip. This tooth is bordered anteriorly by a wide shallow groove, which curves toward the umbilicus but becomes obsolete. C. argyrostoma is more strongly sculptured than $C$. pacificum, which has flat spiral cords. In sculpture, C. pacificum resembles Tegula pellisserpentis (Wood), the type species of Tegula. T. pellisserpentis, however, has 2 teeth on the inner lip rather than 1. The posterior tooth of $T$. pellisserpentis is blunt and rounded, forming a knoblike projection that is much larger than the single tooth of Chlorostoma. The anterior tooth of $T$. pellisserpentis is much smaller than the posterior tooth and is more sharply angulated.

Calliostoma conulus (Linné), the type species of Calliostoma, does not have a tooth on the inner lip. The aperture of $C$. conulus is roughly in the shape of a parallelogram with the base of the inner lip forming a sharp bulge where it is joined to the basal lip. It was Howe (1922, unpublished, p. 157) who first called attention to the tooth on the inner lip of Chlorostoma pacificum.

"Calliostoma" delezinensis Weaver (1912, p. 72, pl. 6, figs. 59-61, 63), collected from the Astoria formation in southwestern Washington, has coarser and less regular spiral sculpture and a more impressed suture than Chlorostoma pacificum.

Most of the specimens of $C$. pacificum were collected from the exposures of the Astoria formation in beach cliffs from Yaquina Head south to Yaquina Bay. Howe (1922, unpublished, p. 157) collected this species from the Astoria formation at the corner of Fifth and Commercial Streets in Astoria. Etherington (1931, p. 89) found $C$. pacificum in the Astoria formation, Grays Harbor County, Wash.

Localities: 1, 152, 154-156, 169, 171, 173, 174.

Occurrence elsewhere: Astoria (?) formation, Washington.

\section{Onidentified trochid?}

Plate 1, figure 5

This species has a slight bulge on the inner lip, bordered anteriorly by a rather wide shallow groove which extends to the umbilicus. This bulge does not seem to be a worn tooth and the species may be a Calliostoma, although it resembles Trochus somewhat. in sculpture.

Five incomplete specimens are in the collections. They range in height from about 18 to $25 \mathrm{~mm}$ and in width from 17 to $25 \mathrm{~mm}$. The shell consists of more 
than 4 whorls, possibly 5 , and the suture is distinctly impressed. The upper surface of the body whorl has 5 slightly nodose spiral cords, 2 of which are paired at the periphery of the whorl, the most posterior cord projecting more than the cord beneath it. The spiral cords are uneven in size, those nearest the suture being smallest and the cord at the periphery of the body whorl largest. The cords are evenly rounded and are separated by interspaces as much as two times as wide; there is a secondary cord in this interspace on some specimens. About seven spiral cords are preserved on the underside of the body whorl; these are closely spaced, are flatter and wider than the cords on the upper surface, and are separated by deep narrow grooves.

Most of the specimens were collected from the sea cliffs between Yaquina Head and Yaquina Bay. One specimen is in the Howe collection (California Acad. Sci. 33) from Newport.

Localities: 139, 154, 156.

\section{Family TURBINIDAE}

Subfamily TURBININAE

Genus ASTRAEA Röding

Astraea Röding, 1798, Museum boltenianum, pt. 2, p. 79 .

Type.-By subsequent designation (Suter, 1913, Manual of New Zealand Mollusca, p. 166), Trochus imperialia Gmelin. Recent, New Zealand.

\section{Subgenus?}

The species described below may belong in the subgenus Pachypoma Gray (1850, Figures of molluscous animals, v. 4, p. 88), but poor preservation does not permit a definite assignment.

\section{Astraea? n. sp.?}

Plate 1, figure 8

Astraea? n. sp.? has 4 whorls preserved which have nodose spiral cords. Only the innermost layers of the shell and one patch of external shell are preserved. The body whorl seems to have had at least 7 nodose spiral cords and the whorls of the spire at least 4 .

The specimen illustrated (USNM 563118) is from locality 156 and is $22.2 \mathrm{~mm}$ wide and more than 15.5 $\mathrm{mm}$ high (apex missing). A specimen in the collections from locality 167 may be the same species as the specimen illustrated. It is poorly preserved and broken but is probably an Astraea. It is larger than the specimen illustrated; $30.2 \mathrm{~mm}$ wide and more than $20 \mathrm{~mm}$ high (apex missing).

Localities: 156, 167.

\section{Unidentified turbinid?}

Plate 1, figures 13, 14

The poorly preserved, corroded shell of this form is moderately large and probably had five whorls. The three whorls preserved are characterized by a sharp noded angulation which forms a shoulder on the whorls of the spire and on the body whorl. Approximately 12 nodes are preserved on the latest whorl of the spire, and the entire shell seems to have been sculptured by spiral cords.

Four specimens of this form have been seen; all were collected in the city of Astoria. One of these specimens is in the California Academy of Sciences (CAS 170).

Localities: 1, 16, 21; CAS 170.

\section{Family VITRINELLIDAE}

Genus COCHLIOLEPIS Stimpson

Cochliolepis Stimpson, 1858, Boston Soc. Nat. History Proc., v. 6, p. 307.

Type.-By monotypy, Cochliolepis parasiticus Stimpson. Recent, Charleston Harbor, S.C.

Cochliolepis? schoonerensis Moore, n. sp.

Plate 1, figures 19-21

Cochliolepis? schoonerensis is small and sublenticular and has a smooth, porcellanous opaque, umbilicate shell of 3 to $3 \frac{1}{2}$ whorls. The nepionic whorls are undifferentiated, and the spire is elevated slightly above the body whorl. The sides of the whorls are evenly and moderately rounded and the sutures impressed. The umbilicus is open to the apex, is wide, and has steep sides. The aperture seems to be subrounded and the lip somewhat thickened, but none of the specimens in the collections have the aperture completely preserved. There are irregularly distributed concentric lines on the entire shell.

Holotype: USNM 563122, $2.1 \mathrm{~mm}$ in greater diameter, $1.6 \mathrm{~mm}$ in lesser diameter, and $1.1 \mathrm{~mm}$ in height.

Type locality: (loc. 149) From $10 \mathrm{ft}$ unit of slightly silty shale, $18 \mathrm{ft}$ above base of measured section in beach cliffs just north of Yaquina Head, Astoria formation, Iincoln County, Oreg.

The greater diameter of the specimens measured ranges from 1.6 to $2.3 \mathrm{~mm}$, with an average of 2.0 $\mathrm{mm}$; the lesser diameter from 1.5 to $2.0 \mathrm{~mm}$; and the altitude averages about $0.9 \mathrm{~mm}$, although most of the specimens are at least partly flattened and may be slightly greater in altitude than indicated.

C.? schoonerensis is not common in the Astoria formation but is found concentrated in lenses and thin 
layers in the silty shale and occasionally in the silty sandstone units. It is associated with Uzita? arnoldi (Anderson), Nucula (Ennucula?) nuculana (Dall), and "Nuculana" epacris Moore.

The nepionic whorls of "Vitrinella" oldroydi Bartsch are larger in diameter than on $C$. ? schoonerensis and the aperture of " $V$." oldroydi is more oval shaped.

The genus Cochliolepis ranges from Miocene to Recent and has not been reported before from Tertiary rocks in Oregon. Three specimens that seem to be assignable to Cochliolepis are in a collection from the Nye mudstone (early Miocene). This collection (USGS 15323) is from the cliff on the north shore of Yaquina Bay, 1,300 feet east of the triangulation target at McLean Point S1/2 sec. 9, T. 11 S., R. 11. W., Yaquina quadrangle, Oregon.

Localities: 73, 75, 142, 145, 149.

Occurrence elsewhere: Nye mudstone, early Miocene, Oregon.

\section{Family TURRITELLIDAE}

\section{Genus TURRITELLA Lamarck}

Turritella Lamarck, 1799, Soc. Hist. Nat. Paris Mém., ser. 1, p. 74.

Type.-By monotypy Turbo terebra Linné. Recent, tropical western Pacific.

\section{Turritella oregonensis (Conrad)}

Plate 1, figures 9-12

Turritella sp. Conrad, 1849, U.S. Explor. Exped., Geology, v. 10, app. p. 728 , atlas pl. 20, figs. 13,14 .

Cerithiopsis? oregonensis Conrad, 1865a, Am. Jour. Conchology, v. 1, p. 151.

Turritella oregonensis (Conrad). Dall, 1909, U.S. Geol. Survey Prof. Paper 59, p. 78.

Merriam, 1941, California Univ., Dept. Geol. Sci., Bull., v. 26, p. 104-105, pl. 20, figs. 17, 19, 20 [not fig. 18].

Weaver, 1942, Washington Univ. [Seattle] Pub. in Geology, v. 5 , p. 370 , pl. 74 , fig. 12 [1943].

Turritella oregonensis is small in size. Specimens in the U.S. National Museum do not exceed a height of $26 \mathrm{~mm}$ and the maximum diameter measured is $9 \mathrm{~mm}$. Most of the specimens are broken, however, and the actual maximum size may be somewhat greater than these measurements indicate. T. oregonensis is sculptured by a prominent pair of spirals just above the base of each whorl; there is a strong concavity between this pair of spirals and the suture beneath them. Above the paired spirals may be 1 or occasionally 2 secondary spirals.

Lectotype: The specimen figured by Conrad (1849, pl. 20, fig. 13) is presumably USNM 110446 (originally USNM 3516) and is herewith designated the lectotype, pl. 1, figs. 9, 10. This specimen bears Dana No. 63. USNM 3515, cataloged as Cardita subtenta, contains the specimen figured by Conrad (1849, pl. 20, fig. 14). This specimen bears the Dana No. 62 and is considered to be a paratype.

The lectotype is incomplete, but the characteristic sculpture is preserved. The prominent pair of spirals, characteristic of $T$. oregoninsis, are preserved on most of the whorls and 1 or 2 secondary threads are visible above these spirals on some parts of the shell. The type specimen is $2 \dot{2} .2 \mathrm{~mm}$ high and the largest diameter is $7.4 \mathrm{~mm}$.

T. oregonensis was described by Merriam (1941, p. 104-105). The specimen illustrated as $T$. oregonensis by Merriam on plate 20 , figure 18 , is said to be from locality A-1411, which is 5 miles north of Buxton, Oreg. This would mean that the specimen is from the Keasey formation, of Eocene and Oligocene age (Warren, Grivetti, Norbisrath, 1945) and not the Astoria. However, A-1411 is not given under the occurrence for $T$. oregonensis (Merriam, 1941, p. 105) and this may be simply an erroneous citation.

$T$. oregonensis is distinct from the middle Miocene turritellids of California; it is a much smaller form and presumably was a cooler-water species. It may be allied to $T$. porterensis Weaver, from the Lincoln formation (Weaver, 1912) of Oligocene age, in Washington, and perhaps it can be assigned to the Turritella uvasana stock of Merriam (1941, p. 42-44), of which it would be the last known survivor.

$T$. oregonensis was collected by Howe (1922, unpublished, p. 166) from the corner of Fifth and Commercial Streets, in Astoria. It was also recorded from Bear River, Humboldt County, Calif., by Merriam (1941, p. 105). T. oregonensis was not collected by Etherington (1931) from the Miocene in southwestern Washington, but specimens of this species from the Astoria(?) formation in the Grays Harbor area of Washington are in the collections in the U.S. National Museum.

Localities: 1, 1a, 4, 67, 79, 83-85, 87a, 90, 94, 95, 102, 108, 109, $156,162,187$.

Occurrence elsewhere: Astoria(?) formation, Washington; Bear River, California.

\section{Family EPITONIIDAE}

\section{Genus OPALIA H. and A. Adams}

Opalia H. and A. Adams, 1853, The genera of Recent Mollusca, v. 1, p. 223 .

Type.-By subsequent designation (Cossmann, 1912, Essais de paleoconchologie comprarée, v. 9, p. 78), Scalaria australis Lamarck. Lower Oligocene to Recent, living in Arctic and Antarctic Oceans, ranging into subtropical water in 53 fathoms, San Diego, Calif. (Durham, 1937, p. 501). 


\section{Subgenus RUGATISCALA de Boury}

Rugatiscala de Boury, 1913, Jour. Conchology, v. 61, p. 72.

Type.-By original designation, Opalia levesquei (de Boury). Eocene, Paris Basin.

\section{Opalia (Rugatiscala) cf. 0 . (R.) williamsoni (Anderson and Martin)}

Plate 1, figure 23

Five poorly preserved and incomplete epitoniids are compared to Opalia williamsoni, a species originally described as an Epitonium by Anderson and Martin (1914, p. 68, pl. 7, figs. 9a, 9b) and later assigned to Opalia (Rugatiscala) by Durham (1937, p. 505-506). The specimens from the Astoria formation in Oregon are small in size; the diameter of the largest whorl preserved is $6.4 \mathrm{~mm}$. This form has rather closely spaced prominent axial ribs and fine spiral lines; the outer lip is thickened and the sutures are deeply impressed.

O. williamsoni was originally described from the Temblor formation, lower and middle Miocene, Kern County, Calif.

Localities: 79, 109, 121, 137, 161.

\section{Family CALYPTRAEIDAE}

Genus TROCHITA Schumacher

Trochita Schumacher, 1817, Essai d'un nouveau systeme des habitations des vers testaces, p. 57, 184.

Type.-By subsequent designation (Rehder, 1943, Biol. Soc. Washington Proc., v. 56, p. 41), Trochita spiralis Schumacher (=Trochus radians Lamarck= Turbo trochiformis Born). Recent, Ecuador to Chile.

Trochita? n. sp.?

Plate 1, figures 6, 7

The specimens in the collections at the U.S. National Museum are too poorly preserved for positive identification or description, and no interiors are accessible. The few specimens with patches of shell preserved show the whorls to have been ribbed.

Localities: 48, 61, 92, 139, 156, 181, 182, 183, 187.

\section{Genus CREPIDULA Lamarck}

Crepidula Lamarek, 1799, Soc. Hist. Nat. Paris Mém., p. 78.

Type.-By monotypy, Patella fornicata Linné. Recent, Atlantic and gulf coasts of North America.

\section{Crepidula praerupta Conrad}

Plate 1, figures 15, 16, 22, 24

Crepidula praerupta Conrad, 1849, U.S. Explor. Exped., Geology, v. 10, atlas, p. 727, app., pl. 19, figs. 9, 9a, 10a, $10 \mathrm{~b}$.
Anderson, 1905, California Acad. Sci. Proc., ser. 3 (Geology), v. 2 , p. 204, pl. 16, figs. 68,69 .

Weaver, 1942, Washington Univ. [Seattle] Pub. in Geology v. 5, p. 359, pl. 73 figs. 1, 2, 3 [1943].

Crepidula sp. (?) Conrad, 1849, U.S. Explor. Exped., Geology, v. 10, app., pl. 19, figs. 11a, $11 \mathrm{~b}$.

Crypta praerupta (Conrad). Meek, 1864, Smithsonian Misc. Colln. 183, p. 16. Conrad, 1865a, Am. Jour. Conchology, v. 1, p. 151.

Crepidula (Crepidula) praerupta Conrad. Etherington, 1931, California Univ., Dept. Geol. Sci. Bull., v. 20, p. 92, pl. 11, figs. 2, 15 .

Crypta rostralis Conrad, 1865a, Am. Jour. Conchology, v. 1, p. 151.

Crepidula rostralis (Conrad). Dall, 1909, U.S. Geol. Survey Prof. Paper 59, p. 83.

Crepidula (Crepidula) rostralis (Conrad). Etherington, 1931, California Univ., Dept. Geol. Sci. Bull., v. 20, p. 91, pl. 11, figs. $9,10,11$.

Weaver, 1942, Washington Univ. [Seattle] Pub. in Geology, v. 5 , p. 359-360, pl. 72 , figs. 13,15 [1943].

Crepidula praerupta is a moderately heavy shelled form of medium size with the sides somewhat flattened and the apex recurved and elevated above the aperture. The apex is curved in a plane that parallels the aperture.

Lectotype: USNM 3564 is herewith designated the lectotype of Crepidula praerupta Conrad, pl. l, fig. 15. (Figured by Conrad, 1849, pl. 19, figs. 9, 9a.)

Holotype: Of "Crypta rostralis Conrad," USNM 110447, pl. 1, fig. 24 .

Figured specimen: USNM 561540 (old number illegible; may be USN M 3496, which number its counterpart still bears) may be the specimen figured by Conrad as Crepidula praerupta (1849, pl. 19, figs. 10a, 10b), pl. 1, fig. 22.

Type locality: Astoria, Oreg.

USNM 3564 is accepted as the specimen figured by Conrad (pl. 19, figs. 9, 9a (as Crepidula praerupta (pl. 1, fig. 15). The specimen agrees exactly with the original illustration in size but not exactly in the configuration of the beak and the outline of the concentric lines. The shell on the lectotype specimen is badly worn and the interior is not accessible.

USNM 561540 is probably the specimen illustrated by Conrad in plate 19, figures 10a, 10b, as Crepidula praerupta (pl. 1, fig. 22). The specimen agrees in size and configuration with the original illustration but differs in that it is contained in a concretion, which is not shown in the original drawing. The specimen is an internal mold and retains a few small patches of the inner shell layers.

The type specimen of Crypta rostralis Conrad, USNM 110447 , (pl. 1, fig. 24) is probably an immature and flattened specimen of C. praerupta. Crepidula is common throughout the Astoria formation, and in all of the collections seen, only the species $C$. praerupta has been found. It seems probable that the variation between immature and mature forms within the species $C$. praerupta is quite sufficient to include $C$. rostralis. The 
type specimen of $C$. rostralis is an internal mold, and all the shell is missing.

Crepidula princeps Conrad (1857, p. 326, pl. 6, figs. 52, 52a), found in the Empire formation (Pliocene?) of Oregon, is much larger and more inflated than C. praerupta and also has a wide asymmetrical indentation on the face of the deck (Woodring in Woodring, Bramlette, and Kew, 1946, p. 70).

Howe (1922, unpublished, p. 117) collected $C$. praerupta from the Astoria formation at the corner of Fifth and Commercial Streets and the foot of 19th Street in Astoria; Etherington collected (1931, p. 92) from the Astoria formation in Grays Harbor County, Wash.; and Anderson (1905, p. 204) from the Temblor formation (Miocene), Kern River, Kern County, Calif. The specimen identified by Dall (1909, p. 83, pl. 7, fig. 8) from the Empire formation (Pliocene?) of Oregon as $P$. praerupta is a worn specimen that is possibly C. princeps.

Localities: 1, 1a, 48, 67, 71, 79, 81, 82-84, 86, 88, 90, 92, 94, 98, $99,101,102 \mathrm{a}, 105,107,108,110-113,116,117,119-122,126,128$, 134, 139, 140, 152, 154, 156, 158, 161, 181a, 183, 184.

Occurrence elsewhere: Astoria(?) formation, Washington: Temblor formation, lower and middle Miocene, Briones sandstone, late Miocene, California.

\section{Family NATICIDAE \\ Subfamily NATICINAE Genus CRYPTONATICA Dall}

Cryptonatica Dall, 1892 (1890-1903), Wagner Free Inst. Sci. Trans., v. 3, pt. 2, p. 362 .

Type.-By subsequent designation (Dall, 1909, p. 85), Natica clausa Broderip. Arctic Ocean to Queen Charlotte Islands.

\section{(Cryptonatica oregonensis Conrad)}

Plate 2, figures 2-4, 16, 17

Sigaretus scopulosus Conrad [in part], 1849, U.S. Explor. Exped., Geology, v. 10, app., p. 727, atlas, pl. 19, figs. 6b, 6c [not] 6, 6a, $6 \mathrm{~d}$.

Lunatia oregonensis Conrad, 1865a, Am. Jour. Conchology, v. 1, p. 151.

Natica oregonensis (Conrad). Dall [in part], 1909, U.S. Geol. Survey Prof. Paper 59, p. 86 [not Empire formation specimens nor figured specimen].

Natica (Tectonatica) oregonensis (Conrad). Weaver, 1942, Washington Univ. [Seattle] Pub. in Geology v. 5, p. 331 [not pl. 100, fig. 27], [1943].

Cryptonatica oregonensis is a small naticid. The umbilicus is plugged, but there is a groove behind the callus which on some specimens is deeper anteriorly (pl. 2, fig. 2).
Holotype: USNM 561551 (original number not determined; probably USNM 3580), pl. 2, figs. 3, 4 .

Type locality: Astoria, Oreg.

The type specimen of $C$. oregonensis is rather poorly preserved and the outer layers of the shell are exfoliated. The callus is partly missing but seems to have filled the umbilicus almost completely and to have been ovate in outline.

The umbilicus of $C$. oregonensis is not completely plugged by a callus. On some specimens there is a groove behind the callus; on some this groove is enlarged to form a depression around the callus which becomes deeper anteriorly (pl. 2, fig. 2). Some specimens on which the shell is exfoliated seem to have a much deeper groove behind the umbilicus than would probably be present if the shell were intact. Dall (1890-1903, p. $362-363,1892$ ) said that the outer layers of the shell of naticids seemed to be less intimately soldered to the inner ones than in many other groups, and that fossil specimens by decortication may lose their normal aspect entirely.

According to Woodring $(1957-59$, p. 88, 1957) the type of Cryptonatica is a large arctic and boreal species, and the umbilicus is completely filled by the umbilical callus. Natica tectula Bonelli, the type species of Tectonatica Sacco, is a small tropical American species (Woodring, 1957-59, p. 88). Sacco gave $12 \mathrm{~mm}$ as the maximum size of $N$. tectula. When the anatomy of the type species of Tectonatica and Cryptonatica is known both names may prove useful (Woodring, 1957-59, p. 88).

The specimen figured by Dall (1909, pl. 4, fig. 7) as Natica oregonensis from the Empire formation, (Pliocene?), Oregon, is a large form more closely related to Cryptonatica clausa than to $C$. oregonensis. However, the umbilical plug is heavier on the Empire form than on C. clausa and is also bordered by a groove.

"Natica" clarki Etherington (1931, p. 93, pl. 12, fig. 12), described from the Astoria formation in southwestern Washington may prove to be $C$. oregonensis, but the holotype has not been seen.

Two opercula are in the U.S. National Museum collections (pl. 2, figs. 1, 6); they are assumed to represent $C$. oregonensis, but it was not possible to uncover the outer face without destroying the specimens. They were found associated with $G$. oregonensis, however, which is the only representative of the Naticinae in the Astoria formation.

Localities: 1a, 4, 7, 25, 48, 60, 69, 75, 79, 80, 83, 84, 86, 87, 87a, $90-92,94,95,96,98,102,103,105,107,107 \mathrm{a}, 108,109,112,118$. $120,122,126-128,145,156-157,160,161,164,167,184,187$.

Occurrence elsewhere: Astoria(?) formation, Washington. 


\section{Subfamily?}

Genus?

Natica saxea Conrad, nomen dubium

Natica saxea Conrad, 1849, U.S. Explor. Exped., Geol., v. 10, app. p. 727 , atlas pl. 19 , figs. $7 \mathrm{a}, 7 \mathrm{~b}$.

The type specimen of Natica saxea is missing. There are four specimens in the type collection that are labeled "Natica saxea Conrad" (USNM 3540) on an old label but not in Conrad's handwriting. Four additional specimens bear USNM 3580 on the shell and USNM 3540 on a paper tab in the vial containing the specimens. Three of the specimens in these lots are of moderate size, but none is as large or as complete as the specimen illustrated (1849, pl. 19, figs. $7 \mathrm{a}, 7 \mathrm{~b})$. They are too poorly preserved for positive generic identification. The remaining five specimens are very small and seem to be Cryptonatica oregonensis (Conrad). Dall referred specimens numbered USNM 3540 to Polinices (Neverita) inezana (Conrad) (1909, p. 87) and to Polinices (Euspira) gallanoi Dall (1909, p. 89).

Holotype: Missing.

Type locality: Astoria, Oreg.

Natica saxea Conrad has been assigned to Neverita by Conrad (1866c, p. 15) and to Natica s. s. and Tectonatica by other authors. The illustration of the type specimen, in my opinion, is too poor for specific determination or for positive generic identification. The original description is brief and there is no way of determining if the specimens now labeled as $N$, saxea in the type collection were ever so identified by Conrad.

Although the name $N$. saxea has been in use for more than 100 years, the generic and specific characters of the type must remain in doubt and this name is considered therefore a nomen dubium.

The specimens figured by Etherington (1931, pl. 12, figs. 2, 3) as Natica (Natica) saxea, and one subsequently refigured by Weaver (1942, pl. 68, fig. 4) as Natica (Tectonatica) saxea, may be Polinices canalis Moore, n. sp.

\section{Subfamily POLINICINAE}

Genus POLINICES Montfort

Polinices Montfort, 1810, Conchyliologie systématique, v. 2, p. 223.

Type.-By original designation, Polinices albus Montfort (=Natica mamillaria Lamarck=Natica brunnea Link). Recent, West Indies.

Polinices canalis Moore, n. sp.

Plate 2, figures 18,22

Polinices canalis is moderately large and has a medium thick to thick shell. The body whorl may be either smooth and evenly rounded or slightly flattened just beneath the suture. On specimens with a smooth body whorl, the spire is small and evenly rounded; on specimens with a slight shoulder on the body whorl, the spire is similarly angulated and higher in proportion to the overall size. This variation may be due to sex differences.

Type: USNM 561534, pl. 2, figs. 18, 22.

Type locality: (loc. 107) From $22 \mathrm{ft}$. of siltstone and silty shale about $51 \mathrm{ft}$. above base of exposed section in beach cliffs forming first headland south of fill at Spencer Creek, Astoria formation, Miocene, Oreg.

This species bears a close resemblance to the type species of Polinices but differs in certain characters of the umbilicus. The entire umbilical area of $P$. canalis is smaller, the callus does not cover as large a part of the umbilicus, and there is a deeper notch at the posterior end of the umbilicus. Polinices varies somewhat in the umbilical characters and the species here described seems to fall within that normal variation.

$P$. canalis may be conspecific with some of the forms for which the trivial name saxea has been used and variously placed in the genera Natica s. s., Tectonatica, and Neverita. Natica saxea Conrad is considered a nomen dubium (p. 28).

Localities: 4, 12, 69a, 87, 87a, 94, 102, 107, 108, 112, 116, $120,129,139,156,161,174,184,187$; cf. 1 .

\section{Genus NEVERITA Risso}

Neverita Risso, 1826, Histoire naturelle des principales productions de l'Europe Méridionale, v. 4, p. 149.

Type--By monotypy, Neverita josephinia Risso. Recent, Mediterranean Sea.

Subgenus GLOSSAULAX Pilsbry

Glossaulax Pilsbry, 1929, Nautilus, v. 42, p. 113.

Type.-By original designation, Neverita reclusiana (Deshayes). Eastern and western Pacific-Japan to Australia and west coast of United States.

Glossaulax was proposed by Pilsbry as a section for Neveritae having a grooved umbilical callus.

\section{Neverita (Glossaulax) jamesae Moore, n. sp.}

Plate 2, figures 5, 15, 19

Neverita (Glossaulax) jamesae is moderate in size, and has a rather thin shell and a grooved umbilical callus which may either partly cover the umbilicus or be quite narrow and leave the umbilicus almost completely open (pl. 2. fig. 19). The shell is usually smooth without shoulders, but there may be a slight flattening just beneath the suture.

Holotype: USNM 563129, pl. 2, figs. 15, 19 . Height $22.0 \mathrm{~mm}$ (incomplete), width $26.4 \mathrm{~mm}$ (broken at aperture). 
Paratype: USNM 563128, pl. 2, fig. 5. Height $19.5 \mathrm{~mm}$, width $21.5 \mathrm{~mm}$.

Type locality: (loc. 94) From big headland in beach cliffs about $600 \mathrm{yd}$. north of Spencer Creek, in $10 \mathrm{ft}$. of siltstone containing Anadara devincta, inflated form, about $17 \mathrm{ft}$. above base of exposed section, Astoria formation, Oregon

$N$. jamesae differs from $N$. reclusiana, which is recorded from rocks in California at least as old as early Miocene and which lives off that coast today, by having a higher spire and a smaller umbilical callus which covers only about one-third of the area that is covered by the umbilical callus of $N$. reclusiana. The umbilical callus on $N$. jamesae forms an angle of about $45^{\circ}$ with the inner lip, whereas on $N$. reclusiana this angle is about $90^{\circ}$. The fossil specimens of Neverita from the Miocene of California, in the U.S. National Museum, all seem to be $N$. reclusiana and to be distinct from the Oregon species.

The name "Natica" inezana has been used for a species of Neverita from the Astoria formation. The type specimen of "Natica" inezana Conrad (Woodring, 1931 , p. 383-385) is very poorly preserved and only a small part of the original shell remains on the specimen; Woodring thought " $N$." inezana is allied to the Eocene species Amaurellina clarki. None of the specimens in the original type lot of this species (USNM 12359, 13347 , and 3575 ) have the umbilical callus preserved. It seems unlikely that "Natica" inezana is a Neverita, but if it could be proved that it is, the name " $N$." inezana would still not be applicable to the forms from the Astoria formation of Oregon to which it has been applied. The type bears no resemblance to the Neverita in the Astoria formation.

A single specimen (USNM 3575) in the type collection with the original type lot of "Natica" inezana was identified by Dall (1909, p. 90) as Ampullina (Ampullinopsis) mississippiensis (Conrad) and was said to have been collected in Astoria, Oreg. This specimen is entered in the U.S. National Museum catalog of Cenozoic fossils with the collection made by J. D. Dana from Astoria, but it is listed as having been collected by George Gibbs. In matrix and preservation it is similar to specimens in the type lot of "Natica" inezana, from the Santa Ynez Mountains of California (Woodring, 1931, p. 383-385). A coral in the Dana Astoria collection also bears USNM 3575 (Woodring, 1931, p. 384) and it seems to be the only specimen to which the number properly belongs. Ampullinopsis, a globularine naticid, is not found in deposits later than those of early Miocene age and is not known to occur on the Pacific coast of the United States.

Dall (1909, p. 87-88) assigned two lots of naticids (USNM 3510 and 3540) from the Astoria formation in Astoria to Polinices (Neverita) inezana (Conrad).
None of the specimens in these two lots show the umbilical characteristics of Neverita. Several specimens in USNM 3540 are assigned to Cryptonatica? sp.; specimen USNM 3510 is too poorly preserved for identification.

Neverita jamesae does not seem to be common in the Astoria formation. It is difficult, however, to obtain specimens with the umbilicus intact, and it is quite possible that some of the exfoliated specimens not identified may be neveritids.

This species is named in honor of my mother, Mildred P. James of Portland, Oreg. The mere naming of a species in her honor is insufficient to express my deep appreciation and indebtedness to her for her constant enthusiasm, encouragement, and assistance as companion and collector in the field.

Localities: 71, 78, 81a, 86, 87, 90, 92, 94, 95, 134, 139, 142 144, 147, 152, 154, 156, 161, 173, 187.

Occurrence elsewhere: Astoria(?) formation, Washington.

\section{Subfamily SININAE}

\section{Genus SINUM Röding}

Sinum Röding, 1798, Museum boltenianum, pt. 2, p. 14.

Type.-By subsequent designation (Dall, 1915, U.S. Natl. Mus. Bull. 90, p. 109), Helix haliotoidea Linné. Recent, western Pacific(?).

\section{Sinum scopulosum (Conrad)}

Plate 1, figures 2, 3; plate 2, figures 20, 21

Sigaretus scopulosus Conrad [in part], 1849, U.S. Explor. Exped., Geology, v. 10, app. p. 727, atlas pl. 19, figs. 6, 6a [not figs. $6 \mathrm{~b}, 6 \mathrm{c}, 6 \mathrm{~d}]$.

Meek, 1864, Smithsonian Misc. Colln. 183, p. 19.

Reagan, 1909, Kansas Acad. Sci. Trans., v. 22, p. 194-195, pl. 3, fig. 30 .

Catinus scopulosus (Conrad). Conrad, 1865a, Am. Jour. Conchology, v. 1, p. 151.

Conrad, 1866a, Smithsonian Misc. Colln. 200, p. 15.

Sinum scopulosum (Conrad). Dall, 1909, U.S. Geol. Survey Prof. Parer 59, p. 91-92, pl. 4, fig. 10, pl. 5, fig. 8.

Stewart, 1926, Acad. Nat. Sci. Philadelphia Proc., v. 78, p. $327-328$, pl. 32 , fig. 4 [1927].

Etherington, 1931, California Univ. (Dept.) Geol. Sci., Bull , v. 20, p. 95-96, pl. 12, fig. 12.

Weaver, 1942, Washington Univ. [Seattle] Pub. in Geology, v. 5, p. 349-350, pl. 71, figs. 12, 14, 17, 18 [1943].

Sinum scopulosum is a large short-spired species that has a large inflated body whorl sculptured with somewhat irregular flat spiral cords and interspaces, usually of equal width, and secondary cords, of varying widths, in the interspaces. The secondary cords are present only in some of the interspaces and do not have any consistent pattern.

Type: CSNM 3553, the specimen figured by Conrad (1849, $\mathrm{pl}$. 19 , figs. $6,6 a$ ) is herewith designated the lectotype, p. 1, figs. $2,3$. 
Figured specimen: "Sigaretus scopulosus Conrad" (1849, pl. 19, fig. 6d?), USNM 3540, pl. 1, figs. 1, 4, may be the specimen figured by Conrad. The specimen is not a Sinum but is poorly preserved and seems to be an unidentifiable naticid.

Type locality: Astoria, Oreg.

The type of $S$. scopulosum is an internal mold and has just enough shell remaining to show spiral cords on a small part of the specimen.

Dall identified two specimens from the Empire formation, Coos Bay (USNM 153913) as Sinum scopulosum (Dall, 1909, p. 91-92, pl. 4, fig. 10; pl. 5, fig. 8).

S. scopulosum resembles the Recent $S$. californicum but has a higher spire than $S$. californicum. These species are considered to be probably conspecific by some authors (for example, Stewart, 1926, p. 328).

S. scopulosum has been found in the Astoria formation and the Empire formation (Pliocene?) in Oregon, the Astoria(?) formation in Washington, and the Temblor (lower and middle Miocene) and Etchegoin (Pliocene) formations in California. It is rare in the Astoria formation in Oregon.

Localities: 1a, 60, 71, 79, 89, 92, 105, 108, 112, 120, 156, 163.

Occurrence elsewhere: Astoria(?) formation, Washington; Vaqueros formation, lower Miocene, Temblor formation, lower and middle Miocene, California; Empire formation, Pliocene(?), Oregon; Etchegoin formation, Pliocene, California.

\section{Family CASSIDIDAE}

Genus LIRACASSIS Moore, n. gen.

Type.-Dolium petrosum Conrad, Miocene, Astoria formation, Oregon and Washington.

Liracassis is large and relatively thick shelled; it has a moderately high spire and a short recurved notched siphonal canal bordered by a wide deep groove. It is sculptured with wide heavy straplike spirals, which may be nodose or slightly spinose and are continuous to the edge of the outer lip. One secondary and 4 to 6 tertiary spirals may be present in the interspaces, which are $1 \frac{11}{2}$ times as wide as the spirals. The outer lip is thickened and the inner margin is denticulate; the denticles are paired and correspond fairly well to the interspaces between the ribs. The inner lip is not known. The suture is bordered by an undulating cord and the body whorl is loosely coiled.

The combination of heavy straplike spirals and of the wide deep groove bordering the notched siphonal canal distinguish Liracassis from other cassids. Buccinum echinophorum Linné, the type species of Galeodea Link (1807, p. 113), has strong generally noded and grooved spirals that are somewhat straplike, but it has a long only slightly recurved truncated siphonal canal. Buccinum intermedium Brocchi, the type species of Echinophoria Sacco (1890, p. 503-504), has the short notched siphonal canal of Liracassis, but lacks the wide deep groove bordering the canal. Moreover, it is not sculptured with straplike spirals.

One of the most characteristic features in the cassids studied is the length, curvature, and termination of the siphonal canal. Echinophoria has a short sharply recurved notched canal, similar to that of Liracassis, but it has a narrow bordering groove. Semicassis Mörch (1852, p. 112), type species Cassis japonica Reeve, has a short very strongly recurved and very deeply notched canal, the ventral side of which extends beyond the dorsal. Phalium Link (1807, p. 112), type species Buccinum glaucum Linné, resembles Semicassis in the characters of the canal, but the ventral side of the canal is not as produced and the entire canal is more strongly recurved.

Liracassis is known only as a northern genus in the United States and has not been collected in California. It is the largest and most strongly sculptured Echinophoria-like cassid found as a fossil in North America. It is represented in Japan by at least two fossil species: Phalium yokoyamai Nomura and Hatai (1933, p. 50, pl. 8, figs. 1, 1a, 3, 7) and Phalium yabei Nomura and Hatai (1933, p. 52, pl. 8, figs. 2, 4-6, 8, 8a). These species were included by Hatai and Nisiyama (1949, p. 93) in their genus Shichiheia, but the type species, Shichiheia etchuensis Hatai and Nisiyama, does not have straplike spirals, being sculptured instead with fine spirals similar to those on Echinophoria s.s. "Phalium (Bezoardica)" iani Schenck (1926, p. 80, pl. 13, figs. 8-11) may be a Liracassis, but the type has not been seen.

The following species are assigned to Liracassis:

Galeodea fax Tegland, 1931, p. 410-412, pl. 60, figs. 5, 6, 7. Lincoln formation, Oligocene, Washington and Oregon.

Galeodea rex Tegland, 1931, p. 413-415, pl. 60, fig. 12, pl. 61, figs. 1-4, pl. 62, figs. 1-6. Blakeley formation, late Oligocene or early Miocene, Washington and Oregon.

Galeodea apta Tegland, 1931, p. 415-417, pl. 63, figs. 1-10. Blakeley formation, Oligocene, Washington and Oregon.

Eudolium oregonense Dall, 1909, p. 71-72, pl. 7, fig. 7. Empire formation, Pliocene?, Oregon.

Phalium yokoyamai Nomura and Hatai (new name for Galeodea (Sconsia) japonica Yokoyama), 1933, p. 50, pl. 8, figs. 1, 1a, 3, 7. Fujina and Sugota formations, Miocene, Japan.

Phalium yabei Nomura and Hatai, 1933, p. 52, pl. 8, figs. 2, 4, $5,6,8,8 \mathrm{a}$. Yanagawa formation, Miocene and Suenomatsuyama formation, Pliocene, Japan. 
?Phalium (Doliocassis) onishpetensis Otuka, 1937, p. 170, pl. 16, fig. 4. Onishpets formation, Miocene, Japan.

?Phalium (Bezoardica) iani Schenck, 1926, p. 80, pl. 13, figs. 8-11, Montesano formation, Miocene, Washington.

\section{Liracassis petrosa (Conrad)}

Plate 2, figures $7,10,11,12,13,14$; plate 4 , figures $2,4,6$; plate 10 , figures 7,17

Dolium petrosum Conrad, 1849, U.S. Explor. Exped., Geology, v. 10 , app. p. 727 , atlas pl. 19 , figs. $3 \mathrm{a}, 3 \mathrm{~b}, 4 \mathrm{a}, 4 \mathrm{~b}, 5 \mathrm{a}, 5 \mathrm{~b}$. Meek, 1864, Smithsonian Misc. Colln. 183, p. 19.

Doliopsis petrosus (Conrad). Conrad, 1865a, Am. Jour. Conchology, p. 150.

Semicassis? petrosa (Conrad), 1866a, Smithsonian Misc. Colln. 200 , p. 15.

Galeodia petrosa (Conrad). Tegland, 1931, California Univ., Dept. Geol. Sci., Bull., v. 19, p. 418-420, pl. 65, figs. 1-5, $8,9,10-15$; [not figs. 6, 7].

Weaver, 1942, Washington Univ. [Seattle] Pub. in Geology, v. 5, p. 405-406, pl. 79, figs. 5, 6, 7 [1943].

Eudolium petrosum (Conrad). Dall, 1909, U.S. Geol. Survey Prof. Paper 59, p. 71 [not pl. 14, fig. 6].

Doliopsis biliratum Conrad, 1865a, Am. Jour. Conchology, v. 1, p. 150 (New name for 1849 , pl. 19, figs. $4 a, 4 b$ ).

[Not] Dolium petrosum Conrad. Reagan, 1909, Kansas Acad. Sci. Trans., v. 22, p. 195-196, pl. 3, fig. 32.

Liracassis petrosa is characterized by having strong subrounded straplike spiral cords on the body whorl beneath the shoulder. The spiral cord at the shoulder is produced into about 17 nodes which continue as ridges to the suture. The cords on the spire are smaller than those on the body whorl but are also produced into nodes at the shoulder, with a faint trace of a ridge continuing from the nodes to the suture. At least 10 cords are present below the shoulder of the body whorl and 3 below the shoulder of the spire. There are fine spiral threads between the cords on the body whorl; the median of these threads may be more strongly developed than the others.

Types: Lectotype of Liracassis petrosa herewith selected as USNM 3536, the same specimen referred to and figured by Tegland (1931, p. 419, pl. 65, figs. 14,15) as the type. Figured by Conrad, 1849 , pl. 19, figs 3a, 3b; $60.9 \mathrm{~mm}$ high (broken), 43.8 mm wide, pl. 4 , figs. 4,6 .

Paratype: USNM 561534.

Holotype: Of Doliopsis biliratum Conrad, USNM 561550 (original No. USNM 3536), pl. 2, figs. 7, 11.

Type locality: Astoria, Oreg., for all types.

The lectotype of L. petrosa is an internal cast and no shell remains, but it is the only mature specimen originally figured by Conrad. Eight spiral cords below the shoulder can be traced on the body whorl. The spiral cord at the shoulder is produced in to nodes, which are visible on part of the specimen. Faint nodes are also visible on the shoulders of the whorls of the spire.

An immature specimen of L. petrosa (USNM 561550) was figured by Conrad (1849, pl. 19, figs. 4a, 4b) as
Dolium petrosum, but in 1865 a (p. 150) Conrad renamed this specimen Doliopsis biliratum. This form differs from L. petrosa by having nodes on the shoulder of the body whorl that are more produced and spinelike, subdued nodes on the spiral cord at the base of the angulation below the shoulder, a more concave shoulder without the strong ridgelike continuations of the nodes to the suture, and finer spiral cords on the shoulder. It is considered conspecific with L. petrosa. This form is rare in the Astoria formation; only one specimen is in the collections in addition to the type of Doliopsis biliratum.

Conrad also figured (1849, pl. 19, figs. 5a, 5b) another small immature specimen of $L$. petrosa. This specimen is incomplete and only the inner shell layers remain. The body whorl has nodes on the shoulder, and the specimen is $18.7 \mathrm{~mm}$ high (broken) and 18.2 mm wide (broken) (pl. 2, fig. 12).

The specimen that may be the one figured by Conrad (1849, pl. 21, fig. 1) as an "unnamed cast" is perhaps a Liracassis (pl. 3, fig. 12).

The specimen figured by Reagan (1909, pl. 3, fig. 32) as Dolium petrosum is assigned to Liracassis apta (Tegland); the specimen figured by Reagan (1909, pl. 3 , fig. 33) as Dolium biliratam (misspelling for biliratum) is poorly preserved but is tentatively referred to $L$. apta. The specimen figured by Dall (1909, p. 71, pl. 14, fig. 6) as Eudolium petrosum from the Blakeley formation is L. apta (Tegland), plate 4, figures 7, 10, as pointed out by Tegland (1931, p. 418) and Weaver (1942, p. 406). The specimen figured as Galeodia petrosa (Conrad) by Tegland (1931, pl. 65, figs. 6, 7) was considered to be "Echinophoria" apta by Durham (1942a, p. 188, footnote).

L. petrosa is rare in the Astoria formation. Howe (1922, unpublished, p. 162) records this speciesperhaps including the form bilirata-from the Astoria formation at the corner of Fifth and Commercial Streets, Astoria.

Localities: 1, 1a, 53, 79, 83, 89, 92, 102, 109, 127; California Univ. Mus. Paleontology, no. B5827; cf. 91.

Occurrence elsewhere: Astoria(?) formation, Washington.

Family CYMATIIDAE

New genus?

"Gyrineum" dilleri (Anderson and Martin)

Plate 2, figures 8,9

Argobuccinum dilleri Anderson and Martin, 1914, California Acad. Sci. Proc., 4th ser., v. 4, p. 71-72, pl. 4, fig. 7.

Weaver, 1942, Washington Univ. [Seattle] Pub. in Geology, v. 5 , p. 420 , pl. 83 , fig. 6 [1943]. 
Ranella dilleri (Anderson and Martin). Grant and Gale, 1931, San Diego Soc. Nat. History Mem., v. 1, p. 735.

"Gyrineum" dilleri is of moderate size and of fusiform shape. It has prominent varices which are not alined. The sculpture consists of subdued axial ribs crossed by spiral cords. The most prominent spirals are grooved or split and are separated by three secondary spirals that are half as wide. The major spirals may be grooved up to the varices but are always split where they cross them.

Holotype: California Acad. Sci. 152.

Type locality: Along the sea cliff a little south of the mouth of Wade Creek, about 6 miles north of Yaquina Bay (Astoria formation, Miocene), Oreg.

"G." dilleri cannot be satisfactorily assigned to any of the described cymatids studied. It differs in sculpture from Gyrineum (type species Murex gyrinus Linné). " $G$." dilleri does not have the long siphonal canal of Ranella (type species Ranella gigantea Lamarck) and is also a smaller thinner shelled form and has finer spirals; the most prominent spirals are split and are not as pronounced in relief as on Ranella. Argobuccinum (type species Murex argus Linné) is heavy shelled and has strong spiral sculpture and only a few varices which are less prominent than those on " $G$." dilleri; it also has a larger body whorl and lower spire, making it much less fusiform than " $G$." dilleri.

Fusitriton oregonensis (Redfield), a Recent species on the west coast, is a large species that has a moderately thick fusiform shell. It lacks the prominent varices of " $G$." dilleri.

Gyrineum mediocre Dall, Empire formation, Oregon is a squatter less fusiform species with strong spiral sculpture, but it is probably generically related to " $G$." dilleri.

A single poorly preserved specimen in the Dana collection from Astoria (USNM 3544) is here idenitfied as "Gyrineum" sp. (pl. 5, fig. 21). This is the specimen included in Dall's (1909, p. 40-41) description of Fusus (Priscofusus) sp. and figured by Weaver (1942, pl. 92 , fig. 3) under the same name.

" $G$." dilleri is rare in the Astoria formation. It has been collected by Howe (1922, unpublished, p. 111) at the corner of Fifth and Commerical Streets in Astoria.

Localities: 1, 59, 65, 128, 183, 187, cf. 1a, 48, 109, 167.

\section{Family FICIDAE \\ Genus FICUS Röding}

Ficus Röding, 1798, Museum boltenianum, p. 148.

Type.-By tautonymy and subsequent designation (Winckworth, 1945, Malacological Soc. London Proc., v. 26, p. 140), Ficus variegata Röding(=Bulla ficus Gmelin $=$ Murex ficus Linné). Recent western Pacific.
Ficus modesta (Conrad)

Plate 3, figures 9, 10; plate 4, figure 3

Pyrula modesta Conrad, 1848, Am. Jour. Sci., v. 5, p. 433, fig. 12 Ficus modesta (Conrad). Meek, 1864, Smithsonian Misc. Colln 183.

Sycotyphus modestus (Conrad). Conrad, 1865a, Am. Jour. Conchology, v. 1, p. 151.

Ficopsis modestus (Conrad). Conrad, 1866c, Smithsonian Misc. Colln. p. 15.

Ficopsis modesta (Conrad). Gabb, 1869, California Geol. Survey, Paleontology, v. 2, section 1, pt. 3, p. 113.

Ficus modestus (Conrad). Dall, 1909, U.S. Geol. Survey Prof. Paper 59, p. 12, 74.

Etherington, 1931, California Univ., Dept. Geol. Sci., Bull., v. 20 , p. 96 , pl. 11 , fig. 6 .

Weaver, 1942, Washington Univ. [Seattle]. Pub. in Geology, v. 5, p. $395-396$, pl. 77 , fig. 1 , pl. 103 , fig. 1 [1943].

Hall, 1958, California Univ., Dept. Geol. Sci., Bull., v. 34, p. 56 , pl. 11, fig. 3 .

Ficus (Ficus) modesta (Conrad). Grant and Gale, 1931, San Diego Soc. Nat. History Mem., v. 1, p. 742.

Ficus pyriformis Gabb, 1869, California Geol. Survey, Paleontology, v. 2 , sec. 1 , pts. 2 and 3 , p. 48,77 , pl. 14, fig. 4.

?Ficus wynoochensis Weaver, 1916, Washington Univ. [Seattle] Pub. in Geology, v. 1, p. 45-46, pl. 3, figs. 38, 39.

?Ficus restorationensis Van Winkle, 1918, Washington Univ. [Seattle] Pub. in Geology, v. 1, p. 88, pl. 7, fig. 20.

[Not] Ficus pyriformis Gabb. English, 1914, California Univ., Dept. Geol. Sci., Bull., v. 8, p. 246, pl. 25, fig. 1.

Ficus modesta attains a large size, but the specimens collected are commonly of moderate size. The top of the body whorl is slightly flattened and on the large specimens this whorl is greatly inflated. The entire shell has subequally spaced rounded spiral cords, and a secondary spiral cord is usually present in the interspace. The secondary spiral cords disappear towards the base of the body whorl. On some specimens there is a secondary deposit of unsculptured shell, which masks the cords just above the suture on the body whorl and the whorls of the spire. The spirals are crossed by fine longitudinal threads, which are crowded together at irregular intervals and form reticulations on the spiral cords.

Holotype: Missing. In February 1957, an unsuccessful search was made for the type of $F$. modesta at the Academy of Natural Sciences of Philadelphia. It is presumed to be lost as reported by Dall (1909, p. 74).

Type locality: Astoria, Oreg.

The type of $F$. wynoochensis (California Acad. Sci. 556 ) is from the east bank of the Wynooche River, Wash. The type of $F$. restorationensis Van Winkle (California Acad. Sci. 7526) is from the north side of Restoration Point, Wash. Weaver (1942, p. 397-398) assigned these two species to the subgenus Trophosycon.

According to Weaver (1942, p. 397), F. restorationensis differs from $F$. modestus in that it has a 
proportionately lower spire and faintly developed longitudinal ribs which are very slightly nodose on the upper shoulder of the body whorl.

Weaver (1942, p. 398) said that $F$. wynoochensis was more tumid than $F$. modesta. Large collections of $F$. modesta, now available for study, show it to be as tumid as $F$. wynoochensis when adult.

$F$. modesta has been compared to $F$. dussumieri, which is living off the coast of China, by Stewart (1926, p. 373) and by Grant and Gale (1931, p. 742). Gabb (1869, p. 48) compared "Ficus pyriformis" to $F$. dussumieri.

Localities: 1a, 3, 4, 45, 48, 61, 70, 79, 81, 83, 84, 86, 87, 90' $91,94,96,102,105,107,108-110,112,115,120-124,126,128$, $135,140,156,161,167,172,181,181 \mathrm{a}, 183,187$; ef. 138.

Occurrence elsewhere: Astoria(?) formation, Washington; Temblor formation, lower and middle Miocene, and Oursan sandstone, middle Miocene, California.

\section{Genus TROPHOSYCON Cooper}

Trophosycon Cooper, 1894, California Min. Bur. Bull. 4, p. 53.

Type.-By monotypy, Agasoma? (Trophosycon) kernianum Cooper (=Sycotypus ocoyanus Conrad). Miocene, California and Oregon.

Trophosycon cf. T. ocoyanum (Conrad)

Plate 3, figures 14-16

Trophosycon cf. T. ocoyanum reaches a large size (more than $65 \mathrm{~mm}$ in diameter) and has 2 rows of nodes on the body whorl: 1 on the shoulder and 1 approximately in the middle of the whorl at the base of the maximum inflation. The shell also has equally spaced spiral threads and fine axial lines. The spire is low and apparently is sculptured like the body whorl.

One specimen of Trophosycon (pl. 3, figs. 14, 16) was collected by Howe from the sea cliffs just north of Jump Off Joe, Lincoln County, Oreg. This specimen is on deposit at the California Academy of Science (CAS 12131). Another specimen (loc. 186) was collected as float on the beach south of Moore Creek, south of Newport (pl. 3, fig. 15). Neither specimen is well enough preserved for positive specific identification, but they are comparable to Trophosycon ocoyanum (Conrad) (1855, p. 19).

Ficus nodifera Gabb (1869, p. 48, 77, pl. 14, fig. 5), Agasoma? (Trophosycon) kernianum Cooper (1894, p. 53-54, 65, pl. 3, fig. 52), and Agasoma stanfordensis Arnold (1908, p. 384 [in part] not "the San Diego specimen") were considered synonyms of $T$. ocoyanum by Grant and Gale (1931, p. 743-746). Some authors (Stewart, 1926, p. 373-375; Dall, 1909, p. 75; and English, 1914, p. 250) have assigned "Fusus" oregonensis Conrad (1848, p. 433, fig. 13) to Trophosycon. " $F "$ ". oregonensis is now considered to be a species of $\mathrm{Bru}$ clarkia.

Locality: 186.

\section{Family MURICIDAE}

Subfamily MURICINAE

Genus TROPHON Montfort

Trophon Montfort, 1810, Conchyliologie systématique, v. 2, p. 483.

Type.-By original designation, Murex magellanicus Gmelin (=Murex geversianum Pallas). Recent, Straits of Magellan to Peru.

The type species of Trophon is a form with coarse cancellate sculpture. The longitudinals are produced into leaflike sheets that may be twisted and pinched at the shoulder to form spines, which are negligible to moderate in length and are more accurately described as open folds. These leaflike sheets continue to the base of the shell but are closely and tightly wrapped, so that they protrude only slightly. The longitudinals are closely and regularly spaced. The spirals are very strong and close together, and about 3 spirals occupy the same space as 2 longitudinals.

\footnotetext{
"Trophon" kernensis Anderson
}

Plate 4, figures 1, 5

Trophon kernensis Anderson, 1905, California Acad. Sci. Proc., v. 2, p. 202, pl. 16, figs. 64,65 .

Loel and Corey, 1932, California Univ., Dept. Geol. Sci., Bull., v. 22, p. 249 , pl. 48 , fig. 1 .

Trophon oregonensis Anderson and Martin, 1914, California Acad. Sci. Proc., v. 4, p. 80-81, pl. 5, fig. 5.

Weaver, 1942, Washington Univ. [Seattle] Pub. in Geology, v. 5, p. 401, pl. 78, fig. 1 [1943].

Most of the specimens of "Trophon" kernensis seem to have had an almost smooth body whorl and spines at the shoulder that may be open like folds. When spiral sculpture is present, it is subdued and appears only on the early whorls of the spire.

Holotype: Of Trophon kernensis Anderson, California Acad. Sci. 73.

Type locality: Kern River, Caliente quadrangle, Temblor formation lower and middle Miocene, Kern County, Calif.

Holotype: Of Trophon oregonensis Anderson and Martin, California Acad. Sci. 176.

Type locality: Beach section on Oregon coast on south side of Yaquina Head, 51/2 miles north of entrance to Yaquina Bay, Lincoln County, Oreg. (Astoria formation).

"Trophon" kernensis (Anderson) is not Trophon s. s. It seems to be allied to the genus Austrotrophon Dall, 1902. Trophon cerrosensis Dall is the type species of Austrotrophon by subsequent designation (Grant and Gale, 1931, p. 726). Trophon cerrosensis, T. pinnatus 
Dall, and T. triangulatus Carpenter were included by Dall in Austrotrophon, which he proposed as a section for forms that were large, had prominent varices, hardly any spiral sculpture, and brown or yellow colortion. The specimens of Austrotrophon in the collection in the U.S. National Museum were dredged from 9 to 74 fathoms off southern California and Lower California.

Austrotrophon differs from Trophon s. s. by having less prominent spiral sculpture on the body whorl and spire ( $T$. cerrosensis) or faint spiral sculpture only on the early whorls of the spire (T. pinnatus and $T$. triangulatus). The leaflike projections of the axials are tightly folded and thickened to form long spines at the shoulders of the whorls and continue to the base of the shell, where they are closely and tightly wrapped and project only slightly.

The spines on "Trophon" kernensis are heavier and thicker, and the spiral projections forming these spines rarely continue to the base of the body whorl, as they do on Austrotrophon. A few specimens of "T." kernensis from the Temblor formation of California (USGS loc. 6624) are yellow, similar to that of Austrotrophon, though this may be a result of secondary discoloration. Two specimens, also from the Temblor formation (USGS loc. 6065), show leaflike projections on the body whorl persisting to the base of the shell.

The type specimen of " $T$." kernensis was blackened in the San Francisco fire. According to L. G. Hertlein (oral communication, 1954), F. M. Anderson sifted through the ashes after the fire, where he thought the cases had been, and recovered many of the types. The body whorl of "T." kernensis is almost smooth, and there are no spines on the specimen. The spines seen to have been broken and worn off on the whorls of the spire, but it is difficult to tell if they were ever present on the body whorl.

The type of "T." oregonensis Anderson and Martin is very spinose, with the spines excavated and numbering about 10 on the body whorl.

The primary basis for separating the two species "T." kernensis and "T." oregonensis seems to have been the excavation of the spines of "T." oregonensis and the supposed lack of this excavation on the spines of "T." kernensis. It is true that some specimens of "T." kernensis possess unexcavated spines or nodes, but it seems to be equally true that many specimens have excavated spines. This seems to be too arbitrary a basis for distinguishing the two species. Howe (1922, unpublished, p. 163) says that at least 50 percent of the specimens of "Trophon" kernensis from the type locality show excavated spines and that specimens of both "T." kernensis and "T." oregonensis show some spines excavated and some not.
Most of the specimens of "T." kernensis are broken or worn and a definite assignment of this species to Austrotrophon or to a new subgenus does not seem wise. "T." kernensis is not common in the Astoria formation in Oregon.

Localities: $53,79,83,84,87,87 \mathrm{a}, 90,92,94,95,133,134,139$, 141, 142, 152, 153, 156, 161, 187.

Occurrence elsewhere: Temblor formation, lower and middle Miocene, California.

\section{Genus OCENEBRA Leach}

Ocenebra Leach in Gray, 1847 (Oct.), Annals and Mag. Nat. History, v. 20, p. 269.

Type--By monotypy, Murex erinacea [Linné] Montagu. Recent, Europe.

\section{Ocenbra depoensis Moore, n. sp.}

Plate 4, figures 8,9

A single specimen of this species was collected from the northwest corner of the inner harbor of Depoe Bay by P. D. Snavely, Jr., U.S. Geological Survey. The shell is fusiform and has prominent inequally spaced spiral cords; 3 spiral cords are present on the whorls of the spire, 9 on the body whorl. Leaflike axial varices are prominently developed between the suture and the first spiral cord; these varices continue across the whorls but are less prominent. A single strong axial lamellar varix is developed on the body whorl, approximately one-third the distance from the aperture to the end of the body whorl. The outer lip is produced and thickened by numerous leaflike lamellae and is concave between spirals. Approximately $1.5 \mathrm{~mm}$ inside the outer lip are at least 6 fine and evenly-spaced denticules; the inner lip is apparently smooth. The siphonal canal is completely closed through half the distance of the outer lip, then is open; the end of the canal is recurved.

Type: USNM 563927.

Type locality: (75a) North side of inner harbor of Depoe Bay, north of Coast Guard Station; $2,250 \mathrm{ft}$ west, $525 \mathrm{ft}$ south of NE cor. sec. 8, T. 9 S., R. 11 W., Cape Foulweather quadrangle, Astoria formation (Miocene), Oregon.

On the basis of illustrations of the fossil forms of Ocenebra described from the west coast, none agree with $O$. depoensis in sculpture, nor do any of the Recent west coast species seen agree in sculpture.

A Japanese fossil Ocenebra, O. lumaria Yokoyama, described from the "upper horizon" of the Sawane formation (Pliocene), Sado Island, more closely resembles $O$. depoensis than any other described form studied. On the basis of the original illustration, O. lumaria differs from $O$. depoensis by having a spine produced at the conjunction of the shoulder with the outer hp 
and by having a slightly higher and more fusiform spire.

This is the first reported fossil occurrence of Ocenebra in Oregon.

Locality: $75 \mathrm{a}$.

\section{Family THAIDIIDAE \\ Genus THAIS Röding}

Thais Röding, 1798, Museum boltenianum, pt. 2, p. 54.

Type.-By subsequent designation (Stewart, 1926 [1927], Acad. Nat. Sci. Philadelphia Proc., v. 78, p. 386), Thais lena Röding (=Murex fucus Gmelin= Murex neritoideus Linné=Nerita nodosa Linné). Recent, Cape Verde and Ascension Islands.

\section{Subgenus POLYTROPA Swainson}

Polytropa Swainson, 1840, A treatise on malacology, London, p. 81,305 .

Type.-By subsequent designation (Gray, 1847), Buccinum lappillus Linné. Recent, coasts of Europe.

Clench (1947, p. 85-86) is followed here and Polytropa is used in place of Nucella of Linné and Lamarck, not of Röding (1798). Clench said that Röding had listed several species when he introduced the name Nucella and that one of these was Nucella lapillus Röding and not the species of Linne and Lamarck, as assumed by some authors. According to Clench, Nucella of Röding is not referable to Thais but is probably a buccinoid belonging to some member of the genus Cantharus. He felt that Nucella should be abandoned or associated with Cantharus.

Thais (Polytropa) aff. T. (P.) lima Gmelin

Fourteen specimens in the U.S. National Museum collections may represent the extremely variable Recent species Thais (Polytropa) lima. Ten of the specimens were collected from the dredgings at Coos Bay, and as they were loose from their matrix could have come originally from either the Astoria or the Empire (Pliocene?) formations. One rather wellpreserved specimen is in the collections from locality 156 and three fragments are from locality 91 , both localities in the Astoria formation. The specimens are not well preserved but seem to be smoother and thicker shelled than the Recent $T$. (P.) lima.

Localities: 91, 156, 187.

\section{Family NEPTUNEIDAE}

\section{Genus BRUCLARKIA Trask}

Bruclarkia Trask, in Stewart, 1926 [1927], Acad. Nat. Sci. Philadelphia Proc., v. 78, p. 397, 399.

Type.-By original designation, Clavella gravida Gabb. "South of Martinez," San Ramon Sandstone, California.
Bruclarkia is an endemic Pacific coast genus first appearing in the Keasey formation, upper Eocene and lower Oligocene, Oregon (an undescribed new species), and becoming extinct before the end of the Miocene. The genus has a geographic range of California north to Alaska.

The genus Whitneyella (Stewart, 1926, p. 401, type by original designation, Hemifusus washingtonensis Weaver) differs from Bruclarkia by having a long straight siphonal canal rather than the much shorter recurved canal of Bruclarkia and by having a higher more conical spire and a more overlapping suture. Whitneyella is assigned to the Fasciolariidae and need have no bearing on Bruclarkia, but it is interesting to note that the body whorl of the highly sculptured form of Bruclarkia oregonensis (Conrad) is sculptured almost exactly as Whitneyella washingtonensis (Weaver).

\section{Bruclarkia oregonensis (Conrad)}

Plate 3, figures 2, 3, 8, 11, 13

Fusus oregonensis Conrad, 1848, Am. Jour. Sci., v. 5, p. 433, fig. 13.

Fulgar oregonensis (Conrad). Conrad, 1853, Acad. Nat. Sci. Philadelphia Proc., 1st ser., v. 6, p. 318-319.

Busycon? oregonensis (Conrad). Meek, 1864, Smithsonian Misc. Colln. 183, p. 22.

Sycotyphus oregonensis (Conrad). Conrad, 1865a, Am. Jour. Conchology, v. 1, p. 151.

Ficus (Trophosycon) oregonensis (Conrad). Dall, 1909, U.S. Geol. Survey Prof. Paper 59, p. 75.

Trophosycon oregonense (Conrad). English, 1914, California Univ., Dept. Geol. Sci., Bull., v. 8, p. 250.

Bruclarkia oregonensis (Conrad). Etherington, 1931, California Univ. Dept. Geol. Sci., Bull., v. 20, p. 104-105, pl. 11, figs. $1,3,4,5,7$.

Lutz, 1951, California Univ., Dept. Geol. Sci., Bull., v. 28, p. 391, pl. 18, figs. 1,6 .

Agasoma yaquinanum Anderson and Martin, 1914, Californa. Acad. Sci. Proc., v. 4, p. 75, pl. 4, figs. 5a, 5b.

Bruclarkia yaquinana (Anderson and Martin). Weaver, 1942, Washington Univ. [Seattle] Pub. in Geology, v. 5, p. 444445 , pl. 87, fig. 6 [1943].

?Undetermined species Conrad, 1849, U.S. Explor. Exped., Geology v. 10, atlas pl. 20, figs. 12, 12a.

?Priscofusus nodiferus Conrad, 1865, Am. Jour. Conchology, v. 1, p. 150 (name for undetermined species, 1849, pl. 20, fig. 12).

?Pisiana clallamensis Reagan, 1909, Kansas Acad. Sci. Trans., v. 22 , p. 190 , pl. 3 , fig. 25 .

?Buccinum? clallamensis (Reagan). Dall, 1922, Am. Jour. Sci. v. 4 , p. 309.

?Bruclarkia oregonensis (Conrad). Hall, 1958, California Univ., Dept. Geol. Sci., Bull., v. 34, p. 58, pl. 11, figs. 1, 2.

[Not] Agasoma oregonense Anderson and Martin, 1914, California Acad. Sci. Proc., v. 4, p. 74, pl. 4, figs. 3a, 3b (=Agasoma andersoni Wiedey).

[Not] Bruclarkia oregonensis (Conrad). Weaver, 1942, Washington Univ. [Seattle] Pub. in Geology, v. 5, p. 444, pl. 86, figs. 21, 22 [1943]. 
Bruclarkia oregonensis is of moderate size and is sculptured by fine spiral lines that alternate in strength. On the body whorl, 5 of these spiral lines are usually raised above the others and may have produced on them beads, nodes, or short squat spines; the same sculpture may or may not be present on the spire. The size and shape of the nodes or nodelike processes are extremely variable; two extremes may be noted. The least scupltured form (pl. 3, fig. 13) possesses an almost smooth body whorl bearing fine spirals, only one of which is enlarged on the shoulder of the body whorl and which may be produced to form small beads. The most highly sculptured form (pl. 3, figs. 8, 11) has short, squat, spinelike nodes on the enlarged spirals nearest the shoulder of the body whorl. Intermediate between these two forms are specimens with well-developed nodes on the shoulder of the body whorl and on the adjacent enlarged spirals (pl. 3, fig. 3 ) and forms that have poorly developed spines on the enlarged spirals (pl. 3, fig. 2). A continuous series can be found from the almost smooth form to the highly sculptured form, and no evidence was found to show that the end forms were separated stratigraphically or had any stratigraphic significance. Howe (1922, unpublished, p. 109) found a complete series, apparently similar to that just described, in collections he made half a mile south of Yaquina Head. Bruclarkia yaquinana (Anderson and Martin) is characteristic of the highly sculptured form and is placed in synonymy with $B$. oregonensis.

Holotype: Of Fusus oregonensis Conrad, missing. A search was made for the type at the Academy of Natural Sciences of Philadelphia. It was not found and is presumed to be lost.

Holotype: Of Priscofusus nodiferus Conrad, missing.

Type locality: Astoria, Oreg., for both species.

Holotype: Of Agasoma yaquinana Anderson and Martin, California Acad. Sci. 161.

Type locality: Sandstone exposed on beach south of Yaquina Head, Lincoln County, 51/2 miles north of entrance to Yaquina Bay, Oreg. (Astoria formation, Miocene).

The degree to which a sutural collar is developed on $B$. oregonensis shows considerable variation. The collar may be moderately well developed, overlapping, or sinuous and recurved.

Bruclarkia acuminatum (Anderson and Martin) and Bruclarkia andersoni (Wiedey) (Wiedey, 1928, p. 115, new name for Agasoma oregonense Anderson and Martin) have less inflated body whorls than $B$. oregonensis and have convex rather than concave shoulders. They also lack the 5 generally well developed produced spirals present on $B$. oregonensis.

$B$. oregonensis also superficially resembles $B$. barkeriana (Anderson and Martin), a species common in the Temblor formation of lower and middle Miocene age in California. B. barkeriana invariably has a suture which overlaps onto the spire and a more de- veloped sutural collar than $B$. oregonensis. The distance between the sutural collar and the first raised spiral thread on the body whorl of $B$. barkeriana is almost twice that distance on $B$. oregonensis. The whorls of the spire are tabulate in the middle on $B$. oregonensis, whereas if a tabulation is present on the spire whorls of $B$. barkeriana it is just above the suture, and some of the whorls may be almost evenly rounded with no angulation. $B$. barkeriana shows the same degree of variation in sculpture as shown by $B$. oregonensis, including forms that range from those that have a completely smooth body whorl sculptured only by spiral cords to those that have noded and spinose spiral cords.

The specimen from East Clallam, Wash., described by Reagan (1909, p. 190) as Pisania clallamensis and later assigned to ?Buccinum by Dall (1922, p. 309) seems to be an internal mold of $B$. oregonensis.

Howe (1922, unpublished, p. 109) recorded this species from Fifth and Commercial Streets, Astoria, and also from the Santa Cruz quadrangle, California.

Localities: 1, 1a, 4, 7, 42, 48, 67, 69, 71, 79, 83, 86, 87, 91, $92,94,98,102,105,108,109,112,116,120,156,159-162,167$, 174,187 ; cf. $45,50,59,127,164$.

Occurrence elsewhere: Astoria formation, Washington; Temblor formation, lower and middle Miocene; Oursan sandstone?, middle Miocene; and Sobrante sandstone, middle Miocene; Californiạ.

\section{Genus SEARLESIA Harmer}

Searlesia Harmer, 1914, The Pliocene mollusca of Great Britain' v. 1, 1914-19.

Type.-By original designation, Trophon costifer $\mathrm{S}$. V. Wood. Pliocene of England; Recent, North Atlantic.

$$
\text { Searlesia? carlsoni (Anderson and Martin) }
$$

Plate 5, figures 2-4; plate 6, figure 10

Turris carlsoni Anderson and Martin, 1914, California, Acad. Sci. Proc., 4th ser., v. 4, p. 89, pl. 5, figs. 2a, 2 b.

Fusinus (Priscofusus) carlsoni (Anderson and Martin). Weaver, 1942, Washington Univ. [Seattle] Pub. in Geology, v. 5, p. 488., pl. 93, figs. 11, 13, [1943].

Searlesia? carlsoni is of moderate size and is fusiform. The species includes forms that have nodes on the spire but none on the body whorl (pl. 5, fig. 4), with the body whorl evenly rounded; forms that have nodes on the spire and subdued nodes on the body whorl where there is a slight angulation (pl. 5, fig. 2) or a more definite tabulation (pl. 5, fig. 3); and forms that have strong riblike nodes (pl. 6, fig. 10).

\section{Holotype: California Acad. Sci. 212}

Type locality: Ocean cliff south of Yaquina Head, 51/2 miles north of entrance to Yaquina Bay, Oreg. Astoria formation, Miocene). 
S.? carlsoni is not congeneric with the Priscofusus medialis-Priscofusus geniculus group, although it has consistently been included with it in the genera to which it has been assigned by various authors. S.? carlsoni invariably possesses an overlapping and sinuous suture and has strong spirals that are separated by much narrower and very deep interspaces. S.? carlsoni does not have as shallow an indentation on the outer lip above the shoulder, has much finer spiral sculpture, and has a more overlapping and sinuous suture than Searlesia; it differs from Calicantharus by having a less inflated siphonal fasciole and a shallower indentation on the outer lip above the shoulder.

$S . ?$ carlsoni is usually coated with an encrusting bryozoan, Membranipora, which is discussed on p. 88 .

Howe (1922, unpublished, p. 132) collected S.? carlsoni from the Astoria formation at the corner of Fifth and Duane Streets in Astoria. He described the noded form (1922, p. 133) as a new species and recorded it from the Astoria formation at the corner of Fifth and Commercial Streets in Astoria.

Localities: 1, 66, 70, 73, 79-81, 82, 90, 97, 99, 102, 102a, 103, $105,107,110-112,116,120-122,124,127,128,134,138,139,141-$ $144,147,149,150,153-156,169,171-174,187$; cf. $4,31,67,68$, $71,89$.

Occurrence elsewhere: Astoria(?) formation, Washington.

\section{Family BUCCINIDAE}

Genus ANTILLOPHOS Woodring

Antillophos Woodring, 1928, Carnegie Inst. Washington Pub., no. 385, p. 259 .

Type.-By original designation, Cancellaria cande $i$ d'Orbigny. Recent, West Indies.

Antillophos dumbleana chehalisensis (Weaver)

Nassa chehalisensis Weaver, 1916, Washington Univ. [Seattle] Pub. in Geology, v. 1, p. 46-47, pl. 5, figs. 69, 70.

Tritaria (Antillophos) dumblei var. chehalisensis (Weaver). Etherington, 1931, California Univ., Dept. Geol. Sci., Bull., v. 20, p. 100-101, pl. 12, figs. 6, 21, 22.

A single poorly preserved and broken specimen of Antillophos dumleana chehalisensis is in the collections from locality 156. A. dumbleana dumbleana (Anderson in Hanna, G. D., 1924, p. 183) has not been recorded north of California and $A$. dumbleana chehalisensis has not been collected south of Newport, Oreg.

According to Etherington (1931, p. 101), A. dumleana chehalisensis is very abundant especially in the lower part of the section of the Astoria(?) formation in southwestern Washington.

Locality: 156.

Occurrence elsewhere: Astoria(?) formation, Washington.
Antillophos? sp.

Plate 5, figures 11, 12

A single poorly preserved specimen was collected from the disposal pile of the dredging operation at Coos Bay. Although this form cannot be properly assigned to Antillophos, it is somewhat like it in overall aspect and is perhaps closely allied. The specimen is poorly preserved, and nothing has been found in the literature reviewed that closely resembles it. It is somewhat like Antillophos moorei costaricensis (Olsson) (1922, p. 290-291, pl. 9, figs. 8, 9) but is more slender.

Antillophos? sp. is a small fairly thick shelled form that has strong axial ribs and fine spiral sculpture, apparently more closely spaced just below the suture on both the body whorl and the whorls of the spire. The spire is slightly higher than the body whorl, and the aperature is about one-third the length of the entire shell.

Locality: 187.

Family BUCCINIDAE?

Genus MOLOPOPHORUS Gabb

Molopophorus Gabb, 1869, California Geol. Survey, Paleontology, v. 2 , p. $156-157,219$, pl. 26 , fig. 36 .

Type.-By monotypy, Bulla (Molopophorus) striata Gabb. Eocene, California.

Molopophorus is an endemic Pacific coast genus appearing in the Eocene and becoming extinct by the end of the Miocene. It is represented in Washington, Oregon, and California and is particularly abundant in the Oligocene.

\section{Molopophorus anglonana (Anderson)}

Plate 3, figures 1, 4

Bullia (Molopophorus) anglonana Anderson, 1905, California Acad. Sci. Proc., ser. 3, v. 2, p. 205, pl. 16, figs. 74-76.

Molopophorus anglonana (Anderson). Etherington, 1931, California Univ. Dept. Geol. Sci., Bull., v. 20, p. 97-98, pl. 13, figs. 1-5, 7, 10, 14-16.

Weaver, 1942, Washington Univ. [Seattle] Pub. in Geology, v. 5 , p. 470-471, pl. 90, figs. 14-16, 18, 23 [1943].

Molopophorus anglonana was originally described from the Miocene of Kern River, Calif.; the holotype is lost. The specimen shown on plate 3 , figures 1,4 , is a topotype. $M$. anglonana has also been reported by Etherington (1931, p. 97-98) from the Astoria(?) formation in Washington. One specimen was collected by Howe from Astoria (pl. 3, fig. 6) that seems similar to forms figured by Etherington as $M$. anglonana.

One single poorly preserved specimen was collected at locality 156. The specimen is much worn, and al- 
though it seems to have had a high spire similar to that of $M$. anglonana, the spire seems to taper evenly without a definite shoulder at the suture of the body whorl and lacks the concavity of the whorls of the spire of $M$. anglonana (pl. 3, fig 5).

Localities: 1; cf. 156.

Occurrence elsewhere: Astoria(?) formation, Washington; Temblor formation, Miocene, California.

\section{Molopophorus anglonana matthewi Etherington}

\section{Plate 3, figure 7}

Molopophorus anglonana (Anderson) var. matthewi Etherington, 1931, California Univ. Dept. Geol. Sci., Bull., v. 20, p. 98-99, pl. 13, figs. $3,6,8,9,13$.

Weaver, 1942, Washington Univ. [Seattle] Pub. in Geology, v. 5 , p. 471, pl. 90, figs. 17, 19 [1943].

The specimens of Molopophorus anglonana matthewi in the collections are all smooth shelled and seem to be quite dictinct from the typical Molopophorus anglonana. They should perhaps be considered of specific rather than subspecific rank, but as only a few poorly preserved specimens were collected, no attempt is made to introduce a new name for this form.

Holotype: California Univ. Mus. Paleontology 32028.

Type locality: (California Univ. 9008) Clemons logging road, on abandoned spur of railroad one-fourth mile north of junction of main line on the point of first curve in road, Grays Harbor County, Wash. (Astoria formation).

It is possible that $M$. anglonana (pl. 3, figs. 1, 4) is sufficiently variable to include the subspecies matthewi. Weaver (1942, p. 471) doubted the advisability of regarding $M$. anglonana matthewi as a form of $M$. anglonana and thought that it was perhaps more closely related to $M$. clarki and $M$. fishii than to $M$. anglonana. One specimen is compared to $M$. anglonana (pl. 3, fig. 5) and another is questionably referred to $M$. anglonana of Etherington (pl. 3, fig. 6).

Localities: 50, 69, 77; cf. 76, 156.

Occurrence elsewhere: Astoria(?) formation, Washington.

\section{Family NASSARIIDAE}

\section{Genus HINIA Leach}

Hinia Leach in Gray, 1847 (Oct.), Annals and Mag. Nat. History, v. 20, p. 269.

Type.-By subsequent designation (Cossmann, 1901, Essais paléoconch. comp. pt. 4, p. 204), Buccinum reticulatum Linné. Pliocene of Italy; Recent, seas of Europe.

Perhaps the nassariids that do not have a lirate inner lip may be assigned to Hinia. This would include at least "Nassa" mendica Gould, "Nassa" perpinguis Hinds, and "Nassa" lincolnensis Andersom and Martin. Howe (1922, unpublished, p. 140) first assigned " $N$." lincolnensis to the genus Hinia.
The specimens of Hinia reticulatum (Linné) in the U.S. National Museum collections include forms with a completely smooth inner lip to forms with a lirate inner lip. The entire inner lip may be lirate or there may be just one or a few lirations. There seems to be no correlation between growth stage and the presence of lirations. To the best of my knowledge, this type of variation within one species is inconsistent with present-day thought on the taxonomic characters of the nassariids. Nassarius ("Schizopyga") rhinetes Berry (1953, p. 415-416) may also belong in this group. Schizopyga californiana Conrad is the type species, by monotypy, of Schizopyga Conrad (1856, p. 315). S. californiana, however, is of uncertain status as the type, a fossil, presumably Pliocene, is lost (Woodring, 1950 [1951], p. 74). This makes the use of Schizopyga for this group undesirable, at least until the status of Schizopyga californiana is fixed by the designation of a neotype.

\section{Hinia? lincolnensis (Anderson and Martin)}

Plate 5, figures 8-10, 13, 15

Nassa lincolnensis Anderson and Martin, 1914, California Acad. Sci. Proc., 4th ser., v. 4, p. 77, pl. 7, figs. 14a, 14 b.

Nassarius lincolnensis (Anderson and Martin). Weaver, 1942, Washington Univ. [Seattle] Pub. in Geology, v. 5, p. 462, pl. 89, fig. 25 [1943].

Hinia? lincolnensis is characterized by the constriction of the body whorl just beneath the first spiral below the shoulder, and the presence of nodes on that spiral. The whorls may be tabulate, but a few specimens have evenly rounded whorls. The shell has strong axial ribs crossed by weaker spirals which give a moderately reticulated effect. The strength and spacing of the axial ribs is quite variable: on some specimens they are farther apart than the spiral cords, on some they are spaced the same as the spiral cords, and on others they tend to disappear entirely on the body whorl. All these variations have been found on specimens collected in close association within one stratigraphic unit.

Holotype: California Acad. Sci. 167.

Type locality: South side of Yaquina Head, north of Newport, Oreg. [Astoria formation].

The assignment of this species to Hinia is uncertain. The few specimens of Hinia? lincolnensis that show the aperture have a smooth inner lip. As stated above, however, Hinia reticulatum varies from forms that have a smooth inner lip to those that have a lirate one. It is hoped that future study will show the taxonomic importance of these lirations and the proper disposition of $H$.? lincolnensis.

$H$. ? lincolnensis is quite common in the section exposed in the headland north of Spencer Creek. 
A specimen collected from the Astoria (?) formation in the Grays Harbor area, Washington, is tentatively identified as $H$.? lincolnensis.

Localities: 4, 79, 83, 85-87, 90-92, 102, 121, 124, 156, 159, $161,187$.

Occurrence elsewhere: Astoria(?) formation, Washington.

\section{Genus UZITA H. and A. Adams}

Uzita H. and A. Adams, 1853, The genera of Recent Mollusca, v. 1, p. 120 .

Type.-By subsequent designation (Cossmann, 1901, Essais de Paléoconchologie comparée pt. 4, p. 205), Buccinum migum Bruguiere. Recent, West Africa.

\section{Uzita? arnoldi (Anderson)}

Plate 5, figures 14, 16-20

Nassa arnoldi Anderson, 1905, California Acad. Sci. Proc., 3d ser., v. 2, p. 204, pl. 16, figs. 70, 71.

Nassarius (Hima) arnoldi (Anderson). Etherington, 1931, California Univ. Dept. Geol. Sci., Bull., v. 20, p. 99, pl. 12, figs. 15,19

Nassarius (Uzita) arnoldi (Anderson). Grant and Gale, 1931, San Diego Soc. Nat. History Mem., v. 1, p. 679.

Nassarius arnoldi (Anderson). Weaver, 1942, Washington Univ. [Seattle] Pub. in Geology, v. 5, p. 461, pl. 89, fig. 14 [1943].

Uzita? arnoldi is characterized by having a thickened varix at the outer lip and two lirations on the inner lip, one elongated and well developed on the posterior parietal wall and one short and poorly developed on the anterior parietal wall. The outer lip is strongly lirate and varicose and has about eight lirations. The outer shell has narrow axial ribs and spiral cords of equal weight and spacing, which form finely reticulate sculpture. The species is commonly a small round form, but larger more fusiform specimens are also fairly common. The Oregon representatives of this species have somewhat stronger axial ribs than are found on specimens of $U$.? arnoldi from California. Examination of about 50 specimens from California showed enough variation within the species to include the Oregon form; a specimen from Kern River, Calif., is figured, plate 5 , figures 16,17 .

Type: Lost.

Type locality: Records give only: "Kern River, Calif." [Temblor formation, lower and middle Miocene].

No specimens of "Buccinum" migum are available in Recent collections in the U.S. National Museum, so "Nassa" arnoldi is therefore only tentatively assigned to Uzita.

The larger specimens of $U$. ? arnold $i$ are superficially similar to Antillophos dumbleana chehalisensis (Weaver). A positive identification is difficult unless the aperture is preserved.
According to Etherington (1931, p. 99), U.? arnoldi is very common in the lower beds of the Astoria formation in southeastern Washington. In the sections studied in Oregon, it seems that this species is common in the siltier parts of the sections regardless of stratigraphic position.

Localities: 52, 59, 69, 73, 75, 96, 108, 109, 112, 139, 142, 145, 147, 149, 155, 156, 187; cf. 33, 105.

Occurrence elsewhere: Astoria(?) formation, Washington; Temblor formation, lower and middle Miocene, California.

Family FUSINIDAE

\section{Genus PRISCOFUSUS Conrad}

Priscofusus Conrad, 1865a, Am. Jour. Conchology, v. 1, p. 150.

Type.-By subsequent designation (Cossmann, 1901 Essais Paléoconch. Comp., p. 8), Fusus geniculus Conrad (pl. 6, figs. 13, 15-18). Astoria formation, Miocene, Oregon.

Priscofusus is fusiform and has a moderate spire and a moderately short canal which is strongly recurved. The spire has round or transversely elongated nodes or intermittent or constant swellings of one spiral cord. The body whorl may be noded like the spire or may be smooth. The entire shell has flat-topped to slightly rounded spiral cords; the weight and pattern of secondary cords varies somewhat between species. The sinuous growth lines show a shallow sinus on the outer lip but not the deep sinus characteristic of the turrids; the suture is appressed and generally even and collared.

Priscofusus was first proposed by Conrad for six species which he assigned to the Muricidae: $P$. corpulentus (Conrad), P. devinctus (Conrad), P. medialis (Conrad), $P$. nodiferus Conrad, $P$. oregonensis Conrad, and $P$. geniculus Conrad). The species were listed by Conrad as part of a catalog, and the genus Priscofusus was not described nor was a type designated. Cossmann designated Fusus geniculus as the type species, although Dall (1909 p. 39) treated Pricofusus as a subgenus of Fusinus and considered P. corpulentus to be the type of Priscofusus. Dall may have been unaware of Cossmann's designation and considered the first-named species to be the type.

Dall (1909, p. 24-27) assigned the three species Turris coli (pl. 5, fig. 1), Turris coosensis, and Turris cammani to the turrids. Turris coli is assigned to Priscofusus and T. coosensis and T. cammani (pl. 5, figs. 22, 23) are assigned to Searlesia?.

The type specimens of Priscofusus devinctus and Priscofusus nodiferus are missing, and those names are considered nomina dubia. $P$. devincutus was originally described as a Buccinum? (Conrad, 1849, p. 728, pl. 20 , figs. 2, 2a), and later (1865a, p. 150) it was assigned to Priscofusus by Conrad. $P$. nodiferus was 


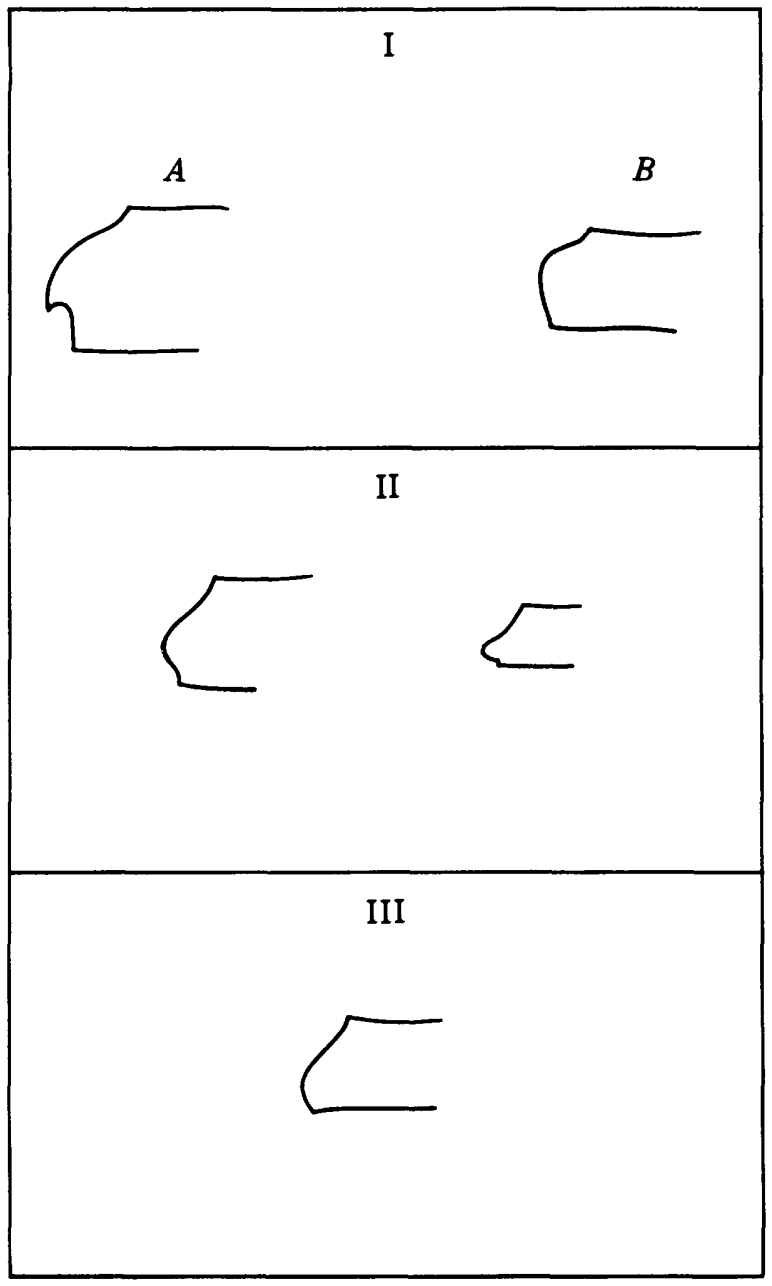

FIGURE 8.-Whorl proflles of Priscofusus discussed in present report.

illustrated by Conrad in 1849 (pl. 20, fig. 12) but not named until 1865 (1865a, p. 150), when Conrad assigned it to Priscofusus.

$A$ key to the species of Priscofusus discussed in the present report is as follows:

I. Spiral cords separated by interspaces of equal width, each of which usually contains a secondary spiral cord:

A. Hooklike nodes; the swelling is above single enlarged spiral eord below center of whorl on spire (p. 40)

$P$. geniculus (Conrad)

B. Elongated nodes; 6 to 8 spiral cords are enlarged over nodes. Nodes taper evenly from maximum swelling slightly above center of whorls on the spire (p. 42)

P. coli (Dall)

II. Spiral cords separated by interspaces $1 \frac{1 / 2}{2}$ to 2 times as wide as cords; an interspace occasionally contains one secondary spiral cord:

Round nodes; 3 to 6 spiral eords are enlarged over nodes and the maximum swelling is below the center of whorls on the spire (p. 41)

III. Spiral cords separated by interspaces about $1 \frac{1 / 2}{2}$ times as wide as cords, each containing 1 secondary and 2 tertiary cords:

Elongated nodes slightly below the middle of the whorl on the spire (p. 42) ........................

\section{Priscofusus geniculus (Conrad)}

Plate 6, figures 13 15-18

Fusus geniculus Conrad, 1849, U.S. Explor. Exped., Geology, v. 10, app. p. 728 , atlas pl. 20 , fig. 3 .

Fusus(?) geniculus Conrad. Meek, 1864, Smithsonian Misc. Colln. 183, p. 22.

Priscofusus geniculus (Conrad), 1865a, Am. Jour. Conchology, v. 1, p. 150.

Fusinus (Priscofusus) geniculus (Conrad). Dall, 1909, U.S. Geol. Survey Prof. Paper 59, p. 40 [not] cotype of $P$. oregonensis, USNM 3565.

Weaver, 1942, Washington, Univ. [Seattle] Pub. in Geology, v. 5, p. 482, pl. 92, fig. 10 [1943].

?Undetermined species. Conrad, 1849, U.S. Explor. Exped., Geology, v. 10, atlas pl. 20, figs. 10, 11.

?Priscofusus oregonensis Conrad, 1865a, Am. Jour. Conchology, v. 1 , p. 150 (name for undetermined species, 1849, pl. 20, figs. 10, 11).

The most characteristic feature of Priscofusus geniculus is the presence of hooklike nodes. The "hook" is formed by the swelling of a single spiral cord, but the maximum swelling, forming the node, occurs above this single enlarged spiral. The nodes are formed somewhat below the midpoint of the whorl. On some specimens the third or fourth spiral cord below the shoulder or the fifth spiral cord above the shoulder may be enlarged but not noded. The nodes disappear entirely on the body whorl of some specimens. On other specimens, nodes are retained on the body whorl as one intermittantly swollen spiral cord, bearing minor protruberences that are not, strictly speaking, nodes. The spiral cords alternate with interspaces of equal or slightly larger width, each of which usually contains a finer secondary cord about half as wide as the primary cord.

Type: Lectotype of Fusus geniculus, herewith designated as USNM 3552, pl. 6, fig. 17. USNM 3552 is considered to be the specimen figured by Conrad (1849, pl. 20, fig 3).

Type: Lectotype of "Priscofusus oregonensis" herewith designated as USNM 3517, pl. 6, fig. 16; figured by Conrad (1849, pl. 20, fig. 10). Counterpart cataloged as USNM 3559. Paratype USNM 3535, pl. 6, fig. 13; figured by Conrad (1849, pl. 20, fig. 11).

Type locality: Astoria, Oreg., for both species.

The lectotype of Fusus geniculus is a poorly preserved immature individual. Both the apex of the spire and the siphonal canal are missing, and the aperture is buried in matrix, which would be difficult to remove without destroying the specimen.

Priscofusus oregonensis was originally figured by Conrad $(1849$, pl. 20, figs. 10, 11) as an undetermined species. Conrad (1865a, p. 150) named the illustrated specimens Priscofusus oregonensis. The lectotype of $P$. oregonensis is a cast in half of a concretion (pl. 6, fig. $16)$; this is the specimen figured by Conrad $(1849, \mathrm{pl} .20$, fig. 10). The lectotype is so poorly preserved that a 
positive specific determination cannot be made. The other specimen, figured by Conrad (1849) on plate 20, figure 11 (USNM 3535), and later referred by him to Priscofusus oregonensis (1865a, p.150) is better preserved than either of the specimens listed by Dall $(1909$, p. 40$)$ as the type and cotype respectively and shows nodes typical of $P$. geniculus (pl. 6, figs. 13, 18). The specimen listed by Dall $(1909, \mathrm{p} .40)$ as the cotype of $P$. oregonensis (USNM 3565, pl. 5, fig.24) is not one of the specimens illustrated by Conrad; it is poorly preserved but is identified as Priscofusus cf. medialis.

$P$. geniculus differs primarily from $P$. medialis and $P$. coli by having but one swollen spiral cord on the node. $P$.medialis has slightly narrower spiral cords and larger interspaces than $P$. geniculus, and secondary spiral cords are rarely present. $P$. coli has wider spiral cords than $P$. geniculus, although they also alternate with interspaces of equal width, each containing a finer secondary cord.

$P$. geniculus is not common in the Astoria formation; $P$. medialis is the common species representing the genus.

Localities: 1a, 48, 89, 92, 94, 105, 111, 112, 116, 128, 132, 134, 156, 183; cf. 1c, 15, 56, 98, 99, 122, 130, 139, 153.

\section{Priscofusus aff $P$. geniculus (Conrad)}

Plate 6, figures 12, 19

Three incomplete specimens of this form were collected; 1 from the vicinity of Tillamook Bay, Oreg., and 2 from the beach cliffs south of Yaquina Bay. These specimens are much larger than any of $P$. geniculus in the collections. The nodes on this form are much like those on $P$. geniculus, being formed primarily by the swelling of a single spiral cord. The spirals are much coarser, however, and on one specimen the swelling for the node is beneath the spiral cord, rather than above, as it is on $P$. geniculus. It seems probable that this form is a new species, but it is not named because of the inadequacy of the available material.

Howe (1922, unpublished, p. 130) collected this form from the beach cliffs 2 miles south of Yaquina Bay, Oreg., plate 6, figure 12. (California Acad. Sci. 12129.)

Localities: 48, 183.

\section{Priscofusus medialis (Conrad)}

Plate 5, figures 6, 7; plate 6 , figures $1-7,9$; plate 7 , figure 10

Cerithium mediale Conrad, 1849, U.S. Explor. Exped., Geology, v. 10, app. p. 728 , atlas pl. 20, figs. 1, la.

Cerithium (?) mediale Conrad. Meek, 1864, Smithsonian Misc. Colln. 183, p. 17.

Priscofusus medialis (Conrad). Conrad, 1865a, Am. Jour. Conchology, v. 1, p. 150.
Fusinus (Priscofusus) medialis (Conrad). Dall, 1909, U.S. Geol. Survey Prof. Paper 59, p. 41.

Weaver, 1942, Washington Univ. [Seattle] Pub. in Geology, v. 5 , p. 483 , pl. 93 , fig. 7 [1943].

Fusus corpulentus Conrad, 1849, U.S. Explor. Exped., Geology, v. 10 , app. p. 728 , atlas pl. 20 , fig. 4 .

Fusus(?) corpulentus Conrad. Meek, 1864, Smithsonian Misc. Colln. 183, p. 22.

Priscofusus corpulentus (Conrad). Conrad, 1865a, Am. Jour. Conchology, v. 1, p. 150.

Fusinus (Priscofusus) corpulentus (Conrad). Dall, 1909, U.S. Geol. Survey Prof. Paper 59, p. 39.

Weaver, 1942, Washington Univ. [Seattle] Pub. in Geology, v. 5, p. 482, pl. 92, fig. 1 [1943].

Fusinus (Priscofusus) sp. indet. Dall, 1909, U.S. Geol. Survey Prof. Paper 59, p. 40-41 (USNM 561973, 561974, not USNM 3544; all originally numbered USNM 3544).

Weaver, 1942, Washington Univ. [Seattle] Pub. Geology, v. 5, p. 483-484, pl. 92, figs. 5, 6, [not pl. 92, fig. 3]. [1943].

Turris lincolnensis Anderson and Martin, 1914, California Acad. Sci. Proc., 4th ser., v. 4, p. 88-89, pl. 6, fig. 8.

Fusinus (Priscofusus) lincolnensis (Anderson and Martin). Weaver, 1942, Washington Univ. [Seattle] Pub. in Geology, v. 4, p. 487, pl. 93, figs. 8, 9 [1943].

[Not] Turris lincolnensis Van Winkle, 1918, Washington Univ. [Seattle] Pub. in Geology, v. 1, p. 92, pl. 7, fig. 24 (renamed Borsonella nuncapatia Hanna, 1924).

Priscofusus medialis is characterized by round almost equidimensional nodes which vary in prominence; some specimens possess larger nodes than others, and some have well-developed nodes on the spire which tend to diminish on the body whorl. Three to six spiral cords are enlarged where they pass over the nodes. The nodes may be near but below the middle of the whorls of the spire or below the middle and just above the suture, but all are at the point of maximum inflation. The suture is appressed and slightly overlapping, even, and collared. The spiral cords are narrow and slightly rounded; the interspaces are usually $1 \frac{11}{2}$ to 2 times as wide as the cords. Secondary spiral cords are occasionally present in the interspaces but not in a consistent alternating pattern.

Types.-Lectotype of Cerithium mediale, herewith designated as USNM 3532, pl. 6, figs. 1, 4. Presumably Conrad (1849, p. 728, pl. 20, figs. 1, 1a) figured two specimens. The specimen represented by his figure 1a has not been recognized and the remaining figured specimen is the obligatory lectotype.

Lectotype: Of Fusus corpulentus, herewith designated as USNM 3551 , pl. 7 , fig. 10 .

Type locality: For both species, Astoria, Oreg.

Holotype: Of Turris lincolnensis, California Acad. Sci. 211, pl. 6, figs. 2, 3 .

Type locality: Sandstone cliff along ocean south of Yaquina Head, 5 $\frac{1}{2}$ miles north of entrance to Yaquina Bay, Oreg. [Astoria formation].

The lectotype of Priscofusus medialis is a small individual with the body whorl missing. The type specimen was in rock and was so illustrated originally 
(Conrad, 1849, pl. 20, fig. 1), but it was broken out of the rock at some later date.

The lectotype of Fusus corpulentus is a poorly preserved mold in half a concretion. No original shell is left, but the specimen is comparable in outline with $P$. medialis and appears to have had round nodes. The specimen cited as a cotype of Priscofusus oregonensis Conrad by Dall (1909, p. 40), USNM 3565, plate 5 , figure 24 , is here identified as $P$. cf. $P$. medialis (Conrad); the specimen was not figured by Conrad. Grant and Gale (1931, p. 490) considered Fusus corpulentus to be a Bruclarkia.

Turris lincolnensis is conspecific with Priscofusus medialis. The original illustration of $T$. lincolnensis is misleading in that it makes the specimen appear to have elongated nodes. The holotype of $T$. lincolninsis has been examined and was found to have the rounded nodes characteristic of $P$. medialis. The holotype (California Acad. Sci. 211) is refigured, plate 6, figures 2, 3 , through the courtesy of Dr. L. G. Hertlein, California Academy of Sciences.

Two of the specimens cited by Dall (1909, p. 40-41) from Astoria as Fusinus (Priscofusus) sp. indet. are sufficiently well preserved to be identified as $P$. medialis, now that there are additional collections available for comparison. These two specimens have been assigned USNM Cenozoic catalog numbers 561973 (pl. 5, fig. 6) and 561974 (pl. 5, fig. 7), respectively; both originally bore USNM 3544. They are counterparts of a concretion. The third specimen, USNM 3544 , is perhaps a "Gyrineum" (p. 132, pl. 5, fig. 21).

"Fusus" hecoxae Arnold (pl. 6, fig. 14) from the San Lorenzo formation (Oligocene), California resembles $P$. medialis (Conrad) but is more slender than is usual for $P$. medialis and the nodes are farther apart on both the spire and the body whorl.

Howe (1922, unpublished, p. 134) collected P. medialis from the Astoria formation at the corner of Fifth and Commercial Streets in Astoria.

Localities: 1a, 71, 78, 80,83, 86, 88, 90, 94, 101, 102,102a, $112,119,129,130,136,137,156,187$; cf. 37,38 .

\section{Priscofusus cf. P. coli (Dall) \\ Plate 5, figure 5}

Priscofusus coli (Dall) was originally described in 1909 (p. 26, pl. 4, fig. 2), and the holotype was assigned the catalog number USNM 107783 . This same number was also assigned to "Turris" coosensis Dall; so P. coli has now been given a new number, USNM 561975 .

Most of the specimens in the collections comparable to P. coli were collected from the dredgings at Coos Bay, Oreg. They were collected on the disposal heap, and it cannot be proved that they actually occurred in association with the Miocene fossils collected there; however, a few poorly preserved specimens from localities 117 and 157 are also comparable to $P$. coli. The type of $P$. coli (pl. 5, fig. 1) from the Empire formation (Pliocene?) Coos Bay and a specimen collected from the disposal heap at Coos Bay, Priscofusus cf. P. coli (pl. 5, fig. 5) are figured for comparison.

$P$. coli may be distinguished from $P$. geniculus and $P$. medialis by its elongated nodes. Six to eight spiral cords are enlarged over the nodes, and there is a tabulation at the center on the whorls of the spire.

Localities: 117, 157, 187.

\section{Priscofusus n. sp.?}

Plate 6, figures 8,11

Three specimens may represent a new species of Priscofusus. These specimens, however, are poorly preserved and may not even be conspecific. One was collected in Astoria (pl. 6, fig. 8) and is in the California Academy of Science collections (CAS 12130); another (loc. 86) was collected from the beach cliffs north of Spencer Creek (pl. 6, fig. 11); and the third (loc. 187) was collected from the Coos Bay dredgings.

One specimen (USNM 563165) has enough shell remaining to be described. The shell is characterized by slightly rounded spiral cords, and interspaces about $1 \frac{112}{2}$ times as wide, each of which contains 1 secondary and 2 tertiary spiral cords. This pattern is consistent on all the shell that remains. The specimen also has elongated nodes slightly below the middle of the whorls on the spire. This form has a shorter spire and a more inflated body whorl than the average representatives of the other described species of Priscofusus from the Astoria. Three specimens of $P$. medialis, however, also have a short spire and inflated body whorl similar to $P$. n. sp.?.

Localities: 1 (California Acad. Sci. 12130), 86, 187.

\section{Family VOLUTIDAE \\ Subfamily VOLUTINAE \\ Genus PSEPHAEA Crosse}

Psephaea Crosse, 1871, Jour. de Conchyl., v. 19 (ser. 3, v. 11), p. 302-304.

Type.-By monotypy, Voluta concinna Broderip. Recent, Japan. (Distribution: Shikoku and Honshu according to Kuroda and Habe, 1950, p. 32).

The genus Psephaea may be distinguished from Fulgoraria (Schumacher, 1817, p. 73, 242, type Fulgoraria chinensis $\quad$ Schumacher $=$ Voluta rupestris Gmelin); Psephaea has fewer and weaker plications on the columella, it does not have a thickened denticulate outer lip, and it has a wider aperture. In addition, the first whorl of the protoconch on Psephaea is twisted 
up and away from the suture, whereas on Fulgoraria the first whorl parallels the suture and is larger.

\section{Subgenus MIOPLEIONA Dall}

Miopleiona Dall, 1907, Smithsonian Misc. Colln., v. 50, p. 11, 13.

Type.-By original designation (p. 13), $M$ [iopleiona] indurata Conrad. Miocene, Oregon, and Washington.

Dall in 1909 (p. 35) described Miopleiona as a new genus and designated Rostellaria indurata Conrad as the type, although he first mentioned the genus and designated a type in 1907. According to the statement on page 12 , the species listed with a genus on pages $12-14$ are "typical species." In his opening statement, Dall (1907, p. 1) says that he was studying the Coos Bay fauna at the time he wrote the shorter paper on the Volutes.

\section{Psephaea (Miopleiona) indurata (Conrad)}

Plate 7, figures $1,2,3-6,7,8,9,11$; plate 8 , figures $1-4,5$

Rostellaria indurata Conrad, 1849, U.S. Explor. Exped., Geology, v. 10, app. p. 727-728, atlas pl. 19, fig. 12 .

Volutilithes? indurata (Conrad). Conrad, 1865a, Am. Jour. Conchology, v. 1, p. 151.

Volutilithes indurata (Conrad). Conrad, 1866a, Smithsonian Misc. Colln. 200, p. 16.

Miopleiona indurata (Conrad). Dall, 1909, U.S. Geol. Survey Prof. Paper 59, p. 35, pl. 18, fig. 5 [not] pl. 18, fig. 6 . Weaver, 1942, Washington Univ. [Seattle] Pub. in Geology, v. 5, p. 491-492, pl. 94, figs. 5, 13, 8? [1943].

Psephaea indurata (Conrad). Grant and Gale, 1931, San Diego Soc. Nat. History Mem., v. 1, p. 634.

Psephaea indurata is moderately thick shelled and has strong axial ribs; about 18 to 21 per whorl. The ribs are slightly deflected near the suture and are separated by interspaces as wide to slightly wider than the ribs. There are faint traces of spiral lines on patches of well-preserved shell, especially on the earlier whorls.

Type: Holotype missing.

Type locality: Astoria, Oreg.

The holotype of $P$. indurata is missing. In the original description of this species, Conrad gives Astoria, Oreg., as the locality and says that, "The specimens are fragments of casts." The specimen originally figured and said to be of natural size is incomplete, but it is certainly not a "fragment." Perhaps the illustration is a composite drawing. There are however, no specimens or "fragments of casts" of $P$. indurata in the type collection. Weaver (1942, p. 491), followed Dall (1909, p. 35), who inadvertently listed USNM 5908 as the type specimen of $P$. indurata. According to Dall (1909), this specimen was collected from a concretion at the base of the bluff in Astoria. USNM 5908 is entered in the U.S. National Museum catalog book as follows: "Rostellaria indurata Conrad, Neeah Bay, Puget Sound, Oregon [Territory]. Miocene?
Lt. J. G. Swan." This specimen was entered at the same time as 11 other specimens collected by Swan at the same locality. The other specimens have labels that cite Conrad as having made the identifications. There is no such label with the specimen of "Rostellaria" indurata, but there is a label in Dall's handwriting. It is possible that this specimen was identified by Conrad but at a later date than the original specific description of " $R$." indurata. USNM 5908 was probably collected from the Blakeley formation; it does not agree with the original illustration of " $R$." indurata and should not be considered the holotype. This poorly preserved specimen may be $P$. (M.) weaveri rather than $P$. (M.) indurata (pl. 7, figs. 3,6 ).

There is a single specimen (USNM 112409) of $P$. indurata in the U.S. National Museum that was collected by T. A. Condon (missionary and pioneer geologist of Oregon) in Astoria, sometime before 1893 when the specimen was cataloged. The specimen is poorly preserved, but it is the only one available from the type locality. It is broken off at the apex and base and has retained only small patches of the inner shell layers. It is $99.2 \mathrm{~mm}$ high (broken) and 40.0 $\mathrm{mm}$ wide (pl. 7 , fig. 4). There are approximately 5 whorls preserved, on which are the impression of axial ribs; 21 of these were counted on the body whorl.

A strongly ribbed form of $P$. indurata was collected by Howe from the Astoria formation at the corner of Fifth and Commercial Streets in Astoria (pl. 7, fig. 2), and this form is also in the collections from the disposal heap at Coos Bay (pl. 7, fig. 7; pl. 8, fig. 5) and the Spencer Creek area (pl. 7, fig. 11). Howe also reported this form in the Hannibal collection from a locality 2 miles south of the entrance to Yaquina Bay. The strongly ribbed form of Psephaea indurata is slimmer, higher spired, and has more axial ribs which are thinner, less prominent, and more strongly deflected near the suture than on the common form of $P$. indurata. Fine spiral ribs are present on at least the early whorls of well-preserved specimens (pl. 7, fig. 7). There are 25 axial ribs on the body whorl of 1 complete specimen. Psephaea (Miopleiona) weaveri (Tegland) (1933, p. 127-128, pl. 11, figs. 1-5) of the Blakeley formation upper Oligocene or lower Miocene in Washington, is thinner shelled, slimmer, and has about half as many axial ribs as the strongly ribbed form of $P$. indurata. Fine spiral ribs are well preserved on the specimen of $P$. weaveri figured by Dall $(1909, \mathrm{pl} .18$, fig. 6) as Miopleiona indurata, and initially separated from $P$. indurata by Tegland (1933, p. 127-128).

$P$. indurata is allied to Psephaea oregonensis Dall $(1907$, p. $11 ; 1909$, p. $35-36)$ from the Purisima formation (Pliocene), California, and the Empire for- 
mation (Pliocene?), Oregon, but $P$. indurata is slimmer, higher-spired, and has more axial ribs, which are heavier. The axial ribs disappear near the base of the body whorl of $P$. oregonensis. The type of $P$. oregonensis is USNM 165469 from the Purisima formation of California (Keen and Bentson, 1944, p. 171; Woodring, in Woodring and Bramlette, 1950, p. 78).

$P$. indurata is not common in the Astoria formation although it is relatively common in the rocks (loc. $56,57)$ exposed south of the igneous headland [Fishing rocks] north of Fogarty Creek (fig. 4).

Localities: 1, 1a, 1b, 56-58, 108-110, 112, 124, 156, 183, 187; ef. 102.

Occurrence elsewhere: Astoria(?) formation, Washington.

\section{Family CANCELLARIIDAE}

Genus CANCELLARIA Lamarck

Cancellaria Lamarck, 1799, Soc. Hist. Nat. Paris Mém., ser. 1, p. 71 .

Type--By monotypy, Voluta reticulata Linné. Recent, Florida and West Indies.

\section{Cancellaria? n. sp.?}

Plate 9, figures 3, 4

This species is represented by a single specimen from the dredgings at Coos Bay (loc. 187). This fossil is incomplete, patches of the shell are missing, and it is broken at the outer lip; the siphonal canal is missing. It is strongly shouldered and has prominent spiral ribs which are evenly spaced. Secondary ribs are present near the base of the body whorl. The outer lip is thickened where it meets the body whorl along the posterior margin. This seems also to be true of "Cancellaria oregonensis Dall" to which this species may be subgenerically related. When Dall named this cancellariid from the Empire formation, Pliocene(?), Coos Bay, Oreg., Cancellaria oregonensis, the name was preoccupied by Cancellaria oregonensis Conrad (1865a, p. 151) and it is therefore a junior homonym.

Locality: 187.

\section{"Cancellaria" wynoochensis Weaver}

Cancellaria wynoochensis Weaver, 1916, Washington Univ. [Seattle] Pub. in Geology, v. 1, p. 50-51, pl. 4, figs. 51-54. Cancellaria (Calcarata) wynoochensis Weaver. Etherington, 1931, California Univ., Dept. Geol. Sci. Bull., v. 20, p. 107 pl. 14, fig. 5.

Cancellaria wynoochensis was recorded by Howe (1922, unpublished, p. 116) from the Astoria formation at the corner of 5 th and Commercial Streets in Astoria. There are no specimens of this species in the U.S. National Museum collections from the Astoria formation in Oregon, but it is present in the Astoria(?) formation in southwestern Washington.
Locality: Fifth and Commercial Streets, Astoria (California Acad. Sci. coll.).

Ocurrence elsewhere: Astoria(?) formation, Washington.

\section{"Cancellaria" siletzensis Anderson}

Plate 9, figures 2, 5

Cancellaria rotunda Anderson and Martin, 1914, California Acad. Sci. Proc., ser. 4, v. 4, p. 87, pl. 8, figs. 4a, 4b; [not] Cancellaria rotunda Dall, 1892, p. 224.

Cancellaria siletzensis Anderson, 1924, in Hanna, G. D., California Acad. Sci. Proc., v. 13, p. 159, new name for $C$. rotunda Anderson and Martin.

"Cancellaria" siletzensis has a low spire in proportion to its size and evenly rounded whorls that are not tabulated. The shell is sculptured by subdued axial ribs, which are more prominent on the spire than on the body whorl, and by spiral cords. The spiral cords are evenly spaced on the shell and are separated by interspaces about $3 \frac{1}{1}$ times as wide as the spiral cords; in the middle of each interspace is a fine spiral thread. The spirals are slightly swollen where they cross the axial ribs.

Holotype: California Acad. Sci. 205.

Type locality: Cliffs along ocean front about $3,000 \mathrm{ft}$. north of Yaquina Bay, Lincoln County, Oreg. [Astoria formation].

" $C$." siletzensis is probably subgenerically related to the Recent "Cancellaria" ventricosa Hinds, which cannot be placed properly in Cancellaria s. s. Until the Recent cancellarids of the Pacific coast are more thoroughly studied, many of the fossil species will have to be referred to "Cancellaria."

When Howe (1922, unpublished, p. 155) was collecting, he found " $C$." siletzensis common in the sandstone exposed north and south of Newport for a distance of 8 miles; but only a few specimens were collected from that area in 1952 and 1954.

Localities: $83,94,156,161$; cf. 89.

\section{Subgenus EUCLIA H. and A. Adams}

Euclia H. and A. Adams, 1854, The genera of Recent Mollusca, v. 1, p. 277.

Type.-By subsequent designation (Cossmann, 1899, Essais de Páleoconchologie comparée, v. 3, p. 10), Cancellaria cassidiformis Sowerby. Recent, Gulf of California to Peru.

The subgenus Euclia has been described by Olsson (1932, p. 157-158), Strong (1945, p. 6), and Marks (1949, p. 457). Olsson (1932, p. 158) considered Euclia, with $C$. cassidiformis as type, to be a section of Cancellaria which included

* * * such species as cassidiformis which have a conic spire; rather large body-whorl not as strongly contracted about the base as in true Cancellaria; the body-whorl shouldered, the shoulder angle more or less tuberculate or spinous; usually a spreading parietal callus: two primary, columellar plaits and a third smaller at the end of the pillar. 
Olsson included the following species in Euclia: C. cassidiformis Sowerby and $C$. balboae Pilsbry from the Recent eastern Pacific fauna, and the fossil species $C$. harrisi Maury from the Dominican Republic, $C$. hettneri Anderson from Colombia, C. venezuelana $\mathrm{H}$. K. Hodson from Venezuela, C. larkinii Nelson from Peru, and $C$. tritonidea Gabb from the Pliocene of California.

Marks (1949, p. 459) gives as the characteristics of Euclia, body whorl with swollen axial ribs and a tendency to form spines on shoulder; outer lip internally smooth or feebly lirate. He assigned the species $C$. triangularis Nelson and C. larkinii Nelson to Euclia.

The following Pacific coast fossil species of Cancellaria are assigned to the subgenus Euclia:

Cancellaria oregonensis Conrad [Cancellaria dalliana Anderson and Cancellaria condoni Anderson are considered the same species as $C$. oregonensis.]

Cancellaria tritonidea $\mathrm{Gabb}$

Cancellaria pacifica Anderson

Cancellaria simplex Anderson

\section{Cancellaria (Euclia) oregonensis Conrad}

Plate 9, figures 15-17, 19-23

Undetermined species Conrad, 1849, U.S. Explor. Exped., Geology v. 10 , atlas pl. 20 , fig. 8 .

Cancellaria? oregonensis Conrad, 1865a, Am. Jour. Conchology, v. 1, p. 151.

Cancellaria oregonensis Conrad, 1866c, Smithsonian Misc. Colln. 200, p. 13. [Not] Cancellaria oregonensis Dall, 1909, U.S. Geol. Survey Prof. Paper 59, p. 28-29, pl. 2, fig. 7.

Trichotropis oregonensis (Conrad). Dall, 1909, U.S. Geol. Survey Prof. Paper 59, p. 77-78.

Cancellaria dalliana Anderson, 1905, California Acad. Sci. Proc., v. 2 , p. 199, pl. 15, figs. $39-42$.

Anderson and Martin, 1914, California Acad. Sci. Proc., v. 4 , p. 86 , pl. 8 , figs. 1a-1d.

Loel and Corey, 1932, California Univ., Dept. Geol. Sci., Bull., v. 22, p. 239, pl. 47, figs. 12, 13 .

Cancellaria condoni Anderson, 1905, California Acad. Sci. Proc. v. 2 , p. 200 , pl. 15 , figs. 49,50 .

Anderson and Martin, 1914, California Acad. Sci. Proc. v. 4 , p. 86 , pl. 8 , figs. $8 \mathrm{a}-8 \mathrm{~d}$.

Cancellaria oregonensis has a spire almost equal in height to the body whorl and all of the whorls are tabulate. The shell is sculptured by strong axial ribs and by weaker spiral threads; the interspaces between the axials and the spirals are not constant in width. The axials form at least a fold where they cross the tabulation of the whorls and often form a spine. The spiral at the edge of the tabulation may be split. Although the sculpture of this species shows variation, the tabulation, the height of spire, and the overall shape are constant.

Holotype: USNM 3554, pl. 9, fig. 16 (latex impression). Type locality: Astoria, Oreg.

The holotype of $C$. oregonensis is an external mold in half of a concretion; the counterpart of the concretion (USNM 3554) is also in the type collection. The specimen illustrated by Conrad (pl. 20, fig. 8) is an an external mold cited as such by Conrad (1849, p. 728), although the illustration looks like a specimen in relief or like an internal mold. The actual position of the external mold in the concretion is not the same as shown in Conrad's illustration. It seems reasonably certain that USNM 3554 is the specimen figured by Conrad; a rubber impression of this holotype is figured, plate 9 , figure 16 .

At least 2 and possibly 3 species of cancellarids proposed by Anderson (1905, p. 199-200, pl. 15, figs. $39-45,49,50)$ are the same species as $C$. oregonensis. $C$. dalliana and $C$. condoni are placed in synonymy; the type specimen of $C$. pacifica is lost.

Anderson (1905, p. 200) considered $C$. condoni to be apparently related to $C$. oregonensis. $C$. dalliana (pl. 9, figs. 20, 21) and C. condoni (pl. 9, fig. 22) were recognized by Howe (1922, unpublished, p. 133) and by Loel and Corey (1932, p. 239) as being the same species. Loel and Corey found that Cancellaria is rare in the Vaqueros horizon, and it is found only in the uppermost or Temblor transition zones. They considered $C$. dalliana and C. condoni (Anderson, 1905), to be intergradational in several Temblor horizon localities. This discussion is under the description of $C$. dalliana, and $C$. condoni is not placed in synonymy. The position of Cancellaria pacifica Anderson is in doubt because the type of this species was lost.

In comparing the illustrations (drawings) of $C$. condoni and $C$. dalli in Anderson's 1905 report with the illustrations (photographs) of the same species in the 1914 report of Anderson and Martin, it seems that the species are interchanged one for the other. This may have been a simple error caused by the mixing of the illustrations or may be a fortuitous result of the different mode of reproduction of the figures. The type specimens agree witb the photographs (Anderson and Martin, 1914) but not with the drawings (Anderson, 1905). Keen and Bentson (1944, p. 138) considered the holotype of $C$. dalliana to be lost and designated California Acad. Sci. 198 as the neotype (pl. 9, figs. $20,21)$.

Cancellaria sp. indet. of Etherington (1931, p. 108, pl. 13, fig. 11) has a higher spire than $C$. oregonensis. $C$. wynoocheensis Weaver has much finer radials and spirals than $C$. oregonensis.

Howe (1922, unpublished, p. 114) collected C. oregonensis from the Astoria formation at the corner of fifth and Commercial Streets in Astoria.

Localities: 1, 1a, 65, 69, 71, 78, 83, 84, 86, 87, 90, 92, 94, 96, 97, $102,103,105,108,112,116,127,134,136,156,161,187$; cf. 7 , $13,70,91,124,138$.

Occurrence elsewhere: Astoria(?) formation, Washington; Temblor formation, lower and middle Miocene, California. 


\section{Genus CRAWFORDINA Dall}

Crawfordina Dall, 1918, Washington Biol. Soc. Proc., v. 31, p. 138.

Type--By original designation, Cancellaria crawfordiana Dall. Recent, Bodega Bay to San Diego, Calif., Pliocene and Pleistocene of California.

\section{Crawfordina? n. sp.?}

Plate 9, figures 1, 6

One specimen is in the collections (loc. 149) which' although poorly preserved, is probably a Crawfordina and a new species. The specimen is small $(20.1 \mathrm{~mm}$ high and $11.3 \mathrm{~mm}$ wide) and has fairly strong spiral lines and less prominent axial lines. Crawfordina? $\mathrm{n}$. sp.? is somewhat similar to Crawfordina crawfordiana but differs by having a more inflated body whorl, a more deeply incised suture, and a higher, more inflated spire. The specimen of $C$. ? n. sp.? is very worn but seems not to have had the well-developed axial ribs of $C$. crawfordiana.

Locality: 149.

\section{Family OLIVIDAE}

Subfamily OLIVELLINAE

Genus OLIVELLA Swainson

Olivella Swainson, 1831, Zoological illustrations, ser. 2, v. 2, pl. 58 and text (no pagination; follows plate).

Type.-By subsequent designation (Dall, 1909, p. 31), Oliva purpurata Swainson (= Oliva dama Mawe). Recent, Pacific coast of Mexico.

\section{Olivella? sp.}

Three specimens of Olivella? were collected on the Coos Bay dredgings (loc. 187). They are poorly preserved, and most of the shell is missing, but they compare in outline and height of spire with the form illustrated by Etherington (1931, p. 106, pl. 14, fig. 10) from the Astoria formation in Washington as Olivella pedroana (Conrad), n. var. Two of the specimens were in rock with other Miocene fossils; so the form was present in the Miocene strata of Coos Bay.

Locality: 187.

\section{Family TURRIDAE Subfamily? \\ Genus SPIROTROPIS Sars}

Spirotropis Sars, 1878, Mollusca regionis Arcticae Norwegicae, p. 242 , pl. 17 , figs. 5 a, 5 b.

Type--By monotypy, Spirotropis carinata Philippi. Recent, Norway to Azores.

It has not been possible to assign Spirotropis to any of the subfamilies of the turrids. The sinus on Spirotropis is moderately deep and U-shaped and confined to the shoulder. According to Powell (1942, p. 29), the Turrinae have the sinus on or adjacent to the keel, and the sinus is deep and V-shaped. The Clavatulinae usually have the suture overlapping high onto the whorl, which is not true of Spirotropis. On the basis of the protonch, Spirotropis can be eliminated from the Turriculinae, and on the basis of the strong keel present on the Cochlespirinae can be eliminated from that subfamily also. A new subfamily may not need to be established for Spirotropis; but on the basis of the collections available and the published information on this group, no subfamily assignment could be made.

In the U.S. National Museum collections, there are two lots of Pleurotoma carinata Philippi, the type species of Spirotropis, which were collected by Sars from Norway. Spirotropis is thin shelled, has a moderately high spire, roundly keeled whorls, and the sinus, which is rather deep and $U$-shaped, is confined to the shoulder above the keel.

Cryptogemma adestia Dall, from a depth of 581 fathoms, Monterey Bay, Calif., and Cryptogemma polycaste Dall, from 786 fathoms off Tillamook Bay, Oreg., of the Recent west coast turrids, are assigned to Spirotropis. Turris kincaidi Weaver (1916, p. 53, pl. 5, fig. 67), from the Lincoln (Oligocene) and Blakeley (upper Oligocene or lower Miocene) formations of southwestern Washington, and Spirotropis washingtonensis Etherington from the Astoria(?) formation of southwestern Washington and western Oregon, of the fossil west coast species, are also included in Spirotropis.

\section{Spirotropis washingtonensis Etherington}

Plate 9, figures 7, 8; plate 10, figures 1,2

Spirotropis washingtonensis Etherington, 1931, California Univ. Dept. Geol. Sci., Bull., v. 20, p. 113, pl. 14, figs. 8, 22, 34 .

Weaver, 1942, Washington Univ. [Seattle] Pub. in Geology, v. 5 , p. 521, pl. 97, figs. 13, 14 [1943].

Spirotropis washingtonensis is of small to medium size and has a somewhat thicker shell than the thinshelled type species of the genus Spirotropis. The aperture is approximately a little less than one-third the height of the shell, and the labial sinus is moderately deep $U$-shaped and confined to the shoulder above the slightly to moderately rounded keel. There are relatively strong spiral lines below the shoulder and fine spiral lines above, which are visible only on well preserved specimens (pl. 9, figs. 7, 8; pl. 10, figs. 1, 2).

Type: California Univ. Mus. Paleontology 32042.

Type locality: Cut in Wynoochee River Highway, $500 \mathrm{ft}$. south of Black Creek railroad track, Grays Harbor County, sec. 26, T. 18 N., R. 8 W., Washington [Astoria(?) formation].

Spirotropis kincaidi (Weaver) (Weaver, 1916, p. 53, pl. 5, fig, 67), which has been collected from the Lincoln 
(Oligocene) and Blakeley (upper Oligocene or lower Miocene) formations of southwestern Washington, has a shorter wider spire and a more sharply rounded, sometimes noded, keel.

S. washingtonensis is not common in the Astoria formation in Oregon, and the specimens in the collections are generally poorly preserved and incomplete.

Localities: 92, 94, 108, 126, 161, 187; cf. 120.

Occurrence elsewhere: Astoria(?) formation, Washington.

Spirotropis calodius Moore, n. sp.

Plate 10, figures 4,9

Spirotropis calodius is a small form that has a high spire and a strongly rounded keel or shoulder. It has a strong fairly wide sutural collar and strong spiral lines beneath the keel and fine spiral lines above.

Type: USNM 563194 is chosen as the holotype.

Type locality: (187) Dredgings at Coos Bay, Oreg., Miocene.

Spirotropis calodius differs from S. washingtonensis in having a more sharply rounded keel, a sutural collar, the sinus more sharply constricted, the keel nearer the suture, and stronger spiral lines below the keel. S. calodius is slimmer and higher spired than S. kincaidi (Weaver).

$S$. calodius was collected only from the dredgings at Coos Bay where it is common.

Locality: 187.

\section{Subfamily TURRICULINAE?}

\section{Genus COMITAS Finlay}

Comitas Finlay, 1926, New Zealand Inst. Trans., v. 56, p. 251.

Type.-By original designation, Surcula oamarutica Suter(=Drillia fusilformis Hutton). Middle Miocene, New Zealand.

\section{Comitas? spencerensis Moore, n. sp.}

Plate 10 , figures 10,11

Comitas? spencerensis is a fusiform turrid that is of medium size and has a fairly thin shell. It is high spired, and the spire is at least twice the height of the aperture. The suture is sinuous, overlapping and is not collared. The sinus is shallow, and the maximum indentation is on the angulation of the shoulder. The shell is sculptured by flat-topped spiral cords and elongated axial nodes. The siphonal canal seens to have been short and straight. C.? spencerensis seems to be a new form of west coast fossil turrid; no other similar fossil turrids have been seen in the collections in the U.S. National Museum or in the literature covered. The species is tentatively assigned to Comitas, although future study may prove the need for a new generic name.
Type: USNM 563197 is chosen as the holotype.

Type locality: (Loc. 92) From big headland in beach cliffs about $600 \mathrm{yds}$. north of Spencer Creek, in 5-6 ft. of siltstone, $8 \mathrm{ft}$. above base of exposed section, Astoria formation, Miocene, Oregon.

C.? spencerensis is quite common at loc. 92 and is named for Spencer Creek, Oreg.

Localities: 83, 84, 86, 87, 92, 94, 156, 159, 161; cf. 187.

\section{Subfamily COCHLESPIRINAE}

Genus Aforia Dall

Aforia Dall, 1889, Harvard Colln. Mus. Comp. Zoology Bull., v. 18, p. 99 .

Type.-By original designation, Pleurotoma circinata Dall (=Pleurotoma insignis Jeffreys). Recent, Bering Sea to Strait of Juan de Fuca

\section{Aforia clallamensis (Weaver)}

Plate 10, figures 16,18

Turris clallamensis Weaver, 1916, Washington Univ. Pub. in Geology, v. 1, p. 52, pl. 4, fig. 59.

Leucosyrinx clallamensis (Weaver). Tegland, 1933, California Univ. Dept. Geol. Sci., Bull., v. 23, p. 123-124, pl. 10, figs. 3,4 .

Aforia clallamensis (Weaver). Weaver, 1942, Washington Univ. [Seattle] Pub. in Geology, v. 5, p. 516, p.. 97, fig. 1 [1943].

Only a few specimens of this species are in the collections. Those well enough preserved for positive identification were collected from float (loc. 157), which might have come from the Yaquina rather than the Astoria formation, or from a sandstone facies of the Nye. However, three additional specimens are in the collections from the Astoria formation (locs. 10, 112, 178) which, although too poorly preserved for positive identification, do seem to be Aforia and can tentatively be referred to $A$. clallamensis. $A$. clallamensis has been collected from the Blakeley formation of Washington (upper Oligocene or lower Miocene).

Holotype: Washington Univ. 117, California Acad. Sci. 555. [Apparently the type specimen was originally assigned a University of Washington number and later deposited in the California Academy of Sciences where it was given another number.]

Type locality: Sea cliff, half a mile west of Twin Rivers, Clallam County, Wash., sec. 27, T. 31 N., R. 10 W., Blakeley formation (upper Oligocene or lower Miocene).

Localities: 157; cf. 10, 112, 178.

Occurrence elsewhere: Blakeley formation, upper Oligocene or lower Miocene, Washington.

\section{Subfamily TURRINAE}

Genus?

"Thesbia" antiselli (Anderson and Martin)

Plate 10, figures $6,12,13,15$

Drillia antiselli Anderson and Martin, 1914, California Acad. Sci. Proc., v. 4, p. 93, pl. 7, figs. 2a, 2 b. 
Clathodrillia (Monilopsis) antiselli (Anderson and Martin). Etherington, 1931, California Univ., Dept. Geol. Sci., Bull., v. 20, p. 112, pl. 14, figs. 16, 18, 19.

Thesbia antiselli (Anderson and Martin). Weaver, 1942, Washington Univ. [Seattle] Pub. in Geology, v. 5, p. 538, pl. 99, figs. 8, 9, 10 [1943].

"Thesbia" antiselli is a small moderately thick shelled turrid; the aperture is a little less than one-third the height of the shell. The sinus is $V$-shaped, but it is tabulate at the base of the $V$, where it crosses the major spiral that forms the keel. Below the major spiral, forming the keel, there are 3 equally-spaced secondary spirals, and below these 5 finer spirals. On the whorls of the spire, there is a major cord forming the keel and one finer cord between it and the suture.

Holotype: California Acad. Sci. 226.

Type locality: According to Keen and Bentson (1944, p. 231), "CAS 65: W bank of a small canyon 11/4 mile NE. of Barker's ranch house [SE $1 / 432$, T $28 \mathrm{~S}, \mathrm{R} 29 \mathrm{E}$, Caliente quad.], Kern County [Temblor Formation], Miocene."

This turrid has most recently been assigned to the genus Thesbia of Jeffreys (1867, p. 359). The type species of Thesbia, by monotypy, is Tritonium? nanum Loven, from the Recent of northern Europe to Orkney Islands (Powell, 1942, p. 22). Thesbia nanum is a small thin-shelled form that has no strong spiral sculpture, and that has a shallow sinus on the shoulder; "Thesbia" antiselli therefore does not belong in the genus Thesbia.

"T." antiselli is closely allied to and congeneric with "Mangilia (Taranis)" strongi Arnold (1903, p. 215, pl. 9, fig. 7), which has been assigned to the genus Taranis. Taranis is small and thin shelled; the sinus is on the first strong spiral below the suture, and the species has strong cancellate sculpture. Neither "Thesbia" antiselli nor "Taranis" strongi can be placed in the genus Taranis.

Although no genus has been found to which "T." antiselli could satisfactorily be assigned, the present state of our knowledge concerning the west coast turrids is such that to propose a new generic name at this time would be undesirable.

A strongly shouldered form of " $T$." antiselli was collected at locality 71 . It is smaller and thinner shelled than the common form and has a wider more pronounced shoulder bearing a strong spiral cord marking the edge of the tabulation. The interspace below the shoulder is wider also and bears no spiral cords; below this interspace are three strong spirals (pl. 10, figs. 12, 13).

"T." antiselli is common in the rocks exposed in the sea cliffs north of Spencer Creek. It was originally described from the Temblor formation, lower and middle Miocene, California.

Localities: 69, 71, 83, 92, 109, 141, 156, 159, 161, 187; cf. 94, 128.
Occurrence elsewhere: Astoria(?) formation, Washington; Temblor formation, lower and middle Miocene, California.

\section{Subfamily CONORBINAE Powell} Genus MEgastrCULA Casey

Megasurcula Casey, 1904, Acad. Sci. St. Louis Trans., v. 14, p. 147.

Type.-By subsequent designation (Grant and Gale, 1931, p. 495), Pleurotoma (Surcula) carpenteriana Gabb. Miocene to Recent; fossil in California, Oregon, and Washington; Recent from Monterey, Calif., to Todos Santos Bay, Lower California.

Megasurcula condonana (Anderson and Martin)

Plate 9, figures 11-14, 18

Bathytoma condonana Anderson and Martin, 1914, California Acad. Sci. Proc., ser. 4, v. 4, p. 89-90, pl. 7, fig. 8.

Pseudotoma condonana (Anderson and Martin). Etherington, 1931, California Univ., Dept. Geol. Sei., Bull., v. 20, p. 110-111, pl. 14, fig. 20.

Surculites (Megasurculites) condonanus (Anderson and Martin). Grant and Gale, 1931, San Diego Soc. Nat History Mem., v. 1, p. 497.

Megasurcula condonana (Anderson and Martin). Weaver, 1942, Washington Univ. [Seattle] Pub. in Geology, v. 5, p. 530, pl. 98, fig. 4 [not?] figs. 10, 12 [1943].

Megasurcula condonana has a large body whorl in proportion to its overall size and a sinuous overlapping suture. The body whorl and spire are noded, and the whorls are very concave above the nodes; this concavity has produced a shouldered effect on the body whorl of the largest specimen (pl. 9, fig. 11). There are 8 strong equally-spaced spiral cords below the nodes on the body whorl and 1 secondary and 2 tertiary spiral cords. There are many fine spiral cords above the nodes on the body whorl and on the spire.

Type: California Acad. Sci. 214.

Type locality: Exposures in ocean cliff on south side of Yaquina Bay [Astoria formation, Oregon].

Megasurcula gabbiana (Dall) (1909, p. 28, pl. 4, fig. 1) from the Empire formation has a less inflated body whorl, slimmer spire, heavier spiral cords, and a less overlapping suture than $M$. condonana.

Megasurcula wynoocheensis (Weaver) (1912, p. 70-71, pl. 11, figs. 87-89, 94) has a higher spire, has stronger angulation above the nodes, which are finer and more numerous, and has finer spiral cords than $M$. condonana.

$M$. condonana is common on the dredgings at Coos Bay but is rare elsewhere in the Astoria formation in Oregon; Howe (1922, unpublished, p. 151) says that it is common in the Miocene [Temblor] of California.

Localities: 87, 92, 94, 108, 161, 187; cf. 83, 84, 97a, 99, 137. Occurrence elsewhere: Astoria(?) formation, Washington; Temblor formation, lower and middle Miocene, California. 


\section{Megasurcula wynoocheensis (Weaver)}

Plate 9, figures 9, 10; plate 10, figures 3, 5, 8, 14

Turris wynoocheensis Weaver, 1912, Washington Geol. Survey Bull. 15, p. 70-71, pl. 11, figs. 87-89, 94.

Weaver, 1916, Washington Univ. [Seattle] Pub. in Geology, v. 1 , p. $52-53$, pl. 5 , fig. 65 .

Pseudotoma wynoocheensis (Weaver). Etherington, 1931, California Univ. Dept. Geol. Sci., Bull., v. 20, p. 110, pl. 14, figs. $25,29$.

Surculites wynoocheensis (Weaver). Grant and Gale, 1931, San Diego Soc. Nat. History Mem., v. 1, p. 492.

Megasurcula wynoocheensis (Weaver). Weaver, 1942, Washington Univ. [Seattle] Pub. in Geology, v. 5, p. 527, pl. 98, figs. 2, 8 [1943].

Megasurcula wynoocheensis is usually a rather short, stout, species that has a moderately inflated body whorl, but it is sufficiently variable to include a rather slender high-spired form (pl. 10, figs. 3, 8), which was in Weaver's original type lot. $M$. wynoocheensis usually has small closely spaced nodes on the body whorl and on the whorls of the spire; the whorls are all shouldered. Below the nodes on the body whorl are spiral cords separated by secondary cords.

Type: California Acad. Sci. 533 is herewith designated the lectotype, pl. 10, figs. $5,14$.

Type locality: Cut on old Chehalis Logging Co. road, 1 mile west of Montesano, Grays Harbor County, sec. 6, T. 17 N., R. 7 W., Astoria (?) formation, Washington.

M. wynoocheensis does not have the sinuous overlapping suture of $M$. condonana (pl. 9, figs. 11-14, 18) and has a higher spire in proportion to size and a definite shoulder on all of the whorls. $M$. gatbiana. (Dall) is more coarsely sculptured than $M$. wynoocheensis.

Localities: 70, 90, 96, 102, 118, 150, 156, 161, 187.

Occurrence elsewhere: Astoria (?) formation, Washington.

\section{Family SCAPHANDRIDAE}

\section{Genus CYLICHNINA Monterosato}

Cylichnina Monterosato, 1884, Nomenclatura generica e specifica di alcune conchiglia Mediterranee, p. 143.

Type.-By subsequent designation (Bucquoy, Dautzenberg, and Dollfuss, 1886, p. 524), Bulla umbilicata Montagu [not Röding] (= Cylichnina strigella Lovén). Recent, Mediterranean and Adriatic seas and Atlantic Ocean.

\section{Cylichnina petrosa (Conrad)}

Plate 8, figures 6, 7

Bulla petrosa Conrad, 1849, U.S. Explor. Exped., Geology, v. 10, app. p. 727, atlas, pl. 19, fig. 8 [not Bullina petrosa Conrad, 1848, Am. Jour. Sci., v. 5, p. 433, fig. 11.]

Cylichna oregona Conrad, 1865a, Am. Jour. Conchology, v. 1, p. 151, new name for Bulla petrosa.

Haminea petrosa (Conrad). Dall, 1909, U.S. Geol. Survey Prof. Paper 59, p. 23.
Haminoea petrosa (Conrad). Weaver, 1942, Washington Univ. [Seattle] Pub. in Geology, v. 5, p. 549-550, pl. 100, figs. $16,17,23$ [not? pl. 100, figs. 18, 19] [1943].

?Haminea petrosa (Conrad). Arnold, 1908, U.S. Natl. Mus. Proc., v. 34, pl. 33, fig. 17.

The type specimen of Cylichnina petrosa is imbedded in rock and is poorly preserved. Faint spiral lines are visible on the specimen, and they seem to be evenly spaced. The aperture is buried in the matrix, and the specimen as exposed appears to be cylindrical without any inflation of the body whorl. It has not been possible to determine beyond doubt that this species has a perforate apex, but it seems to have one and it lacks the anterior flare of the aperture of Haminoea and Scaphander.

Holotype: USNM 3607, pl. 8, fig. 6.

Type locality: Astoria, Oreg.

A single unnumbered specimen with a small part of the shell intact was included in the type lot of $C$. petrosa. The shell has narrow spiral bands separated by grooves $1 / 2$ to $1 / 4$ as wide; the aperture is buried in rock.

A collection from Smiths Point, Astoria (loc. 23), contains several specimens bearing at least parts of the original shell which show the radial grooves. They seem to be identical in outline with the type of $C$. petrosa, and although it cannot be proved beyond doubt that they are conspecific, it is reasonable to conclude that they are. There are flat-topped narrow spiral bands on these specimens, separated by grooves about one-fifth as wide. The bands are usually grooved medially and tend to split into two near the posterior end of the body whorl. On some specimens the grooves are very faint, or perhaps absent, whereas on other specimens the grooves are well developed. On wellpreserved parts of shell the grooves are seen to be minutely serrated along the edges.

Specimens which have the shell intact and show the the radial grooves are in the collections made south of Astoria. The same difficulties as discussed above apply to identifying these specimens conspecifically with the type of $C$. petrosa. Again, however, it seems reasonable that they are the same. On the specimens that have the shell well preserved, it is noted that the spiral bands are not consistently even and regular, rather there are small breaks or jogs in the bands at irregular distances.

The species identified as Haminea petrosa by Arnold (1908, pl. 33, fig. 17) has not been identified.

C. petrosa is not common in the Astoria formation in Oregon.

Localities: 1a, 13, 19, 22-24, 57, 65, 71, 102, 111, 139, 147, $149,150,155,156,169,181 \mathrm{a}, 187$; cf. 63 .

Occurrence elsewhere: Astoria(?) formation, Washington. 


\section{Family ACTEOCINIDAE}

Genus CYLICHNA Lovèn

Cylichna Lovèn, 1846, Index molluscorum litora Scandinaviae occidentalia habitantium, p. 10.

Type.-By subsequent designation (Herrmannsen, 1852, Indicis Gen. Malac., Supp., p. 42), Bulla cylindradea Pennant. Recent, seas of Europe.

\section{Cylichna sp. \\ Plate 8, figures 8, 9}

One specimen which may be a Cylichna is in the collections (loc. 90). The specimen is poorly preserved, but the shell is apparently smooth and the specimen is $7.5 \mathrm{~mm}$ high and $3.0 \mathrm{~mm}$ wide.

Locality: 90 .

\section{Family? \\ Genus?}

Bullina petrosa Conrad, nomen dubium

Bullina petrosa Coprad, 1848, Am. Jour. Sci., v. 5, p. 433, fig. 11.

Cylichna petrosa (Conrad). Conrad, 1865a, Am. Jour. Conchology, v. 1, p. 151.

Cylichnella petrosa (Conrad). Dall, 1909, U.S. Geol. Survey Prof. Paper 59, p. 23.

[Not] Bulla petrosa Conrad, 1849, U.S. Explor. Exped., Geology, v. 10 , app. p. 727 , atlas pl. 19 , fig. 8 .

The type of this species has not been found in the collections of the Academy of Natural Sciences of Philadelphia. The original description is brief and the illustration is too poor for positive generic determination; Bullina petrosa is considered a nomen dubium.

\section{Scaphopods \\ Family DENTALIIDAE \\ Genus DENTALIUM Linné}

Dentalium Linné, 1758, Systema naturae, ed. 10, p. 785.

Type.-By subsequent designation (Montfort, 1810) Dentalium elephantinum Linné. Recent, Amboynaland, Philippine Islands.

\section{Subgenus DENTALIOM s. s.}

Dentalium (Dentalium?) pseudonyma Pilsbry and Sharp

\section{Plate 31, figure 2}

Teredo substriatum Conrad, 1849, U.S. Explor. Exped., Geol. app., v. 10 , p. 728 , atlas, pl. 20 , figs. $7,7 \mathrm{a}, 7 \mathrm{~b}$.

Dentalium? substriatum (Conrad). Conrad, 1865a, Am. Jour. Conchology, v. 1, p. 151. [Not Dentalium substriatum Deshayes, 1825.]

Dentalium pseudonyma Pilsbry and Sharp, 1898, Manual of conchology, ser. 1, v. 17, p. 213 (New name for Teredo substriatum Conrad).

Dentalium (Dentalium?) pseudonyma Pilsbry and Sharp. Emerson, 1958, Washington Biol. Soc. Proc., v. 71, p. 91-93.
Dentalium conradi Dall, 1909, U.S. Geol. Survey Prof. Paper 59, p. 136 (New name for Teredo substriatum Conrad [in part]; pl. 20, fig. 7a of Conrad, 1849).

Weaver, 1942, Washington Univ. [Seattle] Pub. in Geology, v. 5 , p. 267 , pl. 100, fig. 20 [1943].

Dentalium petricola Dall, 1909. U.S. Geol. Survey Prof. Paper 59, p. 136 (New name for Teredo substriatum Conrad [in part]; pl. 20, figs. 7, 7b of Conrad, 1849).

Dentalium (Rhabdus) petricola Dall. Emerson, 1958, Washington Biol. Soc. Proc., v. 71, p. 93-94.

?Dentalium cf. D. conradi Dall. Hall, 1958, California Univ. Dept. Geol. Sci., Bull., v. 34, p. 59, pl. 9, fig. 1.

Dentalium (Dentalium?) pseudonyma is finely to rather strongly striated and is circular in cross section. It is slightly larger in size and perhaps has a somewhat thicker shell on the average than Dentalium schencki. $D$. (D.?) pseudonyma does not seem to be as common in the Astoria formation in Oregon as $D$. schencki, but specimens assigned to $D$. schencki could be worn or eroded specimens of $D$. pseudonyma that do not show the longitudinal striations.

Type: Missing. Conrad's (1849) illustration, pl. 20, fig. 7a, is herewith selected to represent the lectotype.

Type locality: Astoria, Oreg.

When Conrad (1849, p. 728) proposed Teredo substriata he described it as, "Nearly straight and evenly cylindrical, very slightly tapering. Surface minutely and very neatly striate longitudinally." He illustrated three specimens and said in the plate explanation (Conrad, 1849, p. 6), "Fig. 7. Teredo substriata, $a$, another specimen; $b$, internal cast." The specimens originally figured by Conrad have not been recognized in the type collection.

Dall (1909, p. 136) found the name Dentalium substriata to be preoccupied and believing Conrad's illustrated specimens to include 2 species proposed 2 new names: Dentalium conradi for plate 20, figure 7a, which he said was finely striated and Dentalium petricola for plate 20 , figures $7,7 \mathrm{~b}$, which he said was similar to $D$. conradi except that it was perfectly smooth.

Conrad said that plate 20 , figure $7 \mathrm{~b}$, was an internal cast, so this specimen need not be further considered. This leaves $D$. conradi based on Conrad's plate 20, figure 7a, and $D$. petricola based on Conrad's plate 20, figure 7. Examination of these original figures shows figure 7a to be of a finely striated Dentalium, but the Dentalium shown in figure 7 is also drawn as finely striated. Even if it is assumed that the fine striations shown on figure 7 are the result of the method of illustration, the fact remains that Conrad in his original description said his Dentalium was "neatly striate longitudinally."

Dall presumably based $D$. petricola on USNM 3481 (pl. 31 , fig. 8 ) because he believed it to be the original 
of Conrad's figure 7, and the specimen has been so marked, perhaps by Dall. USNM 3481 is decorticated on the exposed parts whereas the specimen shown in figure 7 is not, and although it is in rock, the configuration of the rock bears no resemblance to the rock that seems to be so carefully drawn in figure 7 . The only resemblance of USNM 3481 to the specimen figured by Conrad in figure 7 is its position in the rock and its size. It is difficult to believe that these differences are only the result of artistic expression. For these reasons USNM 3481 is not here accepted as the specimen illustrated in figure 7.

When Dall proposed his substitute names, D. petricola and D. conradi, he was unaware of the prior proposal by Pilsbry and Sharp (1898, p. 213) of Dentalium pseudonyma as a new name for Dentalium substriatum. This reference was noted by Emerson (1958, p. 91). $D$. pseudonyma is a substitute name and must equal $D$. substriatum, which species seems from all available data to have been based on a finely striated Dentalium and not to have included a smooth form.

Emerson (1958, p. 91) suggested that $D$. petricola be retained for the smooth species of Dentalium that occurs in the Astoria formation. D. petricola was proposed, however, for one of Conrad's illustrations and that illustration shows fine longitudinal striations so the name cannot be used for the smooth form and must be put in the synonymy of $D$. pseudonyma. A new specific name is proposed for the smooth Dentalium (p. 51).

Howe (1922, unpublished, p. 168) collected D. pseudonyma from the Astoria formation at 5th and Commercial and 10th and Harrison Streets in Astoria.

Localities: 1, 1a, 4, 7, 12, 58, 59, 63, 71, 102, 118, 127, 136, 181, $181 \mathrm{a}, 187$.

Occurrence elsewhere: Oursan(?) sandstone and Temblor formation, California.

\section{Subgenus RHABDUS Pilsbry and Sharp}

Rhabdus Pilsbry and Sharp, 1897, in G. W. Tryon, Manual of conchology, v. 1, no. 17, pt. 66, p. 112.

Type--By original designation, Dentalium rectius Carpenter. Recent, Stephens Passage, Alaska to Panama Bay.

Dentalium (Rhabdus) schencki Moore, n. sp.

Plate 31, figure 3

Dentalium schencki is a smooth Dentalium with a medium thick shell and a circular cross section. The shell is somewhat curved with the curvature greatest in the early growth stage. This is the same form previously called $D$. petricola Dall, which name is here placed in synonymy with $D$. pseudonyma (p. 50).

Type: USNM 563335 is herewith designated the holotype.
Type locality: (loc. 102) From 25-foot silty shale bed at base of exposed section in beach cliffs forming first headland south of fill at Spencer Creek, Astoria formation, Oregon.

$D$. schencki is very abundant in the finer grained rocks in some of the exposures of the Astoria formation in Oregon. Howe (1922, unpublished, p. 169) collected $D$. schencki from the Astoria formation at 5 th and Commercial and 5th and Duane Streets, in Astoria, and Weaver records this smooth form from the Astoria(?) formation in Washington (1942, p. 267).

Localities: 1, 1a, 52, 82, 83, 91, 92, 96, 102, 116, 118, 127, 137, 139, 141, 147, 156, 187.

Occurrence elsewhere: Astoria(?) formation, Washington.

\section{Pelecypods \\ Family SOLEMYACIDAE}

Genus SOLEMYA Lamarck

Solemya Lamarck, 1818, Histoire naturelle des animaux sans vertebras, v. 5 , p. 488 .

Type.-By subsequent designation, Children, 1823, "Solenomya" mediterranea Lamarck (= Solemya mediterranea Lamarck = Tellina togata Poli, 1791, Quart. Jour. Sci., Lit., and Arts, v. 14, p. 300). (See Vokes, 1955, p. 534-535.) Recent, Mediterranean and Adriatic Seas; southeast coasts Spain and Portugal; Madeira and Senegal.

\section{Subgenus ACHARAX}

Acharax Dall, 1908, Nautilus, v. 22, p. 2.

Type.-By original designation, Solemya johnsoni Dall, 1908, U.S. Natl. Mus. Proc., v. 14, p. 712-713, 731. Recent, Puget Sound, Wash. to Ecuador (Keen, 1937, p. 25).

\section{Solemya (Acharax) ventricosa Conrad}

Plate 11, figures 1, 4, 8, 9, 11, 12

Solemya ventricosa Conrad, 1849, U.S. Explor. Exped., Geology, v. 10 , app. p. 723 , atlas, pl. 17, figs. 7,8 .

Conrad, 1865a, Am. Jour. Conchology, v. 1, p. 153.

Dall, 1909, U.S. Geol. Survey Prof. Paper 59, p. 101.

Reagan, 1909, Kansas Acad. Sci. Trans., v. 22, p. 174, pl. 1, fig. 1.

Solemya (Acharax) ventricosa Conrad. Weaver, 1942, Washington Univ. [Seattle] Pub. in Geology, v. 5, p. 18-19, pl. 5, figs. 1, 2, 3 [1943].

Vokes, 1955, Jour. Paleontology, v. 29, p. 542, 543.

Seven specimens of Solemya ventricosa from the Astoria formation are in the U.S. National Museum collections, in addition to the types. One specimen, USNM 563199, from locality 184 , is well enough preserved to show some of the external characteristics of the shell and the mineralized opisthodetic ligament (pl. 11, figs. 1, 12). The posterior part of the shell has flat-topped ribs and interspaces of equal width; 
there are at least six such ribs. The anterior part of the shell is more worn but the ribs are perhaps somewhat narrower than those on the posterior half; the ligament is large and is preserved on the specimen illustrated.

Type: USNM 3567 is herewith designated the lectotype, pl. 11, fig. 8 (figured by Conrad, 1849, pl. 17, fig. 7).

Paratype: USNM 3486, pl. 11, fig. 11 (figured by Conrad, 1849, pl. 17, fig. 8).

Holotype: Of Donax protexta Conrad = Solemya? sp., USNM 3613 , pl. 11, fig. 9.

Type locality: For all types, Astoria, Oreg.

The specimens of $S$. ventricosa originally figured by Conrad are USNM 3567 and 3486. USNM 3567 is the better preserved of the two flgured specimens and is herewith designated the lectotype. The lectotype is the largest specimen of this species in the collections. The specimen is more than $100 \mathrm{~mm}$ long (broken) and about $35 \mathrm{~mm}$ high. It is double valved and a part of the mineralized ligament remains. It is broken at the margins and only patches of the innermost shell layers are preserved.

USNM 3486 (paratype) is a small crushed specimen in a concretion and is more than $41 \mathrm{~mm}$ long (broken) and about $18 \mathrm{~mm}$ high. Enough shell is preserved to show some of the ribs, but the number was not determined.

Donax? protexta Conrad (1849, pl. 17, fig. 9), USNM 3613 , is a poorly preserved mold but is probably a small Solemya ventricosa (pl. 11, fig. 9). D.? protexta was referred by Conrad (1865a, p. 152) to Solena and then to Plectosolen $(1866 \mathrm{~b}$, p. 103). The type of $D$. ? protexta is more than $29 \mathrm{~mm}$ long (broken) and $13 \mathrm{~mm}$ high (incomplete). It has been referred to Solemya by Woodward (in Carpenter, 1857, p. 367), Meek (1864, p. 367), Dall (1909, p. 101), and Woodring (1938, p. 28).

USNM 562092, figured by Weaver (1942, pl. 5, flg. 3 ) is from the type area of the Astoria formation. The specimen shows a part of the internal shell; the number of ribs was not determined (pl. 11, flg. 4).

Weaver (1942, p. 19), in discussing the type specimens of $S$. ventricosa, suggested the possibility that some of the specimens might have been collected in older rocks than the Astoria formation in the Astoria area. He may have said this because at that time only three specimens were known of this species from the Astoria formation and these were all in the old Dana collection. This species has now been collected from other localities in the Astoria formation and in addition the lithology of the rock containing the type specimen is similar to that of the rest of the type collection from Astoria.

Howe (1922, unpublished, p. 90) said that this species was common at the corner of Fifth and Commercial Streets, in Astoria.
$S$. ventricosa is rare in the Astoria formation. It is possible that this form was restricted to a deeper water facies than usually is represented in the exposed rocks of the Astoria formation. The shell of the Recent Solemya is thin and fragile and covered by a periostracum which is extended into flngerlike projections beyond the margin of the shell; when the periostracum dries there seems to be a tendency for the shell to break. The rarity of $S$. ventricosa may be due in part to difficulty of preservation.

$S$. ventricosa resembles $S$. johnsoni Dall of the Recent, but the number of grooves on $S$. ventricosa could not be determined and on the basis of the collections in the U.S. National Museum no certain comparisons could be made.

$S$. ventricosa has been recorded from the Blakeley formation (late Oligocene or early Miocene) of Washington (Tegland, 1933, p. 100-103) and from the Pliocene of the Eel River basin, California (Martin, 1916 , p. 238, 240, 254).

Localities: 1, 1a, 1c, 5, 13, 21, 65, 184.

Ocurrence elsewhere: Blakeley formation, upper Oligocene or lower Miocene, Washington; Pliocene, Eel River basin, California.

\section{Family NUCULIDAE}

Genus NOCULA Lamarck

Nucula Lamarck, 1799, Soc. Hist. Nat. Paris Mém., ser. 1, p. 87.

Type--By monotypy, Arca nuculeus Linné. Recent, seas of Europe.

\section{Subgenus ENNUCULA Iredale}

Ennucula Iredale, 1931, Australian Mus. Rec., v. 18, p. 202, 231.

Type.-By original designation, Nucula obliqua Lamarck. Recent, Tasmania and Victoria.

The hinge has been exposed of a double-valved specimen of Nucula obliqua in the U.S. National Museum collections. This double-valved specimen was 1 of 4 dredged from Port Phillip, Victoria. The condrophore of $N$. obliqua is longer and narrower than $N$. (E.?) nuculana, and the posterior hinge margin is narrower and less produced.

Nucula (Ennucula?) nuculana (Dall)

Plate 11, figures 2, 5, 10; plate 12, figure 1

Tellina (Moerella) nuculana Dall, 1909, U.S. Geol. Survey Prof. Paper 59, p. 125-126, pl. 18, fig. 2.

Tellina nuculana Dall. Weaver, 1942, Washington Univ. [Seattle] Pub. in Geology, v. 5, p. 205-206, pl. 48, fig. 21 [1943].

Nucula washingtonensis Weaver, 1916, Washington Univ. [Seattle] Pub. in Geology, v. 1, p. 34, pl. 3, figs. 27-29.

Etherington, 1931, California Univ. Dept. Geol. Sci., Bull., v. 20 , p. 64 , pl. 1 , figs. $10-12$.

Weaver, 1942, Washington Univ. [Seattle] Pub. in Geology, v. 5 , p. 35 , pl. 8 , figs. 3,8 [1943]. 
Nucula nuculana is a small nuculid; the specimens in the collections are 6.0 to $14.3 \mathrm{~mm}$ long and 4.9 to 11.6 $\mathrm{mm}$ high. The escutcheon is well defined and heart shaped; the shell turns outward within the escutcheonal area where the valves meet and protrudes beyond the posterior margin of the rest of the shell. Fairly deep concentric irregularly-spaced grooves can be seen on well-preserved specimens; these grooves cross the escutcheon but are not as deeply incised. The hinge of a right valve (pl. 12, fig. 1, USNM 563203) has been exposed and shows 7 teeth on the posterior hinge and about 17 teeth on the anterior hinge. The condrophore is triangular and extends beneath the first six teeth of the anterior hinge. The inner margin of the shell is smooth.

Holotype: Of Tellina (Moerella) nuculana Dall, USNM $3529 \mathrm{a}$, pl. 11, fig. 10.

Type locality: Astoria, Oreg.

Holotype: Of Nucula washingtonensis Weaver, Washington Univ. 84, California Acad. Sci. 449 (apparently the holotype was first given a University of Washington number and later deposited at the California Academy of Sciences where it was also assigned a number).

Type locality: Railway cut on North River branch of the Union Pacific Railway about 2 miles south of its junction with the Grays Harbor branch in sec. 29, T. 17 N., R. 8 W., Astoria(?) formation, Washington.

The holotype of N. nuculana is a left valve, and only patches of preserved shell remain at the ventral margin. The specimen was broken off the concretion that contains one of Conrad's specimens of "Tellina" albaria (USNM 3529) by Dall. The type has a typical nuculid escutcheon, agrees in configuration with specimens formerly referred to $N$. washingtonensis and shows traces of concentric ridges. The specimen is $9.6 \mathrm{~mm}$ long, $9.0 \mathrm{~mm}$ high, and approximately $2.0 \mathrm{~mm}$ wide (oriented for measurements according to Schenck, 1936, p. 13). There is a small specimen of $N$. nuculana, in a glass vial in the same tray as the type, that can be fitted into the original rock that contains the type. This specimen was not discussed by Dall and was not numbered; it is $6.0 \mathrm{~mm}$ long, $4.9 \mathrm{~mm}$ high, and $2.9 \mathrm{~mm}$ wide (both valves).

$N$. nuculana differs from $N$. birchi Keen (1943, p. 41, pl. 3, figs. 9-12) by having an impressed escutcheon.

$N$. nuculana is not abundant throughout the Astoria formation but is very abundant in concentrated small lenses or thin layers within the silty sandstones and silty shale; it has not been found in the fine-grained shale. It is commonly associated with Cochliolepis? schoonerensis, "Nuculana" epacris, and Macoma albaria.

Localities: 1a, 33, 56, 57, 65, 66, 69a, 75, 139, 142, 145-147, $149,150,156,162,169,171,174,179,181 \mathrm{a}, 187$.

Occurrence elsewhere: Astoria(?) formation, Washington.
Nucula townsendi Dall, nomen dubium

Plate 11, figure 3

Nucula cuneiformis Conrad, 1848, Am. Jour. Sci., v. 5, p. 432, fig. 2. [Not] Nucula cuneiformis Sowerby, 1837.

Nucula townsendi Dall, 1909, U.S. Geol. Survey Prof. Paper 59, p. 101, new name for Nucula cuneiformis Conrad.

The holotype of Nucula cuneiformis Conrad was missing (Dall, 1909, p. 101) when Dall proposed the new name Nucula townsendi. An unsuccessful search was made for the type at the Academy of Natural Sciences of Philadelphia in 1958, and it is still presumed to be lost. The original illustration of $N$. cuneiformis is poor, and the description is brief. It is possible, however, that Conrad may have been describing a specimen of Nucula (Ennucula?) nuculana (Dall), but this can not be proved.

Type: Missing.

Type locality: Astoria, Oreg.

The specimen of " $N$. townsendi" (USNM 3526a) that Dall figured was said by him to have been part of the Dana Astoria collection. The fact that no other specimen similar to this form has been collected from the Astoria formation, with the possible exception of two referred to "Nucula" n. sp.?, casts doubt on the correctness of the locality data. Inasmuch as $N$. cuneiformis is considered a nomen dubium, $N$. townsendi, which has the same type, also is considered a nomen dubium.

Dall's specimen "N. townsendi" is crushed and too poorly preserved for positive identification, in my opinion, but it is probably a "Nucula" (pl. 11, fig. 3). It has strong irregularly spaced concentric ridges of varying widths and fine radial ribs visible near the posterior margin of the left valve, separated by interspaces about three times as wide as the ribs. It is also sculptured by fine closely-spaced concentric lines which split and coalesce, producing a wavy pattern, and by raised dark irregular radial ridges (particularly apparent on the left valve) that seem to be the result of secondary mineralization and not an original feature of the shell.

" $N$. townsendi" is more than two times as large as $N$. (E.?) nuculana and has strong concentric ridges and radial ribs whereas $N$. (E.?) nuculana is smooth.

Locality: Dana collection (1a)?, Astoria, Oreg.?

$$
\begin{aligned}
& \text { "Nucula" n. sp.? } \\
& \text { Plate 11, figure } 7
\end{aligned}
$$

Two specimens of "Nucula" were collected opposite 1774 Franklin Street, Astoria, by R. F. Rogers. One specimen is too poorly preserved to merit description or a definite generic assignment. The other specimen (USNM 563202, pl. 11, fig. 7) is double valved with 
the valves slightly apart but the hinge inaccessible. The shell bears regularly-spaced concentric ridges, separated by interspaces of equal width and also finer radial ribs separated by interspaces twice as wide as the ribs. The concentric ridges are crenulate where crossed by the radial ribs. This specimen seems to have finer concentric ridges than " $N$. townsendi" of Dall.

" $N . "$ n. sp.? is not quite as large as Dall's specimen of " $N$. townsendi" but is larger (12.6 mm long and $9.4 \mathrm{~mm}$ high) than the average specimens of Nucula (Ennucula?) nuculana (Dall). In addition, it has radial ribs and concentric ridges, whereas $N$. (E.?) nuculana is smooth.

Locality: 6.

\section{Genus ACILA H. and A. Adams}

Acila H. and A. Adams, 1858, Genera of Recent Mollusca, v. 2, p. 545 .

Type.-By subsequent designation (Stoliczka, 1871, India Geol. Survey Mem. Palaeontologia Indica, v. 3, p. 325), Nucula divaricata Hinds. Early Cretaceous to Recent, northern and tropical Pacific.

\section{Acila (Acila) gettysburgensis (Reagan)}

Plate 12, figures 5, 10, 12, 13

Nucula (Acila) gettysburgensis Reagan, 1909, Kansas Acad. Sci. Trans., v. 22, p. 171, 175, 177, pl. 1, fig. 3.

Dall, 1922, Am. Jour. Sci. ser. 5, v. 4, p. 306.

Schenck, 1927, California Univ., Dept. Geol. Sci., Bull., v. 16, p. $458-459$.

Tegland, 1933, California Univ., Dept. Geol. Sci. Bull., v. 23, p. 105.

Nucula gettysburgensis Reagan. Weaver, 1912, Washington Geol. Survey Bull,. 15, p. 18.

Acila gettysburgensis (Reagan). Weaver, 1916, Washington Univ. [Seattle] Pub. in Geology, v. 1, p. 28.

Clark, 1918, California Univ., Dept. Geol. Sci., Bull., v.11, p. 119 , pl. 13, fig. 9 .

Acila (Acila) gettysburgensis (Reagan). Schenck, 1936, Geol. Soc. America Special Paper 4, p. 78-81, pl. 12, figs. 1-15, pl. 13, figs. 4, 7, 9, text fig. 8 .

Weaver, 1942, Washington Univ. [Seattle] Pub. in Geology, v. 5, p. 32-34, pl. 7, figs. 1-4, pl. 8, fig. 1 [1943].

Acila gettysburgensis is moderately large and inflated, and mature specimens have a distinct rostral sinus and also a secondary bifurcation. A. gettysburgensis has been described by Schenck (1936, p. 78-81) on the basis of a suite of 41 specimens.

Holotype: USNM 328302, pl. 12, fig. 5.

Type locality: In sea cliffs near Gettysburg, Wash. Blakeley formation(?), upper Oligocene or lower Miocene.

The holotype is a right valve; the hinge is not exposed. It has a distinct rostral sinus and a secondary bifurcation just posterior to the sinus. The shell is somewhat worn but has ribs on the entire surface. A specimen with the type and from the same locality is in the type collection (pl. 12, figs. 12, 13). It is considerably larger than the holotype, and in addition to the secondary bifurcation near the rostral sinus, it shows an area of secondary bifurcation along the ventral margin. This area extends at least from the posterior end of the shell to the middle, but the rest of the shell is either worn or missing.

A. (A.). gettysburgensis differs from the associated Acila (Truncacila) conradi by having a rostral sinus, secondary bifurcation and by being larger and more inflated.

A. gettysburgensis is in the collections from the city of Astoria and from beds exposed at low tide just south of Otter Rock. Howe (1922, unpublished, p. 58) said that this species was abundant in the limestone concretions of Miocene age at the corner of 10th and Harrison Streets and also at the corner of Fifth and Duane Streets in Astoria. Schenck (1936, p. 80) records $A$. gettysburgensis from the shale in Astoria. This species is rare in the Astoria formation, but it is present, and it is not restricted to, or an indisputable guide to, beds of Blakeley age or equivalent, as suggested by some authors. It has also been collected from the Monterey formation (Miocene) of California (Schenck, 1936, p. 80).

Localities: 1, 13, 19, 156; ? cf. 7, 9, 38, 174, 177.

Occurrence elsewhere: Blakeley formation, upper Oligocene or lower Miocene Washington and Oregon; Monterey formation, Miocene, California.

\section{Subgenus TRONCACILA Schenck}

Truncacila Schenck, 1931, in Grant and Gale, San Diego Soc. Nat. History Mem., v. 1, p. 115.

Type.-By original designation, Nucula castrensis Hinds. Type locality, Recent, Sitka, Alaska. Pliocene of California and Oregon, Pleistocene of California, Recent, Bering Sea to San Diego, Calif.

\section{Acila (Truncacila) conradi (Meek)}

Plate 12, figures $2-4,6-9$

Nucula divaricata Conrad, 1848, Am. Jour. Sci, v. 5, p. 432, figs. 1a, $1 \mathrm{~b}$.

Conrad, 1849, U.S. Explor. Exped., Geology, v. 10, app. p. 725-726, atlas pl. 18, figs. 6, 6a. [Not Nucula divaricata Hinds, 1843, Zool. Soc. London Proc., pt. 11, p. 97 (a Recent species).]

Nucula (Acila) conradi Meek, 1864, Smithsonian Misc. Colln., v. 7 , no. 183 , p. 27 , new name.

Conrad, 1865a, Am. Jour. Conchology, v. 1, p. 153.

Dall, 1909, U.S. Geol. Survey Prof. Paper 59, p. 102-103 [not pl. 12, figs. 4, 5, nor Empire specimens].

Etherington, 1931, California Univ. Dept. Geol. Sci. Bull., v. 20, p. 64 , pl. 1, figs. 1, 3, 18.

Acila (Truncacila) conradi (Meek). Schenck, 1936, Geol. Soc. America Spec. Paper 4, p. 82-85, pl. 8, figs. 1-3, 5-10, 12-14, text fig. 7 . 
Weaver, 1942, Univ. Washington [Seattle] Pub. in Geology v. 5 , p. $29-30$, pl. 4 , fig. 3 , pl. 6 , figs. $10-12,18$, pl. 8 , figs. 4 , 10 [1943].

In addition to the features of Acila conradi described by Schenck (1936, p. 82-85), young specimens have bifurcated radial ribs which extend to the ventral margin, whereas on mature specimens these ribs may be obliterated by concentric lines. Fine concentric lines are numerous on the entire surface of the shell and form concentric ridges where they are crowded together at irregular intervals.

Type: USNM 3526 is herewith designated the neotype, pl. 12, fig. 6. This is the specimen cited by Weaver (1942, p. 30) as the holotype, but the U.S. National Museum number was inadvertently printed as 5526 .

Type locality: Astoria, Oreg.

The type specimen of Conrad's Nucula divaricata, collected by Townsend from Astoria, Oreg., is presumably lost. A search was made at the Philadelphia Academy of Natural Sciences in 1957 for the holotype but it was not found. The specimen illustrated subsequently by Conrad in 1849 (pl. 18, figs. 6, 6a) has not been recognized but could be the specimen here designated the neotype. The neotype is a single left valve contained in a concretion with the internal mold in one half and the impression of the outer shell layers, showing the sculpture, in the other half. The specimen Conrad illustrates is not shown in rock, but specimens contained in rock were not always so drawn by Dana. The neotype agrees in size with the specimen Conrad illustrates but not in exact configuration nor does it show the marked growth stages; it is 14.4 $\mathrm{mm}$ long and about $10.3 \mathrm{~mm}$ high. It is assumed that the specimen was handled by Conrad.

Dall (1909, p. 102) thought that the specimen here designated the neotype was the original type of this species, collected by Townsend and described by Conrad in 1848 (p. 432, figs. 1a, 1b), but the neotype is entered in the U.S. National Museum catalog book as having been collected by Dana, not Townsend, and it seems reasonable to assume that the entire Townsend collection was kept in the Academy of Natural Sciences of Philadelphia.

A. conradi is common in the Astoria and is particularly abundant in beds exposed from Spencer Creek on the north, south to Yaquina Head. Most of the specimens collected occur with the valves articulated and closed.

Howe (1922, unpublished, p. 5-7) collected $A$. conradi from the Astoria formation at Fifth and Commercial Streets in Astoria.

Localities: 1, 1a, 26, 33c, 36, 37, 48, 50, 68, 69, 71, 79, 81, $83,84,87,89-92,94,98,99,102 a, 104-108,110-112,116,117$,
$120-122,124,126,128,130,134,138-140,144,145,149,156$, $161,163,164,167,187$.

Occurrence elsewhere: Astoria(?) formation, Washington; Temblor formation, lower and middle Miocene, California.

\section{Family NUCULANIDAE}

New genus?

"Nuculana"' epacris Moore, n. sp.

Plate 12, figures 15, 16, 18; plate 13, figure 8

"Nuculana" epacris is small to moderately large, rather highly inflated for its size, high in proportion to length, and the beaks slightly anterior. It has a sharply-pointed posterior end and an evenly rounded anterior end. The shell is produced along the dorsal hinge margin - slightly at the anterior end and markedly at the posterior end. There are deep concentric grooves on the shell, more closely spaced at the ventral than the dorsal margin and absent at the anterior and posterior dorsal margin. The anterior and posterior series of teeth are approximately equal in length and the chondrophore is trigonal and deeply inset.

Holotype: USNM 563208, pl. 12, figs. 15, 16, 18.

Type locality: (loc. 150) From siltstone on north side of Yaquina Head, beneath igneous extrusion of basalt which forms the head, Astoria formation, Miocene, Oregon.

Paratype: USNM 563215, pl. 13, fig. 8.

Locality: (loc. 139) From $10 \mathrm{ft}$ of silty shale, $25 \mathrm{ft}$ above the base of exposed section in headland about $1,250 \mathrm{ft}$ north of Schooner Creek, Astoria formation, Miocene, Oregon.

This nuculanid cannot be properly assigned to any of the genera or subgenera of the Nuculanidae studied, but a great deal more work is needed on both the Recent and the fossil genera and subgenera of nuculanids before a new name is proposed.

"N." epacris is more elongate than "Nuculana" chehalisensis (Weaver) and more pointed at the posterior end, according to W. P. Woodring (written communication, 1959), who kindly compared my specimens with the types of "N." chehalisensis. " $N$." epacris is higher in proportion to length and also more pointed at the posterior end than Saccella ochsneri (Anderson and Martin): the holotype and a paratype of S. ochsneri from the Temblor formation are figured, plate 13 , figures 1-3, 7. " $N$." epacris also lacks the flattened area bordered by a slight ridge present at the posterior dorsal margin of S. ochsneri.

" $N$." epacris is common throughtout the Astoria formation in Oregon, particularly in the siltier rocks, where it is apt to be associated with Cochliolepis? schoonerensis Moore.

Localities: $33,52,68,73,81 \mathrm{a}, 94,102,111,134,139,144-150$, $152-156,158,169,171,172,174$; cf. 57. 


\section{Genus IITORHADIA Stewart}

Litorhadia Stewart, 1930, Acad. Nat. Sci. Philadelphia Spec. Pub. 3, p. 52-53.

Type,-By original designation, Leda acala Dall (1898, Wagner Free Inst. Sci. Trans., p. 586, pl. 32, fig. 3). Eocene, Wood's Bluff, Ala.

\section{Litorhadia astoriana (Henderson)}

Plate 12, figures 11, 14, 17, 21

Nucula impressa Conrad, 1849, U.S. Explor. Exped. Geology, v. 10, append. p. 726 , atlas pl. 18, figs. 7a-7c. [Not Nucula impressa Sowerby, 1825 or Hall, 1845.]

Yoldia (Portlandia) astoriana Henderson, 1920, Nautilus, v. 33, p. 122, new name for Nucula impressa Conrad.

Hanna, 1924, California Acad. Sci. Proc. ser. 4, v. 13, p. 185-186.

Nuculana astoriana (Henderson). Grant and Gale, 1931, San Diego Soc. Nat. History Mem. 1, p. 122, pl. 32, figs. 46-48.

Nuculana impressa (Conrad). Weaver, 1942, Washington Univ. [Seattle], Pub. in Geology, v. 5, p. 42-43, pl. 4, figs. 9, 10 [not pl. 8, fig. 31], [1943].

[Not] Yoldia impressa (Conrad). Reagan, 1909, Kansas Acad. Sci. Trans., v. 22, p. 177, pl. 1, fig. 4 (Yoldia reagani Dall, new name, 1922, Am Jour. Sci., v. 4, p. 306.)

The lectotype of Litorhadia astoriana (USNM 3490) is a double-valved specimen with the valves together and hinged but not completely closed. The shell of the right valve is broken along the ventral margin and covered by matrix at the posterior margin; only small patches of the original shell remain on the left valve. The anterior end is rounded, the posterior end is pointed and abruptly terminated; the beaks are slightly anterior of the middle of the shell. The lunule is long, incised, and flat; the escutcheon is wide, long, and deeply impressed, and the shell is produced at the dorsal margin within the escutcheonal area. There are concentric grooves on the shell separated by slight ridges. These grooves are particularly noticeable on the middle of the shell and near the ventral margins, but they seem to be missing from the umbonal area and the anterior and posterior ends of the shell. The type specimen is more than $18.9 \mathrm{~mm}$ leng (posterior end covered), more than $9 \mathrm{~mm}$ high (ventral margin broken), and $6.7 \mathrm{~mm}$ wide. The type may not have been one of the specimens figured by Conrad; although it resembles somewhat in configuration, the specimen figured on plate 18 , figure $7 \mathrm{~d}$, it is smaller and not as complete as the drawing.

Type: Lectotype (Grant and Gale, 1931, pl. 32, fig. 46), USNM 3490, pl. 12, fig. 11.

Paratypes: USNM 561529, pl. 12, fig. 14 and USNM 3491 pl. 12, fig. 17.

Type locality: Astoria, Oreg.

Four additional specimens of L. astoriana are in the type lot. Two of these specimens are internal molds that have no shell remaining and were originally contained in the same nodule. These are the specimens figured by Grant and Gale (1931, pl. 32, figs. 47, 48); the specimen figured in plate 32 , figure 48 has been assigned the number USNM 561529; that in plate 32 , figure 47 retains USNM 3491. Two additional specimens, USNM 561528 (original number, 3491), are broken at the margins and have only retained very small patches of the original shell.

The specimens originally figured by Conrad (pl. 18, figs. $7 \mathrm{a}-7 \mathrm{e}$ ) have not been recognized in the type lot of L. astoriana. Either the specimens illustrated are all missing or the drawings are poor representations.

I. astoriana is not abundant throughout the Astoria formation in Oregon. Most of the specimens were collected from the city of Astoria and from the Coos Bay dredgings. The largest specimen (USNM 563210) measures more than $27 \mathrm{~mm}$ long (broken at posterior margin), $14.4 \mathrm{~mm}$ high, and $9.7 \mathrm{~mm}$ wide, plate 12 , figure 21; this specimen was collected from silty shale exposed just south of Fogarty Creek, north of Newport (loc. 63).

Localities: 1a, 7, 19, 22, 36, 45, 55, 56, 58, 61, 63, 64, 108, $109,130,183,184,187$; cf. 48.

Occurrence elsewhere: Monterey formation (Miocene), California.

\section{Genus SACELLA Woodring}

Sacella Woodring, 1925, Carnegie Inst. Washington Pub. 366, p. 15, new name for Ledina Sacco, 1898.

Type.-By original designation, Arca fragilis Chemnitz (=Leda commutata Philippi). Miocene to Recent, Mediterranean Sea.

\section{Saccella calkinsi Moore, n. sp.}

Plate 13, figures 10-13

Saccella calkinsi is moderately large, the beaks are centrally located, and it is highly inflated for its size. The rostrum is blunt and slightly recurved, and the escutcheonal area is large and ovate and extends from the umbos almost to the posterior margin. The escutcheon is bounded by a narrow flat-topped ridge and is separated into two parts by a smaller, somewhat obscure secondary ridge. The entire shell has equallyspaced concentric ridges which continue without interruption into the escutcheonal area, but they disappear almost completely at the secondary ridge an $\rfloor$ are absent in the lunule area.

Holotype: USNM 563219; pl. 13, figs. 12, 13.

Type locality: (loc. 181) In $40 \mathrm{ft}$ of silty shale exposed in beach cliffs, at end of first long straight stretch of U.S. Highway 101 south of Yaquina Bay bridge, half a mile south of Nye mudstone fossil-collecting locality on U.S. Geol. Survey Oil and Gas Inv. Map 88. Astoria formation, Oregon.

Paratype: USNM 563218, pl. 13, fig. 11.

Locality: (loc. 181a) About 3 miles south of Newport, Oreg. From $50 \mathrm{ft}$ of siltstone exposed in beach cliffs south of Grant Creek, sec. 31, T. 11 S., R. 11 W., Astoria formation. 
Paratype: USNM 563217; pl. 13, fig. 10.

Locality: (loc. 120) From 1-2 ft extremely fossiliferous siltstone, same stratigraphic horizon as loc. 106, in beach cliffs immediately south of Wade Creek, Astoria formation, Oregon.

$S$. calkinsi resembles the Recent California species Saccella taphria (Dall), but the rostrum of S. calkinsi is not as strongly recurved, and the escutcheon is longer, narrower, and has a secondary ridge. In addition, the lunule of $S$. taphria is wider and more ovate in outline.

This species is named in honor of my friend and critic, F. C. Calkins of the U.S. Geological Survey, to whom I am indebted for reading and criticizing this paper in his inimitable way.

Localities: 48, 69, 79, 86, 102, 104, 116, 120, 124, 167, 180a, 181, 181a, 183, 184.

Occurrence elsewhere: Astoria(?) formation, Washington.

Saccella amelga Moore, n. sp.

Plate 13, figures 4-6

Saccella amelga can be distinguished by its small size, elongation, and the presence of heavy concentric ridges widely spaced on the shell. These ridges are less prominent on the anterior end than on the middle of the shell and are barely perceptible at the posterior end. The escutcheon is deep and bordered by a ridge-. typical of Saccella-and the shell is produced in the escutcheonal area along the hinge (pl. 13, fig. 5). The posterior end of the shell is abruptly truncated but slightly pointed. The beaks are situated about one-third the distance from the anterior end. 4-6.

Type: USNM 563214 is chosen as the holotype, pl. 13, figs.

Type locality: (loc. 156) From shale and siltstone exposed in beach at low tide, just south of Yaquina Head, Astoria formation, Miocene, Oregon.

S. amelga resembles Saccella ochsneri (pl. 13, figs. 1-3, 7) from the Temblor formation California, but differs by having sharp concentric ridges which are not flattened as on $S$. ochsneri and by having them more widely spaced. S. amelga is also shorter anteriorly, the beaks are closer to the anterior margin, and it lacks the deeply incised, ridgelike lunule of $S$. ochsneri.

S. amelga differs from Saccella calkinsi by being smaller, more elongate, less pointed at the posterior end and by having the beaks much closer to the anterior margin and the concentric ridges more widely spaced and more ridgelike.

Localities: $60,69,71,83,84,86,87,90-92,94,108,110,112$, 116, 156, 161.
Genus PORTLANDIA Mörch

Portlandia Mörch, 1857, Prodromus Mollusea Grønlandica, p. 21.

Type.-By subsequent designation, Yoldia glacialis Wood (=Yoldia portlandia Hitchcock). Pleistocene and Recent.

\section{Subgenus PORTLANDELLA Stewart}

Portlandella Stewart, 1930, Acad. Nat. Sci. Philadelphia Proc., Spec. Pub. 3, p. 61-62.

Type.-By original designation, Leda rosa Hanna. Eocene, La Jolla, Calif.

Portlandia (Portlandella) reagani (Dall)

Plate 12, figures 22,23

Yoldia impressa (Conrad). Reagan, 1909, Kansas Acad. Sci. Trans., v. 22, p. 177, pl. 1, fig. 4. [Not Nucula impressa Conrad, 1849, U.S. Explor. Exped., Geology v. 10, app. p. 726 , atlas pl. 18, figs. $7 \mathrm{a}-7 \mathrm{c}$.]

Yoldia reagani Dall, 1922, Am. Jour. Sci., ser. 4, v. 4, p. 306, new name for Yoldia impressa (Conrad) of Reagan.

Weaver, 1942, Washington Univ. [Seattle] Pub. in Geology, v. 5 , p. 52 , pl. 9 , fig. 6 [1943].

?Yoldia chehalisensis (Arnold). Tegland, 1933, California Univ., Dept. Geol. Sci., Bull., v. 23, p. 110-111, pl. 5, figs. 16-18.

Weaver, 1942, Washington Univ. [Seattle] Pub. in Geology, v. 5 , p. $45-46$, pl. 8 , figs. $35-38$ [1943].

Three specimens from the Astoria formation in Oregon are assigned to Portlandia reagani on the basis of external shell characters only; no hinge was available for study. The anterior margin of $P$. reagani is evenly rounded; the posterior margin is abruptly truncatedalmost at a right angle to the dorsal margin. The shell is produced at the posterior dorsal margin and apparently gapes slightly at the posterior end; the umbos are slightly anterior. The shell is almost smooth but may have a few concentric ridges.

Holotype: USNM 328303, pl. 12, figure 23.

Type locality: Gettysburg, East Clallam, Wash. [Blakeley formation, late Oligocene or early Miocene].

It is possible that $P$. reagani should be assigned to "Malletia" chehalisensis Arnold (1908, p. 365, pl. 33, figs. 9, 9a; holotype USNM 165447), but the type of this species is an immature specimen, and its affinities have not been determined. On the basis of the original illustrations only, "Malletia" packardi Clark (1918, p. 125 , pl. 12 , fig. 3 , pl. 14 , figs. 5,6 ) is more conca ve at the posterior dorsal margin than Portlandia reagani and is more sharply pointed posteriorly.

The type of $P$. reagani $(24.1 \mathrm{~mm}$ long, $13.7 \mathrm{~mm}$ high, and $8.8 \mathrm{~mm}$ wide, both valves) is smaller than the three 
specimens from Oregon, and it has only retained small patches of the original shell. The shell is worn in the hinge area, and 18 posterior teeth are revealed; the anterior hinge has more than 10 teeth, possibly 13 or 14. The specimen figured from Oregon (pl. 12, fig. 22) is $29.4 \mathrm{~mm}$ long, $17.0 \mathrm{~mm}$ high, and $11.4 \mathrm{~mm}$ wide (both valves).

Howe collected "Yoldia (Portlandia) impressa (Conrad)" from the Astoria formation at Fifth and Commercial Streets in Astoria; this may be $P$. reagani.

Localities: 174, 180a, 183; cf. 1.

Occurrence elsewhere: Blakeley(?) formation, upper Oligocene or lower Miocene and Astoria formation, Washington.

\section{Genus yoLdIA Möller}

Yoldia Möller, 1842, Index molluscorum groenlandiae, p. 18.

Type.-By subsequent designation, Yoldia arctica (Gray) Möller $[=Y$. hyperborea (Gould)]. Recent, northern seas of Europe.

\section{Yoldia n. sp.?}

Plate 12, figure 19

Seven poorly preserved specimens of a Yoldia that is apparently undescribed are in the collections from the Astoria formation. Yoldia n. sp.? is small, thin, and has concentric grooves. The umbos are situated in the middle of the shell; the anterior end is fairly evenly rounded; and the posterior end is strongly rostrate.

Yoldia n. sp.? may be conspecific with the form identified by Etherington (1931, p. 67, pl. 1, fig. 8) as "Yoldia oregona (Shumard)," from the Astoria(?) formation in southwestern Washington. The lectotype of Yoldia oregona has been located at Washington University and is now on permanent deposit in the U.S. National Museum (Trumbull, 1958, p. 900, pl. 115, fig. 3). Y. oregona (pl. 12, fig. 20) is higher in proportion to length; the beaks are nearer the anterior margin; the posterior end is more rostrate; and the posterior dorsal margin is more concave than Yoldia n. sp.? and the specimen figured by Etherington (1931).

Localities: 58, 63, 69, 104, 120.

\section{Subgenus KALAYOLDIA Grant and Gale}

Kalayoldia Grant and Gale, 1931, San Diego Soc. Nat. History Mem., v. 1, p. 128.

Type.-By original designation, Yoldia cooperi Gabb. Miocene? to Recent, Pacific coast of the United States.

Yoldia (Kalayoldia) cf. Y. (K.) cooperi Gabb

A few fragments of Yoldia (Kalayoldia) sp. were collected from the rocks at Whale Cove and Cape Kiwanda; these are compared to Yoldia (Kalayoldia) cooperi Gabb (1865, p. 189). The fragments are too poorly preserved for positive identification, but they show the form to have been rather large, bearing deeply incised concentric grooves; the fragments compare favorably with Recent specimens of $Y$. cooperi in the U.S. National Museum collections.

Howe (1922, unpublished, p. 104) collected Yoldia cooperi from the Astoria formation at the foot of 19th Street in Astoria.

Localities: $50,76$.

\section{Family GLYCYMERIDIDAE ${ }^{2}$}

Subfamily GLYCYMERIDINAE

Genus GLYCYMERIS da Costa

Glycymeris da Costa, 1778, Historia naturalis testaceorum Brittanniae, or the British conchology, p. 168.

Type.-By tautonomy, Glycymeris orbicularis da Costa (=Arca glycymeris Linné). Recent, seas of Europe.

\section{Glycymeris sp.}

Plate 11 , figure 6 ; plate 13 , fig. 9

There are 3 specimens of Glycymeris in the collections; 1 from Astoria, 1 from Cape Kiwanda, and 1 from the Newport area. One additional specimen from Astoria has been seen in the H. V. Howe collection at the California Academy of Science (pl. 11, fig. 6). These specimens may not be the same species, but they are too poorly preserved for comparison.

The specimen in the U.S. National Museum collections from Astoria (USNM 3541) is part of the old Dana collection and was labeled "Cardium sp." with Conrad as identifier, but not in Conrad's handwriting. Dall (1909, p. 107-108) questionably referred this specimen to Glycymeris conradi Dall (Empire formation, Pliocene?), stating that it was too imperfect to be certain of the species but that it was positively a Glycymeris. This specimen consists of impressions of pieces of shell and a small part of the hinge. The specimen may have been about $30 \mathrm{~mm}$ high, and the impression shows the ribs to be raised and grooved.

The specimen of Glycymeris from Astoria in the Howe collection at the California Academy of Science is small $(21.7 \mathrm{~mm}$ long, $21.6 \mathrm{~mm}$ high, and $13.0 \mathrm{~mm}$ thick, both valves) and very much worn. The ribs are raised and apparently were not grooved (pl. 11, fig. 6).

The specimen collected at Cape Kiwanda (loc. 50) is poorly preserved with patches of worn shell present at the margins only (pl. 13, fig. 9). The shell may have been smooth without raised ribs. It is more sharply pointed at the umbo and higher in proportion to the length than Glycymeris grewingki Dall (1909, p. 107, pl. 2, fig. 13) from the Empire formation (Pliocene?) of Coos Bay, Oreg.

\footnotetext{
2 Stenzel, Krause, and Twining (1957, p. 60), feminine ending.
} 
A small worn broken immature specimen was collected from the beach cliffs south of Schooner Creek (loc. 108). It may have had a smooth shell.

Glycymeris is rare in the Astoria formation in Oregon; it has been collected by Howe from the corner of Fifth and Commercial Streets in Astoria.

Localities: 1, 1a, 50, 108.

\section{Family ARCIDAE Subfamily ANADARINAE \\ Genus ANADARA Gray}

Anadara Gray, 1847, Zool. Soc. London Proc., pt. 14, p. 198

Type.-By original designation, Arca antiquata Linné. Type locality not determined.

Subgenus ANADARA s. s.

Anadara (Anadara) devincta (Conrad)

Plate 13 , figures 14,15 ; plate 14 , figures 1-13

Arca devincta Conrad, 1849, U.S. Explor, Exped., Geology, v. 10, app. p. 726, atlas pl. 18, figs. 10, 10a.

Anomalocardia? devincta (Conrad). Conrad, 1865a, Am. Jour. Conchology, v. 1, p. 153.

Anomalocardia devincta (Conrad). Conrad, 1866c, Smithsonian Misc. Colln. 200, v. 7, p. 4.

Arca (Scapharca) devincta Conrad. Dall, 1909, U.S. Geol. Survey Prof. Paper 59, p. 109-110.

Arca (Anadara) devincta Conrad. Etherington, 1931, California Univ., Dept. Geol. Sci., Bull., p. 68-69, pi. 2, figs. 1-5, 8, pl. 3 , fig. 6 .

Anadara (Anadara) devincta (Conrad). Weaver, 1942, Washington Univ. [Seattle] Pub. in Geol., v. 5, p. 72-73, pl. 12, fig. 16, pl. 13, figs. 4,8 , [1943].

Anadara (Anadara) devincta subsp. devincta (Conrad). Reinhart, 1943, Geol. Soc. America, Spec. Paper 47, p. 43-45, pl. 6 , figs. 6,8 .

Anadara devincta (Conrad). Stewart, 1946, U.S. Geol. Survey Prof. Paper 205-c, pl. 17, fig. 7.

Arca (Scapharca) microdonta Conrad. Dall, 1909, U.S. Geol. Survey Prof. Paper 59, p. 110, USNM 3497 Dall's specimens only [not USNM 1844, type $A$. microdonta Conrad, in Blake, H. Doc. 129, app. prelim. rept., p. 13, 1855.]

Arca procumbens Wiedey, 1928, San Diego Soc. Nat. History Trans., v. 5, p. 132, pl. 13, figs. 9-11.

Arca (Arca) trilineata wantanabei Kanehara, 1935, Venus, v. 5, no. 5 , p. $275,276-277$, pl. 13 , figs. $1,2$.

?Arca (Anadara) ogawai Makiyama, 1926, Kyoto Imp. Univ., Coll. Sci. Mem., ser. B, v. 2, no. 3, p. 154, pl. 12, fig. 16.

?Arca (Arca) ogawai Makiyama. Kanehara, 1935, Vemus, v. 5 , no. 5 , p. 275,276, pl. 13 , figs. 3,4 .

?Anadara devincta (Conrad). Lutz, 1951, Califormia Univ., Dept. Geol. Sci., Bull., v. 28, p. 385, pl. 16, figs. 7, 8 .

Anadara devincta includes forms quadrate to posteriorly elongate in outline, thin to highly inflated, possessing a narrow to very wide cardinal area, and forms that have smooth ribs, ribs medially split, or smooth ribs split at the ventral margin. On specimens preserved with the valves articulated and closed, the left valve is seen to overlap the right valve slightly along the ventral margin. The variations in outline, inflation, and ribbing bear no correlation to the size of the specimens, except that the thin forms become inflated as they mature and the cardinal area is coincidentally widened.

Type: USNM 3499 is herewith considered the obligatory lectotype, pl. 13, figs. 14,$15 ;$ pl. 14, fig. 2 . This is the same specimen that was called the holotype by Schuchert $(1905$, p. 55), Weaver (1942, p. 73), and by Reinhart (1943, p. 44, pl. 6, figs. 6, 8).

Paratype: USNM 563379 (original No. 3499), pl. 14, figs. 1, 3. Type locality: Astoria, Oreg.

The lectotype figured by Conrad (1849, pl. 18, fig. 10) was in a rock in which several specimens of Anadara were partially exposed. Dall (1909, p. 109) broke up this rock to expose the specimens. He recovered four incomplete and broken specimens which were retained under USNM catalog No. 3499. Loose pieces of shell have been reglued to the specimens where possible; so the lectotype as illustrated here (pl. 13, figs. 14, 15, pl. 14, fig. 2) differs slightly from Reinhart's (1943, pl. 6 , figs. 6,8 ) illustrations of the type. When all the pieces of the rock and Anadara were put back together and held in place, the overall outline differed from that shown in the original illustration (Conrad, 1849, pl. 18, fig. 10), and there was no sign of the specimens that seem to be carditids shown on the original drawing. The Anadara shown exposed in the rock in the original illustration, however, agrees closely with the specimen here designated the lectotype, and the carditids shown in the original drawing are presumed to be anadarids.

The lectotype is poorly preserved and lacks some of the original shell. The right valve is almost complete and measures approximately $37 \mathrm{~mm}$ long, $29 \mathrm{~mm}$ high, and $15 \mathrm{~mm}$ wide, but the beak has been worn and the ribs are exposed only on the posterior dorsal margin. The ribs seem to be split by three grooves; the number of ribs was not determined. The cardinal area is not exposed but seems to have been fairly wide for the size of the specimen. A paratype in the original type lot, USNM 563379 (pl. 14, figs. 1, 3), although quite incomplete, does show that the ribs are split by three grooves and that the middle groove is apparently deeper and wider than the grooves on either side. The lectotype is quadrate in outline and inflated; it belongs in either the split rib or inflated form groups. The type specimen has been described by Dall (1909, p. 109-110) and supplementary descriptions of the Anadara devincta group have been made by Etherington (1931, p. 68-70) and by Reinhart (1943, p. 44-45).

There are three forms of Anadara devincta in the Astoria formation in Oregon; a thin, an inflated, and a split-rib form. The names that have been assigned to these forms in the Astoria are: Anadara devincta (Conrad) or $A$. devincta var. devincta or $A$. devincta 
subsp. devincta; Anadara montereyana (Osmont) or $A$. devincta var. montereyana; and Anadara procumbens (Wiedey).

Young specimens of the split-rib form (pl. 14, figs. $4,7,9,12$ ) have usually been referred to Anadara devincta or the subspecies devincta. These young specimens are quadrate in shape (length 2.5 to $5 \mathrm{~cm}$ ), thin to moderately inflated (thickness, 1.5 to $3 \mathrm{~cm}$ ), have a narrow cardinal area, and have ribs split by one deep center groove. The mature forms are posteriorly elongated (length, 6 to $6.5 \mathrm{~cm}$ ), are moderately to greatly inflated (thickness, 3.5 to $4.5 \mathrm{~cm}$ ), have a wide cardinal area, and have ribs split by three grooves. The beaks are situated about two-thirds the distance from the posterior margin.

The thin form (pl. 14, fig. 6) is usually moderate in size (length, 3 to $3.5 \mathrm{~cm}$ ), subquadrate in shape, and thin (thickness, 1.5 to $2.5 \mathrm{~cm}$ ) and has a narrow cardinal area and ribs split by 1 or 3 grooves.

Anadara montereyana seems to be related to the Anadara devincta group, on the basis of the original illustration and description. The thin form of $A$. devincta closely resembles $A$. montereyana but differs from this species (or possibly form of $A$. devincta) in the following characters: anterior dorsal margin is more rounded, beaks are more anteriorly located and less pronounced, and specimens never reach the size of the type specimen $A$. montereyana. It is possible that the variability of $A$. montereyana is sufficient to include these discrepancies, in which case $A$. montereyana might be considered a form of $A$. devincta.

The inflated form (pl. 14, figs. 5, 8, 10, 13) is subovate when young (length, 2.5 to $5 \mathrm{~cm}$ ) and posteriorly elongated when mature (length, 5.5 to $7 \mathrm{~cm}$ ), it is moderately to greatly inflated when small (thickness, 2 to $4 \mathrm{~cm}$ ) and greatly inflated when large (thickness 4.5 to $5.5 \mathrm{~cm}$ ). The beaks are three-fourths the distance from the posterior margin on young specimens and two-thirds this distance on mature specimens. The ribs are smooth on young specimens and split by 1 or 3 grooves at the ventral margin on large specimens.

The small form originally named Anadara procumbens (Wiedey) (pl. 14, figs, $5,8,10,13$ ) is quite distinct from the form that has usually been called $A$. devincta (pl. 14, figs. 4, 7, 9, 12). The young specimens previously referred to $A$. procumbens (pl. 14, fig. 5) and here called $A$. devincta, inflated form, are greatly inflated for their size, have a wide inequilateral cardinal area, the beaks close to the anterior margin, and smooth rounded ribs. On the basis of large collections, including mature specimens, it is not possible to separate the inflated form of $A$. devincta into a distinct speciesthat formerly called $A$. procumbens.
The inflated form that has been called $A$. procumbens and the split-rib form that has been called $A$. devincta are usually readily separated when well preserved and immature. However, out of a total of more than 500 mature specimens of Anadara, representing these two forms, less than 30 percent could be separated. $A$. devincta, split-rib form, although usually thin and quadrate in outline when immature, tends to become posteriorly elongated and quite inflated as it reaches maturity, and the cardinal area is coincidently widened. On specimens that are somewhat worn, the grooving of the ribs which might serve as a distinguishing feature is destroyed. Large specimens of $A$. devincta, inflated form, that appear identical with the typical young form that has been called $A$. procumbens, develop split ribs along the ventral margin particularly at the posterior end. As a result of the variations noted within these two groups it is impossible to separate any but the best preserved specimens on the basis of the grooving of the ribs, which seems to be the only consistent character, and then there is often some question as to which form is represented. Of pertinency is the fact that the splitrib form and inflated form of $A$. devincta occur together at the same locality and in the same horizon within a single stratigraphic unit.

In addition to the difficulties just mentioned, it has not been possible to determine if the poorly preserved type specimen of Anadara devincta belongs to the inflated form or to the split-rib form, as these names are used here. On the basis of the poorly preserved type specimen, $A$. devincta could be considered perhaps a doubtful species and be disregarded, but inasmuch as this name has been used extensively on the west coast for more than one hundred years, it seems that this might be carrying taxonomical rules beyond the best practical limits.

Dall (1909, p. 110) assigned USNM 3497 in the Dana Astoria collection to Arca (Scapharca) microdonta Conrad. This internal mold is referred to A. devincta. Arca microdonta Conrad is presumably a synonym of either Arca auriculata Lamarck (Woodring, 1938, p. 31) or of Arca deshayesii Hanley (Reinhart, 1943, p. 47), currently known as Arca notabilis Röding, which has priority (Abbott, 1954, p. 344). Apparently Arca microdonta is not a west coast species and according to Woodring $(1938$, p. 31$)$ the type was possibly collected by Blake from Pleistocene deposits on the Atlantic coast of Panama near Colon. Anadara? mierodonta (Conrad) of Weaver (1942, pl. 12, fig. 14) is probably Anadara (Anadara) topangensis Reinhart (1943, p. 53-54).

The California Miocene species of Anadara that seems to be most closely related to the Oregon Miocene 
Anadara devincta group (split-rib and inflated forms) is Anadara osmonti (Dall). Dall proposed this name for a specimen of Anadara identified by Osmont (1904, p. 90-91, pl. 9, fig. 2a, 2b) as $A$. microdonta Conrad. $A$. osmonti (Dall) differs from $A$. devincta, on the basis of the poorly preserved topotype material available for comparison, by having a flattened ridge beginning beneath the anterior edge of the beak and extending to the anterior margin along the upper edge of the cardinal area. The cardinal area is inequilateral on all specimens, including the smallest, which possess a narrow cardinal area. The larger specimens of $A$. osmonti have a wide inequilateral cardinal area and resemble Anadara devincta, inflated form, in outline. However, the anterior cardinal ridge of $A$. osmonti is not found on $A$. devincta, inflated form; and the ribs of $A$. osmonti are split by 1 groove on small specimens and 3 grooves on larger specimens, whereas the ribs are smooth on $A$. devincta, inflated form, except on the ventral margin of large specimens.

Anadara trilineata (Conrad) of Arnold (Woodring, Stewart, and Richards, 1940, p. 89), a Pliocene species in California, differs from $A$. devincta by generally maintaining a moderately.inflated shell throughout its growth, by usually having a fairly narrow cardinal area which is however wide on some large specimens, and by being higher usually in proportion to length. The ribs are grooved like $A$. devincta, split-rib form, but they seem to be consistently fewer in number, $A$. trilineata averaging about 25 and $A$. devincta, split-rib form, about 32 .

Anadara (Anadara) devincta montesanoana (Etherington) (1931, p. 69-70, pl. 3, figs. $1-5,7,8$ ) is trigonal rather than quadrate in outline and seems to be allied more closely to Anadara (Anadara) trilineata (Conrad) than to $A$. devincta.

Through the kindness of paleontologists at Tōhoku University, Japan, there is a topotype specimen of Anadara (Anadara) watanabei (Kanehara) (pl. 14, fig. 11 ) in the collections. On the basis of shell characters, this Japanese species cannot be separated from $A$. devincta, split-rib form. On the basis of illustrations only, it seems possible that $A$. ogawai may also be $A$. devincta, split-rib form. A. watanabei was collected from the Taga series (Kokozura formation), Miocene, and A. ogawai was collected from the Tanagura formation, Miocene, Japan.

The fossil Anadara on the west coast has probably been assigned too many names, and some of the single characters on which species have been based are too variable to be reliable. For example, the splitting of ribs is variable and often changes as a species matures with the splitting becoming more complex, or appearing for the first time along the ventral margin. The infla- tion of the shell also changes markedly with size as does the width of the cardinal area. Also, specimens which are quadrate when immature may be elongated posteriorly when adult. In other words, $A$. devincta, splitrib form, when immature is quadrate in outline, only slightly elongated posteriorly, and thin to moderately inflated and has a narrow cardinal area and ribs split often by a single groove, whereas when it is mature it is much more elongated posteriorly, is highly inflated, and possesses a wide cardinal area, and the ribs are split by three grooves.

Typical small specimens of $A$. devincta, inflated form, occur in great abundance in the rocks exposed in beach cliffs and roadcuts north of Spencer Creek. Larger specimens are abundant in the Anadara layer beneath the lower barren marker (fig. 7) at all localities where this layer is exposed south of Spencer Creek.

A. devincta, thin form, is not common in the Astoria formation of Oregon and seems to be restricted to the siltier rocks.

$A$. devincta, split-rib form, occurs commonly throughout the sections exposed. The largest specimens occur with $A$. devincta, inflated form, in the Anadara bed beneath the lower barren marker.

Howe (1922, unpublished, p. 62) collected $A$. devincta from the Astoria formation at Fifth and Commercial Streets in Astoria.

Localities: Thin form-65, 66, 145, 149, 150, 153, 155, 156, 158; inflated form-87a, 94, 95, 95a, 99, 102, 110, 112, 116, 119, $121,125,128,139,149,156,161,163$; split-rib form-48, 55, 58, $61,67,69 \mathrm{a}, 71,75,78-84,87,87 \mathrm{a}, 87 \mathrm{~b}, 88,90-92,94,95,98,99$, $101,102,102 \mathrm{a}, 103,104,107,108,110-112,116,117,120,125$, $128-130,137-139,142,143,146,156,158,159,161,169,173$, $174,177,181,181 \mathrm{a}, 183,184$; form indet.-1, 1a, 4, 38, 48, 79, $81,86,87,94,99,101,102,104,105,107,108,116,117,119-$ $122,124,125,128,136-138,140,146,156,158,159,161,163$, $181,181 \mathrm{a}$.

Occurrences elsewhere: Astoria(?) formation, Washington; Temblor formation, lower and middle Miocene, Sobrante and Briones sandstone, late Miocene. California; Kokozura formation and Tanagura formation, Miocene, Japan.

\section{Family LIMOPSIDAE}

\section{Genus LIMOPSIS Sasso}

Limopsis Sasso, 1827, Giornale Ligustico di Scienze, Lettere, ed Arti, year 1, p. 476 .

Type--By monotypy, Arca aurita Brocchi. Miocene and Pliocene, Italy.

\section{Limopsis nitens (Conrad)}

Plate 15, figures 2, 5

Pectunculus nitens Conrad, 1849, U.S. Explor. Exped., Geol., v . 10 app. p. 726 , atlas pl. 18, figs. 9a, 9b.

Limopsis nitens (Conrad). Meek, 1864, Smithsonian Mise. Colln., v. 7, no. 183, p. 6 .

Conrad, 1865a, Am. Jour. Conchology, v. 1, p. 153. 
Dall, 1909, U.S. Geol. Survey Prof. Paper 59, p. 106-107.

Weaver, 1942, Wash. Univ. [Seattle] Pub. in Geology, v. 5, p. 75-76, pl. 13, fig. 15 [1943].

Limopsis nitens has fine irregular concentric lines and small punctures arranged in radial lines which may cover the entire shell, only the margins, or be absent entirely. The lectotype is $7.6 \mathrm{~mm}$ wide and $7.5 \mathrm{~mm}$ high; the hinge is not accessible. The shell has exfoliated on a left valve in the type collection and reveals some of the taxodont hinge; there are perhaps 5 anterior and 4 posterior teeth.

Type: USNM 3579, specifically the specimen illustrated (pl. 15, fig. 2) and shown by an arrow (pl. 15, fig. 5), is herewith designated the lectotype.

Type locality: Cited as Astoria, Oreg.; this locality may be erroneous.

In the Dana collection there is a piece of a very fine grained shale (USNM 3579), about 4 by 4 inches, on which there are many specimens of Limopsis nitens, one Solemya? sp., fish remains, and an unidentified coral; this is the specimen that bears the lectotype. There is an old label with this specimen on which is written, "Pectunculus nitens (Con), Miocene, Astoria, Oregon"; T. A. Conrad is listed as the identifier, but the writing is not in Conrad's hand. The printed No. 31 on a small white square of paper is glued to the rock; similar numbers are commonly found on the Dana collections. Although the data just cited concur with the locality given (Astoria, Oreg.), it is possible that this specimen was not collected from Astoria. Weaver $(1942$, p. 76$)$ says that nodules containing large numbers of $L$. nitens occur on the north side of the Columbia River opposite Astoria in the cliffs at the river's edge about half a mile east of Knappton, and he suggests that the type may have been collected from Knappton opposite Astoria on the north side of the Columbia River. This suggestion merits consideration. There is no reason to suppose, however, that Dana collected on the north side of the Columbia. The specimen concerned is a very fine grained, dense shale, unlike rock types usually found in the Astoria formation farther south, and the only specimens of $L$. nitens in the collections are from this rock. Howe (1922, unpublished, p. 70) said that he was unable to obtain any specimens of this species at Astoria.

Locality: Dana collection (1a) from Astoria, Oreg.?

Limopsis? oregonensis Conrad, nomen dubium

Arca Conrad, 1849, U.S. Explor. Exped., Geol., v. 10 , app. p. 726 , atlas pl. 18 , figs. $11 \mathrm{a}, 11 \mathrm{~b}$.

Limopsis? oregonensis Conrad, 1865a, Am. Jour. Conchology, v. 1, p. 153.

The holotype of this species has not been recognized. It was originally described by Conrad (1849, p. 726) as "A cast having a rhomboidal outline, with prominent beaks." On the basis of the original description and illustration, no conclusions as to the generic assignment of $L$.? oregonensis were reached. Dall $(1909$, p. 106) placed $L$.? oregonensis in synonymy with $L$. nitens in order to dispose of the name; it is here considered a nomen dubium.

Holotype: Not recognized, missing?

Type locality: Astoria, Oreg.

\section{Family MYTILIDAE \\ Genus MYTILUS Linné}

Mytilus Linné, 1758, Systema naturae, ed. 10, p 704.

Type.-By subsequent designation (Anton, 1839, Verzeichniss der conchylien welche sich in der Sammlung von H. E. Anton befinden, p. 17) Mytilus edulis Linné. Mesozoic to Recent, Cosmopolitan.

\section{Mytilus sp. \\ Plate 15, figure 4}

Two small immature specimens of Mytilus are in the U.S. National Museum collections. The shell seems to have been smooth and not to have had any plications. It is abruptly angulated at the anterior ventral margin and seems to have been evenly rounded posteriorly.

Localities: 90, 144.

\section{Mytilus cf. M. middendorff Grewingk}

About a dozen specimens of this form were collected in the dredgings of Coos Bay. They do not occur with any other species that can be identified, and they may have been dredged from the Empire formation (Pliocene?). None of the specimens are complete, but they are heavy-shelled and have strong plications. Dall (1890, p. 89) named a new mytilid, Mytilus condoni, from the marine Pliocene of Shoalwater Bay, Wash. I am indebted to H. G. Hertlein (written communication, 1956) for calling this reference to my attention. Mytilus condoni was based on specimens that probably belonged to Thomas Condon and may be in the Condon collection at the University of Oregon. No type was designated, the species is not figured, and the descriptive remarks are brief. If the original specimens cannot be located, Mytilus condoni should be considered a nomen dubium. Dall said that the species could be identified by a few strong divaricating ridges extending from about the middle of the valves toward the posterior margin.

Mytilus middendorffi has been reported from the Oligocene of Alaska (F. S. MacNeil, oral communication, 1960) and the Miocene of Alaska and California.

Locality: 187. 


\section{Genus MODIOLDS Lamarck}

Modiolus Lamarck, 1799, Mémoires de la Société d'Histoire Naturelle de Paris, p. 87, 88.

Type.-By tautonymy, Mytilus modiolus Linné. Recent in northern seas.

\section{Modiolus directus Dall}

Plate 15, figure 1, 11

Modiolus directus Dall, 1909, U.S. Geol. Survey Prof. Paper 59, p. 113-114, pl. 12, figs. 11, 12 .

Clark, 1915, California Univ., Dept. Geol. Sci., Bull., v. 8, pl. 42 , fig. 4 .

Etherington, 1931, California Univ. Dept. Geol. Sei. Bull., v. 20, p. 73 , pl. 4 , fig. 4 .

Weaver, 1942, Washington Univ. [Seattle] Pub. in Geology, v. 5 , p. 108 , pl. 23 , fig. 6 , pl. 25, fig. 2 [1943].

Four specifically identifiable specimens are in the collections at the U.S. National Museum. The specimens are intermediate in size between Modiolus directus Dall, plate 15, figure 11, and Modiolus inflatus Dall (1909, p. 114, pl. 12, figs. 8, 9) (=Modiolus trinominata Hanna, new name), pl. 15, fig. 3. Weaver (1942, p. 110 ) suggested that $M$. inflatus may have been collected from the Tunnel Point sandstone of Oligocene age in Oregon. The type specimen was purchased by Dall from Camman and the locality data given is "Empire beds, Coos Bay, Oregon." The lectotype of Modiolus inflatus is herewith designated as USNM 153946 (pl. 15, fig. 3), the specimen figured by Dall; the remaining specimen in the type lot bears no catalog number.

Holotype: USNM 153947, pl. 15, fig. 11.

Type locality: USGS 2954, "Empire beds, Coos Bay, Oregon"; purchased from Camman.

Etherington (1931, p. 73, pl. 4, fig. 4) illustrated a specimen from the Astoria formation of southwestern Washington which he assigned to Modiolus directus. Howe (1922, unpublished, p. 76) collected Modiolus rectus Conrad, which he considered to be conspecific with Modiolus directus, from the Astoria formation at the foot of 19th Street in Astoria.

Modiolus directus seems to be allied to the Recent species $M$. recta Conrad. $M$. directus is higher in proportion to overall length than $M$. recta, and $M$. directus does not seem to have been as produced anteriorly as $M$. recta, although the anterior margins of the fossil specimens are broken.

Localities: 1, 1a, 146, 149; ef. 7 .

Occurrence elsewhere: Astoria(?) formation, Washington; Empire formation, Pliocene(?), Oregon; San Pablo group, Miocene, Callifornia.

\section{Genus CRENELLA Brown}

Crenella Brown, 1827, Illus. Conchology, Great Britain, v. 1, pl. 31 , figs. $12-14 ; 1844$, ed. 2 , p. 75 , pl. 23 , figs. $12-14$.

Type.-By monotypy?, Mytilus decussatus Montagu. Recent, Scottish coast, type locality.
Crenella cf. C. porterensis Weaver

Plate 15, figure 6

Crenella cf. C. porterensis is subovate in outline, somewhat flattened along the posterior dorsal margin, and moderately inflated. The outer shell has fine closely spaced radial ribs and incremental concentric threads with irregularly spaced concentric lines. The inner shell layers are pearly. A small part of the posterior hinge on one left valve shows closely spaced small teeth.

This form is represented by about 20 specimens in the collections and is perhaps a new species. Because of poor preservation and the lack of comparative material in the U.S. National Museum, it has not been possible to determine if this Crenella is a new species or if it should be assigned to $C$. porterensis (Weaver) (1912, pl. 14, fig. 116; 1916, p. 36-37, pl. 3, figs. 41, 42).

Crenella is rare in the Astoria formation, but the fragileness of the original shell and the resulting difficulties of preservation may be the factors determining abundance.

Localities: 1c, 7, 31-33, 45, 48, 60, 61, 94, 108, 119, 167, 174, 187.

\section{Family PECTINIDAE}

\section{Genus PATINOPECTEN Dall}

Patinopecten Dall, 1898, Wagner Free Inst. Sci. Trans., v. 4, p. 695.

Type--By original designation, Pecten caurinus Gould. Recent, Cordova, Alaska to Point Reyes, Calif. (Hertlein, 1940, Nautilus, v. 54, p. 68-69).

In the course of this study, it has been noted that the right valve of Patinopecten caurinus extends beyond the left valve at the anterior and posterior and dorsal margins. The left valve of a Recent specimen in the collections at the U.S. National Museum (USNM 134823 ) is about $180 \mathrm{~mm}$ high and $198 \mathrm{~mm}$ wide; the right valve extends beyond the left valve a maximum of $8 \mathrm{~mm}$. It has also been noted that the byssal notch of the right anterior ear if folded slightly, so that it protrudes beyond the rest of the ear, and that the left anterior ear is folded at the dorsal margin away from the interior and then folded in towards the right valve. There are fine interribs irregularly spaced on parts of the left valve and interribs are also occasionally present on the right valve, but without a regular pattern or spacing.

An imbricated lamellar microsculpture may be preserved on Patinopecten and Vertipecten. This sculpture is usually seen on left valves, but it may be present on either valve. It is present on exceptionally well preserved specimens of Patinopecten propatulus (pl. 17, fig. 7), on Patinopecten oregonensis oregonesis, and on 
Vertipecten fucanus, from the Astoria formation; it is also seen on Recent specimens of Patinopecten yessoensis (Jay) from Japan. The only microsculpture seen on Recent specimens of Patinopecten caurinus in the collections is thin lamellar projections on the growth lines. These lamellae may be slightly irregular but are usually even, regular, and closely spaced. The imbricated lamellar microsculpture on Patinopecten and Vertipecten is composed of thin lamellae that are closely scalloped, with the scallops in each row alternating with those in the next (pl. 17, fig. 4) to form an imbricated pattern. On $P$. yessoensis these imbricated lamellae are topped with a thin shell layer, apparently leaving a honeycomblike structure beneath. On Recent specimens it is apparent that the shell layer showing this sculpture is very loosely cemented to the underlying shell, for this layer is rarely present and then only in small patches. When the lamellae are completely removed by abrasion, a scalloped barely traceable pattern remains on the shell. It is my opinion that this type of sculpture on $P$. yessoensis is the same as that remaining on well-preserved specimens of $P$. propatulus and $V$. fucanus.

Patinopecten propatulus (Conrad)

Plate 16, figures 1-4; plate 17 , figures $2-5,7$

Pecten propatulus Conrad, 1849, U.S. Explor. Exped., Geology, v. 10 , app. p. 726 , atlas pl. 18, figs. 13,13 a.

Meek, 1864, Smithsonian Misc. Colln., v. 4, no. 183, p. 26.

Conrad, 1865a, Am. Jour. Conchology, v. 1, p. 154.

Pecten (Patinopecten) propatulus Conrad. Dall, 1898, Wagner Free Inst. Sci. Bull., v. 3, p. 699.

Arnold, 1906, U.S. Geol. Survey Prof. Paper 47, p. 64-65, pl. 7, fig. 1 [not pl. 9, figs. 1, 1a, 2, 2a].

Dall, 1909, U.S. Geol. Survey Prof. Paper 59, p. 112, pl. 16, fig. 1, [not pl. 15, figs. 1, 1a, 2, 2a].

Grant and Gale, 1931, San Diego Soc. Nat. History Mem., v. 1, p. 192-193, pl. 22, fig. 5 .

Weaver, 1942, Washington Univ. [Seattle] Pub. in Geology, v. 5, p. 91, pl. 19, fig. 6, pl. 20, fig.2 [1943].

Vertipecten cf. $V$. propatulus (Conrad). Stewart, 1946, U.S. Geol. Survey Prof. Paper 205-C, pl. 17, fig. 4.

Patinopecten propatulus is of moderate size and the valves are slightly and equally inflated. There are 16 to 22 flat-topped to slightly rounded or flattened finely striated ribs on the right valves and 15 to 18 evenly rounded or ridgelike ribs on the left valves. The right anterior ear has a moderately deep byssal sinus and the surface of the ear above the sinus is ribbed; the right posterior and left valve ears are finely ribbed. The right and left anterior ears are folded. Well-preserved left valves show the surface to be sculptured by an imbricated lamellar microsculpture (pl. 16, fig. 2); this sculpture may also be present on the left valve ears; it has not been found on right valves.

Type: USNM 3504 is herewith designated the lectotype, pl. 16, figs. 1,4 . This is probably the specimen figured by Conrad
(1849, pl. 18, fig. 13). The lectotype has been previously figured by Grant and Gale (1931, pl. 22, fig. 5) and Weaver (1942, pl. 20, fig. 2).

Paratypes: USNM 3568.

Type locality: Astoria, Oreg.

The lectotype is an internal mold of both valves and only fragments of the innermost shell layer remain. The specimen was contained in a concretion and apparently only the right valve was exposed when Conrad described the species; the specimen was removed from the concretion at some later date, and both valves are now exposed. There are 16 flat-topped to slightly rounded ribs on the right valve and the interspaces are flat to slightly rounded and wider than the ribs. The left valve has probably more than 13 rounded ribs and the interspaces are slightly rounded and wider than the ribs. The lectotype is approximately $10.3 \mathrm{~cm}$ high and $10.2 \mathrm{~cm}$ wide (broken along margins).

The number and configuration of the ribs and interspaces on both valves of Patinopecten propatulus is variable. The right valve has 16 to 22 ribs; 19 ribs are most common. The interspaces may be narrow, less than a third the width of the rib, or more commonly as wide or somewhat wider than the rib. Both the ribs and the interspaces are usually flat, but they may be slightly rounded. The ribs are often square but may be moderately undercut, and show fine radial striations on well-preserved specimens. There is occasionally an interrib in some of the interspaces especially near the anterior and posterior margins of the shell. There may also be as many as five threadlike ribs on the anterior or posterior margin of the shell; these fine ribs were not included in the rib counts.

The anterior ear on the right valve has a moderately deep byssal sinus covering more than a third of the total area of the ear and 3 to perhaps more than 5 imbricated ribs on the upper part of the ear. The posterior right ear has 5 to 10 ribs usually about half as wide as those on the anterior ear. These ribs may be of equal width and may alternate with very fine threadlike ribs.

The left valve has 15 to 18 ribs which are usually evenly rounded, but which may rise abruptly to a narrow ridge or may be flat-topped. Both types of ribs may be present on the same specimen. The interspaces may be flat, slightly rounded, or moderately round and may contain a fine interrib. The interribs when present are usually centered in the interspace but may be crowded close to the posterior side of the rib. Flangelike lamellae are present near the dorsal end of the first few posterior ribs on two left valves (loc. 104), plate 17, figure 4.

The left anterior ear has 5 to 8 or more ribs, similar in size to those on the posterior ear of the right valve, 
and it usually has fine threadlike interribs. On all but immature specimens, the posterior ear is depressed medially. The left posterior ear is sculptured by 6 to 8 ribs, similar in weight to those on the anterior ear but without the fine interribs that are often present on the anterior ear.

An imbricated lammelar microsculpture may be present on the left valve of $P$. propatulus and is fairly well preserved on one specimen (pl. 16, fig. 2). This microsculpture is on a thin now chalky shell layer that flakes off leaving no trace of the presence of the microsculpture and the remaining shell seems to be perfectly preserved. This microsculpture is described under the generic heading (p. 63).

Poorly preserved specimens of $P$. propatulus, or specimens of only the right valve, are difficult to separate from Vertipecten fucanus (Dall). The shell of $P$. propatulus is usually thinner; the ribs on the right valve are often flatter; and the byssal sinus somewhat more shallow. Ribs on the right valve of $V$. fucanus may be split, whereas they commonly are not on $P$. propatulus and may be more conspicuous, narrower, and more closely and irregularly spaced; and in some specimens unevenly split, with one part half the width of the other. Because of variations in the ribs on both $P$. propatulus and $V$. fucanus, it has not always been possible to separate incomplete specimens of the two forms beyond any possible doubt.

The specimen in the original type lot of $P$. propatulus figured by Arnold (1906a, pl. 9, figs. 1, 1a, 2, 2a) and Dall (1909, pl. 15, figs. 1, 1a, 2, 2a) as a cotype, but questioned as being conspecific by Grant and Gale (1931, p. 192), is assigned to Vertipecten fucanus (Dall) (p. 66).

$P$. propatulus is allied to $P$. caurinus (Gould) of the Recent, which has been collected from sedimentary Rocks as old as Pliocene and possibly Miocene in age. Recent specimens of $P$. caurinus reach a much larger maximum size than $P$. propatulus. The ribs on the right valve of $P$. caurinus tend to disappear near the margins on large specimens, and the ribs on both ears of the right valve are poorly developed, being barely discernible on some specimens. The ribs on the left valves of $P$. caurinus are usually flat topped whereas on $P$. propatulus this is rare, although they may be rounded similar to those of $P$. propatulus. The ribs on the left valve also tend to disappear along the margins of large specimens of $P$. caurinus. The ribs on the ears of the left valve of $P$. caurinus tend to be finer than those on $P$. propatulus. Interribs are less frequently present on both the right and the left valves of $P$. caurinus. The umbonal angle on $P$. propatulus is narrower than on $P$. caurinus, $P$. pro- patulus averaging about $100^{\circ}$ and $P$. caurinus averaging about $125^{\circ}$.

P. propatulus is common in the Astoria formation and is particularly abundant in the rocks exposed in the Johnson Creek area, just south of Otter Rock, and in the 6 feet of siltstone $1 \frac{1 / 2}{2}$ feet beneath the lower barren marker in the rocks intermittently exposed south of Spencer Creek to south of Schooner Creek (pl. 33). Howe (1922, unpublished, p. 85) collected this species from Fifth and Commercial Streets in Astoria and from concretions in the "Astoria shale." He also recorded $P$. propatulus from the Miocene of Contra Costa County, Calif. The abundance of Patinopecten is not always indicated by the number of specimens in the collections; the thinness of the shell in relation to its overall size makes it difficult to collect.

Localities: 1, 1a, 3, 4, 22, 32, 37, 56, 59, 60, 61, 66, 67, 71, $79,82-84,89,94,99-101,102 \mathrm{a}, 103-108,112,119,123,134$, $135,137,139,140,144,149,156,158,181$.

Occurrence elsewhere: Astoria(?) formation, Washington; Temblor formation, lower and middle Miocene, California.

Patinopecten oregonensis cancellosus Moore, n. subsp.

Plate 17 , figures $6,8,9$; plate 18 , figures 1,4

The right valve of Patinopecten oregonensis cancellosus has 14 to 18 , most commonly 14 or 15, flat-topped undercut ribs and interspaces usually of equal width, but $1 \frac{1}{2}$ times as wide on the largest specimens. The right anterior ear has a moderately deep byssal sinus above which are 3 or 4 imbricated ribs. The right posterior ear is sculptured by 4 to 6 imbricated ribs. The left valve has 13 to 16 , most commonly 13 or 14 , evenly rounded high ribs which may in some places be slightly flattened. Interribs are present on some specimens, usually near the posterior and anterior margins of the shell. The left anterior ear, entire on only 1 specimen, has 9 fine ribs; the left posterior ear has 6 or 7 ribs equal in width to those on the anterior ear. The entire surface of the disk of the left valve has an imbricated, lamellar microsculpture present only on well-preserved specimens; this sculpture is apparently not present on the right valve and is the same microsculpture seen on left valves of $P$. propatulus and Vertipecten fucanus.

Holotype: USNM 563242, pl. 18, fig. 4

Type locality: (loc. 187) Dredgings from the Miocene rocks, Coos Bay, Oreg.

Patinopecten oregonensis oregonensis (Howe) (1922, p. $98-99$, pl. 11 , fig. 1 , pl. 12, figs. 1,2 ) has been collected from the Empire formation (Pliocene?) at Coos Bay, Oreg. It is a heavier shelled form than $P$. propatulus, has higher ribs, which are undercut, and also has a wider umbonal angle than $P$. propatulus. 
$P$. oregonensis cancellosus differs from $P$. oregonensis oregonensis by having fewer ribs separated by wider interspaces and larger ears bearing a wider and deeper byssal sinus. The left valve of $P$. oregonensis cancellosus is more inflated than $P$. oregonensis oregonensis and has fewer ribs, and these ribs are higher and usually less rounded. $P$. oregonensis cancellosus reaches a larger maximum size than any of the specimens of either $P$. propatulus or $P$. oregonensis oregonensis in the collections in the U.S. National Museum; the largest specimen is about $170 \mathrm{~mm}$ high and $190 \mathrm{~mm}$ wide.

$P$. oregonensis cancellosus differs from $P$. propatulus by having a heavier shell and fewer ribs on both valves, and these ribs higher and more strongly developed than on $P$. propatulus. In addition the ears on both valves of $P$. oregonensis cancellosus are larger than on $P$. propatulus, and the byssal sinus is wider and deeper.

$P$. oregonensis cancellosus resembles $P$. coosensis (Shumard) from the Empire formation (Pliocene?) of Coos Bay, differing only in the number of ribs. $P$. oregonensis cancellosus has 14 to 18 ribs on the right valve and 13 to 16 on the left valve, whereas $P$. coosensis has 24 to 29 and about 27 , respectively.

$P$. oregonensis cancellosus has only been collected from the dredgings at Coos Bay, but it has been found associated in rock with known Miocene mollusks and is therefore known to have been a Miocene species.

Locality: 187

\section{Genus VERTIPECTEN Grant and Gale}

Vertipecten Grant and Gale, 1931, San Diego Soc. Nat. History Mem., v. 1, p. 188-189.

Type.-By original designation, Pecten nevadanus Conrad. Lower and middle Miocene of California.

Vertipecten is an endemic Pacific coast species first recorded from the Tejon formation (upper Eocene) in California, and perhaps it became extinct before the late Miocene, being last recorded in rocks of middle Miocene age in Washington, Oregon, and California, and possibly in Alaska.

\section{Vertipecten fucanus (Dall)}

Plate 19, figures 1,2 ; plate 20 , figure 8 ; plate 21 , figures 1 , 3 ; plate 22 , figures 1,4

Pecten (Chlamys) fucanus Dall, 1900, Wagner Free Inst. SciTrans., v. 3, pt. 4, p. 704, pl. 26, fig. 7 .

Dall, 1904, Harriman Exped. Repts., Alaska geology, Neozoic invertebrate fossils, p. 113.

Arnold, 1906, U.S. Geol. Survey Prof. Paper 47, p. 66-67, pl. 10, figs. 1, 2, 2a.

Pecten (Vertipecten) nevadanus (Conrad) var. fucanus Dall. Grant and Gale, 1931, San Diego Soc. Nat. History Mem., v. 1, p. 190 [not? pl. 7, figs. la, 1b.].

Pecten (Patinopecten) propatulus Conrad. Arnold, 1906, U.S. Geol. Survey Prof. Paper 47, p. 64-65, pl. 9, figs. 1, 1a, 2, 2a [not pl. 7, fig. 1].
Dall, 1909, U.S. Geol. Survey Prof. Paper 59, p. 64-65, pl. 9, figs. 1, 1a, 2, 2a; [not pl. 7, fig. 1].

The median rib on the left valve of Vertipecten fucanus is always elevated above the others; the fourth rib on either side may also be elevated, but to a lesser degree; and in some places the second rib on the anterior and posterior side of the median rib is elevated. The ribs on the left valve are usually strong, narrow, and rounded, and the median rib is less rounded than the others. An imbricated, lamellar microsculpture is often preserved on the left valve and is usually particularly apparent on the elevated median rib. This is the same sculpture (see p. 63) that is present on left valves of Patinopecten propatulus (pl. 16, fig. 2) and $P$. oregonensis cancellosus. This microsculpture may be seen also on some places on the left valve ears of $V$. fucanus. There is usually one interrib in each interspace on the left valve, but there may be as many as 2 or 3 . On the right valve of $V$. fucanus there are about 15 or 16 slightly rounded flat-topped finely striated ribs in some places with a median groove. The interspaces seem to be smooth, without any interribs.

Holotype: USNM 107790, pl. 19, figs. 1, 2.

Type locality: In shaly sandstone in cliff of beach section $11,000 \mathrm{ft}$ southeast of Slip Point and 13,000 ft due east of the town of Clallam Bay, Clallam County, $\mathrm{NE}^{1 / 4} \mathrm{SE}_{1 / 4}^{1 / 4}$ sec. 22, $\mathrm{T}$. 32 N., R. 12 W., Astoria formation, Washington (Weaver, 1942, p. 88); USGS 2464, Clallam Bay, on the Strait of Juan de Fuca, about 25 miles east of Cape Flattery, Clallam County, Wash. J. S. Diller, collector, 1892 (U.S. Geol. Survey Cenozoic loc. book).

The holotype of $V$. fucanus is the external cast of a left valve (pl. 19, fig. 2). A gutta-percha impression was made to show the characters of the shell more clearly (Arnold, 1906a, pl. 10, figs. 2, 2a); and a latex impression is figured herein (pl. 19, fig. 1). The holotype is $81.8 \mathrm{~mm}$ wide, $84.3 \mathrm{~mm}$ high, and approximately $12 \mathrm{~mm}$ thick (left valve).

In the original type lot of Patinopecten propatulus there is a single incomplete specimen (USNM 3558), figured by Arnold (1906, pl. 9, figs. 1, 1a, 2, 2a) and Dall (1909, pl. 15, figs. 1, 1a, 2, 2a), which should be assigned to Vertipecten fucanus (pl. 22, figs. 1, 4).

$V$. fucanus may be closely related to $V$. nevadanus (Conrad). On the basis of a comparison of the type and topotype specimens of $V$. fucanus with specimens of $V$. nevadanus possibly from near the type locality, they are considered separate species. The right valve of $V$. nevadanus is usually much more highly sculptured and has numerous interribs. The left valve of $V$. nevadanus seems to have more ribs and more interribs than $V$.fucanus. 
As discussed under Patinopecten protatulus (p. 65), when only a right valve of $V$. fucanus is preserved it is often difficult to distinguish from $P$. propatulus (pl. 19, fig. 3 ; pl. 21, fig. 4).

Localities: 1a, 2, 181, 181a, 184, 185, 185a; cf. 48-50.

Occurrence elsewhere: Astoria (?) formation, Washington

\section{Genus AEQUIPECTEN Fischer}

Aequipecten Fischer, 1886, Manuel conchyliologie et de paléontologie, p. 944.

Type.-By monotypy, Ostrea opercularis Linné. Recent, Norway to the Mediterranean.

\section{Aequipecten andersoni clemonensis (Etherington)}

Plate 17, figure 1

Pecten (Plagioctenium) andersoni clemonensis Etherington, 1931, California Univ., Dept. Geol. Sci., Bull., v. 20, p. 72, pl. 1, figs. 13,15 , pl. 4 , figs. 2 , 3, pl. 5 , figs. $1,2,3$.

Weaver, 1942, Washington Univ. [Seattle] Pub. in Geology v. 5 , p. 89 , pl. 19, figs. 3,5 [1943].

Two complete right valves of this subspecies and numerous fragments were collected from the rocks exposed at Boiler Bay. Although $A$. andersoni clemonensis has been recorded in faunal lists of the Astoria formation in Oregon from other localities, no specimens have been found other than those from Boiler Bay, during the course of this study.

This subspecies differs from $A$. andersoni, as pointed out by Etherington (1931, p. 72), by having flattopped rather than rounded ribs on the right valve.

Type: Univ. California 31933.

Type locality: Univ. California A-340. In cut on Clemons logging road, one-fourth of a mile south of the 8-mile post, sec. 26, T. 17 N., R. 7 W., Grays Harbor County, Astoria (?) formation, Washington.

The type of $A$. andersoni clemonensis was not examined; this identification is based on the illustrations and description of the subspecies.

Localities: $65,69 \mathrm{a}$.

Occurrence elsewhere: Astoria(?) formation, Washington.

\section{Genus DELECTOPECTEN Stewart}

Delectopecten Stewart, 1930, Acad. Nat. Sci. Philadelphia, Spec. Pub. no. 3, p. 118-119.

Type.-By original designation, Pecten (Pseudamusium) vancouverensis Whiteaves. Recent, Sitka Harbor, Alaska, to Catalina Island, Calif.

\section{Delectopecten peckhami (Gabb) of Arnold}

Plate 18, figures 2, 3; plate 20, figures $1,3-5$; plate 21 , figure 2

Pecten (Pseudamusium) peckhami Gabb. Arnold, 1906a, U.S. Geol. Survey Prof. Paper 47, p. 56-57, pl. 3, figs. 6-8.

?Pecten peckhami Gabb, 1869, Paleontology California, v. 2, p. $59-60$, pl. 16, figs. $6-8$.

?Palliolum (Delectopecten) peckhami (Gabb). Stewart, 1930, Acad. Nat. Sci. Philadelphia Proc., Spec. Pub. no. 3, p. 119-120, pl. 13, fig. 4 .
Delectopecten peckhami (Gabb) of Arnold is thin shelled, small, and possesses very weak to moderately strong concentric undulations. The concentric undulations are most apparent on specimens preserved in shale and subsequently flattened. Specimens collected from limestone and not flattened have barely discernable concentric undulations. The entire surface of the left valve has camptonectes sculpture; most of the specimens of right valves in the collections seem to have smooth shells, but patches of camptonectes sculpture are preserved on a few specimens. A few left valves have radial ribs 0.5 to $1 \mathrm{~mm}$ apart, which apparently disappear near the anterior and posterior margins of the shell. Four right valves were found to possess radial ribs crowded together at the anterior margin. The maximum number of such ribs counted was eight, and they seem to have been slightly spinose. No attempt is made here to separate these four specimens taxonomically. The presence or absence of radial ribs on parts of the shell other than the right anterior ear is considered of doubtful value in differentiation of species (Woodring, 1938, p. 38).

Figured specimen: Of Arnold (1906a, pl. 3, fig. 8), USNM 164839, pl. 20, fig. 4 ; pl. 21 , fig. 2 .

Locality: Monterey shale, Miocene, southeast of Pinole, Contra Costa County, Calif. (U.S. Geol. Survey Cenozoic loc. 2593.)

Type of Pecten peckhami Gabb: Mus. Comp. Zoology 15045 was designated the lectotype by Stewart $(1930$, p. 120). The lectotype was not available for study and Arnold's usage is followed here.

Type locality: Modelo formation, Miocene, Ojai ranch, Santa Barbara County, Calif. (Keen and Bentson, 1944, p. 92).

Delectopecten was proposed by Stewart (1930, p. 118119) for small forms which do not have the posterior ear differentiated. The anterior ear of the right valve has 4 to 6 , or perhaps more, radial ribs which seem to have been beaded. D. peckhami reaches a maximum height of about $25 \mathrm{~mm}$ and a width of $25 \mathrm{~mm}$, as measured in the collections in the U.S. National Museum. Specimens reaching this maximum size were collected only from the shale of the Astoria formation; smaller specimens were collected from fine-grained tuffaceous siltstone. Howe (1922, unpublished, p. 83) said that this species is common in the Astoria shale at Astoria.

Slodkewitsch (1938, p. 113, pl. 42, figs. 2-7) records "Palliolum (Delectopecten) pedroanus var. peckhami (Gabb)" from the Kovachina and Vayempolka series of Kamchatka, and the Upper-Pil series of Sakhalin, U.S.S.R., from late Oligocene, Miocene, and possibly Pliocene. The forms illustrated by him are certainly at least very closely allied to $D$. peckhami in the Astoria.

Localities: 1, 1e, 5, 7, 10-13, 15, 18, 23, 24, 26-29, 31, 32, 34, 43. Occurrence elsewhere: Temblor formation, lower and middle Miocene, Monterey shale, Miocene, and Modelo formation, late 
Miocene, California; possibly in Kamchatka, in late Oligocene to Pliocene(?) rocks.

\section{Family PROPEAMUSSIIDAE}

\section{Genus PROPEAMUSSIUM Gregorio}

Propeamussium Gregorio, 1883, Nota Intorno ad Alcune Moube Conchiglie Mioceniche di Sicilia, Naturalista Siciliano, v. 3 , no. 4, p. 119.

Type.-By monotypy, Pecten (Propeamussium) ceciliae de Gregorio. Miocene, Sicily.

\section{Propeamussium ef. P. clallamensis (Arnold)}

Plate 20, figure 6

Three incomplete specimens of Propeamussium, all collected from the Astoria formation in the city of Astoria in 1910, are in the U.S. National Museum collections. These specimens are not well preserved, but they seem to be similar to $P$. clallamensis (Arnold) (1906a, p. 57-58, pl. 3, figs. 1, 2, 3, 3a, collected near Pillar Point, Wash.) described from the Blakeley formation (lower Oligocene or early Miocene), pl. 20, figs. $2,7$.

The most complete specimen (pl. 20, fig. 6), from locality 13 , is a small right valve, almost circular in outline. It has equidimensional ears, a hinge line somewhat longer than half the length of the shell, and eight internal ribs. The internal ribs extend almost to the margin of the shell and are arcuate on the anterior half. Faint traces of fine concentric lines are visible on part of the impression. A specimen from locality 23 also has internal ribs, visible on the small part of the impression that is preserved. A specimen from locality 6 is incomplete, and the ears are missing, but a small amount of internal shell is present near the ventral margin, on which can be seen traces of fine radiating lines.

Localities: 6, 13, 23.

Occurrence elsewhere: Astoria(?) formation, Washington.

\section{Genus PaRaMUSSIOM Verrill}

Paramussium, Verrill, 1897, Connecticut Acad. Arts and Sci. Trans., v. 10, p. 72.

Type.-By original designation, Amusium dalli Smith. Recent, Gulf of Mexico to Barbados (Verrill), Cape Hatteras to the Antilles (U.S. Natl. Mus. coll.).

This genus is moderately large and thin shelled and has small ears and no byssal sinus. Both valves of the shell are internally reinforced by strong ribs which do not extend to the ventral margin or to the anterior or posterior margins. These internal ribs are most often fairly straight but may turn upward near the anterior and posterior margins of the shell. These ribs are often reinforced, wider and more raised and ridgelike at their ventral ends. The number of internal ribs is apparently fairly consistent within a species, but their length and strength varies. The ribs in the center of the shell may be shorter and thinner than those at the margins, and an extra rib, short in length, may appear near the ventral margin. The genus has cardinal crura and may have fine concentric or radial lines on the exterior.

Paramussium may be distinguished from Propeamussium by the lack of a byssal notch, the larger maximum size of the shell, the stronger internal ribs, and the smallness of the ears in proportion to the overall size. The internal ribs of Paramussium are usually straighter, are seldom curved at the ends, and are present only on the center three-fifths of the shell, being absent from the margins.

Paramussium is distinguished from Amusium by the fewer number and the arrangement of the internal ribs. Paramussium is also usually a smaller and much thinner shelled form, although the disk containing the internal ribs may be thickened.

Paramussium has not been recorded previously as fossil, to my knowledge, and apparently the only Recent species that have been assigned to this genus are the type species and $P$. meridionale (Smith), assigned to Paramussium by Verrill (1897, p. 72). Paramussium dalli has been collected from Cape Hatteras to the Antilles at recorded depths of from 218 to 1,591 fathoms.

Specimens of Paramussium were found in the U.S. National Museum collections of Recent mollusks from the Philippine Islands area. It seems probable that the genus Paramussium is much more widespread in the Recent seas than the current literature would lead one to suppose.

In the following description right and left valves have been designated according to Smith (1885, p. 308), who in describing Amusium dalli said that it is almost equivalve but that the smoother valve was perhaps a trifle more swollen than the other. He also said that the right valve has fine concentric lines of growth and very fine radiating substriae and that the left valve is more beautifully ornamented, being concentrically and closely and finely lirate. Verrill $(1897$, p. 72$)$ in describing Paramussium said that the lower valve (right valve, Verrill, 1897, p. 43) has concentric undulations.

\section{Paramussium astoriana Moore, n. sp.}

Plate 21, figure 5; plate 22, figures 2, 3, 5

Paramussium astoriana is a rather large (maximum size $48.1 \mathrm{~mm}$ long and $51.0 \mathrm{~mm}$ high) thin-shelled form, slightly higher than long, with small equidimensional beaks. One valve, here considered the right as defined in the generic discussion, has fine concentric lines. 
The other valve, here considered the left, has concentric and radial lines of equal width; the concentric lines are separated by interspaces about twice as wide as those between the radials. The shell is reinforced by 8 or 9 internal ribs of varying lengths and widths. Some of these ribs extend from the umbo across about one-half of the shell, whereas others seem to have been shorter. The ribs are usually straight from the umbonal area to their ventral end, and they are present on the central three-fifths of the shell. The ribs apparently did not curve upward at the margins. The shell seems to have been thickened along a line closely following the concentric lines and beginning with the ventral extension of the most anterior or posterior rib. A pair of well-developed and relatively strong crura are present.

\section{Holotype: US NM 563253.}

Type locality: (Loc. 10) One block south of the old high school building on Harrison Avenue, southwest corner of Ninth Street in Astoria.

Figured specimens: USNM 563252, 563254, 563255.

Localities: (loc. 20) Opposite 382 Alameda Avenue in Astoria; (loc. 10) Same as holotype; (loc. 19) Irving Avenue, near 37th Street in Astoria.

Twenty-three specimens of this species are present in the collections. Most of these specimens are incomplete, and most are preserved as impressions in shale or limestone and lack all, or most all, of their original shell. All the specimens were collected in 1910 from the Astoria formation in Astoria, and more than half of them are presumably from the shale of Howe (1926). The following is a descriptive list of the specimens in the museum:

Size and other features of Paramussium astoriana

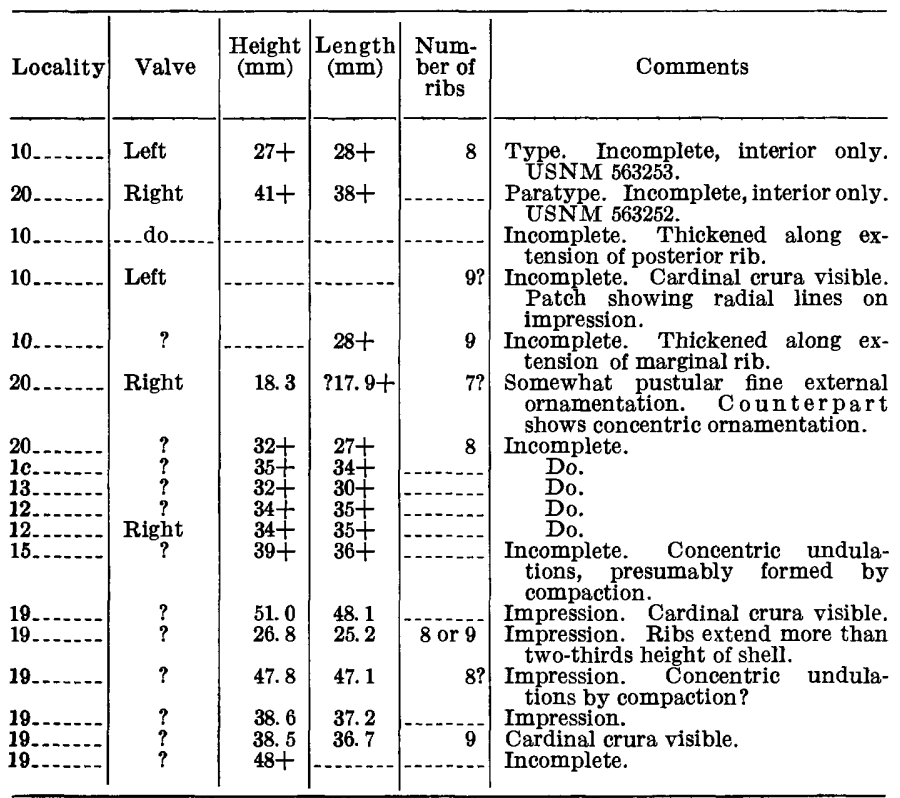

Family CARDITIDAE

\section{Genus CYCLOCARDIA Conrad}

Cyclocardia Conrad, 1867, Am. Jour. Conchology, v. 3, p. 191.

Type.-By subsequent designation (Dall, 1903, p. 1409), Cardita borealis Conrad. Labrador to Cape Hatteras, Eastern United States.

\section{Cyclocardia subtenta (Conrad) \\ Plate 23, figures $1-5,10,12,13$.}

Cardita subtenta Conrad, 1849, U.S. Explor. Exped., Geology, v. 10, app. p. 726 , atlas pl. 18 , figs. 12,12 a.

Cardium subtentum (Conrad). Conrad, 1865a, Am. Jour. Conchology, v. 1, p. 153.

Venericardia subtenta (Conrad). Dall, 1909, U.S. Geol. Survey Prof. Paper 59, p. 115-116.

Weaver, 1942, Washington Univ. [Seattle], Pub. in Geology, v. 5 , p. $140-141$, pl. 27 , figs. $8,13,14$; pl. 33 , figs. $5,7,9$, 12 ; pl. 34, fig. 4 [1943].

Venericardia (Cyclocardia) subtenta (Conrad). Etherington, 1931, California Univ., Dept. Geol. Sci., Bull., v. 20, p. 75 , pl. 5 , figs. $7,9,10,12$; pl. 9 , fig. 1 .

Venericardia chehalisensis Weaver, 1912, Washington Geol. Survey Bull. 15, p. 59-60, pl. 12, figs. 101, 102; pl. 15, figs. 133, 137.

?Venericardia subtenta var. quadrata Dall, 1909, U.S. Geol. Survey Prof. Paper 59, p. 115-116.

Cyclocardia subtenta is a rather small carditid and subtrigonal in outline, and it has approximately 21 to 27 rounded ribs. The ribs are crossed by concentric lines that may be raised and crowded together. The right hinge plate of C. subtenta (pl. 23, fig. 1) has a wide, blunt cardinal tooth bordered posteriorly by a long socket and anteriorly by a short socket and has a small toothlike projection on the anterior side. The left hinge plate (pl. 23, fig. 4) has two cardinal teeth; the anterior tooth is short, heavy, and blunt; the posterior tooth is long and rather thin. There is a small toothlike projection on the anterior ventral margin of the left hinge.

Type: USNM 3502 is herewith designated the lectotype, pl. 23, figs. 5, 13.

Paratypes: USNM 563259, 3484.

Type locality: Astoria, Oreg.

No specimens were found in the type lot of Cyclocardia subtenta that exactly agree with Conrad's illustrations. Two specimens (USNM 3502) have been segregated as types, perhaps by Dall; one of these specimens is designated the lectotype (pl. 23, figs. 5, 13); the other has been assigned to USNM 563259. The lectotype of C. subtenta is of smaller than average size for this species (15.5 mm long, $15.9 \mathrm{~mm}$ high, and $10.5 \mathrm{~mm}$ thick, both valves), and it has about 27 low rounded ribs that are crossed by unevenly spaced irregular concentric lines which imbricate slightly the radial 
ribs. The largest specimen in the collections is from locality 184 and is $22.8 \mathrm{~mm}$ long, $20.9 \mathrm{~mm}$ high, and about $12.2 \mathrm{~mm}$ wide (both valves).

Dall (1909, p. 115-116) in his discussion of "Venericardia" subtenta named a new variety, "Venericardia" subtenta var. quadrata, which was not illustrated. In his original discussion Dall lists as " $V$." subtenta var. quadrata, USNM 110455 from 1 mile east of Clallan Bay, Wash., and USNM 153936a from Coos Bay, Oreg. There are 12 specimens in lot 110455 , and they all seem to be identical with the type and topotypes of Cyclocardia subtenta; therefore, they are not separated here as Dall's form. A single specimen, USNM 153936a, in the type collection was obtained near the city of Empire, Oreg., presumably from the Empire formation (Pliocene?), and it was part of the collection purchased by Dall from B. H. Camman. The specimen is poorly preserved, and the hinge is inaccessible, but it seems to differ from $C$. subtenta only in size, averaging about 5 or $6 \mathrm{~mm}$ more in each direction; this specimen is chosen for the lectotype. The lectotype, herewith designated as USNM 153936a (pl. 23, fig. 16), is $27.0 \mathrm{~mm}$ long, $27.0 \mathrm{~mm}$ high, and $18.0 \mathrm{~mm}$ wide.

"Venericardia" castor Dall (1909, p. 116, pl. 11, figs. 1, 3) from the Blakeley formation east of East Twin River, Wash. (pl. 23, fig. 7) is much larger than C. subtenta and has very high, prominent beaks close to the anterior margin.

Howe (1922, unpublished, p. 101) collected $C . s u b$ tenta from the Astoria formation at the corner of Fifth and Commercial Streets in Astoria.

Localities: 1, 1a, 4, 59-63, 69a, 79, 102, 108-110, 128, 162, 174, 184, 187.

Occurrence elsewhere: Astoria(?) formation, Washington.

\section{Family LUCINIDAE}

Genus LUCINOMA Dall

Lucinoma Dall, 1901, U.S. Natl. Mus. Proc., v. 23, p. 806.

Type.-By original designation, Lucina filosa Stimpson. Recent, Grand Banks to Gulf of Mexico.

Lucinoma acutilineata (Conrad)

Plate 15, figures 7-10, 12

Lucina acutilineata Conrad, 1849, U.S. Explor. Exped., Geology, v. 10 , app. p. 725 , atlas, pl. 18, figs. 2, 2a, 2 b.

Weaver, 1942, Washington Univ. [Seattle] Pub. in Geology, v. 5, p. 143-144, pl. 34, figs. 8, 11, 16 [1943].

Cyclas acutilineata (Conrad). Conrad, 1865a, Am. Jour. Conchology, v. 1, p. 153.

Phacoides acutiiineatus Conrad. Dall, 1909, U.S. Geol. Survev Prof. Paper 59, p. 116-117, pl. 12, fig. 6.

Phacoides (Lucinoma) acutilineatus (Conrad). Etherington, 1931, California Univ., Dept. Geol. Sci., Bull., v. 20, p. $76-77$, pl. 4 , fig. 5 .

Pectunculus patulus Conrad, 1849, U.S. Explor. Exped., Geology, v. 10 , app. p. 726 , atlas pl. 18 , figs. 8,8 a.
[Not] Pectunculus patulus? Conrad. Reagan, 1909, Kansas Acad. Sei. Trans. v. 22, p. 178.

Lucinoma acutilineata is commonly a rather small lucinid moderately inflated form, and it bears rather closely spaced raised concentric lamellae. Some specimens are large and inflated and bear concentric lamellae twice as far apart as on the smaller specimens. In single lots of the Recent species, Lucinoma annulata (Reeve), variation can be seen in the degree of inflation and the spacing of the concentric lamellae.

Type: USNM 3519, designated the lectotype of $L$. acutilineata by Woodring $(1938$, p. 52$)$, pl. 15, figs. 8, 9; paratypes, USNM 561524, 3501.

Holotype: Of Pectunculus patulus Conrad, USNM 3605, pl. 15, fig. 12 .

Type locality: For types listed above, Astoria, Oreg.

The lectotype of $L$. acutilineata is double valved, and the shell is missing on the umbonal area of the left valve and on more than half of the right valve. This specimen is $37.3 \mathrm{~mm}$ long, $35.2 \mathrm{~mm}$ high, and $16.7 \mathrm{~mm}$ wide. Conrad said in his original description that the figures of $L$. acutilineata were of natural size $(1849$, p. 725$)$. In the plate explanation bound in the front of the atlas $(1849$, p. 5$)$, figure 2 is said to be a lateral view enlarged 1.6 times, and figures $2 \mathrm{a}$ and $2 \mathrm{~b}$ are said to be other views. No indication has been found as to who wrote the plate explanations in the atlas, but perhaps they were written by Dana. The lectotype does concur with a 1.6 enlargement, and the area of missing shell conforms fairly well with that shown in figure 2. The largest specimen of $L$. acutilineata in the collections is a paratype in the original type lot (USNM 561524) and is $47.9 \mathrm{~mm}$ long, $41.7 \mathrm{~mm}$ high, and about $9 \mathrm{~mm}$ wide (right valve only).

Pectunculus patulus is a mold of $L$. acutilineata, as pointed out by Meek (1864, p. 29) and Woodring (1938, p. 52-53). Apparently Conrad also thought this might be true, as in 1865 (1865a, p. 153) he questionably referred Pectunculus patulus to the synonymy of Cyclas acutilineata. Dall (1909, p. 116) placed Pectunculus patulus into synonymy with $L$. acutilineata without discussion. The specimen from East Clallam Wash., identified by Reagan (1909, p. 178) as Pectunculus patulus? is perhaps a cardid.

$L$. acutilineata is comparable to the Recent species L. annulata, but $L$. acutilineata has a heavier hinge and, as pointed out by Stewart (in Tegland, 1933, p. 116), a shorter posterior dorsal margin. In the right hinge plate of $L$. acutilineata, plate 15 , figure 7 , the anterior tooth is short and blunt, whereas on L. annulata it is thin and bladelike; the cardinal tooth also seems to be shorter on $L$. annulata. The left anterior tooth on $L$. acutilineata is heavier and not as deeply incised as on L. annulata. 
L. acutilineata is the only lucinid present in the Astoria formation, with the possible exception of a single specimen (loc. 13) discussed by Woodring (1938, p. 53), which he thought indicated the presence of a species of the aequizonata group.

L. acutilineata has been collected from the Astoria formation in Washington and the Vaqueros (lower Miocene) and Temblor (lower and middle Miocene) formations in California. Howe (1922, unpublished, p. 88) collected L. acutilineata from the Astoria formation at Fifth and Commercial Streets, in Astoria. It has also been reported from the Oligocene and Miocene of Japan.

Localities: 1, 1a, 1c, 4, 7, 13, 16, 21, 56, 57, 92, 112, 116, 120, 140, 153, 156, 187.

Occurrence elsewhere: Vaqueros formation, lower Miocene; Temblor formation, lower and middle Miocene; and Sobrante sandstone, middle Miocene, California; Astoria(?) formation, Washington; possibly also Oligocene and Miocene in Japan.

\section{Family DIPLODONTIDAE}

\section{Genus DIPLODONTA Bronn}

Diplodonta Bronn, 1831, Italiens Tertiar-Gebilde und deren organisch Einschlusse, p. 12.

Type.-By subsequent designation (Gray, 1847; Herrmannsen, 1847), Venus lupina Brocchi [not Linné] (=Tellina rotundata Montagu var. aequilateralis Cerulli) (Chavan, 1952, p. 121). Miocene and Pliocene, Italy.

Diplodonta is used here rather than Taras because according to Chavan (1952, p. 121) the type by monotypy of Taras, $T$. antiquatas Risso, could have been a specimen of Mysia undata (Pennant), which also is found at Trinte, the type locality of $T$. antiquatus. In addition, Chavan was unable to find any specimens labelled $T$. antiquatus in the Risso Collection in Paris.

\section{Diplodonta parilis (Conrad)}

Plate 23, figure 9

Loripes parilis Conrad, 1848, Am. Jour. Sci., v. 5, ser. 2, p. 432, fig. 7.

Mysia parilis (Conrad). Conrad, 1865a, Am. Jour. Conchology, v. 1 , p. 153.

Diplodonta (Felaniella) parilis (Conrad). Dall, 1909, U.S. Geol. Survey Prof. Paper 59, p. 117, pl. 11, fig. 6.

Etherington, 1931, California Univ., Dept. Geol. Sci., Bull., v. 20, p. 76, pl. 5 , figs. 4,6 .

Taris parilis (Conrad). Grant and Gale, 1931, San Diego Soc. Nat. History Mem., v. 1, p. 294.

Weaver, 1942, Washington Univ. [Seattle] Pub. in Geology, v. 5, p. 149-150, pl. 35, fig. 6 [not? pl. 36, fig. 4] [1943].

[Not] Mysia parilis Conrad, 1860, Acad. Nat. Sci. Philadelphia Jour., v. 2, p. 278, pl. 46, fig. 8 [probably error for 16].

Conrad, 1866a, Am. Jour. Conchology, v. 2, p. 71, pl. 4, fig. 1 .

The holotype of Loripes parilis, reported lost in most discussions of the species, was found at the Academy of Natural Sciences of Philadelphia. It is labeled Mysia parilis in Conrad's handwriting.
Holotype: Acad. Nat. Sci. Philadelphia no. 4546, pl. 23, fig. 9. Type locality: Astoria, Oreg. The holotype was collected by J. K. Townsend, who was an ornithologist at the Academy of Natural Sciences of Philadelphia. Townsend was in Astoria intermittently from 1834 to 1837 (Townsend, 1839).

The holotype of Diplodonta parilis is an immature right valve; the apex of the beak is broken and the hinge is not exposed, but it is presumably a Diplodonta. The type is thin shelled and has concentric grooves and ridges, irregularly spaced. The hinge line forms an abrupt angle of about $35^{\circ}$ with the beak, posteriorly and anteriorly. The shell is almost perfectly circular in outline, if the angulation of the hinge is ignored. The holotype is $13.6 \mathrm{~mm}$ high and $14.3 \mathrm{~mm}$ wide, and the single right valve is approximately 2.5 $\mathrm{mm}$ thick. The specimen is slightly larger than the original drawing, but there is no indication of scale on the illustration; the type agrees closely in all other respects with the original description and illustration.

Conrad (1866a, p. 71, pl. 4, fig. 1) assigned the name Mysia parilis to a diplodontid from the Miocene of Shiloh, N.J.; Dall (1900, p. 1184-1185) renamed this species Diplodonta shilohensis.

Three specimens of Diplodonta that can perhaps be assigned to Diplodonta parilis are in the collections from the Astoria formation in Oregon. Two of the specimens are casts and no shell remains; the third is a cast that retains fragments of shell. Howe (1922, unpublished, p. 66) collected $D$. parilis from the foot of 19th Street in Astoria.

Etherington (1931, p. 76, pl. 5, fig. 4, 6) collected D. parilis from the Astoria (?) in southwestern Washington, and he said that it was well represented and that all the specimens found had both valves intact.

Dall (1909, p. 117, pl. 11, fig. 6) described D. parilis from the Empire formation of Pliocene(?) age at Coos Bay, Oreg. (pl. 23, fig. 6).

$D$. parilis was perhaps rare in the Astoria sea. The shell is somewhat fragile, however, and may be rare because of difficulties in preservation, or the species may have lived at depths not usually represented in the exposed sections of the Astoria formation.

Localities: 1a, cf. 49, 139.

\section{Family THYASIRIDAE}

\section{Genus THYASIRA Leach in Lamarck}

Thyasira Leach, 1818, in Lamarck, Histoire naturell des animaux sans vertebres, v. 5, p. 492.

Type.-By monotypy, Tellina flexuosa Montagu. Cenozoic of Europe, Recent in northern Europe, the North Atlantic south to the Canary Islands, and the Azores (Dall, 1890-1903, p. 1338-1339, 1903).

Thyasira disjuncta (Gabb) is the type of Conchocele Gabb, 1866. The shell characters of Thyasira and 
Conchocele seem to be the same, the only difference being one of size: Conchocele is much larger than Thyasira. Nakazima (1958, p. 186-197) discussed the anatomy of $T$. disjuncta but did not compare it with the small Recent species; so whether there are anatomical differences is still not known.

\section{Thyasira bisecta (Conrad)}

Plate 23, figures $8,14,15$

Venus bisecta Conrad, 1849, U.S. Explor. Exped., Geol., v. 10, append. p. 724, atlas pl. 17, figs. 10, 10a.

Thyatira? bisecta (Conrad). Meek, 1864, Smithsonian Misc. Colln. 183, p. 8.

Cyprina bisecta (Conrad). Conrad, 1865a, Am. Jour. Conchology, v. 1, p. 153.

Thyasira bisecta (Conrad). Dall, 1909, U.S. Geol. Survey Prof. Paper 59, p. 118.

Reagan, 1909, Kansas Acad. Sci. Trans., v. 22, p. 180.

Weaver, 1942, Washington Univ. [Seattle] Pub. in Geology, v. 5, p. 142-143, pl. 34, figs. 5, 6 [1943].

Thyasira bisecta is most commonly found as a small form which is subovate in outline. The largest specimen in the collections $(58.3 \mathrm{~mm}$ long, $53.0 \mathrm{~mm}$ high, and $38.9 \mathrm{~mm}$ wide), however (USNM 563440, pl. 23, figs. 14, 15), has a very straight anterior end and is quadrate in outline. Inflation increases with size, but even small forms are inflated. The shell is smooth but has fine concentric lines that may be bunched together, consequently roughening the shell. Radial striations can be seen on the innermost shell layer.

Holotype: USNM 3518, pl. 23, fig. 8.

Paratypes: USNM 561518 (original No. USNM 3518), USNM 563440 (original No. USNM 3500), pl. 23, figs. 14, 15, and four specimens remaining in lot 3500 .

Type locality: Astoria, Oreg.

The specimen here considered to be the holotype agrees closely with the original illustration (Conrad, 1849, pl. 17, fig. 10), and it agrees fairly well with figure 10a in the same plate. The holotype consists of two almost complete valves which are together and are closed. A large part of the original shell remains, but the anterior dorsal part of the left valve is missing; the shell is $46.5 \mathrm{~mm}$ long, $38.9 \mathrm{~mm}$ high, and $24.9 \mathrm{~mm}$ wide (both valves). Five specimens are in the original type collection, all of which agree in size and configuration with the holotype. One additional specimen cited above is much larger and more truncated anteriorly.

Thyasira disjuncta (Gabb) has been considered conspecific with $T$. bisecta by some paleontologists. As pointed out by Woodring (in Woodring, Bramlette, and Kew, 1946, p. 83), T. disjuncta is larger and more quadrate and has a more truncated anterior end than T. bisecta. Tegland (1928, p. 130) also noted the differences in the anterior truncation, outline, and size of the two species.
Tegland (1933, p. 114-115, pl. 7, figs. 18-22) identified a Thyasira from the Blakeley formation in Washington as $T$. cf. disjuncta. On the basis of her illustrations and the collections in the U.S. National Museum from the Blakeley formation, Tegland's form seems to be more closely allied to $T$. bisecta than to $T$. disjuncta.

Howe (1922, unpublished, p. 99) collected T. bisecta in Astoria from Fifth and Commercial and Fifth and Duane Streets. This species is rare and most of the specimens in the collections at the U.S. National Museum came from Astoria, which may have been close to the southern limit of range; the Recent species, T. disjuncta, has been recorded from Alaska to Oregon.

There is a single broken specimen (USNM 352604) of Thyasira cf. T. bisecta in the collections from "Tymi on the west coast of Russian Sakhalin, Siberia." Only the inner shell layers of the specimen are preserved, and it seems to be less inflated and not as straight at the posterior margin of the hinge as $T$. bisecta.

Localities: 1, 1a, 19, 184.

Occurrence elsewhere: Astoria(?) formation, Washington.

\section{Family CARDIIDAE \\ Subfamily PROTOCARDIINAE \\ Genus NEMOCARDIUM Meek}

Nemocardium Meek, 1876, U.S. Geol. Survey Terr. 9th Ann. Rept., v. 9, p. 167.

Type.-By subsequent designation (Sacco, 1899), Cardium semiasperum Deshayes. Eocene, France.

\section{Subgenus ARCTOPRATULOM Keen}

Arctopratulum Keen, 1954, Bull. Am. Paleontology, v. 35, no 153, p. 11.

Type.--By original designation, Nemocardium (Arctopratulum) griphus Keen. Middle Miocene, Grays Harbor County, Wash.

\section{Nemocardium (Arctopratulum?) cf. N. (A.) griphus Keen}

In the collections are two poorly preserved specimens from Coos Bay (loc. 187) whose shells are either worn or missing and a double-valved mold from the Cathlamet quadrangle (loc. 31), Oregon. These specimens are referred tentatively to Nemocardium (Arctopratulum) griphus Keen (1954, p. 12-14); they seem to be more quadrate in outline than $N$. (A.) griphus. The largest specimen (incomplete) is $9.5 \mathrm{~mm}$ long and $9.4 \mathrm{~mm}$ high.

Localities: $31,187$.

\section{Genus CLINOCARDIOM Keen}

Clinocardium Keen, 1936, San Diego Soc. Nat. History Trans., v. 8 , p. 119-120.

Type.--By original designation, Cardium nuttallii Conrad. Recent, Nunivak, Pribilof, and Commander Islands, Bering Sea, south to Hakodate, Japan, and to San Diego, Calif. Fossil, Miocene through Pleistocene 
in Washington, Oregon, and California (Grant and Gale, 1931, p. 308).

\section{Clinocardium aff. C. nuttallii (Conrad) \\ Plate 30, figures 1, 2}

Three specimens of Clinocardium, one well preserved (pl. 30, figs. 1, 2), were collected in the Coos Bay dredgings (loc. 187) and are compared to Clinocardium nuttallii (Conrad, 1837, p. 229, pl. 17, fig. 3), with which they may be conspecific. This form is higher in proportion to length and has wider and higher ribs that have wider and deeper interspaces than $C$. nuttallii. In addition, the ribs are more prominent at the posterior end and the umbos are higher than on $C$. nuttallii. The hinge has not been exposed.

Locality: 187.

\section{Family VENERIDAE \\ Subfamily DOSININAE}

Genus DOSINIA Scopoli

Dosinia Scopoli, 1777, Introducio ad historian naturalem, p. 399.

Type.-By monotypy, Chama dosin Adanson (Hist. Nat. Sénégal, pl. 16, fig. 5, in text "Le Dosin", p. 255, $1757)=$ Venus concentrica Born, Testacea Mussei Caesarei Vindobonensis, p. 11, pl. 5, fig. 5, 1780, according to Fischer-Piette, 1942, p. 308-314. Recent, Florida Keys to Brazil.

\section{Subgenus DOSONIA s. s.}

Fischer-Piette (1942, p. 308-314) has made a convincing case which proves that the specimen described by Adanson from Sénégal as Chama dosin is actually a specimen of Dosinia concentrica (Born) and was only in the collection of Adanson through some accident and cannot be assigned to Dosinia africana Gray. Thus Dosinidea of Dall is replaced by Dosinia s. s.

\section{Dosinia (Dosinia) whitneyi (Gabb)}

Plate 24, figures 1-10

Chione whitneyi Gabb, 1866, California Geol. Survey, Paleontology, v. 2, sec. 1, pt. 1, p. 23-24, pl. 5, fig. 40 .

Dosinia (Dosinidia) whitneyi (Gabb). Lutz, 1951, California Univ., Dept. Geol. Sci., Bull., v. 28, p. 389-390, pl. 16, figs. 1, 2.

Dosinia mathewsonii Gabb, 1869, California Geol. Survey, Paleontology, v. 2, sec. 1, pt. 2, p. 57, pl. 15, fig. 16.

Stewart, 1930, Acad. Nat. Sci. Philadelphia, Spec. Pub. no. 3 , p. 230-232, pl. 14, fig. 7 .

Dosinia (Dosinidia) mathewsoni Gabb. Clark, 1918, California Univ., Dept. Geol. Sci., Bull., v. 11, p. 141-142, pl. 7, figs. 1, 2, 5, 6, 9 .

?Dosinia (Dosinidia) whitneyi (Gabb). Clark, 1918, California Univ., Dept. Geol. Sci., Bull., v. 11, p. 143, pl. 7, figs. 3, 4.

[Not] Dosinia mathewsoni Gabb. Arnold, 1910, U.S. Geol. Survey Bull. 396, p. 116, pl. 5, fig. 2. Figure reprinted in Arnold and Anderson, 1910, U.S. Geol. Survey Bull. 398, pl. 27, fig. 2.

Dosinia whitneyi is of medium size, subcircular in outline, and moderately thin shelled. The shell is con- centrically grooved (pl. 24, fig. 10), as is Dosinia concentrica (Born), but the grooves are not often preserved on the specimens in the collections. D. whitneyi is somewhat inflated, varying in degree, and is produced anteriorly in an evenly rounded manner, also with some variation. The lunule is small and incised, and there is no defined escutcheon. The posterior margin is evenly curved from the umbos to just above the middle of the posterior margin where it is slightly flattened. The right hinge (pl. 24, figs. 4, 6) has a long bifid posterior cardinal tooth; the anterior part is thin, raised and bladelike. The middle cardinal is thick and blunt; the anterior cardinal is thin. The posterior socket of the right valve is bordered posteriorly by a thin raised ridge. There are two small laterals bordering a small oval pit on the anterior part of the right hinge. On the left hinge (pl. 24, figs. 5, 7) the posterior cardinal tooth is long, thin, and bladelike; the middle cardinal is moderately long, thick, and slightly bifid and the anterior cardinal is thin. The middle and anterior cardinals are joined at their dorsal ends by a small shelf. There is a small round lateral tooth at the ventral anterior margin. The specimens measured range in size from 25 to $55 \mathrm{~mm}$ in length, 26 to $56 \mathrm{~mm}$ in height, and 11 to $36 \mathrm{~mm}$ in width (both valves).

Holotype: Of Chione whitneyi Gabb, California Univ. Mus. Paleontology 11999, pl. 24, fig. 2.

Type locality: Near Martinez Creek, San Ramon sandstone, Contra Costa County, Calif.

Syntypes: Of Dosinia mathewsoni Gabb, Acad. Nat. Sci. Philadelphia 4485.

Type locality: Martinez, Walnut Creek, San Ramon(?) sandstone, Contra Costa County, Calif.

D. whitneyi resembles Dosinia (Dosinia) merriami Clark (1915, p. 460-462, pl. 49, figs. 1, 2 ; pl. 52, figs. $1,2)$, but it can be distinguished by its higher beaks, greater inflation, generally smaller size, and less circular outline. In addition, the left hinge of $D$. merriami has a thicker middle cardinal and a thicker anterior cardinal, which is shorter and does not extend to the ventral margin of the hinge plate as it does on $D$. whitneyi, and there seems to be no shelf connecting the middle and anterior cardinals. The left anterior lateral of D. merriami is stronger, and the hinge plate curves beneath it rather than being straight as on $D$. whitneyi. According to the illustration of $D$. merriami, its right middle cardinal is bifid, and the right anterior cardinal does not closely parallel the anterior shell margin. "Dosinia mathewsoni Gabb" of Clark (1918, p. 141-142, pl. 7 , figs. $1,2,5,6,9$ ) is D. whitneyi (Gabb), plate 24, figure 1.

One of the most outstanding features of the mollusks collected from the Coos Bay dredgings is the abundance of $D$. whitneyi. Dosinia has been collected only from one other locality in the Astoria formation in Oregon, 
at Cape Kiwanda, 20 feet above the base of the Astoria formation (loc. 50). Specimens that have been compared to D. whitneyi are in the Stanford University collection (NP 160, 161) made by Harold Hannibal from middle Miocene rocks at Pillar Point, Clallam County, Wash.

The abundance of Dosinia but the almost complete lack of any specimens of Anadara in the dredgingswith the abundance of each just the reverse in the sections exposed to the north-is probably a reflection of environment. It can be assumed reasonably that Coos Bay was more protected in the Miocene than the coast of Oregon to the north, and that the Bay would have furnished an environment particularly suitable to Dosinia. It is possible that the water may have been somewhat warmer, also, and that this was a factor in the distribution, but the occurrence of Dosinia in northern Washington argues against this possibility.

Localities: 187 , cf. 50.

Occurrence elsewhere: Vaqueros formation, lower Miocene; Temblor formation, lower and middle Miocene; and Sobrante sandstone, middle Miocene; California. Astoria(?) formation, Washington.

\section{Subfamily CHIONINAE}

\section{Genus CHIONE Megerle von Muihlfeld}

Chione Mergerle von Mühlfeld, 1811, Gesellschaft naturforschender Freunde zu Berlin, Magazin für die neuesten Entdeckungen in der gesammten Naturkunde, year 5, p. 51.

Type.-By subsequent designation (Gray, 1847), Chione dysera Megerle von Mühlfeld=Venus cancellata Linné. Recent, West Indies.

\section{Subgenus SECURELLA Parker}

Securella Parker, 1949, Jour. Paleontology, v. 23, p. 587.

Type.-By original designation, Venus securis Shumard pl. 27, figs. 9, 12, 13). Weaver's Montesano formation (Miocene), Washington; Empire formation (Pliocene?), Oregon; and the Wildcat formation (Pliocene) of Lawson (1894), and the Etchegoin formation (Pliocene), California.

Securella is so closely related to Chione s. s. that it has been assigned subgeneric rank (Keen, 1951, p. 6), although Securella was originally proposed by Parker $(1949$, p. 587$)$ as a generic name. Securella is a northern extinct subgenus. It differs from Chionopsis Olsson, 1932 (p. 111-112, type by original designation Chione amathusia Philippi) a southern Miocene to Recent subgenus, in outline and sculpture. Chionopsis is more produced anteriorly and more obliquely truncated posteriorly than Securella, and in addition to concentric lamellae has strong radial ribs on the exterior of the shell. (Gnidiella Parker, 1949, p. 582, is a synonym of Chionopsis.)
Venus securis Shumard, the type of Securella, was described in 1858 (p. 122) without a type designation or an illustration, and the type of $V$. securis has been listed as missing or lost. The type lot of Venus securis Shumard was located in the fall of 1956, through the kindness of the late James Steele Williams (oral communication), and is now on permanent deposit at the U.S. National Museum. USNM 562474 (pl. 27, figs. $12,13)$ has been designated the lectotype (Trumbull, 1958 , p. 903). The type locality of " $V$." securis has been listed as undetermined. Shumard in the original locality description of "V." securis said that the specimens were collected at the mouth of Coos Bay, Cape Blanco, and on the shores of the Columbia River a short distance above Astoria. None of the nine specimens in the type lot resembles the Miocene species Chione (Securella) ensifera (Dall) in the collections from the Astoria formation. They all closely resemble specimens of " $V$." securis collected by Camman from "Empire beds, Coos Bay, Oregon" and described and illustrated by Dall (1909, p. 120, pl. 11, fig. 8; pl. 13, figs. 2, 8, 9). The type lot may have been collected from the Empire formation at the mouth of Coos Bay or Cape Blanco, Oreg. It seems more probable that the specimens were collected at Coos Bay, and the type locality has been so restricted (Trumbull, 1958, p. 904).

In the course of this investigation, it has been noted that the Recent species "Venus" stimpsoni Gould from Japan seems to be more closely related to Securella than to Mercenaria, to which it has been assigned by many authors. The rugose nymph plate seems to be characteristic of Mercenaria, and this character is missing on "Venus" stimpsoni. Palmer (1926, p. 391) noted that Mercenaria when developed typically in the adult has the heavy rugose area on the nymphs.

The Recent species Mercenaria kennicottii described by Dall (1872, p. 147-148) from Washington has a narrow rugose area on the nymphs. Dall in comparing $M$. kennicottii with " $V$." stimpsomi said that " $V$." stimpsoni did not have the roughened dental process which distinguishes the genus Mercenaria. Grant and Gale (1931, p. 324) said that "Venus kennicottii Dall from Washington is so similar to the Atlantic $V$. mercenaria that the two are very difficult to distinguish; and the fact that it is very rare suggests that it may have been founded on adventious specimens of the latter." There are three specimens in Dall's original material: the type (USNM 75017), a double-valved specimen from Neah Bay, Wash., and an immature left valve (USNM 75018) from Little River, Mendocino County, Calif. The small specimen (USNM 75018) does not have a rugose nymph, but it resembles " $V$." 
kennicottii in other respects. Immature specimens of Mercenaria in the collections of Recent mollusks in the U.S. National Museum always show some rugosity on the nymph plate. $V$. kennicottii (type) may not have originally come from the Pacific coast, and the specimen from California (USNM 75018) in Dall's type material may not be congeneric.

If rugosity of the nymph plate is a good generic characteristic of Mercenaria, this genus may not now be living in the Pacific area, and possibly the species from the Pacific that have been assigned to it may more properly be assigned to Securella. Mercenaria has been recorded as fossil from rocks as old as Miocene in Japan (Hayasaka and Uozumi, 1954, p. 165-172, pl. 22), but as the hinge is not illustrated it is impossible to determine the relationship to Mercenaria.

\section{Chione (Securella) ensifera (Dall)}

Plate 26, figures $1,2,7,9,10$; plate 27 , figures $1-8,10,11$

Venus lamellifera Conrad, 1849, U.S. Explor. Exped., Geol. v. 10, app. p. 724, atlas, pl. 17, fig. 12, 12a. [Not Venus lamellifera Conrad, 1837, Acad. Nat. Sci. Philadelphia Proc., v. 7, p. 25, pl. 19, fig. 19].

Venus? lamellifera Conrad, 1865a, Am. Jour. Conchology, v. 1, p. 152 .

Venus? ensifera Dall, 1909, U.S. Geol. Survey Prof. Paper 59, p. 122 (New name).

Chione (Chione) ensifera (Dall). Etherington, 1931, California Univ., Dept. Geol. Sci., Bull., v. 20, p. 79, pl. 7, figs. $4-8$; pl. 8, fig. 1 [not? pl. 8 , fig. 2 nor pl. 9 , figs. $4,5,8,11$ ].

Venus (Chione) securis var. ensifera Dall. Grant and Gale, 1931, San Diego Soc. Natural History Mem., v. 1, p. 320 , pl. 17, figs. $2 \mathrm{a}, 2 \mathrm{~b}, 3$.

Chione ensifera (Dall). Weaver, 1942, Washington Univ. [Seattle] in Geology, v. 5, p. 164-165, pl. 37, fig. 9; pl. 39, figs. 2, 3 [1943].

Securella ensifera (Dall). Parker, 1949, Jour. Paleontology, v. 23, p. 590-591, pl. 93, figs. 3, 10, 12 ; pl. 94, figs. 4, 18, 20.

Venus (Chione) clallamensis Reagan, 1909, Kansas Acad. Sci. Trans., v. 22, p. 183, pl. 1, fig. 13.

Venus (Chione?) olympidea Reagan, 1909, Kansas Acad. Sci. Trans., v. 22, p. 182-183, pl. 1, fig. 12.

"Venus (Chione?) olympidea" Reagan. Weaver, 1942, Washington Univ. [Seattle] Pub. in Geology, v. 5, p. 169, pl. 39, fig. 14 [1943].

?Chione aff. securis (Shumard). Etherington, 1931, California Univ., Dept. Geol. Sci., Bull., v. 20, p. 80-81, pl. 8, figs. 4,5 .

Chione ensifera is of moderate size and subtrigonal in outline and has a posterior angulation (pl. 26, fig. 2). The shell bears concentric lamellae that extend beyond the shell as much as $2.8 \mathrm{~mm}$ (pl. 27, fig. 2), but these lamellae are rarely preserved. Shells that are moderately worn have raised concentric ridges spaced at a maximum of about $3.8 \mathrm{~mm}$ apart, whereas shells that are more worn retain only closely spaced concentric threads. Specimens that are worn may appear on cursory examination to have had different patterns of concentric lamellae on the outer shell.
There are closely spaced radial ribs on the inner shell beneath the concentric lamellae. The lunule is wide, deeply incised, and protrudes slightly at the shell margin (pl. 27, fig. 4). The escutcheon is fairly long and wide, and the ligament pit is deep; the ligament protrudes beyond the valves (pl. 27, fig. 10). There are three cardinal teeth in the right hinge (pl. 27, figs. 3 , $6,7)$. The right posterior tooth is moderately thick and bifurcate and parallels the posterior margin of the shell. The posterior socket is bordered posteriorly by a narrow raised ridge. The middle cardinal is short and thick; the anterior cardinal is thin and curved, so that it almost parallels the anterior margin. The anterior dorsal margin of the hinge plate is crenulate (pl. 27, fig. 6). A right hinge of $C$. securis is figured for comparison (pl. 27, fig. 9). There are three cardinal teeth in the left hinge (pl. 27, figs. 5, 8). The left posterior cardinal is long and rather narrow and parallels the posterior margin of the shell. The middle left cardinal is thick and bifurcate, and the anteriormost part is the smallest. The left anterior cardinal is thinner and longer than the middle cardinal and curves towards the ventral hinge margin until almost parallel with the anterior margin of the shell. The anterior dorsal margin of the hinge plate is crenulate.

Type: USNM 3611 is herewith designated the lectotype of Venus lamellifera Conrad, pl. 26, figs. 7, 10.

Type locality: Astoria, Oreg.

Holotype: Of Venus (Chione) clallamensis Reagan, USNM 328312.

Type locality: East Clallam, Wash.

Holotype: Of Venus (Chione) olympidea Reagan, USNM 328311.

Type locality: East of Clallam Bay, Astoria(?) formation, Washington.

Conrad described "Venus lamellifera" from the Dana Astoria collection, but as that name was preoccupied (Conrad, 1837, p. 25, pl. 19, fig. 19), Dall (1909, p. 122) renamed the species Venus? ensifera. The specimen figured by Conrad (1849) in plate 17, figure 12, is missing from the type collection; the specimen figured in plate 17 , figure $12 \mathrm{a}$, is the designated lectotype. The doublevalved lectotype is contained in rock, and the left valve is barely exposed, but the entire right valve is exposed except the posterior dorsal margin and a part of the ventral margin. The hinge is not accessible and only patches of the inner shell layers are present on the exposed right valve, but produced concentric lamellae can be seen on the outer shell of the left valve. The lectotype is poorly preserved, but by comparing it to the large collections of Chione ensifera the species can be definitely established. It would be improper not to recognize the name $C$. ensifera, for there is but one species of Chione (Securella) in the Astoria formation in Oregon, and the lectotype is undoubtedly Chione 
(Securella) and compares favorably with better preserved specimens of the species. The lectotype is 48.8 $\mathrm{mm}$ long, $41.0 \mathrm{~mm}$ high (approximate), and $9.5 \mathrm{~mm}$ wide (one valve, approximate).

Specimens of $C$. ensifera vary in ratio of height to length, in highness of umbos, and in degree of inflation. The degree of variation is not inconsistent with the variation noted in Recent species of Chione s.s. in collections at the U.S. National Museum.

Chione chehalisensis was described by Weaver (1912, p. 60, pl. 8, fig. 71) from the Montesano formation (Miocene) in Washington. Etherington (1931, p. 80-81, pl. 8, fig. 2; pl. 9, figs. 4, 5, 8, 11) considered $C$. chehalisensis to be a variety of $C$. ensifera, and he said that a complete series from the Astoria showed a gradation from $C$. ensifera to $C$. chehalisensis and that the typical $C$. ensifera did not occur beyond the middle Miocene and that the rounder thicker variety lived on into lower Montesano time.

Reagan (1909) named two new species of Chione, on the basis of two internal casts, from the Astoria formation near Clallam, on the south shore of the Strait of Juan de Fuca, Wash. "Venus (Chione) olympidea" (Reagan, 1909, p. 182-183, pl. 1, fig. 12) is based on a small highly inflated specimen that bears a few small patches of the original shell on the internal cast. This specimen is similar to the more inflated forms of C. ensifera. "Venus (Chione) clallamensis" (Reagan, 1909, p. 183, pl. 1, fig. 13) is based on a moderately small internal cast that retains none of the original shell, and that is broken at the anterior margin. This specimen is similar in outline to the less inflated forms of $C$. ensifera. These two species of Reagan's are placed in the synonymy of $C$. ensifera.

$C$. ensifera is not common throughout the Astoria formation, but it is very abundant in the dredgings at Coos Bay and in the rocks exposed north and south of Grant Creek in the sea cliffs south of Newport. Howe (1922, unpublished p. 102) collected this species from the Astoria formation at Fifth and Commercial Streets and at the foot of 19th Street in Astoria. Etherington (1931, p. 80) said that $C$. ensifera was well represented in the Astoria(?) formation of Washington, especially in the Clemons section between 1,200 and 1,600 feet above the base.

Localities: 1, 1a, 38, 42, 45, 48, 156, 157, 160, 165-167, 174, 181, 181a, 183, 184, 187.

Occurrence elsewhere: Astoria(?) Formation, Washington.

Subfamily PITARINAE

\section{Genus KATHERINELLA Tegland}

Katherinella Tegland, 1929, California Univ., Dept. Geol. Sci., Bull., v. 18, p. 280.

Type--By original designation Callocallista arnoldi Weaver (1916, Washington Univ. [Seattle] Pub. in
Geology, v. 1, p. 40, pl. 2, fig. 13), Blakeley formation, Washington, plate 25, figure 4. (According to Tegland, 1929 , p. 280, C. arnoldi was not collected from the type locality of the Lincoln formation in Washington.)

\section{Subgenus KATHERINELLA}

Katherinella s.s. may be distinguished from other genera of the Pitarinae by having an anterior lamella in the left hinge plate parallel to the anterior cardinal tooth and situated midway between the cardinal tooth and the anterior margin of the shell (pl. 25, fig. 4). The lamella is not parallel to the hinge plate and cannot be considered a true lateral. There is no feature corresponding to the left lamella on the right valve. Three specimens of the hinge of Katherinella from the Astoria formation out of a total of eight prepared have no left anterior lamellae. The remainder of the specimens have lamellae that may be sharp, toothlike structures parallel to the left anterior cardinal or forms intermediate between that and a small swelling at the anterior ventral margin of the left hinge plate.

Compsomyax has been regarded as a subgenus of Katherinella by some authors. There are no anterior lamellae or laterals on either the right or left hinge plates of Compsomyax. It has been suggested (Woodring, 1938, p. 54-55; Stenzel, Krause, and Twining, 1957, p. 133-135) that Compsomyax is a descendant of Katherinella. Stenzel and Krause (in Stenzel, Krause, and Twining, 1957, p. 135) said that in the family Veneridae it seems evident that some of the progressive evolutionary changes are the gradual suppression of lateral hinge teeth, both anterior and posterior. The variability in size, shape, and position of the left anterior lamellae and the lack of any corresponding features on the right hinge plates of Katherinella support this statement.

It seems probable that Katherinella angustifrons (Conrad) from the Astoria formation in Oregon had reached an evolutionary stage where the suppression of the left anterior lamellae had begun and was complete on some specimens and indicated on the remaining by the degree of variability of the expression of the lamella.

The hinge was exposed on a single left valve of the form from the Empire formation (Pliocene?) of Oregon that has been assigned by other workers to "Marcia oregonensis." This specimen (USGS 2950) has no anterior lamella on the left hinge. On the basis of a single specimen, it cannot be said that Katherinella had completed the suppression of the left anterior lamellae by Pliocene time; but study of the hinge of more specimens may prove this to be so. "Marcia oregonensis" of some authors (not Conrad, 1848) may prove to be Katherinella (Composomyax) sub- 
diaphana (Carpenter). Specimens of $K$. (C.) subdiaphana described by Woodring (in Woodring, Bramlette, and Kew, 1946, p. 84, pl. 33, figs. 7-9) from the Timms Point silt (lower Pleistocene) of California have no left anterior lamellae.

Stenzel and Krause (in Stenzel, Krause, and Twining, 1957, p. 133-134), in describing Texas Eocene forms, said that the hinge of the right valve of Katherinella has two anterior lateral lamellae flanking a slightly elongate anterior lateral hinge tooth, which is placed far forward and near the ventral hinge-plate margin. The right anterior lamellae would exclude these Texas Eocene forms from Katherinella s.s.

\section{Katherinella (Katherinella) angustifrons (Conrad)}

Plate 24, figs. 11-14; plate 25, figs. 1-3, 5-15; plate 26, figs. 4-6, 8

Venus angustifrons Conrad, 1949, U.S. Explor. Exped, Geology' v. 10, app. p. 724 , atlas pl. 17 , fig. 11 .

Dione angustifrons (Conrad). Conrad, 1865a, Am. Jour. Conchology, v. 1, p. 152.

Marcia (Mercimonia) angustifrons (Conrad). Etherington, 1931, California Univ., Dept. Geol. Sci., Bull., v. 20, p. 81-82, pl. 6, fig. 4 ; pl. 7 , fig. 3 .

Durham, 1944, California Univ., Dept. Geol. Sci., Bull., v. 27 , p. 147 .

Marcia angustifrons (Conrad). Weaver, 1942, Washington Univ. [Seattle] Pub. in Geology, v. 5, p. 191, pl. 45, figs. $1,2,4,3$ ? [1943].

Lutz, 1951, California Univ., Dept. Geol. Sci., Bull., v. 28 , p. 390 , pl. 15 , fig. 5 .

Venus brevilineata Conrad, 1849, U.S. Explor. Exped., Geology, v. 10, app. p. 724, atlas pl. 17, fig. 13 .

Dione brevilineata (Conrad). Conrad, 1865a, Am. Jour. Conchology, v. 1, p. 152.

Venus —? Conrad, 1849, U.S. Explor. Exped., Geology, v. 10, atlas pl. 18, figs. 1, 1a.

Cyprina bisecta Conrad, 1865a [in part], Am. Jour. Conchology, v. 1, p. 152,1849 , p!. 18, fig. 1 [not pl. 17, fig. 10].

?Venus (Chione) angustifrons Conrad. Reagan, 1909, Kansas Acad. Sci. Trans., v. 22, p. 181, pl. 1, fig. 9.

?Marcia oregonensis (Conrad). Dall, 1909, U.S. Geol. Survey Prof. Paper 59, p. 123-124, pl. 2, fig. 12, pl. 11, fig. 9, pl. 12, fig. 3.

Howe, 1922, California Univ., Dept. Geol. Sci., Bull, v. 14, check list facing p. 92.

?Saxidomus gibbosus Gabb. Reagan 1909, Kansas Acad. Sci. Trans., v. 22, p. 184, pl. 2, fig. 14.

[Not?] Cytheria oregonensis Conrad, 1848, Am. Jour. Sci., v. 5, p. 432, fig. 8 .

Katherinella angustifrons is moderately thin shelled, of medium size, and highly variable in overall outline and inflation. Some forms are almost circular in outline and moderately inflated (pl. 25, figs. 12, 15), some are subcircular in outline (pl. 25, figs. 6, 7), and others are elongate and highly inflated and the anterior end is produced to varying degrees (pl. 25, figs. 1-3, 5, 11, 14). Katherinella (Compsomyax) subdiaphana (Carpenter) in the Recent collections shows a similar degree of variation within single lots. In addition, the various fossil forms may be found within a single stratigraphic unit at one locality, and forms that show all stages of development between the forms illustrated are also in the collections. The right anterior cardinal tooth of $K$. angustifrons is split, the anterior part thin and bladelike; the right posterior cardinal tooth is grooved, the anterior part thinner and higher; there are no lateral teeth in the right hinge plate (pl. 26, figs. 5, $6,8)$. The left anterior cardinal tooth is bifurcated and the anterior part seems to have been grooved or split (pl. 25, fig. 9); the left posterior cardinal is long, thin, and bladelike. There is an anterior lamella present on some specimens; this lamella may be a sharp, toothlike structure parallel to the anterior cardinal or a small swelling at the anterior ventral margin of the hinge plate, or forms in between (pl. 25 , figs. $8-10,13$ ).

Type: USNM 3492, designated lectotype of Venus angustifrons (Woodring, 19ध8, p. 54), pl. 26, fig. 4; paratypes USNM 561520, 3521 , and 3615 .

Holotype: Of Venus brevilineata Conrad, USNM 3606, pl. 24, figs. 11, 13; paratype, USNM j61522.

Figured specimen: Venus _ Conrad, USNM 561523 (original No. 3492), pl. 24, figs. 12, 14; paratypes USNM 561520.

Type locality: For all types listed, Astoria, Oreg.

The lectotype of Venus angustifrons (pl. 26, fig. 4) is a double-valved specimen in a concretion; only the left valve is exposed. The anterior dorsal margin is not exposed, and only two patches of the outer shell remain; this is the best specimen in the original type lot. The lectotype is $42.4 \mathrm{~mm}$ long, $32.5 \mathrm{~mm}$ high, and approximately $8 \mathrm{~mm}$ thick (left valve only).

The holotype of Venus brevilineata (pl. 24, figs. 11, 13 ) is a double-valved internal mold; the umbos and margins of the mold are broken. The specimen is 49.6 $\mathrm{mm}$ long, more than $41 \mathrm{~mm}$ high, and $26.9 \mathrm{~mm}$ thick (both valves). Some workers have considered "V." brevilineata to be a variety of $K$. angustifrons; the variety was considered to be the short form. Large collections of $K$. angustifrons have made it possible to note the great variation in shape and thickness of this species. The variation is not of stratigraphic significance nor is it possible to separate the forms into groups, as they grade imperceptibly from one to another.

The specimen figured by Conrad as Venus____ ? (1849, pl. 18, figs. 1, 1a) is an internal mold of $K$. angustifrons broken at the anterior end, plate 24, figures $12,14$.

"Cytherea oregonensis" may be an immature specimen of $K$. angustifrons (p. 78).

There are 10 additional specimens of $K$. angustifrons in the Dana Astoria collection (USNM 3521, 3615, 561520 -original No. 3492) and 1 specimen that originally had the same catalog number as Venus brevili- 
neata, USNM 3606, and has now been renumbered USNM 561520. These specimens although poorly preserved are all identified as $K$. angustifrons.

$K$. angustifrons seems to be closely allied to "Pitaria" (Katherinella) arnoldi etheringtoni Tegland (1929, p. 283, pl. 23, figs. 12-14), on the basis of the original illustrations only. "P." $(K$.$) arnoldi etheringtoni was collected$ from the Astoria formation near the town of Clallam Bay, Wash.; Durham (1944, p. 148) records it from his Echinophoria apta zone in the Twin River formation (late Oligocene) in Clallam County, Wash. Because of the lack of comparative material, no determination of affinity is made.

$K$. angustifrons is common throughout the Astoria formation in Oregon, and it is very abundant in some sections in concentrated discontinuous lenses and thin layers, particularly in the units above the Anadara devincta layer exposed between Spencer Creek and Yaquina Head (pl. 33). The specimens are usually double valved, and they often have the valves completely closed or only slightly open.

Localities: 1a, 7, 32, 37, 43, 45, 47-49, 55-64, 67, 68, 70, 71, 75, 78-81, 82-87, 90-94, 97, 99, 101, 102, 102a, 103-109, 111-113, $115-122,124,125,128-130,134,137-144,147,149-153,156$, $158,160-163,165,167,169,171,172,174,177,181,181 \mathrm{a}, 183-$ 185,187 ; cf. 98.

Occurrence elsewhere: Astoria(?) formation, Washington; Temblor formation, lower and middle Miocene, and Sobrante sandstone, middle Miocene, California.

\section{Genus?}

"Cytherea oregonensis Conrad", nomen dubium

Plate 25, figure 16

Cytherea oregonensis Conrad, 1848, Am. Jour. Sci., v. 5, p. 432, fig. 8.

Dione oregonensis (Conrad). Conrad, 1865a, Am. Jour. Conchology, v. 1, p. 152.

[Not] Marcia oregonensis (Conrad). Dall, 1909, U.S. Geol. Survey Prof. Paper 59, p. 123-124, pl. 2, fig. 12; pl. 11, fig. 9 ; pl. 12, fig. 3.

[Not] Pitaria oregonensis (Conrad). Etherington, 1931, California Univ. Dept. Geol. Sci. Bull., v. 20, p. 78-79, pl. 6, figs. 1, 2, 3.

[Not] Pitar oregonensis (Conrad). Weaver, 1942, Washington Univ. [Seattle] Pub. in Geology, v. 5, p. 181, pl. 42, figs. 12, 13, 15, 21 [1943].

The type specimen of "Cytherea oregonensis" is an immature small right valve; the hinge is inaccessible. It is possible that this could be an immature specimen of Katherinella angustifrons, but it is also possible that it could be an immature Pitar. No Pitars have been identified in the collections from the Astoria formation in the U.S. National Museum, but Etherington (1931, p. 78-79, pl. 6, figs. 1, 2,3) apparently had a Pitar in the Astoria formation in southwestern Washington. The type of "Cytherea oregonensis" is poorly preserved and "Cytherea oregonensis" is considered a nomen dubium.

Holotype: Acad. Nat. Sci. Philadelipha 4526, pl. 25, fig. 16. Type locality: Astoria, Oreg.

\section{Family TELLINIDAE \\ Genus TELLINA Linné}

Tellina Iinné, 1758, Systema naturae, ed. 10, p. 674.

Type.-By subsequent designation (Gray, 1847), Tellina radiata Linné. Recent, West Indies.

Tellina emacerata Conrad

Plate 29, figures 6, 7, 13, 14

Tellina emacerata Conrad, 1849, U. S. Explor. Exped., Geology, v. 10 , app. p. 725 , atlas pl. 18 , fig. 4 .

Dall, 1909, U.S. Geol. Survey Prof. Paper 59, p. 125.

Weaver, 1942, Washington Univ. [Seattle] Pub. in Geology, v. 5, p. 206, pl. 48, fig. 20, [not?] pl. 48, fig. 18 [1943].

Tellina (Peronida) oregonensis Conrad. Etherington, 1931, California Univ., Dept. Geol., Sci., Bull., v. 20, p. 83-84, pl. 10, figs. 6,7 .

Tellina clallamensis Reagan, 1909, Kansas Acad. Sci. Trans., v. 22 , p. 186-187, pl. 2, fig. 18.

Tellina emacerata is a small thin-shelled form with concentric grooves and ridges visible on well-preserved shells. There is a conspicuous flattened angulation at the posterior end of the shell; the concentric ridges turn upward at the anterior end of the angulation at an angle of about $45^{\circ}$. The ridges are higher on the angulation than on the rest of the shell; so the shell is rougher there. The right posterior cardinal is small and bifid and is the only tooth remaining on the hinge exposed; no left valve hinge was available.

Holotype: Of Tellina emacerata Conrad, USNM 3494, pl. 29, fig. 14.

Type locality: Astoria, Oreg.

Holotype: Of Tellina clallamensis Reagan, USNM 328320, pl. 29, fig. 6.

Type locality: East of Clallam, Wash., Miocene.

The type specimen of Tellina emacerata, reported missing by Dall (1909, p. 125) but subsequently recogmized in the U.S. National Museum type collections, is a single right valve in fossiliferous sandstone. Approximately one-half of the original shell is missing, and the beak is not exposed. The specimen is thin shelled and has evenly spaced concentric grooves separated by interspaces about five times as wide as the grooves at the anterior ventral margin, but tending to become more closely spaced towards the anterior dorsal margin and the posterior margin, until the grooves are separated by interspaces of equal width. There is a conspicuous flattened angulation near the posterior margin which has concentric ridges. These ridges seem to be the continuation of the concentric grooves on the rest of the shell, which change direction abruptly at the angulation and trend towards the posterior dorsal 
margin at an angle of about $45^{\circ}$. The type specimen is about $33 \mathrm{~mm}$ long and more than $16 \mathrm{~mm}$ high (beak not exposed).

The grooves and ridges on the exterior of the shell are not too helpful a criterion for purposes of identification; the specimens in the collections rarely show this sculpture except on fragments of the shell that are not worn. The concentric grooves are apt to be most noticeable near the anterior ventral margin.

T. emacerata is similar in overall shape to Tellina bodegensis Hinds, subsp.? of Clark and Arnold (1923, p. 149 , pl. 22, figs. 7,8 ) collected from the Sooke formation (Miocene) of Vancouver Island, but no specimens were a vailable for comparison.

Localities: 1a, 4, 79, 83, 90, 94, 105, 108, 120,139, 156, 159, 161, 167, 187; cf. 7, 80, 104.

Occurrence elsewhere: Astoria(?) formation, Washington.

\section{Tellina aff. T. idae Dall}

Plate 29, figures $1-5$

A tellinid was collected from the dredgings at Coos Bay, Oreg. It was not found in any of the exposures of the Astoria formation farther north and may be a new species although it is comparable to the Recent form, Tellina idae Dall. Tellina aff. T. idae is of moderate size and has a relatively thick shell and a sinus near the posterior margin that is bordered posteriorly by two radial ridges separated by a groove. The concentric grooves and ridges are folded on the radial ridges, and the open end of the folds faces the dorsal margin. The posterior end of the valves is twisted towards the left, as the shell is held in oriented position. The right posterior cardinal is bifid, and the anterior cardinal is thin; the hinge is not completely exposed, but anterior and posterior laterals are present. The left anterior cardinal (broken) is deeply bifid, and the anterior part is thicker. The posterior cardinal is broken but is apparently small; the hinge is not completely exposed, but laterals are present (pl. 29, figs. 1, 2).

All the specimens of this species in the collections are incomplete, broken at the anterior or posterior end and along the ventral margin. T. aff. T. idae is, however, shorter at the anterior end and is smaller in overall size than $T$. idae. In addition, the concentric lines on the right valve are more closely spaced and more numerous than on $T$. idae, although this character shows some variation on Recent specimens of T. idae. The lunule is larger and wider (almost two times as wide), and the escutcheon seems to have been slightly wider and perhaps not as long as on T. idae.

Specimens of $T$. aff. $T$. idae range in size from $28+$ $\mathrm{mm}$ long, $19+\mathrm{mm}$ high, and $7.6 \mathrm{~mm}$ wide to $46+$ $\mathrm{mm}$ long, $29+\mathrm{mm}$ high, and about $10 \mathrm{~mm}$ wide (both valves).

The type specimens of California species similar to $T$. aff. $T$. idae have not been examined; the following observations have been made on the basis of descriptions and illustrations only. T. nevadensis Anderson and Martin (1914, p. 61-62, pl. 2, figs. 3a, 3b, 3c) is higher in proportion to length and larger than $T$. aff T. idae. T. english Clark (1915, p. 472-473, pl. 61 , figs. 6, 7) is more elongate anteriorly, and the beaks are posterior to the center, whereas on $T$. aff. $T$. idae they are almost medial in position. T. tenuistriata Davis (1913, p. 457, fig. 7), renamed T. insurana Hanna in 1924 and then T. davisi Salisbury in 1932, seems to be more elongate posteriorly and longer in proportion to height than $T$. aff. $T$. $\imath$ dae.

Locality: 187.

\section{Tellina oregonensis Conrad, nomen dubium}

Tellina oregonensis Conrad, 1848, Am. Jour. Sci., v. 5, p. 432, fig. 5 .

Conrad described a tellinid from the Townsend collection and assigned it the name Tellina oregonensis. The holotype is missing, presumably lost, and the original description is brief and the illustration a drawing. On the basis of the description and the illustration of $T$. oregonensis, it appears likely that it is the same species as T. emacerata. If this is true, the name $T$. oregonensis would have priority over $T$. emacerata. Under the circumstances, however, it seems best to consider $T$. oregonensis a nomen dubium and to use the name $T$. emacerata, which is not in doubt.

Holotype: Missing.

Type locality: Astoria, Oreg.

Howe (1922, unpublished, p. 97) collected a tellinid, which he indentified as $T$. oregonensis, from the Astoria formation at Fifth and Commercial Streets in Astoria. This is the same form, presumably that is here called T. emacerata.

\section{Tellina nasuta Conrad, nomen dubium}

Tellina nasuta Conrad, 1849, U.S. Explor. Exped., Geol., v. 10, app. p. 725 [Not Tellina nasuta Conrad, 1837, Acad. Nat. Sci. Philadelphia Jour., ser. 1, v. 7, p. 258-259.]

Tellina subnasuta (Conrad). Conrad, 1865, Am. Jour. Conchology, v. 1, p. 152, new name for T. nasuta.

This species was described by Conrad as follows:

Subtriangular, convex, anterior side with a slight prominent fold, angulated anteriorly; anterior margin curved above, truncated at the extremity; posterior margin rounded. Beaks medial. Anterior basal margin arcuated; basal margin tumid near the middle. Astoria, Oregon.

Type: Undetermined, presumably lost.

Type locality: Astoria, Oreg. 
This species was not illustrated, and no measurements were given. Tellina nasuta is considered a nomen dubium. The specimens of tellinids with Conrad's type material can all be assigned to $T$. emacerata, Macoma albaria, or Macoma arctata.

Tellina bitruncata Conrad, nomen dubium

Tellina bitruncata Conrad, 1849, U.S. Explor. Exped., Geol., v. 10, app. p. 725 .

Conrad, 1865a, Am. Jour. Conchology, v. 1. p. 152.

This species was described by Conrad as follows:

Elliptical, compressed; anterior side reflected; extremity truncated; posterior margin obliquely truncated. Ligament margin short, straight, parallel with the anterior basal margin; basal margin slightly contracted in the middle; posterior extremity acutely rounded. Astoria, Oregon.

Type: Undetermined, presumably lost.

Type locality: Astoria, Oreg.

T. bitruncata was not illustrated, and no measurements were given. The species is considered a nomen dubium.

\section{Genus MACOMA Leach}

Macoma Leach, 1819, in John Ross, A voyage of discovery *** for the purpose of exploring Buffins Bay and inquiring into the probability of a northwest passage, appendix 11, p. 62 .

Type--By monotypy, Macoma tenera Leach (=Tellina calcarea Gmelin). Recent, northern seas of Europe and North America.

\section{Macoma albaria (Conrad)}

Plate 28, figures $8,9,12,14$; plate 29 , figure 9

Tellina albaria Conrad, 1849, U.S. Explor. Exped., Geol., v. 10, app. p. 725, atlas pl. 18, fig. 5 .

Conrad, 1865a, Am. Jour. Conchology, v. 1, p. 152.

Tellina (Angulus) albaria Conrad. Dall, 1909, U.S. Geol. Survey Prof. Paper 59, p. 126.

[Not] Tellina albaria Conrad, 1865a, Am. Jour. Conchology, v. 1, p. 138 , pl. 11 , fig. 7 .

[Not] Tellina albaria Conrad. Regan, 1909, Kansas Acad. Sci. Trans., v. 22, p. 184, pl. 2, fig. 15.

Macoma albaria is a small thin-shelled subovate species bearing irregularly spaced concentric grooves; the largest specimen in the collections is $23 \mathrm{~mm}$ long and $17 \mathrm{~mm}$ high. An almost complete left hinge was exposed on one specimen (pl. 29, fig. 9), and this hinge does not show any lateral teeth; therefore, this species is assigned to Macoma. In addition, $M$. albaria lacks the evenly spaced concentric grooves on the exterior shell, common on Tellina, and it bears close resemblance in outline to some of the small specimens of Macoma in the Recent collections of mollusks from the Pacific coast.

Type: USNM 3614 is herewith designated the lectotype, pl. 28, fig. 12.

Type locality: Astoria, Oreg.
Three specimens in Conrad's type collection are labeled Tellina albaria; it is probable that these three specimens were available to and handled by Conrad. Two of the specimens are free of matrix, and neither of these agree at all in outline with the original drawing; the third specimen is contained in rock and does agree in general outline with the illustration. However, more than half of the original shell of the specimen is missing, whereas the illustration is of an entire shell, and J. D. Dana, the illustrator, was usually careful to show breaks in the shell or missing shell. The fact that the specimen is not drawn as contained in rock is not pertinent, as the specimen of Tellina emacerata which is without doubt that illustrated is contained in rock and yet not so illustrated. The single valve contained in rock (USNM 3614) is the specimen designated the lectotype; the remaining two specimens have been assigned the catalog No. USNM 563381.

"Tellina albaria Conrad" of Reagan (1909, p. 184, pl. 2, fig. 15) is much larger than any specimens of $M$. albaria in the collections from the Astoria formation, and although it agrees somewhat in overall outline with M. albaria (pl. 28, fig. 4), it is not considered here to be the same species. The specimen is worn but may be more closely allied to Macoma twinensis Clark, a species that has been collected from the Blakeley formation (upper Oligocene or lower Miocene) in Washington. M. albaria is somewhat similar to $M$. twinensis Clark (1925, p. 96 , pl. 12, fig. 7) in configuration but is not as high in proportion to length and the beaks are nearer the posterior end.

$M$. albaria is particularly common in the fine-grained stratigraphic units of the Astoria formation. Howe (1922, unpublished, p. 94) collected $M$. albaria from the Astoria formation at the corner of Fifth and Commercial Streets in Astoria; it is also present in the Nye mudstone (lower Miocene) in the Newport area, Oregon.

Localities: 1, 1a, 7, 22, 23, 29, 32, 33, 45, 48, 49, 52, 55-57, 59, $60,62,63,69,69 \mathrm{a}, 71,73,79,81 \mathrm{a}, 83,87,91-94,98,102,104,105$, $108,109,112,116,119-122,124,128-130,134,138,139,144$, $145,148-150,152-154,156,161,164,167,169,171,172,174$, 181, 181a, 187; cf. 6, 31, 66 .

Occurence elsewhere: Nye mudstone, early Miocene, Oregon; Astoria(?) formation, Washington.

Tellina obruta Conrad, nomen dubium

Tellina obruta Conrad, 1848, Am. Jour. Sci., v. 5, p. 432, fig. 6.

Tellina obruta seems to be closely related to if not conspecific with Macoma albaria (Conrad), on the basis of the original drawing and description. The original description of T. obruta is brief, the illustration a rather poor drawing, and the type is presumed to be lost. It seems advisable therefore to consider $T$. obruta a nomen dubium.

Holotype: Missing, presumed lost.

Type locality: Astoria, Oreg. 


\section{Macoma arctata (Conrad)}

Plate 28 , figures $6,7,10,11,13$; plate 29 , figure 8

Tellina arctata Conrad, 1849, U.S. Explor. Exped., Geology, v. 10 , app. p. 725 , atlas pl. 18, figs. 3, 3a.

Conrad, 1865a, Am. Jour. Conchology, v. 1, p. 152,

Reagan, 1909, Kansas Acad. Sci. Trans., v. 22, p 184, 186, pl. 2, figs. 16, 16a.

Tellina arctata Conrad var. juana Reagan, 1909, Kansas Acad. Sci. Trans., v. 22, p. 186, pl. 1, fig. 17.

Macoma arctata (Conrad). Dall, 1909, U.S. Geol. Survey Prof. Paper 59, p. 126.

Weaver, 1942, Washington Univ. [Seattle] Pub. in Geology, v. 5, p. 208-209, pl. 49, figs. 3, 5, 12, pl. 59, fig. 15 [1943].

Macoma (Psammacoma) arctata (Conrad). Etherington, 1931, California Univ., Dept. Geol. Sci., Bull., v. 20, p. 84-85, pl. 10, figs. $1,2$.

?Macoma arctata (Conrad). Hall, 1958, California Univ., Dept. Geol. Sci., Bull., v. 34, p. 55, pl. 8, fig. 4.

Macoma arctata is a moderately thin shelled species bearing irregularly spaced uneven concentric ridges and grooves. The shell is angulated near the posterior margin and often has a strong posterior flexure. On the right hinge plate, the anterior cardinal is squat and deeply bifurcate; the posterior cardinal extends to the ventral margin of the hinge and is thickest at the dorsal margin. The posterior cardinal on the left hinge plate is short and squat (pl. 28, fig. 6).

Holotype: USNM 3489, pl. 28, figs, 7, 10.

Paratypes: USNM 561525.

Type locality: Astoria, Oreg.

Five specimens, all numbered USNM 3489, were in the original type lot of Macoma arctata; all but the holotype have been renumbered USNM 561525. Three of the specimens are internal casts of both valves, one is an internal cast in a concretion, and the remaining specimen is a partial mold in a concretion. The specimen that is labeled with a green diamond-shaped sticker, indicating type, does not correspond with the original illustration of $M$. arctata. The specimen here illustrated (pl. 28, figs, 7, 10), USNM 3489, is not the specimen with the sticker, but it does exactly correspond with the original illustration. This is the same specimen figured by Weaver as the type (1942, pl. 49, fig. 12). The type of $M$. arctata is an internal cast, but a few patches of the innermost shell layers remain; the specimen is $52.0 \mathrm{~mm}$ long, $33.6 \mathrm{~mm}$ high, and $14.0 \mathrm{~mm}$ wide (both valves).

The holotype of Tellina arctata var. juana Reagan (USNM 328315) is an internal cast of a left valve broken off at the umbo and at the anterior, posterior, and ventral margins (pl. 28, fig. 11). It is poorly preserved, but it agrees with Macoma arctata sufficiently well to be placed in synonymy, and this action will remove a questionable name from the literature.

$M$. arctata is common in the Astoria formation in Oregon and is particularly abundant in the siltier units of the formation. Howe (1922, unpublished, p. 71) collected this species from the Astoria formation at the foot of 19th Street in Astoria.

Localities: 1a, 22, 31, 33, 33c, 38, 48, 52, 56-64, 67-69, 70, 71, $78-80,82,83,85-87,87$ a , 88, 90-94, 96, 97, 98, 99, 101, 102, 103$108,110-113,116,118-122,126,128,130,136,137,139-144,147$, $150,152,153,156,159-161,164,165,167,171,172,174,181$, 181a, 183-185, 185a, 187.

Occurrence elsewhere: Astoria(?) formation, Washington; Vaqueros (lower Miocene) and Temblor (lower, and middle Miocene) Formations, California.

\section{Macoma cf. M. astori Dall \\ Plate 28, figure 15}

Four specimens were collected from the dredgings at Coos Bay and one from locality 99 near Spencer Creek; these specimens can be compared with Macoma astori (Dall, 1909, p. 128, pl. 14, figs. 1, 11) from the Empire formation at Coos Bay, Oreg. One of Dall's specimens, labeled by him as type, is figured here, plate 29, figure 12 . The specimens compared to $M$. astori are not well preserved; those collected from the Coos Bay dredgings were collected singly without any other identifiable species and could have been dredged from the Pliocene(?) part of the section exposed in the channel. The specimen from the Astoria formation (loc. 99) is broken, and only the anterior part of a left valve remains. The hinge was not exposed.

Localities: 99, 187.

\section{Macoma n. sp.? \\ Plate 29, figures 10,11}

This Macoma is thin shelled, high in proportion to length, and perhaps almost circular in outline. The shell is slightly to moderately inflated and concentrically grooved. The eight specimens available are all incomplete; the one hinge exposed is poorly preserved.

The specimens were all collected 2 to 3 miles south of Newport, from beach cliffs in which the Astoria formation is exposed. These exposures of the Astoria formation are not recorded in publication, but they were mentioned by Howe (1922, unpublished). Macoma n. sp.? has not been found in the exposures of the Astoria farther north. This Macoma will probably prove to be a new species when better specimens are collected. The specimen figured is in the collections at the California Academy of Sciences.

Localities: 181, 181a, 184.

\section{Family SANGUINOLARIIDAE \\ Genus GARI Schumacher}

Gari Schumacher, 1817, Essai d'un nouveau système des habitations des vers testáces, p. 44, 131.

Type.-By tautonomy, Gari vulgaris Schumacher= Tellina gari Linné. Recent, East Indies, Philippines, Orient (Grant and Gale, 1931, p. 381-382). 
Gari? aff. G. edentula (Gabb)

Plate 31, figure 10

Eight incomplete specimens of this form were collected in the Coos Bay dredgings. The specimens are externally similar to Gari edentula (Gabb) (1869, p. 53, 89, pl. 13, fig. 3), recorded from Pliocene to Recent in California and questionably from late Miocene, but the hinge is not available for comparison, and the specimens are not well-enough preserved for positive identification. The largest and best preserved specimen is figured; it is $69 \mathrm{~mm}$ long (incomplete) and $43.7 \mathrm{~mm}$ high.

Locality: 187.

\section{Family SOLENIDAE}

Genus SOLEN Linné

Solen Linné, 1758, Systema naturae, 10th edition, p. 672.

Type.-By subsequent designation (Schumacher, 1817, Essai d'un nouveau système des habitations des vers testacès, p. 124 , pl. 6 , fig. 3 ), Solen vagina Linné. Recent, East Indies?

\section{Solen conradi Dall}

Plate 23, figure 11

Solen curtus Conrad, 1848, Am. Jour. Sci., v. 5, p. 433, fig. 14. Weaver, 1942, Wash. Univ. [Seattle] Pub. in Geology, v. 5, p. 226-227 [1943]. [Not Solen curtus Des Moulins, 1832.]

Ensis curtus (Conrad). Meek, 1864, Smithsonian Misc. Colln. 183, p. 12. Conrad, 1865a, Am. Jour. Conchology, v. 1, p. 152 .

Plectosolen curtus (Conrad). Conrad, 1866c, Smithsonian Misc. Colln. 200, p. 8

Solen (Plectosolen) curtus Conrad. Dall, 1909, U.S. Geol. Survey Prof. Paper 59, p. 129.

Solen (Plectosolen) curtus(?) Conrad. Etherington, 1931, California Univ. Dept. Geol. Sci., Bull., v. 20, p. 88-89.

Solen conradi Dall, 1890-1903, Wagner Free Inst. Sci. Trans., v. 3 , pt. 5, p. 953, 1900, new name.

?Solen curtus Conrad. Clark, 1918, California Univ., Dept. Geol. Sci., Bull, v. 11, p. 155-156, pl. 10, fig. 6.

[Not?] Solen (Plectosolen curtus var.?) conradi Dall, 1909, U.S. Geol. Survey Prof. Paper 59, p. 129-130, pl. 12, figs. 7, 10.

Solen conradi is a small smooth-shelled form that has an almost straight dorsal margin and a slightly curved ventral margin.

Holotype: Acad. Nat. Sci. Philadelphia no. 4526, pl. 23, fig. 11. Type locality: Astoria, Oreg.

A single specimen of "Solen curtus Conrad" that was at least handled by Conrad, if it is not the specimen on which the original description was based, has been located at the Academy of Natural Sciences of Philadelphia (pl. 23, fig. 11). This specimen is on the other side of the type specimen of Cytherea oregonensis Conrad, is numbered Academy Natural Sciences Philadelphia 4526, and is here considered to be the holotype.
The type of Solen curtus is small and has been broken in the middle and glued back together. The type does not show the rather strongly curved dorsal margin of Conrad's original illustration, having instead an almost straight dorsal margin. Almost all of the shell is missing except a small part along the ventral margin. The type is $29.5 \mathrm{~mm}$ long and about $8 \mathrm{~mm}$ high; the single (left?) valve is about $2.5 \mathrm{~mm}$ thick.

In 1900, Dall proposed the new name Solen conradi for Conrad's S. curtus and said (1890-1903, p. 953, 1900) that he had collected what he supposed to be this species from the Empire beds at Coos Bay. In 1909, however, Dall inadvertently (p. 129) described the form from Coos Bay as a new species, again using the name Solen conradi. The collections in the U.S. National Museum are not adequate to determine if the Empire Solen is a different species; if it should prove to be distinct, it will of course need a new name.

$S$. conradi is represented in the collections by a few poorly preserved specimens. All but one of these (loc. 39) are small and compare favorably with the type specimen. The specimen from locality 39 is much larger and may not be related to $S$. conradi.

$S$. conradi has been collected from the Astoria(?) formation in Washington (Etherington, 1931, p. 88-89) and from the San Ramon (late Oligocene or early Miocene) in Califormia (Clark, 1918, p. 158-159).

Localities: 1a, 33c, 48, 61, 71, 89, 105, 108, 116, 120, 138, 139, 156, 183, 187.

Occurrence elsewhere: Astoria(?) formation, Washington; San Ramon formation, upper Oligocene or lower Miocene and Temblor formation, lower and middle Miocene, California.

\section{Family MACTRIDAE \\ Genus SPISULA Gray}

Spisula Gray, 1837, Mag. Nat. History, new ser., v. 1, p. 372.

Type.-By subsequent designation (Gray, 1847, Zool. Soc. London Proc., no. 179, p. 185), Mactra solida (Linné). Recent, seas of Europe.

\section{Subgenus MACTROMERIS Conrad}

Mactromeris Conrad, 1868, Am. Jour. Conchology, v. 3, app. p. 45 .

Type.-By subsequent designation (Stoliczka, 1870, Geol. Survey India, Palaeontologia Indica, v. 3, p. 16), Standella ovalis (Gould) = Mactra polynyma Stimpson). Recent, East coast of the United States.

Spisula (Mactromeris) albaria (Conrad)

Plate 28, figures 1-3, 5; plate 31, figures 9, 11

Mactra albaria Conrad, 1848, Am. Jour. Sci., v. 5, p. 432, fig. 4. Conrad, 1865a, Am. Jour. Conchology, v. 1, p. 152.

Spisula (Mactromeris) albaria (Conrad). Etherington, 1931, California Univ., Dept. Geol. Sci. Bull., v. 20, p. 86, pl. 10, figs. 8,9 . 
Weaver, 1942, [in part], Washington Univ. [Seattle] Pub. in Geology, v. 5, p. 239, pl. 57, fig. 5 [1943]; [not pl. 57, fig. $10=$ Spisula (Mactromeris) albaria var. coosensis Howe, according to Weaver, p. 242].

Spisula albaria (Conrad). Howe, 1922 California Univ., Geol. Sci., Bull., v. 14, pl. 9, figs. 1, 2.

Lutz, 1951, California Univ., Dept. Geol. Sci., Bull., v. 28 , p. 388.

?Mactra (Spisula) albaria Conrad. Grant and Gale, 1931, San Diego Soc. Nat. History Mem., v. 1, p. 395-396, pl. 23, figs. $3 a, 3 b$.

?Mactra gibbsana Meek. Reagan, 1909, Kansas Acad. Sci. Trans., v. 22, p. 187, pl. 2, figs. 19a, $19 \mathrm{~b}$.

Spisula albaria is of small to moderate size and varies in outline between forms subovate and almost equilateral (pl. 28, fig. 2) to ones that have the anterior end markedly produced (pl. 28, fig. 1). There is no variation in the hinge of the forms studied, and in addition the same amount of variation in outline has been noted in single collections of Recent species of Spisula. Well-preserved specimens of S. albaria show a prominent posterior ridge extending from the umbo to the ventral margin and bordered on either side by a slight depression (pl. 28, fig. 2). The concentric lines are more prominent on this ridge than elsewhere on the shell. One specimen was collected (loc. 139) that shows a broad anterior furrow extending from the umbo along the anterior margin to the ventral edge of the shell (pl. 31, fig. 9).

Holotype: Missing and presumed lost.

Type locality: Astoria, Oreg.

A search was made for the holotype of $S$. albaria at the Academy of Natural Sciences of Philadelphia, but the type was not found. A single lot of specimens labeled as collected by George Gibbs in Astoria, and numbered 4550, was found at the Academy. These specimens had been handled by Dall, but there was no evidence that Conrad ever saw them. In addition, the accuracy of the locality data for some of the specimens collected by Gibbs and on deposit in the U.S. National Museum is in doubt.

The right anterior cardinal tooth is thin and bladelike and almost parallels the dorsal margin of the shell, to which it is fused (pl. 28, fig. 5). The middle cardinal borders the anterior edge of the chondrophore, which is fairly deep and oblique and seems to have been partly roofed over at the dorsal margin. Both the anterior and the posterior laterals are thin and bladelike, parallel and close to the dorsal margin and bordered dorsally by a moderately deep pit and ventrally by a very deep pit. The left anterior cardinal (pl. 28 , fig. 3) is bifid and projects beyond the hinge plate. There apparently was a thin bladelike posterior cardinal paralleling the anterior cardinal and barely separated from it. The anterior and posterior laterals are thin and border the ventral margin of the hinge plate, being separated from the dorsal margin by a moderately deep groove.

The specimen from East Clallam, Wash., identified by Reagan (1909, p. 187, pl. 2, figs. 19a, 19b) as Mactra gibbsana Meek is an internal mold and no shell remains, but it probably is Spisula albaria.

$S$. albaria is moderately common in the Astoria formation in Oregon and is quite abundant in the dredgings of Coos Bay.

Localities: 1a, 33c, 37, 38, 50, 60, 65, 66, 68, 69a, 76, 77, 79, $83,84,86,87,90,92,94,116,139,145,146,149,150,156,161$, $167,173,187$; cf. 71 .

Occurrence elsewhere: Astoria(?) formation, Washington; Temblor and San Pablo formations, Miocene, and Etchegoin formation, Pliocene, California.

\section{Family HIATELLIDAE}

Genus PANOPE Ménard de la Groye

Panope Ménard de la Groye, 1807, Mémoire sur un nouveau genre de coquille bivalve-équivalve de la famille des Solenoides, p. 16, 31 (Dall, 1912, Malacological Soc. Proc., v. 10, p. 34-35)

Type.-By subsequent designation (Schmidt, 1818, Vers Conch.-Samml., p. 47, 177), Mya glycimeris Gmelin (cited by Ménard de la Groye, 1807, p. 32, in synonymy of Panope aldrovandi). Recent, Mediterranean Sea.

\section{Panope (Panope) abrupta (Conrad)}

Plate 30, figures 3, 4; plate 31, figures 4, 7

Mya abrupta Conrad, 1849, U.S. Explor. Exped., Geol., v. 10, app. p. 723, atlas pl. 17, fig. 5. [Not Pholodaomya abrupta Conrad, 1832, Fossil shells tertiary formations North America, v. 1, no. 2, p. 26, pl. 12; nor Panopoea abrupta (Conrad), Deshayes, 1835, Hist. nat. animaux sans vertebres, ed. 2, v. 6, p. 66.$]$

Glycimeris abrupta (Conrad). Conrad, 1865a, Am. Jour. Conchology, v. 1, p. 152.

Panopaea generosa Gould, 1850, Boston Soc. Nat. History Proc., v. 3, p. 215 . Reagan, 1909, Kansas Acad. Sci. Trans., v. 22, p. 188, pl. 3, fig. 20.

Panopea generosa (Gould). Arnold, 1910, U.S. Geol. Survey Bull. 396, p. 142, pl. 18, fig. 4; repeated in Arnold and Anderson, 1910, U.S. Geol. Survey Bull. 398, pl. 40, fig. 4.

Panope generosa (Gould). Clark, 1915, California Univ., Dept. Geol. Sci., Bull., v. 8, pl. 62, fig. 1.

Etherington, 1931, California Univ., Dept. Geol. Sci., Bull., v. 20, p. 88.

Tegland, 1933, California Univ., Dept. Geol. Sci., Bull., v. 23 , p. 121 , pl. 9, fig. 13 .

Weaver, 1942, Washington Univ. [Seattle] Pub. in Geol., v. 5 , p. 262, pl. 60, figs. 2, 4 [1943].

Panope (Panope) generosa (Gould). Grant and Gale, 1931, San Diego Soc. Nat. Hist. Mem., v. 1, p. 424-425, pl. 21, figs. $12 \mathrm{a}, 12 \mathrm{~b}$.

Panope of. generosa (Gould). Loel and Corey, 1932, California Univ., Dept. Geol. Sci., Bull., v. 22, p. 234, pl. 44, fig. 7.

Glycimeris estrellana Conrad, 1857, U.S. Pacific R. R. Repts., v. 7, p. 194, pl. 7, fig. 5 . 
Panopea estrellana (Conrad). Dall, 1909, U.S. Geol. Survey Prof. Paper 59, p. 133.

Arnold, 1910, U.S. Geol. Survey Bull, 396, p. 64, pl. 15, fig. 1; repeated in Arnold and Anderson, 1910, U.S. Geol. Survey Bull, 398, pl. 37, fig. 1.

Panope abrupta is a thin-shelled form of moderate size, is rectangular in outline, and bears concentric lines grouped together to form concentric ridges.

Holotype: Of Mya abrupta Conrad, USNM 3608, pl. 31, figs. 4, 7; counterparts of holotype, USNM 3479. Counterparts retain much of the shell showing sculpture.

Type locality: Astoria, Oreg.

Holotype: Of Panopaea generosa Gould, USNM 5894.

Type locality: Puget Sound, Wash. (Recent).

Holotype: Of Glycimeris estrellana Conrad, USNM 13320.

Type locality: Estrella Valley, Miocene, San Luis Obispo County, Calif. [Estrella Valley on label.]

The type of Panope abrupta (pl. 31, figs. 4, 7) is 65.8 $\mathrm{mm}$ long, $39.2 \mathrm{~mm}$ high, and $22.8 \mathrm{~mm}$ wide (both valves); the specimen has retained patches of the inner shell layers only and is smaller than the average size for the species.

The type of Glycimeris estrellana Conrad is an internal cast, and none of the original shell remains; the specimen is brolzen at the anterior and posterior margins but is approximately $65 \mathrm{~mm}$ long, $44 \mathrm{~mm}$ high, and $29 \mathrm{~mm}$ wide (both valves). Although this type is poorly preserved, it can be assigned to Panope abrupta.

The type of Panopaea generosa Gould (USNM 5894) was collected from Puget Sound, Wash., during the U.S. Exploring Expedition. It is a moderately large double-valved specimen that is about $150 \mathrm{~mm}$ long, $97 \mathrm{~mm}$ high, and $27 \mathrm{~mm}$ wide (one valve). These measurements agree reasonably well with those given by Gould-length 6 inches, height 3 inches, and width 4 inches, which were apparently approximate measurements. None of the fossil specimens of $P$. abrupta from the Astoria formation attain the maximum average size of Recent specimens, formerly assigned to $P$. generosa.

Mya abrupta Conrad (1849, p. 723, pl. 17, fig. 5) has been placed in synonymy with Panopaea generosa Gould (1850, p. 215) by many authors. Some placed Mya abrupta in synonymy because they considered Pholadomya abrupta Conrad (1832, p. 26, pl, 12) to be a Panope. I am indebted to Myra Keen, Stanford University, for first calling my attention to the fact that Pholadomya abrupta Conrad is not a Panope. Pholadomya abrupta has been made the type of Margaritaria (Conrad, 1863, p. 572). Margaritaria abrupta was originally described from the upper Miocene, Yorktown formation, Virginia, and is also recorded by Glenn (1904, p. 361) from the St. Marys formation of Maryland. Glenn assigned this species to Margaritaria as did Meek (1864, p. 572) and Dall (1890-1903, p. 1532, 1903). Dall (1890-1903, p. 830-831, 1898) placed Mya abrupta in synonymy with Panopea generosa Gould because he thought that Deshayes was desscribing a new species, Panopoea abrupta, when actually Deshayes was simply changing the generic assignment of Pholodaomya abrupta to Panope. Thus the proper name for the Panope originally described by Conrad (1849, p. 723) from the Astoria formation is Panope abrupta (Conrad) and the name P. generosa should beplaced in synonymy.

P. abrupta is found throughout the Astoria formation but never locally concentrated. The specimens most often have the valves together or only slightly apart and are usually flattened and somewhat distorted. The specimens measured ranged in size from 50 to $110 \mathrm{~mm}$ in length, 30 to $80 \mathrm{~mm}$ in height and 10 to $40 \mathrm{~mm}$ in width. Howe (1922, unpublished, p. 79) collected P. abrupta from the Astoria formation at Fifth and Commercial Streets in Astoria. This species has been recorded from the Miocene to Recent of the Pacific coast, with the Recent form being recorded from Puget Sound, Wash., to Baja California, in the Gulf of California, and in Japan.

Localities: 1, la, 38, 48, 49, 58, 61, 62, 71, 79, 83, 87, 90, 92, $94,98,101,102 \mathrm{a}, 103,105,108,111,112,116,117,120-122$, 126, 128, 140, 156, 161, 165, 178, 181, 181a, 184, 187.

Occurrence elsewhere: Middle Miocene to Recent in Washington, Oregon, and California; Recent, Puget Sound, Wash., to Baja California and Japan.

\section{Family THRACIDAE}

\section{Genus THRACIA Blainville}

Thracia Blainville, 1824, Dictionnaire des sciences naturelles, v. 32, p. 347 .

Type.-By subsequent monotypy (Blainville, 1825, Manuel de malacologie et de conchyliologie, p. 660, removes his division B from Thracia leaving but one species in the genus), Thracia corbuloides Blainville. Recent, Mediterranean.

\section{Thracia (Thracia) trapezoides Conrad \\ Plate 26, figure 3 ; plate 31 , figure 6}

Thracia trapezoides Conrad, 1849, U.S. Explor. Exped., Geol., v. 10, app. p. 723 , atlas pl. 17, fig. 6a. Conrad, 1865a, Am. Jour. Conchology, v. 1, p. 152.

Weaver, 1942, Washington Univ. [Seattle] Pub. in Geology, v. 5, p. 117-118, pl. 25, fig. 7 , pl. 29 , fig. 5, pl. 104, fig. 11 [1943].

Oldroyd, 1924, Stanford Univ., Pub. Geol. Sci., v. 1, p. 84, pl. 43 , fig. 8 [1925].

Thracia trapezoidea Conrad. Dall, 1909, U.S. Geol. Survey Prof. Paper 59, p. 135, pl. 2, fig. 14 , pl. 13 , fig. 7 .

Etherington, 1931, California Univ. Dept. Geol. Sci., Bull., v. 20, p. 74 , pl. 5 , fig. 8 .

Grant and Gale, 1931, San Diego Soc. Nat. History Mem., v. 1 , p. $257-258$, pl. 13 , fig. 8 . 
Thracia trapezoides is thin shelled and small to moderate in size and bears fine concentric lines that may be bunched together to form ridges. The anterior angulation covers about one-seventh of the shell area; the anterior dorsal margin is concave.

Holotype: USNM 3604, pl. 31, fig. 6; latex impression of counterpart of cast, pl. 26, fig. 3 .

Type locality: Astoria, Or $\because \mathrm{g}$.

The figured holotype of Thracia trapezoides is an internal cast; none of the original shell remains. The holotype is $33.8 \mathrm{~mm}$ long (broken at anterior and posterior margins), $26.7 \mathrm{~mm}$ high (broken at ventral margin), and $15.5 \mathrm{~mm}$ wide (both valves). The holotype was originally in a concretion, half of which remains in the type collection. A latex impression of this mold shows the concentric lines (pl. 26, fig. 3). There are three paratypes (USNM 561515, original No. 3604) in the type collection; they are internal casts and no shell remains.

Thracia condoni Dall (1909, p. 135-136, pl. 19, fig. 5), originally described from the Eugene formation (Oligocene), Smith's quarry, Eugene, Oreg., is larger, higher in proportion to length, and has a wider anterior angulation than $T$. trapezoides.

Thracia schencki Tegland (1933, p. 112-113, pl. 6, figs. 6-11) seems, on the basis of the original illustrations, to be allied to and perhaps is the same species as $T$. trapezoides. T. schencki was collected from the Blakeley formation (upper Oligocene or lower Miocene) of Washington.

T. trapezoides is not common in the Astoria formation in Oregon; it was collected by Howe (1922, unpublished, p. 98) from the corner of Fifth and Commercial Streets in Astoria. Etherington (1931, p. 74) said that $T$. trapezoides occurs in considerable numbers in the fine-grained sandstone and shale of the Astoria formation in the Chehalis Valley area, Washington. $T$. trapezoides is living today and has a range of at least Sitka, Alaska, to Santa Barbara Islands.

Localities: 1, 1a, 4, 7, 22, 31, 32, 33c, 37, 38, 45, 48, 49, 61, $79,80,98,102,112,116,150,172,174,187$.

Occurrence elsewhere: Middle Miocene to Recent, Oregon, Washington, and California; Recent, Alaska.

\section{Cephalopod \\ Family NAUTILIDAE \\ Subfamily ATURINAE \\ Genus ATURIA Bronn}

Aturia Bronn, 1838, Lethaea geognostica, v. 2, p. 1122-1123, pl. 42 , figs. 17 , a-c.

Type.-By tautonomy, Nautilus aturi Basterot. Miocene, "Dax" (St. Paul de Dax), "Houdan," and "Courtagnon?," southwestern France (Miller, 1947, p. 77).

\section{Aturia angustata (Conrad)}

Plate 31, figures 1, 5

Nautilus angustatus Conrad, 1849, U.S. Explor. Exped., Geology, v. 10, app. p. 728 , atlas, pl. 20, figs. 5, 6 .

Reagan, 1908, Kansas Acad. Sci. Trans., v. 22, p. 171.

Nautilites angustatus (Conrad). Conrad, 1858, Acad. Nat. Sci. Philadelphia Jour., v. 3 (new ser.), p. 335.

Aturia angustata (Conrad). Dall, in Diller, 1896, U.S. Geol. Survey 17th Ann. Rept., pt. 1, p. 459, 465, 467, 468.

Dall, 1909, U.S. Geol. Survey Prof. Paper 59, p. 21.

Schenck, 1931, California Univ., Dept. Geol. Sci., Bull., v. 19 , p. $457-462$, pl. 69 , figs. $1-3$, pl. 70 , figs. $1-5$, pl. 71 , figs. $1,3-8$, pl. 72 , figs. $1,2,5,6$, text figs. $4-5,7-9,20-23$, 30,33 .

Weaver, 1942, Washington Univ. [Seattle] Pub. in Geology, v. 5 , p. 551-552, pl. 102, figs. 1-7, 10 [1943].

Miller, 1947, Geol. Soc. America Mem. 23, p. 85-88, pl. 48, figs. 5, 6, pl. 88, fig. 1, pl. 90, figs. 1-3, pl. 91, figs. 1-2, pl. 92, figs. 1, 2, 8, 9, pl. 93, figs. 3,4 .

Aturia ziczac (Sowerby). Conrad, 1865a, Am. Jour. Conchology, v. 1, p. 150.

Gabb, 1869, Paleontology California, v. 2, p. 69.

Dall and Harris, 1892, U.S. Geol. Survey Bull. 84, p. 223224. [Not Nautilus ziczac Sowerby, 1812, Mineral Conch. Great Britain, v. 1, pl. 12, lowest fig.]

Aturia cf. ziczac (Sowerby). Reagan, 1908, Kansas Acad. Sci. Trans., v. 22, p. 171.

Aturia angustata has been described in detail by Schenck (1931, p. 457-462) and Miller (1947, p. 85-88).

Type: Liwgrer figured syntype, USNM 3610, pl. 31, fig. 1. This is the only specimen originally figured by Conrad (pl. 20, fig. 5) that remains in the U.S. National Museum type collection.

Type locality: Astoria, Oreg.

The figured syntype is $105 \mathrm{~mm}$ in greatest diameter (incomplete) and $80 \mathrm{~mm}$ in least diameter; the maximum thickness (incomplete) is $40 \mathrm{~mm}$. Most of the shell is missing on the type, and some is replaced by chalcedony. In addition to the figured syntype, there is one very large specimen that was not figured by Conrad but which is probably the one he referred to as 9 inches in diameter $(1849$, p. 728$)$, and there is also a small specimen subsequently figured by Weaver (1942, pl. 102, fig. 4). Two small specimens and a fragment are in the type collection; these are recorded as having been collected by George Gibbs in Astoria. The Gibbs collection was made later than 1849 , and it is not certain that Conrad ever saw the collection.

Kummel (1956, p. 330-331) has called attention to the rarity of post-Triassic nautiloids, which has resulted in species being described on the basis of one or few specimens. He said,

To my knowledge, no large collection representing a population has ever been assembled from a single horizon and locality nor are any known where the fossils are sufficiently well preserved to allow a thorough study of intraspecific variation. The great majority of species are defined in terms of being slightly thinner, fatter or more involute or evolute than other already established species; or there are slight variations in the whorl shape or 
character of the suture. However, in none of these species is the range of variations in any of their morphological features known. Because of these factors, the so-called species of Mesozoic and Tertiary nautiloids have little reality in terms of our concepts of neontological species.

It is not surprising that almost a hundred years ago Conrad (1865a, p. 150) confused Aturia angustata with Aturia ziczac (Sowerby), an Eocene species, and changed the age assignment of the Astoria formation from Miocene to Eocene. A year later, however, Conrad (1866c, p. 36-37) said that he had been able to work out the outline of the septa on a specimen of Aturia from California, had found the lobes to be wider than those of Aturia ziczac, and was therefore retaining the name Aturia angustata.

Aturia angustata is very rare in the Astoria formation, and the few specimens in the collections are poorly preserved. A. angustata has been collected from the Oligocene of Washington and the Miocene of Washington, Oregon, and California. Howe (1922, unpublished, p. 167) records $A$. angustata from both the shale and the sandstone in Astoria but said that he obtained only a single fragment of this species from the shale bluffs between 20th and 21st Streets in Astoria.

Localities: 1, 1a, 45, 48, 153.

Occurrence elsewhere: Early Oligocene to middle Miocene in the Coast Ranges of Washington, Oregon, and California.

\section{FOSSILS OTHER THAN MOLLUSKS}

In addition to the mollusks described from the Astoria formation in Oregon, there are included in the fauna collected 77 species of Foraminifera, 2 species of bryozoa, 2 species of corals, echinoid spines and fragments of a star fish, 3 species of brachiopods, 1 species of decapod, 1 barnacle, fish remains, marine mammals, and plant remains.

Foraminifera from the Astoria formation were studied through the kindness of V. Standish Mallory, University of Washington. Table 3 is a composite check list of the Foraminifera identified by him in the samples submitted.

Mallory thought seven collections from localities 8, $14,18,54,81 \mathrm{a}, 95$, and 102 , might be restricted to the lower "Epistominella" parva (=Pseudoparrella parva of Mallory's report herein cited) zone of Rau (1958), lower Saucesian. Mallory assigned four collections, $75,145,149$, and 170 , to the "E." parva zone, undifferentiated. Collection 158 he assigned to the Saucesian, collection 66 questionably to the Saucesian, and collection 160 to the post Zemorrian. Detailed comments from his report follow:

Locality 8: Saucesian, probably Rau's (1958) lower Epistominella parva Zone. Bolivina advena has its earliest occurrence in the lower Saucesian; Siphogenerina transversa appears for the last time in the Uvigerinella obesa Zone of the Upper Saucesian.
Although Cassidulina pulchella has been reported from the Upper Zemorrian questionably (Kleinpell, 1938, p. 140), it characteristically occurs in the Californian section for the first time in the Upper Saucesian. Cibicides floridanus appears for the last time in the Uvigerinella obesa Zone. Rau (1958) reports Siphogenerina transversa as being restricted to his Epistominella parva Zone.

Uvigerinella obesa impolita is reported by Kleinpell as having its last occurrence in the upper Saucesian, and Bolivina marginata adelaidana to be restricted to the lower Saucesian (Kleinpell, 1938, p. 116), his Siphogenerina transversa and Plectofrondicularia miocenica Zones.

Species in this assemblage which seem to have a lower range in the northwest than in the California section include: Valvulineria araucana (first appearance in the Mohnian of California), Eponides healdi (first appearance in the Delmontian of California), and Pseudoparrella pacifica (first appearance of "Pulvinulinella" pacifica in the California Relizian). From Rau's data (1958) this assemblage would appear to be restricted to the lower part of his Epistominella parva Zone from the occurrence of Nonion cf. $N$. belridgensis, and species ranging into his upper Pseudoglandulina ef. $P$. inflata Zone from the lower E. parva Zone as Uvigerinella obesa impolita and Bolivina marginata adelaidana. The occurrence of a few species with seemingly anomalous ranges relative to reported occurrences may indicate increased range for Bolivina advena (reported upper Epistominella parva Zone), Pullenia salisburyi, and Karreriella washingtonensis (reported last occurrence in Pseudoglandulina ef. P. inflata Zone).

Locality 14: The presence of certain restricted species such as Dentalina guadrulata and Bulimina inflata alligata indicates the Saucesian age of this assemblage. Bolivina marginata adelaidana (restricted to the lower Saucesian according to Kleinpell) and Plectofrondicularia californica (only questionably reported higher than the lower Saucesian) indicate that this is possibly lower Saucesian in age. The presence of Bolivina marginata adelaidana and Planulina astoriensis would restrict this to Rau's lower Epistominella parva Zone.

Locality 18: Saucesian, possibly Uvigerinella obesa Zone (Kleinpell, 1938, fig. 14). The comments under locality 8 concerning Bolivina advena, Siphogenerina transversa, Cassidulina pulchella, and Cibicides foridanus apply to this collection also.

Locality 54: Saucesian, possibly lower Saucesian. This assemblage is similar to locality 145 with certain exceptions and additions. The presence of Saracenaria n. sp. (possibly referred to by Rau as Saracenaria sp. $A$ and listed as being restricted to the lower Epistominella parva Zone) and Pullenia salisburyi (listed by Rau as ranging downward from the upper part but not the top of the E. parva Zone, through the Pseudoglandulina cf. $P$. inflata Zone) suggest that this assemblage is older than the youngest $E$. parva Zone of Rau, and possibly lower Saucesian.

Locality 66: Saucesian? According to data reported by Kleinpell this sample would be difficult to date since most of the reported ranges of its species transcend several stages. Nonionella miocenica and Bolivina advena range upward from the lower Saucesian, thus perhaps providing a maximum age limit; Pullenia salisburyi has its last unquestionable occurrence in California strata in the lower Saucesian, but has been identified with question as high as the Upper Luisian. Rau (1958) shows Globobulimina pacifica ranging downward from the lower Epistominella parva Zone and Pullenia salisburyi as ranging downward from his Pseudoglandulina cf. $P$. inflata Zone in his northwest sections. Valvulineria menloensis is shown as being restricted to the lower $E$. parva zone, and this perhaps provides the best clue to the age. 
TABLE 3.-Geographic distribution of Foraminifera in the Astoria formation [Identification by V. S. Mallory. A, abundant; C, common; F, few; R, rare]




Locality 75: Saucesian. Diagnostic species in this assemblage are Nonion costiferum (ranges upward from the lower Saucesian, fide Kleinpell, 1938, p. 146; ranges up from the base of the Epistominella parva Zone according to Rau, 1958) and Nonionella miocenica (ranges upward from the base of the Saucesian, according to Kleinpell, 1938 , p. 146; occurs within the $E$. part'a Zone as reported by Rau, 1958).

Locality 81a: Saucesian, possibly lower Saucesian. This assemblage with the exception of different species of Robulus and the presence of Elphidium n. sp., Gyroidina sp., Parrella cf. P. smithi, and Cassidulina modeloensis? is very similar, even to proportions, to locality 54 and is very possibly lower Saucesian, lower Epistominella parva Zone, for the reasons stated under the discussion of that sample.

Locality 95: Saucesian. Bolivina advena has its lowest reported occurrence in the lower Saucesian as do Nonion costiferum and Nonionella miocenica; Cassidulina pulchella, as indicated in the discussion of locality 18, has been questionably reported from the upper Zemorrian but characteristically $\mathrm{m}$ ikes its first appearance in the upper Saucesian. Buliminella elegantissima and $B$. subfusiformis are also present, the latter species ranging in California in both older and younger strata, while the former makes its first reported appearance in California strata in upper Relizian times. According to Rau's data (1958), the overlap in range of Bolivina advena and Nonionella miocenica would place the age of this sample within the Epistominella parva Zone.

Locality 102: Saucesian. This assemblage with certain exceptions and additions is similar in general composition to locality 8 but notably lacks its Siphogenerina transversa. The presence of Plectofrondicularia n. sp. (the Plectofrondicularia sp. of Cushman and Laiming which Kleinpell reports only from the Lower Saucesian), plus data on the range in the northwest for such species (reported by Rau, 1958) as Globobulimina pacifica (ranges downward from the lower Epistominella parva Zone) and Uvigerinella obesa impolita (ranges through approximately the lower half of the $E$. parva Zone into the upper portion of the $P$ seudoglandulina ef. $P$. inflata Zone), suggest strongly that the age of this sample may be lower $E$. parva Zone. Opposed to this conclusion is the occurrence in this sample of Bolivina advana (listed by Rau as ranging down only into the upper $E$. parva Zone) and the range of Cassidulina pulchella in its characteristic appearance in the upper Saucesian of California. Rau lists the range of Robulus cf. $R$. nikobarensis as extending from the lower two-thirds of the E. parva Zone through the next lowest zone, the Pseudoglandulina of. $P$. inflata Zone, which would make an age assignment of lower Saucesian or lower E. parva Zone for this sample and for 8,18 , and 95 .

Locality 145: Saucesian. The assemblage from this sample can be no older than lower Saucesian according to reported ranges of the following: Nonionella miocenica, Nonion costiferum, and Bolivina advena. Buliminella subfusiformis has its lowest reported appearance in the California section in the Zemorrian, and B. elegantissima in the upper Relizian, perhaps a case of more extended range for this latter species than in the California Tertiary. Such species as Pseudoparrella parva are unreported in California higher than the upper Saucesian. Rau's data (1958) would restrict this assemblage to his Epistominella parva Zone, as indicated by restricted ranges of Pseudsparrella parva, Bolivina advena (upper E. parva Zone), Nonion costiferum, and Nonionella miocenica (overlaps lower portion of range of Bolivina advena and extends into the lower part of this Zone).

Locality 149: Saucesion. According to Kleinpell's reported ranges of foraminifers in the California section, this sample is no older than lower Saucesian because of the occurrences of the following species unreported at older horizons: Nonion costiferum, Nonionella miocenica, Bolivina advena, and the last recorded occurrence of Siphogenerina transversa. Pseudoparrella parva has its last occurrence in the Upper Saucesian thus providing an upper age limit. The occurences of Robulus cf. R. nikobarensis, Siphogenerina transversa, and Buliminella subfusiformis suggest an age within Rau's Epistominella parva Zone.

Locality 158: Saucesian. Jointly occurring species Nonion costiferum, Nonionella miocenica, and Pseudoparrella parva place the age of this assemblage within the limits of the Saucesian stage.

Locality 160: Post-Zemorrian. This assemblage contains Nonion pizarrense (questionably reported from the lower Saucesian by Kleinpell, but characteristically ranging from the upper Relizian through the Mohnian) and Eponides mansfieldi oregonensis which according to Rau ranges through the Pseudoglandulina cf. P. inflata zone and upward.

Locality 170: Saucesian. This assemblage is very similar to that in locality 149, though lacking in Siphogenerina transversa and Elphidium n. sp., and possessing Saracenaria and Lagena which are lacking in locality 149 . The age of the two samples is similar.

Bryozoa.-Two species of encrusting bryozoa are present in the fauna. One species has been identified as Membranipora sp. through the kindness of $\mathbf{R}$. S. Bassler, U.S. National Museum. Membranipora sp. forms a coating as much as $9 \mathrm{~mm}$ in thickness on the gastropod Searlesia? carlsoni (Anderson and Martin) (pl. 32, fig. 1). It has not been found encrusting any other gastropod, although Priscofusus medialis (Conrad) is found in close association and would seem to offer the same relative shape and to have lived in a similar environment. It has been suggested (Helen Duncan, oral communication) that this bryozoan-gastropod relation is perhaps symbiotic and not an after-death association. But there seems to be no thinning towards the aperture as might be expected had the shell contained its original occupant at the time of the growth of the bryozoan, and there is no bare spot on the shell such as might be expected had the shell been empty at the time of such growth. Hermit crabs are often most particular in their choice of homes, and the shells with the encrusting bryozoan may be evidence of a symbiotic relationship between Membranipora sp. and a hermit crab.

Celliopora sp., identified by R. S. Bassler (pl. 32, fig. 4) was found encrusting an unidentified gastropod collected from locality 187.

Corals.-Stephanocyathus diadema (Pourtalès) (pl. 32 , fig. 14) and Lophelia sp. have been identified in the Astoria formation at Astoria. They were identified through the kindness of J. W. Wells, of Cornell University and the U.S. Geological Survey (oral communication). Lophelia lives today at the edge of the Continental Shelf, and both Lophelia and Stephanocyathus indicate either deep water or shallow cold 
water, according to Wells. Stephanocyathus diadema is represented by a single specimen in the Dana collection. Lophelia sp. was collected by Howe from Fifth and Commercial Streets, Astoria, and the eight fragments identified are in the California Academy of Sciences collection.

Nomland has described two species of coral from the Astoria formation. Astreopora occidentalis Nomland $(1917$, p. 187) was described from the ocean beach near Newport, and Caryophyllis oregonensis Nomland (1917, p. 187-188) was described from a fine-grained soft black shale on the street grade above Smith's Point, just east of Astoria.

Echinoderms.--Echinoid spines are moderately common in the shale at Astoria. Fragments of star fish (pl. 32, figs. 2, 3) were collected at localities 5 and 43 . In addition, a syntype of Galerites? oregonensis Dana is in the Dana collection (pl. 32, fig. 8), and a specimen that may be an ophiuroid (Dall, 1909, p. 140) (pl. 32 , fig. 16) is retained in the same collection. Dall (1909, p. 139) identified indeterminable fragments of sea urchin tests (USNM 3509) and spines (USNM 3522 ) that he thought belonged to some form like Toxopneustes or Strongylocentrotus.

Brachiopods.-Three brachiopods are represented in the collections: Frieleia astoriana (Dall), plate 32, figures 10-12, Terebratulina? sp., plate 32, figure 5, and Terebratalia? sp. plate 32, figures 6, 7, 9, 13, 15 . Frieleia astoriana (Dall) was originally described as Terebratula nitens Conrad (1849, p. 726, pl. 19, figs. 1, 1a). The holotype (USNM 3487) is poorly preserved with the shell worn but the corresponding valves together (pl. 32, figs. 10-12). G. A. Cooper, U.S. National Museum, has kindly informed me (oral communication) that this species should be assigned to the genus Frieleia; it has most recently been assigned to the genus Hemithyris. Hertlein and Grant (1944, p. 45) thought it possible that $F$. astoriana should be assigned to the genus Frieleia, and they have described the species in detail.

According to Howe (1922, unpublished, p. 170) $F$. astoriana is very common in the band of pebbly material which underlies shale of the Astoria, and which is best exposed at the corner of Fifth and Duane Streets, Astoria. $F$. astoriana has been collected from the Oligocene of Washington and California and the Miocene of Washington, Oregon, and California.

One small poorly preserved specimen is doubtfully referred to Terebratulina (pl. 32, fig. 5). This may be the same form that Howe (1922, unpublished, p. 171) identified as Terebratulina unguicula Carpenter, from the Astoria formation, 4 miles north of Yaquina Head, Oreg.
Decapods.-The following report on decapods from locality 187 was prepared by H. B. Roberts, U.S. National Museum, and I am indebted to him for this kindness.

Upogebia sp. and undeterminable fragments of walking legs are in the collections from locality 187. Upogebia is a mud shrimp with worldwide distribution, and it inhabits burrows and rock crevices in shallow temperate to tropical waters. Fossil forms range from late Jurassic to Pliocene age, but apparently this is the first Miocene record of the genus. Shallow water seems to be indicated for this locality although no inferences regarding thermal conditions can be made.

Fish remains.--Poorly preserved teeth, spines, scales, vertebra, and bone fragments of fish are not uncommon in the Astoria formation, but they are often not well enough preserved to be identified. One specimen from locality 187 has been examined by D. H. Dunkle, U.S. National Museum, and I am indebted to him for the following information:

This specimen consists of the posterior half of a fish brain case. The character of the pre-operculum and the presence of a temporal fossa and of a preepiotic fenestra denote a member of the family Clupeidae.

Marine mammals.-The mammalian remains in the Astoria formation in Oregon have attracted the interest of specialists for many years. Such remains are most commonly found in concretions and are particularly abundant in the rocks exposed in the Spencer Creek area on the coast of Oregon. Dana $(1849$, p. 722) said that vertebrae and other cetacean bones were in some places found in the argillaceous sandstone of Astoria and also could be picked up along the south shores of the Columbia River.

Packard (1940, p. 5-6) said that:

The rocks near the mouth of Spencer Creek have yielded Desmostylus hesperus Marsh *** Cophocetus oregonensis Packard and Kellogg ***. The skull of the genotype of Desmatophoca oregonensis Condon was found at the same horizon a few miles farther south, and two incomplete skulls, recognized as porpoises by Kellogg (personal communication) have been obtained recently from these beds.

Plant remains.- $\mathrm{A}$ few plant remains are present in the Astoria formation and are represented primarily by carbonized wood. There is a single seed or nut (oral communication R. W. Brown (deceased), formerly with the U.S. Geol. Survey, 1955) in the collections (loc. 139) and a few poorly preserved leaves. R. W. Brown kindly identified as Metasequoia a single specimen collected from the quarry within the magazine area of the submarine base on the southeast side of Tongue Point, near Astoria. 
Dana (1849, p. 730 , pl. 21, fig. 1) described and and figured a specimen he thought might be a calcareous algae.

Organic remains of doubtful affinities. - In addition to the forms already mentioned, Dana (1849, p. 729-730) described two fossils of uncertain identity. One he thought might suggest the ink bag of a sepia (1849, pl. 21, fig. 7) but felt that other characters did not coincide. The other he thought might possibly represent the spawn of a mollusk $(1849$, pl. 21 , fig. 8 , cited in text as fig. 203).

The following list of fossil localities in the Astoria formation includes all of the known collections on deposit in the U.S. National Museum. One collection from the California Academy of Science is included. The collections were made between 1834 and 1958 .

Fossil Localities

\begin{tabular}{|c|c|c|c|c|}
\hline $\begin{array}{l}\text { No. } \\
\text { used } \\
\text { in this } \\
\text { report }\end{array}$ & $\begin{array}{l}\text { USGS } \\
\text { Cenozoic } \\
\text { loc. No. }\end{array}$ & Description of locality & Collector & $\begin{array}{c}\text { Date } \\
\text { collected }\end{array}$ \\
\hline \multicolumn{5}{|c|}{ Type area, Astoria, Oreg. } \\
\hline $1 \ldots$ & \multirow{2}{*}{$\begin{array}{l}\text { California } \\
\text { Acad. Sci. }\end{array}$} & & \multirow{2}{*}{$\begin{array}{l}\text { H. V. Howe } \\
\text { J. K. Townsend } \\
\text { J. D. Dana } \\
\text { T. A. Condon... }\end{array}$} & \multirow{4}{*}{$\begin{array}{l}1910 \text { 's to } \\
1920 \text { 's. } \\
1834-37 . \\
1841 . \\
? \text { (late } \\
1800 \text { 's) } \\
1910 . \\
1890 . \\
1891 .\end{array}$} \\
\hline $1 a_{-}$ & & $\mathrm{d}^{-1}$ & & \\
\hline $1 \mathrm{c}$ & 5315 & \multirow{2}{*}{$\begin{array}{l}\text { From loose concretions on river } \\
\text { bank, lower part of Astoria. } \\
\text { Astoria, Oreg. }\end{array}$} & \multirow{2}{*}{$\begin{array}{l}\text { C. W. Wash- } \\
\text { burn. } \\
\text { W. H. Dall } \\
\text { W. Q. Brown. }\end{array}$} & \\
\hline & $\begin{array}{l}2275 \\
2407\end{array}$ & & & \\
\hline \multicolumn{5}{|c|}{ Lower sandstone of Howe (1926), Astoria, Oreg. } \\
\hline & & $\begin{array}{l}\text { Southeast corner of } 6 \text { th and } \\
\text { Commercial St. }\end{array}$ & R. F. Rogers & \\
\hline & 5379 & $\begin{array}{l}\text { In rear of southwest corner } \\
\text { house at } 6 \text { th and Duane St., } \\
\text { alt } 40 \text { ft. }\end{array}$ & R. F. Rogers & 1910. \\
\hline & 5320 & Opposite 1774 Franklin St....... & R. F. Rogers. & 1910. \\
\hline \multicolumn{5}{|c|}{ Middle shale of Howe (1926), Astoria, Oreg. } \\
\hline & 2263 & Collected from the clay & W. H. Dall. & 1890. \\
\hline & 5380 & $\begin{array}{l}\text { Road cut on Commercial St., } \\
2,650 \mathrm{ft} \text { west of } 6 \text { th } \mathrm{St} \text {., in } \\
\text { dark-gray shale. }\end{array}$ & $\begin{array}{l}\text { R. F. Rogers } \\
\text { and G. A. } \\
\text { Macready. }\end{array}$ & 1910. \\
\hline & & Exchange St. & 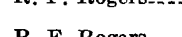 & \\
\hline & 5319 & $\begin{array}{l}\text { One block south of old high } \\
\text { school building on Harrison } \\
\text { Ave., southwest corner of } \\
\text { 8th St. }\end{array}$ & R. F. Rogers & 1910. \\
\hline & 19069 & $\begin{array}{l}\text { From the shale at the south- } \\
\text { west corner of } 9 \text { th and Har- } \\
\text { rison St. }\end{array}$ & E. J. Moore. & 1952. \\
\hline 12 . & 5314 & From 10th and Harrison St.... & C. W. Wash- & 1910. \\
\hline 13. & 5318 & Northwest corner of 10 th and & R. F. Rogers.... & 1910. \\
\hline & 19070 & $\begin{array}{l}\text { From the shale at the southeast } \\
\text { corner of 10th and Harrison } \\
\text { St. }\end{array}$ & E. J. Moore & 1952. \\
\hline & 5317 & Opposite 766 Irving Ave & R. F. Rogers & 1910. \\
\hline & 5405 & Irving A ve. west of 13th St & R.F. Rogers & 1910. \\
\hline & 5322 & From Irving $\mathrm{Ave}$. and $34 \mathrm{th} \mathrm{St}$. & R. F. Rogers & 1910. \\
\hline & 5323 & $\begin{array}{l}\text { Irving Ave, near 37th St., } \\
\text { from the lower part of the } \\
\text { shale of the Astoria as ex- } \\
\text { posed in Astoria. }\end{array}$ & R. F. Rogers & 1910. \\
\hline
\end{tabular}

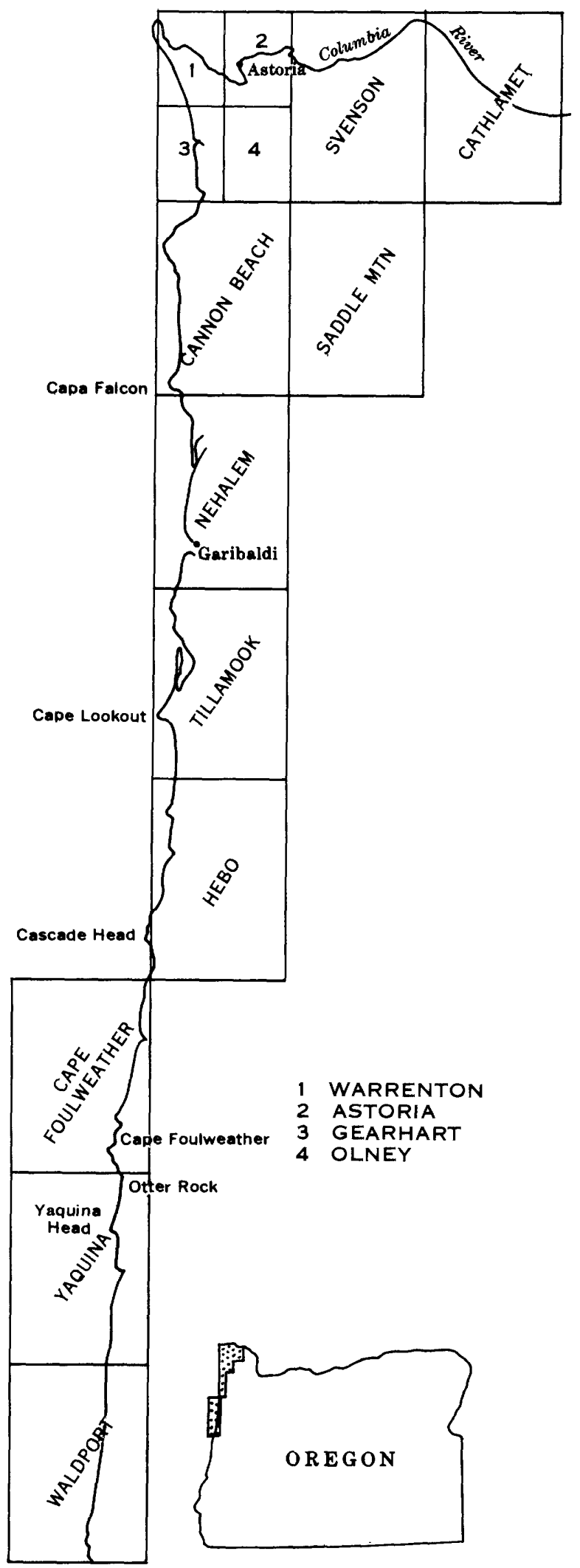

FIGURE 9.-Outline map of northwestern Oregon showing the location of quadrangles pertinent to the locality descriptions. 
Fossil Localities-Continued

\begin{tabular}{|c|c|c|c|c|}
\hline $\begin{array}{c}\text { No. } \\
\text { used } \\
\text { in this } \\
\text { report }\end{array}$ & $\begin{array}{l}\text { USGS } \\
\text { Cenozoic } \\
\text { loc. No. }\end{array}$ & Description of locality & Collector & $\begin{array}{l}\text { Date } \\
\text { collected }\end{array}$ \\
\hline \multicolumn{5}{|c|}{ From unknown horizon, Astoria, Oreg. } \\
\hline 20 & 5378 & Opposite 382 Alameda Ave,, & G. A. Macready. & 1910. \\
\hline 21 & 15521 & $\begin{array}{l}\text { SW1/4 sec. } 7, \text { T. } 8 \mathrm{~N}_{\text {, }} \mathrm{R}, 9 \mathrm{~W} \text {. } \\
\text { New road cut at south side of } \\
\text { A storia airport }\end{array}$ & R. M. Grivetti.- & 1944. \\
\hline 22. & 2735 & East end of Astoria & J. s. Diller. & 1895. \\
\hline 23. & 5316 & $\begin{array}{l}\text { From north side of Smiths } \\
\text { Point. }\end{array}$ & R. F. Rogers... & 1910. \\
\hline & 5339 & $\begin{array}{l}\text { At Smiths Point from bank } \\
50 \text { ft above Columbia River, } \\
\text { SW1/4 sec. 7, T. } 8 \text { N., R. } 9 \text { W' }\end{array}$ & G. A. Macready - & 1910. \\
\hline 25 & 5340 & $\begin{array}{l}\text { Smiths Point on Youngs River, } \\
\text { SW1/4 sec. } 7, \text { T. } 8 \text { N., R. } 9 \text { W. }\end{array}$ & G. A Macready. & 1910. \\
\hline
\end{tabular}

\begin{tabular}{l|l|c|c|c}
\hline \multicolumn{3}{|c|}{ Astoria quadrangle } \\
\hline $26 \ldots$ & 5332 & $\begin{array}{c}\text { Exposure at bridge on Portland- } \\
\text { Astoria wagon road, 2 miles } \\
\text { out on Youngs River, NW1/4 } \\
\text { sec. 21, T. 8 N., R.9 9. }\end{array}$ & $\begin{array}{c}\text { G. A. Mac- } \\
\text { ready and R. } \\
\text { F. Rogers. }\end{array}$ & 1910. \\
\hline
\end{tabular}

\begin{tabular}{|c|c|c|c|c|}
\hline \multicolumn{5}{|c|}{ Cathlamet Bay quadrangle } \\
\hline $27 \ldots$ & 19042 & $\begin{array}{l}\text { Road cut on U.S. Highway 30, } \\
\text { opposite and immediately } \\
\text { northwest of entrance to sub- } \\
\text { marine and destroyer base, } \\
\text { Tongue Point. }\end{array}$ & E. J. Moore.... & 1952. \\
\hline & 5324 & $\begin{array}{l}\text { One mile east of the "John Day" } \\
\text { Station on the A. and C. Rail- } \\
\text { road, about } 51 / 2 \text { miles east of } \\
\text { Astoria. }\end{array}$ & $\begin{array}{l}\text { R. F. Rogers } \\
\text { and G. A. } \\
\text { Macready. }\end{array}$ & 1910. \\
\hline 29 & 5325 & $\begin{array}{l}\text { Six telegraph poles east of mile- } \\
\text { post " } 92 \text { " of A. and C. Rail- } \\
\text { road, about } 81 / 2 \text { miles east of } \\
\text { Astoria, sec. } 21, \text { T. } 8 \text { N., R. } \\
8 \mathrm{~W} \text {. }\end{array}$ & $\begin{array}{l}\text { R. F. Rogers } \\
\text { and G. A. } \\
\text { Macready. }\end{array}$ & 1910. \\
\hline 31. & 15455 & $\begin{array}{l}\text { Cut on logging road (not shown } \\
\text { on map) just west of third } \\
\text { logging railroad trestle over } \\
\text { stream } 1.9 \text { miles from branch } \\
\text { road which bejins about } 1 / 4 \\
\text { mile north of Elk Creek, Cath- } \\
\text { lamet quadrangle. }\end{array}$ & $\begin{array}{l}\text { R. M. Grivetti } \\
\text { and W. C. } \\
\text { Warren. }\end{array}$ & 1944. \\
\hline \multicolumn{5}{|c|}{ Svenson quadrangle } \\
\hline 32. & 15458 & $\begin{array}{l}\text { South side of logging road up } \\
\text { Big Creek from shale below } \\
\text { basaltic flow at point about } \\
100-150 \text { yds beyond small } \\
\text { stream, below "k" in "Big } \\
\text { Creek" on Svenson quadran- } \\
\text { gle (U.S. Army Engrs.). }\end{array}$ & $\begin{array}{l}\text { R. M. Grivetti } \\
\text { and W. C. } \\
\text { Warren. }\end{array}$ & 1944. \\
\hline $33 \ldots$ & 15459 & $\begin{array}{l}\text { Road cut in shaly sandstone on } \\
\text { west side of Wickiup Look- } \\
\text { out Road, about } 125 \text { yds from } \\
\text { Last Junction, Svenson quad- } \\
\text { rangle. }\end{array}$ & $\begin{array}{l}\text { W. C. Warren } \\
\text { and R. M. } \\
\text { Grivetti. }\end{array}$ & 1944. \\
\hline
\end{tabular}

\begin{tabular}{l|l|l|l|l}
\hline \multicolumn{3}{|c}{ Vernonia quadrangle } \\
\hline $33 c-.-$ & 15529 & $\begin{array}{l}\text { Cut on south side of Vernonia- } \\
\text { Scappoose Road, 3.5 miles by } \\
\text { road southeast of junction at } \\
\text { Wilark. }\end{array}$ & W. C. Warren.-- & 1944. \\
\hline
\end{tabular}

\begin{tabular}{|c|c|c|c|c|}
\hline \multicolumn{5}{|c|}{ Tillamook Head quadrangle? } \\
\hline 34 & $\begin{array}{r}5337 \\
5336\end{array}$ & $\begin{array}{l}\text { Half a mile toward Seaside from } \\
\text { Elk Creek Hotel, sec. } 20, \mathrm{~T} \text {. } \\
5 \mathrm{~N} \text {., R. } 10 \text { W., alt } 120 \mathrm{ft} \text {. } \\
\text { Ocean Bluff, near Haystack } \\
\text { Rock; } 1 \text { mile south of Elk } \\
\text { Creek on Cannon Beach. }\end{array}$ & $\begin{array}{l}\text { G. A. Mac- } \\
\text { ready. } \\
\text { G. A. Mac- } \\
\text { ready. }\end{array}$ & $\begin{array}{l}1910 . \\
1910 .\end{array}$ \\
\hline \multicolumn{5}{|c|}{ Saddle Mountain quadrangle } \\
\hline 37. & 15515 & $\begin{array}{l}\text { South side of Saddle Mountain, } \\
\text { on fire-trail road just east of } \\
\text { erossing of second main creek. } \\
\mathbf{N} .5^{\circ} \mathrm{W} \text {. to } 3,100 \mathrm{ft} \text { east peak } \\
\text { of Saddle Mountain. }\end{array}$ & $\begin{array}{l}\text { W. C. Warren } \\
\text { and R. M. } \\
\text { Grivetti. }\end{array}$ & 1944. \\
\hline
\end{tabular}

Fossil Localities-Continued

\begin{tabular}{c|c|c|c|c}
$\begin{array}{c}\text { No. } \\
\text { used } \\
\text { in this } \\
\text { report }\end{array}$ & $\begin{array}{c}\text { USGS } \\
\text { Cenozoic } \\
\text { loc. No. }\end{array}$ & Description of locality & Collector & $\begin{array}{c}\text { Date } \\
\text { collected }\end{array}$ \\
\hline
\end{tabular}

Saddle Mountain quadrangle-Con tinued

\begin{tabular}{l|l|l|l|l}
\hline 38 & 19044 & $\begin{array}{l}\text { Road cut about 300 yds north } \\
\text { of Lewis and Clark River on } \\
\text { Saddle Mountain Road off } \\
\text { Highway 26. }\end{array}$ & E. J. Moore..... & 1952. \\
\hline
\end{tabular}

Tillamook quadrangle

\begin{tabular}{|c|c|c|c|c|}
\hline $42 \ldots \ldots$ & 15301 & $\begin{array}{l}\text { West side of Tillamook-Bay- } \\
\text { ocean Road, } 1.3 \text { miles west of } \\
\text { junction of Bayocean and } \\
\text { Netarts Bay Roads; } 5,500 \mathrm{ft} \\
\text { west of orid } 755 ; 5,400 \mathrm{ft} \text { south } \\
\text { of grid } 2610\end{array}$ & $\begin{array}{l}\text { W. C. Warren } \\
\text { and R. M. } \\
\text { Grivetti. }\end{array}$ & 1945. \\
\hline $43 \ldots \ldots$ & 15290 & $\begin{array}{l}\text { On Zellerback Logging Co. } \\
\text { road, 0.4 mile south of junc- } \\
\text { tion with Tillamook-Netarts } \\
\text { Bay Highway. NW1/4SE1/4 } \\
\text { sec. 4, T. 1 S., R. } 10 \text { W. }\end{array}$ & $\begin{array}{l}\text { W. C. Warren, } \\
\text { Rex Grivetti, } \\
\text { and H. E. } \\
\text { Vokes. }\end{array}$ & 1944. \\
\hline 45 & 2741 & Old jetty quarry for jetty, south & J. S. Diller & 1895. \\
\hline 47--- & 19045 & $\begin{array}{l}\text { At southernmost corner of Till- } \\
\text { amook Bay, } 1 \text { mile north of } \\
\text { Tillamook kiver Bridge, on } \\
\text { fork to Bayocean. M-134 on } \\
\text { U.S. Geol. Survey Oil and } \\
\text { Gas Inv. Map 47. }\end{array}$ & E. J. Moore.. & 1952. \\
\hline $48 \ldots \ldots$ & 15460 & $\begin{array}{l}\text { Road cut in road following } \\
\text { south shore of Tillamook Bay } \\
\text { en route to Cape Meares } \\
\text { Light. Locality is 1.3 miles } \\
\text { north of junction of Cape } \\
\text { Meares and Netarts Bay } \\
\text { Roads. }\end{array}$ & R. M. Grivetti.- & 1944. \\
\hline $49 \ldots \ldots-$ & 15611 & $\begin{array}{l}\text { Cut on logging road on North } \\
\text { Beaver Creek, solth branch } \\
\text { of road near top of hill } 300 \mathrm{ft} \\
\text { east of fork. }\end{array}$ & R. M. Grivetti.- & 1945. \\
\hline
\end{tabular}

Nestucca Bay quadrangle

\begin{tabular}{|c|c|c|c|c|}
\hline 50 & 16050 & $\begin{array}{l}\text { Sea cliffs at Cape Kiwanda. } \\
\text { Fossils from concretionary } \\
\text { sandstone approximately } 20 \\
\text { ft above the base of the } \\
\text { Astoria formation; } 1,100 \mathrm{ft} \text {. } \\
\text { west of Army grid 745 and } \\
4,400 \mathrm{ft} \text {. south of grid } 2580 \text {. } \\
\text { Sea cliffs at Cape Kiwanda. } \\
\text { Fossils from a sandstone ap- } \\
\text { proximately } 150 \mathrm{ft} \text { above } 16049 \text {; } \\
2,050 \mathrm{ft} \text { west of Army grid } 745 \\
\text { and } 5,900 \text { ft south of grid } 2580 \text {. }\end{array}$ & P. D. Snavely, & 1946. \\
\hline
\end{tabular}

Cape Foulweather quadrangle

\begin{tabular}{|c|c|c|c|c|}
\hline $52 \ldots \ldots$ & 18848 & $\begin{array}{l}\text { From } 8 \mathrm{ft} \text { of silty shale in beach } \\
\text { cliffs immediately south of } \\
\text { igneous headland, north of } \\
\text { Fogarty Creek; about } 30 \mathrm{ft} \\
\text { above base of exposed section. }\end{array}$ & E. J. Moore..... & $1952,1954$. \\
\hline $53 \ldots \ldots$ & 19098 & Presumably from same locality & M. P. James.-. & 1953. \\
\hline $54 \ldots \ldots$ & 18854 & $\begin{array}{l}\text { From } 30 \mathrm{ft} \text { of silty shale in beach } \\
\text { cliffs about } 300 \mathrm{ft} \text { south of igne- } \\
\text { ous headland, north of } \\
\text { Fogarty Creek; about } 40 \mathrm{ft} \\
\text { above base of exposed sec- } \\
\text { tion. }\end{array}$ & E. J. Moore--- & 1952. \\
\hline $55 \ldots$ & 18852 & $\begin{array}{l}\text { From } 15 \mathrm{ft} \text { of very silty shale in } \\
\text { beach cliffs about } 350 \mathrm{ft} \text { south } \\
\text { of igneous headland, north of } \\
\text { Fogarty Creek; about } 175 \mathrm{ft} \\
\text { above base of exposed sec- } \\
\text { tion. }\end{array}$ & E. J. Moore.... & 1952. \\
\hline 56 & 18851 & $\begin{array}{l}\text { From about } 60 \mathrm{ft} \text { of extremely } \\
\text { silty shale in beach cliffs } 300 \\
\text { to } 400 \mathrm{ft} \text { south of igneous } \\
\text { headland, north of Fogarty } \\
\text { Creek about } 200 \mathrm{ft} \text { above base } \\
\text { of exposed section. }\end{array}$ & E. J. Moore & 1952. \\
\hline $57 \ldots$ & 18850 & $\begin{array}{l}\text { From about same locality as } \\
\text { above. }\end{array}$ & E. J. Moore & 1954. \\
\hline 58 & 18864 & $\begin{array}{l}\text { From } 20 \mathrm{ft} \text { of silty shale in } \\
\text { beach cliffs just north of } \\
\text { Fogarty Creek. }\end{array}$ & E. J. Moore..... & 1952. \\
\hline
\end{tabular}


Fossil Localities-Continued

\begin{tabular}{c|c|c|c|c}
\hline $\begin{array}{c}\text { No. } \\
\text { used } \\
\text { in this } \\
\text { report }\end{array}$ & $\begin{array}{l}\text { USGS } \\
\text { Cenozoic } \\
\text { loc. No. }\end{array}$ & Description of locality & Collector & $\begin{array}{c}\text { Date } \\
\text { collected }\end{array}$ \\
\hline
\end{tabular}

Cape Foulweather quadrangle-Continued

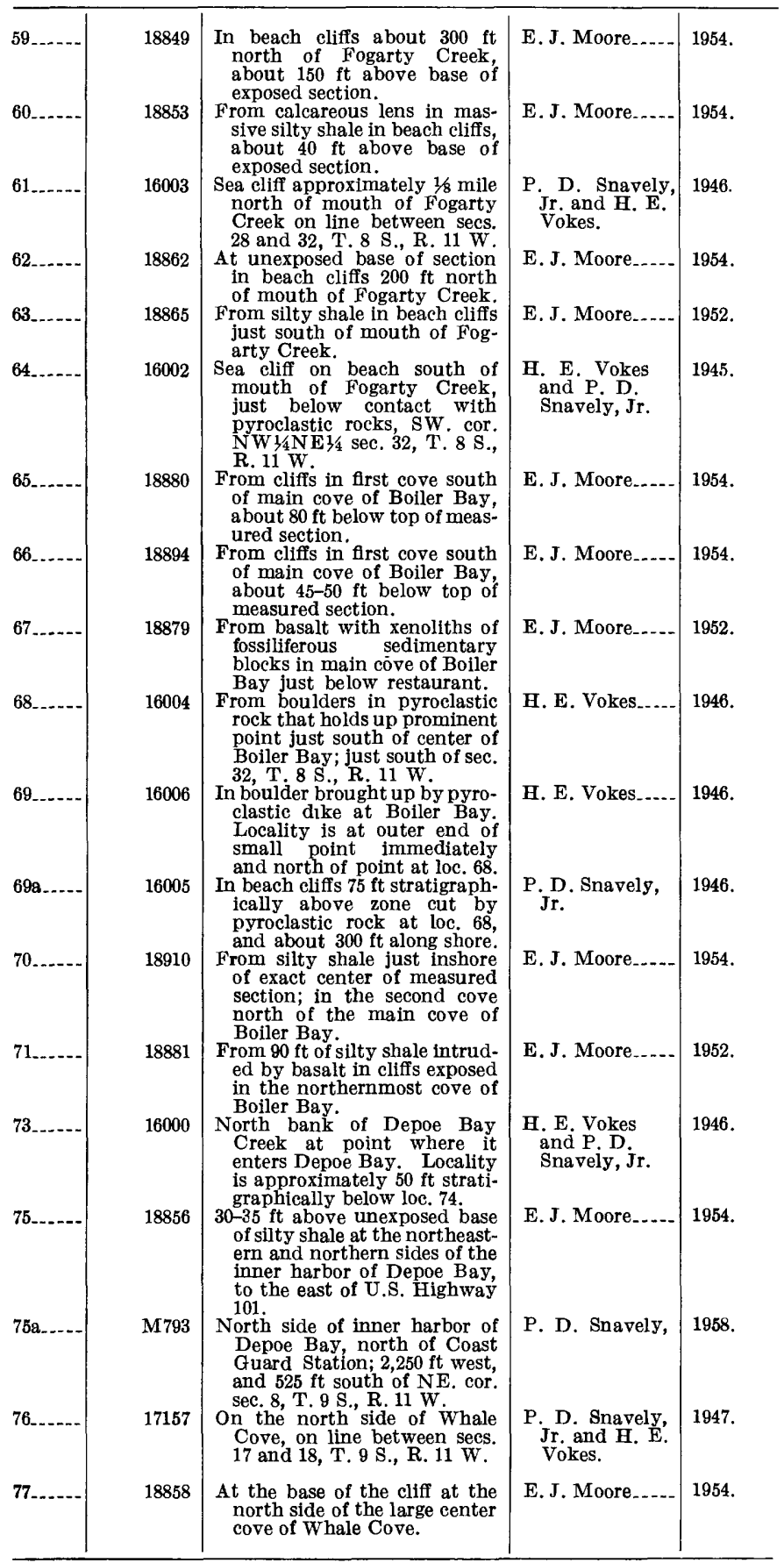

Yaquina quadrangle

\begin{tabular}{l|l|l|l|}
\hline $78 .-18891$ & $\begin{array}{c}\text { From } 7 \mathrm{ft} \text { of silty shale at base } \\
\text { of exposed section north and } \\
\text { south of Johnson Creek, south } \\
\text { of Otter Rock, in beach cliffs. }\end{array}$ & E. J. Moore..... 1952.
\end{tabular}

Fossil Localities-Continued

\begin{tabular}{c|c|c|c|c}
\hline $\begin{array}{c}\text { No. } \\
\text { used } \\
\text { in this } \\
\text { report }\end{array}$ & $\begin{array}{c}\text { USGS } \\
\text { Cenozoic } \\
\text { loc. No. }\end{array}$ & Description of locality & Collector & $\begin{array}{c}\text { Date } \\
\text { collected }\end{array}$ \\
\hline
\end{tabular}

Yaquina quadrangle-Continued

\begin{tabular}{|c|c|c|c|c|}
\hline 79 & 18892 & $\begin{array}{l}\text { From } 10 \mathrm{ft} \text { of shale, } 7 \mathrm{ft} \text { above } \\
\text { base of exposed section north } \\
\text { and sonth of Johnson Creek, } \\
\text { so'ith of Otter Rock, in beach } \\
\text { cliffs. }\end{array}$ & E. J. Moore & 1952. \\
\hline 80 & 18893 & $\begin{array}{l}\text { From lower } 7 \mathrm{ft} \text { of extremely } \\
\text { silty shale, } 17 \mathrm{ft} \text { above base of } \\
\text { exposed section, north and } \\
\text { south of Johnson Creek and } \\
\text { sonth of Otter Rock, in beach } \\
\text { cliffs. }\end{array}$ & E. J. Moore & 1952. \\
\hline 81. & 19008 & $\begin{array}{l}\text { Rocks in beach exposed only at } \\
\text { low tide between } 800 \text { and } \\
1,400 \mathrm{ft} \text { south of the north } \\
\text { end of the beach on the south } \\
\text { side of Otter Rock. }\end{array}$ & E. J. Moore & 1954. \\
\hline $81 a$ & 18932 & $\begin{array}{l}\text { From the south end of loc. } 81 \\
\text { to Thompson Creek, sonth } \\
\text { of Otter Rock, in beach eliffs. }\end{array}$ & E. J. Moore & 1954. \\
\hline $81 b_{\ldots} \ldots$ & 21834 & $\begin{array}{l}\text { From beach cliff immediately } \\
\text { South of Thompson Creek, } \\
\text { south of Otter Rock; N. } 8^{\circ} \\
\text { W. } 10^{\circ} \text { dip. }\end{array}$ & E. J. Moore & 1954. \\
\hline 82 & 16016 & $\begin{array}{l}\text { From new cut being made for } \\
\text { realinement of U.S. Hiohway } \\
101 \text {, just south of Johnson } \\
\text { Creek. Center of NE1/4 sec. } \\
5 . T \text {. }\end{array}$ & $\begin{array}{l}\text { H. E. Vokes and } \\
\text { P. D.Snavely, } \\
\text { Jr. }\end{array}$ & 1946. \\
\hline 83 & 16017 & $\begin{array}{l}\text { Cut on new realinement of U.S. } \\
\text { Hiohway } 101,0.2 \text { mile north } \\
\text { of Spencer Creek. Locality } \\
\text { is } 100 \text { to } 150 \mathrm{ft} \text { stratigraphic- } \\
\text { all above loc. 82. NE1/4 } \\
\text { NW } 14 \mathrm{SE} 1 / 4 \text { sec. } 5 \text {, R. 10 S., } \\
\text { R 11 W. }\end{array}$ & $\begin{array}{l}\text { P.D. Snavely, } \\
\text { Jr. and H. E. } \\
\text { Vokes. }\end{array}$ & 1946. \\
\hline 84 & 16018 & $\begin{array}{l}\text { Fill on north side of Spencer } \\
\text { Creek immediately south of } \\
\text { loc. } 83 \text {. Material is from cut } \\
\text { at loc. } 83 \text {. }\end{array}$ & H. E. Vokes.... & 1946. \\
\hline $85 \ldots$ & 18889 & $\begin{array}{l}\text { Road cut on U.S. Highway } 101 \text {, } \\
\text { immediately north of Spen- } \\
\text { cer Creek Bridge. From } \\
\text { same stratigraphic horizon } \\
\text { as } 93 \text {. }\end{array}$ & E. J. Moore & 1952. \\
\hline 86. & 18890 & $\begin{array}{l}\text { Road cut on U.S. Highway 101, } \\
\text { immediately north of Spencer } \\
\text { Creek Bridge. From un- } \\
\text { known stratioraphic horizon; } \\
\text { in fault block and landslide. }\end{array}$ & E. J. Moore & 1952. \\
\hline 87 & 18887 & $\begin{array}{l}\text { Road cut on U.S. Highway } 101 \text {, } \\
\text { immediately north of Spencer } \\
\text { Creek Bridge on east side } \\
\text { of highway. From same } \\
\text { stratioraphic horizon as loc. } \\
\text { 94, below zone of small Ana- } \\
\text { dara devincta, inflated form. }\end{array}$ & E.J. Moore. & 1952. \\
\hline $87 a_{-}$ & $18887 \mathrm{a}$ & $\begin{array}{l}\text { Same horizon as loc. } 87 \text { but } \\
\text { within zone of Anadara de- } \\
\text { vincta, inflated form, only. }\end{array}$ & E. J. Moore & 1952. \\
\hline $87 \mathrm{~b}$ & $18887 \mathrm{~b}$ & $\begin{array}{l}\text { Same horizon as loc. } 87 \text { but } \\
\text { above zone of Anadara de- }\end{array}$ & E. J. Moore & 1952. \\
\hline 88 & 18888 & $\begin{array}{l}\text { Road cut on U.S. Highway } 101 \text {, } \\
\text { immediately north of Spen- } \\
\text { cer Creek Bridge on east side } \\
\text { of highway and north of loc. } \\
\text { 87. Stratigraphic position } \\
\text { undetermined. }\end{array}$ & E. J. Moore & 1952. \\
\hline 89. & 19056 & $\begin{array}{l}\text { In beach cliffs between Johnson } \\
\text { and Spencer Creeks. }\end{array}$ & M. P. James.... & 1953. \\
\hline 90. & 16019 & $\begin{array}{l}\text { Beach cliff immediately north } \\
\text { of mouth of Spencer Creek. } \\
\text { Collection is from } 2,000 \mathrm{ft} \text { of } \\
\text { exposures that are much } \\
\text { fanlted and disrupted by } \\
\text { slides. Same general hori- } \\
\text { zon as loc. } 83 \text {. }\end{array}$ & $\begin{array}{l}\text { H. E. Vokes and } \\
\text { P. D. Snave- } \\
\text { ly, Jr. }\end{array}$ & 1946. \\
\hline 91. & 18873 & $\begin{array}{l}\text { From big headland in beach } \\
\text { cliffs about } 600 \text { yds north of } \\
\text { Spencer Creek, in } 8 \mathrm{ft} \text { of silt- } \\
\text { stone at base of exposed } \\
\text { section. }\end{array}$ & E. J. Moore & 1952. \\
\hline $92 \ldots$ & 18874 & $\begin{array}{l}\text { From big headland in beach } \\
\text { cliffs about } 600 \text { yds north of } \\
\text { Spencer Creek, in } 5-6 \mathrm{ft} \text { of } \\
\text { siltstone, } 8 \mathrm{ft} \text { above base of } \\
\text { exposed section. }\end{array}$ & E. J. Moore & 1952. \\
\hline 93. & 18875 & $\begin{array}{l}\text { From big headland in beach } \\
\text { cliffs about } 600 \text { yds north of } \\
\text { Spencer Creek, in } 3 \mathrm{ft} \text { of mas- } \\
\text { sive shale, about } 14 \mathrm{ft} \text { above } \\
\text { base of exposed section. }\end{array}$ & E. J. Moore & 1952. \\
\hline
\end{tabular}


Fossil Localities--Continued

\begin{tabular}{l|l|l|l|l}
\hline $\begin{array}{c}\text { No. } \\
\text { used } \\
\text { in this } \\
\text { report }\end{array}$ & $\begin{array}{l}\text { USGS } \\
\text { Cenozoic } \\
\text { loc. No. }\end{array}$ & Description of locality & Collector & $\begin{array}{c}\text { Date } \\
\text { collected }\end{array}$ \\
\hline
\end{tabular}

\begin{tabular}{|c|c|c|c|c|}
\hline \multicolumn{5}{|c|}{ Yaquina quadrangle-Con tinued } \\
\hline $94 \ldots$ & 18876 & $\begin{array}{l}\text { From big headland in beach } \\
\text { cliffs about } 600 \text { yds north of } \\
\text { Spencer Creek, in } 10 \mathrm{ft} \text { of silt- } \\
\text { stone containing Anadara } \\
\text { devincta, inflated form, about } \\
17 \mathrm{ft} \text { above base of exposed } \\
\text { section. }\end{array}$ & E. J. Moore.... & 1952. \\
\hline $95 \ldots \ldots$ & $18876 \mathrm{a}$ & $\begin{array}{l}\text { Same stratigraphic position as } \\
\text { loc. } 94 \text { but within the zone of } \\
\text { Anadara devincta, inflated } \\
\text { form, only. }\end{array}$ & E. J. Moore & 1952. \\
\hline $95 \mathrm{a}$ & 188766 & Same horizon as loc. 95 , sepa- & E. J. Moore & 1952. \\
\hline $96 \ldots$ & 18877 & $\begin{array}{l}\text { From big headland in beach } \\
\text { cliffs about } 600 \text { yds north of } \\
\text { Spencer Creek, in } 10 \mathrm{ft} \text { of silty } \\
\text { shale about } 27 \mathrm{ft} \text { above base of } \\
\text { exposed section. }\end{array}$ & E. J. Moore... & 1952. \\
\hline $97 \ldots$ & 18878 & $\begin{array}{l}\text { From big headland in beach } \\
\text { cliffs about } 600 \text { yds north of } \\
\text { Spencer Creek, in } 16 \mathrm{ft} \text { of silty } \\
\text { shale about } 37 \mathrm{ft} \text { above base of } \\
\text { exposed section. }\end{array}$ & E. J. Moore & 1952. \\
\hline 97 & $18878 a$ & $\begin{array}{l}\text { Same horizon as loc. } 97 \text {, sepa- } \\
\text { rated by small fault. }\end{array}$ & E. J. Moore & 1952. \\
\hline 98_-- & 17876 & $\begin{array}{l}\text { Road cut on realinement of } \\
\text { U.S. Highway } 1 / 4 \text { mile north } \\
\text { of loc. 114. This is the first } \\
\text { road cut south of Spencer } \\
\text { Creek. }\end{array}$ & $\begin{array}{l}\text { H. E. Vokes and } \\
\text { D. A. Myers. }\end{array}$ & 1948. \\
\hline $99 \ldots$ & 18898 & $\begin{array}{l}\text { Road cut on U.S. Highway 101, } \\
\text { east side of highway, just } \\
\text { south of Spencer Creek } \\
\text { Bridge and north of Beverly } \\
\text { Beach. }\end{array}$ & E. J. Moore & 1952. \\
\hline $100 \ldots$ & 18860 & $\begin{array}{l}\text { Road cut on U.S. Highway } 101 \text {, } \\
\text { east side of highway, about } \\
1,000 \mathrm{ft} \text { south of Spencer } \\
\text { Creek. }\end{array}$ & E. J. Moore & 1954. \\
\hline 101. & 18914 & $\begin{array}{l}\text { Fill for highway south of } \\
\text { Spencer Creek at Beverly } \\
\text { Beach on U.S. Highway 101. }\end{array}$ & E. J. Moore & 1952. \\
\hline 102 & 18882 & $\begin{array}{l}\text { From } 25 \mathrm{ft} \text { of siltv shale at base } \\
\text { of exposed section in beach } \\
\text { cliffs forming frst headland } \\
\text { south of fill at Spencer Creek. }\end{array}$ & E. J. Moore & $1952,1954$. \\
\hline $\begin{array}{l}102 a \ldots \\
103 \ldots\end{array}$ & $\begin{array}{r}18882 \mathrm{a} \\
18883\end{array}$ & $\begin{array}{l}1 \mathrm{ft} \text { above top of loc. } 102 \\
\text { From } 10 \mathrm{ft} \text { of silty shale, } 25 \mathrm{ft}\end{array}$ & $\begin{array}{l}\text { E. J. Moore } \\
\text { E. J. Moore.... }\end{array}$ & $\begin{array}{l}1952,1954 . \\
1952,1954 .\end{array}$ \\
\hline & & $\begin{array}{l}\text { above base of exposed section } \\
\text { in beach cliffs forming first } \\
\text { headland south of fill at } \\
\text { Spencer Creek. }\end{array}$ & & \\
\hline 104 & 18884 & $\begin{array}{l}\text { From } 8 \mathrm{ft} \text { massive siltstone, } \\
\text { about } 37 \mathrm{ft} \text { above base of ex- } \\
\text { posed section in beach cliffs } \\
\text { forming first headland south } \\
\text { of fill at Spencer Creek. }\end{array}$ & E. J. Moore & $1952,1954$. \\
\hline 105. & 18885 & $\begin{array}{l}\text { From 1-2 ft of extremely fossilif- } \\
\text { erous siltstone, about } 45 \mathrm{ft} \\
\text { above base of exposed sec- } \\
\text { tion in beach cliffs forming } \\
\text { first headland south of fill at } \\
\text { Spencer Creek. }\end{array}$ & E. J. Moore..... & $1952,1954$. \\
\hline $106 \ldots$ & 18895 & $\begin{array}{l}\text { From } 3 \mathrm{ft} \text { of very fine grained } \\
\text { sandstone about } 49 \mathrm{ft} \text { above } \\
\text { base of exposed section in } \\
\text { beach cliffs forming first } \\
\text { headland south of fill at } \\
\text { Spencer Creek. }\end{array}$ & E. J. Moore_. & $1952,1954$. \\
\hline 107 & 18896 & $\begin{array}{l}\text { From } 22 \mathrm{ft} \text { of siltstone and silty } \\
\text { shale about } 51 \mathrm{ft} \text { above base of } \\
\text { exposed section in beach cliffs } \\
\text { forming first headland south } \\
\text { of fill at Spencer Creek. }\end{array}$ & E. J. Moore & 1952,1954 \\
\hline 107 & $18896 \mathrm{a}$ & Slump, from loc. $107 ?$ & E. J. Moore... & 1952. \\
\hline & 18899 & $\begin{array}{l}\text { Slump, presumably from loc. } \\
107 \text {. }\end{array}$ & E. J. Moore & 1952. \\
\hline 109 & 18897 & $\begin{array}{l}\text { Probably from same horizon as } \\
107 \text {, but farther south. }\end{array}$ & E. J. Moore..... & 1952. \\
\hline 110 . & 18900 & $\begin{array}{l}\text { From } 101 / 2 \mathrm{ft} \text { of shaly siltstone } \\
\text { about } 59 \mathrm{ft} \text { above base of ex- } \\
\text { posed section in beach cliffs } \\
\text { forming first headland south } \\
\text { of fill at Spencer Creek. }\end{array}$ & E. J. Moore & 1952. \\
\hline 111 & 18908 & $\begin{array}{l}\text { From middle of } 22 \mathrm{ft} \text { of silt- } \\
\text { stone, same stratigraphic ho- } \\
\text { rizon as loc. } 107 \text {, in beach } \\
\text { cliffs } 800-900 \mathrm{ft} \text { south of } \\
\text { Spencer Creek. }\end{array}$ & E. J. Moore & 1952. \\
\hline
\end{tabular}

Fossil Localities-Continued

\begin{tabular}{c|c|c|c|c}
\hline $\begin{array}{c}\text { No. } \\
\text { used } \\
\text { in this } \\
\text { report }\end{array}$ & $\begin{array}{c}\text { USGS } \\
\text { Cenozoic } \\
\text { loc. No. }\end{array}$ & Description of locality & Collector & $\begin{array}{c}\text { Date } \\
\text { collected }\end{array}$ \\
\hline
\end{tabular}

Yaquina quadrangle-Con tinued

112 15993 Sea Cliff immediately north of $\mid$ H. E Vokes town of Beverly Beach; on line between secs. 5 and 8 , $T$,

$113 \ldots . .15987 \quad \begin{gathered}10 \mathrm{~S}, \mathrm{R}_{1} 11 \mathrm{~W} . \\ \text { Cut on the northwest side of }\end{gathered}$ U.S. Highway 101, immediately north of Wade Creek. Center of IW $1 / 4 \mathrm{SE} 14$ sec. 8 ,

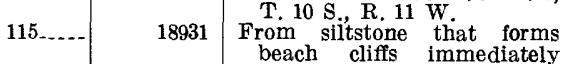
beach cliffs immediately

$116 \ldots . . .-15989$ Sea beach cliffs immediately south of mouth of Wade Creek. SW $14 \mathrm{NW} 1 / 4 \mathrm{SE} 1 / 4 \mathrm{sec}$. $117 \ldots . .-18909 \quad \begin{gathered}8, T .10 \text { S., R. 11 W. } \\ \text { From beach cliffs } 200-300 \mathrm{ft} \text { south }\end{gathered}$ $118 \ldots . .-18869 \quad \begin{gathered}\text { of mouth of Wade Creek. } \\ \text { From 10 ft of silty shale, same } \\ \text { stratigraphic horizon as loc. }\end{gathered}$ 103, in beach cliffs immedi-

$119 \ldots . . .-18870 \quad \begin{gathered}\text { 1ately south of Wade Creek. } \\ \text { From 8 } \mathrm{ft} \text { of siltstone, same }\end{gathered}$ stratigraphic horizon as loc. 104, in beach cliffis immedi-

$120 \ldots 1 . .-18872 \begin{gathered}\text { ately south of Wade Creek. } \\ \text { From 1-2 ft of extremely fossil- } \\ \text { iforeus }\end{gathered}$ iferous siltstone, same stratigraphic horizon as loc. 105 , in beach cliffs immediately

18871 Frouth of Wade Creek. $3 \mathrm{ft}$ of silty sandstone, same stratigraphic horizon as oc. 106, in beach cliffs im. mediately south of Wade rom very silty shale, same stratigraphic horizon as loc. 107, in beach clifs immedately south of Wade Creek. pro south of Wade Creek, probably from same stratipame horizon as loc 120 from beach cliffs on the south side of first fault south of Wade of first fault south of Wade
Creek.

From very silty shale, same stratigraphic horizon as loc. 122 , in beach cliffs on the south side of first fault south

$126 \ldots$.... $18936 \quad \begin{gathered}\begin{array}{c}\text { of Wade Creek. } \\ \text { From } 101 / 2 \mathrm{ft} \text { of siltstone, same }\end{array} \\ \text { From }\end{gathered}$ stratigraphic horizon as loc. 110 , in beach cliffs on the south side of first fault south

$127 \ldots 937 \quad \begin{aligned} & \text { of W ade Creek. } \\ & \text { From uppermost part of sec- } \\ & \text { tion exposed in beach cliffs } \\ & \text { on the south side of first fault } \\ & \text { south of Wade Creek. }\end{aligned}$

\begin{tabular}{l|l}
18937 & $\begin{array}{l}\text { From uppermost part of sec- } \\
\text { tion exposed in beach cliffs } \\
\text { on the south side of first fault } \\
\text { south of Wade Creek. }\end{array}$
\end{tabular}

\begin{tabular}{l|l}
18937 & $\begin{array}{l}\text { From uppermost part of sec- } \\
\text { tion exposed in beach cliffs } \\
\text { on the south side of first fault } \\
\text { south of Wade Creek. }\end{array}$
\end{tabular}

\begin{tabular}{l|l}
18937 & $\begin{array}{l}\text { From uppermost part of sec- } \\
\text { tion exposed in beach cliffs } \\
\text { on the south side of first fault } \\
\text { south of Wade Creek. }\end{array}$
\end{tabular} stratigraphic horizon as loc. 25 , in beach cliffs on the outh side of the second fault

$129 . . .-18912 \quad \begin{gathered}\text { south of Wade Creek. } \\ \text { From sandy siltstone and very } \\ \text { fine grained sandstone, 74-89 }\end{gathered}$ fine grained sandstone, 74-89 it above barren marker, in of Coal Creek.
of $4000 \mathrm{ft}$ north
.

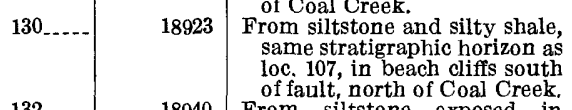

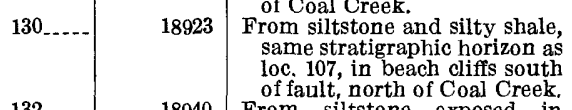

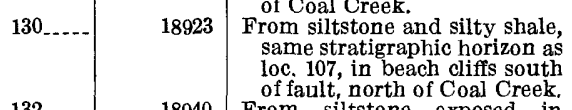

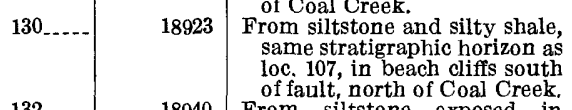
$18940 \quad \begin{gathered}\text { From siltstone exposed in } \\ \text { beach cliffs just south of big } \\ \text { headland between Molock }\end{gathered}$ and Wade Creeks. From ame stratigraphic horizon as

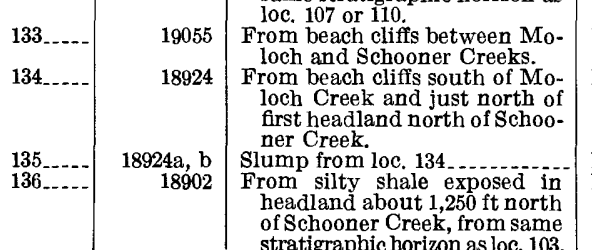


Fossil Localities-Continued

\begin{tabular}{|c|c|c|c|c|}
\hline $\begin{array}{l}\text { No. } \\
\text { used } \\
\text { in this } \\
\text { report }\end{array}$ & $\begin{array}{l}\text { USGS } \\
\text { Cenozoic } \\
\text { loc. No. }\end{array}$ & Description of locality & Collector & $\begin{array}{c}\text { Date } \\
\text { collected }\end{array}$ \\
\hline
\end{tabular}

Fossil Localities-Continued

\begin{tabular}{c|c|c|c|c}
\hline $\begin{array}{c}\text { No. } \\
\text { used } \\
\text { in this } \\
\text { report }\end{array}$ & $\begin{array}{c}\text { USGS } \\
\text { Cenozoic } \\
\text { loc. No. }\end{array}$ & Description of locality & Collector & $\begin{array}{c}\text { Date } \\
\text { collected }\end{array}$ \\
\hline
\end{tabular}

Yaquina quadrangle-Continued

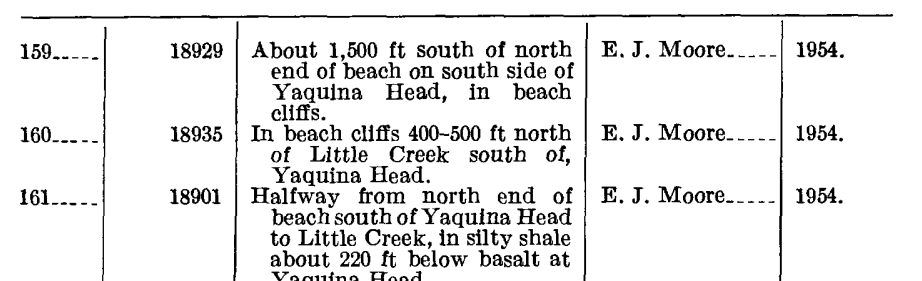

\begin{tabular}{|l|l|l} 
E. J. Moore....- & 1952. \\
& E. J. Moore_.... & 1952.
\end{tabular}

\section{.}

\section{7} E.

\section{w}

m.

\section{0 \\ (19.}

\section{0.}

\section{0.}

\section{m.}

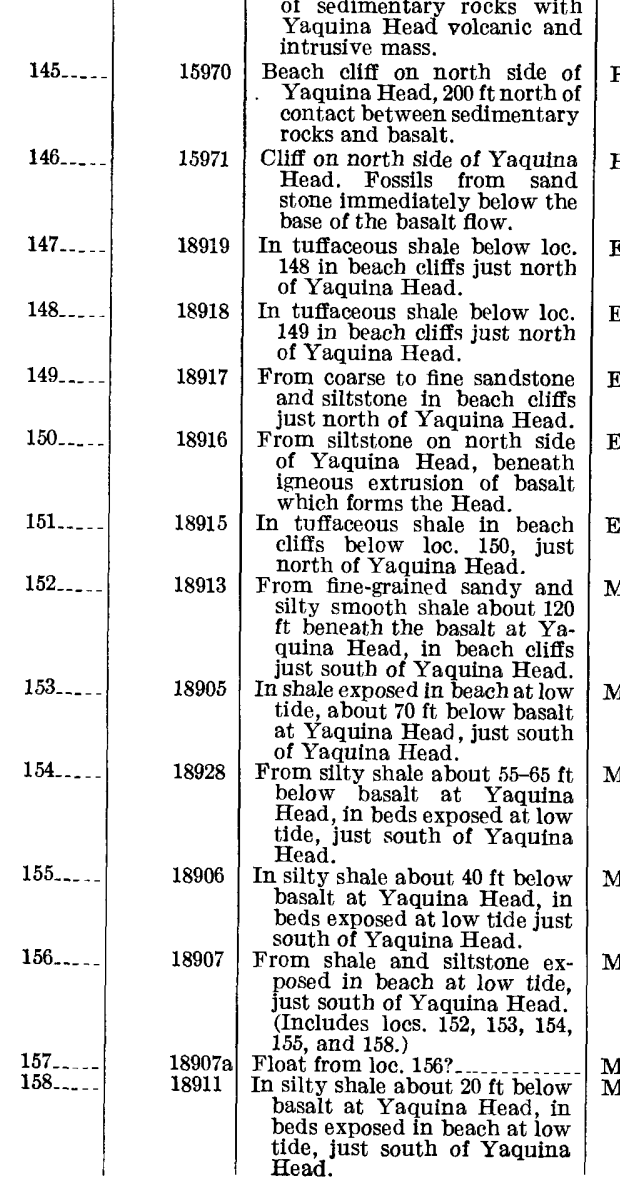
(1) iffs or of ne T. h t d P. P. D. Snavely, 1946. Vokes H. E.

H. E. Vokes. ... 1946.

\begin{tabular}{l|l} 
E. J. Moore__._- 1952. &
\end{tabular}

\begin{tabular}{l|l} 
E. J. Moore & 1952.
\end{tabular}

\begin{tabular}{l|l} 
E. J. Moore _. _- 1952. &.
\end{tabular}

\begin{tabular}{l|l} 
E. J. Moore....- 1952. &.
\end{tabular}

\begin{tabular}{l|l} 
E. J. Moore-_-- 1952. &.
\end{tabular}

$\begin{array}{lll}\text { M. P. James_._- } 1953 . & .\end{array}$

M. P. James..-- 1953.

\begin{tabular}{ll|l} 
M. P. James_._-_ 1953. &.
\end{tabular} 1953. M. P. James_... 1953. \begin{tabular}{l|l} 
M. P. James__- & 1953. \\
M. P. James_._- & 1953.
\end{tabular}

162

\section{1}

167

15

Yaquina Head.

ase of beach cliff about 0.4 mile south of mouth of Big Creek, SE1/4 SW $1 / 4$ sec. $32, \mathrm{~T}$

$18933 \quad \begin{aligned} & 10 \mathrm{~S} \text {., } \mathrm{R} \text {. 1I W. } \mathrm{W} \text {. } \\ & \text { 163...- }\end{aligned}$ Creek and about $1 \frac{1}{2}$ miles north of Newport.
Cliffs on north side of Jump Off

164 16930-- $18922 \begin{gathered}\text { Clifs on north side of Jump Off } \\ \text { Joe Point, northwest part of } \\ \text { Newport, beds lmmediately } \\ \text { overlying the Nye mudstone. } \\ \text { From Coast Guard Station }\end{gathered} \mid$

164 16930-- $18922 \begin{gathered}\text { Clifs on north side of Jump Off } \\ \text { Joe Point, northwest part of } \\ \text { Newport, beds lmmediately } \\ \text { overlying the Nye mudstone. } \\ \text { From Coast Guard Station }\end{gathered} \mid$

164 16930-- $18922 \begin{gathered}\text { Clifs on north side of Jump Off } \\ \text { Joe Point, northwest part of } \\ \text { Newport, beds lmmediately } \\ \text { overlying the Nye mudstone. } \\ \text { From Coast Guard Station }\end{gathered} \mid$

$18922 \quad \begin{gathered}\text { From Coast Guerd Station } \\ \text { north of Jump Off Joe Rock. } \\ \text { 165_...- }\end{gathered}$

$18920 \quad \begin{gathered}\text { From siltstone in beach cliffs. } \\ \text { Jump Off Joe } R \text {. }\end{gathered}$ Jump Off Joe Rock, in massive

15320 Astoria formation, overlying Nye shale at Jump Off Joe, on north side of small point 14.4 mile north of city limits at Newport, Oreg., in sea cliffs,
SW14

$16921 \begin{aligned} & \text { R.11 W. } \\ & \begin{array}{c}\text { South of the Newport Natato- } \\ \text { rium, from shaly slitstone in } \\ \text { beach cliffs }\end{array}\end{aligned}$

$19071 \quad \begin{gathered}\text { beach cliffs. } \\ \text { South of small headland south } \\ \text { of Newport Natatorium from }\end{gathered}$ $4 \mathrm{ft}$ sllty shale, base and top

171..... $18934 \begin{gathered}\text { not exposed. } \\ \text { From silty shale in sea cllffs }\end{gathered}$

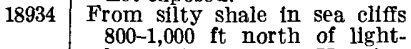
house at entrance to Yaquina

16042 Fossils from ocean beach cliffs 0.2 to 0.3 mile north of junction of ocean beach and entrance to Yaquina Bay.

2758 Nye Creek Beach from Newport Point to Cape Foulweather.

16047 South tip of rock point at junction of ocean beach and north shore of Yaquina Bay. Locality is $1,200 \mathrm{ft}$ west and 200 ft south of intersection of Yaquina Bay Bridge and

177.... 2755 Beach along north side of

178_... $\quad 2761$ Yo beach, near point 3/4 mile

2761 On beach, near point $3 / 4$

2274 Newport, Yaquina Bay

Road cut on outer side of curve
on U.S. 101, about 2.5 miles on U.S. 101, about 2.5 miles N 36SE14 NE14 sec. 30, T. 11 $S, R, 11 \mathrm{~W}$.

181

18830 S., R. $11 \mathrm{~W}$. port. From $40 \mathrm{ft}$ of silty shale exposed in beach cliffs north of Grant Creek, sees. north of Grant Creek, sees.

$181 \mathrm{a}$

18831 About 3 miles south of Newport. From $50 \mathrm{ft}$ of siltstone exposed in beach cliffs south
of Grant Creek, sec. 31, T. 11 S., R. $11 \mathrm{~W}$.

182

19099 In $40 \mathrm{ft}$ of silty shale exposed in beach cliffs at end of first long straight stretch of U.S. Highway 101, south of $\mathrm{Ya}$ quina Bay bridge, $1 / 2$ mile south of Nye midstone fossilcollecting locality on U.S. Geol. Survey Oil and Gas

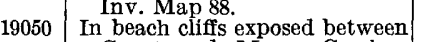

183
H. E. Vokes .... 1946.

E. J. Moore_.... 1954.

\begin{tabular}{l|l} 
E. J. Moore_...- 1954. \\
\hline
\end{tabular}

\begin{tabular}{l|l} 
E. J. Moore & 1954.
\end{tabular}

\begin{tabular}{l|l} 
E. J. Moore & 1952.
\end{tabular}

W. C. Warren, 1944.

H. E. Vokes,

can, and $\mathrm{C}$.

G. Duncan.

E. J. Moore _... 1952.

E. J. Moore..... 1954.

\begin{tabular}{|l|l} 
E. J. Moore ..... 1954. &
\end{tabular}

\begin{tabular}{l|l} 
Hans & 1945.
\end{tabular}

Norbisrath.

\begin{tabular}{|l|l|} 
J. S. Diller ....... 1895. &
\end{tabular}

Hans
Norbisrath.

\begin{tabular}{|l|l} 
J. S. Diller_.....- 1895. &
\end{tabular}

\begin{tabular}{|l|l} 
J. S. Diller_._._- 1895. &
\end{tabular}

\begin{tabular}{l|l} 
W. H. Dall & 1890. \\
P. D. Snavely, & 1946. \\
Jr. and H. E. &
\end{tabular}

Vokes.

E. J. Moore_.... 1954.

\begin{tabular}{l|l} 
E. J. Moore 1954. \\
\hline
\end{tabular}

E. J. Moore..... 1954. Grant and Moore Creeks, about $13 / 2$ 
Fossil Localities-Continued

\begin{tabular}{c|c|c|c|c}
\hline $\begin{array}{c}\text { No. } \\
\text { used } \\
\text { in this } \\
\text { report }\end{array}$ & $\begin{array}{c}\text { USGS } \\
\text { Cenozoic } \\
\text { loc. No. }\end{array}$ & Description of locality & Collector & $\begin{array}{c}\text { Date } \\
\text { collected }\end{array}$ \\
\hline
\end{tabular}

Yaquina quadrangle-Continued

\begin{tabular}{|c|c|c|c|c|}
\hline $184 \ldots$ & 18941 & $\begin{array}{l}\text { In beach cliffs north of Moore } \\
\text { Creek about } 112 \text { miles south }\end{array}$ & E. J. Moore & 1954. \\
\hline 185 & 18942 & $\begin{array}{l}\text { of Newport. } \\
\text { Low sea cliffs between Moore } \\
\text { Creek and Lost Creek, about }\end{array}$ & E. J. Moore & 1954. \\
\hline $185 \mathrm{a}$ & 15967 & $\begin{array}{l}\text { In sea cliffs, SW } 1 / 4 \text { sec. } 6, T \text {. } 12 \\
\text { S., R. } 11 \text { W., north of road } \\
\text { that is } 0.3 \text { mile north of Lost }\end{array}$ & $\begin{array}{l}\text { H. E. Vokes } \\
\text { and P. D. } \\
\text { Snavely, Jr. }\end{array}$ & 1946. \\
\hline $186 \ldots$ & $18942 \mathrm{a}$ & $\begin{array}{l}\text { Creek, south of Newport. } \\
\text { Float south of Moore Creek }\end{array}$ & & 1954. \\
\hline
\end{tabular}

\begin{tabular}{l|l|l|l|l}
\hline \multicolumn{3}{c}{ Coos Bay quadrangle } \\
\hline $187 \ldots . .$. & 18284 & Dredgings at Coos Bay _........- & E. J. Moore..... & $\begin{array}{c}1949,1952, \\
1954 .\end{array}$ \\
\hline
\end{tabular}

\section{REFERENCES CITED}

Abbott, R. T., 1954, American seashells: New York, D. Van Nostrand Co., Inc., 541 p., 40 pls., 100 figs.

Allen, J. E., and Baldwin, E. M., 1944, Geology and coal resources of the Coos Bay quadrangle, Oregon: Oregon Dept. Geology and Mineral Industries Bull. 27, 157 p., 31 pls.

Anderson, F. M., 1905, A stratigraphic study in the Mount Diablo Range of California: California Acad. Sci. Proc., ser. 3, v. 2, no. 2, p. 155-248, 23 pls.

Anderson, F. M., and Martin, Bruce, 1914, Neocene record in the Temblor Basin, California, and Neocene deposits of the San Juan district, San Luis Obispo County: California Acad. Sci. Proc., ser. 4, v. 4, no. 3, p. 15-112, 8 pls., 1 map.

Arnold, Ralph, 1903, The paleontology and stratigraphy of the marine Pliocene and Pleistocene of San Pedro, California: California Acad. Sci. Mem. 3, 420 p., 37 pls.

1906a, The Tertiary and Quaternary pectens of California: U.S. Geol. Survey Prof. Paper 47, 264 p., 53 pls., 2 figs.

$1906 \mathrm{~b}$, Geological reconnaissance of the coast of the Olympic Peninsula, Washington: Geol. Soc. America Bull., v. 17, p. 451-468, 1 map.

1908, Descriptions of new Cretaceous and Tertiary fossils from the Santa Cruz Mountains, California: U.S. Natl. Mus. Proc., v. 34, p. 345-390, pls. 31-37.

1909, Environment of the Tertiary faunas of the Pacific coast of the United States: Jour. Geology, v. 17, p. 509-533.

Arnold, Ralph, and Hannibal, Harold, 1913, The marine Tertiary stratigraphy of the North Pacific coast of America: Am. Philos. Soc. Proc., v. 52, no. 212, p. 559-605.

Berry, S. S., 1953, Notices of new west american marine Mollusca: San Diego Soc. Nat. History Trans., v. 11, no. 16, p. 405-428, pls. 28,29 , text fig. 1-10.

Bode, F. D., 1935, The fauna of the Merychippus zone, North Coalinga district, California: Carnegie Inst. Washington Pub., Contrib. to Paleontology, no. 6, p. 65-96, 2 pls., 10 text figs.

Carpenter, P. P., 1857, Report on the present state of our knowledge with regard to the Mollusca of the west coast of North America: British Assoc. Adv. Sci. Rept. for 1856, p. 159368 , pls. 6-9.

Chavan, André, 1952, Nomenclatural notes on carditids and lucinids: Washington Acad. Sci. Jour., v. 42, no. 4, p. 116-122.
Clark, B. L., 1915, Fauna of the San Pablo group of middle California: California Univ., Dept. Geol. Sci., Bull., v. 8, no. 22 , p. $385-572$, pls. $42-71$.

1918, The San Lorenzo series of middle California: California Univ., Dept. Geol. Sci., Bull., v. 11, no. 2, p. 45234, pls. 3-24, 4 text figs.

1921a, The marine Tertiary of the west coast of the United States; its sequence, paleogeography, and the problems of correlation: Jour. Geology, v. 29, p. 583-614, 12 figs.

$1921 \mathrm{~b}$, Correlation of the Tertiary marine formations of the west coast of North America: Pan Pacific Scientific Conference, First Proc., B. P. Bishop Mus. Spec. Pub., no. 7, pt. 3, p. 801-818.

1925, Pelecypoda from the marine Oligocene of western North America: California Univ., Dept. Geol. Sci., Bull., v. 15 , no. 4 , p. $69-136$, pls. 8-22.

1929, Stratigraphy and faunal horizons of the Coast Ranges of California: (privately published), 132 p., 50 pls.

-1932, Fauna of the Poul and Yakataga formations (upper Oligocene) of southern Alaska: Geol. Soc. America Bull., v. 43, p. 797-846, pls. 14-21, 1 fig.

Clark, B. L., and Arnold, Ralph, 1918, Marine Oligocene of the west coast of North America: Geol. Soc. America Bull., v. 29 , p. 297-308.

___ 1923, Fauna of the Sooke formation Vancouver Island with description of a new coral by $T$. W. Vaughan: California Univ. Dept. Geol. Sci., Bull., v. 14, no. 5, p. 123234, pls. 15-42.

Cloud, P. E., Jr., 1955, Physical limits of glauconite formation: Am. Assoc. Petroleum Geologists Bull., v. 39, p. 484-492.

Condon, Thomas, 1880, in Cope, E. D., Corrections of the geological maps of Oregon: Am. Naturalist, v. 14, no. 6, p. 457-458.

1906, A new fossil pinniped from the Miocene of the Oregon coast: Oregon Univ. Bull., supp. to v. 3, no. 3, 14 p.

Conrad, T. A., 1832-1833, Fossil shells of the Tertiary formations of North America: Philadelphia, v. 1, nos. 1-4 [1832: no. 1 , p. $1-8,9-20$, pls. $1-6$; no. 2 , p. 21-28, pls. 7-14; 1833: no. 3 , p. $29-38$; no. 4 , p. 39-46, no. 3 , "republished," p. 29-56, pls. 15-18]. Reprinted by Harris, G. D., 1893, republication of Conrad's fossil shells of the Tertiary formations of North America: Washington, 121 p., 20 pls. 1837, Description of new marine shells from upper California, collected by Thomas Nutall, Esq.: Acad. Nat. Sci. Philadelphia Jour., v. 7, pt. 2, p. 227-268, pls. 17-20. 1848, Fossil shells from Tertiary deposits on Columbia River, near Astoria: Am. Jour. Science, ser. 2, v. 5, p. 432-433, 14 figs.

- 1849, Fossils from Northwestern America: in Dana, J. D., U.S. Explor. Exped., 1838-1842, under Charles Wilkes, Geology, v. 10, app. p. 723-728; atlas, pls. 17-21. 1855, Report of Mr. T. A. Conrad on the fossil shells collected in California by W. P. Blake, geologist of the expedition under the command of Lt. R. S. Williamson, U.S. Topographical Engineers, 1852, in the preliminary geological report of W. P. Blake: U.S. 33d Congress, 1st session, House Ex. Doc. no. 129, p. 5-20. [Reprinted in Dall, 1909.]

- 1856, Descriptions of three new genera; twenty-three new species middle Tertiary fossils from California, and one from Texas: Acad. Nat. Sci. Philadelphia Proc., v. 8, p. $312-316$. 
Conrad, T. A., 1857, Descriptions of the fossil shells, in Williamson, R. S., Report of explorations in California for railroad routes ***: U.S. 33d Congress, 2d session, Senate Ex Doc. 78 and House Ex. Doc. 91, v. 5, pt. 2, app. 2, p. 317329, pls. 2-9 [U.S. Pacific R.R. Repts.]

1863, Catalogue of Miocene shells of the Atlantic slope: Acad. Nat. Sci. Philadelphia Proc., v. 6, 2d ser., p. 559-586. 1865a, Catalogue of the older Eocene shells of Oregon: Am. Jour. Conchology, v. 1, p. 150-54.

- 1865b, Observations on the Eocene Lignite formation of the United States: Acad. Nat. Sei. Philadelphia Proc., v. 9, 2d ser., p. 70-73.

- 1866a, Illustrations of Miocene fossils, with deseriptions of new species: Am. Jour. Conchology, v. 2, p. 65-73, pls. 3,4 .

1866b, Observations on Recent and fossil shells with proposed new genera and species: Am. Jour. Conchology, v. 2, p. 101-103.

- 1866e, Check list of the invertebrate fossils of North America: Smithsonian Mise. Colln. v. 7, no. 200, 41 p.

Cooper, J. G., 1894, Catalogue of Californian fossils, parts 2-5: California Min. Bur. Bull. 4, 65 p., 6 pls., Sacramento.

Cope, E. D., 1880a, Corrections of the geological maps of Oregon: Am. Naturalist, v. 14, p. 457-458.

- 1880b, Second contribution to the Miocene fauna of Oregon: Am. Philos. Soc. Proc., v. 18, p. 370-371.

Cossmann, Maurice, 1901, Essais de Paléoconehologie Comparée: Paris, v. 4, 293 p., 10 pls.

Cushman, J. A., Stewart, R. E., and Stewart, K. C., 1947, Five papers on Forminifera from the Tertiary of western Oregon: Oregon Dept. Geology and Mineral Industries Bull. 36, pts. $1-5$, p. $11-110$ [1948].

Dall, W. H., 1872, Descriptions of sixty new forms of mollusks from the west coast of North America and the North Pacific Ocean, with notes on others already described: Am. Jour. Conchology, v. 7, p. 93-160, pls. 13-16.

-1890-1903, Contributions to the Tertiary fauna of Florida, with especial reference to the Miocene silex beds of Tampa and the Pliocene beds of the Caloosahatchie River: Wagner Free Inst. Sci. Trans., v. 3, pts. 1-6, 1654 p., 60 pls. 1890 , pt. 1 , p. $1-200$, pls. $1-12$. 1892, pt. 2 , p. 201-473, pls. $13-22$. 1895 , pt. 3 , p. $474-570$. 1898 , pt. 4 , p. 571-947, pls. $23-35$. 1900 , pt. 5, p. 948-1218, pls. 37-47. 1903, pt. 6, p. 1219-1654, pls. 48-60.

1890, Conchological notes from Oregon: Nautilus, v. 4, p $87-89$.

-1898, A table of North American Tertiary formations, correlated with one another and with those of Western Europe, with annotations: U.S. Geol. Survey 18th Ann. Rept., pt. 2, p. 327-348. (First pub. as House Doc. 5, U.S. 55th Cong., 2d sess., 1897.)

1901, A new Lyropecten: Nautilus, v. 14, no. 10, p. $117-118$.

- 1902, Illustrations and descriptions of new unfigured, or imperfectly known shells, chiefly American, in the U.S. National Museum: U.S. Natl. Mus. Proc., v. 24, p. 499-566" pls. $27-40$.

1907, Notes on some Upper Cretaceous Volutidae with descriptions of new species and a revision of the groups to which they belong: Smithsonian Misc. Colln., v. 50, pt. 1, p. 1-23, 13 figs.
Dall, W. H., 1908, The Mollusca and Brachiopoda: Reports on dredging operations *** earried on by the U.S. Fish Commission steamer Albatross: Harvard Colln. Mus. Comp. Zoology Bull., v. 43, p. 205-487.

-1909, Contributions to the Tertiary paleontology of the Pacific coast, I. The Miocene of Astoria and Coos Bay, Oregon: U.S. Geol. Survey Prof. Paper 59, 278 p., 23 pls., 14 figs. (Conrad's 1848 and 1849 papers reprinted.)

- 1922, Fossils of the Olympic Peninsula: Am. Jour. Science ser. 5, v. 4, p. 305-314.

Dall, W. H., and Harris, G. D., 1892, Correlation papers: Neocene: U.S. Geol. Survey Bull. 84, 349 p., 3 pls., 43 figs.

Dana, J. D., 1849, Geological observations on Oregon and northern California: U.S. Explor. Exped., 1838-42, under the command of Charles Wilkes, Geology, v. 10, chap. 17 , p. $611-678$, app. p. $722-723,729-730$, atlas pls. 16 , 17, 21.

Davis, C. H., 1913, New speeies from the Santa Lucia Mountains, California, with a discussion of the Jurassic age of the slates at Slate's Springs: Jour. Geology, v. 21, p. 453-458, 7 text figs.

Diller, J. S., 1896, A geological reconnaissance in northwestern Oregon: U.S. Geol. Survey 17th Ann. Rept., pt. 1, p. 441-520.

Dollfus, G. F., 1909, Essai sur l'étage Aquitanien: Serv. Carte Géol. France Bull., v. 19, no . 124, p 379-508, 6 pls.

Durham, J. W., 1937, Gastropods of the family Epitoniidae from Mesozoic and Cenozoic rocks of the west coast of North America, including one new species by F. Earl Turner and one by R. A. Brankamp: Jour. Paleontology, v. 11 , no. 6 , p. $479-512$, pls. $56-57$.

1942a, Eocene and Oligocene coral faunas of Washington: Jour. Paleontology, v. 16 , no. 1, p. $84-104$, pls. $15-17,1$ text fig.

1942b, Notes on Pacific coast Galeodeas: Jour. Paleontology, v. 16 , no. 2 , p 183-191, pls. $29-30$, 2 figs.

-1944, Megafaunal zones of the Oligocene of northwestern Washington: California Univ., Geol. Sci., Bull., v. 27, no. 5, p. 101-211, pls. 13-18. 7 text figs., 1 map.

1950, in E. W. Scripps Cruise to the Gulf of California; pt. 2, Megascopic paleontology and marine stratigraphy: Geol. Soc. America Mem. 43, p. 1-216, 48 pls.

1953, Miocene at Cape Blanco, Oregon [abs.]: Geol Soc. America Bull., v. 64, no. 12, pt. 2, p. 1504-1505.

Durham, J. W., Harper, Herbert, and Wilder, Beverly, Jr., 1942, Lower Miocene in the Willamette Valley, Oregon [abs.]: Geol. Soc. America Bull., v. 53, pt. 2, p. 1817.

Emerson, W. K., 1958, Notes on the scaphopod mollusks: rectifications of nomenclature II: Washington Biol. Soc. Proc., v. 71, p. 91-94.

English, W. A., 1914, The Agasoma-like gastropods of the California Tertiary: California Univ., Dept. Geol. Sci., Bull., v. 8 , no. 10 , p. $243-256$, pls. 24-25.

Etherington, T. J., 1931, Stratigraphy and fauna of the Astoria Miocene of southwest Washington: California Univ., Dept. Geol. Sci., Bull., v. 20, no. 5, p. 31-142, 14 pls., 1 map.

Fischer-Piette, E., 1942, Les Mollusques d'Adanson: Jour. de Conchyliologie, v. 85 , nos. $2-4$, p. $103-366,16$ pls.

Gabb, W. M., 1865, Description of new species of marine shells from the coast of California: California Acad. Sci. Proc., ser. 1 , v. 3 , p. $182-190$.

- 1869, Tertiary invertebrate fossils (continued): Paleontology of California, v. 2, sec. 1, 2, 299 p., 34 pls. 
Glenn, L. C., 1904, in Maryland Geol. Survey, Miocene, Systematic Paleontology, Miocene: Baltimore, Md., The Johns Hopkins Press, p. 272-401.

Gould, A. A., 1850, *** Shells from the Exploring Expedition * * * : Boston Soc. Nat. History Proc., v. 3, p. 214-219.

Gower, H. D., 1960, Geology of the Pysht quadrangle, Washington: U.S. Geol. Survey Geol. Quad. Map GQ-129.

Grant, U.S., 4th, and Gale, H. R., 1931, Catalogue of the marine Pliocene and Pleistocene Mollusca of California and adjacent regions: San Diego Soc. Nat. History Mem., v. 1, 1036 p., 32 pls., 15 figs., 3 tables.

Grant, U.S., 4th, Gale, H. R., and Quayle, E. H., 1934, A new middle Miocene Neptunea from California: Nautilus, v. 47, p. 91-93, 2 text figs.

Grau, Gilbert, 1959, Pectinidae of the eastern Pacific: Allan Hancock Pacific Expeditions, v. 23, complete, Los Angeles, Calif., Southern California Univ. Press, 308 p., 57 pls.

Hall, C. A., Jr., 1958, Geologv and paleontology of the Pleasanton area, Alameda and Contra Costa Counties, California: California Univ., Dept. Geol. Sci., Bull., v. 34, no. 1, p. 1-90, pls. 1-12, 2 figs., 5 maps.

Hanna, G. D., 1924, Rectifications of nomenclature: California Acad. Sci. Proc. ser. 4, v. 13, no. 10, p. 151-186.

Hanna, G. D., and Hertlein, L. G., 1938, New Tertiary mollusks from western North America: Jour. Paleontology, v. 12, no. 1 , p. $106-110$, pl. 21 .

Harrison and Eaton (firm), 1920, Report on investigation of oil and gas possibilities of western Oregon: Oregon Bur. mines and Geology, Mineral Resources of Oregon, v. 3, p. 3-40.

Hatai, Kotora and Nisiyama, Syozo, 1949, New Tertiary Mollusca from Japan: Jour. Paleontology, v. 23, no. 1, p. 87-94, pls. 23, 24.

- 1952, Check list of Japanese Tertiary marine Mollusca: Tohoku Imp. Univ. Repts., 2d ser., Sendai, Japan, (Geology) spec. v., no. 3,464 p.

Hay, O. P., 1903, Two new species of fossil turtles from Oregon: California Univ. Dept. Geol. Sci., Bull,, v. 3, p. 237-241.

Hayasaka, Ichiro, and Uozumi, Satoru, 1954, Fossil species of genus Mercenaria from the Cenozoic deposits of Hokkaido: Japan Paleont. Soc. Trans. Proc., new ser., p. 165-172, pl. 22.

Hertlein, L. G., 1940, Additions to the range of Pecten caurinis Gould: Nautilus, v. 54, p. 68-69.

Hertlein, L. G., and Crickmay, C. H., 1925, A summary of the nomenclature and stratigraphy of the marine Tertiary of Oregon and Washington: Am. Philos. Soc. Proc., v. 64, p. 224-282.

Hertlein, L. G., and Grant, U.S., 4th, 1944, The Cenozoic Brachiopoda of western North America: California Univ. Pub. Math. and Phys. Sci., v. 3, 236 p., 21 pls., 34 text figs.

Hertlein, L. G., and Strong, A. M., 1945, Family Cancellariidae: Conchological Club of Southern California Minutes, p. 6-15.

1955, Marine mollusks collected during the "Askoy" expedition to Panama, Columbia, and Ecuador in 1941: Am. Mus. Nat. History Bull., v. 107, art. 2, 317 p., 3 pls.

Howe, H. V. W., 1922, The Miocene of Clatsop and Lincoln Counties, Oregon: Unpublished doctorate thesis, Stanford Univ., California, 186 p., 14 pls., 1 map.

- 1922a, Faunal and stratigraphic relationships of the Empire formation, Coos Bay, Oregon: California Univ., Dept. Geol. Sci., Bull., v. 14, no. 3, p. 85-114, pls. 7-12.

1926, Astoria: Mid-Tertic type of Pacific coast: PanAm. Geologist, v. 45, p. 296-306, 1 pl. (map).
Isbister, A. K., 1855, On the Geology of the Hudson's Bay territories and of portions of the Arctic and northwestern regions of America; with a coloured geological map: Geol. Soc. London Quart. Jour., v. 11, p. 497-520.

Jeffreys, J. G., 1867, British Conchology: v. 4, London.

Kanehara, Kinji, 1935, Description of a new subspecies of Arca with tripartite ribs: Venus (Japanese Jour. Malacology), v. 5, no. 5, p. 273-278, pl. 13.

Keen, A. M., 1936, A new pelecypod genus of the family Cardiidae: San Diego Soc. Nat. History Trans., v. 8, p. 119-120.

- 1937, An abridged check list and bibliography of west North American marine Mollusca: Stanford, Calif., Stanford Univ. Press, $87 \mathrm{p}$.

1943, New mollusks from the Round Mountain Silt (Temblor) Miocene of California: San Diego Soc. Nat History Trans., v. 10 , no. 2, p. 25-60, pls. 3-4, 5 text figs. - 1951, Outline of a proposed classification of the pelecypod family Veneridae: Conch. Club Southern California, Minutes 113, p. 2-11.

1954, Five new species and a new subgenus in the pelecypod family Cardiidae: Am. Paleontology Bull., v. 35, p. 5-24, 1 pl., 9 text figs.

1958, Sea shells of tropical west America: Stanford, Calif., Stanford Univ. Press, 624 p., 10 pls., 1709 figs.

Keen, A. M., and Bentson, Herdis, 1944, Check list of California Tertiary marine Mollusca: Geol. Soc. America, Spec. Pub. no. 56, 280 p.

Kleinpell, R. M., 1938, Miocene Stratigraphy of California: Tulsa, Okla., Am. Assoc. Petroleum Geologists, 450 p., 22 pls., 14 figs.

Kummel, Bernhard, 1956, Post-Triassic nautiloid genera: Harvard Colln. Mus. Comp. Zoology Bull., v. 114, p. 324-494, 28 pls., 35 text figs.

Lawson, A. C., 1894, The geomorphogeny of the coast of northern California: California Univ., Dept. Geol. Sci. Bull., v. 1, p. 241-271.

Link, H. F., 1807, Beschreibung der Naturalien-Sammlung der Universität zu Rostock, v. 1, Mollusca, pts. 2-4, 160 p.

Loel, Wayne, and Corey, W. H., 1932, The Vaqueros formation, lower Miocene of California, I, Paleontology: California Univ., Dept. Geol. Sci. Bull., v. 22, no. 3, p. 31-410, pls. 4-65, 2 maps.

Lutz, G. C., 1951, The Sobrante Sandstone: California Univ., Dept. Geol. Sci. Bull., v. 28, no. 13, p. 367-406, pls. 15-18, 3 text figs.

Marcou, J. B., 1885, A list of the Mesozoic and Cenozoic types in the U.S. National Museum: U.S. Natl. Mus. Proc., v. 8, p. $290-344$.

Marks, J. G., 1949, Nomenclatural units and tropical American Miocene species of the gastropod family Cancellariidae: Jour. Paleontology, v. 23, no. 5, p. 453-464, pl. 78, 1 text fig.

Martin, Bruce, 1916, The Pliocene of middle and northern California: California Univ., Dept. Geol. Sci. Bull., v. 9, p. 215-259.

Meek, F. B., 1864, Check list of the invertebrate fossils of North America: Smithsonian Misc. Colln. 183, 32 p.

Merriam, C. W., 1941, Fossil Turritellas from the Pacific coast region of North America: California Univ., Dept. Geol. Sci. Bull., v. 26, no. 1, p. 1-214, pls. 1-41, 19 text figs., 1 map.

Merriam, J. C., 1896, Note on two Tertiary faunas from the rocks of the southern coast of Vancouver Island: California Univ., Dept. Geol. Sci. Bull., v. 2, no. 3, p. 101-108. 
Merriam, J. C., 1915, Tertiary vertebrate faunas of the North Coalinga region of California: Am. Philos. Soc. Trans., new ser., v. 22 , pt. 3 , p. 191-234.

Miller, A. K., 1947, Tertiary nautiloids of the Americas: Geol. Soc. America Mem. 23, 234 p., 100 pls., 107 figs., 1 table.

Mörch, O. A. L., 1852, Catalogue conchyliorum quae reliquit D. Alphonso d'Aguirra et Gadea Comes de Yoldi ***: Hafniae, 1852.

Nakazima, Masao, 1958, Notes on gross anatomy of Conchocele disjuncta: Venus (Japanese Jour. Malacology), v. 20, no. 2, p. 186-197, pls. 8-11.

Newberry, J. S., 1856, Report upon the geology of the route [Williamson's survey in California and Oregon]: U.S. Pacific R. R. Explor. Repts. (U.S. 33d Cong. 2d sess., Senate Ex. Doc. 78 and House Ex. Doc. 91), v. 6, pt. 2, p. 5-68.

Nomland, J. O., 1916, Corals from the Cretaceous and Tertiary of California and Oregon: California Univ., Dept. Geol. Sci. Bull., v. 9, p. 59-76, pls. 3-6.

- 1917, New fossil corals from the Pacific coast: California Univ., Dept. Geol. Sci. Bull., v. 10, p. 185-190, pl. 5.

Nomura, Shichihei, and Hatai, Kotora, 1933, On two species of Phalium from the Neogene of Japan: Japanese Jour. Geology and Geography Trans., v. 11, p. 49-53, pl. 8.

Olsson, A. A., 1922, The Miocene of northern Costa Rica with notes on its general stratigraphic relations: Am. Paleontology Bull., v. 9, no. 39, 460 p., 32 pls.

- 1932, Contributions to the Tertiary paleontology of northern Peru; pt. 5, The Peruvian Miocene: Am. Paleontology Bull., v. 19, 272 p., 24 pls.

Osmont, V. C., 1904, Arcas of the California Neocene: California Univ., Dept. Geol. Sci. Bull., v. 4, no. 4, p. 89-100, pls. 8-11.

Otuka, Yanosuke, 1937, Middle Tertiary Mollusca from North Hokkaido and Zyoban Coal-Field, Japan: Japanese Jour. Geology and Geography, v. 14, p. 167-171, pl. 16.

Oyama, Katura, 1951, Amusiinae in Japan: Illustrated catalogue of Japanese shells, no. 13, p. 79-86, pl. 13, figs. 1-4.

Packard, E. L., 1921, An addition to the marine mammalian fauna of Newport, Oregon [abs.]: Geol. Soc. America Bull., v. 32, p. 148.

- 1935, Additional Cetacean material from Astoria formation: The Mineralogist, v. 3, p. 9-10.

1940, A new turtle from the marine Miocene of Oregon: Oregon State College Studies in Geology, no. 2, 31 p., 4 pls. 2 text figs.

- 1941, Additions to the vertebrate fauna of Astoria formation of Oregon [abs.]: Geol. Soc. America Bull., v. 52 , pt. 2 , p. 1981-1982.

- 1942, Additional information on the carapace of Psephophorus (?) oregonensis Packard: Oregon Country Geol. Soc. News Letter, v. 10, p. 99-100.

- 1947 , A pinniped humerus from the Astoria Miocene of Oregon: Oregon State College Studies in Geology, no. 7, p. 25-31,

Packard, E. L., and Kellogg, Remington, 1934, A new cetothere from the Miocene Astoria formation of Newport, Oregon: Carnegie Inst. Washington, Contr. Paleontology, Pub. no. 447, p. 1-62.

Palmer, K. V. W., 1926, The Veneridae of eastern America; Cenozoic and Recent: Paleontographica Americana, v. I, no. 5, p. 209-428, 35 figs., 45 pls. [1927, text; 1929, plates].

Parker, Pierre, 1949, Fossil and Recent species of the pelecypod genera Chione and Securella from the Pacific coast: Jour. Paleontology, v. 23, no. 6, p. 577-593, 7 pls.
Pilsbry, H. A., and Sharp, B., 1898, Fossil Scaphopoda: Manual of Conchology, ser. 1, v. 17, app. A, p. 197-240.

Powell, A. W. B., 1942, The New Zeland Recent and fossil Mollusca of the family Turridae, with general notes on turrid nomenclature and systematics: Auckland Inst. and Mus. Rec., no. 2, 188 p., 14 pls., 6 text figs.

Rathbun, M. J., 1916, Description of a new genus and species of fossil crab from Port Townsend, Washington: Am. Jour. Sci., v. 41, p. 344-346.

1926, The fossil stalk-eyed Crustacea of the Pacific slope of North America: U.S. Natl. Mus. Bull. 138, 155 p., 39 pls.

Rau, W. W., 1948, Foraminifera from the Miocene Astoria formation in southwestern Washington: Jour. Paleontology, v. 22 , no. 6 , p. $774-782$, pl. 119.

- 1951, Tertiary Foraminifera from the Willapa River Valley of southwest Washington: Jour. Paleontology, v. 25 , no. 4 , p. $417-453$, pls. $63-67,3$ text figs.

1958, Stratigraphy and foraminiferal zonation in some of the Tertiary rocks of southwestern Washington: U.S. Geol. Survey, Oil and Gas Inv. Chart OC 57.

Reagan, A. B., 1909, Some notes on the Olympic Peninsula, Washington: Kansas Acad. Sci. Trans., v. 22, p. 131-238, 6 pls. 1910, Die Fossilien der Clallamformation mit denjenigen der Tertiärformationen in Vancouver-Insel und mit denjenigen der Astoria-Miocänformation in Oregon verglichen: Centralblatt Miner., p. 646-651.

Reinhart, P. W., 1943, Mesozoic and Cenozoic Arcidae from the Pacific slope of North America: Geol. Soc. America Spec. Paper 47, 117 p., 15 pls., 3 figs.

Ricketts, E. F., and Calvin, Jack, 1952, Between Pacific tides Stanford, Calif., Stanford Univ. Press, 3d ed., 502 p., 46 pls., 134 figs.

Sacco, Frederico, 1890, I Molluschi Dei Terreni Terziarii Del Piemonte E Della Liguria Parte 7. Harpidae E Cassididae: Reale Accad. Sci. di Torino Mem., ser. 2, v. 40, p. 469-560, pls. $1,2$.

Schenck, H. G., 1926, Cassididae of Western America: California Univ., Dept. Geol. Sci., Bull., v. 16, no. 4, p 69-98, pls 12-15

1928, Stratigraphic relations of western Oregon Oligocene formations: California Univ., Dept. Geol. Sci., Bull., v. 18, p. $1-50$.

1931, Cephalopods of the genus Aturia from Western North America: California Univ., Dept. Geol. Sci. Bull., v. 19 , no. 19 , p. $435-490$, pls. 66-78.

1936, Nuculid bivalves of the genus Acila: Geol. Soc. America, Spec. Paper 4, 149 p., 18 pls., 15 figs.

Schuchert, Charles 1905, Catalogue of the type specimens of fossil invertebrates in the Department of Geology, United States National Museum: U.S. Natl. Mus. Bull. 53, pt. 1, 704 p.

Schumacher, C. F., 1817, Essai d'un nonueau systèms des habitations des vers testacés, 287 p., 22 pls.

Shotwell, J. A., 1950, New locality of Desmostylus hesperus Marsh, from the Astoria Miocene [Oregon], [abs.]: Geol. Soc. America Bull., v. 61, p. 1541.

Shumard, B. F., 1858, Descriptions of new fossils from the Tertiary formations of Oregon and Washington Territories and the Cretaceous of Vancouver's Island, collected by Dr. Jno. Evans, U.S. Geologist, under instructions from the Department of the Interior: Acad. Sci. St. Louis Trans., v. 1, no. 2, p. 120-125. (Reprinted in Dall, 1909, p. 186-188.) 
Slodkewitsch, W. S., 1938, Paleontology of U.S.S.R.: Acad. Sci. U.S.S.R. Press, v. 10, pt. 3, fasc. 19, 275 p., 106 pls.

Smith, E. A., 1885, Report on the Lamellibranchiata collected by H. M. S. Challenger during the years 1873-76: Voyage of H. M. S. Challenger Rept., Zoology, v. 13, pt. 35, p. 1-341, pls. 1-25.

Smith, W. D. P.; 1917, Summary of the salient features of the geology of the Oregon Cascades with correlations between the geology of the east coast of Asia and of the west coast of America: Oregon Univ. Bull. 15, new ser., v. 14, no. 16 , p. 1-54.

Smith, W. D. P., and Packard, E. L., 1919, The salient features of the geology of Oregon: Jour. Geology, v. 27, no. 2, p. 79-121, 3 figs., 1 pl. [Also in Oregon Univ. Bull., v. 16, no. 7 , p. $79-120,3$ figs., 1 pl.]

Snavely, P. D., Jr., Brown, R. D., Jr., Roberts, A. E., and Rau, W. W., 1958, Geology and coal resources of the Centralia-Chahalis district, Washington: U.S. Geol. Survey Bull. 1053, 159 p., 13 pls., 25 figs.

Snavely, P. D., Jr., and Vokes, H. E., 1949, Geology of the coastal area between Cape Kiwanda to Cape Foulweather, Oregon: U.S. Geol. Survey Oil and Gas Inv. Prelim. Map 97.

Stenzel, H. B., Krause, E. K., and Twining, J. T., 1957, Pelecypoda from the type locality of the Stone City beds (Middle Eocene) of Texas: Texas Univ. Bur. Econ. Geol. Pub. no. 5704,237 p., 22 pls., 31 figs., 4 tables.

Stevens, J. A., Jr., 1874, A memorial of George Gibbs: Smithsonian Inst. Ann. Rept. for 1873, p. 219-225.

Stewart, Ralph, 1926, Gabb's California fossile type gastropods: Acad. Nat. Sci. Philadelphia Proc., v. 78, p. 287-447, pls. 20-32, 5 text figs. [1927].

1930, Gabb's California Cretaceous and Tertiary type lamellibranchs: Acad. Nat. Sci. Philadelphia, Spec. Pub., no. 3, 314 p., 17 pls., 5 text figs.

Stewart, R. E., 1956-57, Stratigraphic implications of some Cenozoic Foraminifera from western Oregon: The Ore.Bin., Oregon Dept. of Geology and Mineral Industries: v. 18 , p. $1-6,57-63$, v. 19 , p. 11-15, bibliography, p. 1-4 in supplement.

Stewart, R. E., and Stewart, K. C., 1951, Oligocene shale in Astoria Oregon: The Ore.-Bin., Oregon Dept. of Geology and Mineral Industries, v. 13, p. 74.

__ 1952, Oligocene shale in Astoria, Oregon: Oregon Country Geol. Soc. News Letter, v. 18, p. 4.

Strong, A. M., 1945, Family Cancellariidae: Conch. Club Southern California Minutes, 49, p. 2-15.

Tegland, N. M., 1928, Thyasira disjuncta Gabb not Thyasira bisecta Conrad, the Recent west coast shell: Nautilus, v. 41, p. $129-130$.

_ 1929, Correlations and affinities of certain species of Pitaria: California Univ. Dept. Geol. Sci., Bull., v. 18, no. 10 , p. $275-290$, pls. 21-23.

1931, The gastropod genus Galeodea in the Oligocene of Washington: California Univ., Dept. Geol. Sci. Bull., v. 19 , no. 18 , p. 397-434, pls. 59-65.

- 1933, The fauna of the type Blakeley upper Oligocene of Washington: California Univ., Dept. Geol. Sci., Bull., v. 23 , no. 3, p. 81-174, pls. 2-15, 2 maps.

Thwaites, R. G., 1905, Early western travels, 1748-1846: Cleveland, Ohio, A. H. Clark Co., 32 v.
Townsend, J. K., 1839, Narrative of a journey across the Rocky Mountains to the Columbia River, and a visit to the Sandwich Islands, Chili, etc., with a scientific appendix: Philadelphia, Henry Perkins.

—_ 1905, in Thwaites, R. G., Early western travels, 1748-1846: Cleveland, Ohio, A. H. Clark Co., v. 21, p. 107-369. (Reprint of Townsend, 1839, scientific app. omitted.)

True, F. W., 1909, A further account of the fossil sea lion, Pontolis magmus, from the Miocene of Oregon: U.S. Geol. Survey Prof. Paper 59, p. 143-148.

Trumbull, E. J., 1958, Shumard's type specimens of Tertiary mollusks from Oregon and other types formerly at Washington University, St. Louis: Jour. Paleontology, v. 32, no. 5, p. 893-906, pls. 115-117.

Verrill, A. E., 1897, A study of the family Pectinidae, with a revision of the genera and subgenera: Connecticut Acad. Arts and Sei. Trans., v. 10, p. 41-95.

Vokes, H. E., 1955, Notes on Tertiary and Recent Solemyacidae: Jour. Paleontology, v. 29, no. 3, p. 534-545.

Vokes, H. E., Norbisrath, Hans, and Snavely, P. D., Jr., 1949, Geology of the Newport-Waldport area, Lincoln County, Oregon: U.S. Geol. Survey Oil and Gas Inv. Prelim. Map 88, geol. map and text.

Warren, W. C., Grivetti, R. M., and Norbisrath, Hans, 1945, Geology of northwestern Oregon, west of Willamette River and north of latitude $45^{\circ} 15^{\prime}$ : U.S. Geol. Survey Oil and Gas Inv. Prelim. Map 42, geol. map and text.

Washburne, C. W., 1914, Reconnaissance of the geology and oil prospects of northwestern Oregon: U.S. Geol. Survey Bull. 590, 111 p., 1 pl.

Weaver, C. E., 1912, A preliminary report on the Tertiary paleontology of western Washington: Washington Geol. Survey Bull. 15, p. 1-80, pls. 1-15.

- 1916, Tertiary faunal horizons of western Washington: Washington Univ. [Seattle] Pub. in Geology, v. 1, no. 1, p. 1-67, pls. 1-5.

1937, Tertiary stratigraphy of western Washington and northwestern Oregon: Washington Univ. [Seattle] Pub. in Geol., v. 4, p. 1-266.

- 1942, Paleontology of the marine Tertiary formations of Oregon and Washington: Washington Univ. [Seattle] Pub. in Geology, v. 5, pts. 1, 2, 3, 789 p., 104 pls., [1943].

- 1945a, Stratigraphy and paleontology of the Tertiary formations at Coos Bay, Oregon: Washington Univ. [Seattle] Pub. in Geology, v. 6, p. 31-62, 10 pls.

- 1945b, Geology of Oregon and Washington and its relation to occurrence of oil and gas: Am. Assoc. Petroleum Geologists Bull., v. 29, no. 10, p. 1377-1415.

White, C. A., 1889, On invertebrate fossils from the Pacific coast: U.S. Geol. Survey Bull. 51, 102 p., 14 pls.

Wiedey, L. W., 1928, Notes on the Vaqueros and Temblor formations of the California Miocene with descriptions of new species: San Diego Soc. Nat. History Trans., v. 5, no. 10 , p. 95-182, pls. 9-21.

Wilkes, Charles, 1842, Synopsis of the cruise of the U.S. Exploring Expedition, during the years 1838-42; delivered before the National Institute by its Commander, Charles Wilkes, Esq., on the 20th of June, 1842: Washington, D.C., printed by Peter Force, 50 p., 1 map.

1845, Narrative of the U.S. Exploring Expedition during the years 1838-42: U.S. Explor. Exped., v. 5, chap. 4, p. 115-158. 
Woodring, W. P., 1931, Age of the orbitoid-bearing Eocene limestone and Turritella variata zone of the western Santa Ynez Range, California: San Diego Soc. Nat. History Trans., v. 6, no. 25, p. 371-388.

1938, Lower Pliocene mollusks and echinoids from the Los Angeles Basin, California, and their environment: U.S. Geol. Survey Prof. Paper 190, 67 p., 9 pls., 2 figs.

- 1957-59, Geology and paleontology of Canal Zone and adjoining parts of Panama: U.S. Geol. Survey Prof. Paper 306-A, 146 p., 23 pls., 4 figs., 1957; 306-B, p. 147-239, pls. 24-38, 1959.

Woodring, W. P., Stewart, R. B., and Richards, R. W., 1940, Geology of the Kettleman Hills oil field, California, stratigraphy, paleontology, and structure: U.S. Geol. Survey Prof. Paper 195, 170 p., 61 pls., incl. geol. maps, 15 figs. [1941].
Woodring, W. P., Bramlette, M. N., and Kew, W. S. W., 1946 , Geology and paleontology of Palos Verdes Hills, California: U.S. Geol. Survey Prof. Paper 207, 145 p., 37 pls.

Woodring, W. P., and Bramlette, M. N., 1950, Geology and paleontology of the Santa Maria district, California: U.S. Geol. Survey Prof. Paper 222, 185 p., 23 pls., 9 figs. [1951].

Wortman, J. L., 1906, A new fossil seal from the marine Miocene of the Oregon coast region: Science, new ser., v. 24, p. 89-92.

Wrigley, Arthur, 1934, English Eocene and Oligocene Cassididae, with notes on the nomenclature and morphology of the family: Malac. Soc. London Proc., v. 21, p. 108-130, pls. $15-17$.

Yokoyama, Matajiro, 1923, On some fossil Mollusca from the Neogene of Izuma: Japanese Jour. Geology and Geography. v. 2 , p. 1-9, pls. 1,2 .

1926, Fossil shells from Sado: Tokyo Imp. Univ., Fac, Sci., Jour., v. 1, pt. 8, p. 249-312, pls. 32-37. 


\section{INDEX}

[Italic numbers indicate descriptions]

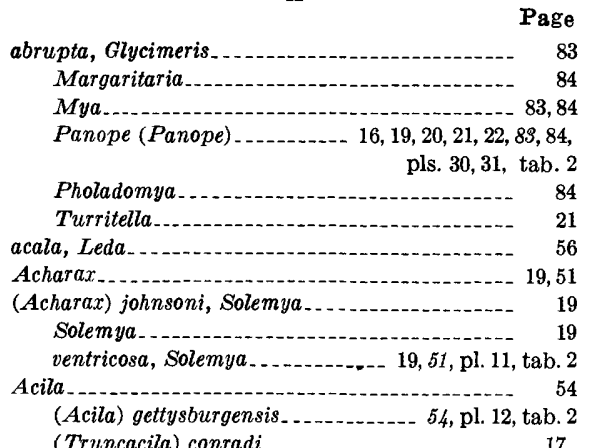

$19,21,22,54,55$, pl. 12, tab. 2

(Acila) gettysburgensis, Acila_..._-_ 54, pl. 12, tab. 2 gettysburgensis, Nucula.

Acknowledgments.

Acteocinidae.

acuminatum, Bruclarkia.

acutilineata, Cyclas acutilineatus, Phacoides........-.-.-.-.-.-. 70

Phacoides (Lucinoma) adelaidana, Bolivina marginata............. 86, 87 adesta, Cryptogemma...................... 46 advena, Bolivina ........... $86,87,88$

Nodogenerin

aequilateralis, Tellina rotundat

Aequipecten

Aforia

clallamensis... . . _........... 47 , pl. 10, tab. 2

africana, Dosinia.................. 73

Agasoma oregonense

stanfordensis_................ 33

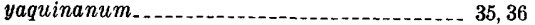

(Trophosycon) kernianum 33

Age and correlation of Astoria formation ........ 20-23 albaria, Macoma Mactra...

(Spisula)

Spisula (Mactromeris) Tellina. (Angulus)

albus, Polinices...

aldrovandi, Panope

Alluvium of Recent age

amathusia, Chione..

A maurellina clarki

amelga, Saccella

americanus, Cibicides.

Ampullinopsis.

(Ampullinopsis) mississippiensis, Ampullina $\ldots .-29$

Amusium.

dalli.

-53, 80

Anadara devincta montereyana.................... 60 microdonta....................... 60, 61

montereyana.

ogawai.

$\begin{array}{rr}\text { Anadara-Continued } & \begin{array}{r}\text { Page } \\ \text { osmonti. }\end{array} \\ \text { procumbens } & 61 \\ \text { (Anadara) devincta } & 60 \\ 21,23,29,59,60,61,78, \text { pls. } 13,14,33, \text { tab. } 2\end{array}$

$21,23,29,59,60,61,78$, pls. $13,14,33$, tab. 2 devincta montesanoana.............. 61 topangensis......... 60

trilineata....... 61

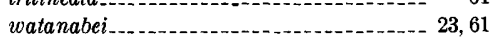

(Anadara), Anadara devincta montesanoana....- 61

devincta, Anadara $21,23,29,59,60,61,78$, pls. $13,14,33$, tab. 2

ogawai, Arca................. 59

topangensis, Anadara....................- 60

trilineata, Anadara

watanabei, Anadara..... 61

Anadarinae -...-59-61

andersoni, Bruclarkia

clemonensis, Aequipecten_..._. 22,67, pl. 17, tab. 2 Pecten (Plagioctenium)

anglonana Molopophorus_._- 21, 22, s7, 38, pl. 3, tab. 2 anglonana matthewi, Molopophorus_.._._._. 22, $38, \mathrm{pl} .3$ Angulogerina astoriensis.

(Angulus) albaria, Tellina ... 80 angustata, Aturia _.......... 1, 6, 22, 85, 86, pl. 31, tab. 2 angustatus, Nautilus.

Nautilites

angustifrons, Dione...

Katherinella (Katherinella) $17,20,21,22,76,7 \%, 78$, pls $24-26$, tab

6,77 $\begin{array}{rr}\text { (Mercimonia) } & 77 \\ \text { Venus_... } & \end{array}$

Chione)

9,77
77

Annotated list of reports dealing with Astoria Formation and its fossils........ $5-10$ annulata, Lucinoma ................ . . . 19, 20, 70 anomala, Nodosaria Anomalina.

sp.

Anomalocardia devincta

Antillophos

dumbleana chehalisensis dumbleana.................... 37

moorei costaricensis

sp ...... 37, pl. 5 tab. 2 (Antillophos), Tritaria dumblei chehalisensis _... $\quad 37$ antiquanta, Arca

antiquatas, Taras.................... 71

antiselli, Clathodrillia (Monilopsis) _.... _ . .

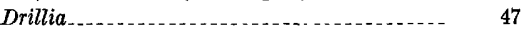

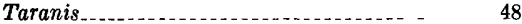

Thesbia.............. 21, 22, 47, 48, pl.10, tab. 2

apta, Echinophoria

Galeodea

Liracassis _........................ 4

araucana, Valvulineria._._. 86,87

Arca

antiquata............. 59

auriculata

aurita.

deshayesii................................ 60

devincta........... 8,59

$$
\text { montereyana.. }
$$

fragilis....

glycymeris .
Arca-Continued Page

microdonta................................... 60

montereyana............................ 8

notabilis................. 60

nuculeus .................................-.- 52

procumbens......... 9,59

(Anadara) ogawai_..................... 59

(Arca) ogawai

trilineata wantanabei.................. 59

(Scapharca) devincta...... 59

microdonta

(Arca), Arca trilineata wantanabei.......... 59 ogawai, Arca

Arcidae........... 59-61

Arctopratulum ......................... 72

arctata, Macoma _.- 16,18,21, 22, 80, 81, pls. 28, 29, tab. 2 Macoma (Psammacoma) Tellina

juana, Tellina......................... 81

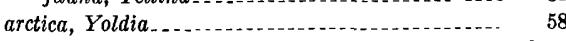

(Arctopratulum) griphus, Nemocardium ....- 72, tab. 2

Argobuccinum......... 32 dilleri.

argus, Murex

argurostoma, Chlorostoma $---2--$

argyrostomus, Trochus.

arnoldi, Callocallista.

etheringtoni, Pitaria (Katherinella)

Nassa

Nassarius .......... 39

(Hima)

(Uzita) $\ldots$

Uzita $\ldots \ldots \ldots$ 21, 22, 25, 39, pl. 5, tab. 2

astori, Mucoma

Astoria fauna

astoriana, Frieleia

Litorhadia ............... 16, 56, pl. 12, tab. 2

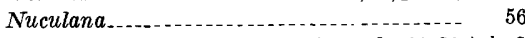

Paramussium_......... 16,68, 69, pls. 21, 22, tab. 2

Yoldia (Portlandia) ..................... 56

astoriensis, Angulogerina

Planulina........ 86, 87

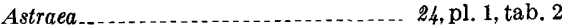

Astreopora occidentalis .

aturi, Nautilus

Aturia

angustata............. 1, $6,22,85,86$, pl. 31, tab. 2

ziczac

Aturinae . . . . . . .

auriculata, Arca

aurita, Arca

australis, Scalaria.... 25

Austrotrophon ............................... 33, 34

B

balboae, Cancellaria

barkeriana, Bruclarkia ... _................ 36

Barker's Ranch Temblor fauna .............. 15, 20

Barnacle . .

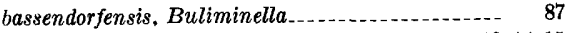

Bastendorff shale.......................... 13,14,15

Bathysiphon sp....... 87

Bathytoma condonana........................ 48

Beaver Creek .......... 12

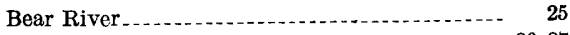

belridgensis, Nonion 


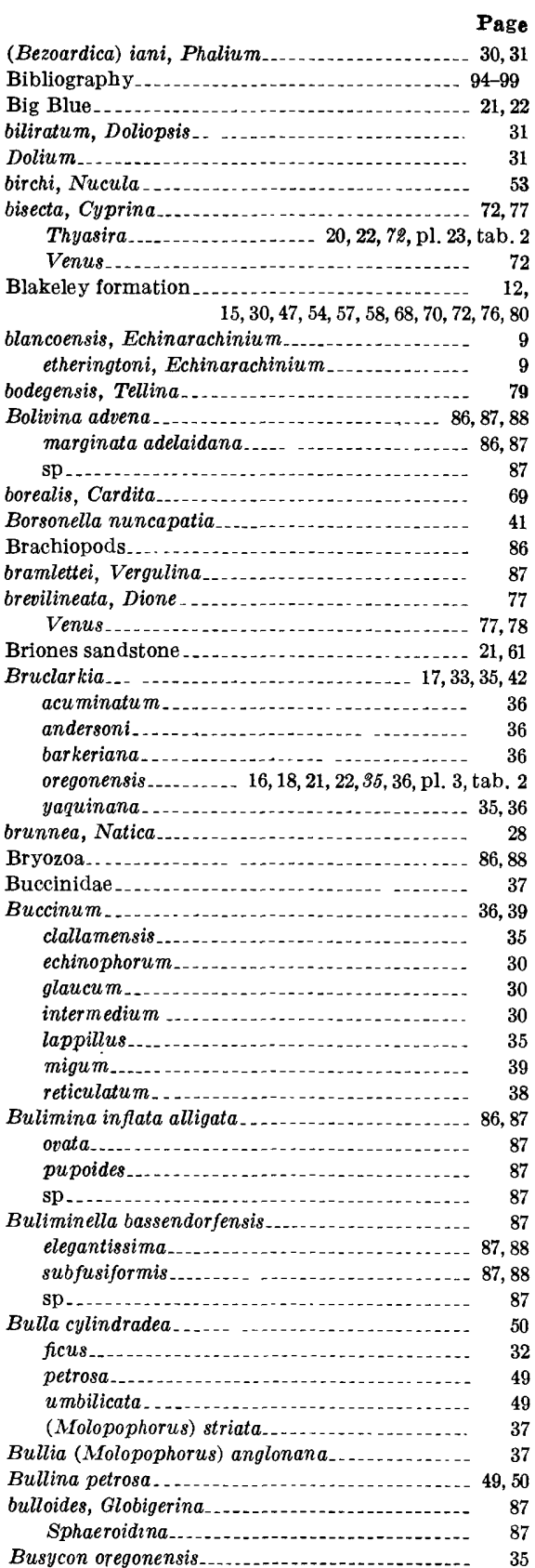

\section{$\mathrm{C}$}

(Calcarata) wynoochensis, Cancellaria calcarea, Tellina.

Calicantharus

Caliente quadrangle.

californiana, Schizopyga

californica, Plectofrondicularia

californicum, Sinum

californicus, Merychippus._._........
calkinsi, Saccella

Calliostoma conulus

delezinensis.

pacificum.

Callocallista arnoldi.

17,47, pl. 10, tab.

Calyptraeidae ......................... 26-27 $\begin{array}{r}\text { cammani, Searlesia } \\ \text { Turris_...... } 39 \text {, } 5 \\ \hline\end{array}$

canalis, Polinices_................ 28, pl. 2, tab. 2
Page

Cancellaria._._._._._._._. 17, 44, 45, pl. 9, tab. 2 balboae

candei

cassidiformis

condoni.

crawfordiana

dalli

dalliana

harrisi.

hettneri.

larkinii

oregonensis

pacifica.

rotunda

siletzensis

simplex.

triangularis

tritonidea.

venezuelana

ventricosa.

wynoochensis...

(Calcarata) wynoochensis.

(Euclia) oregonensis....... 21, 22, 45, pl. 9, tab. 2

Cancellariidae._.

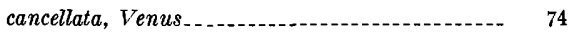
cancellosus, Platinopecten oregonensis_._-- 16, 17, 65,

candei, Cancellaria..

66 , pls. 7,8 , tab. 2

Cantharus.

Cape Blanco.

Cape Flattery

Cape Foulweather quadrangle............ 34, 91

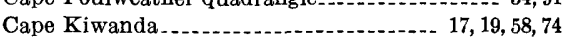

Cardiidae.... $72-73$

Cardita borealis............................... 69

subtenta.

Carditidae

Cardium

nuttallii..........

semiasperum

subtentum.

Spirotropis.

carlsoni, Fusinus (Priscofusus)

Searlesia_____._._._22, $36,37,88$, pls. 5,6 , tab. 2

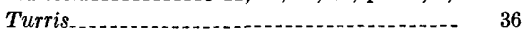

carpenteriana, Pleurotoma (Surcula) ............ 48

Caryophyllis oregonensis.................-... 89

Cassididae............ 30-31

cassidiformis, Cancellaria.

Cassidulina margareta...................... 87

modeloensis....... 87, 88

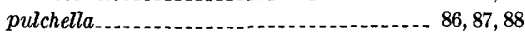

subglogosa.

Cassis japonica

castor, V'enericardia

castrensis, Nucula...

Cathlamet Bay quardrangle

Catinus scopulosus......... 29

caurinus, Patinopecten Pecten.

ceciliae, Pecten (Propeamussium)

Celliopora

Cenozoic Fossil Catalog.

Cephalopod ..................... 85-86, tab. 2

Cerithiopsis oregonensis....................... 25

Cerithium mediale

cerrosensis, Trophon

(Chalmys) fucanus, Pecten

Chama dosin.

Chehalis formation.

Chehalis Valley area . .

chehalisensis, Antillophos dumbleana. 22, 37, 39, tab. 2

Chione.

Malletia

Nassa.

Tritaria (Antillophos) dumblei_..........- 37

I'enericardia.

Yoldia.
Page

chinensis, Fulgoraria Chione.

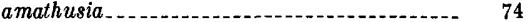

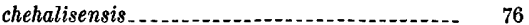

dysera

securis_._._. 75

whitneyi -..-.-13

(Chione) ensifera........ 75

(Securella)

ensifera

(Chione) angustifrons, Venus.............. 77

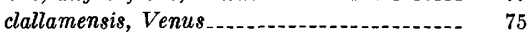

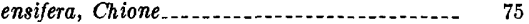

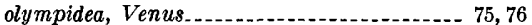

securis ensifera, Venus..................... 75

Chioninae_.......... 74-76

Chionopsis........... 20,74

Chipola formation................. 21

Chlorostoma. - 23

argyrostoma

pacificum_........ 22,23, pl. 1, tab. 2

Cibicides americanus.......................... 87 floridanus.................. 86, 87 sp

Clallam formation...... 15

clallamensis, Aforia .......... 47 , pl. 10, tab. 2 Buccinum .................................. 35

Pisiana_._._._. 35, 36

Propeamussium

Tellina.

Turris

Venus (Chione)

clarki, Amaurellina

38

Clathodrillia (Monilopsis) antiselli_............ 48

clausa, Cryptonatica ......................... 27

Natica

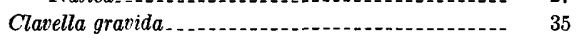

clemonensis, Aequipecten andersoni $. .22,67$, pl. 17, tab. 2 Pecten (Plagioctenium) andersoni-_..... 67

Clinocardium_................................. 72 nuttalii.

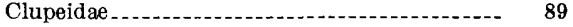

Coaledo formation

Coastal outcrop area of Astoria formation..... $\quad 12$

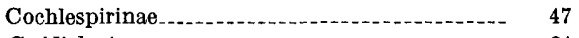

Cochliolepis............. 24 parasiticus..................... 24 schoonerensis _ _ coli, Priscofusus.............. 40,41, 42, pl. 5, tab. 2 Turris.

Columbia River

Columbia River basalt.

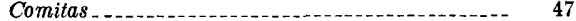
spencerensis............ 47 , pl. 10, tab. 2 communis, Dentalina ........... 87 commutata, Leda.......................... 56

Compsomyax - . (Compsomyax) suhdiaphana, Katherinella...- 20, 76, 77

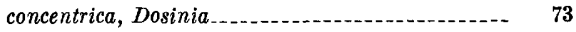

Venus_........ 73

Conchocele

concinna, Voluta.... 42

Condon collection.

condonana, Bathytoma..................... 48

Megasurcula

Pseudotoma............................... 48

condonanus, Surculites (Megasurculites) -...-.-- 48

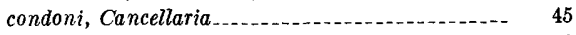
Mytilus.

Thracia

conglomerata, Globigerina..................... 87

Conorbinae conradi, Acila (Truncacila)

$19,21,22,54,55$, pl. 12 , tab. 2 Glycymeris_-_- 50,51

Solen (Plectosolen curtus) 
Page

Conrad's types.

conulus, Calliostoma

cooperi, Yoldia Coos Bay_............... 5, 13, 16, 17, 18, 19, 30, $37,43,58,62,63,65,66,70,71,74,79,82,83$

Coos Bay area Coos Bay dredgings .... 13-15, 16, 17, 18, 35, 48, 73, 81, 82 Coos Bay quadrangle....................... 2,94 coosensis, Patinopecten

Turris.

Cophocetus oregonensis

Cora corbuloides, Thracia. corpulentus, Fusinus (Priscofusus)

Fusus

$41,42, \mathrm{pl}, 7$

Priscofusus.

costaricensis, Antillophos moorei.

costata, Lagena

costifer, Trophor

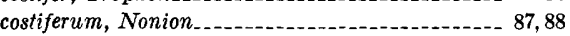

crawfordiana, Cancellaria.

Crawfordina

Crawfordina.

crawfordiana.

17,46, pl. 9 , tab. 2

Crenella...

porterensis

Crepidula

praerupta.............. 21, 22, 26, 27, pl. 1, tab. 2

princeps

rostralis

(Crepidula) rostralis.

(Crepidula) rostralis, Crepidula

Crypta praerupta rostralis...

Cryptogemma adesta

polycaste

clausa
$\quad$ c...

operculum _._. 27, pl. 2

oregonensis................ 16, 22, $27,28, \mathrm{pl} .2$, tab. 2

cuneiformis, Nucula.... 53

curtus, Ensis.

Plectosolen

Solen

(Plectosolen)

Cyclammina inciso

Cyclas acutilineata

Cyclocardia.

(Cyclocardia) subtenta, Venericardia........... 69

Cylichna.... 50 oregona...._-_. 49

petrosa

sp.

Cylichnella petrosa.......... 50

Cylichnina

petrosa

strigella.-- 49

cylindradea, Bulla.......................... 50

Cymatiidae.

Cyprina bisecta - ...-_. 72,77

Cytherea oregonensis_................ 2, 77, 78, 82, pl. 25

$\mathrm{D}$

dalli, Amusium

Cancellaria

dama, Oliva...- 46

Dana collection.............._- $3,52,53,75,89$

davisi, Tellina_-_._-_._- 79

Decapod . - . 86,89

decussatus, Mytilus..._. 63

Delectopecten.

$17,19,67$

peckhami.

16 ,
Delectopecten-Continued randolphi

$$
\text { tillamookensis. }
$$

(Delectopecten), pedroanus peckhami, Palliolum peckhami, Palliolum.

delezinensis, Calliostoma......................

Dentaliidae.......... $50-51$

Dentalina communis.

pauperata

quadrulsta $\quad 86,87$

soluta

Dentxlium

conradi....._._._. 50,51

elephantinum - 50

petricola.

rectius.

51

(Dentalium) pseudonyma...- 21, 50,51, pl. 31, tab. 2

(Rhadbus) petricola. schencki_............ 22, 50, 51, pl. 31, tab. 2

(Dentalium) pseudonyma, Dentalium.......... 21,

Depoe Bay $50,51, \mathrm{pl} .31, \mathrm{tab} .2$

depoensis, Ocenebra .............. 34, pl. 4, tab. 2

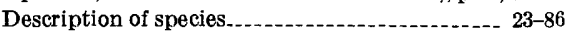

deshayesii, Arca

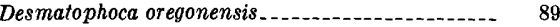

Desmostylus.

hesperus.

devincta, Anadara (Anadara)

$21,23,29,59,60,61,78$, pls. $13,14,33$, tab. 2

Anomalocardia

Arca

montereyana, Anadara.

Arca

montesanoana, Anadara (Anadara)

Scapharca.

devinctus, Priscofusus.

diadema, Stephanocyathus

dilleri, Argobuccinum

Gyrineum.

Ranella.

Dione angustifrons.

brevilineata

oregonensis

Diplodonta

shilohensis.

(Felaniella) parilis

Diplodontidae.

directus, Modiolus

disjuncta, Thyasira

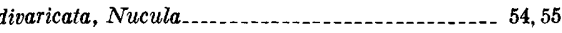

(Doliocassis) onishpetensis, Phalium

Doliopsis biliratum

petrosus. -

Dolium biliratam

petrosum....

Domengine Creek.

Donax protexta.

dosin, Chama

Dosinia.

africana.-

concentrica

dunkeri...

mathewsonii.

merriami....

(Dosinia) merriami whitneyi......................... 16

$17,18,19,20,21,22,73,74$, pl. 24, tab. 2

(Dosinidea) mathewsoni......-..- 18

(Dosinidia)

$$
\text { mathewsoni. }
$$

(Dosinia) merriami, Dosinia

whitneyi, Dosinia.-

$17,21,22,73$, pl. 24, tab. 2

Dosinidea.

(Dosinidea) mathewsoni, Dosinia

19

Dosinidia), Dosinia.

Thewsoni, Dosinia......-- 73

whitneyi, Dosinia

Drillia antiselli.....- 47

fusilformis........-...- 47

dumbleana, Antillophos dumbleana.......... - 37 chehalisensis, Antillophos_._-_._-_ 22, s7, 39, tab. 2

dumbleana, Antillophos................ 37

dumblei chehalisensis, Tritaria (Antillophos)_.... $\quad 37$

dunkeri, Dosinia.

dussumieri, Ficus............. 33

dysera, Chione.............................. 74

E

Echinarachinium blancoensis.

blancoensis etheringtoni

Echinoderms............. 89

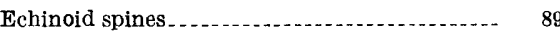

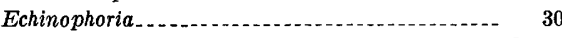

apta

echinophorum, Buccinum ................ 30

edentula, Gari $\ldots$..... 17, 82, pl. 31, tab. 2

edulis, Mytilus.................... 62

Eel River

elegantissima, Buliminella

elephantinum, Dentalium ................. 50

Elphidium

emacerata, Tellina .......... 16, 22, 78, 80, pl, 29, tab. 2

Empire formation ... 2, 212, 13, $14,27,30,35,43,48,59,62$,

$63,65,66,70,71,74,76,81$

englishi, Tellina.

79

Ennucula

(Ennucula) nuculana, Nucula....

$25,52,53,54$, pls. 11,12 , tab. 2

ensifera Chione (Chione) (Securella) _ 16, 18, 22, 74, 75, 76, pls. 26,27 , tab. 2

Securella................. 75

Venus_....... 75

(Chione) securis_... 75

Ensis curtus ........... 82

Entosolenia orbignyana...... 25, 53,55, pls. 12,13 , tab. 2

epacris, Nuculana

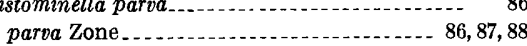

Epitoniidae _.

Epitonium

Eponides healdi....... 86,87

mansfieldi oregonensis _..................... 87, 88

umbonatus.

erinacea, Murex

estrellana, Glycimeris.......... 83,84

Panopea.......... 84

Etchegoin formation..................... 30,74, 83

etchuensis, Shichiheia

etheringtoni, Echinarachinium blancoensis...-.-..

$\begin{array}{lr}\text { Megasurcula } & 9 \\ \text { Pitaria (Katherinella) arnoldi._._............... } & 78\end{array}$

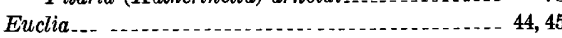

(Euclia) oregonensis, Cancellaria _ 21, 22, 45, pl. 9, tab. 2

Eudolium oregonense...................... 30

petrosum

Eugene formation........... 85

European Aquitanian stage.................... 20

(Euspira) gallanoi, Polinices

Fasciolariidae. . . .

Faunal composition of Astoria formation...... 16-17

fax, Galeodea

(Felaniella) parilis, Diplodonta_...............- 71

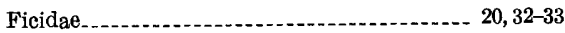

Ficopsis modesta

modestus

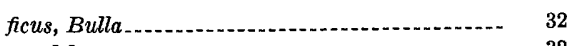

Murex 


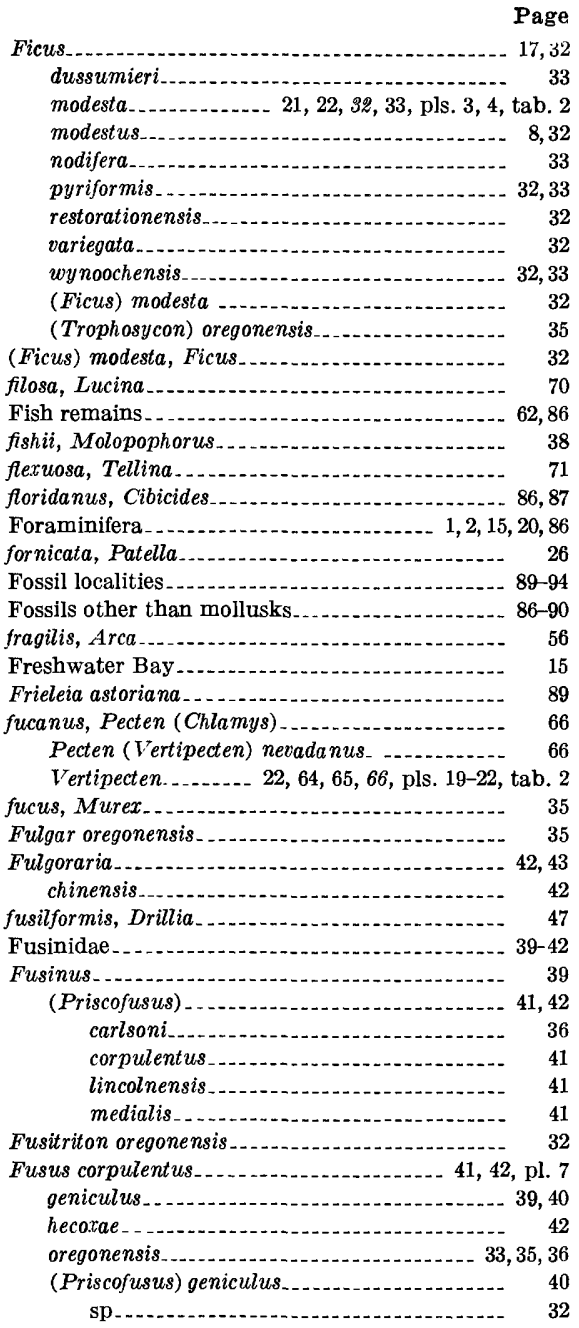

gabbiana, Megasurcula. 48,49 Galeodea

$$
\begin{aligned}
& \text { apta }- \\
& \text { fax. } \\
& \text { rex. }
\end{aligned}
$$$$
\text { (Sconsia) japonica }
$$

Galeodia petrosa.

Galerites oregonensis

gallanoi, Polinices (Euspira)

Gari. edentula vulgaris

gari, Tellina

Gastropods....................... 16, 21, 22, 23-50, tab. 2 General features and geographic distribution of Astoria formation

generosa, Panopaea Panope

$$
\text { (Panope) }
$$

Panopea

geniculus, Fusus............. 39,40

Fusus (Priscofusus)

Priscofusus_._._._._._. 40, 41, 42, pl. 6, tab. 2

Geoducks.

gettysburgensis, Acila (Acila) $\ldots \ldots \ldots$....... 54, pl. 12, tab. 2 Nucula.... $($ Acila $)$

geversianum, Murex.

gibbosus, Saxidomus.

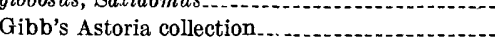

gibbsana, Mactra. gigantea, Ranella

glacialis, Yoldia

Glauconite.

glaucum, Buccinum

Globigerina bulloides

conglomerata

sp.

Globobulimina hannai.

pacifica.

Globularine naticid

Glossaulax.

(Glossaulax) jamesae, Neverita $22,28, \mathrm{pl} 2$, tab.

Glycimeris abrupta.......................... 83 estrellana

Glycymerididae _. .

Glycymeridinae............... 58-59

Glycymeris sp...... 58 ,

conradi.

59, pl. 11,13

grewingki.

orbicularis.

sp.

58

glycymeris, Arca

Gnidiella

gravida, Clavella

pls. 11,13, tab. 2

Grays Harbor area.

Grays Harbor County

Greensand_......

grewingki, Glycymeris........................ 58

griphus, Nemocardium (Arctopratulum) _... 72, tab. 2

Gyrineum dilleri.............. 31, 32, pl. 2, tab. 2 mediocre

sp.

gyrinus, Murex

Gyroidina...

soldanii.

sp.

32,42

haliotoidea, Helix

Haminea petrosa

Haminoea.

$$
\text { petrosa. }
$$

hannai, Globobulimina

Haplophragmoides trullisata..

sp.

harrisi, Cancellaria

healdi, Eponides.

hecoxae, Fusus

Helix haliotoidea.

Hemifusus washingtonensis

Hemithyris

hesperus, Desmostylus,

hettneri, Cancellaria

Hiatellidae.

(Hima) arnoldi, Nassarius.

Hinia

lincolnensis. reticulatum.

16, 22, 38,39, pl. 5 , tab. 2

Historical backgroun

Homalopoma pacifica

hyperborea, Yoldia

I

iani, Phalium (Bezoardica).

idae, Tellina $a$ perialia, Trochus................ 16, 20, 79, pl. 29 , tab. 2 impolita, Uvigerinella obesa......... impressa, Nuculu........................ 56 Nuculana

Yoldia....

(Portlandia)

incisa, Cyclammina 87
Page

indurata, Miopleiona

Psephaea 43,44

(Miopleiona) _............22, 43, pls. 7, 8, tab. 2

Rostellaria

Volutilithes................................... 43

inezana, Natica

Polinices (Neverita) ........ 28,29

inflata alligata, Bulimina

inflatus, Modiolus...... 63

insignis, Pleurotoma.

insurana, Tellina_... 79

intermedium, Buccinum..................... 30

Introduction........ 1-10

jamesae, Neverita (Glossaulax) $22,28,29$, pl. 2, tab. 2

Japan . .

japonica, Cassis.................................. 30

Galeodea (Sconsia)

John Day River........ 10,12

Johnson Creek area

johnsoni, Solemya

Solemya (Acharax)

josephinia, Neverita.

juana, Tellina arctata.......... 81

Jump Off Joe............. 33, pl, 33

\section{$\mathbf{K}$}

Kalayoldia (Kalayoldia) cooperi, Yoldia............. 58, tab. 2

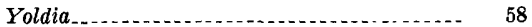

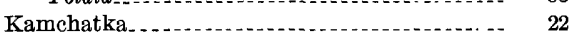
Karreriella washingtonensis_..... 86,87

Katherinella................. 17,76 (Compsomyax) subdiaphana............ 20, 76, 77 Pitaria arnoldi etheringtoni.............. 78

Keasey formation

kennicottii, Mercenaria Venus_... 74,75 Kern River $\ldots \ldots \ldots$ kernensis, Trophon _........... 21, 39, 34, pl, 4, tab. 2 kernianum, Agasoma (Trophosycon) _........... 33 kincaidi, Spirotropis_._. 47 Turris.................................. 46

$\mathbf{L}$

laevis, Lagena.................................... 87

Lagena costata laevis....... 87 lamellifera, Venus....................... $\quad 75$ lapillus, Nucella........................... 35 lappillus, Buccinum larkinii, Cancellaria................ 45

Leda acala commutata..... 56 rosa........ 57

lena, Thais .... 35

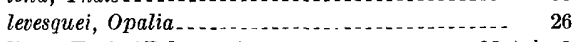
lima, Thais (Polytropa) Limopsidae...................... 61-62 Limopsis . . ......................... 61 nitens oregonensis......... 62

lincolnensis, Fusinus (Priscofusus) Hinia.... 16, 22, 38, 39, pl. 5, tab. 2 Nassa_. Nassarius_........... 38 Turris $\ldots \ldots \ldots$. 41,42 Liracassis.......... 17, 20, 22, 23, 30

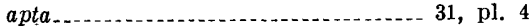
petrosa ............. 5, 22, 31, pls. 2, 4, 10, tab. 2 yabei..... 22 sp 


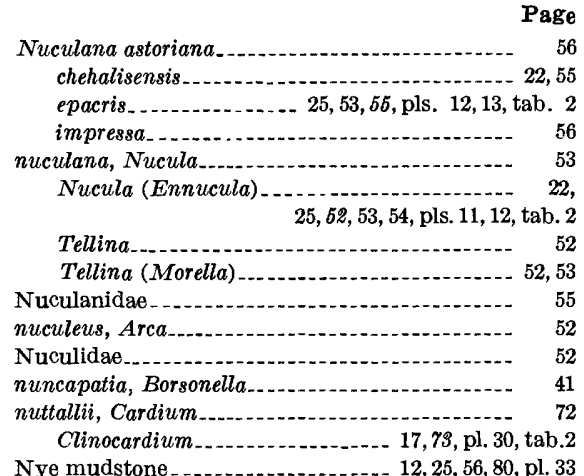

oamarutica, Surcula

obesa, Uvigerinella Uvigerinella obliqua, Nucula

obruta, Tellina

occidentalis, Astreopora.

89

depoensis. . ......... 34, pl. tab. 2

lumaria

ochsneri, Saccella

ocoyana, Turritella

ocoyanum, Trophosycon_.............. 39, pl. 3, tab. 2

ocoyanus, Sycotypus

ogawai,

Arca (Anadara) (Arca)

Oliva dama.

purpurata.

Olivella pedroana

sp

Olivellinae

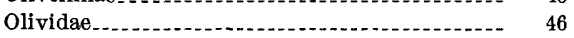

olympidea, Venus (Chione)

onishpetensis, Phalium (Doliocassis)

Opalia

levesquei _............................... 26

williamsoni . 26

(Rugatiscala) ............................ 26 williamsoni

opercularis, Ostrea........................ 67

operculum, Cryptonatica.................. 27, pl. 2

Ophiuroid _......... 89

orbicularis, Glycymeris.................... 58

Robulus $\quad 87$

orbignyana, Entosolenia..._._._............ 87

Orbulina universa.

oregona, Cylichna..

Yoldia

oregonense, Agasoma..... 35, 36 Eudolium

Trophosycon 35

oregonensis, Bruclarkia_-- 16, 18, 21, 22, 35, 36, pl. 3, tab. 2 Busycon Cancellaria.

(Euclia) _.............. 21, 22, 45, pl. 9, tab. 2 cancellosus, Patinopecten..... 16,

Caryophyllis

$17,65,66$, pls. 7,8, tab. 2

Cerithiopsis

Cophocetus.......... 89

Cryptonatica

Cytherea._._._............. 2,77,78,82, pl. 25

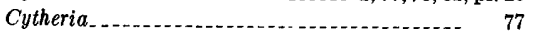

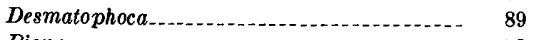

Dione

Eponides mansfieldi

Ficus (Trophosycon)

Fulgar.

Fusitriton

Fusus
oregonensis-Continued

Galerites...

Limopsis_........ 62

Lunatia. . .

Marcia . .

Natica._.

(Tectonatica)

Patinopecten oregonensis........... 63, 65, 66

oregonensis, Patinopecten ................. 63,65,66

Pitar

Pitaria . . 78

Priscofusus_._._._._._._. 39, 40, 41, 42, pl. 5

Psephaea................................. 43, 44

Sycotyphus . .

Tellina.

(Peronida)

16,79

Trichotropis

Trophon...

Trophosycon.

Turritella

33,34

Organic remains of doubtful affinities......... 90

osmonti, Anadara

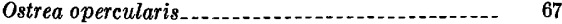

Otter Rock

ovalis, Standella

82

ovata, Bulimina

$\mathbf{P}$

Pachypoma

pacifica, Cancellaria.... 45

Globobulimina...... 86, 87, 88

Homalopoma _........................... 23

Pseudoparrella

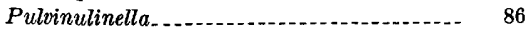

pacificum, Calliostoma....................... 23

Chlorostoma

packardi, Malletia

Paleoecology of Astoria formation

Paleontology of Astoria formation. . . . ....... 16-17

Palliolum (Delectopecten) peckhami............. 67 (Delectopecten) pedroanus peckhami-.....- 67

Panopaea generosa.......................... 83, 84

Panope $\quad 19,83,84$ aldrovandi generosa $\ldots$

(Panope) abrupta....... $19,20,21,22,83,84$, pls. 30,31 , tab. 2 generosa................. 83

(Panope) abrupta, Panope................. 16 generosa, Panope_... 20, 21, 22,83, pls. 30,31, tab. 2 Panopea estrellana.......................... 84 generosa

Paramussium astoriana $\ldots \ldots \ldots$............. 16, 68,69 , pls. 21,22 , tab. 2 dalli....

19,68

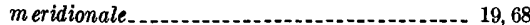

parasiticus, Cochliolepis..................-. 24

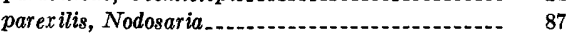

parilis, Diplodonta................ 71, pl. 23, tab. 2 Diplodonta (Felaniella) ........ 71 Loripes_._.

Mysia

Taris 71

Parrella smithi......- 87, 88

parva, Epistominella.......................... 86

Pseudoparrella

Patella fornicata.
Patinopecten

Patinopecten

caurinus_................

oregonensis cancellosus, $16,17,65,66$, pls. 7,8 , tab. 2 oregonensis........... 65,66

propatulus

$20,21,22,63,64,65,66,67$, pls. 16,17 , tab. 2

yessonensis.-...............-. 64

(Patinopecten) propatulus, Pecten.............. 64, 66

patulus, Pectunculus.

pauperata, Dentalina
Pawnee Creek stage...

Page

peckhami, Delectopecten

$19,20,21,67$, pls. $18,20,21$, tab. 2

Palliolum (Delectopecten).

(Delectopecten) pedroanus.

Pecten (Pseudamusium)

Pecten caurinus.

nevadanus.

peckhami.

propatulus

(Chlamys) fucanus

(Patinopecten) propatulus

(Plagioctenium) andersoni clemonensis ....... 64

(Propeamussium) ceciliae

(Pseudamusium) peckhami

vancouverensis

(Vertipecten) nevadanus fucanu

Pectinidae

Pectunculus nitens............................... 61, 62 patulus.

pedroana, Olivella

pedroanus peckhami, Palliolum (Delectopecten) _. 67

Pelecypods.............. 16, 21, 22, 51-85

pellisserpentis, Tegula

perginguis, Nassa................ 38

(Peronida) oregonensis, Tellina.....-..-.........- 78

petricola, Dentalium .

Dentalium (Rhabdus) ................... 50

petrosa, Bulla

Bullina

Cylichna

Cylichnella_................................. 50

Cylichnina_.............. 16,22, 49, pl. 8, tab. 2

Galeodia...- 31

Haminea... .

Haminoea

Semicassis..................................... 31

petrosum, Dolium ........................... 30,

Eudolium

petrosus, Doliopsis._... 31

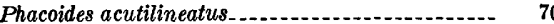

(Lucinoma) acutilineatus.................... 70

Phalium

yabei...

yokoyamai

(Bezoardica) iani.........................................

(Doliocassis) onishpetensis_................ 31

Pholadomya abrupta................ 84

pinnatus, Trophon

Pinnipeds............. 22

Pisiana clallamensis.................... 35, 36

Pitar

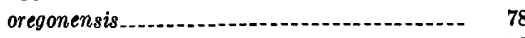

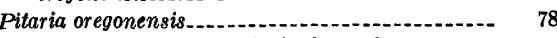

(Katherinella) arnoldi etheringtoni.......-.- 78

Pitarinae...

pizarrense, Nonion.

(Plagioctenium), Pecten andersoni clemonensis... 67

Plant remains........................ 86, 89

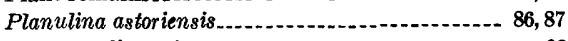

Plectofrondicularia .............. 88

californica. . . . .

miocenica

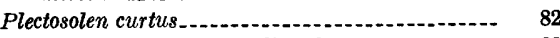

(Plectosolen curtus) conradi, Solen

(Plectosolen) curtus, Solen

Pleistocene terrace deposits........................ 14

Pleurotoma carinata

insignis

(Surcula) carpenteriana....................- 48

Pliocene strata. ...

Polinices-_.....- 28

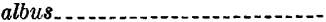

canalis_............................ 28, pl. tab. 2

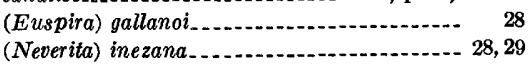

Polinicinae. . .

polycaste, Cryptogemma......... 46 


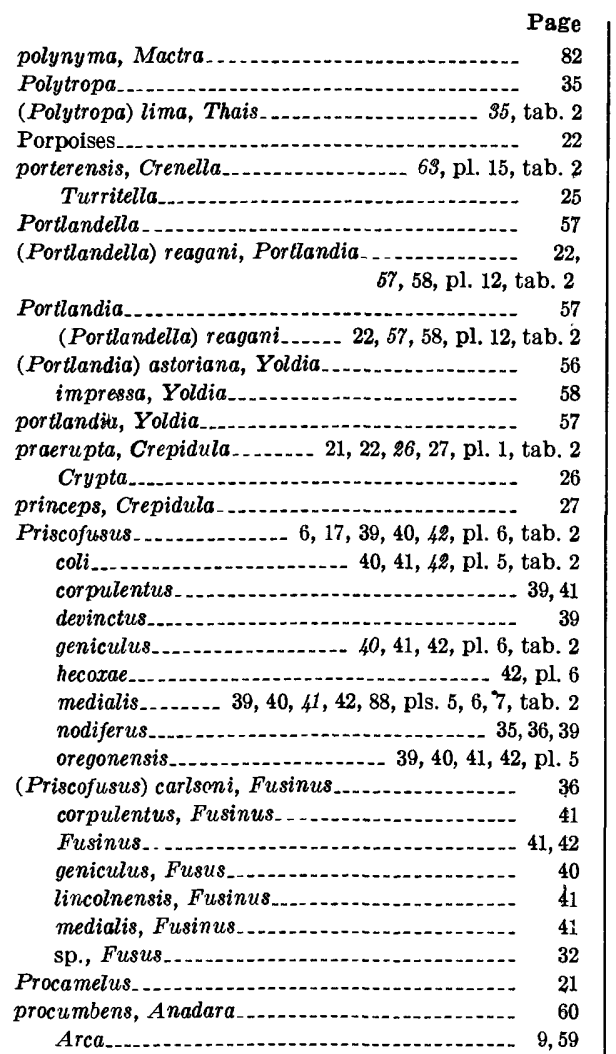

Pyrula modesta.
Pysht River.-.

Page 32

quadrata, Venericardia subtenta................ 69,70 quadrulata, Dentalina.

Quinqueloculina_............................... 87 sp..

$\mathbf{R}$

radians, Trochus

radiata, Tellina.

randol phi, Delectopecten

tillamookensis, Delcetopecten

Ranella

dilleri.

gigantea...... 32

Portlandia (Portlandella) Yoldia

reclusiana, Nererita

recta, Modiolus.

recticulata, Voluta

rectius, Dentalium.

rectus, Modiotus.

restorationensis, Ficus.

reticulatum, Buccinum

Hinia.

rex, Galeodea

Rhabdus

(Rhabdus) petricola, Dentalium schenci, Dentan

$\begin{array}{rr}\text { rhinetes, Nassarius (Schizopyga) } & 38 \\ \text { Robulus } & 87\end{array}$

nikobarensis_............................... 87,88

orbicularis.

sp....

rosa, Leda

Rostellaria indurata

rostralis, Crepidula

Crepidula (Crepidula)

Crypta. .

rotunda, Cancellaria

rotundata, Tellina

aequilateralis, Tellina.....................

Rugatiscala

(Rugatiscala), Opalia

williamsoni, Opalia _..._._._._. 26, pl. 1 , tab. 2

rupestris, Voluta............................ 42

(Psammacoma) arctata, Macoma............ 81

Psephaea......... 17,42

indurata

oregonensis ................................. 43,44

(Miopleiona) indurata..... 22, 43, pls. 7,8 , tab. 2 weaveri.

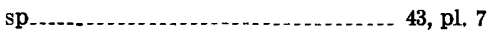

$\begin{array}{cr}\text { (Pseuda musium) peckhami, Pecten. } & 67 \\ \text { vancouverensis, Pecten.................. } & 67\end{array}$

Pseudoglandulina inflata Zone..._._. 86, 88

pseudonyma, Dentalium (Dentalium) _... 21, 50, pl. 31,

tab. 2

Pseudoparrella pacifica._. _._._. .

parva _....... 86, 87,88

Pseudotoma condonana wynoocheensis...

Puget Sound

Puget Sound area.

pulchella, Cassidulina..................... 86, 87,88

Pullenia salisburyi

sp......................... 87

Pulleniatina........

$$
\text { sp. }
$$

Pulvinulinella pacifica

pupoides, Bulimina

Purisima formation

Purisima region.

Purpose and scope

purpurata, Oliva.

pyrivormis, Ficus.
$\mathbf{S}$

Sacella. amelga...... 57, pl. 13, tab. 2 calkinsi_...................... 20, 22, 56, pl. 1s, tab. 2

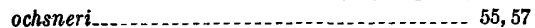

taphria........ 20,57

Saddle Mountain quadrangle.................. 90-91

salisburyi, Pullenia _.

San Ignacio region.

San Pablo formation.

San Pablo group.

San Pablo series of Califormia

San Ramon . . . .

San Ramon formation.

San Ramon sandstone..................... 35, 73

Sanguinolariidae

Santa Cruz quadrangle.................. 36

Santa Ynez Mountains....................... 29

Saracenaria $\ldots . . . . . . . .68,87,88$

sp...

saxea, Natica.

Natica (Natica)

(Tectonatica)

Saxidomus gibbosus

Scalaria australis...................................

Scaphander.

Scapharca devincta
Scaphandridae
(Scapharca) denincta, microdonta, Arca.... 59

Scaphopods............... 19, 21, 22, 50-51, tab. Dentalium (Rhabdus)..... 22, 50, 51, pl. 31, tab. 2 Thracia

Schizopyoa californiana.... 38

(Schizopyga) rhinetes, Nassarius_............... 38

Schooner Creek......... 59,65

schoonerensis, Cochliolepis... 24, 25, 53, 55, pl. 1, tab. 2

(Sconsia) japonica, Galeodea

scopulosum, Sinum.-- 20, 21, 22, 29, 30, pls. 1, 2, tab. 2

scopulosus, Catinus........................

Sigaretus..................... 27, 29, 30, pl. 1

Scotts Mills

Searlesia.-

cammani..... 39, pl. 5 carlsoni.............. 22, 36, 37, 88, pls. 5,6 , tab. 2

Securella............. 74

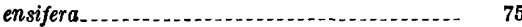

(Securella), Chione........................ 75 ensifera, Chione .... 16, 22, 74, 75, pls. 26,27 , tab. 2

securis, Chione-.............................. 75

Venus........ 74

sediment, bottom

ensifera, Venus (Chione)

Selachian teeth............................... 21

semiasperum, Cardium

Semicassis.......... 30 petrosa

Shichiheia... 30

etchuensis...................................... 30

shilohensis, Diplodonta................. 71

Shoalwater Bay ............................ 62

Sigaretus scopulosus_................. 27, 29, 30, pl. 1

siletzensis, Cancellaria

simplex, Cancellaria......................... 45

Sininae................. 29-30

Sinum californicum . . . . . . 20,30 scopulosum ....... 20, 21, 22, 29,30 , pls. 1,2 , tab. 2

Siphogenerina_............................. 87 transversa........ $86,87,88$ sp

smithi, Parrella

Smiths Point . . .

Sobrante sandstone

soldanii, Gyroidina

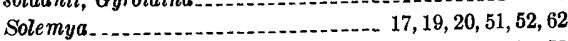
johnsoni. . . . . ventricosa

(Acharax)

johnsoni.

ventricosa _..._......... 19,51, pl. 11, tab. 2

Solemyacidae_._...... $51-52$

Solen conradi_....... 82

curtus

(Plectosoler) curtus.

(Plectosolen curtus) conradi

Solena

Solenidae.

Solenomya mediterrar ea.........................

solida, Mactra

soluta, Dentalina

Sooke formation

Spencer Creek

spencerensis, Comitas . . .

Sphaeroidina bulloides........................ 87

spiralis, Trochita......... 26

Spirotropis

calodius ......... 47, pl. 10, tab. 2

carinata

kincaidi

Spisula 


\begin{tabular}{|c|c|}
\hline & $\mathrm{Pag}$ \\
\hline Spisula) albaria, Mactra & 83 \\
\hline Standella ovalis & 82 \\
\hline tanfordensis, Agosoma. & 33 \\
\hline Starfish fragments......... & 89 \\
\hline tephanocyathus..... & 0,88 \\
\hline diadema...... & 89 \\
\hline stimpsoni, Venus...... & 74 \\
\hline Strait of Juan de Fuca & 15 \\
\hline Stratigraphy of Astoria formation & 10-16 \\
\hline striata, Bulla (Molopophorus) & 37 \\
\hline strigella, Cylichnina................... & 49 \\
\hline strongi, Mangilia (Taranis) & 48 \\
\hline Taranis........... & 48 \\
\hline rongylocentrotus. & 89 \\
\hline suldiaphana, Katherinella (Compsomyax) & \\
\hline subfusiformis, Buliminella & \\
\hline subglobosa, Cassidulina & 87 \\
\hline subgrundifera, Turritella & 21 \\
\hline subnasuta, Tellina & 79 \\
\hline subperegrina, Uvigerinella & 87 \\
\hline substriata, Teredo & 50 \\
\hline substriatum, Dentalium & 50,51 \\
\hline Teredo & 50 \\
\hline subtenta, Cardita & 5,69 \\
\hline Cyclocardia & \\
\hline Venericardia & 9,70 \\
\hline (Cyclocardia) & 69 \\
\hline quadrata, Venericardia & 69,70 \\
\hline subtentum, Cardium & 69 \\
\hline Surcula oamarutica. & 47 \\
\hline (Surcula) carpenteriana, Pleurotoma......... & 48 \\
\hline Surculites uynoocheensis.............. & 49 \\
\hline (Megasurculites) condonanus_.............. & 48 \\
\hline Svenson quadrangle & 90 \\
\hline ycotyphus modestus & 32 \\
\hline oregonensis. & 35 \\
\hline cotypus ocoyanus. & 33 \\
\hline
\end{tabular}

$\mathrm{T}$

taphria, Saccella.

Taranis antiselli. strongi.

(Taranis) strongi, Mangilia

Taras antiquatas.

Taris parilis.

Tectonatica) oregonensis, Natica............... 27 saxea, Natica

tectula, Natica . . .

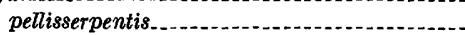

Tejon formation

albaria

arctata

juana...-.-- 81

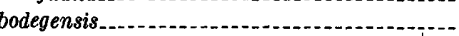

calcarea...

davisi_..--.-.-.-.- 78

emacerata................. 16, $22,78,80$, pl. 29, tab. 2

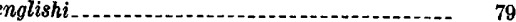

flexuosa

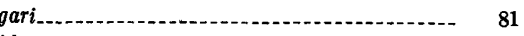

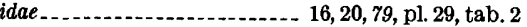

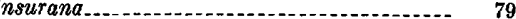

nasuta.

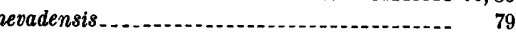

nuculana.

obruta

oregonensis._....... 16,79

radiata.

rotundata

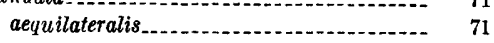

subnasuta.

tenuistriata

togata

(Angulus) albaria...

(Moerella) nuculana.
Tellina-Continued

(Peronida) oregonensis

Tellinidae.

Temblor fauna.

Temblor formation.

$20,21,22,26,27,30,33,34,36,38,39,45,48,51$,

$57,61,65,67,71,74,78,81,82,83$.

tenera, Macoma...

tenuistriata, Tellina.

terebra, Turbo

terebralis, Turritella.

Terebratula nitens.

Terebratulina.

unguicula...

Teredo substriata

substriatum

Tetrabelodon

Thaidiidae.

Thais.

lena.

(Polytropa) lima

Thesbia.

antiselli.

$21,22,47,48$, pl. 10, tab. 2

Thracia.

condoni.

corbuloides

schencki.

trapezoidea.

(Thracia) trapezoides

Thraciidae.

Thyasira.

bisecta...

disjuncta

Thyasiridae.

Tillamook Bay -

Tillamook County.

Tillamook Head quadrangle

Tillamook quadrangle.

tillamookensis, Delectopecten randolphi

Timms Point silt.

togata, Tellina.

Tongue Point

topangensis, Anadara (Anadara)

townsendi, Nucula

Toxopneustes.

86, 87,88

trapezoidea, Thracia.

triangularis, Can cellaria.

triangulatus, Trophon...

Trichotropis oregonensis

trilineata, Anadara (Anadara)

wantanabei, Arca (Arca)

trinominata, Modiolus

Tritaria (antillophos) dumblei chehalisensis

tritonidea, Cancellaria.

Tritonium nanum .

Trochidae

trochiformis, Turbo

Trochita................... 26, pl. 1ab. 2 spiralis....................................... 26

Trochus.argyrostomus

imperialia.

radians.

Trophon cerrosensis . . . . . . . costifer

kernensis

$21,98,34$, pl. 4 , tab. 2

oregonensis ................................ 33, 34

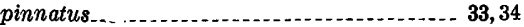

triangulatus.

Trophosycon.

S3, pl. 3, tab. 2

oregonense..... 35

oregonensis

(Trophosycon) oregonensis, Ficus_............ 35

kernianum, Agasoma

trullisata, Haplophragmoides.

Truncacila.

(Truncacila) conradi, Acila
Tunnel Point sandstone...... Page

Turbinidae

Turbininae.............. 24

Turbo terebra.................... 25

trochiformis.

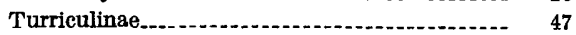

Turridae _ .

Turrinae......... 47

Turris cammani.............................. 39

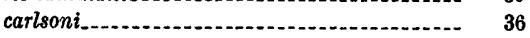

clallamensis_.................................. 47

coli.-.... $\quad 39$

coosensis ........... 39, 42

kincaidi..._._._._. 46

lincolnensis _................................ 41, 42

wynoocheensis_.............................. 49

Turritella

abrupta $\ldots$

ocoyana

zone.

oregonensis_.......... 8, 19, 22, $25, \mathrm{pl} .1$, tab. 2

porterensis.............. 25

subgrundifera............................... 21

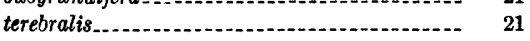

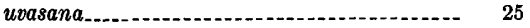

Turritellidae . . .

twinensis, Macoma

Type area of Astoria formation.............. 10-12

U

umbilicata, Bulla

umbonatus, Eponides

undata, Mysia .

unguicula, Terebratulina

Unidentified trochid.

Unidentified turbinid

universa, Orbulina ........ 87

Upogebia.

uvasana, Turritella

Uvigerinella obesa

obesa impolita

zita arnoldi (Uzita) arnoldi, Nassarius........................ 39

$\mathrm{V}$

vagina, Solen

Valvulineria araucana...................... 86, 87

menloensis

vancouverensis, Pecten (Pseudamusium)

Vaqueros formation . .............. 19, 21, 30, 71, 74, 81

Vaqueros-Temblor transition beds............... 21

variegata, Ficus .

Venericardia castor..... 70

chehalisensis _._._. 69

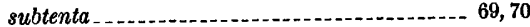

quadrata................. 69, 70

(Cyclocardia) subtenta........................ 69

Veneridae ................................. 20,78

venezualana, Cancellaria

ventricosa, Cancellaria

Solemya

(Acharax) _........... 19, 51, pl. 11, tab. 2

Venus (Acherax). 77 angustifrons

bisecta............ 72

brevilineata

cancellata......... 74

concentrica

ensifera

kennicottii . . . . . . . . 74,75

lamellifera........... 75

lupina.............................. 71

securis_............... 74

stimpsoni.................. 74

(Chione) angustifrons........................ 77

clallamensis............ 75,76
olympidea

olympidea
securis ensifera. 


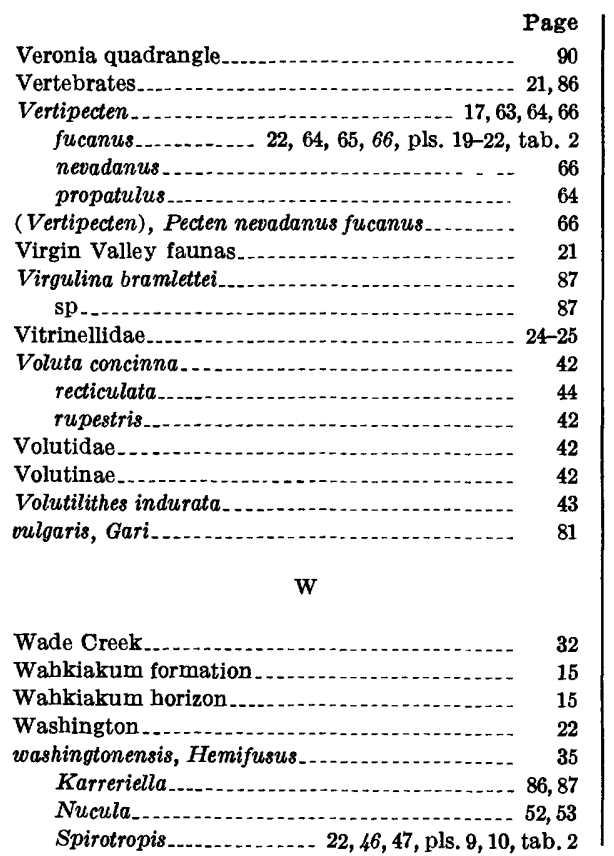

\begin{tabular}{|c|c|}
\hline wash ingtonensis-Continued & age \\
\hline Whitneyella. & 35 \\
\hline Anadara (Anadara) & 61 \\
\hline Arca $($ Arca) trilineata. & 59 \\
\hline water, cool & 20 \\
\hline deep & 7,19 \\
\hline shallow & 7,19 \\
\hline tropical & 20 \\
\hline warm & 20 \\
\hline warm-temperate & 17 \\
\hline weaveri, Psephaea (Miopleiona) & 43 \\
\hline Whale, primitive whalebone & 22 \\
\hline sperm & 22 \\
\hline Whitneyella... & 35 \\
\hline washingtonensis.... & 35 \\
\hline whitneyi, Chione & 73 \\
\hline (Dosinia) & 16 , \\
\hline $17,18,19,20,21,22,73,74, \mathrm{pl} .24$, & b. 2 \\
\hline Wildcat formation. & 74 \\
\hline williamsoni, Opalia & 26 \\
\hline Opalia (Rugatiscala) & b. 2 \\
\hline Wynooche River & 32 \\
\hline Wynoochee River Highway & 46 \\
\hline wynoochensis, Cancellaria & b. 2 \\
\hline Cancellaria (Calcarata) & 44 \\
\hline Ficus_. & 2,33 \\
\hline Megasurcula & \\
\hline 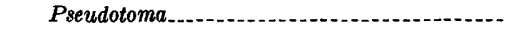 & 49 \\
\hline Surculites........ & 49 \\
\hline Turris_. & 49 \\
\hline
\end{tabular}

$\mathbf{Y}$

Page

yabei, Liracassis.................................... 22

Phalium Yaquina Bay .............. 17, 23, 24, 25, 32, 33, 36, 41, 43

Yaquina Bay bridge...................
Yaquina Head_... 12, 17, 23, 24, 33, 36, 38, 41, 55, 57, 78, 89

Yaquina Head_... 12, 17, 23, 24, 33, 36, 38, 41, 55, 57, 78, 89
Yaquina quadrangle.......................... 25, 91-94

yaquinana, Bruclarkia ....................... 35, 36

yaquinanum, Agasoma

yessoensis, Patinopecten...................... 64

yokoyami, Liracassis

yokoyamai, Phalium .

Yoldia

arctica........-. 58

cooperi_...

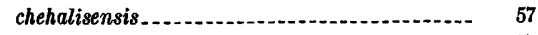

glacialis..................................... 57

hyperborea.

impressa_........ 56,57

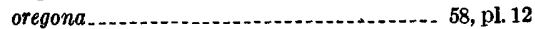

portlandia...

reagani_..... 56,57

(Kalayoldia)

cooperi.

(Portlandia) astoriana......................... 56

impressa_. 58

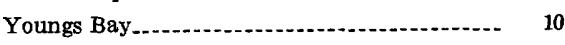

Turris 49 ziczac, Aturia.................................. 1, 6,85,86 
PLATES 1-32 


\section{PLATE 1}

Figure 1, 4. Unidentified naticid, "Sigaretus scopulosus Conrad" (1849, pl. 19, fig. 6d?) (p. 30).

Height $17 \mathrm{~mm}$ (incomplete), width $19 \mathrm{~mm}$ (incomplete). Loc. 1a. USNM 3540.

2, 3. Sinum scopulosum (Conrad) (p. 29).

Holotype. Height $22 \mathrm{~mm}$ (incomplete), width $24 \mathrm{~mm}$ (incomplete). Loc. 1a. USNM 3553.

5. Unidentified trochid (p. 23).

Height $22 \mathrm{~mm}$ (incomplete), width $22 \mathrm{~mm}$ (incomplete). Loc. 156 USNM 563116.

6, 7. Trochita? n. sp. ? (p. 26).

Height $8 \mathrm{~mm}$ (incomplete), width $25 \mathrm{~mm}$ (incomplete). Loc. 48 . USNM 563117.

8. Astraea? n. sp.? (p. 24).

Height $15.5 \mathrm{~mm}$ (incomplete), width $22.2 \mathrm{~mm}$ (incomplete). Loc. 156 . USNM 563118.

9-12. Turritella oregonensis (Conrad) (p. 25).

9, 10. Lecotype. Height $22.2 \mathrm{~mm}$ (incomplete), width $7.4 \mathrm{~mm}$. Loc. 1a. USNM 110446.

11. Height $25 \mathrm{~mm}$ (incomplete), width $9 \mathrm{~mm}$. Loc. 95 . USNM 563119.

12. Height $20 \mathrm{~mm}$ (incomplete), width $7 \mathrm{~mm}$. Loc. 187 . USNM 563120.

13, 14. Unidentified turbinid (p. 24).

Height $30 \mathrm{~mm}$ (incomplete), width $29 \mathrm{~mm}$ (incomplete). Loc. 16. USNM 563121.

15, 16, 22, 24. Crepidula praerupta Conrad (p. 26).

15. Lecotype. Height $25 \mathrm{~mm}$ (incomplete), length $43 \mathrm{~mm}$ (incomplete), width $26 \mathrm{~mm}$ (incomplete). Loc. 1a. USNM 3564.

16. Height $11.4 \mathrm{~mm}$, length $35 \mathrm{~mm}$ (incomplete), width $21 \mathrm{~mm}$ (incomplete). Loc. 92 . USNM 563124.

22. (Conrad, 1849, pl. 19, figs. 10a, b?). Height $10 \mathrm{~mm}$ (incomplete), length $29 \mathrm{~mm}$ (incomplete), width $19 \mathrm{~mm}$ (incomplete). Loc. 1a. USNM 561540.

24. Holotype of "Crypta rostralis Conrad." Height $7 \mathrm{~mm}$ (incomplete), length $21 \mathrm{~mm}$ (incomplete), width $13 \mathrm{~mm}$ (incomplete). Loc. 1a. USNM 110447.

17, 18. Chlorostoma pacificum (Anderson and Martin), (p. 23).

Height $15 \mathrm{~mm}$ (incomplete), width $16 \mathrm{~mm}$ (incomplete). Loc. 155 . USNM 563123.

19-21. Cochliolepis? schoonerensis Moore, n. sp. (p. 24).

Holotype. Height $1.1 \mathrm{~mm}, 2.1 \mathrm{~mm}$ in greater diameter, $1.6 \mathrm{~mm}$ in lesser diameter. Loc. 149. USNM 563122.

23. Opalia (Rugatiscala) cf. O. (R.) williamsoni (Anderson and Martin) (p. 26).

Height $10 \mathrm{~mm}$ (incomplete), width $5.5 \mathrm{~mm}$. Loc. 79 . USNM 563125 . 
GEOLOGICAL SURVEY
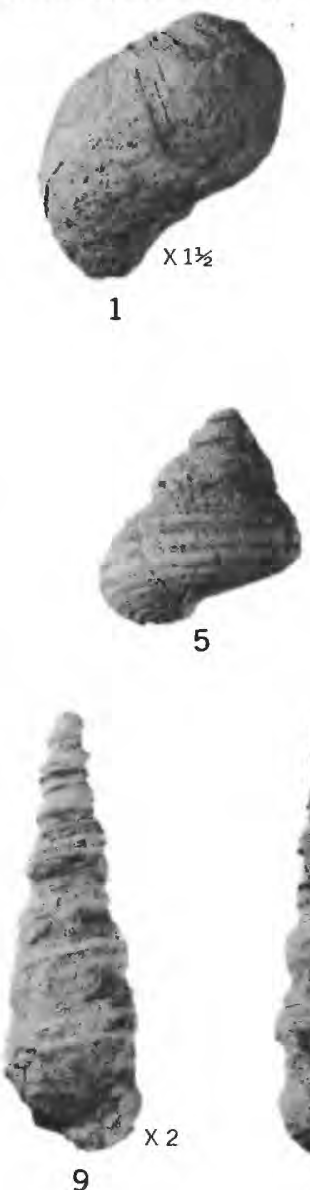

9
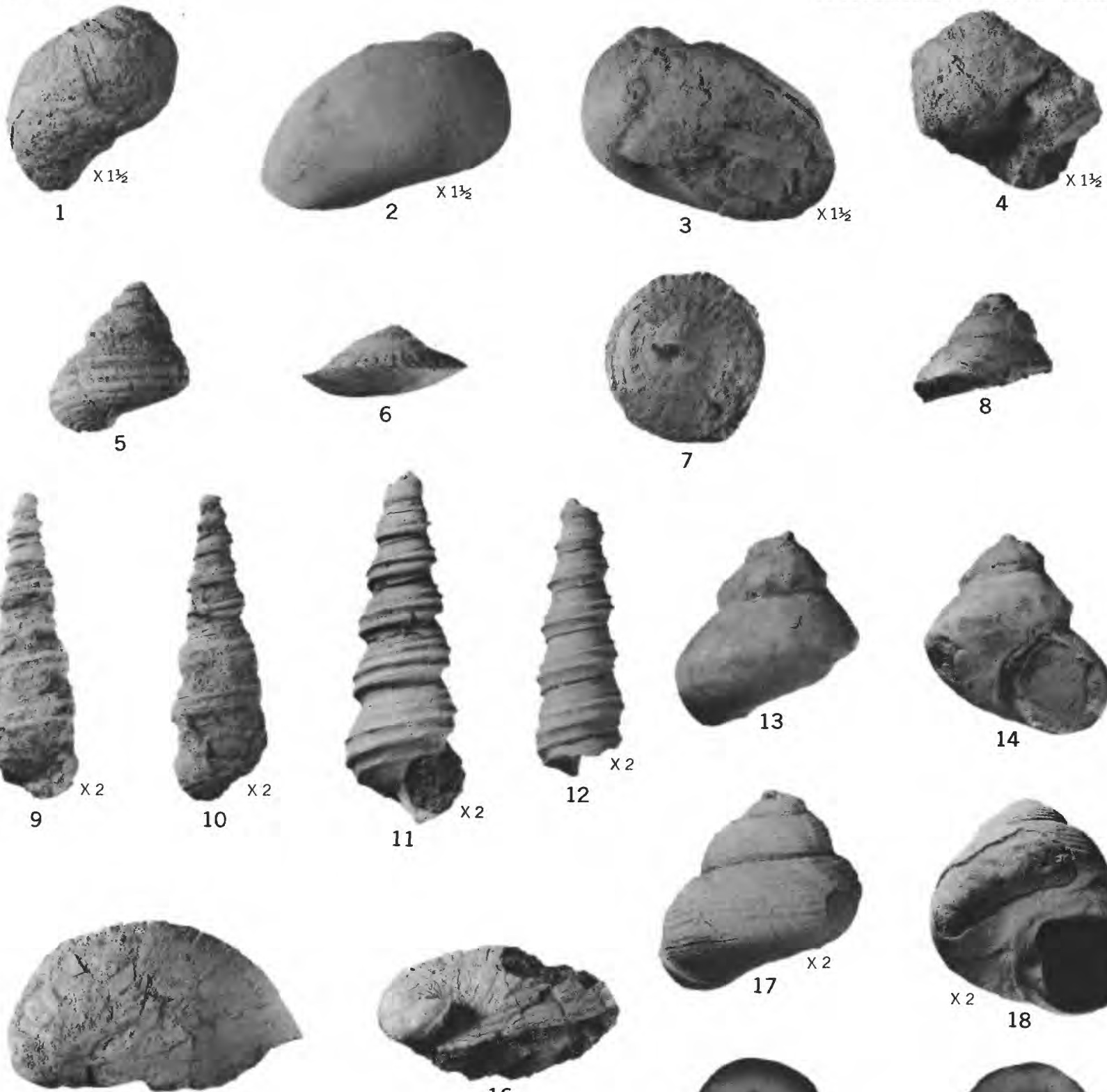

15
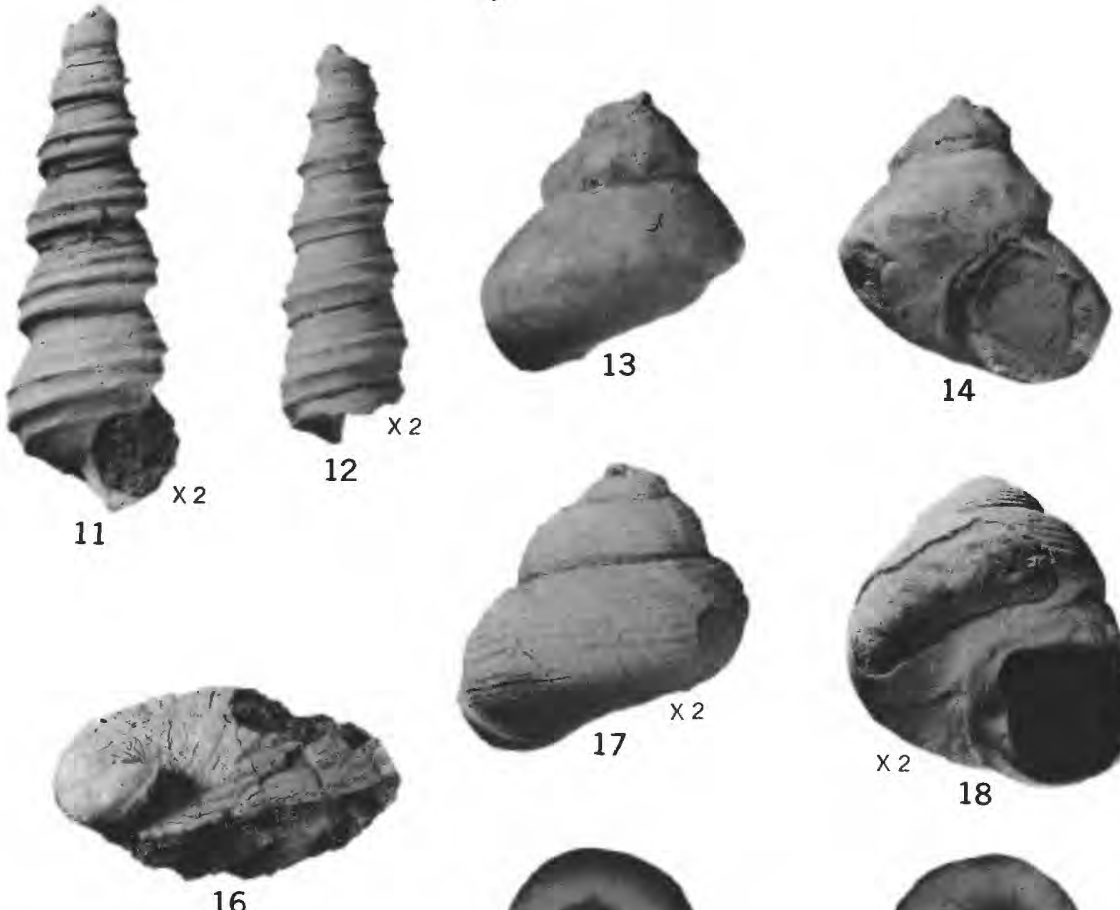

12
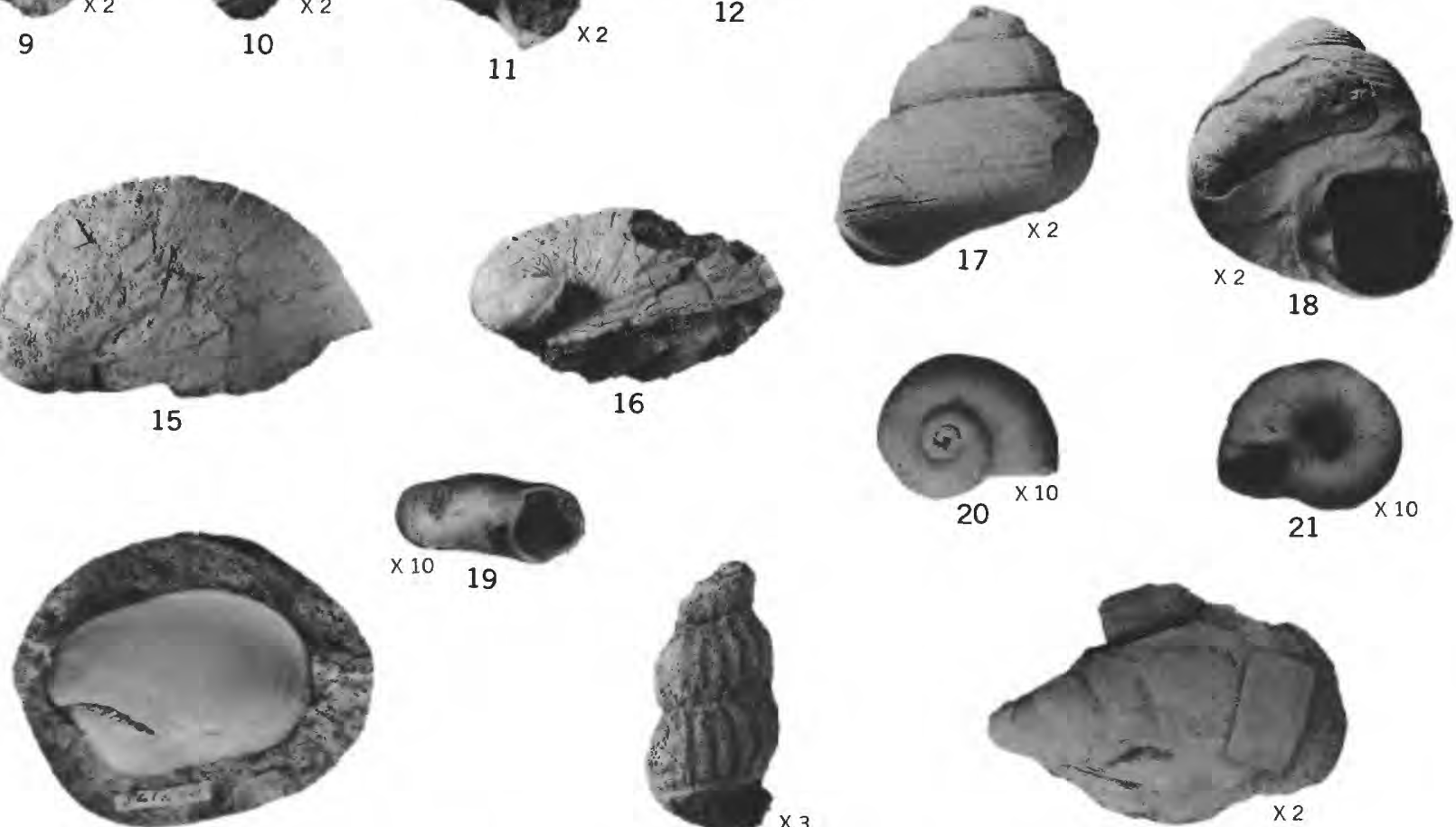

22

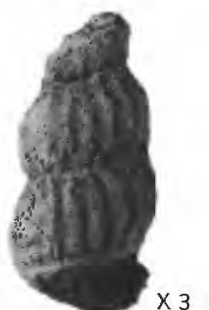

23

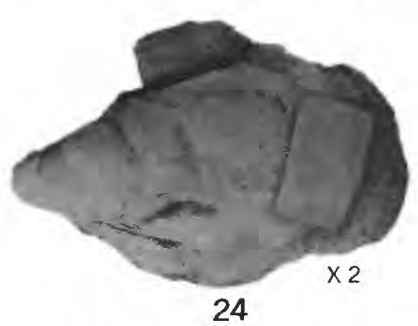

NATICID, SINUM, TROCHID, TROCHITA?, ASTRAEA?, TURRITELLA, TURBINID, CREPIDULA, CHLOROSTOMA, COCHLIOLEPIS?, AND OPALIA 


\section{PLATE 2}

Frgure 1, 6. Cryptonatica? operculum (p. 27).

1. Height $7 \mathrm{~mm}$, width $4.5 \mathrm{~mm}$. Loc. 65. USNM 563132.

6. Height $15.5 \mathrm{~mm}$, width $10.4 \mathrm{~mm}$. Loc. 66 . USNM 563126.

2-4, 16, 17. Cryptonatica oregonensis (Conrad) (p. 27).

2. Height $20 \mathrm{~mm}$ (incomplete), width $20 \mathrm{~mm}$ (incomplete). Loc. 187 . USNM 563127.

3, 4. Holotype. Height $14 \mathrm{~mm}$ (incomplete), width $13 \mathrm{~mm}$ (incomplete). Loc. 1a. USNM 561551.

16, 17. Height $12 \mathrm{~mm}$ (incomplete), width $10.5 \mathrm{~mm}$. Loc. 187 . USNM 563133.

5, 15, 19. Neverita (Glossaulax) jamesae Moore, n. sp. (p. 28).

5. Paratype. Height $19.5 \mathrm{~mm}$, width $21.5 \mathrm{~mm}$ (incomplete). Loc. 94 . USN M 563128.

15, 19. Holotype. Height $22 \mathrm{~mm}$ (incomplete), width $26.4 \mathrm{~mm}$ (incomplete). Loc. 94. USNM 563129.

7, 10-14. Liracassis petrosa (Conrad) (p. 31).

7, 11. Holotype of Doliopsis biliratum. Height $27 \mathrm{~mm}$ (incomplete), width $24 \mathrm{~mm}$ (incomplete). Loc. 1 a. USNM 561550.

10, 14. Height $40 \mathrm{~mm}$ (incomplete), width $34 \mathrm{~mm}$ (incomplete). Loc. 102 . USNM 563131.

12. (Conrad, 1849, pl. 19, figs. 5a, 5b.) Height $18.7 \mathrm{~mm}$ (incomplete), width $18.2 \mathrm{~mm}$ (incomplete). Loc. 1a. USNM 561535.

13. (Figured by Tegland, 1931, pl. 65, figs. 12, 13.) (p. 31). Height $43 \mathrm{~mm}$ (incomplete), width $36 \mathrm{~mm}$. Loc. 1 a.

8, 9. "Gyrineum" dilleri (Anderson and Martin) (p. 31). Height $45 \mathrm{~mm}$ (incomplete), width $28 \mathrm{~mm}$ (incomplete). Loc. 128. USNM 563130.

18, 22. Polinices canalis Moore, n. sp. (p. 28).

Holotype. Height $31 \mathrm{~mm}$ (incomplete), width $32 \mathrm{~mm}$ (incomplete). Loc. 107. USNM 563134.

20, 21. Sinum scopulosum (Conrad) (p. 29).

Height $29 \mathrm{~mm}$ (incomplete), width $33 \mathrm{~mm}$ (incomplete). Loc. 92 . USN M 563135. 
GEOLOGICAL SURVEY

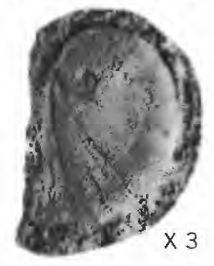

1

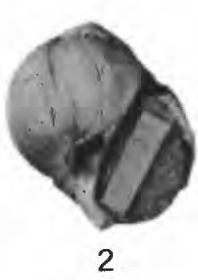

2
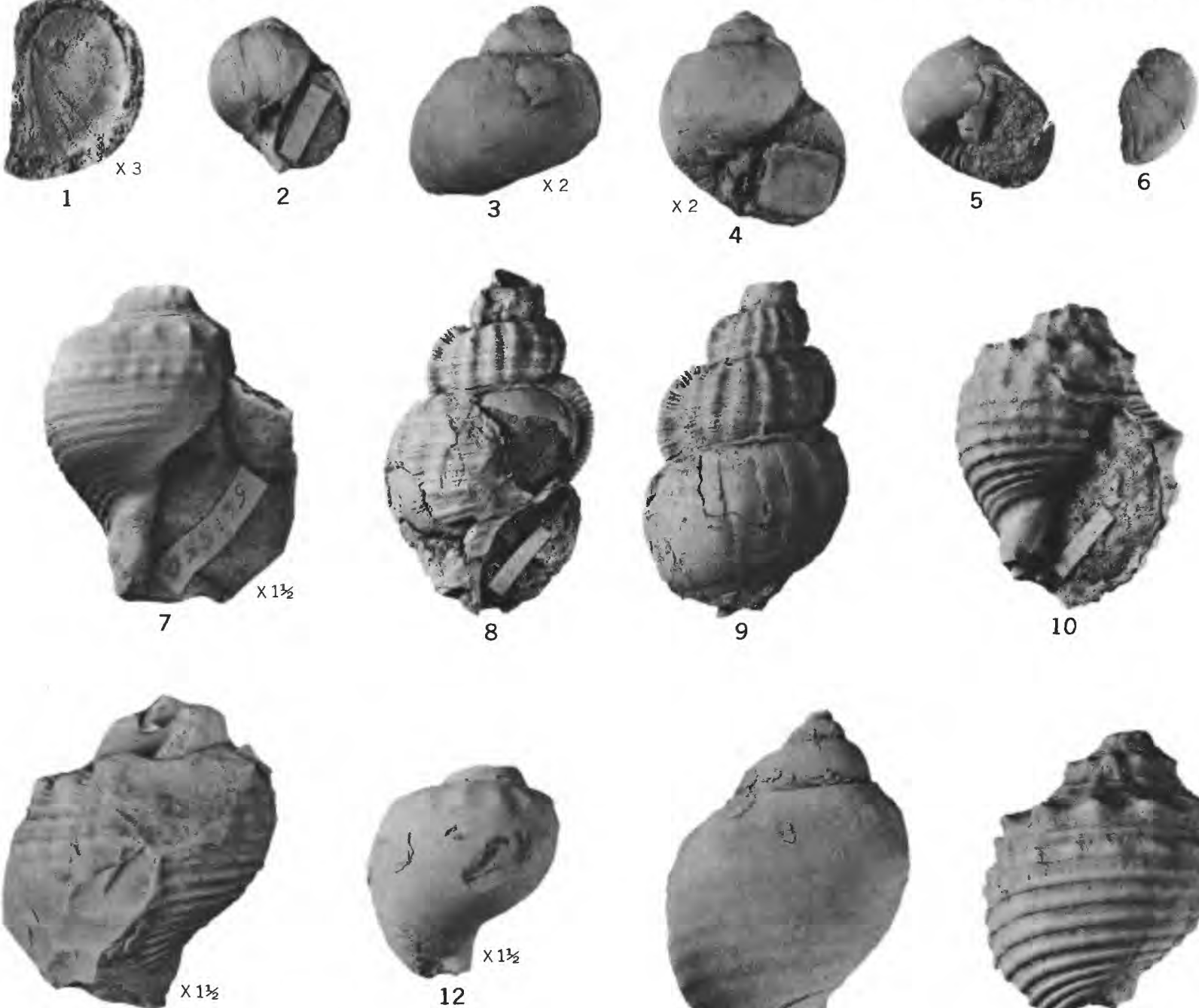

11
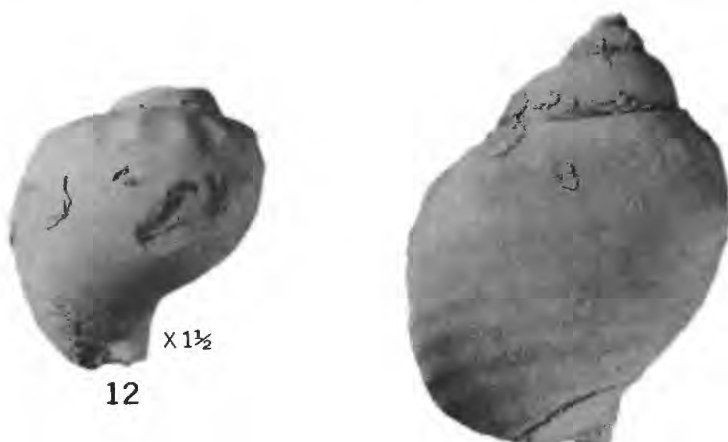

13

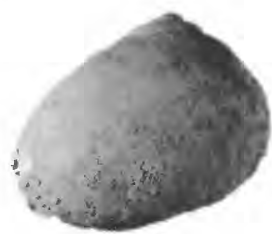

15
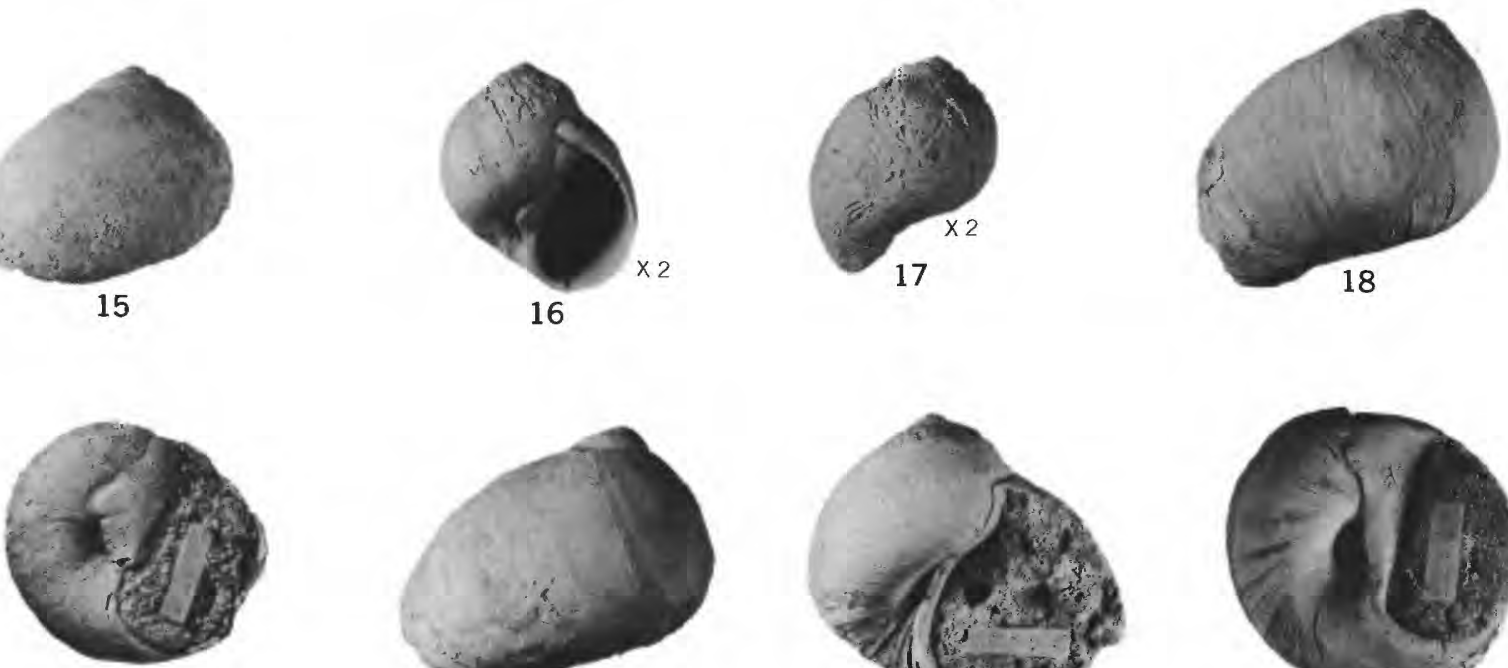

19
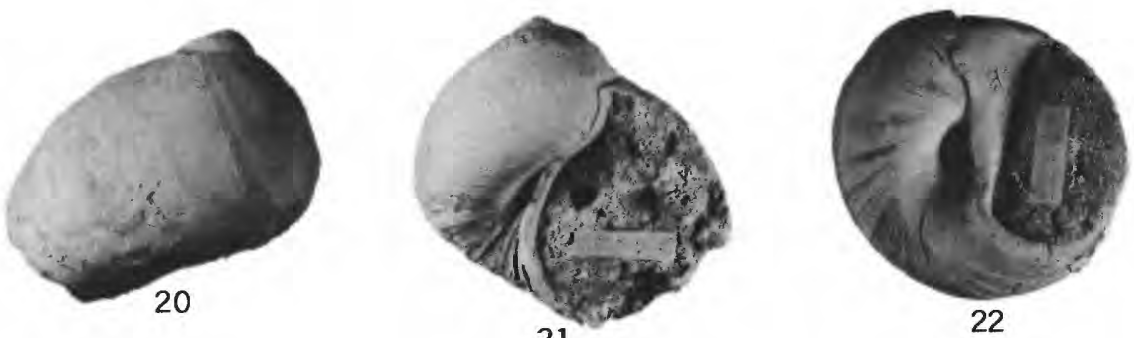

CRYPTONATICA?, NEVERITA, LIRACASSIS, “GYRINEUM," POLINICES, AND SINUM 


\section{PLATE 3}

Figure 1, 4. Molopophorus anglonanus (Anderson) (p. 37).

Height $36 \mathrm{~mm}$ (incomplete), width $21 \mathrm{~mm}$ (incomplete). Loc. USGS 6613, south bank of Kern River, Barker's Ranch, Kern County, Calif. USNM 563136.

5. Molopophora ef. M. anglonanus (Anderson) (p. 38).

Height $29 \mathrm{~mm}$ (incomplete), width $20 \mathrm{~mm}$ (incomplete). Loc. 156. USNM 563137.

2, 3, 8, 11, 13. Bruclarkia oregonensis (Conrad) (p. 35).

2. Beaded form. Height $36 \mathrm{~mm}$ (incomplete), width $29.3 \mathrm{~mm}$. Loc. 187. USNM 563138 .

3. Noded form. Height $32 \mathrm{~mm}$ (incomplete), width $25 \mathrm{~mm}$ (incomplete). Loc. 187 . USNM 563139.

8, 11. Spinose form. Height $28 \mathrm{~mm}$ (incomplete), width $19 \mathrm{~mm}$ (incomplete). Loc. 187. USNM 563140.

13. Smooth form. Height $36 \mathrm{~mm}$ (incomplete), width $26 \mathrm{~mm}$ (incomplete). Loc. 187. USNM 563141.

6. Molopophorus anglonanus (Anderson) of Etherington? (p. 38).

Height $30 \mathrm{~mm}$ (incomplete), width $15 \mathrm{~mm}$ (incomplete). Locality, corner of 5 th and Commercial St. Astoria, Oreg. Calif. Acad. Sci. 12128.

7. Molopophorus anglonana mathewi Etherington (p. 38).

Height $21 \mathrm{~mm}$ (incomplete), width $15 \mathrm{~mm}$ (incomplete). Loc. 156 . USNM 563142.

9, 10. Ficus modesta (Conrad) (p. 32).

9. Height $86 \mathrm{~mm}$ (incomplete), width $47 \mathrm{~mm}$ (incomplete). Loc. 123 . USNM 563212.

10. Height $78 \mathrm{~mm}$ (incomplete), width $57 \mathrm{~mm}$ (incomplete). Loc. 187. USNM 563143.

12. Liracassis? sp. ("unnamed cast"' of Conrad, 1849, pl. 21, fig. 1?) (p. 31).

Height $36 \mathrm{~mm}$ (incomplete), width $30 \mathrm{~mm}$ (incomplete). Loc. la. USNM 3546.

14-16. Trophosycon ef. T. ocoyanum (Conrad) (p. 33).

14, 16. Height $47 \mathrm{~mm}$ (incomplete), width $36 \mathrm{~mm}$ (incomplete). Locality, sea cliffs just north of Jump Off Joe, Lincoln County, Oreg. Calif. Acad. Sci. 12131.

15. Height $68 \mathrm{~mm}$ (incomplete), width $65 \mathrm{~mm}$ (incomplete). Loc. 186 . USNM 563144 . 


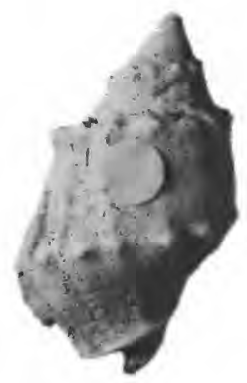

1
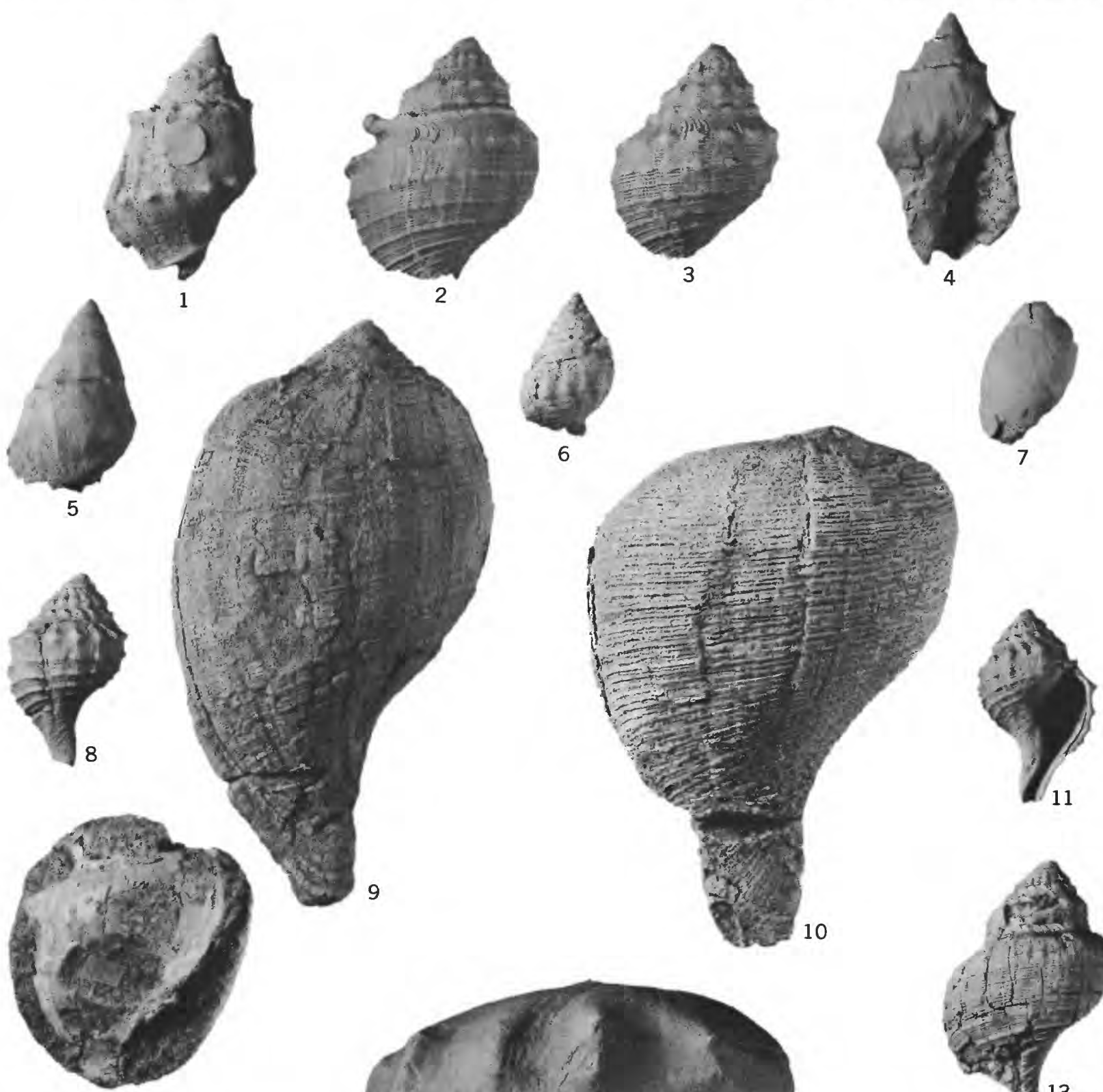

12

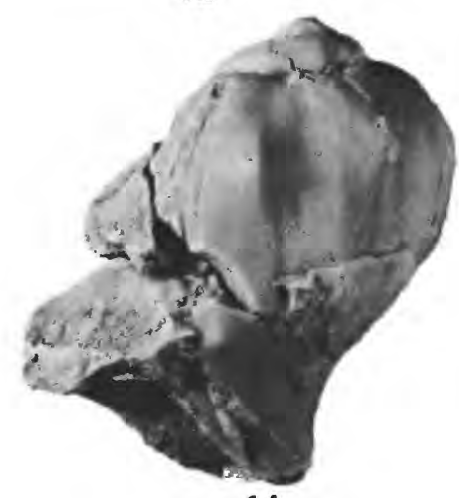

14
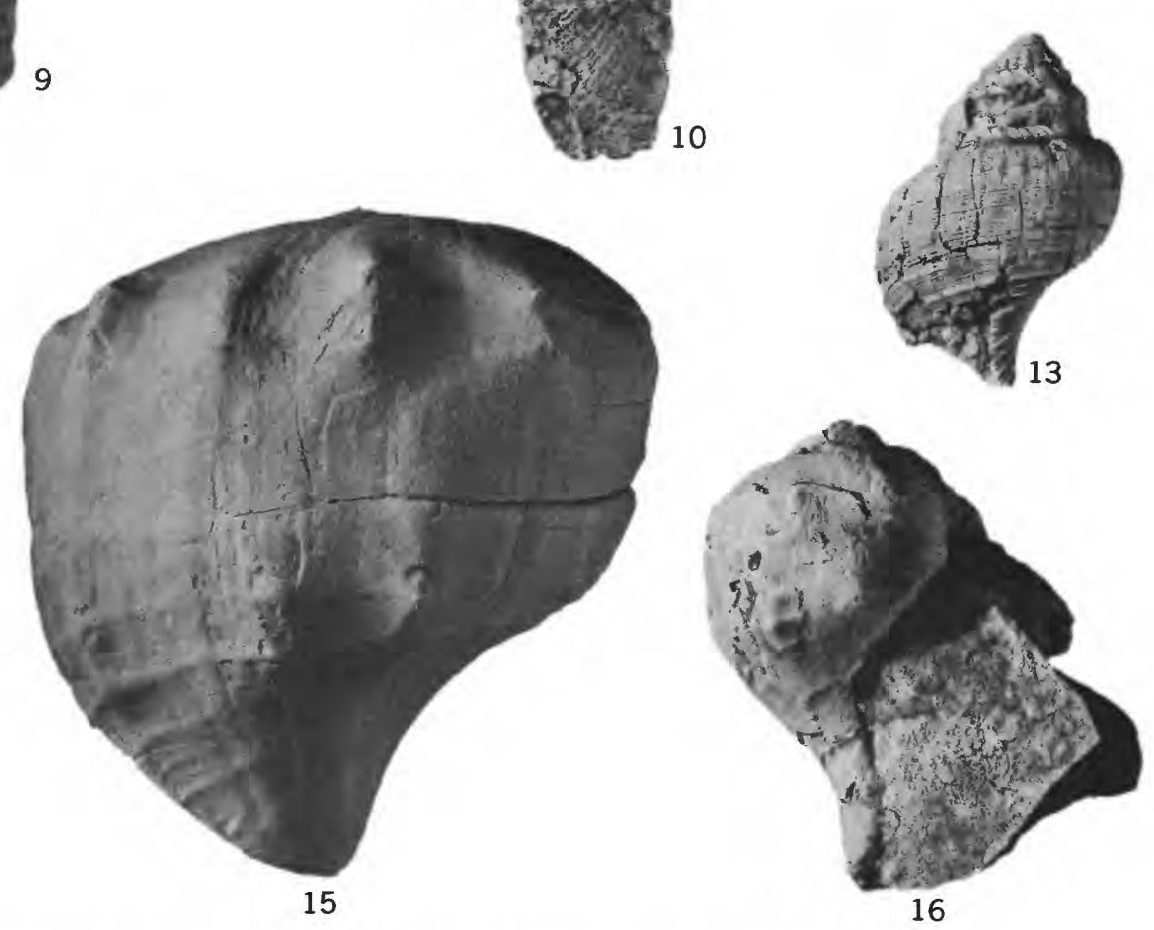

MOLOPOPHORUS, BRUCLARKIA, FICUS, LIRACASSIS?, AND TROPHOSYCON 


\section{PLATE 4}

Figure 1, 5. "Trophon" kernensis (Anderson) (p. 33).

1. Height $17 \mathrm{~mm}$ (incomplete), width $11.7 \mathrm{~mm}$. Loc. 83 . USNM 563145.

5. Height $66 \mathrm{~mm}$ (incomplete), width $49 \mathrm{~mm}$ (incomplete). Loc. 83 . USNM 563146.

2, 4, 6. Liracassis petrosa (Conrad) (p. 31).

2. Height $53 \mathrm{~mm}$ (incomplete), width $42 \mathrm{~mm}$ (incomplete). Loc. 53 . USNM 563147.

4, 6. Lectotype. Height $60.9 \mathrm{~mm}$ (incomplete), width $43.8 \mathrm{~mm}$ (incomplete). Loc. la. USNM 3536.

3. Ficus modesta (Conrad) (p. 32).

Height $48 \mathrm{~mm}$ (incomplete), width $32 \mathrm{~mm}$ (incomplete). Loc. 3. USNM 110457.

7, 10. Liracassis apta (Tegland) (p. 31).

(Figured by Dall, 1909, pl. 14, fig. 6, as Eudolium petrosum). Height $81 \mathrm{~mm}$ (incomplete), width $58 \mathrm{~mm}$ (incomplete). Locality, Freshwater Bay, Blakeley formation (Weaver, 1912), Clallam County, Washington. USNM 110425.

8, 9. Ocenebra depoensis Moore, n. sp. (p. 34).

Height $30 \mathrm{~mm}$ (incomplete), width $15.6 \mathrm{~mm}$. Loc. 75a. USNM 563927. 
GEOLOGICAL SURVEY

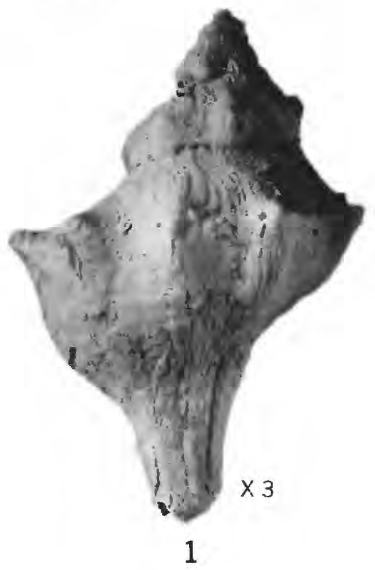

1

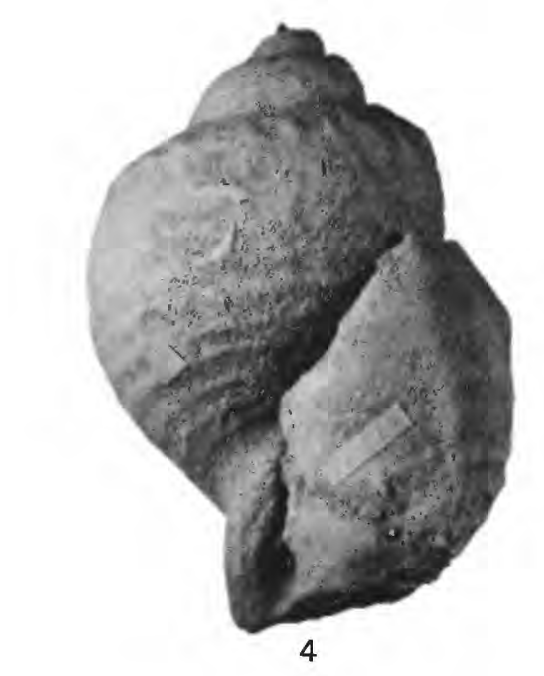

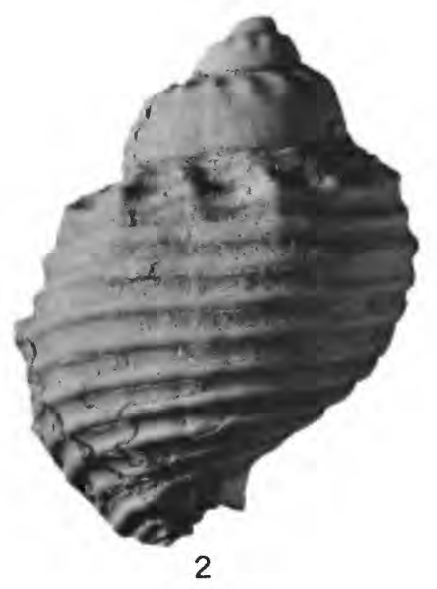
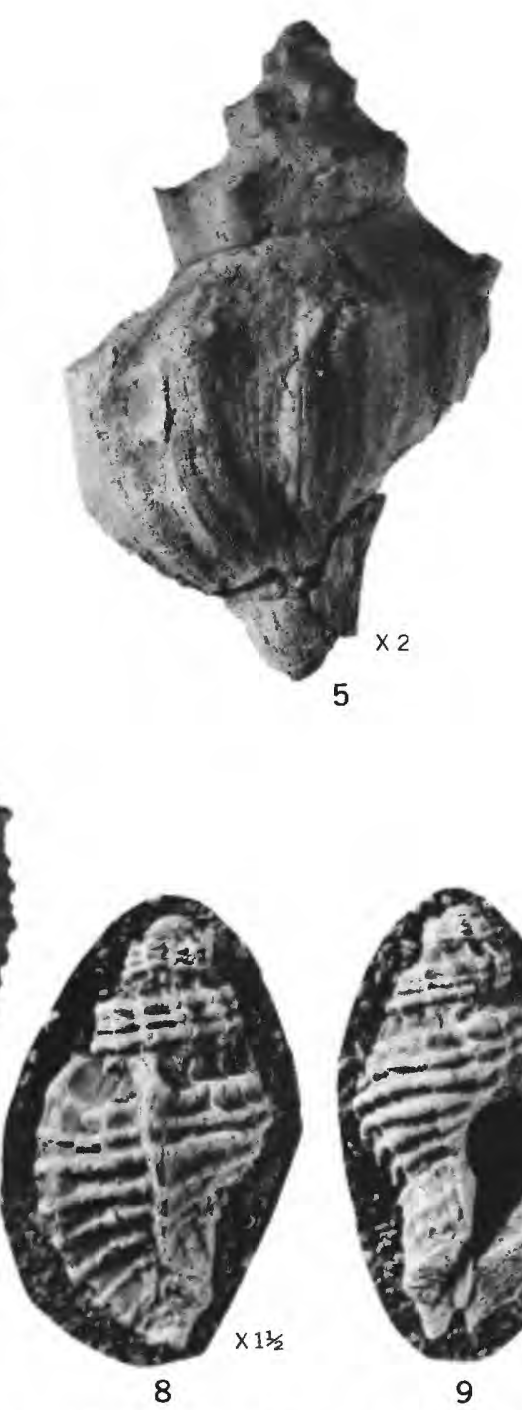

PROFESSIONAL PAPER 419 PLATE 4
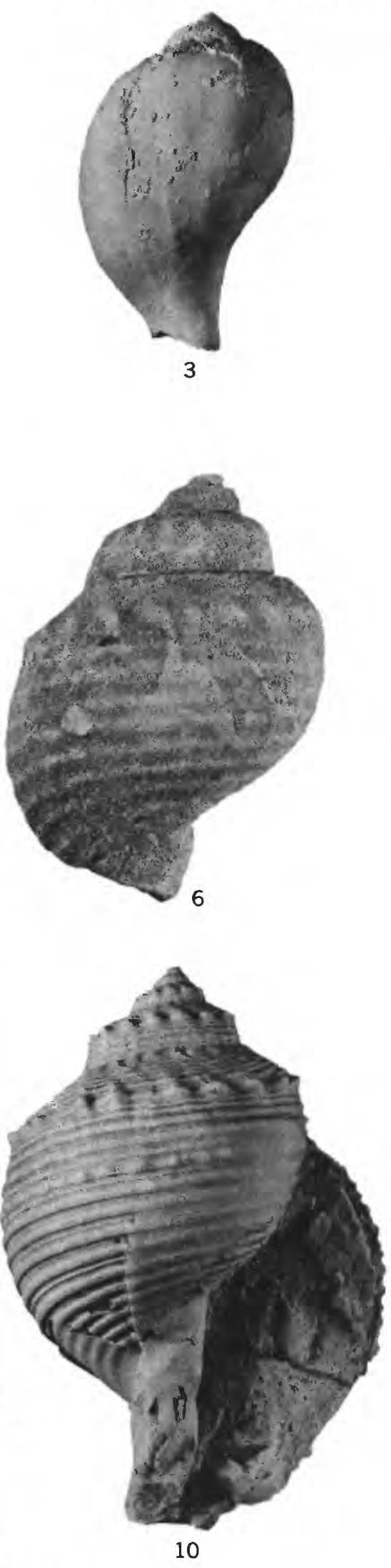

"TROPHON," LIRACASSIS, FICUS, AND OCENEBRA 


\section{PLATE 5}

Figure 1. Priscofusus coli (Dall) (p. 39, 42).

Holotype. Height $33 \mathrm{~mm}$ (incomplete), width $22 \mathrm{~mm}$ (incomplete). Locality, Empire formation, (Pliocene?), Coos Bay, Oreg. USNM 561975.

2-4. Searlesia? carlsoni (Anderson and Martin) (p. 36).

2. Height $41 \mathrm{~mm}$ (incomplete), width $21 \mathrm{~mm}$. Loc. 102. USNM 563148.

3. Height $45 \mathrm{~mm}$ (incomplete), width $23 \mathrm{~mm}$. Loc. 143 . USNM 563149.

4. Height $38 \mathrm{~mm}$ (incomplete), width $20.3 \mathrm{~mm}$. Loc. 187 . USNM 563150.

5. Priscofusus cf. P. coli (Dall) (p. 42).

Height $31 \mathrm{~mm}$, width $28.7 \mathrm{~mm}$. Loc. 187. USNM 563151.

6, 7. Priscofusus medialis (Conrad) (p. 41).

6. Height $27 \mathrm{~mm}$ (incomplete), width $12 \mathrm{~mm}$ (incomplete). Loc. 1a. USNM 561973.

7. Latex impression. Height $27 \mathrm{~mm}$ (incomplete), width $12 \mathrm{~mm}$ (incomplete). Loc. 1a. USNM 561974.

24. "Priscofusus oregonensis Conrad", cotype of Dall (1909, p. 40)=Priscofusus ef. P. medialis (Conrad) (p. 39).

Height $27 \mathrm{~mm}$ (incomplete), width $15 \mathrm{~mm}$ (incomplete). Loc. 1a. USNM 3565.

8-10, 13, 15. Hinia? lincolnensis (Anderson) (p. 38).

8. Height $8 \mathrm{~mm}$ (incomplete), width $5 \mathrm{~mm}$. Loc. 92 . USNM 563152.

9, 10. Height $10 \mathrm{~mm}$ (incomplete), width $6.7 \mathrm{~mm}$. Loc. 92 . USNM 563153 .

13. Height $6 \mathrm{~mm}$ (incomplete), width $4 \mathrm{~mm}$ (incomplete). Loc. 92 . USNM 563154 .

15. Height $11 \mathrm{~mm}$ (incomplete), width $6 \mathrm{~mm}$ (incomplete). Loc. 92 . USNM 563155.

11, 12. Antillophos? sp. (p. 37).

Height $18 \mathrm{~mm}$ (incomplete), width $9 \mathrm{~mm}$ (incomplete). Loc. 187 . USNM 563156.

14, 16-20. Uzita? arnoldi (Anderson) (p. 39).

14. Height $8 \mathrm{~mm}$ (incomplete), width $5.5 \mathrm{~mm}$. Loc. 109. USNM 563157.

16, 17. Height $7 \mathrm{~mm}$ (incomplete), width $4.9 \mathrm{~mm}$. Loc., USGS 6623, Kern River, Calif. USNM 563158.

18, 19. Height $8 \mathrm{~mm}$ (incomplete), width $5.3 \mathrm{~mm}$. Loc. 149 . USNM 563159.

20. Height $7 \mathrm{~mm}$ (incomplete), width $4.5 \mathrm{~mm}$. Loc. 75 . USNM 563160.

21. "Gyrineum" sp. (p. 32).

Height $27 \mathrm{~mm}$ (incomplete), width $11 \mathrm{~mm}$ (incomplete). Loc. 1a. USNM 3544.

22, 23. Searlesia? cammani (Dall) (p. 39).

Holotype. Height $48 \mathrm{~mm}$ (incomplete), width $38 \mathrm{~mm}$ (incomplete). Locality, Empire formation, (Pliocene?), Coos Bay, Oreg. USNM 153909. 


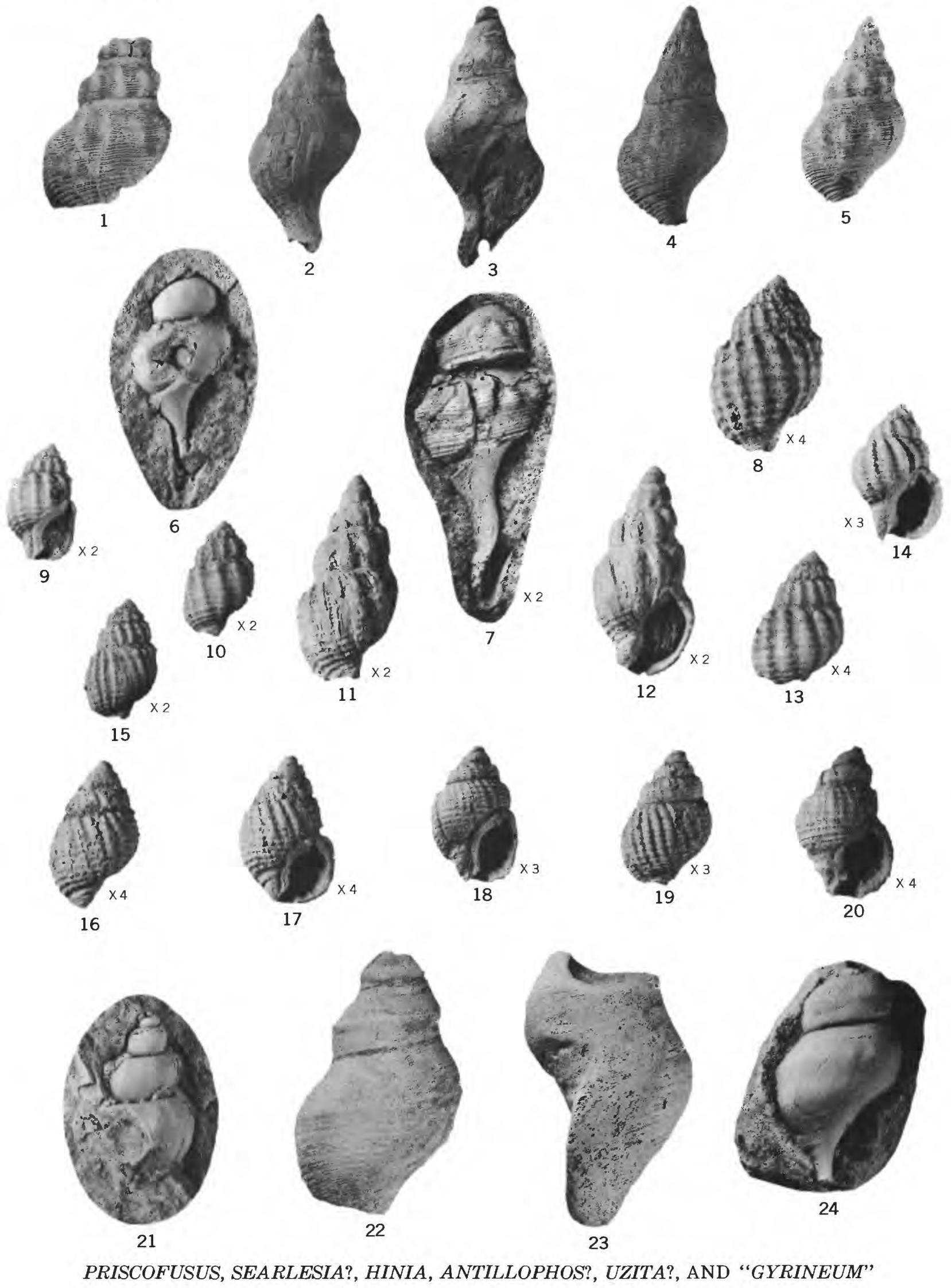




\section{PLATE 6}

Figure 1-7, 9. Priscofusus medialis (Conrad) (p. 41).

1, 4. Lectotype. Height $32 \mathrm{~mm}$ (incomplete), width $19 \mathrm{~mm}$ (incomplete). Loc. 1a. USNM 3532.

2, 3. Holotype of "Turris lincolnensis Anderson and Martin" (1914, p. 88-89, pl. 6, fig. 8). Locality, sandstone cliff along ocean south of Yaquina Head, $5 \frac{1}{2}$ miles north of entrance to Yaquina Bay, Oreg. Calif. Acad. Sci. 211.

5. Height $38 \mathrm{~mm}$ (incomplete), width $23 \mathrm{~mm}$ (incomplete). Loc. 187 . USNM 563161.

6. Height $38 \mathrm{~mm}$ (incomplete), width $26 \mathrm{~mm}$ (incomplete). Loc. 71 . USNM 563162.

7. Height $35 \mathrm{~mm}$ (incomplete), width $27 \mathrm{~mm}$ (incomplete). Loc. 187 . USNM 563163.

9. Height $48 \mathrm{~mm}$ (incomplete), width $28 \mathrm{~mm}$ (incomplete). Loc. 83 . USNM 563164.

8, 11. Priscofusus n. sp.? (p. 42).

8. Height $37 \mathrm{~mm}$ (incomplete), width $25 \mathrm{~mm}$ (incomplete). Locality, Astoria, Oreg. Calif. Acad. Sci. 12130.

11. Height $26 \mathrm{~mm}$ (incomplete), width $18 \mathrm{~mm}$ (incomplete). Loc. 86 . USNM 563165 .

10. Searlesia? carlsoni (Anderson and Martin) (p. 36).

Height $21 \mathrm{~mm}$ (incomplete), width $16 \mathrm{~mm}$ (incomplete and crushed). Loc. 112 . USNM 563166.

12, 19. Priscofusus aff. P. geniculus (Conrad) (p. 41).

12. Height $66 \mathrm{~mm}$ (incomplete), width $41 \mathrm{~mm}$ (incomplete). Locality, 2 miles south of Yaquina Bay, Oreg. Calif. Acad. Sci. 12129

19. Height $40 \mathrm{~mm}$ (incomplete), width $41 \mathrm{~mm}$ (incomplete). Loc. 183. USNM 563168.

13, 15-18. Priscofusus geniculus (Conrad) (p. 40).

13. Paratype of "Priscofusus oregonensis Conrad," (1865, p. 150; 1849, pl. 20, fig. 11). Height 45 mm (incomplete), width $16 \mathrm{~mm}$ (incomplete). Loc 1a. USNM 3535.

15. Height $43 \mathrm{~mm}$ (incomplete), width $21 \mathrm{~mm}$ (incomplete). Loc. 128 . USNM 563169.

16. Latex impression of lectotype of "Priscofusus oregonensis Conrad" (1865, p. 150; 1849, pl. 20, fig. 10). Height $42 \mathrm{~mm}$ (incomplete). Loc. 1a. USNM 3517.

17. Lectotype of $P$. geniculus. Height $18 \mathrm{~mm}$ (incomplete), width $9 \mathrm{~mm}$ (incomplete). Loc. 1a. USNM 3552 .

18. Latex impression of counterpart of concretion (fig. 13) showing paratype. Height $46 \mathrm{~mm}$ (incomplete), width $17 \mathrm{~mm}$ (incomplete). Loc. 1a USNM 561549.

14. Priscofusus hecoxae (Arnold) (p. 42).

Holotype. Height $35 \mathrm{~mm}$ (incomplete), width $19 \mathrm{~mm}$ (incomplete). Locality, 3 miles above town of Boulder Creek on San Lorenzo River, Santa Cruz County, San Lorenzo formation, California. USNM 165446. 


\section{PLATE 7}

Figure 1, 2, 4, 5, 7-9, 11. Psephaea (Miopleiona) indurata (Conrad) (p.43).

1. Height $39 \mathrm{~mm}$ (incomplete), width $21 \mathrm{~mm}$ (incomplete). Locality, 4th and Duane St., Astoria, Oreg. Calif. Univ. Mus. Paleontology 3693.

2. Height $31 \mathrm{~mm}$ (incomplete), width $15 \mathrm{~mm}$ (incomplete). Locality, 5th and Commercial Sts., Astoria, Oreg. Calif. Acad. Sci. 12126.

4. Height $99.2 \mathrm{~mm}$ (incomplete), width $40 \mathrm{~mm}$ (incomplete). Loc. 1 b. USNM 112409.

5. Height $10 \mathrm{~mm}$ (incomplete), width $6 \mathrm{~mm}$ (incomplete). Loc. 187 . USNM 563172.

7. Height $40 \mathrm{~mm}$ (incomplete), width $19 \mathrm{~mm}$ (incomplete). Loc. 187 . USNM 563173.

8. Height $34 \mathrm{~mm}$ (incomplete), width $18 \mathrm{~mm}$ (incomplete). Locality, 5th and Commercial Sts., Astoria, Oreg. Calif. Acad. Sci. 12127.

9. Height $26 \mathrm{~mm}$ (incomplete), width $12 \mathrm{~mm}$ (incomplete). Loc. 187 . USNM 563170.

11. Height $54 \mathrm{~mm}$ (incomplete), width $26 \mathrm{~mm}$ (incomplete). Loc. 109. USNM 563171. 3, 6. Psephaea (Miopleiona) sp. (p. 43).

Height $102 \mathrm{~mm}$ (incomplete), width $37 \mathrm{~mm}$ (incomplete). Locality, Neah Bay, Puget Sound, Wash. USNM 5908.

10. Fusus corpulentus Conrad=Priscofusus medialis (Conrad) (p. 41).

Height $39 \mathrm{~mm}$ (incomplete), width $21 \mathrm{~mm}$. Loc. 1a. USNM 3551. 


$$
b_{1}
$$




\section{PLATE 8}

Figure 1-4, 5. Psephaea (Miopleiona) indurata (Conrad) (p. 43).

1. Height $91 \mathrm{~mm}$ (incomplete), width $43 \mathrm{~mm}$ (incomplete). Loc. 187 . USNM 563174.

2. Latex impression of mold. Height $100 \mathrm{~mm}$ (incomplete), width $35 \mathrm{~mm}$ (incomplete). Loc. 56. USNM 563175 .

3. Height $93 \mathrm{~mm}$ (incomplete), width $42 \mathrm{~mm}$ (incomplete). Locality, Stanford Univ. NP 14, between Yaquina Head and Otter Rock, Oreg. Stanford Univ. Paleontology type colln. 9066.

4. Height $130 \mathrm{~mm}$ (incomplete), width $57 \mathrm{~mm}$ (incomplete). Loc. 56 . USNM 563176 .

5. Height $145 \mathrm{~mm}$ (incomplete), width $53 \mathrm{~mm}$ (incomplete). Loc. 187. USNM 563340.

6, 7. Cylichnina petrosa (Conrad) (p. 49).

6. Holotype. Height $10 \mathrm{~mm}$ (incomplete), width $5 \mathrm{~mm}$ (incomplete). Loc. 1a. USNM 3607.

7. Height $6 \mathrm{~mm}$ (incomplete), width $3 \mathrm{~mm}$ (incomplete). Loc. 147. USNM 563177. 8, 9. Cylichna sp. (p. 50).

Height $7.5 \mathrm{~mm}$ (incomplete), width $3 \mathrm{~mm}$ (incomplete). Loc. $90 . \quad$ USNM 563178. 
GEOLOGICAL SURVEY

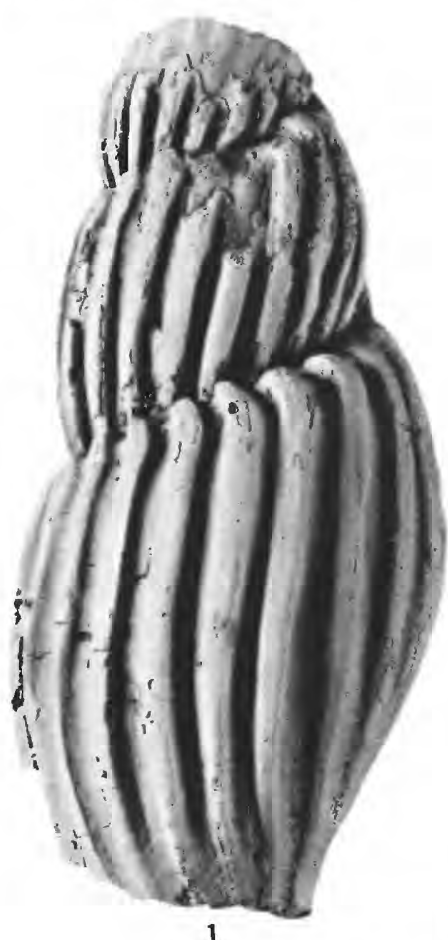

1

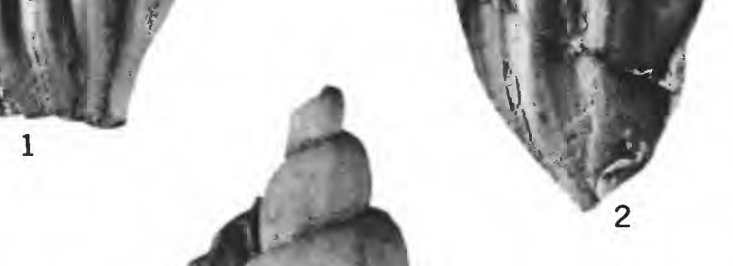

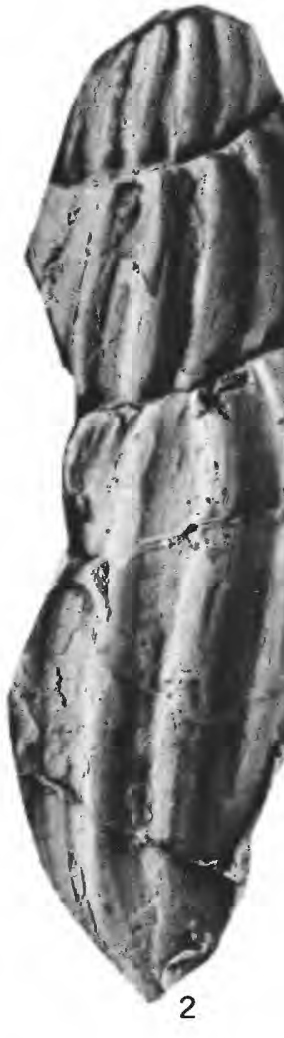

PROFESSIONAL PAPER 419 PLATE 8
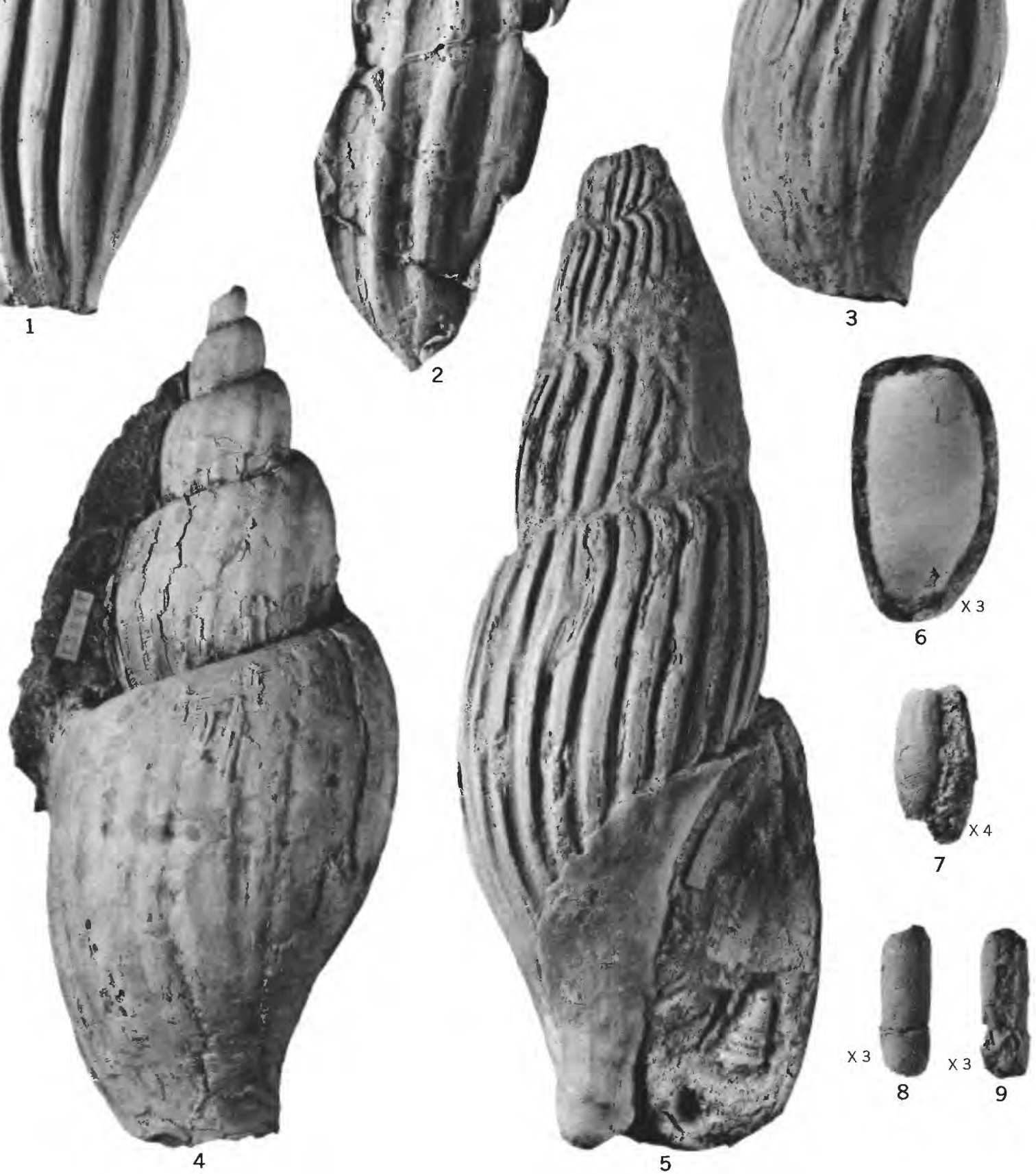

PSEPHAEA, CYLICHNINA, AND CYLICHNA 


\section{PLATE 9}

Figure 1, 6. Crawfordina? n. sp.? (p. 46).

Height $20 \mathrm{~mm}$ (incomplete), width $11.3 \mathrm{~mm}$ (incomplete). Loc. 149. USNM 563179.

2, 5. "Cancellaria" siletzensis Anderson (p. 44).

Height $25 \mathrm{~mm}$ (incomplete), width $18 \mathrm{~mm}$ (incomplete). Loc. 161. USNM 563180.

3, 4. Cancellaria? n. sp.? (p. 44).

Height $27 \mathrm{~mm}$ (incomplete), width $21 \mathrm{~mm}$ (incomplete). Loc. 187. USNM 563181.

7, 8. Spirotropis washingtonensis Etherington (p. 46).

Height $16.8 \mathrm{~mm}$ (incomplete), width $6.8 \mathrm{~mm}$ (incomplete). Loc. 187 . USNM 563620.

9, 10. Megasurcula wynoocheensis (Weaver) (p. 49).

9. Height $24 \mathrm{~mm}$ (incomplete), width $14 \mathrm{~mm}$. Loc. 187 . USNM 563182.

10. Height $16 \mathrm{~mm}$ (incomplete), width $13 \mathrm{~mm}$ (incomplete). Loc. 156 . USNM 563183.

11-14, 18. Megasurcula condonana (Anderson and Martin) (p. 48).

11. Height $32 \mathrm{~mm}$ (incomplete), width $18 \mathrm{~mm}$ (incomplete). Loc. 187 . USNM 563184 .

12. Height $40 \mathrm{~mm}$ (incomplete), width $24 \mathrm{~mm}$ (incomplete). Loc. 94 . USNM 563185.

13. Height $18 \mathrm{~mm}$ (incomplete), width $11 \mathrm{~mm}$ (incomplete). Loc. 187 . USNM 563186.

14. Height $24 \mathrm{~mm}$ (incomplete), width $14 \mathrm{~mm}$ (incomplete). Loc. 187. USNM 563187.

18. Height $18 \mathrm{~mm}$ (incomplete), width $10 \mathrm{~mm}$ (incomplete). Loc. 187 . USNM 563188.

15-17, 19-23. Cancellaria (Euclia) oregonensis Conrad (p. 45).

15. Height $23 \mathrm{~mm}$ (incomplete), width $18 \mathrm{~mm}$ (incomplete). Loc. 156 . USNM 563189.

16. Latex impression of mold of holotype. Height $24 \mathrm{~mm}$ (incomplete), width $16 \mathrm{~mm}$ (incomplete). Loc.

1a. USNM 3554.

17. Height $20 \mathrm{~mm}$ (incomplete), width $17 \mathrm{~mm}$ (incomplete). Loc. 83 . USNM 563190.

19. Height $26 \mathrm{~mm}$ (incomplete), width $17 \mathrm{~mm}$ (incomplete). Loc. 187 . USNM 563191.

20, 21. Neotype of "Cancellaria dalliana Anderson" (p. 45).

Locality, Barker's Ranch on Kern River, Kern County, Calif., Calif. Acad. Sci. 198.

22. Holotype of "Cancellaria condoni Anderson" (p. 45).

Locality, Kern River, Kern County, Calif. Calif. Acad. Sei. 67.

23. Height $27 \mathrm{~mm}$ (incomplete), width $19 \mathrm{~mm}$ (incomplete). Loc. 187. USNM 563213. 

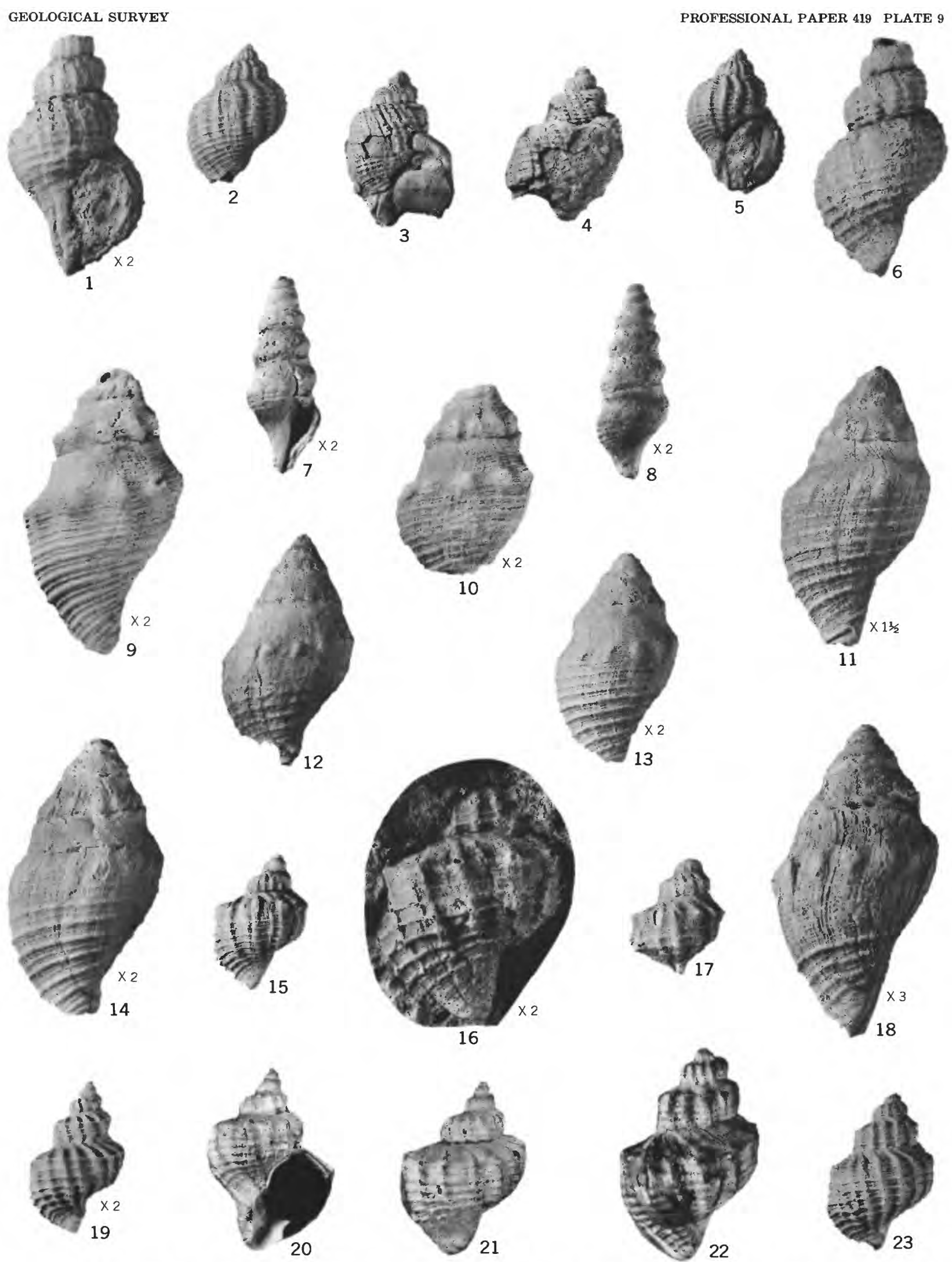

CRAWFORDINA?, "CANCELLARIA," CANCELLARIA?, SPIROTROPIS, MEGASURCULA AND CANCELLARIA 


\section{PLATE 10}

Frgure 1, 2. Spirotropsis washingtonensis Etherington (p. 46).

Height $16 \mathrm{~mm}$ (incomplete), width $7 \mathrm{~mm}$ (incomplete). Loc. 108. USNM 563193.

4, 9. Spirotropsis calodius Moore, n. sp. (p. 47).

Holotype. Height $13 \mathrm{~mm}$ (incomplete), width $7 \mathrm{~mm}$ (incomplete). Loc. 187. USNM 563194.

$3,5,8,14$. Megasurcula wynoocheensis (Weaver) (p. 49).

3, 8. Paratype. $52.3 \mathrm{~mm}$ high (incomplete), $23.6 \mathrm{~mm}$ wide. Locality, cut on old Chehalis Logging Co. road 1 mile west of Montesano, Grays Harbor County, Wash. Calif. Acad. Sci. 534.

5, 14. Lectotype. $26.8 \mathrm{~mm}$ high (incomplete), $16.1 \mathrm{~mm}$ wide. Locality, cut on old Chehalis Logging Co. road 1 mile west of Montesano, Grays Harbor County, Wash. Calif. Acad. Sci. 533.

6, 12, 13, 15. "Thesbia" antiselli (Anderson and Martin) (p. 47).

6, 15. Height $13 \mathrm{~mm}$ (incomplete), width $6 \mathrm{~mm}$ (incomplete). Loc. 187 . USNM 563195.

12, 13. Height $9 \mathrm{~mm}$ (incomplete), width $5 \mathrm{~mm}$ (incomplete). Loc. 71. USNM 563196.

7, 17. Liracassis petrosa (Conrad), n. gen. (p. 31).

Height $88 \mathrm{~mm}$ (incomplete), width $67.9 \mathrm{~mm}$. Locality, from bed of Fogarty Creek, just west of U.S. highway 101. Calif. Univ. Mus. Paleontology 32540.

10, 11. Comitas? spencerensis Moore, n, sp. (p. 47).

Holotype. Height $24 \mathrm{~mm}$ (incomplete), width $10 \mathrm{~mm}$ (incomplete). Loc. 92 . USNM 563197.

16, 18. Aforia clallamensis (Weaver) (p. 47).

Height $58 \mathrm{~mm}$ (incomplete), width $27 \mathrm{~mm}$ (incomplete). Loc. 157 . USNM 563198. 

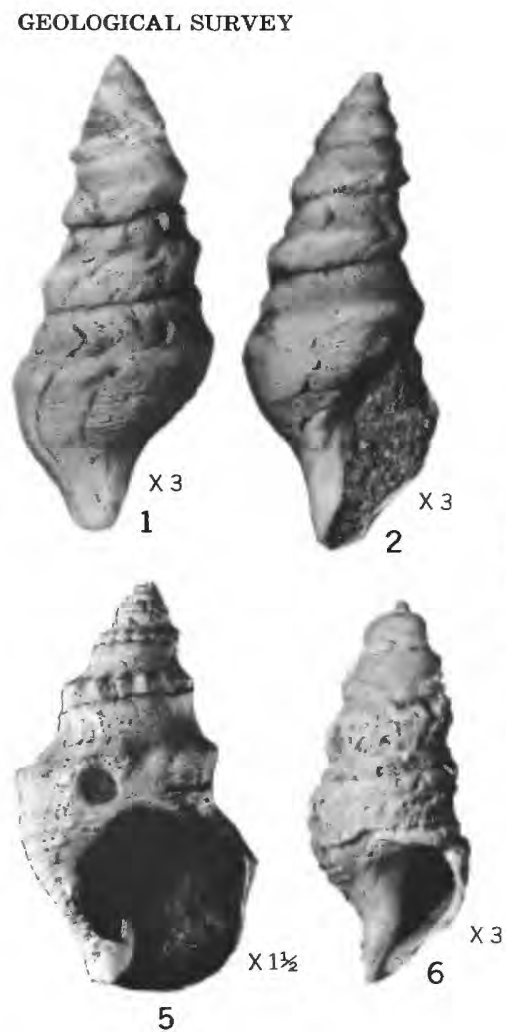

$x$
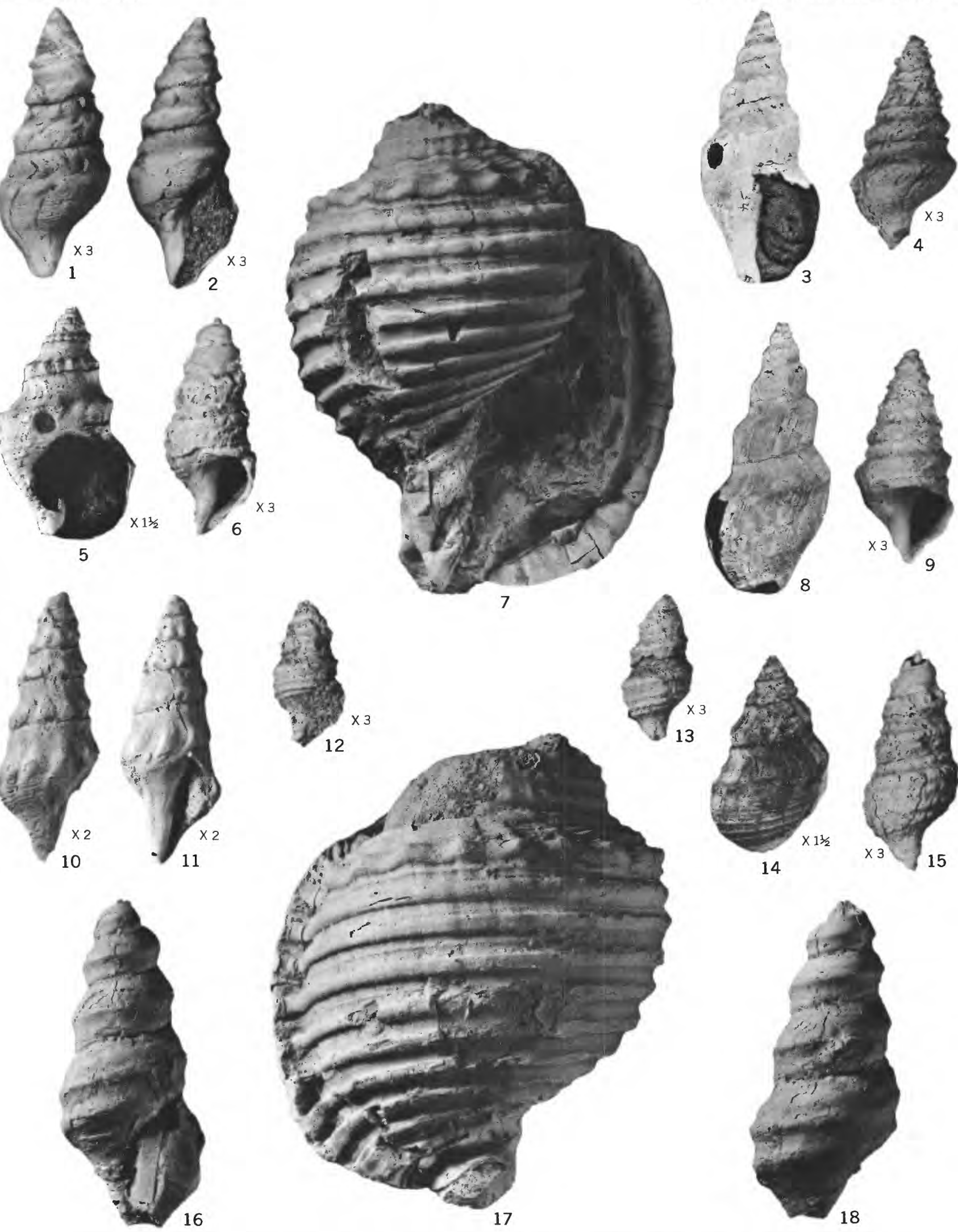

SPIROTROPSIS, MEGASURCULA, "THESBIA," LIRACASSIS, COMITAS?, AND AFORIA 


\section{PIATE 11}

Figure 1, 4, 8, 9, 11, 12. Solemya (Acharax) ventricosa Conrad (p. 51).

1, 12. Length $76 \mathrm{~mm}$ (incomplete), height $28 \mathrm{~mm}$ (incomplete), thickness $28 \mathrm{~mm}$. Loc. 184. USNM 563199.

4. Length $47 \mathrm{~mm}$ (incomplete), height $20 \mathrm{~mm}$ (incomplete). Loc. 13 . USNM 562092.

8. Lectotype. Length $100 \mathrm{~mm}$ (incomplete), height $36 \mathrm{~mm}$ (incomplete). Loc. 1a. USNM 3567.

9. Holotype of "Donax protexta Conrad" (= Solemya? sp.) (p. 52). Length $29 \mathrm{~mm}$ (incomplete), height $13 \mathrm{~mm}$ (incomplete). Loc. 1a. USNM 3613.

11. Paratype. Length $41 \mathrm{~mm}$ (incomplete), height $18 \mathrm{~mm}$ (incomplete). Loc. 1a. USNM 3486.

2, 5, 10. Nucula (Enucula?) nuculana (Dall) (p. 52).

2, 5. Length $8.2 \mathrm{~mm}$, height $6.8 \mathrm{~mm}$, thickness $4.7 \mathrm{~mm}$. Loc. 149 . USNM 563201 .

10. Holotype. Length $9.6 \mathrm{~mm}$ (incomplete), height $9.0 \mathrm{~mm}$ (incomplete). Loc. 1a. USNM 3529a.

3. "Nucula townsendi Dall" (p. 53).

Length $18 \mathrm{~mm}$ (incomplete), height $15 \mathrm{~mm}$ (incomplete). Loc. 1a? USNM 3526a.

6. Glycymeris sp. (p. 58).

Length $21.7 \mathrm{~mm}$ (incomplete), height $21.6 \mathrm{~mm}$ (incomplete). Locality, 5th and Commercial Sts., Astoria, Oreg. Calif. Acad. Science 12125.

7. "Nucula" n. sp.? (p. 53).

Length $12.6 \mathrm{~mm}$ (incomplete), height $9.4 \mathrm{~mm}$ (incomplete), thickness $7 \mathrm{~mm}$ (incomplete, both valves). Loc. 6. USNM 563202. 
GEOLOGICAL SURVEY
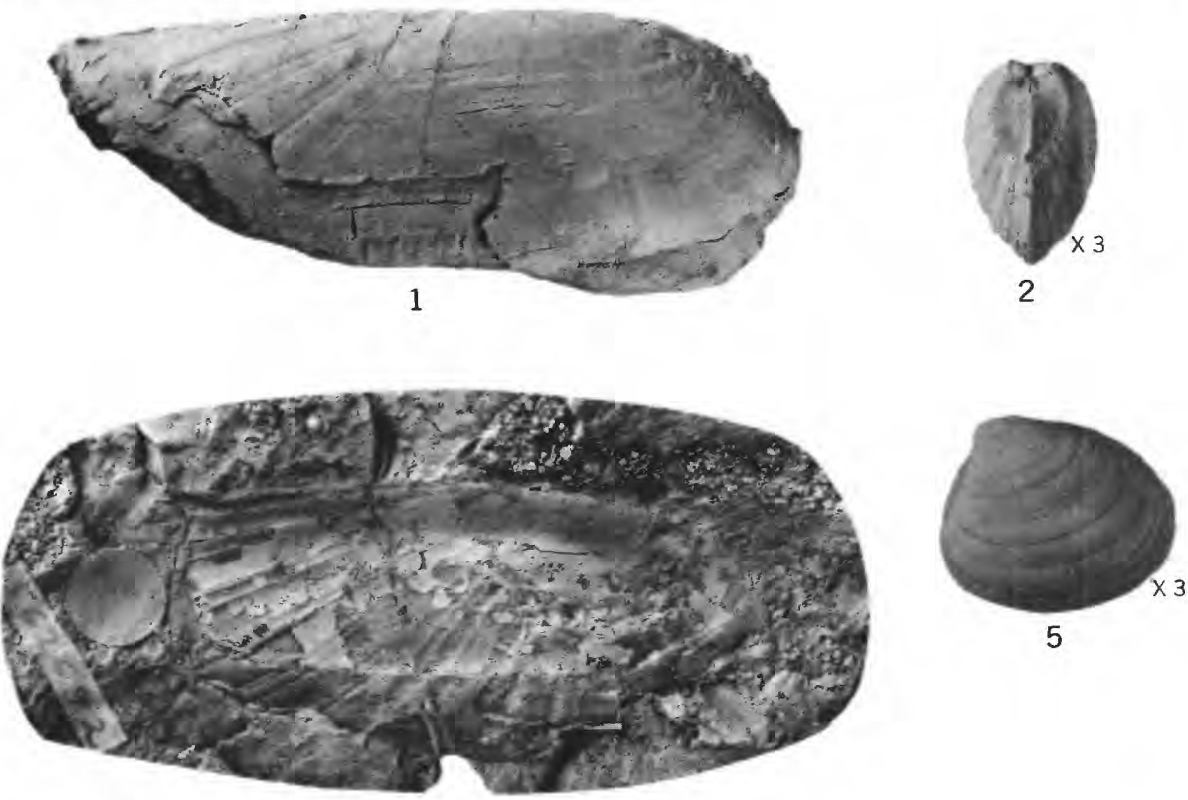

4
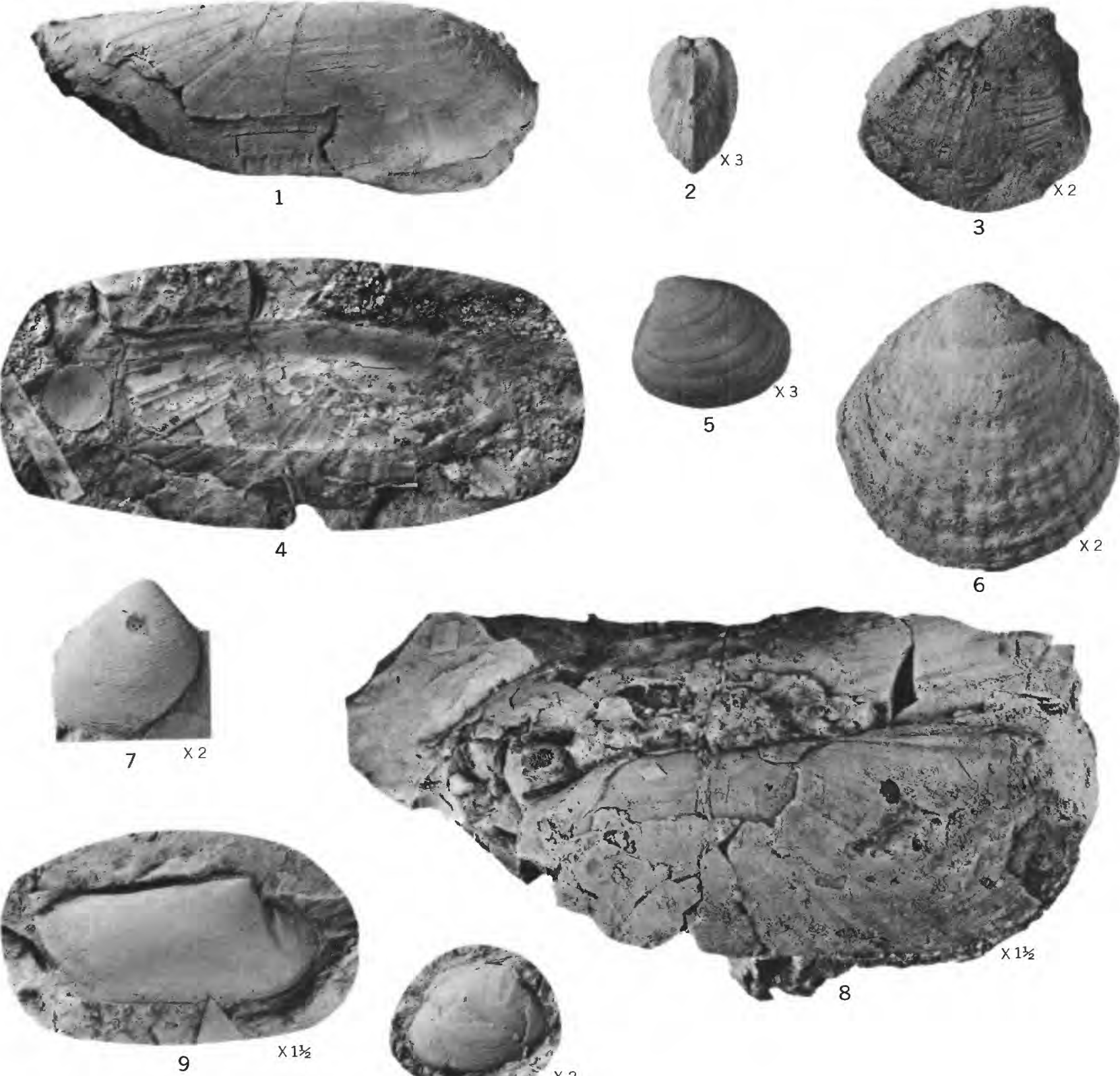

6
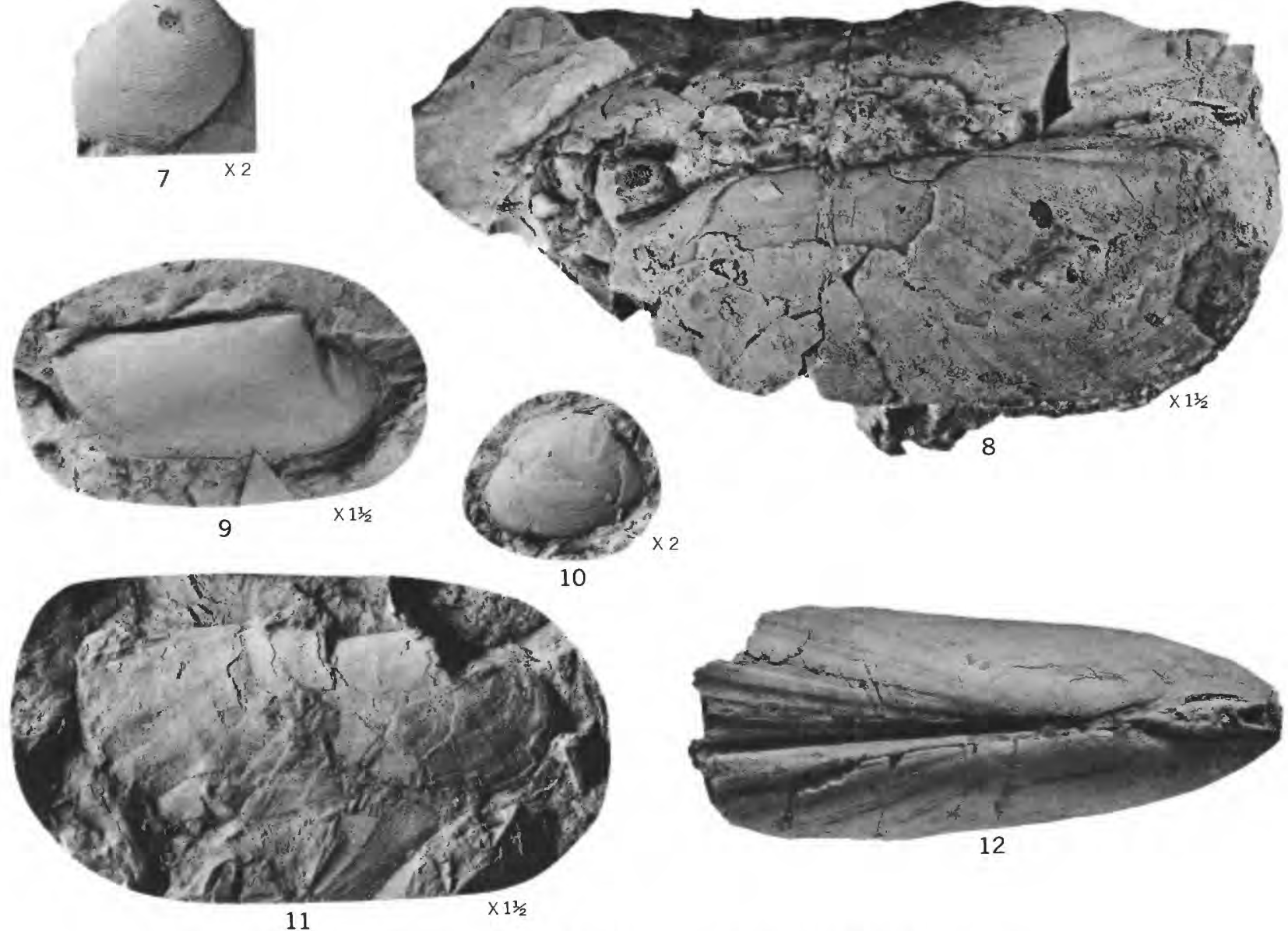

SOLEMYA, NUCULA, “NUCULA," AND GLYCYMERIS 


\section{PLATE 12}

Figdre 1. Nucula (Enucula?) nuculana (Dall) (p. 52).

Length $7.9 \mathrm{~mm}$, height $6.6 \mathrm{~mm}$, thickness $2.5 \mathrm{~mm}$ (one valve). Loc. 149 . USNM 563203.

2-4, 6-9. Acila (Truncacila) conradi (Meek) (p. 54).

2, 4. Length $21 \mathrm{~mm}$ (incomplete), height $17 \mathrm{~mm}$ (ińcomplete), thickness $9.8 \mathrm{~mm}$ (both valves). Loc. 111. USNM 563204.

3. Length $7 \mathrm{~mm}$ (incomplete), height $6.3 \mathrm{~mm}$. Loc. 145 . USNM 563205 .

6. Neotype. Length $14.4 \mathrm{~mm}$ (incomplete), height $10.3 \mathrm{~mm}$ (incomplete). Loc. 1a. USNM 3526 .

7. Latex impression of mold of lectotype.

8 Length $25 \mathrm{~mm}$ (incomplete), height $18 \mathrm{~mm}$ (incomplete), thickness $6.6 \mathrm{~mm}$ (one valve). Loc. 104. USNM 563206.

9. Length $7 \mathrm{~mm}$ (incomplete), height $6 \mathrm{~mm}$ (incomplete), thickness $3.4 \mathrm{~mm}$ (both valves). Loc. 149 . USNM 563167.

5, 10, 12, 13. Acila (Acila) gettysburgensis (Reagan) (p. 54).

5. Holotype. Length $26 \mathrm{~mm}$ (incomplete), height $19 \mathrm{~mm}$, thickness $8 \mathrm{~mm}$ (one valve). Locality, Gettysburg?, Wash. USNM 328302.

10. Length $26 \mathrm{~mm}$ (incomplete), height $20 \mathrm{~mm}$ (incomplete), thickness $16 \mathrm{~mm}$ (incomplete, both valves). Loc. 156. USNM 563207.

12, 13. Paratype. Length $35 \mathrm{~mm}$ (incomplete), height $27 \mathrm{~mm}$ (incomplete), thickness $22 \mathrm{~mm}$ (both valves, slightly gaping). Loc. USGS 10127, Gettysburg?, Wash. USNM 328302.

11, 14, 17, 21. Litorhadia astoriana (Henderson) (p. 56).

11. Lectotype. Length $18.9 \mathrm{~mm}$ (incomplete), height $9 \mathrm{~mm}$ (incomplete), thickness $6.8 \mathrm{~mm}$ (both valves). Loc. 1a. USNM 3490.

14. Paratype. Length $22 \mathrm{~mm}$ (incomplete), height $10 \mathrm{~mm}$ (incomplete). Loc. 1a. USNM 561529.

17. Paratype. Length $23 \mathrm{~mm}$ (incomplete), height $11 \mathrm{~mm}$ (incomplete). Loc. 1a. USNM 3491.

21. Length $27 \mathrm{~mm}$ (incomplete), height $14.4 \mathrm{~mm}$ (incomplete), thickness $9.7 \mathrm{~mm}$ (incomplete). Loc. 63. USNM 563210.

15, 16, 18. "Nuculana" epacris Moore, n. sp. (p. 55).

Holotype. Length $20 \mathrm{~mm}$ (incomplete), height $11.8 \mathrm{~mm}$ thickness $8 \mathrm{~mm}$ (incomplete). Loc. 150 . USNM 563208.

19. Yoldia n. sp.? (p. 58).

Length $23 \mathrm{~mm}$, height $11 \mathrm{~mm}$ (incomplete), thickness $6 \mathrm{~mm}$ (incomplete, both valves). Loc. 104. USNM 563209.

20. Yoldia (Kalayoldia) oregona (Shumard) (p. 58).

Lectotype. Length $39.5 \mathrm{~mm}$, height $20.8 \mathrm{~mm}$. Locality, Willamette Valley, a few miles south of Oregon City, Oreg. (Oligocene). USNM 562470.

22, 23. Portlandia (Portlandella) reagani (Dall) (p. 57).

22. Length $29.4 \mathrm{~mm}$ (incomplete), height $17 \mathrm{~mm}$ (incomplete), thickness $11.4 \mathrm{~mm}$ (incomplete). Loc. 174. USNM 563211.

23. Holotype. Length $24.1 \mathrm{~mm}$ (incomplete), height $13.7 \mathrm{~m}$, thickness $8.8 \mathrm{~mm}$. Gettysburg, Wash. USNM 328303. 
GEOLOGICAL SURVEY
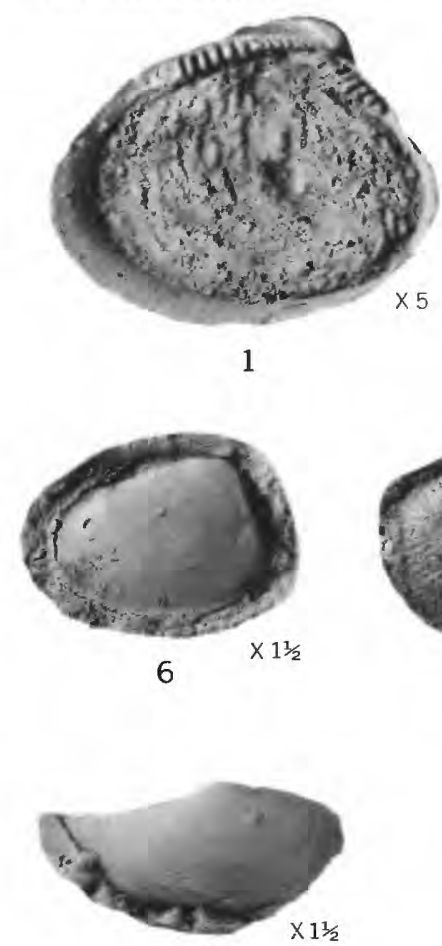

11
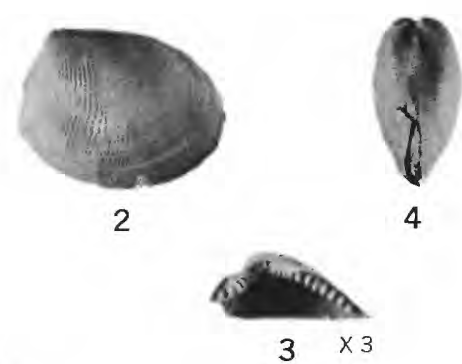

PROFESSIONAL PAPER 419 PLATE 12
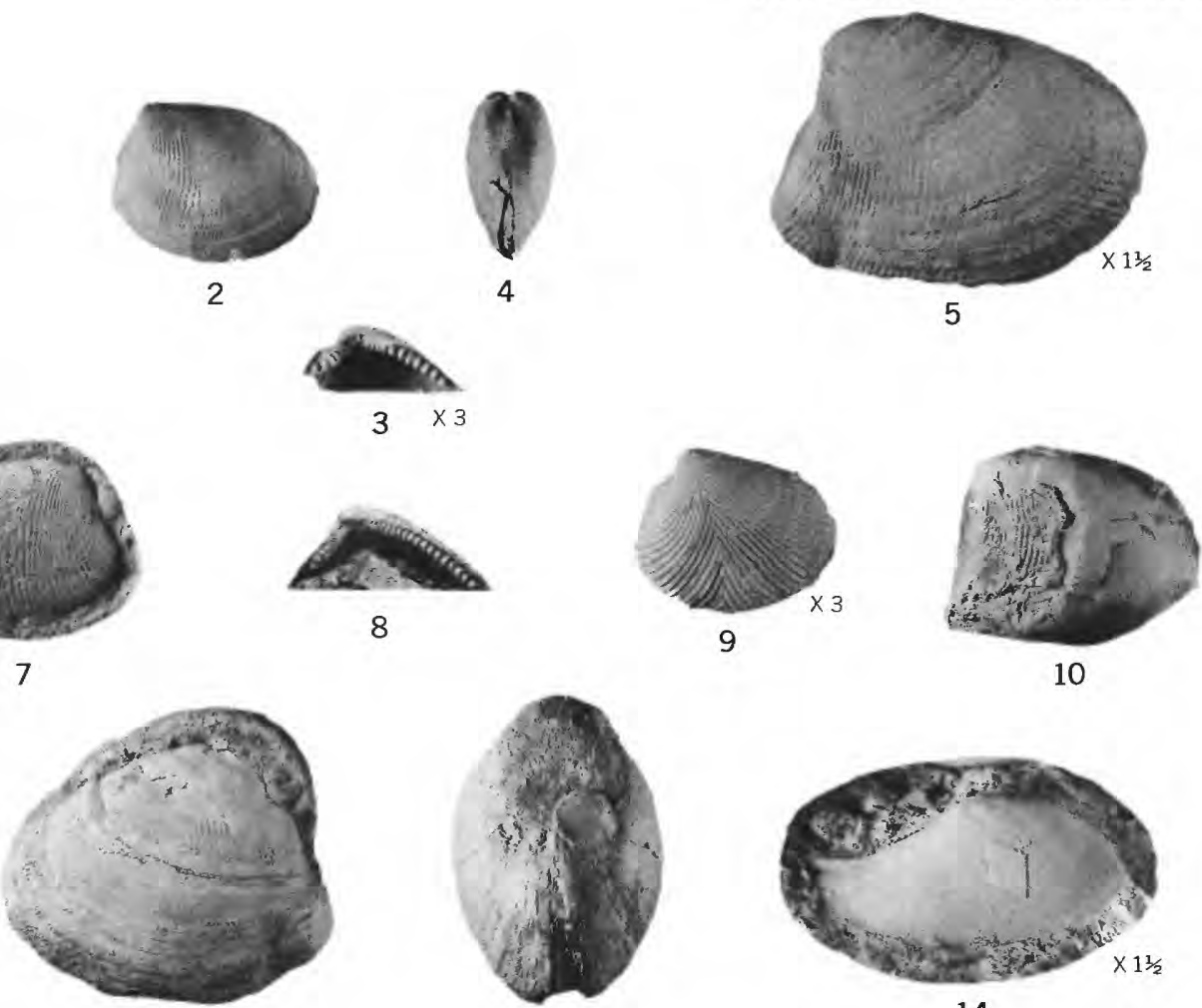

12

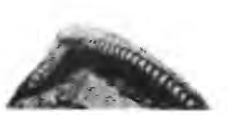

8

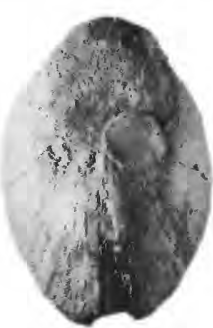

13

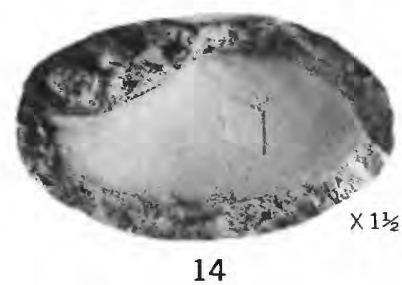

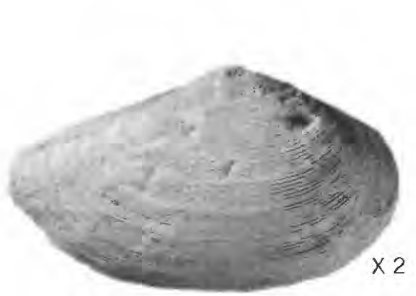

16

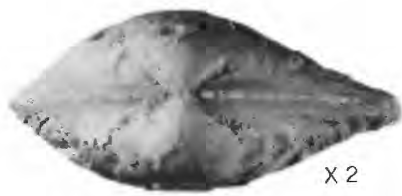

18

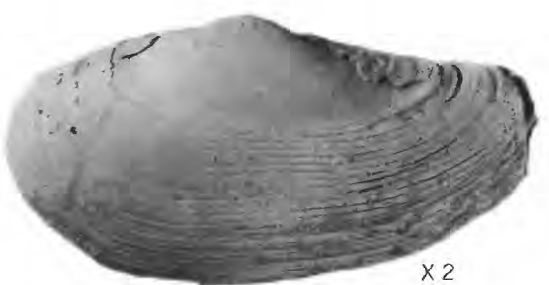

21

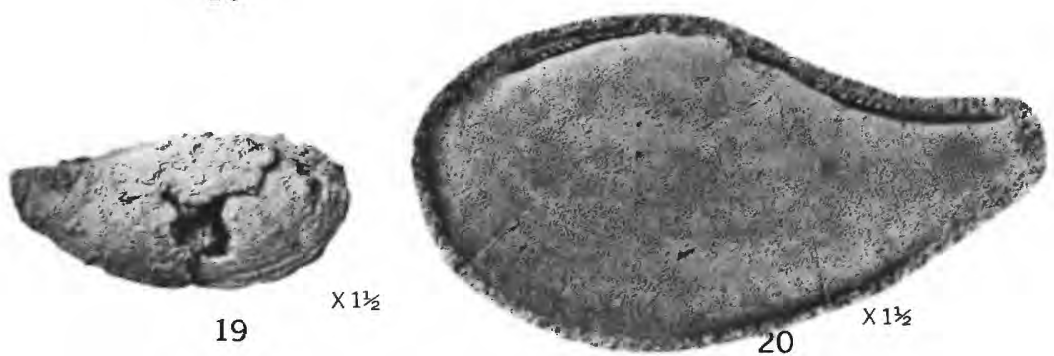

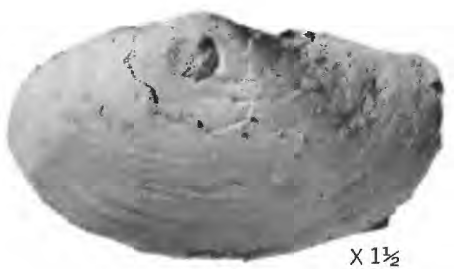

22

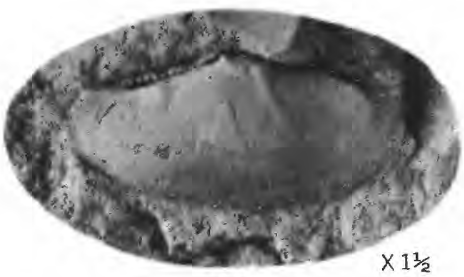

17

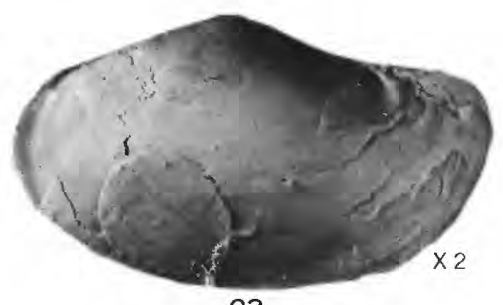

23

NUCULA, ACILA, LITORHADIA, "NUCULANA," YOLDIA, AND PORTLANDIA 


\section{PLATE 13}

FigURE 1-3, 7. Saccella ochsneri (Anderson and Martin) (p. 57).

1, 2. Paratype, $19.5 \mathrm{~mm}$ long, $10.0 \mathrm{~mm}$ high (incomplete). Loc. CAS 68, Kern County, Calif., Temblor formation. Calif. Acad. Sci. 105.

3, 7. Holotype, $15.0 \mathrm{~mm}$ long, $8.2 \mathrm{~mm}$ high. Loc., CAS 68, Kern County, Calif., Temblor formation. Calif. Acad. Sci. 103.

4-6. Saccella amelga (Moore,) n. sp. (p. 57).

Holotype. Length $11 \mathrm{~mm}$ (incomplete), height $6 \mathrm{~mm}$ (incomplete), thickness $4 \mathrm{~mm}$ (incomplete, both valves). Loc. 156. USNM 563214.

8. "Nuculana" epachris (Moore), n. sp. (p. 55).

Paratype. Length $13 \mathrm{~mm}$ (incomplete), height $7 \mathrm{~mm}$ (incomplete), thickness $3 \mathrm{~mm}$ (incomplete), thickness 3 $\mathrm{mm}$ (incomplete, one valve). Loc. 139. USNM 563215.

9. Glycymeris sp. (p. 58).

Length $30 \mathrm{~mm}$ (incomplete), height $31 \mathrm{~mm}$ (incomplete). Loc. 50 . USNM 563216.

10-13. Saccella calkinsi (Moore), n. sp. (p. 56).

10. Paratype. Length $17 \mathrm{~mm}$ (incomplete), height $9 \mathrm{~mm}$ (incomplete), thickness $7 \mathrm{~mm}$ (incomplete). Loc. 120. USNM 563217.

11. Paratype. Length $19 \mathrm{~mm}$ (incomplete), height $11 \mathrm{~mm}$ (incomplete), thickness $8.3 \mathrm{~mm}$ (both valves). Loc. 181a. USNM 563218.

12, 13. Holotype. Length $20 \mathrm{~mm}$ (incomplete), height $11.7 \mathrm{~mm}$ (incomplete), thickness $9.5 \mathrm{~mm}$. Loc. 181. USNM 563219 .

14, 15. Anadara (Anadara) devincta (Conrad) (p. 59).

15. Lectotype. Right valve, length $37 \mathrm{~mm}$ (incomplete), height $29 \mathrm{~mm}$ (incomplete), thickness $15 \mathrm{~mm}$ (incomplete). Loc. 1a. USNM 3499 .

14. Lectotype. Left valve, length undetermined, height $30 \mathrm{~mm}$ (incomplete), thickness $16 \mathrm{~mm}$ (incomplete). Loc. 1a. USNM 3499. 
GEOLOGICAL SURVEY

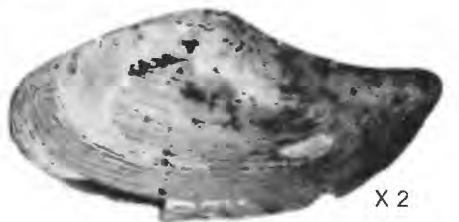

1
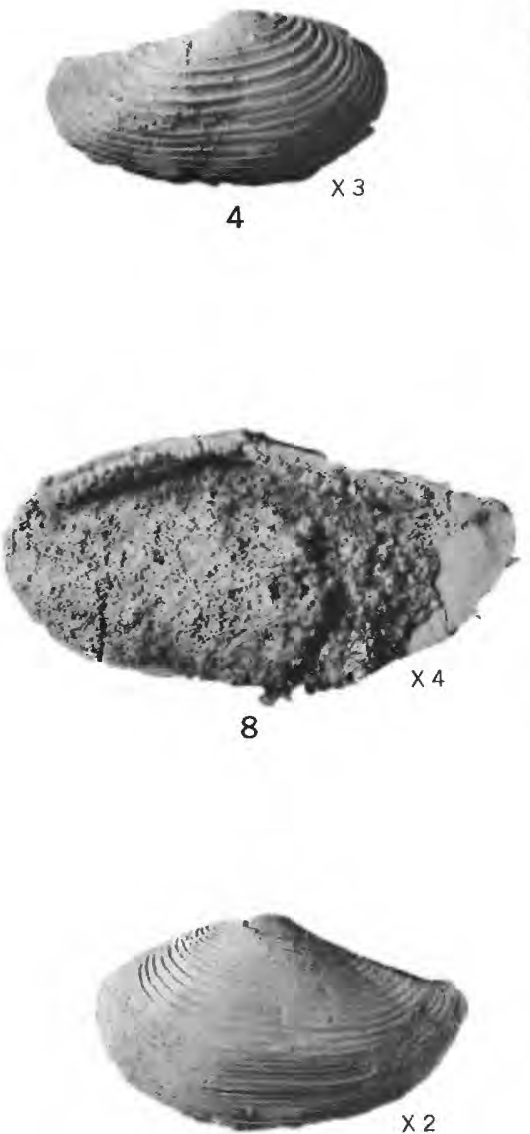

11
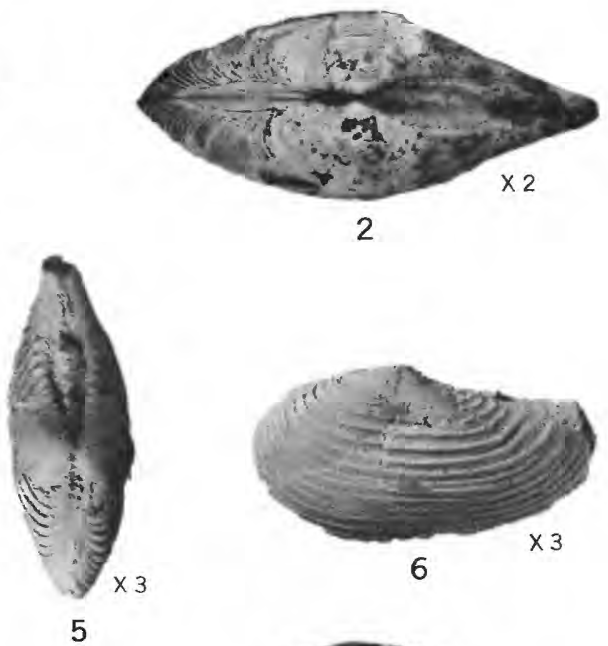

5
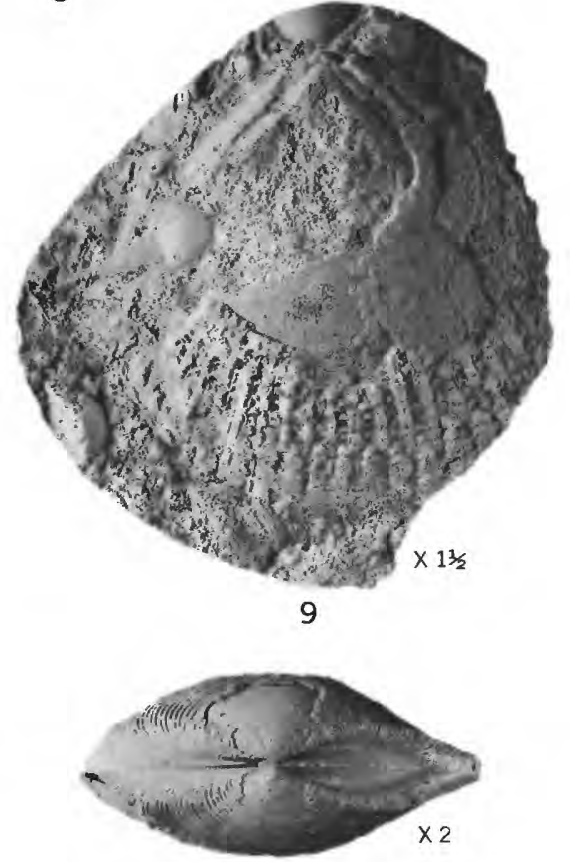

12
PROFESSIONAL PAPER 419 PLATE 19
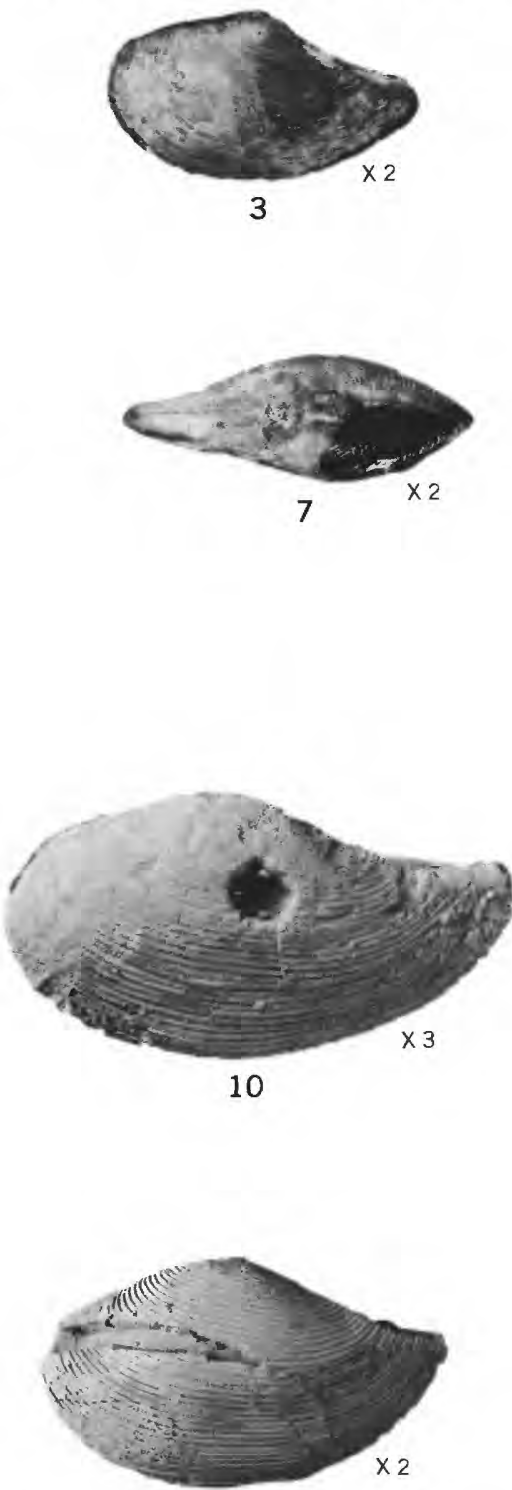

13
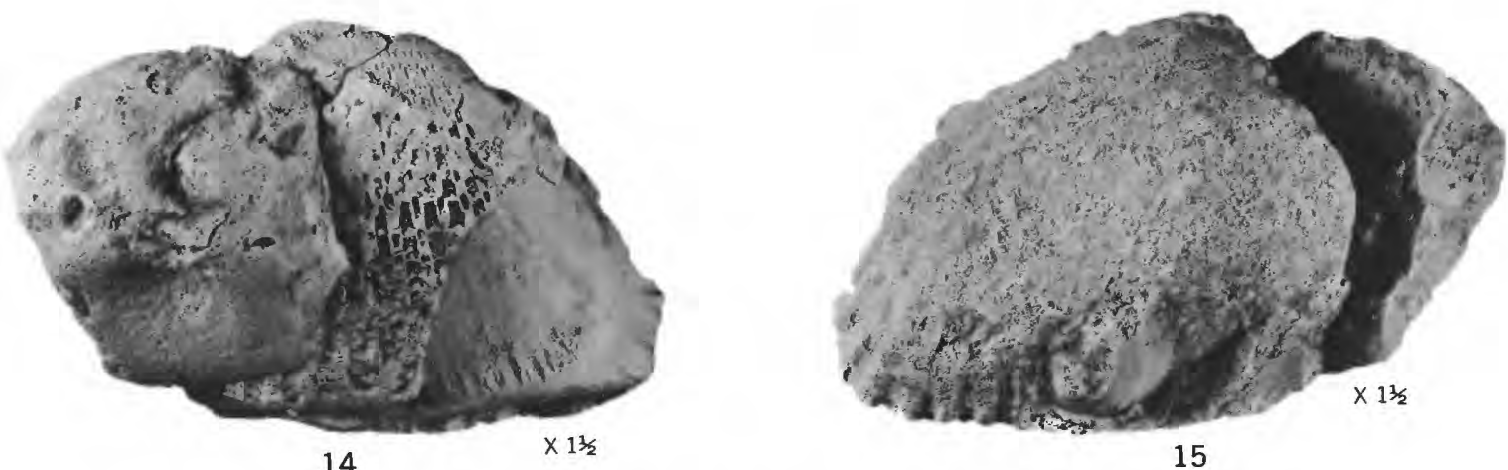

15

SACCELLA, "NUCULANA," GLYCYMERIS, AND ANADARA 


\section{PLATE 14}

Figure 1-13. Anadara (Anadara) devincta (Conrad) (p. 59).

1, 3. Paratype. Loc. 1a. USNM 563379.

2. Lectotype. Length $37 \mathrm{~mm}$ (incomplete), height $29 \mathrm{~mm}$ (incomplete), thickness of right valve $15 \mathrm{~mm}$ (incomplete). Loc. 1a. USNM 3499.

4. Split-rib form. Length $35.3 \mathrm{~mm}$, height $28.3 \mathrm{~mm}$, thickness $23.0 \mathrm{~mm}$ (both valves). Loc. 156. USNM 563220 .

5. Inflated form. Length $32.9 \mathrm{~mm}$, height $26.8 \mathrm{~mm}$, thickness $24.5 \mathrm{~mm}$. Loc. 95a. USNM 563221.

6. Thin form. Length $35.5 \mathrm{~mm}$, height $25.7 \mathrm{~mm}$, thickness $4 \mathrm{~mm}$ (approximate). Loc. 149. USNM 563222.

7. Split-rib form. Length $25.4 \mathrm{~mm}$, height $19.3 \mathrm{~mm}$, thickness $14.2 \mathrm{~mm}$. Loc. 130. USNM 563223 .

8. Inflated form. Length $26 \mathrm{~mm}$ (incomplete), height $21.8 \mathrm{~mm}$, thickness $10.3 \mathrm{~mm}$. Loc. 95a. USNM 563224 .

9. Split-rib form. Length $43.3 \mathrm{~mm}$, height $34.9 \mathrm{~mm}$, thickness $14.0 \mathrm{~mm}$ (one valve). Loc. 102a. USNM 563225 .

10. Inflated form. Length $53 \mathrm{~mm}$ (incomplete), height $39 \mathrm{~mm}$ (incomplete), thickness $20 \mathrm{~mm}$ (incomplete). Loc. 99. USNM 563226.

11. "Anadara (Anadara) watanabei (Kanehara)"=Anadara (Anadara) devincta (Conrad) (p. 59).

Topotype. Length $43.0 \mathrm{~mm}$, height $33.2 \mathrm{~mm}$. Locality, Kokozura formation, Japan. USNM 563619.

12. Split-rib form. Length $65 \mathrm{~mm}$ (incomplete), height $45.4 \mathrm{~mm}$, thickness $21.4 \mathrm{~mm}$ (one valve). Loc. 112 . USNM 563227.

13. Inflated form. Length $67.3 \mathrm{~mm}$, height $49.9 \mathrm{~mm}$, thickness $28.3 \mathrm{~mm}$ (one valve). Loc. 116 . USNM 563228. 
GEOLOGICAL SURVEY
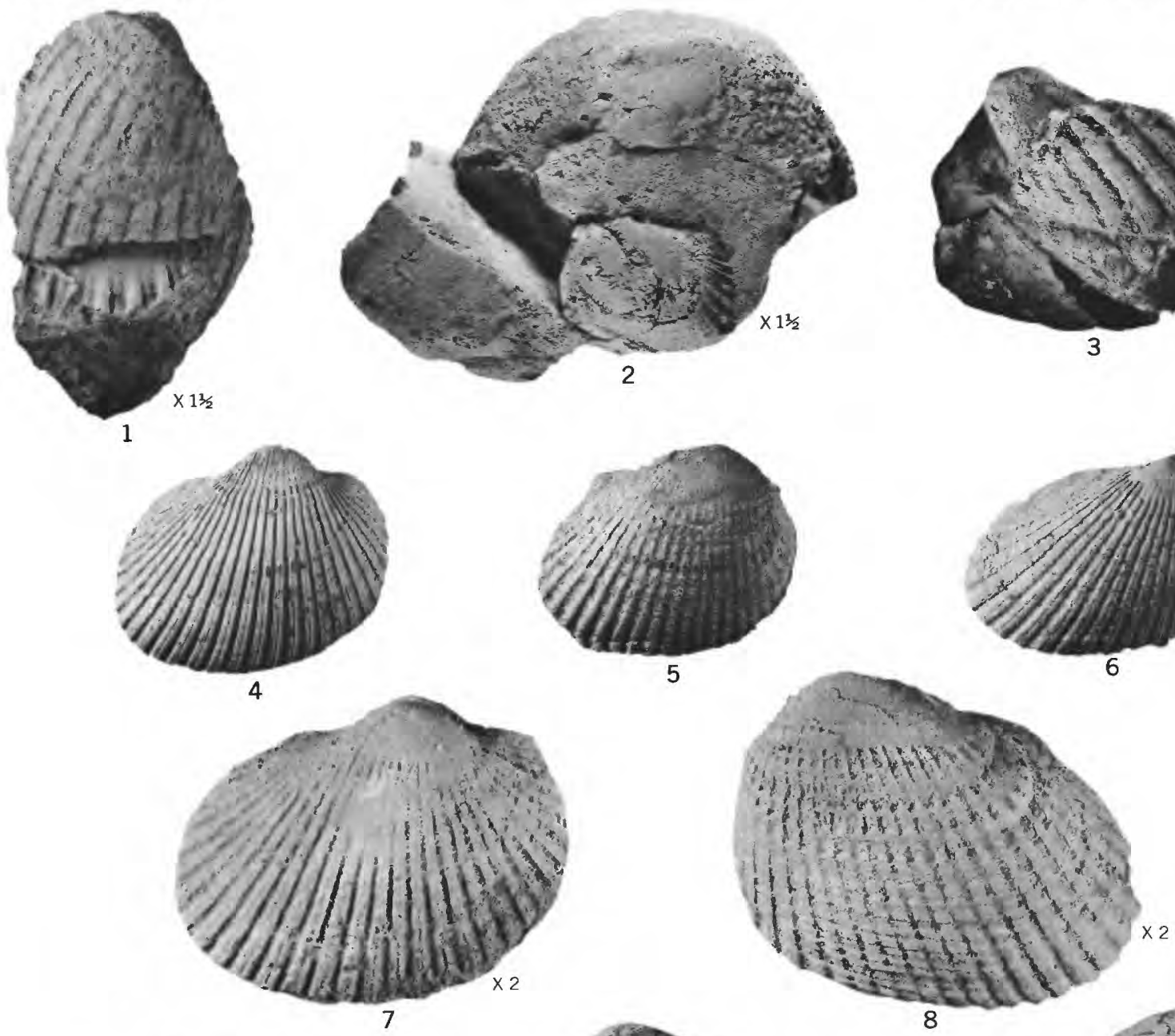
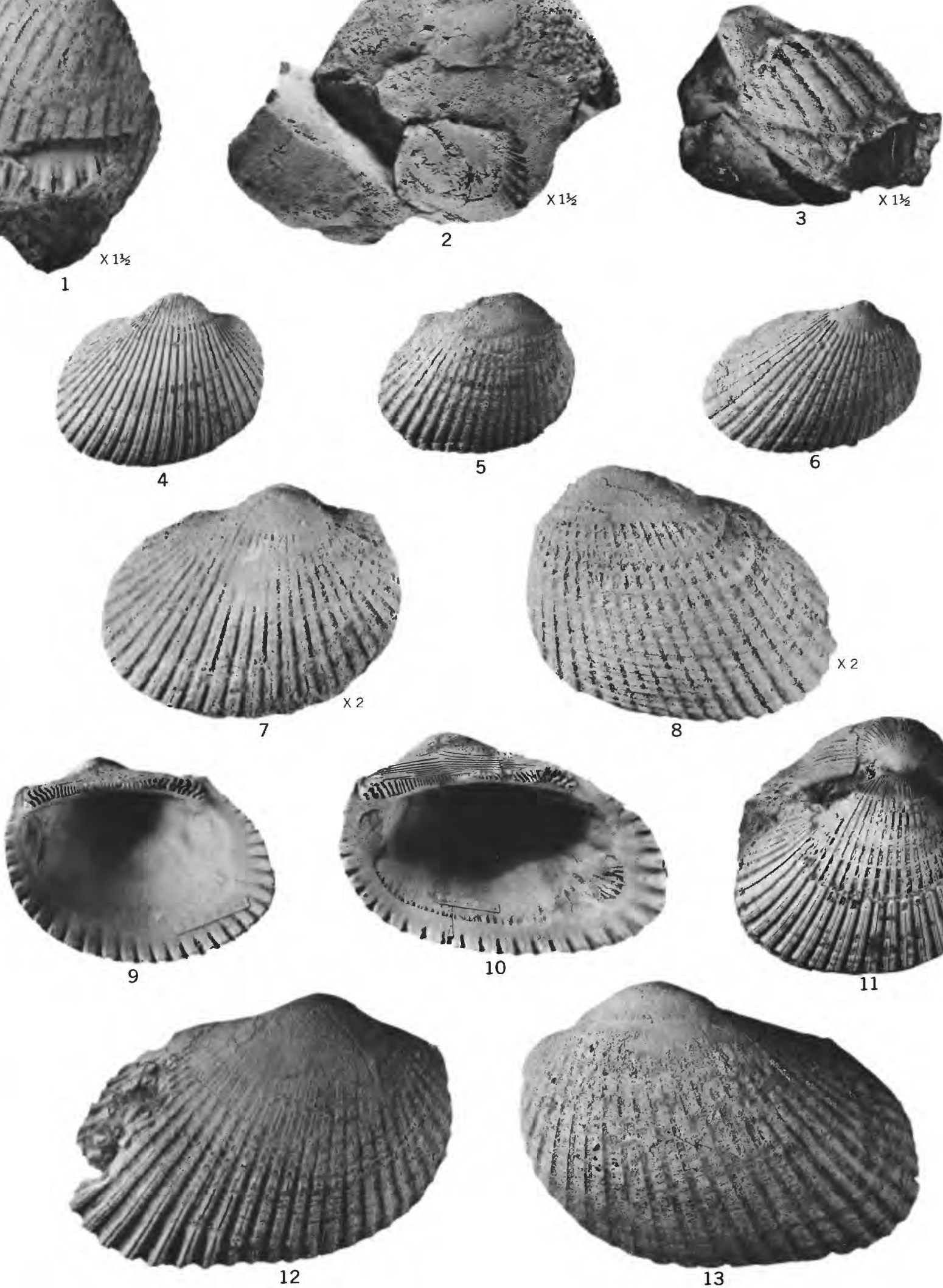

13

ANADARA 


\section{PLATE 15}

FIGURE 1, 11. Modiolus directus (Dall) (p. 63).

1. Length $61 \mathrm{~mm}$ (incomplete), height $29 \mathrm{~mm}$ (incomplete), thickness $11 \mathrm{~mm}$ (incomplete, one valve). Loc. 146. USNM 563229 .

11. Holotype. Length $150 \mathrm{~mm}$ (incomplete), height $38 \mathrm{~mm}$ (incomplete), thickness $31 \mathrm{~mm}$ (incomplete, both valves). Locality, Empire formation (Pliocene?), Coos Bay, Oreg. USNM 153947.

2, 5. Limopsis nitens (Conrad) (p. 61).

Lectotype. Length $7.6 \mathrm{~mm}$ (incomplete), height $7.5 \mathrm{~mm}$ (incomplete). Loc. 1a. USNM 3579.

3. Modiolus inflatus (Dall) (p. 63).

Lectotype. Length $49 \mathrm{~mm}$ (incomplete), height $28 \mathrm{~mm}$ (incomplete), thickness $24 \mathrm{~mm}$ (incomplete). Locality, Empire formation (Pliocene?), Coos Bay, Oreg. USNM 153946.

4. Mytilus sp. (p. 62)

Length $30 \mathrm{~mm}$ (incomplete), height $20 \mathrm{~mm}$ (incomplete). Loc. 144 . USNM 563230.

6. Crenella ef. C. porterensis Weaver (p. 63).

Length $13 \mathrm{~mm}$ (incomplete), height $16.5 \mathrm{~mm}$ (incomplete), thickness $8 \mathrm{~mm}$ (incomplete). Loc. 119. USNM 563231 .

7-10, 12. Lucinoma acutilineata (Conrad) (p. 70)

7. Loc. 187. USNM 563232.

8, 9. Lectotype. Length $37.3 \mathrm{~mm}$ (incomplete), height $35.2 \mathrm{~mm}$ (incomplete), thickness $16.7 \mathrm{~mm}$ (incomplete). Loc. 1a. USNM 3519.

10. Loc. 92. USNM 563233.

12. Holotype of "Pectunculus patulus Conrad" =Lucinoma acutilineata (Conrad) (p. 70). Length $39 \mathrm{~mm}$ (incomplete), height $31 \mathrm{~mm}$ (incomplete), thickness $19 \mathrm{~mm}$ (incomplete, both valves). Loc. 1a. USNM 3605 . 
GEOLOGICAL SURVEY

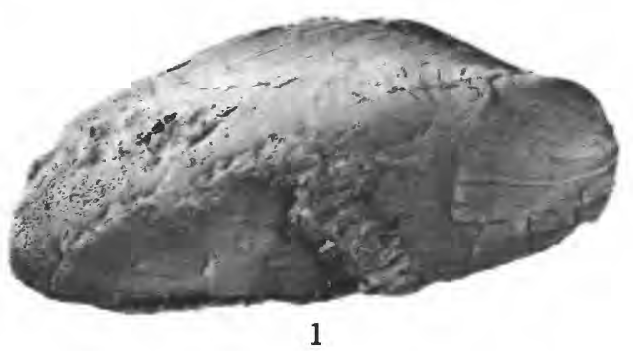

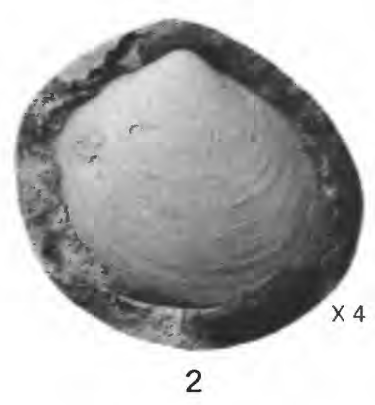

PROFESSIONAL PAPER 419 PLATE 15
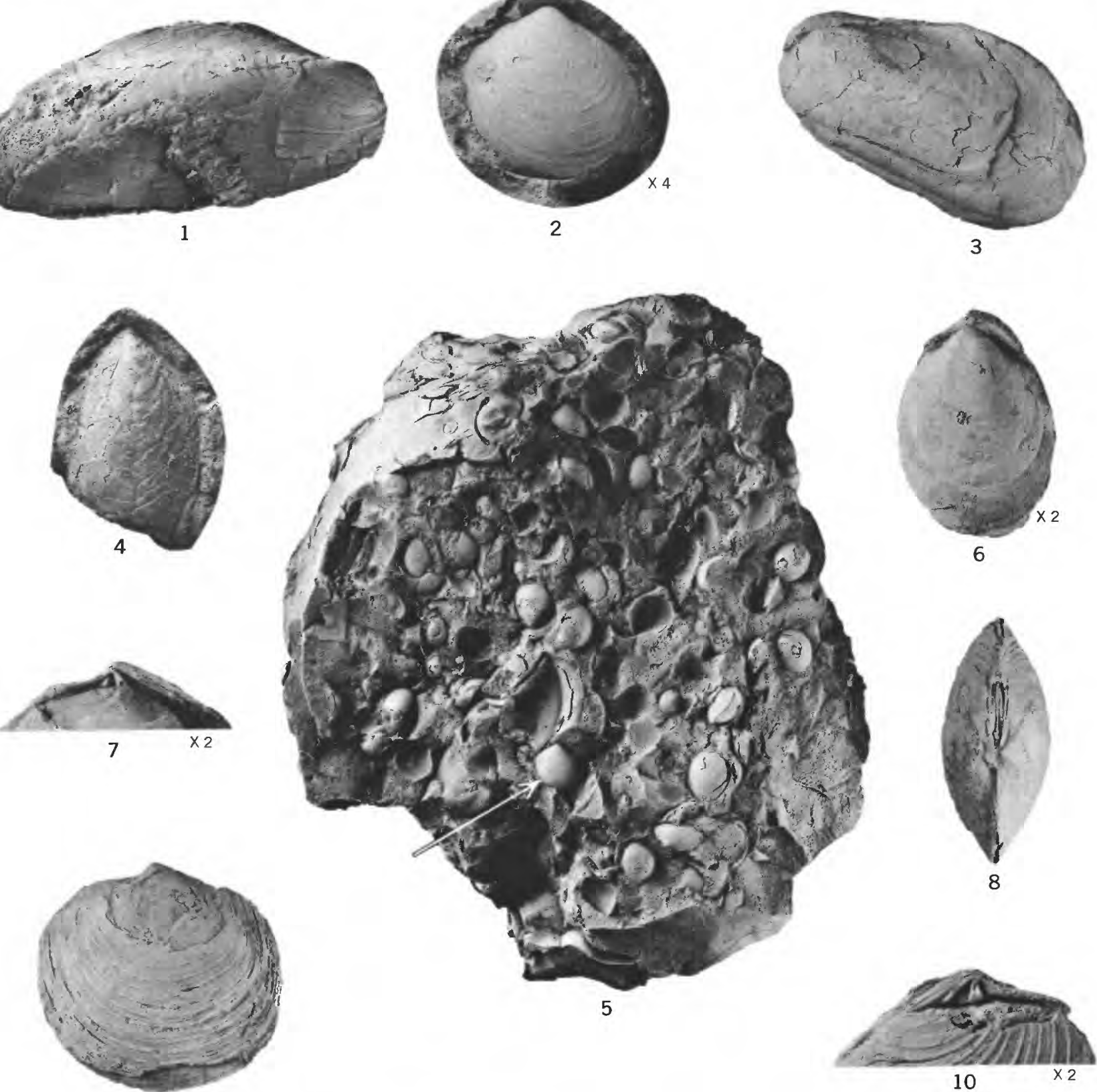

9

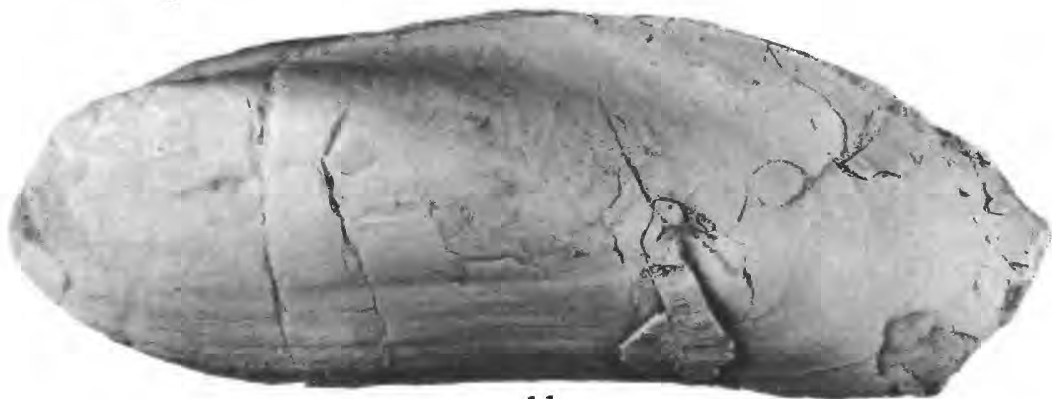

11

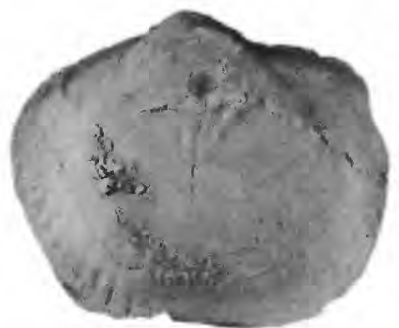

12

MODIOLUS, LIMOPSIS, MYTILUS, CRENELLA, AND LUCINOMA 


\section{PLATE 16}

Figure 1-4. Patinopecten propatulus (Conrad) (p. 64).

1. Lectotype. Left valve. Length $102 \mathrm{~mm}$ (incomplete), height $103 \mathrm{~mm}$ (incomplete). Loc. 1a. USNM 3504.

2. Enlarged part of a left valve near middle of valve showing imbricated lamellar microsculpture. Loc. 79. USNM 563234.

3. Left valve. Imbricated lamellar microsculpture on anterior ear and between ribs near ventral margin. Length $17 \mathrm{~mm}$ (incomplete), height $18 \mathrm{~mm}$ (incomplete), width of left valve $2.6 \mathrm{~mm}$. Loc. 59 . USNM 563235 .

4. Lectotype. Right valve. Length $102 \mathrm{~mm}$ (incomplete), height $103 \mathrm{~mm}$ (incomplete). Loc. 1a. USNM 3504. 


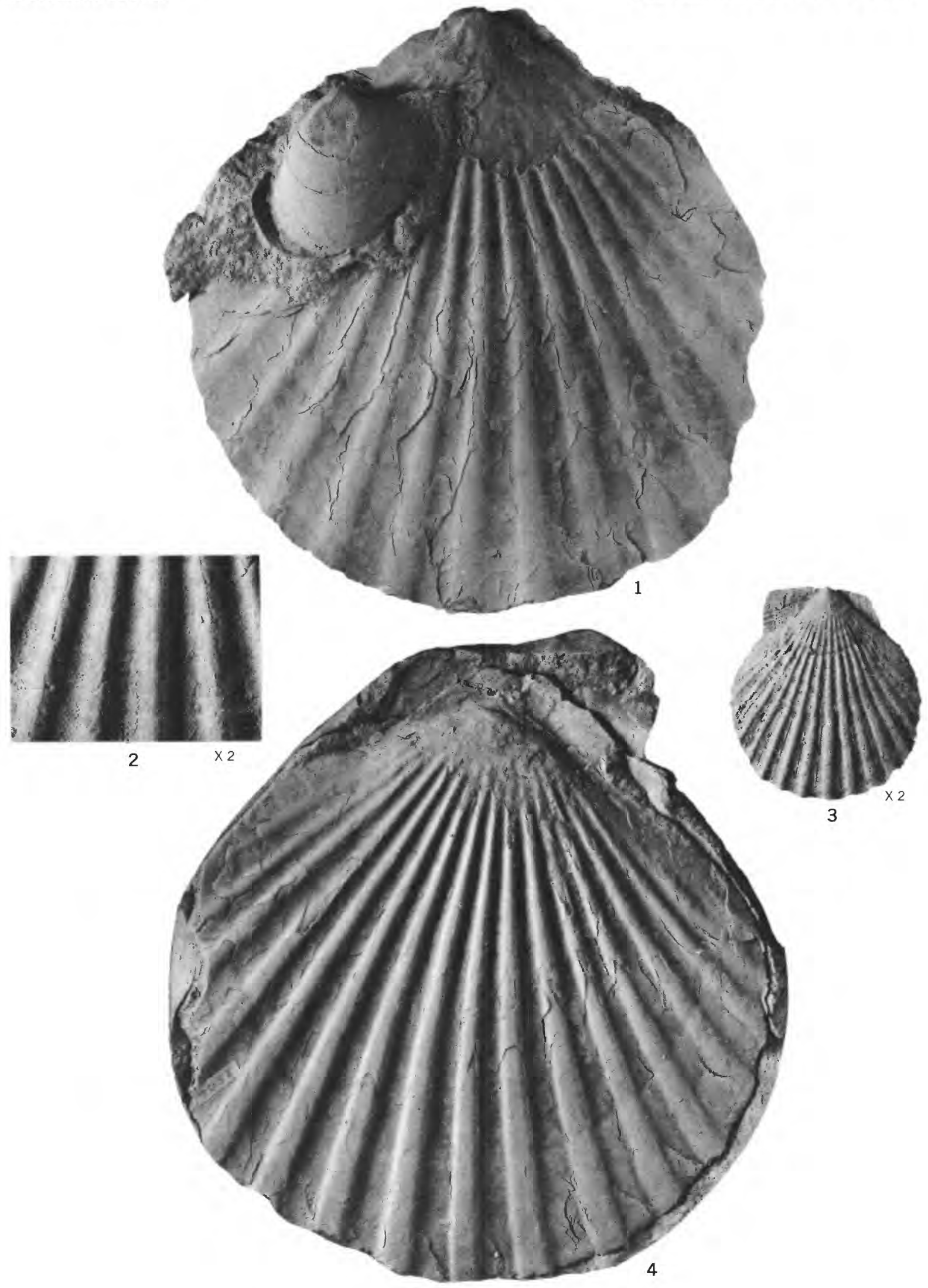




\section{PLATE 17}

FigurE 1. Aequipecten andersoni clemonensis Etherington (p. 67).

Length $28 \mathrm{~mm}$ (incomplete), height $25 \mathrm{~mm}$ (incomplete), thickness $3.9 \mathrm{~mm}$ (right valve only). Loc. 69a. USNM 563240.

2-5, 7. Patinopecten propatulus (Conrad) (p. 64).

2, 7. Length $75 \mathrm{~mm}$ (incomplete), height $71 \mathrm{~mm}$, thickness $13.2 \mathrm{~mm}$ (both valves). Loc. 104. USNM 563238.

3. Length $75 \mathrm{~mm}$ (incomplete), height $77 \mathrm{~mm}$ (incomplete). Loc. 104 . USNM 563236.

4. Enlargement showing lamellae on first three posterior ribs and imbricated microsculpture on left posterior ear. Specimen incomplete. Loc. 104. USNM 563618.

5. Loc. 100. USNM 563237.

6, 8, 9. Patinopecten oregonensis cancellosus (Moore,) n. subsp. (p. 65).

Paratype. Length $44 \mathrm{~mm}$ (incomplete), height $47 \mathrm{~mm}$ (incomplete), thickness $11.8 \mathrm{~mm}$ (both valves). Loc. 187. USNM 563239.

6. Left valve. Imbricated, lamellar microsculpture at ventral ends of ribs.

8. Right valve.

9. Ventral edge. 

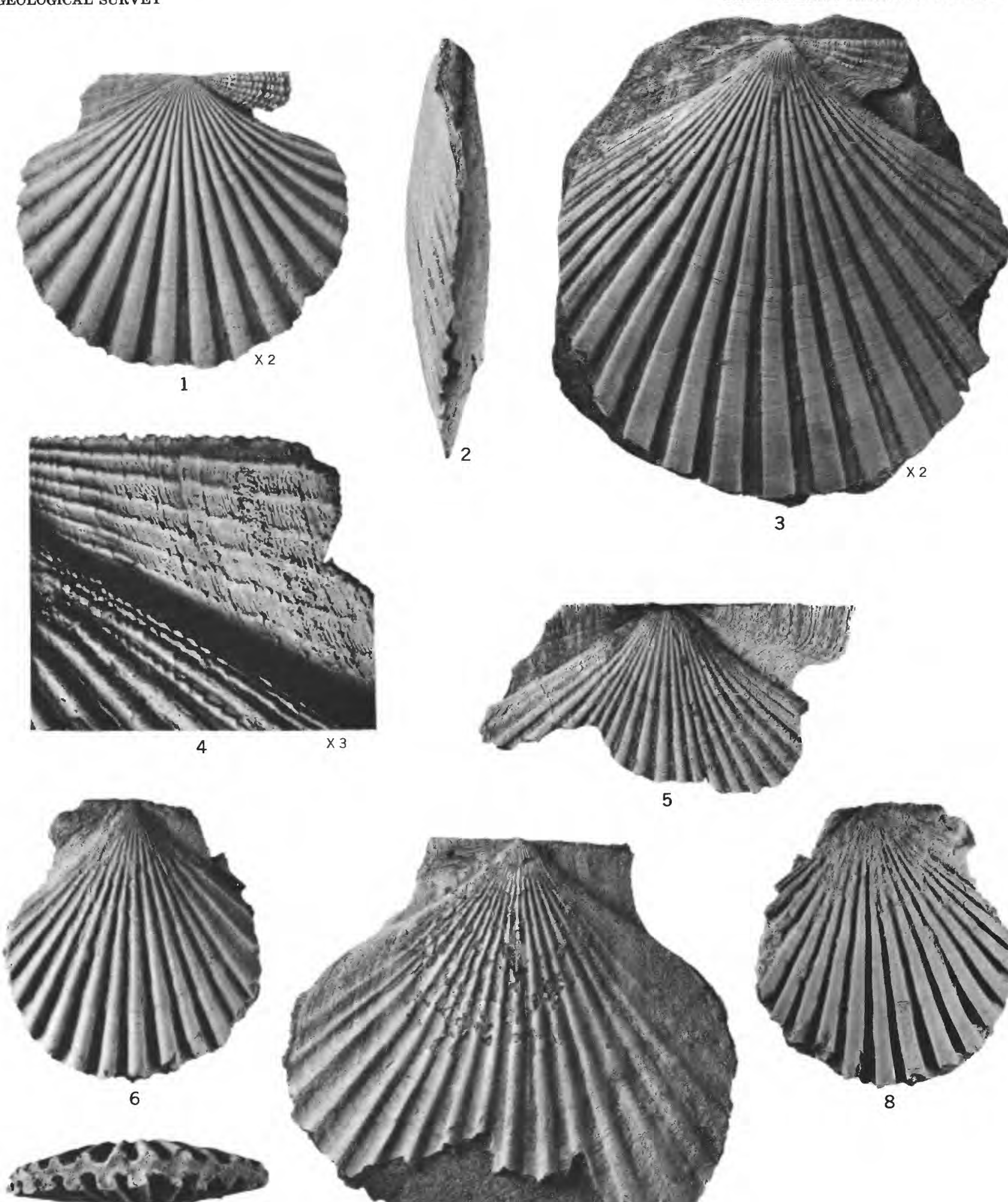

9
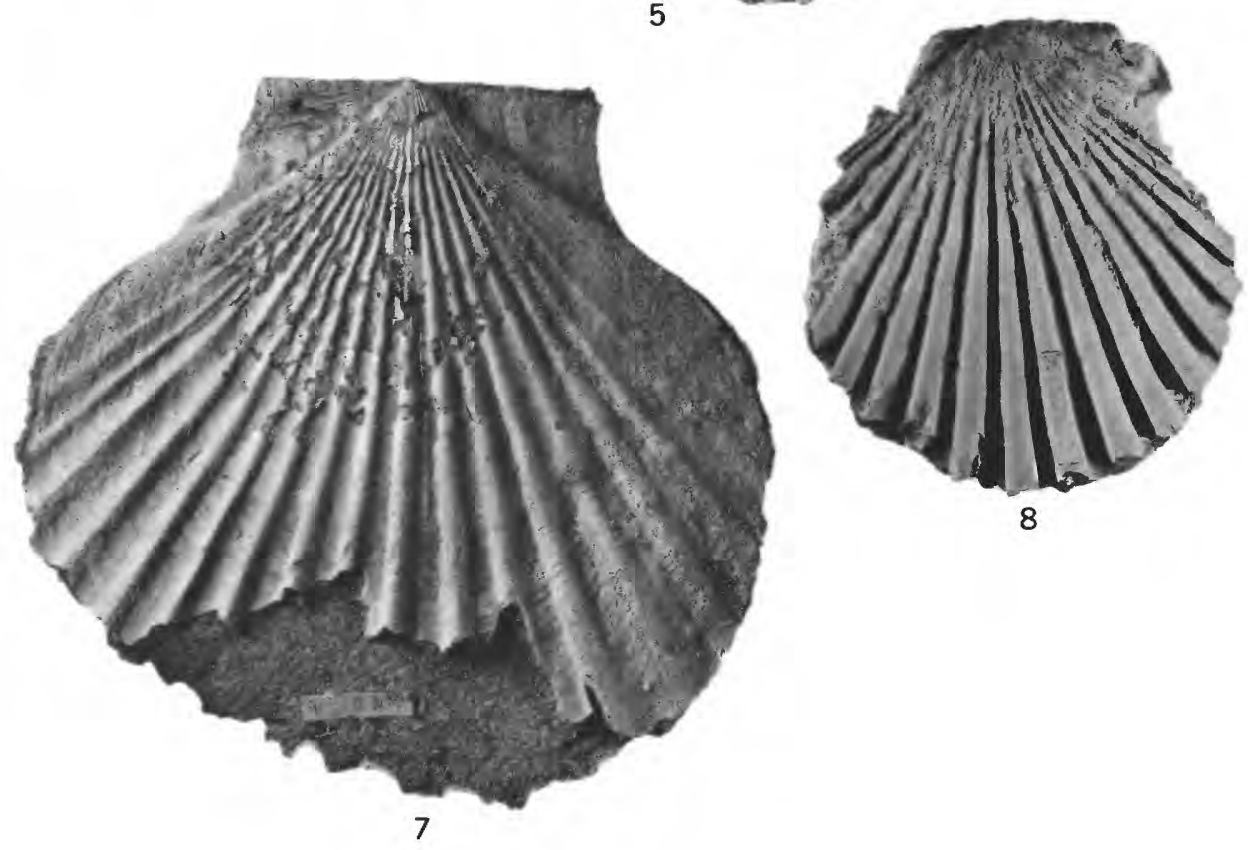

AEQUIPECTEN AND PATINOPECTEN 


\section{PLATE 18}

Figure 1, 4. Patinopecten oregonensis cancellosus (Moore,) n. subsp. (p. 65).

1. Left valve. Length $116 \mathrm{~mm}$ (incomplete). Loc. 187. USNM 563241.

4. Holotype, right valve. Length $113 \mathrm{~mm}$ (incomplete), height $110 \mathrm{~mm}$ (incomplete). Loc. 187. USNM 563242. 2,3. Delectopecten peckhami (Gabb) of Arnold (p. 67).

2. Left valve. Length $10 \mathrm{~mm}$ (incomplete), height $11.5 \mathrm{~mm}$ (incomplete). Loc. 43 . USNM 563243.

3. Right valve. Length $14 \mathrm{~mm}$ (incomplete), height $16 \mathrm{~mm}$ (incomplete). Loc. 1c. USNM 563244. 


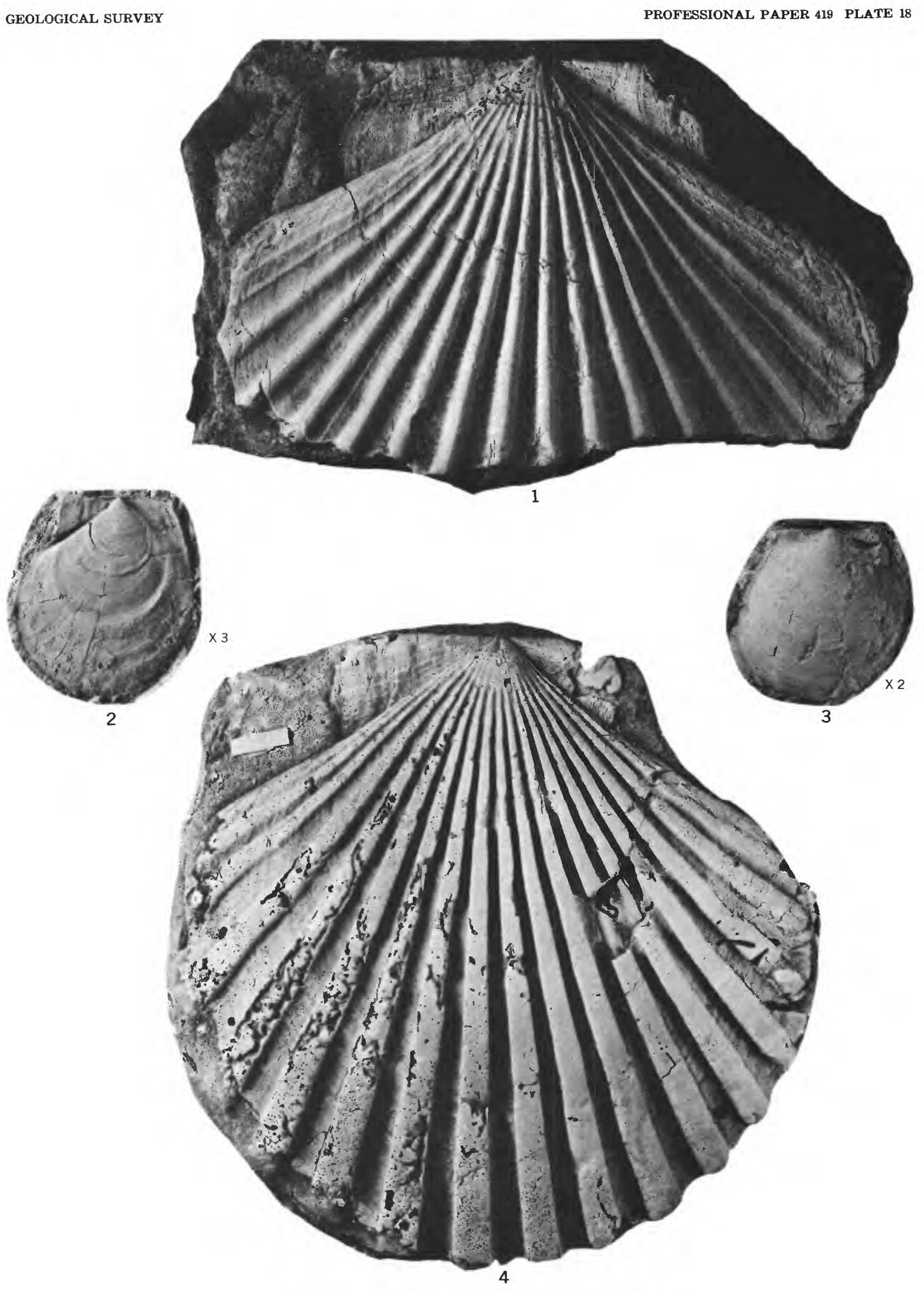

PATINOPECTEN AND DELECTOPECTEN 


\section{PLATE 19}

Figtre 1, 2. Vertipecten fucanus (Dall) (p. 66).

1. Latex impression of holotype. Left valve. Length $81.8 \mathrm{~mm}$ (incomplete), height $84.3 \mathrm{~mm}$ (incomplete), thickness $12 \mathrm{~mm}$ (approximate, one valve). Locality, "Astoria" formation, Clallam Bay, Wash. USNM 107790 .

2. Holotype. Left valve. Length $81.8 \mathrm{~mm}$ (incomplete), height $84.3 \mathrm{~mm}$ (incomplete), thickness $12 \mathrm{~mm}$ (approximate, incomplete, one valve). Locality, "Astoria" formation, Clallam Bay, Wash. USMN 107790.

3. Vertipecten? ef. V. fucanus (Dall) (p. 67).

Right valve. Length $142 \mathrm{~mm}$ (incomplete), height $131 \mathrm{~mm}$ (incomplete), thickness $36 \mathrm{~mm}$ (incomplete). Locality, Memaloosa Point, Tillamook Bay, Oreg. Calif. Acad. Science 12115. 

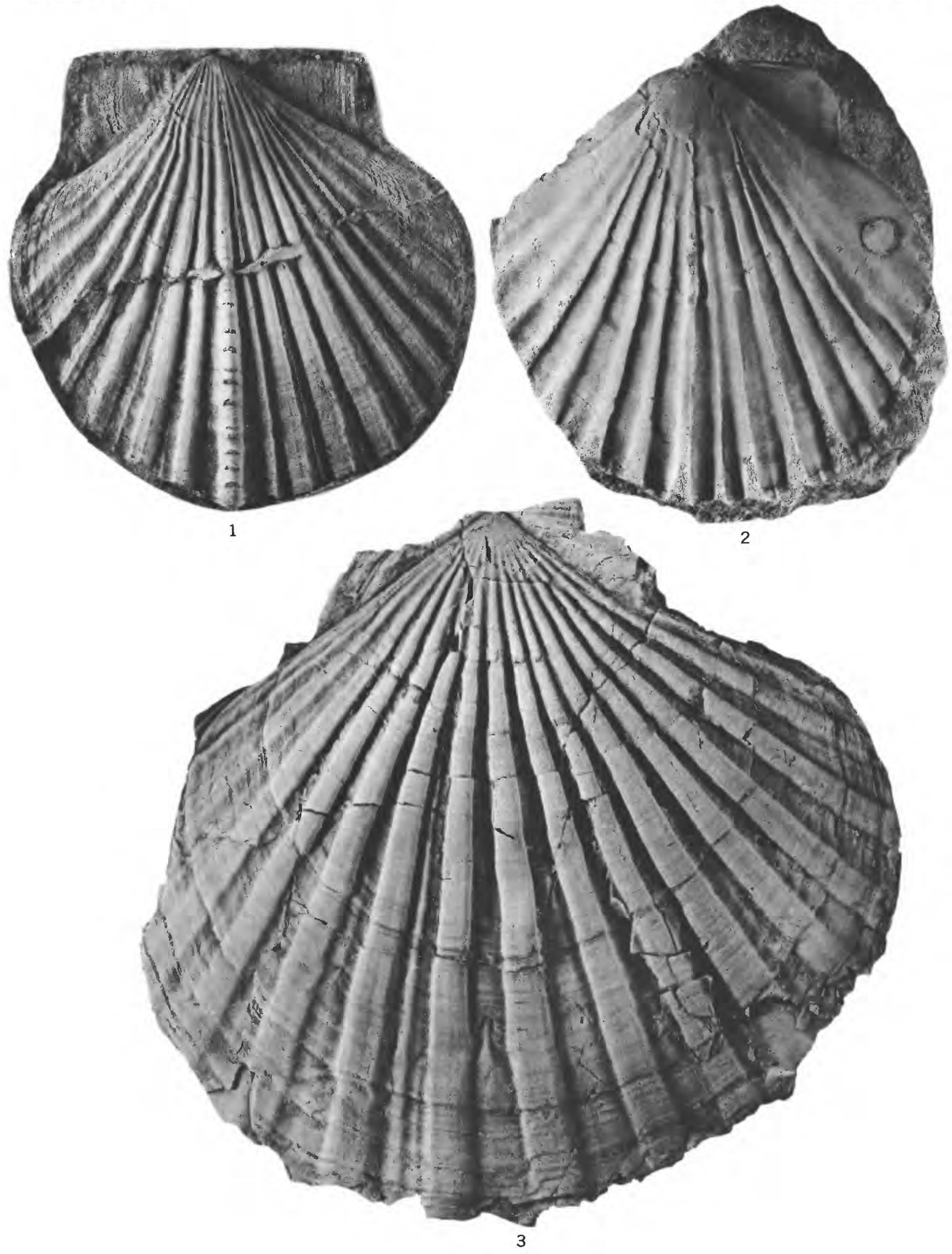

VERTIPECTEN AND VERTIPECTEN? 


\section{PLATE 20}

Figure 1, 3-5. Delectopecten peckhami (Gabb) or Arnold (p. 67).

1. Right valve. Length $24 \mathrm{~mm}$ (incomplete), height $24 \mathrm{~mm}$ (incomplete). Loc. 27 . USNM 563248.

3. Interior of right valve. Loc. 43 . USNM 563246.

4. One of specimens on rock figured by Arnold (1906, pl. 3, fig. 8) : see pl. 21, fig. 2. Right valve. Length $13 \mathrm{~mm}$ (incomplete), height $13 \mathrm{~mm}$ (incomplete). Loc., USGS 2593, southeast of Pinola, Contra Costa County, Calif. USNM 164839.

5. Interior of left valve. Length $12 \mathrm{~mm}$ (incomplete), height $14.1 \mathrm{~mm}$. Loc. $43 . \quad$ USNM 563247.

6. Propeamusium cf. P. clallamensis (Arnold) (p. 68).

Right valve. Length $8.5 \mathrm{~mm}$ (incomplete), height $7.7 \mathrm{~mm}$ (incomplete). Loc. 13. USNM 563248.

2, 7. Propeamusium clallamensis (Arnold) (p. 68).

2. Paratype. Mold of exterior of right valve. Length $9 \mathrm{~mm}$ (incomplete), height $8 \mathrm{~mm}$ (incomplete). Loc., USGS 4070, point opposite Seattle, in King County, Wash. (Blakeley formation). USNM 164923.

7. Paratype. Left valve. Length $6 \mathrm{~mm}$ (incomplete), height $7 \mathrm{~mm}$ (incomplete). Loc., USGS 4100, Mouth of Pysht River, Clallam County, Wash. (Blakeley formation). USNM 164922.

8. Vertipecten fucanus (Dall) (p. 66).

Left valve. Length $126 \mathrm{~mm}$ (incomplete), height $130 \mathrm{~mm}$ (incomplete), thickness $36 \mathrm{~mm}$ (incomplete, both valves). Loc. 2 . USNM 563249. 


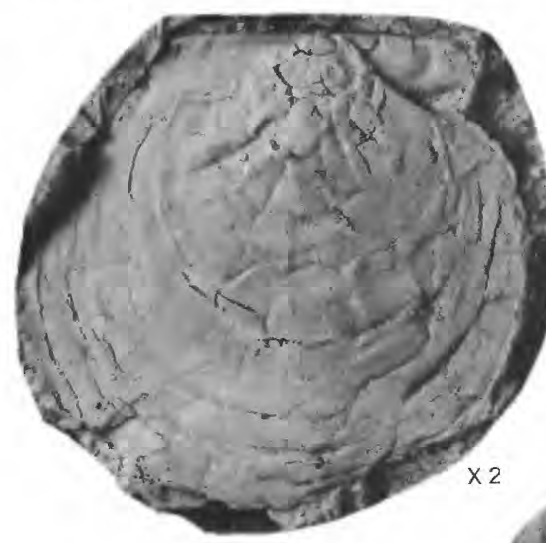

1
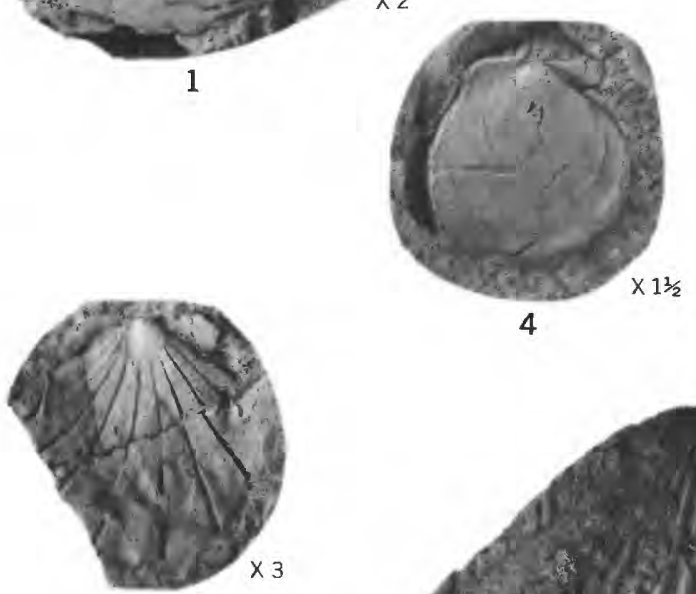

6
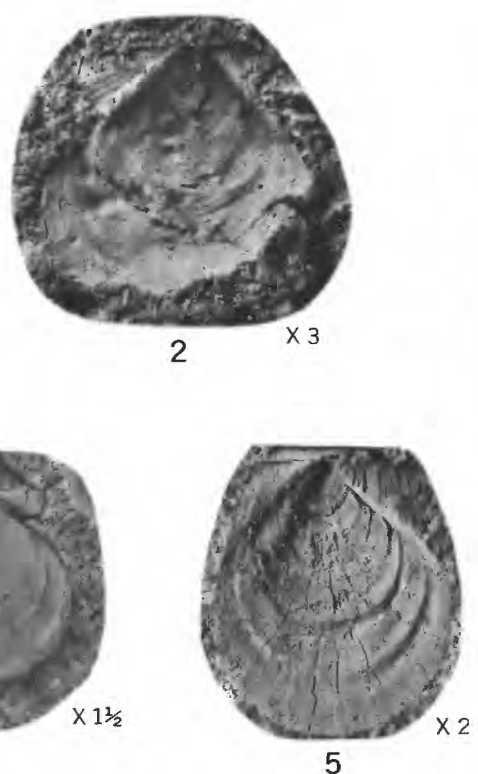

4

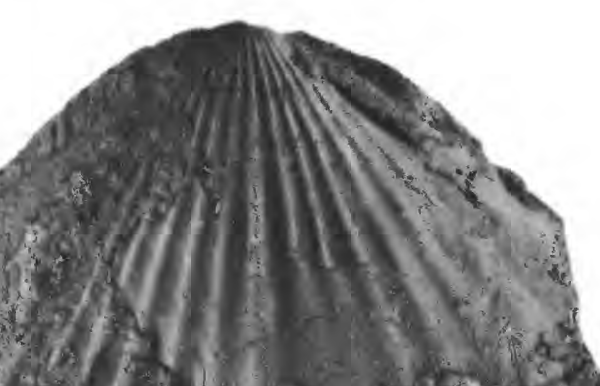

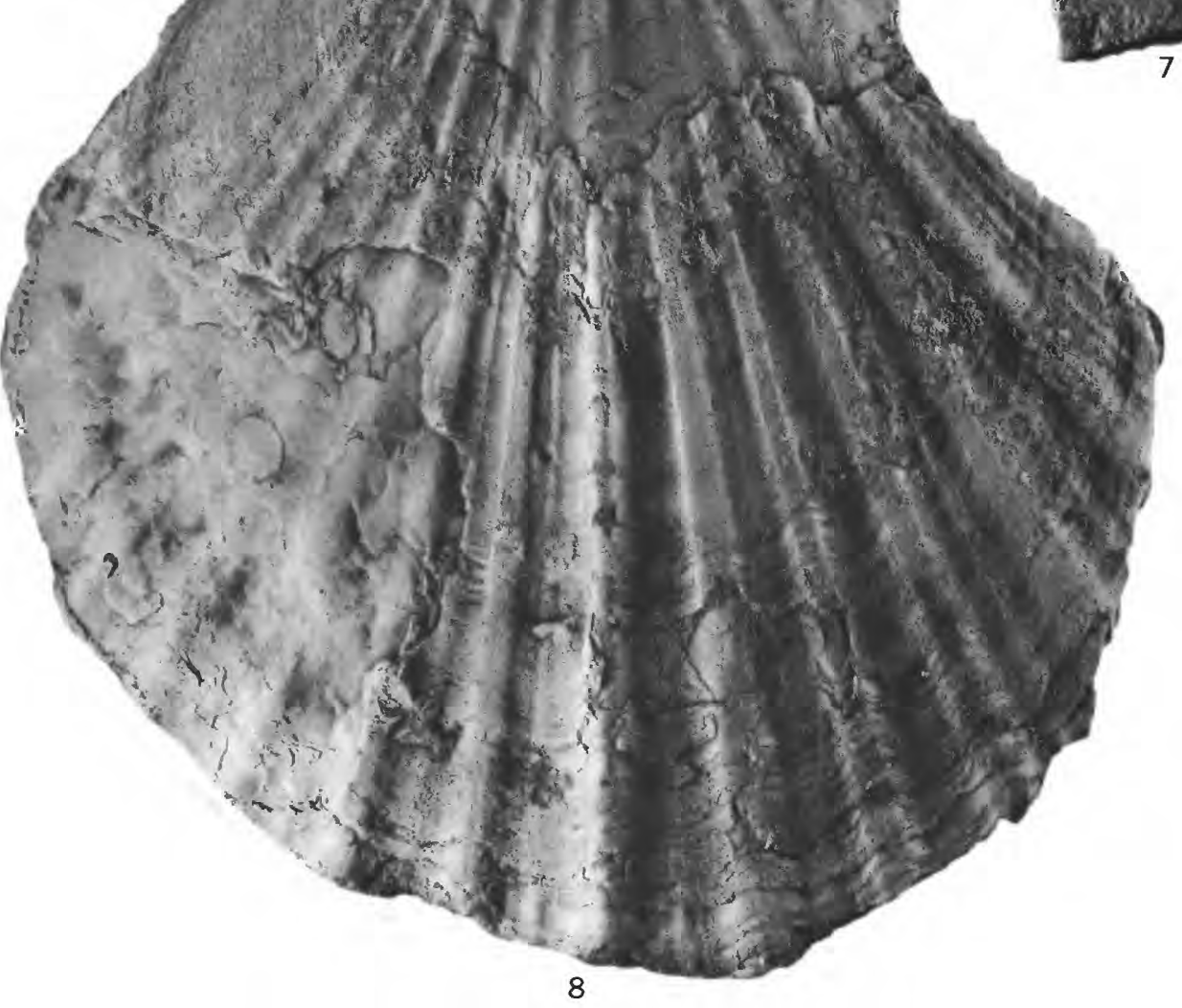
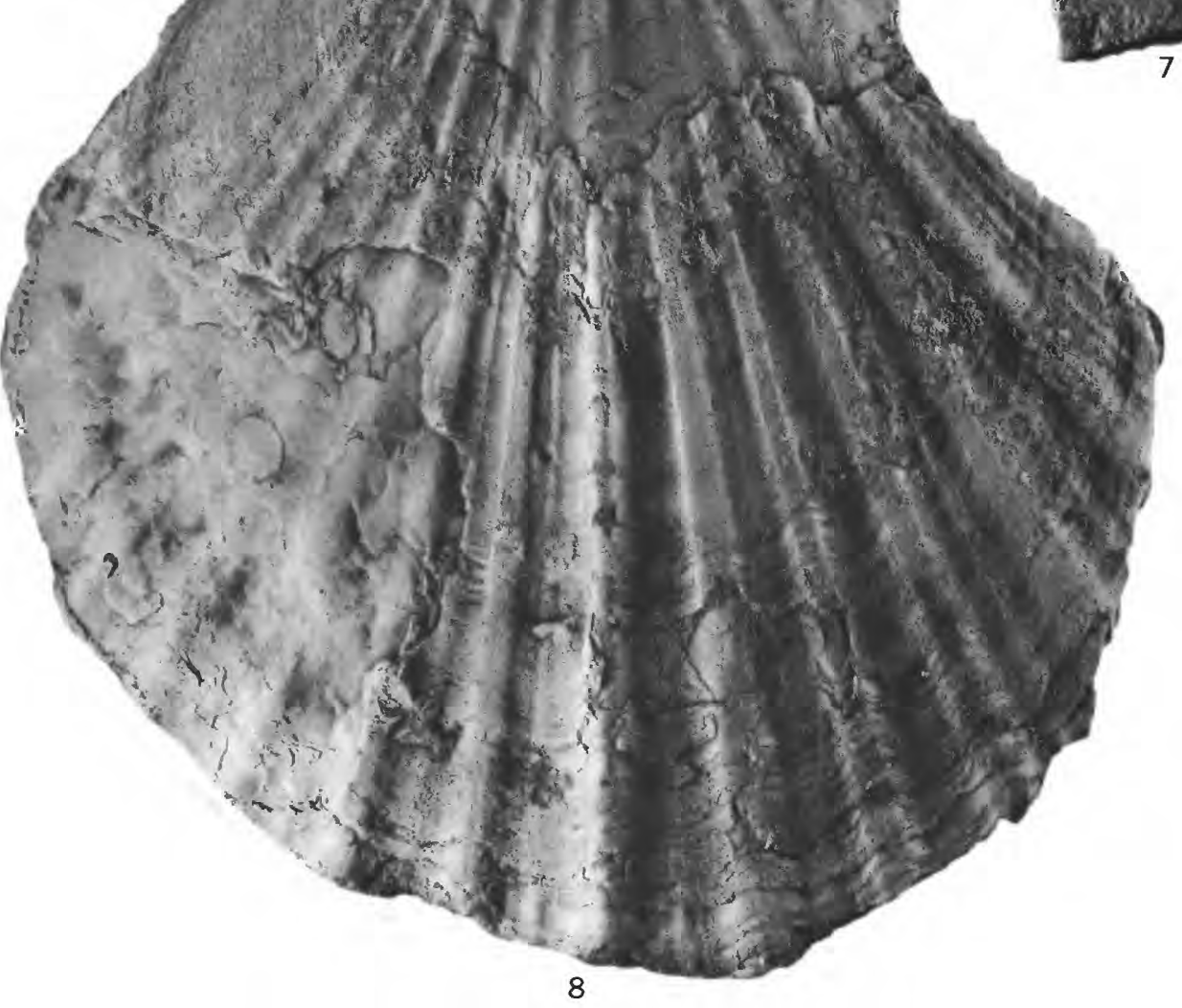
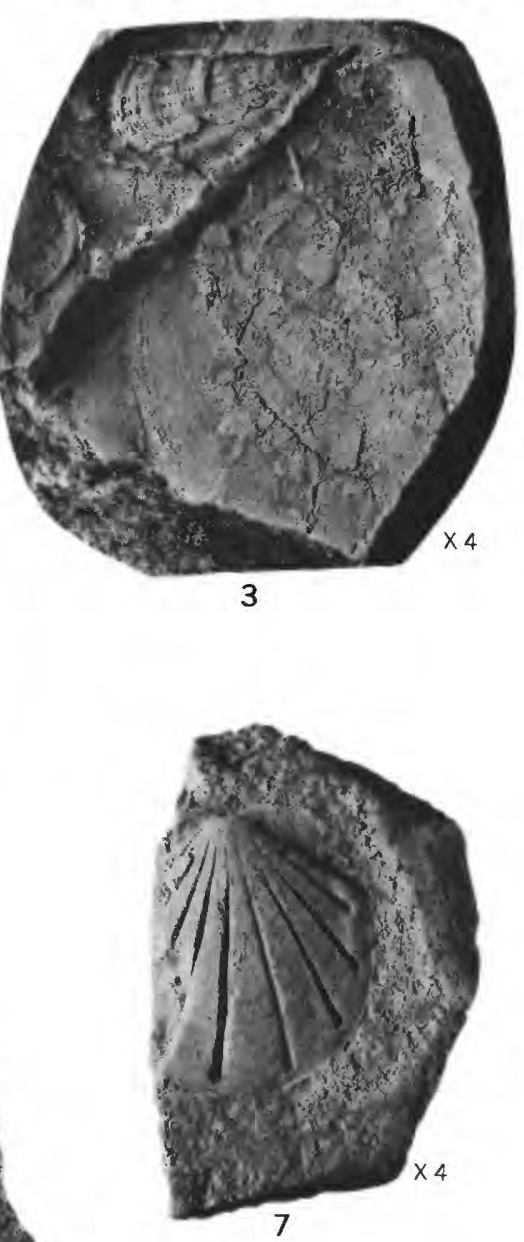

DELECTOPECTEN, PROPEAMUSIUM, AND VERTIPECTEN 


\section{PLATE 21}

Figure 1, 3. Vertipecten fucanus (Dall) (p. 66).

1. Left valve. Length $108 \mathrm{~mm}$ (incomplete), height $111 \mathrm{~mm}$ (incomplete), thickness $23 \mathrm{~mm}$ (incomplete). Loc. 181a. USNM 563250.

3. Right valve. Length $56 \mathrm{~mm}$ (incomplete), height $57 \mathrm{~mm}$ (incomplete), thickness $17 \mathrm{~mm}$ (incomplete, both valves). Loc. 181a. USNM 563251.

2. Delectopecten peckhami (Gabb) of Arnold (p. 67).

(Figured by Arnold, 1996, pl. 3, fig. 28). Loc., USGS 2593, southeast of Pinnole, Contra Costa County, Calif. USNM 164839.

4. Vertipecten cf. V. fucanus (Dall) (p. 67).

Right valve. Length $99 \mathrm{~mm}$ (incomplete), height $112 \mathrm{~mm}$ (incomplete). Locality, 2 miles north of Yaquina Head, Lincoln County, Oreg. Calif. Acad. Science 12132.

5. Paramusium astoriana Moore, n. sp. (p. 68).

Right valve. Length $38 \mathrm{~mm}$ (incomplete), height $41 \mathrm{~mm}$ (incomplete). Loc. 20. USNM 563252. 


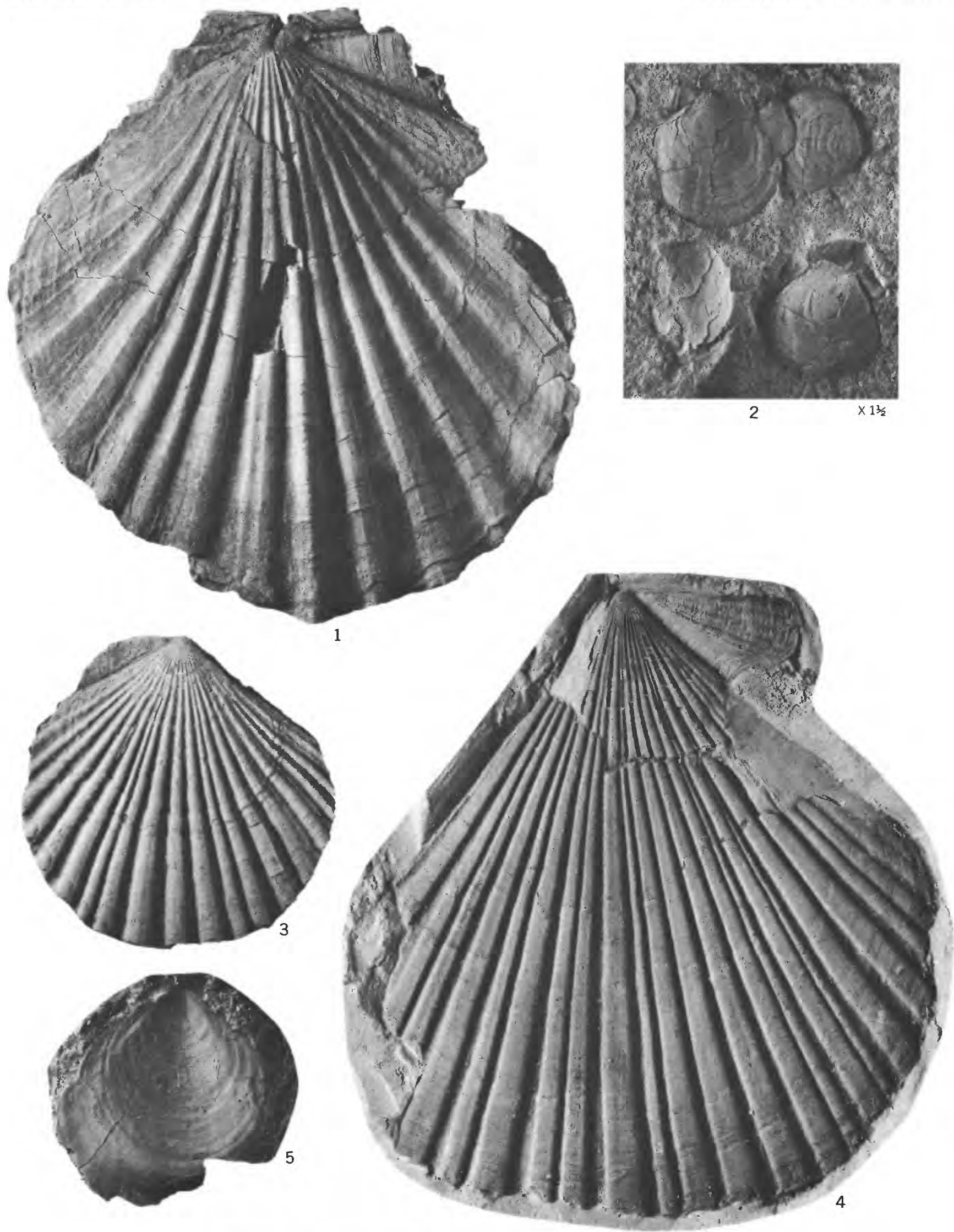

VERTIPECTEN, DELECTOPECTEN, AND PARAMUSIUM 


\section{PLATE 22}

FiguRe 1, 4. Vertipecten fucanus (Dall) (p. 66).

1. Left valve. [Figured by Arnold, 1906, pl. 9, figs. 2, 2a, as cotype of Patinopecten propatulus (Conrad).] Shows imbricated lamellar microsculpture. Loc. 1a. USNM 3558.

4. Right valve. [Figured by Arnold, 1906, pl. 9, figs. 1, 1a, as cotype of Patinopecten propatulus (Conrad).] Loc. 1a. USNM 3558.

2, 3, 5. Paramusium astoriana (Moore), n. sp. (p. 68).

2. Holotype. Left valve. Length $27 \mathrm{~mm}$ (incomplete), height $28 \mathrm{~mm}$ (incomplete). Loc. 10 . USNM 563253.

3. Left valve. Length $28 \mathrm{~mm}$ (incomplete), height $25 \mathrm{~mm}$ (incomplete). Loc. 10 . USNM 563254 .

5. Paratype. Left valve. Length $50 \mathrm{~mm}$ (incomplete), height $50 \mathrm{~mm}$ (incomplete). Loc. 19. USNM 563255. 


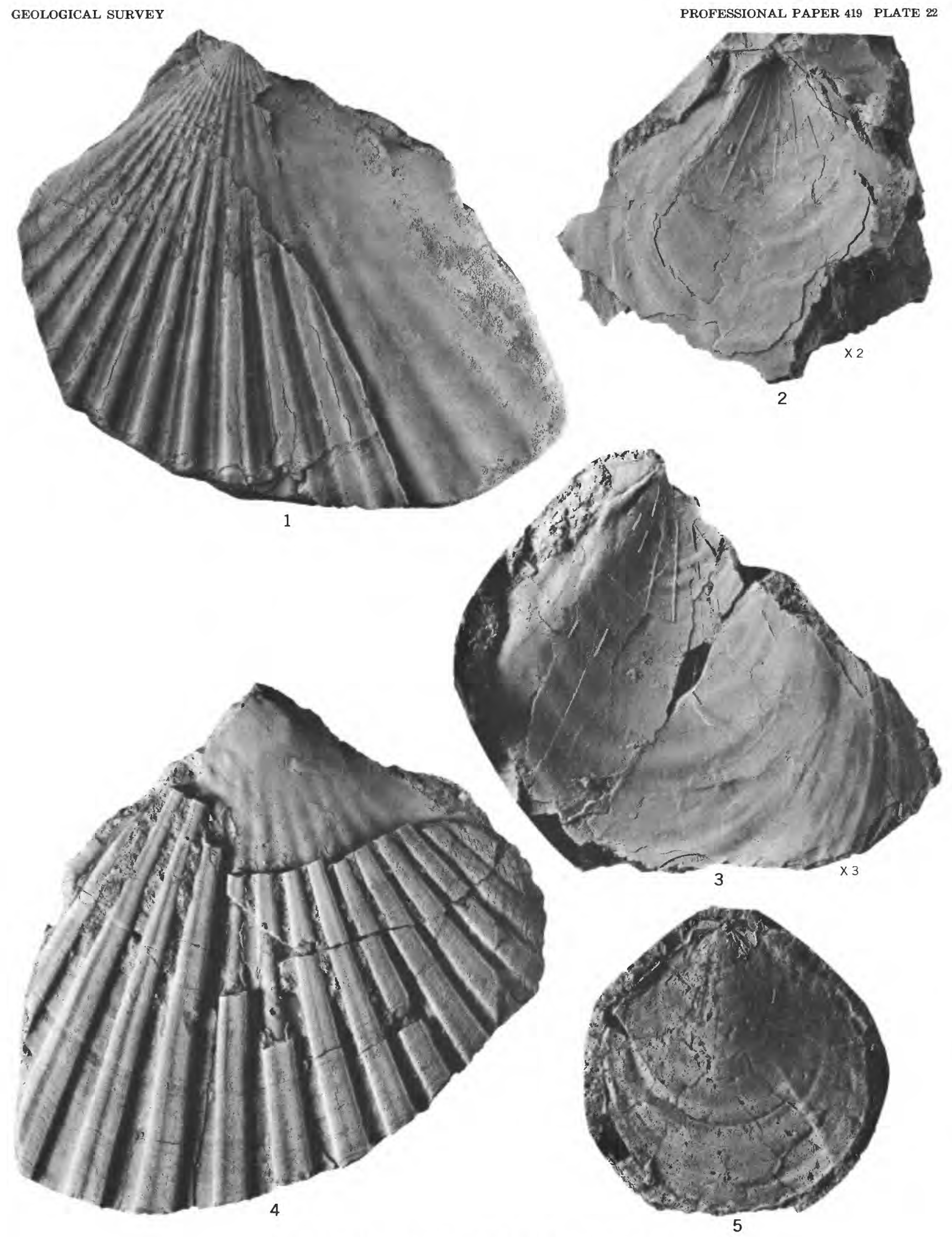

VERTIPECTEN AND PARAMUSIUM 


\section{PLATE 23}

Figure 1-5, 10, 12, 13. Cyclocardia subtenta (Conrad) (p. 69).

1. Length $10 \mathrm{~mm}$, height $9 \mathrm{~mm}$ (incomplete), thickness $3.7 \mathrm{~mm}$ (one valve). Loc. 109. USNM 563256.

2. Length $13.5 \mathrm{~mm}$ (incomplete), height $12.5 \mathrm{~mm}$ (incomplete). Loc. 109 . USNM 563257.

3 , 10. Length $22 \mathrm{~mm}$ (incomplete), height $21 \mathrm{~mm}$ (incomplete), thickness $7 \mathrm{~mm}$ (one valve). Locality, corner of 5th and Commercial St., Astoria, Oreg. Calif. Acad. Sci. 12124.

4. Length $10 \mathrm{~mm}$ (incomplete), height $9.7 \mathrm{~mm}$ (incomplete), thickness $3.5 \mathrm{~mm}$ (one valve). Loc. 109. USNM 563258.

5, 13. Lectotype. Length $15.5 \mathrm{~mm}$ (incomplete), height $15.9 \mathrm{~mm}$ (incomplete), thickness $10.5 \mathrm{~mm}$ (incomplete, both valves). Loc. 1a. USNM 3502.

12. Length $19 \mathrm{~mm}$ (incomplete), height $17 \mathrm{~mm}$ (incomplete), thickness $12 \mathrm{~mm}$ (incomplete, both valves). Loc. 174. USNM 563260.

6. Diplodonta parilis (Conrad) of Dall (p. 71).

Length $25 \mathrm{~mm}$ (incomplete), height $22 \mathrm{~mm}$ (incomplete). Loc., USGS 2954, Empire formation, Pliocene(?), Coos Bay, Oreg. USNM 153930.

7. Cyclocardia castor (Dall) (p. 70).

Holotype. Length $25 \mathrm{~mm}$ (incomplete), height $26 \mathrm{~mm}$ (incomplete). Loc., USGS 4102, Clallam County, Wash. (Blakeley formation). USNM 153936.

8, 14, 15. Thyasira bisecta (Conrad) (p. 72).

8. Holotype. Length $46.5 \mathrm{~mm}$ (incomplete), height $38.9 \mathrm{~mm}$ (incomplete), thickness $24.9 \mathrm{~mm}$ (incomplete). Loc. 1a. USNM 3518.

14, 15. Paratype. Length $58.3 \mathrm{~mm}$ (incomplete), height $53 \mathrm{~mm}$ (incomplete), $38.9 \mathrm{~mm}$ (incomplete). Loc. 1a. USNM 563440.

9. Diplodonta parilis (Conrad) (p. 71).

Holotype. Length $14.3 \mathrm{~mm}$ (incomplete), height $13.6 \mathrm{~mm}$ (incomplete). Loc. 1a. Acad. Nat. Sci. Philadelphia 4546.

11. Solen curtus Conrad $=$ Solen conradi Dall (p. 82).

Holotype. Length $29.5 \mathrm{~mm}$, height $8 \mathrm{~mm}$ (incomplete). Loc. 1a. Acad. Nat. Sci. Philadelphia 4546. 16. Cyclocardia subtenta quadrata (Dall) (p. 70).

Lectotype. Length $27 \mathrm{~mm}$ (incomplete), height $27 \mathrm{~mm}$ (incomplete), thickness $18 \mathrm{~mm}$ (incomplete, both valves). Loc. USGS 2954, Empire formation, (Pliocene?) Coos Bay, Oreg. USNM 153؟36a. 
GEOLOGICAL SURVEY

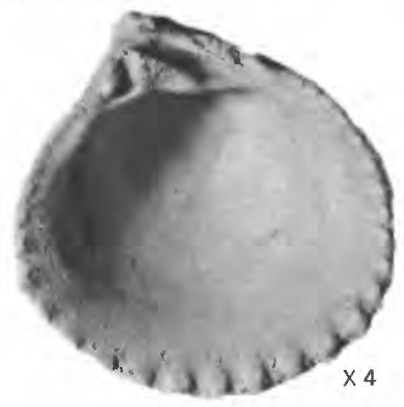

1
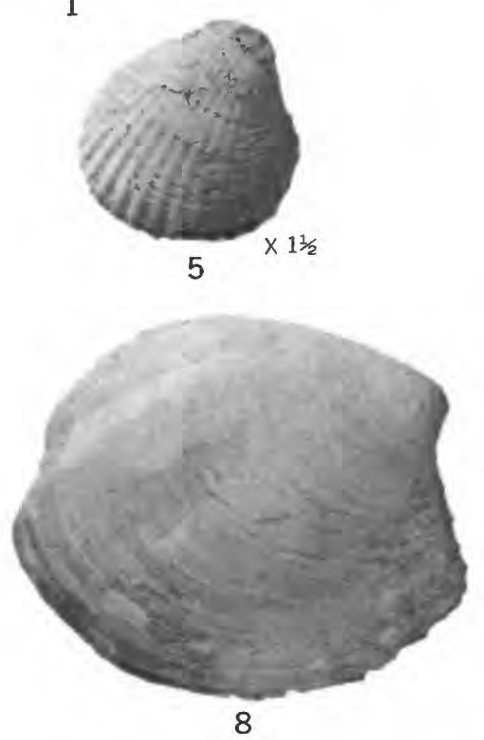

PROFESSIONAL PAPER 419 PLATE 23
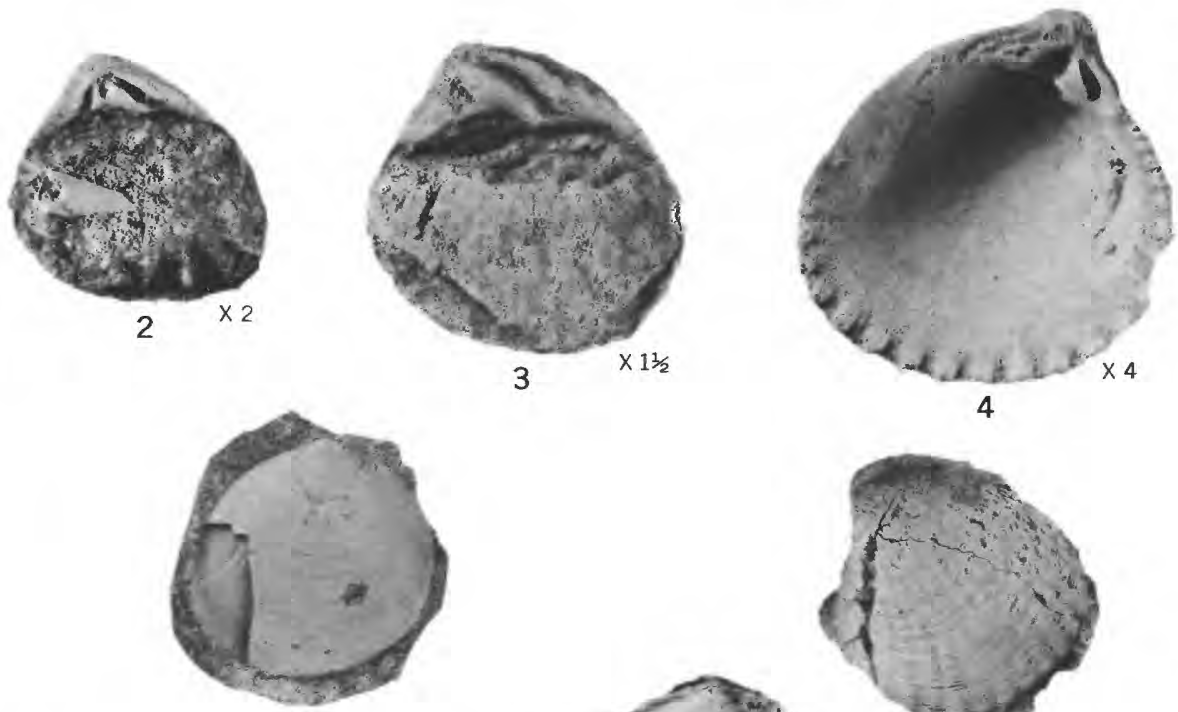

6
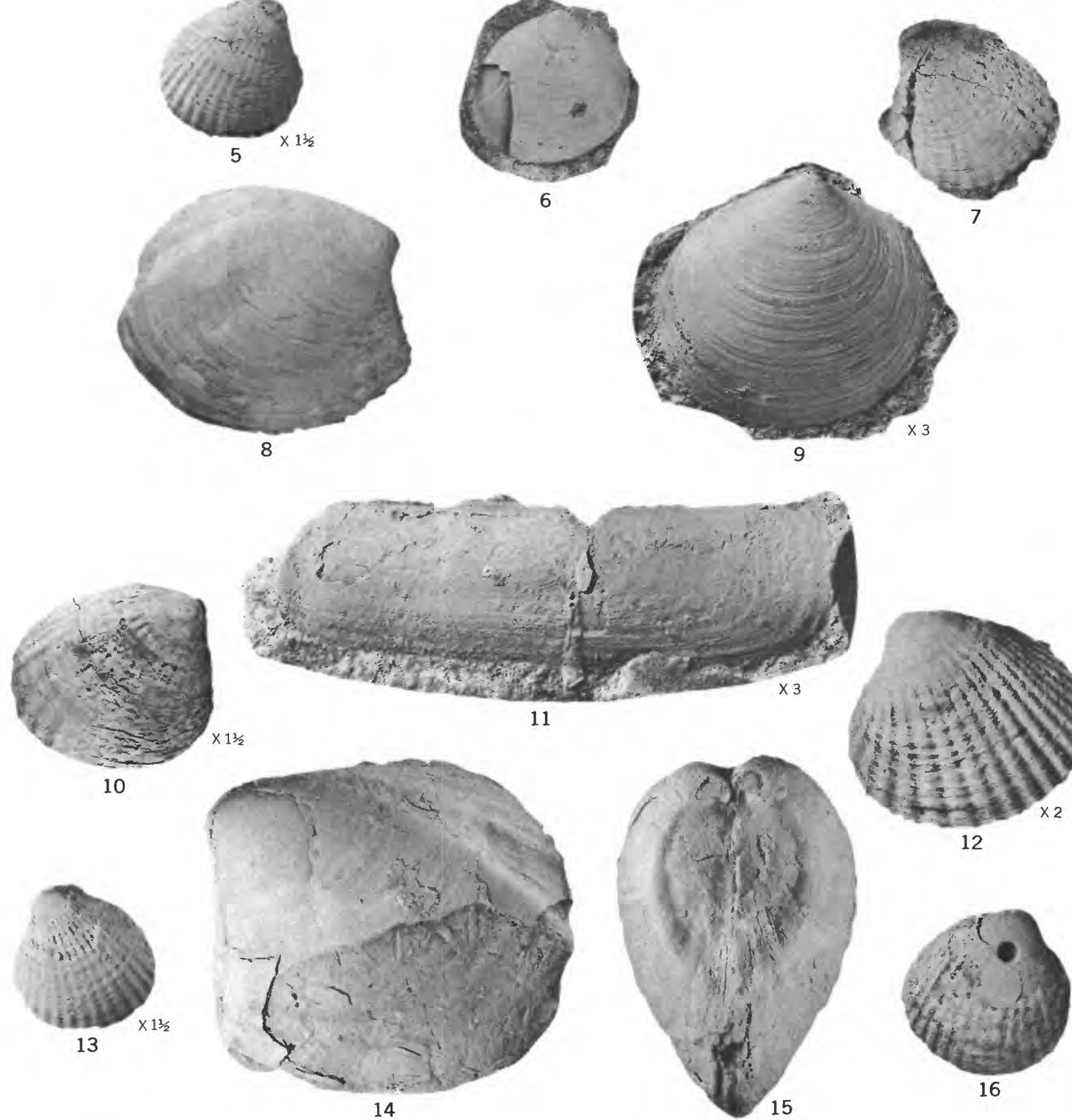

11

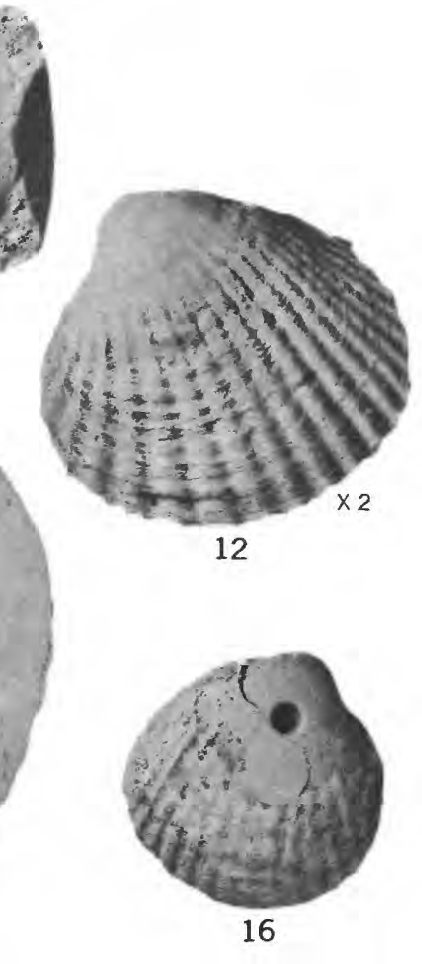

CYCLOCARDIA, DIPLODONTA, THYASIRA, AND SOLEN

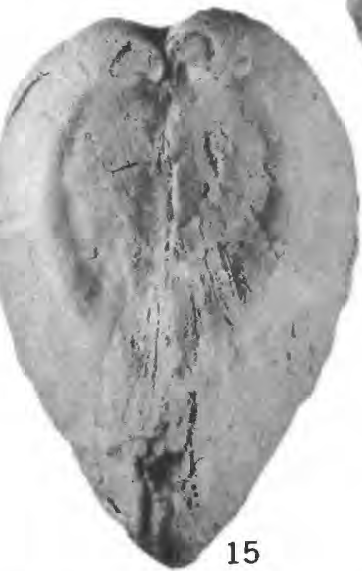




\section{PLATE 24}

Figdre 1-10. Dosinia (Dosinia) whitneyi (Gabb) (p. 73).

1. "Dosinia mathewsoni Gabb" of Clark. Locality, California Univ. Mus. Paleontology 1131. From San Ramon sandstone (Oligocene), California, half a mile southwest of town of Walnut Creek, in creek bed about $100 \mathrm{yds}$. east of Oakland-Antioch Bridge, alt. $150 \mathrm{ft}$. Calif. Univ. Mus. Paleontology 33734.

2. Holotype. Calif. Univ Mus. Paleontology 11999, original State Survey 272. Locality, "Oligocene, San Ramon (Martinez), California."

3. Length $53 \mathrm{~mm}$ (incomplete), height $50 \mathrm{~mm}$ (incomplete), thickness $27.2 \mathrm{~mm}$ (both valves). Loc. 187. USNM 563261.

4. Loc. 187. USNM 563262.

5. Loc. 187. USNM 563263.

6. Loc. 187. USNM 563264.

7. Loc. 187. USNM 563265.

8. Length $49 \mathrm{~mm}$, (incomplete), height $45 \mathrm{~mm}$ (incomplete), thickness $25 \mathrm{~mm}$ (incomplete, both valves). Loc. 187. USNM 563266.

9. Length $43 \mathrm{~mm}$ (incomplete), height $42 \mathrm{~mm}$ (incomplete), thickness $20 \mathrm{~mm}$ (incomplete, both valves). Loc. 187. USNM 563267.

10. Length $26 \mathrm{~mm}$ (incomplete), height $25 \mathrm{~mm}$ (incomplete), thickness $10 \mathrm{~mm}$ (incomplete, both valves). Loc. 187. USNM 563268.

11-14. Katherinella (Katherinella) angustifrons (Conrad) (p. 77).

11, 13. Holotype of "Venus brevilineata Conrad" (p. 77). Length $49.6 \mathrm{~mm}$ (incomplete), height $41 \mathrm{~mm}$ (incomplete), thickness $26.9 \mathrm{~mm}$ (incomplete, both valves). Loc. 1a. USNM 3606.

12, 14. "Venus—? Conrad" (p. 77). Length $52 \mathrm{~mm}$ (incomplete), height $43 \mathrm{~mm}$ (incomplete), thickness $26 \mathrm{~mm}$ (incomplete, both valves). Loc. 1a. USNM 561523. 
GEOLOGICAL SURVEY
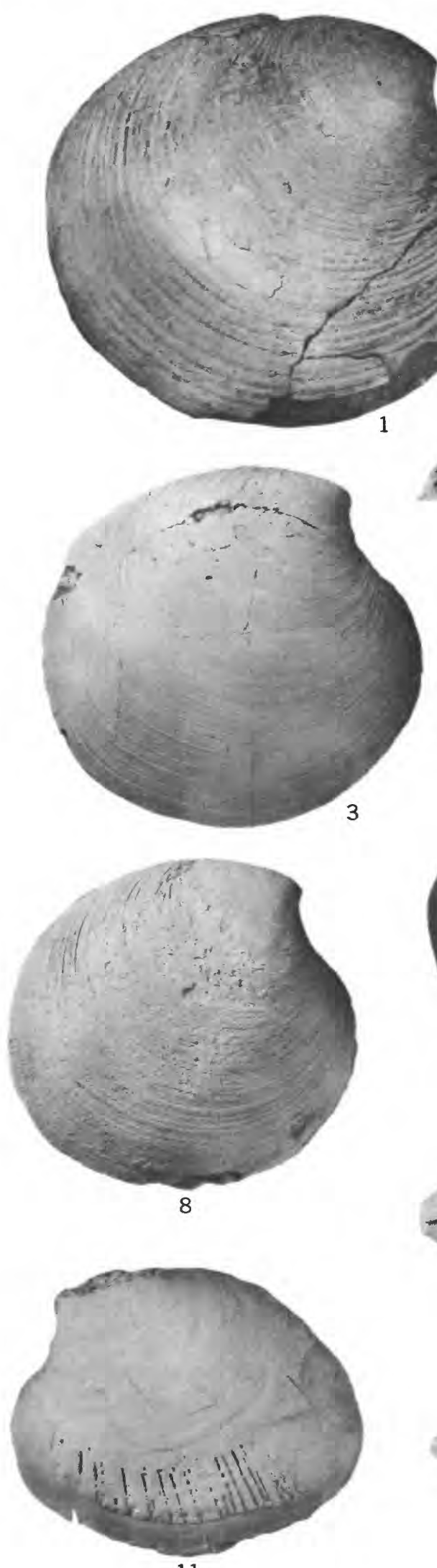

11
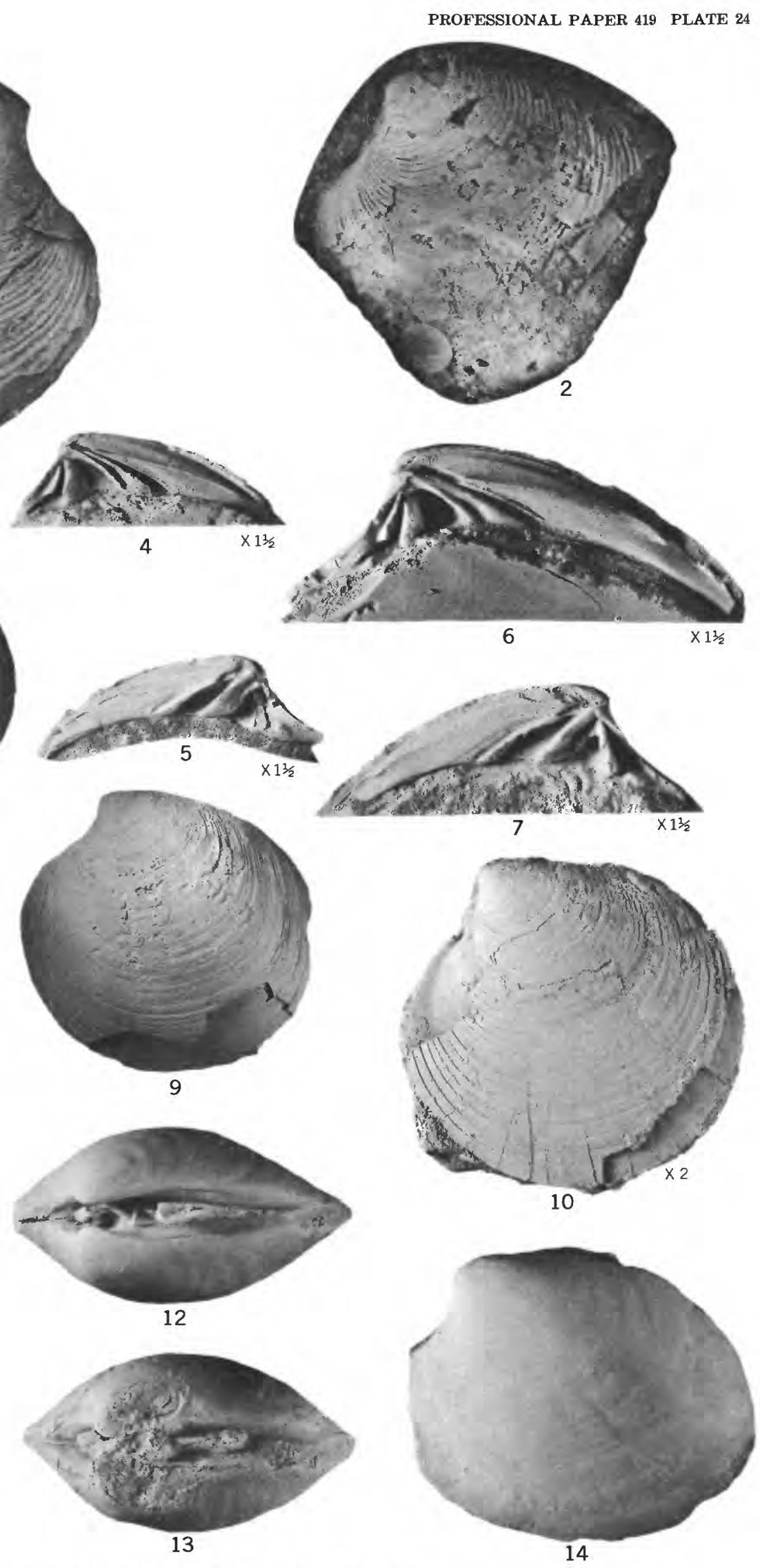

DOSINIA, KATHERINELLA, AND "VENUS" 


\section{PLATE 25}

FiguRE 1-3, 5-15. Katherinella (Katherinella) angustifrons (Conrad) (p. 77).

1, 2. Length $54 \mathrm{~mm}$ (incomplete), height $41 \mathrm{~mm}$ (incomplete), thickness $33 \mathrm{~mm}$ (incomplete, both valves). Loc. 48. USNM 563269.

3, 5. Length $56 \mathrm{~mm}$ (incomplete), height $43 \mathrm{~mm}$ (incomplete), thickness $28.6 \mathrm{~mm}$ (both valves). Loc. 86 . USNM 563270.

6, 7. Length $55 \mathrm{~mm}$ (incomplete), height $47 \mathrm{~mm}$ (incomplete), thickness $28.5 \mathrm{~mm}$ (both valves). Loc. 86 . USNM 563272.

8. Loc. 162 . USNM 563273.

9. Loc. 86. USNM 563274.

10. Loc. 181 . USNM 563275.

11, 14. Length $56.8 \mathrm{~mm}$, height $43.0 \mathrm{~mm}$, thickness $33.4 \mathrm{~mm}$ (both valves). Loc. 128 . USNM 563276 .

12, 15. Length $43 \mathrm{~mm}$ (incomplete), height $38 \mathrm{~mm}$ (incomplete), thickness $24 \mathrm{~mm}$ (incomplete, both valves). Loc. 184. USNM 563277.

13. Loc. 90 . USNM 563278 .

4. Katherinella (Katherinella) arnoldi (Weaver) (p. 76).

Type species of Katherinella; left hinge showing anterior lamellae. Loc. USGS 4110 , west of Port Orchard, near Seattle, Wash. Blakeley formation, USNM 563271.

16. "Cytherea oregonensis Conrad", nomen dubium (p. 78).

Holotype of "Cytherea oregonensis Conrad." Locality, Astoria, Oreg. Acad. Nat. Sci. Philadelphia 4526. 

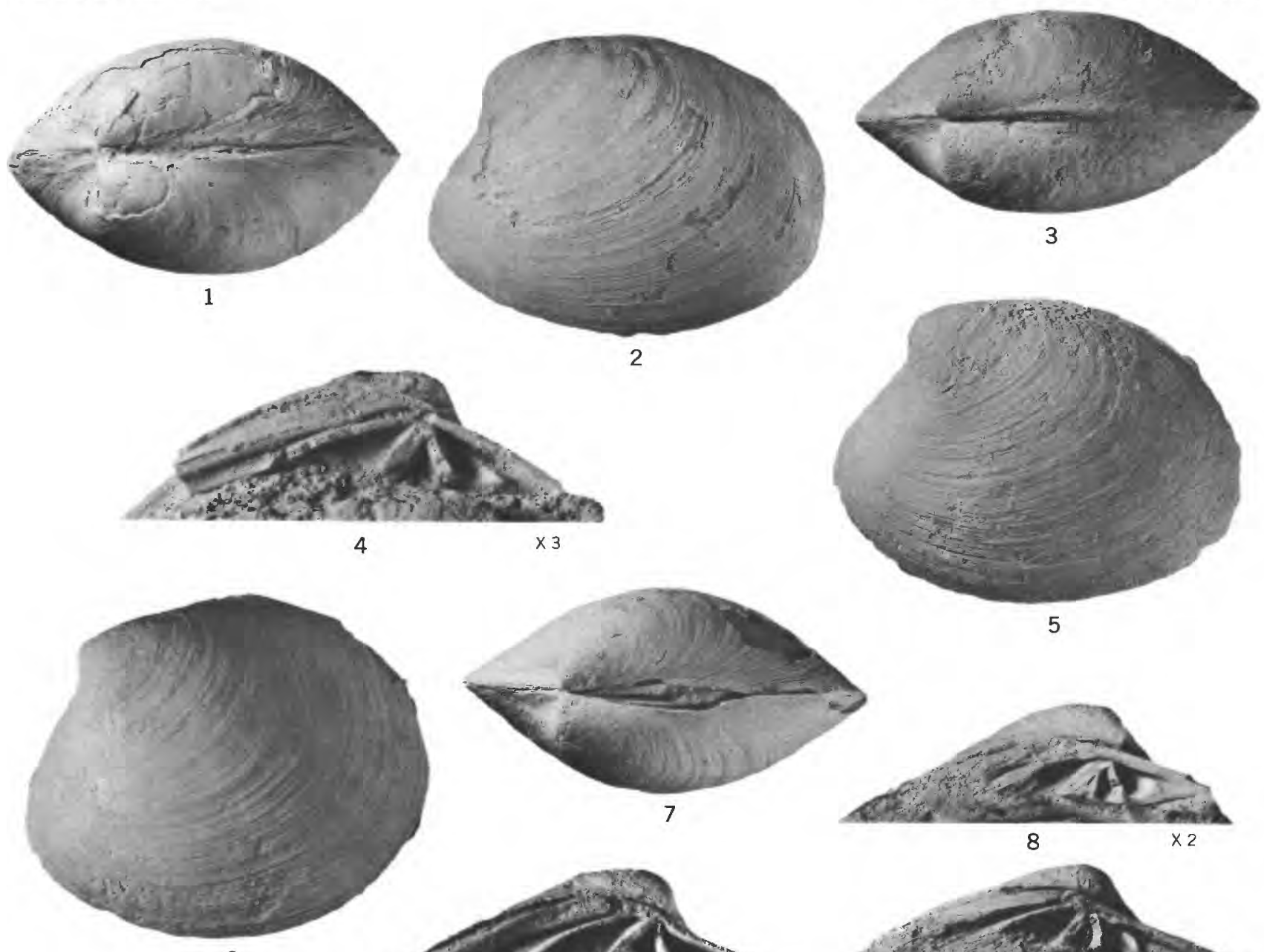

5

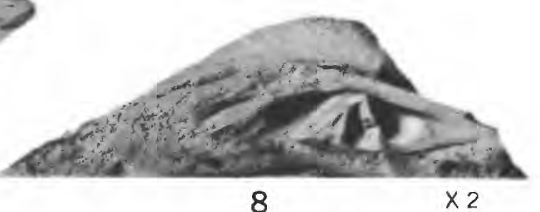

6
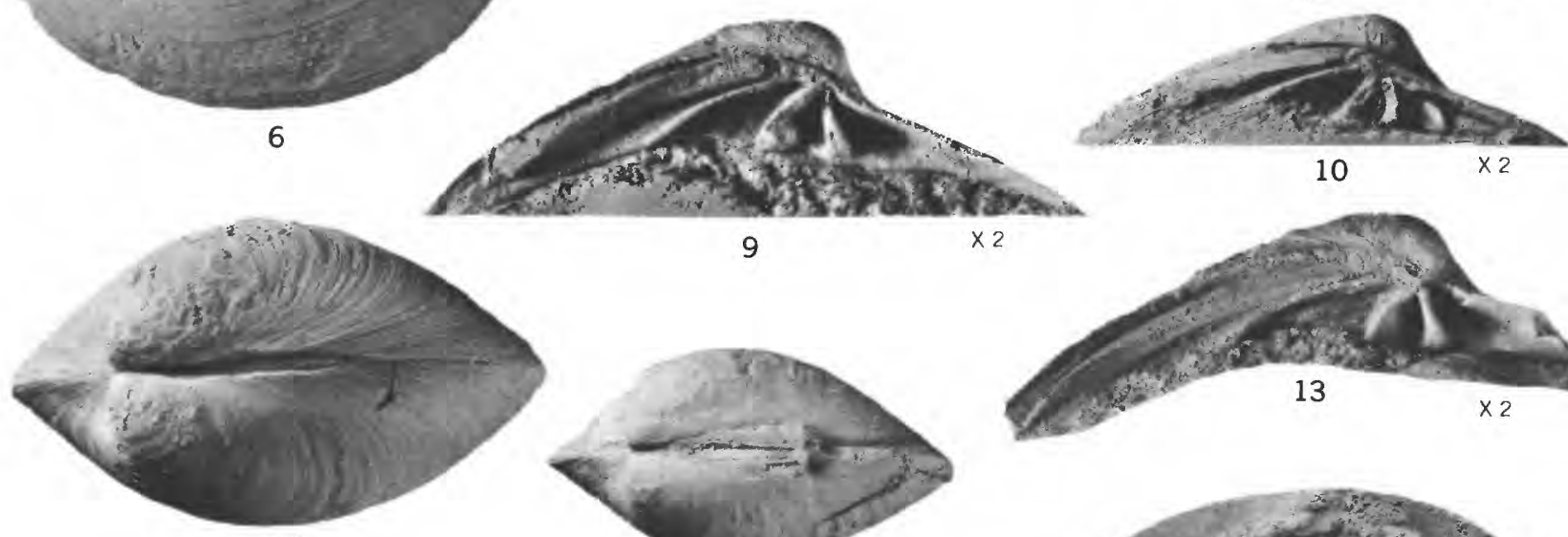

11
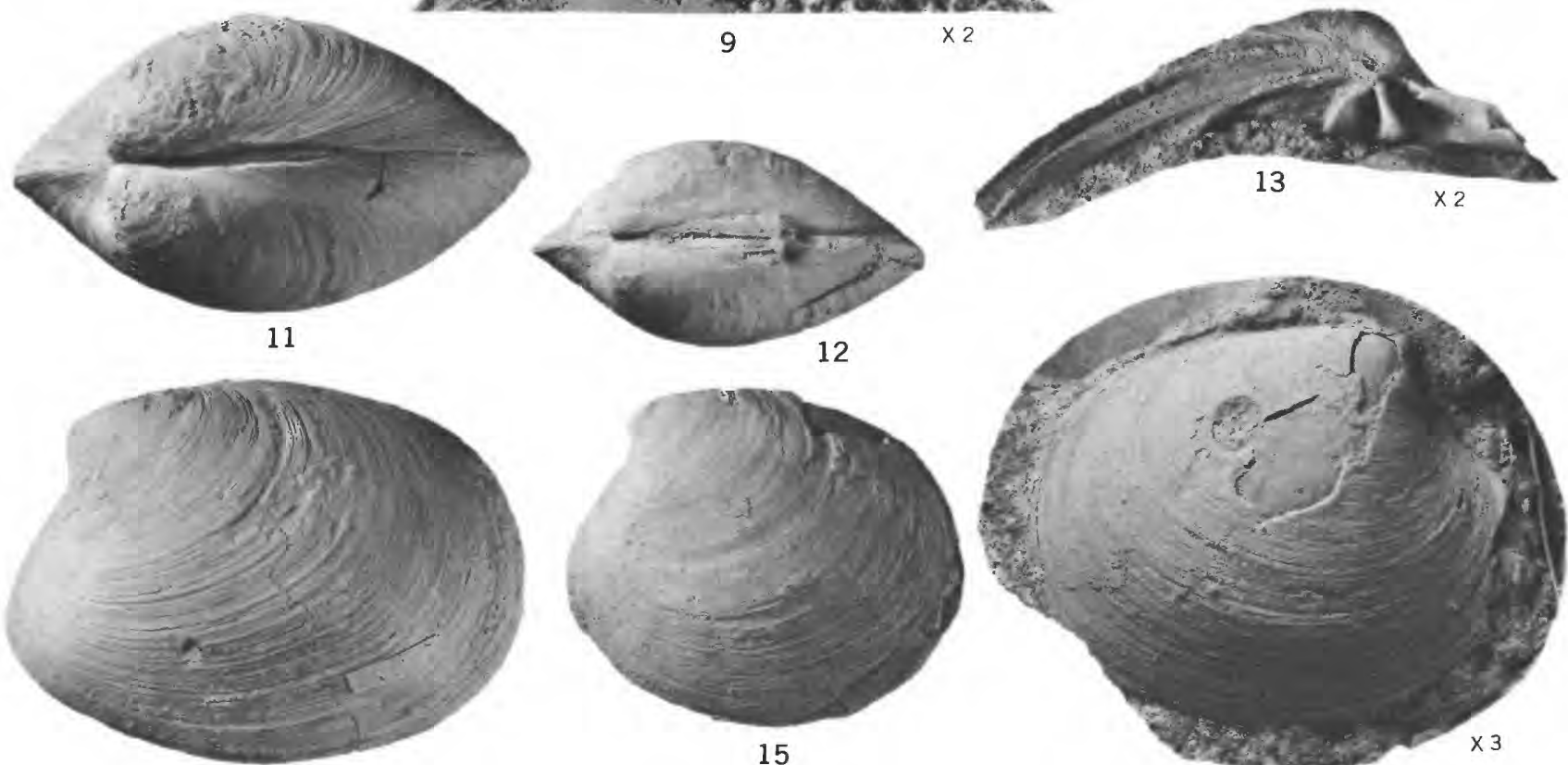

14

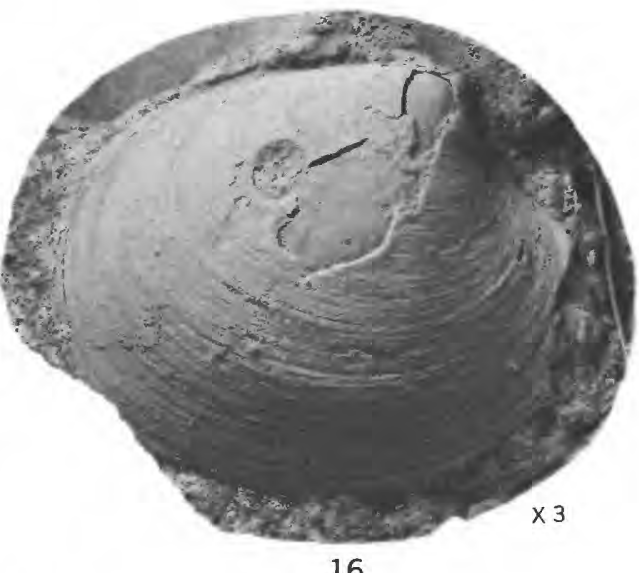

KATHERINELLA AND "CYTHEREA" 


\section{PLATE 26}

Figdre 1, 2, 7, 9, 10. Chione (Securella) ensifera (Dall) (p. 75).

1. Length $39.1 \mathrm{~mm}$, height $32.8 \mathrm{~mm}$, thickness $24 \mathrm{~mm}$ (incomplete, both valves). Loc. 187. USNM 563279 .

2. Length $42.3 \mathrm{~mm}$, height $37 \mathrm{~mm}$ (incomplete), thickness $26 \mathrm{~mm}$ (incomplete, both valves). Loc. 187 . USNM 563280 .

7, 10. Lectotype. Length $48.8 \mathrm{~mm}$ (incomplete), height $41 \mathrm{~mm}$ (incomplete). Loc. 1a. USNM 3611.

9. Loc. 187. USNM 563281.

3. Thracia (Thracia) trapezoides (Conrad) (p. 84).

Latex impression of counterpart of holotype. Length $33.8 \mathrm{~mm}$ (incomplete), height $26.7 \mathrm{~mm}$ (incomplete). See pl. 31, fig. 6 .

4-6, 8. Katherinella (Katherinella) angustifrons (Conrad) (p. 77).

4. Lectotype. Length $42.4 \mathrm{~mm}$ (incomplete), height $32.5 \mathrm{~mm}$ (incomplete). Loc. 1a. USNM 3492.

5. Loc. 181a. USNM 563282.

6. Loc. 130. USNM 563283.

8. Loc. 162. USNM 563284 . 

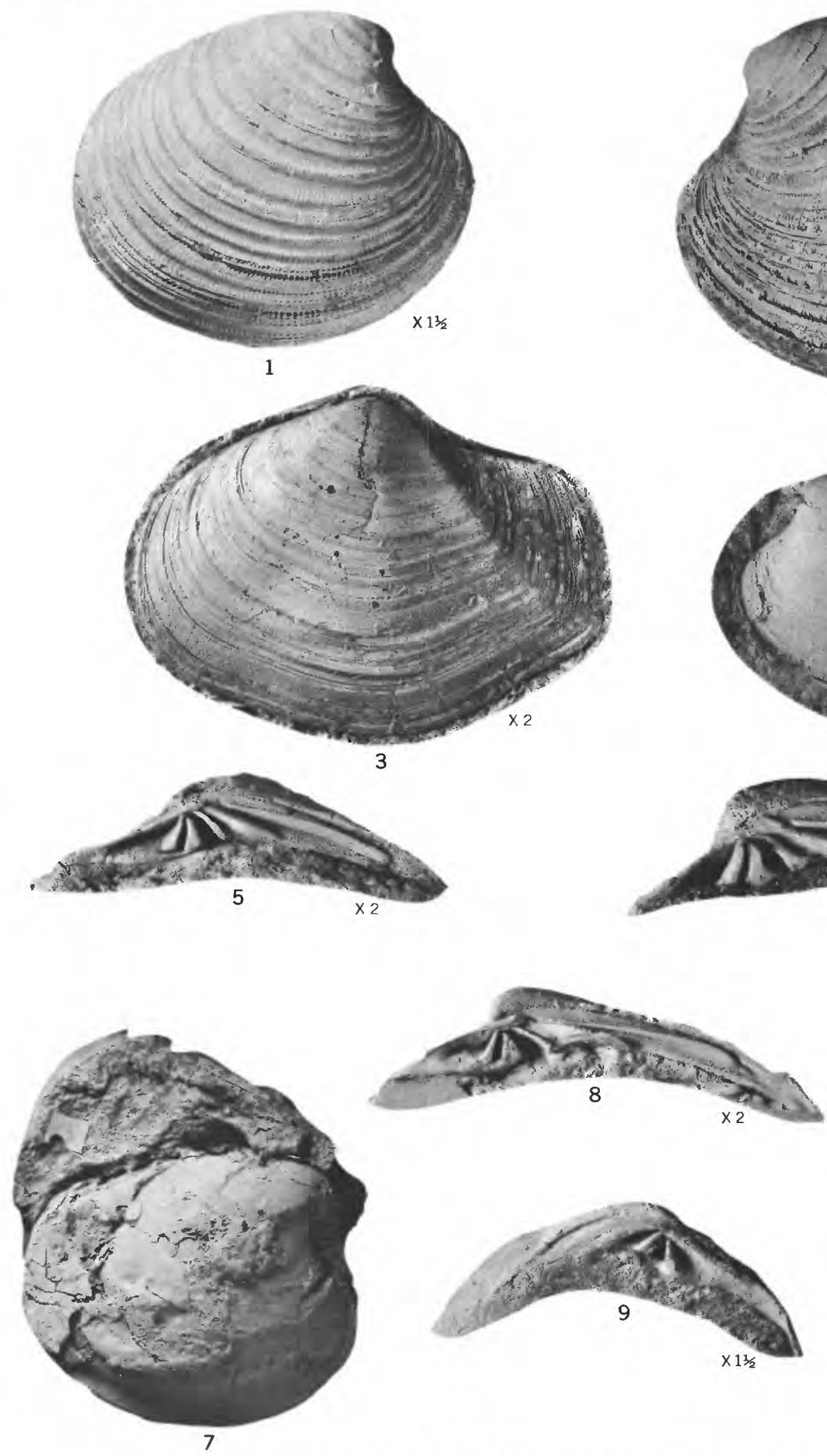

CHIONE, THRACIA, AND KATHERINELLA
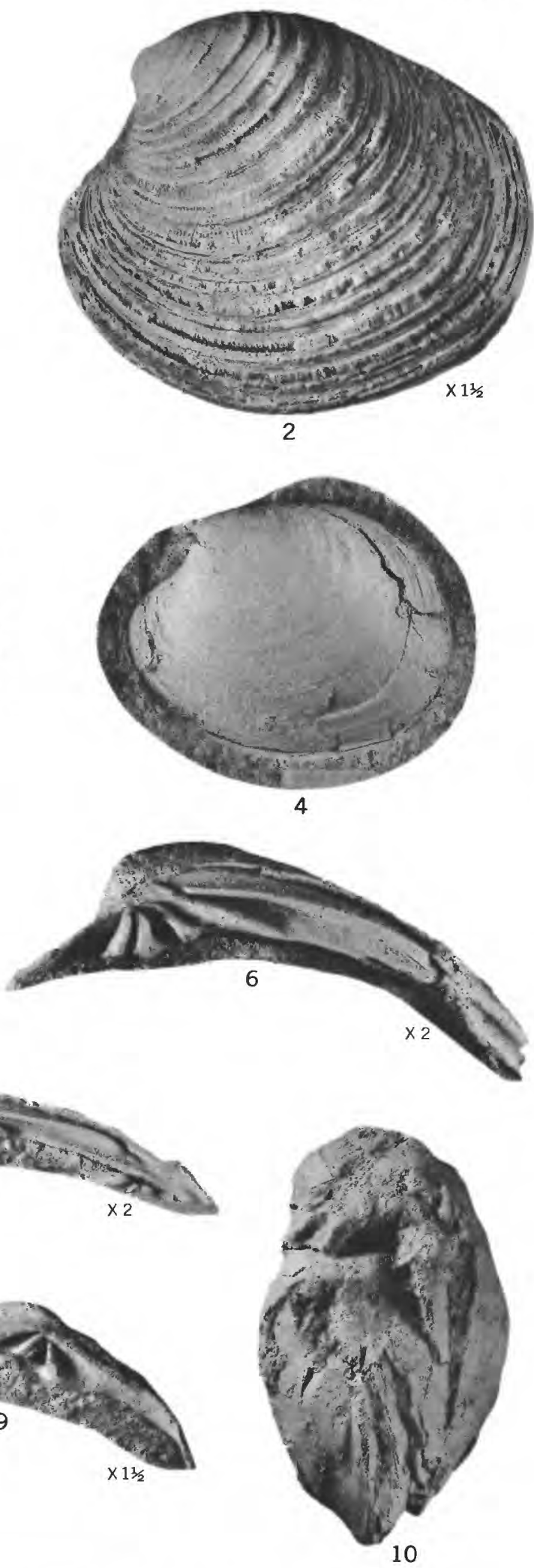


\section{PLATE 27}

Figure 1-8, 10, 11. Chione (Securella) ensifera (Dall) p. 75).

1, 4. Length $40.3 \mathrm{~mm}$, height $37 \mathrm{~mm}$ (incomplete), thickness $28 \mathrm{~mm}$ (incomplete). Loc. 181. USNM 563285.

2. End view of concentric lamellae. Loc. 187. USNM 563286.

3. Loc. 187. USNM 563287.

5. Loc. 181 . USNM 563288.

6. Loc. 187. USNM 563289.

7. Loc. 187. USNM 563290.

8. Loc. 187 . USNM 563291.

10, 11. Length $46 \mathrm{~mm}$ (incomplete), height $40 \mathrm{~mm}$ (incomplete), thickness $24 \mathrm{~mm}$ (incomplete). Loc. 181. USNM 563292.

9, 12, 13. Chione (Securella) securis (Shumard) (p. 74).

9. Loc., USGS 2950, Empire formation, Coos Bay, Oreg. USNM 153971.

12, 13. Lectotype. Length $77 \mathrm{~mm}$ (incomplete), height $70 \mathrm{~mm}$ (incomplete), thickness $42 \mathrm{~mm}$ (incomplete). Locality, at the mouth of Coos Bay, Oreg., Empire formation, Pliocene(?). USNM 562474. 

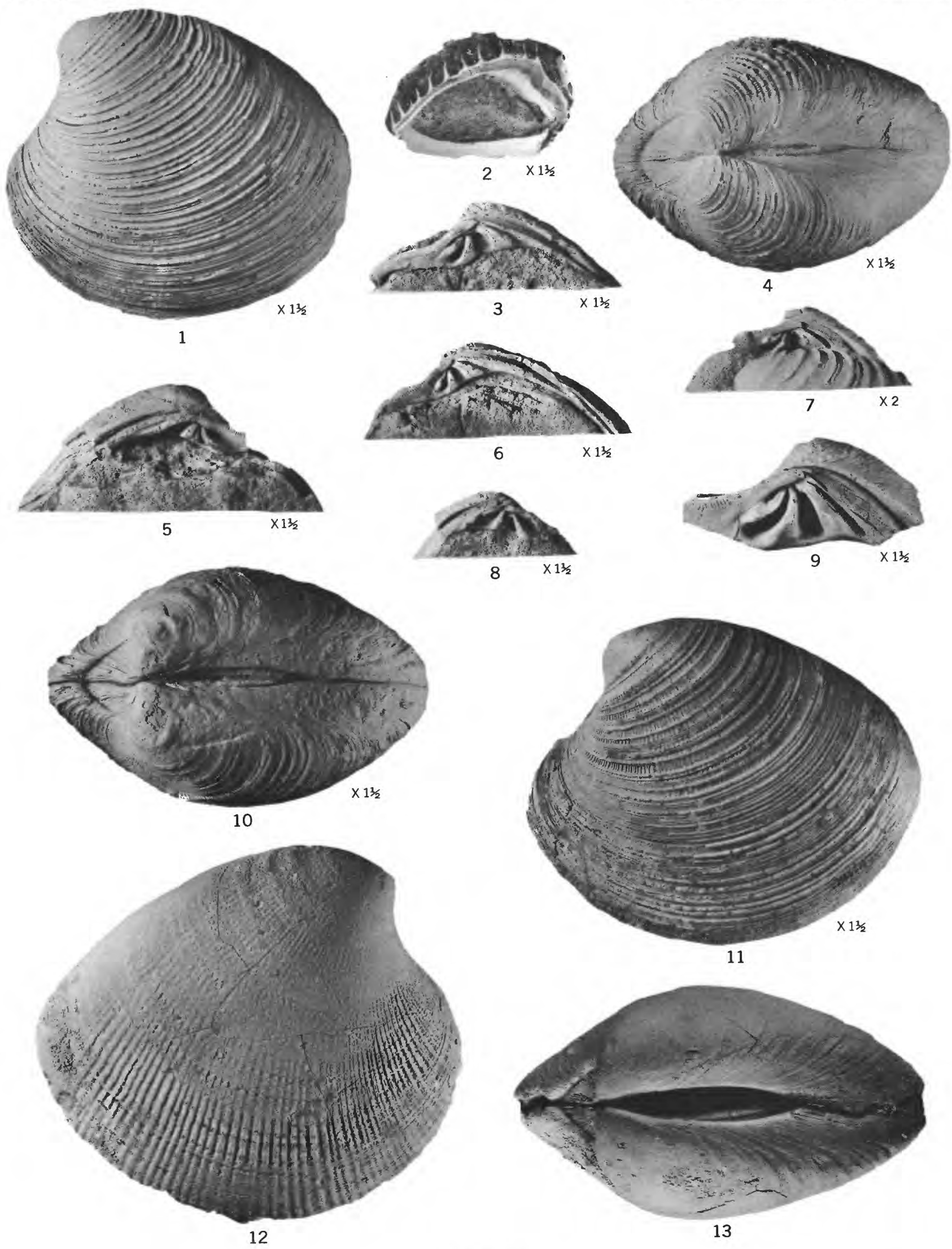

CHIONE 


\section{PLATE 28}

Figure 1-3, 5. Spisula (Mactromeris) albaria (Conrad) (p. 82).

1. Length $71 \mathrm{~mm}$ (incomplete), height $52 \mathrm{~mm}$ (incomplete). Loc. 187 . USNM 563332.

2. Length $69 \mathrm{~mm}$ (incomplete), height $52 \mathrm{~mm}$ (incomplete). Loc. 187. USNM 563333.

3. Loc. 149 . USNM 563294.

5. Loc. 149. USNM 563293.

4. "Tellina albaria Conrad" of Reagan (p. 80).

Length $30 \mathrm{~mm}$ (incomplete), height $22 \mathrm{~mm}$ (incomplete). Locality, Gettysburg, Wash. USNM 328314.

6, 7, 10, 11, 13. Macoma arctata (Conrad) (p. 81).

6. Loc. 156. USNM 563295 .

7, 10. Holotype. Length $52 \mathrm{~mm}$ (incomplete), height $33.6 \mathrm{~mm}$ (incomplete), thickness $14 \mathrm{~mm}$ (incomplete, both valves). Loc. 1a. USNM 3489.

11. Holotype of "Tellina arctata var. juana Reagan." Length $55 \mathrm{~mm}$ (incomplete), height $33 \mathrm{~mm}$ (incomplete). Locality, East Clallam, Wash. USNM 328315.

13. Length $55 \mathrm{~mm}$ (incomplete), height $39 \mathrm{~mm}$ (incomplete), thickness $16 \mathrm{~mm}$ (both valves, twisted). Loc. 107. USNM 563296.

8, 9, 12, 14. Macoma albaria (Conrad) (p. 80).

8, 9. Length $18 \mathrm{~mm}$ (incomplete), height $11 \mathrm{~mm}$ (incomplete), thickness $6 \mathrm{~mm}$ (both valves, slightly apart). Loc. 187 . USNM 563297.

12. Lectotype. Length $16 \mathrm{~mm}$ (incomplete), height $11 \mathrm{~mm}$ (incomplete). Loc. 1a. USNM 3614.

14. Length $19 \mathrm{~mm}$ (incomplete), height $14.5 \mathrm{~mm}$ (incomplete). Loc. 144 . USNM 563348.

15. Macoma ef. $M$. astori Dall (p. 81).

Length $51 \mathrm{~mm}$ (incomplete), height $38 \mathrm{~mm}$ (incomplete). Loc. 187. USNM 563298. 
GEOLOGICAL SURVEY

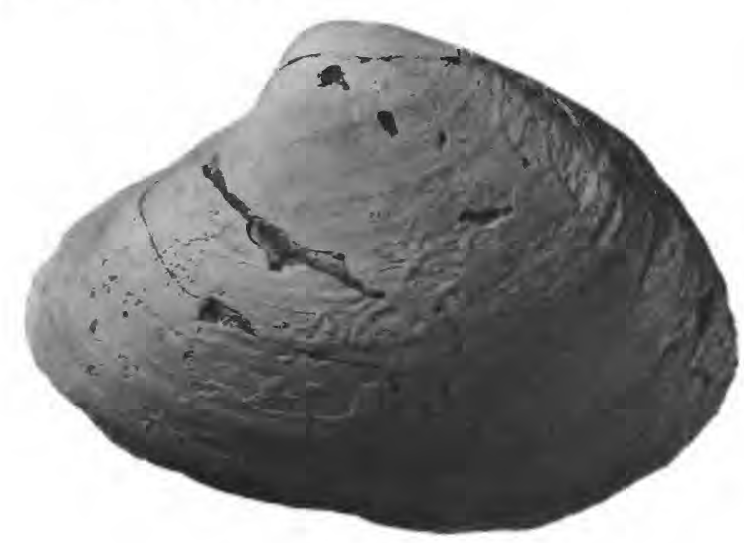

1
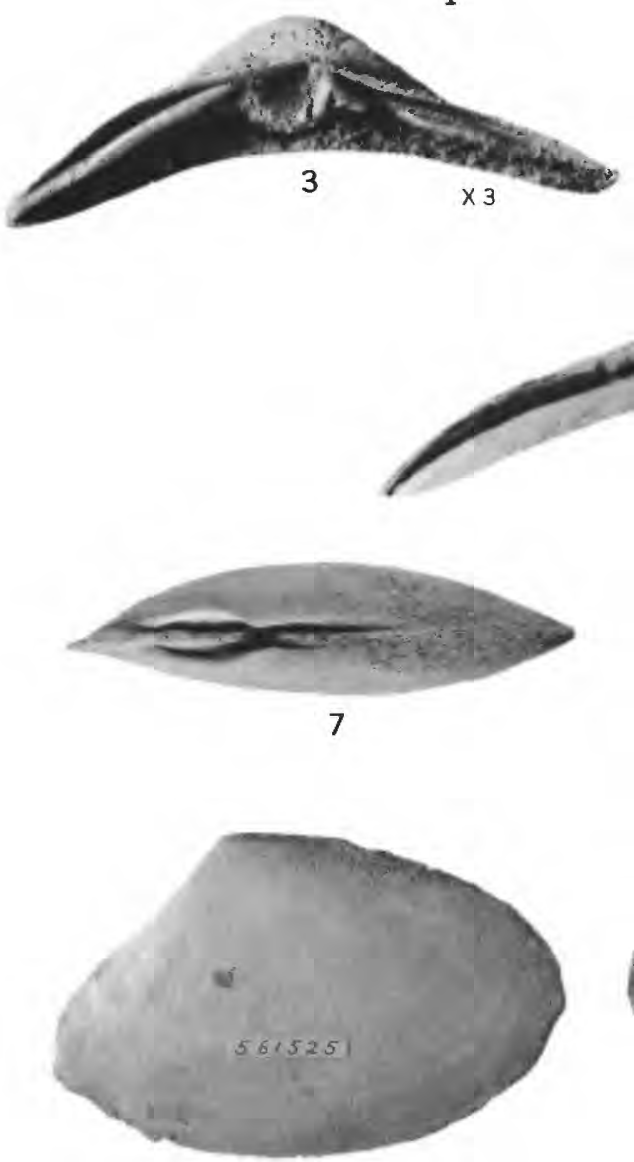

10

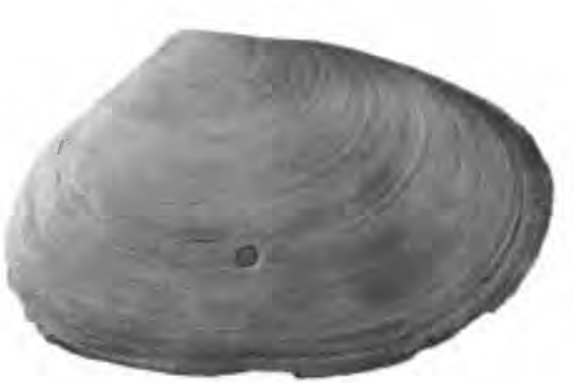

13
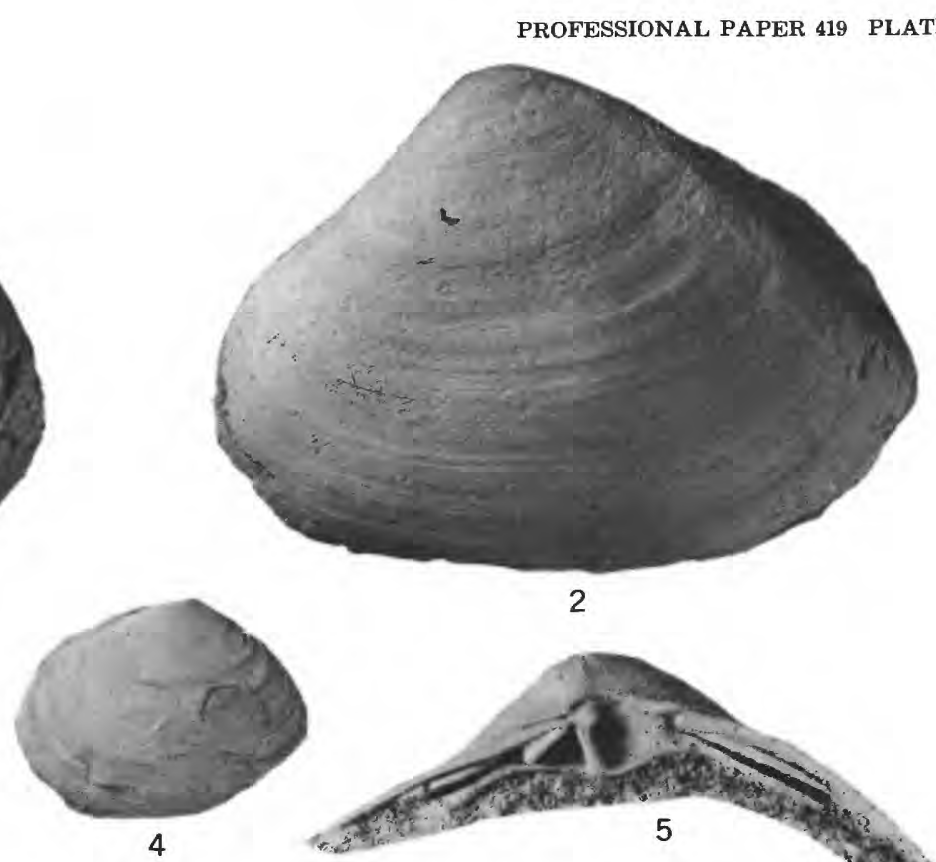

4. 3) 5
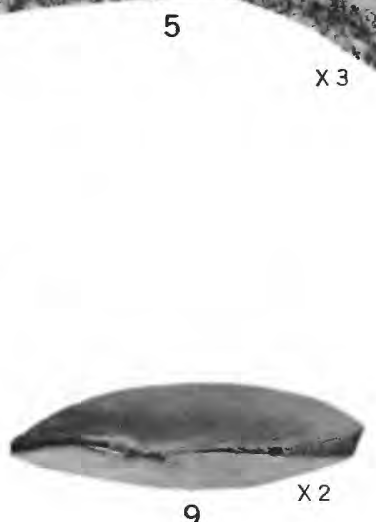

8

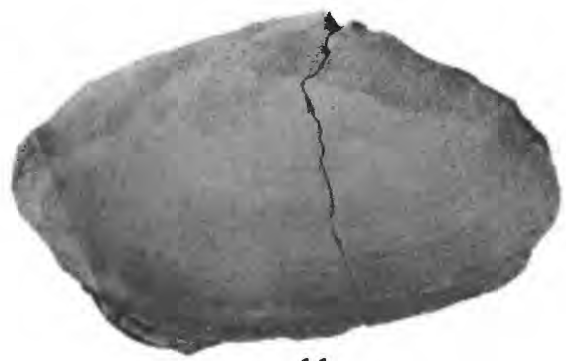

11
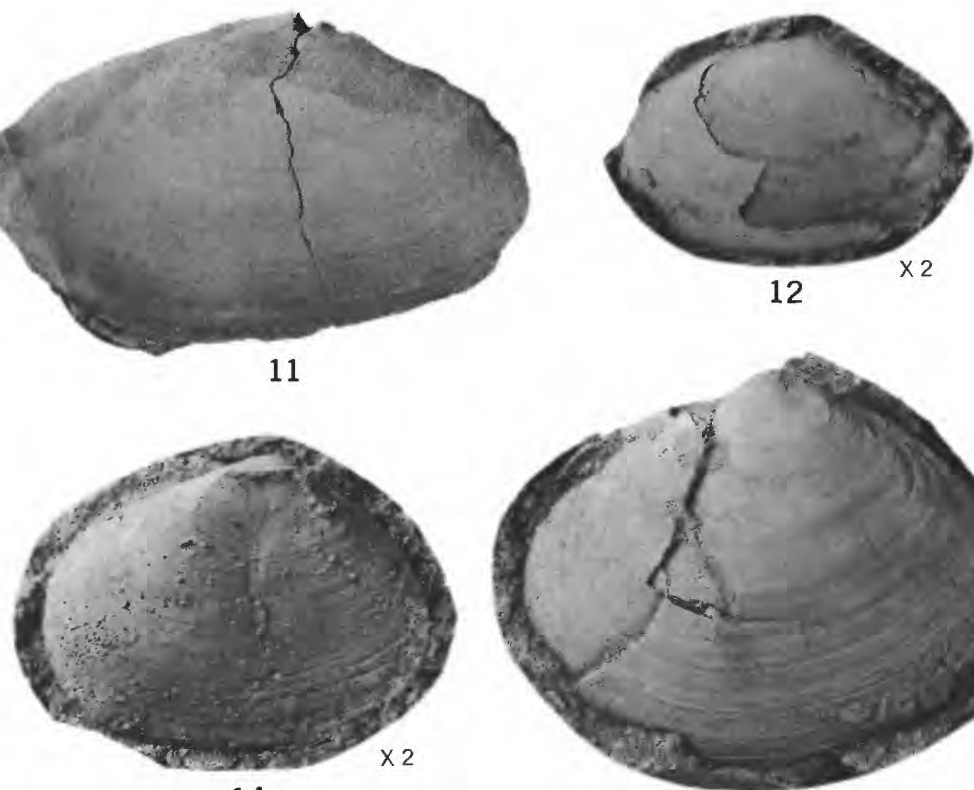

14

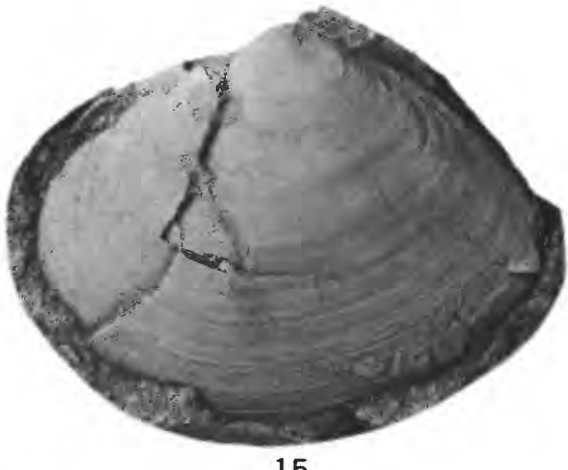

15

SPISULA, "TELLINA," MACOMA 


\section{PLATE 29}

Figure 1-5. Tellina aff. T. idae Dall (p. 79).

1, 2. Loc. 187. USNM 563299.

3, 5. Loc. 187 . USNM 563300.

4. Loc. 187. USNM 563301.

6, 7, 13, 14. Tellina emacerata Conrad (p. 78).

6. Holotype of "Tellina clallamensis Reagan." Length $33 \mathrm{~mm}$ (incomplete), height $16 \mathrm{~mm}$ (incomplete), thickness $6 \mathrm{~mm}$ (incomplete). Locality, east Clallam, Wash. USNM 328320.

7. Loc. 108. USNM 563302.

13. Length $31 \mathrm{~mm}$ (incomplete), height $17 \mathrm{~mm}$ (incomplete). Loc. 156 . USNM 563303.

14. Holotype. Length $30 \mathrm{~mm}$ (incomplete), height $16 \mathrm{~mm}$ (incomplete). Loc. 1a. USNM 3494.

8. Macoma arctata (Conrad) (p. 81).

Loc. 102. USNM 563304.

9. Macoma albaria (Conrad) (p. 80).

Loc. 156. USNM 563305.

10, 11. Macoma n. sp.? (p. 81).

Length $42 \mathrm{~mm}$ (incomplete), height $35 \mathrm{~mm}$ (incomplete). Locality, 2 miles south of entrance to Yaquina Bay, Oreg. Calif. Acad. Sci. 12123.

12. Macoma astori Dall, (p. 81).

Length $50 \mathrm{~mm}$ (incomplete), height $37 \mathrm{~mm}$ (incomplete), thickness $15 \mathrm{~mm}$ (incomplete, both valves). Locality Empire formation, Pliocene(?), Coos Bay, Oreg. USNM 153937. (Figured by Dall, 1909, pl. 14, fig. 1.) 

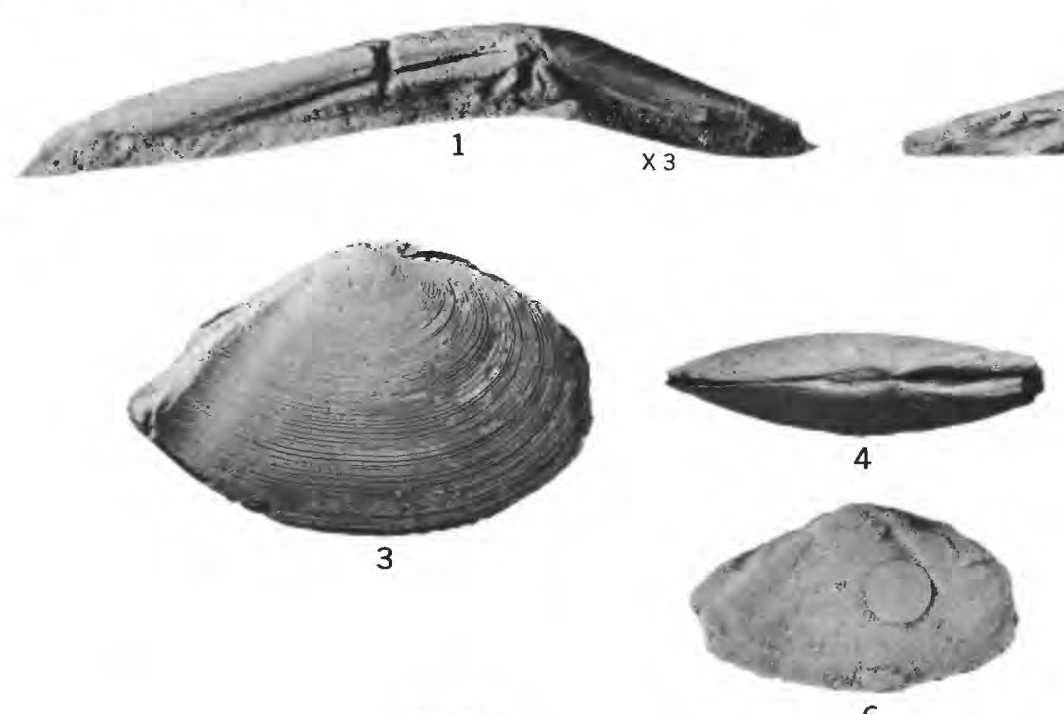

6
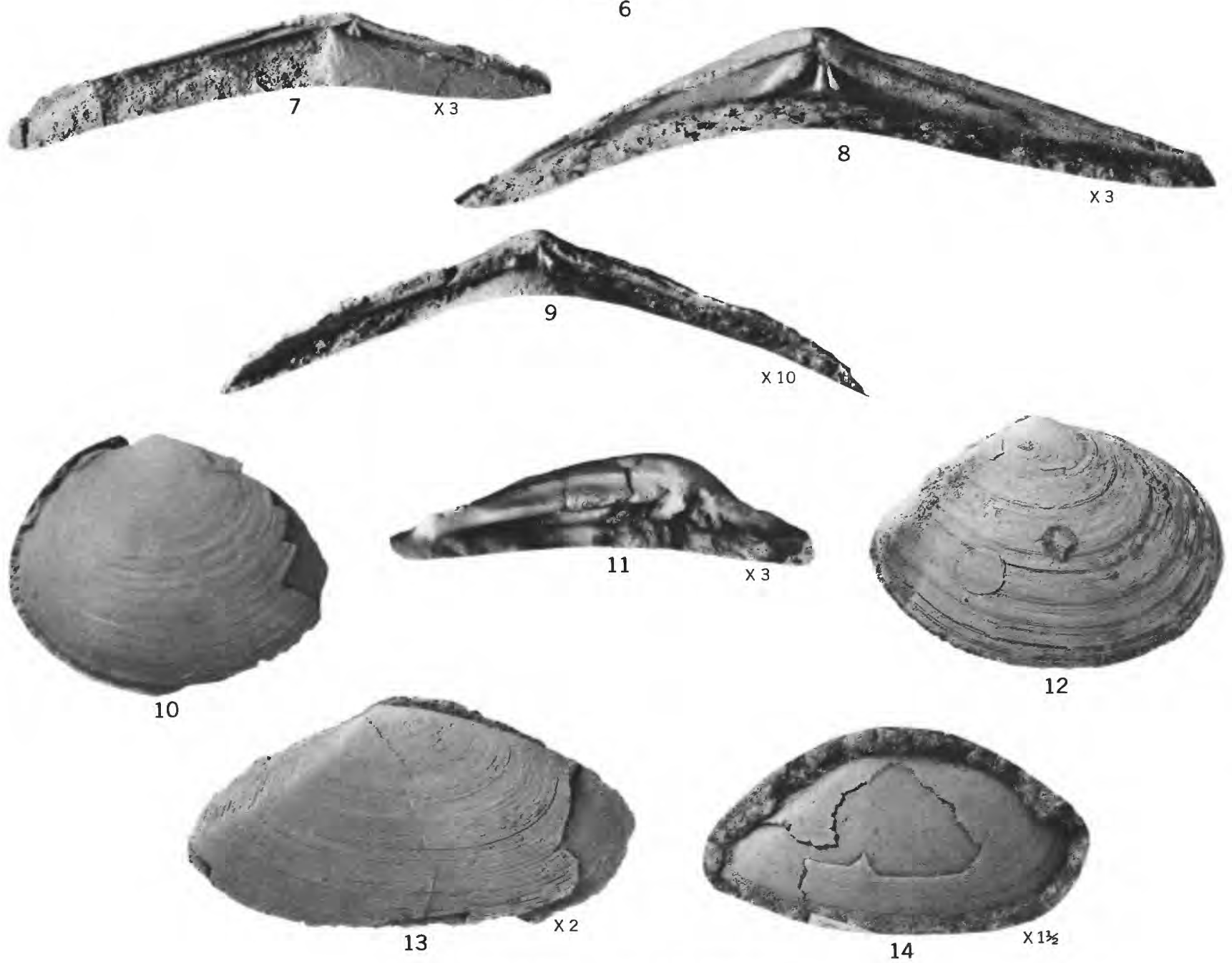

TELLINA AND MACOMA 


\section{PLATE 31}

Figure 1, 5. Aturia angustata (Conrad) (p. 85).

1. Syntype. Greatest diameter $105 \mathrm{~mm}$ (incomplete), least diameter $80 \mathrm{~mm}$ (incomplete). Loc. 1a. USNM 3610.

5. Greatest diameter $51 \mathrm{~mm}$ (incomplete), least diameter $40 \mathrm{~mm}$ (incomplete). Loc. 1a. USNM 3534.

2. Dentalium (Dentalium?) pseudonyma Pilsbry and Sharp (p. 50).

Length $32 \mathrm{~mm}$ (incomplete), greatest diameter $7 \mathrm{~mm}$. Loc. 181 . USNM 563336.

3. Dentalium (Rhabdus) schencki, Moore, n. sp. (p. 51).

Holotype. Length $53 \mathrm{~mm}$ (incomplete), greatest diameter $8 \mathrm{~mm}$. Loc. 102 . USNM 563335 .

8. Dentalium sp. (p. 50).

Loc. 1a. USNM 3481.

4, 7. Panope (Panope) abrupta (Conrad) (p. 83).

Holotype. Length $65.8 \mathrm{~mm}$ (incomplete), height $39.2 \mathrm{~mm}$ (incomplete), thickness $22.8 \mathrm{~mm}$ (incomplete, both valves). Loc. 1 a. USNM 3608.

6. Thracia (Thracia) trapezoides (Conrad) (p. 84).

Holotype. Length $33.8 \mathrm{~mm}$ (incomplete), height $26.7 \mathrm{~mm}$ (incomplete), thickness $15.5 \mathrm{~mm}$ (both valves, distorted). Loc. 1a. USNM 3604.

9, 11. Spisula (Mactromeris) albaria (Conrad) (p. 82).

9. Left valve. Length $70 \mathrm{~mm}$ (incomplete). Loc. 139 . USNM 563337.

11. Left valve. Length $44 \mathrm{~mm}$ (incomplete), height $31 \mathrm{~mm}$ (incomplete), thickness $20.5 \mathrm{~mm}$. Loc. 187. USNM 563338.

10. Gari? aff. G. edentula (Gabb) (p. 82).

Length $69 \mathrm{~mm}$ (incomplete), height $43.7 \mathrm{~mm}$ (incomplete). Loc. 187 . USNM 563339. 

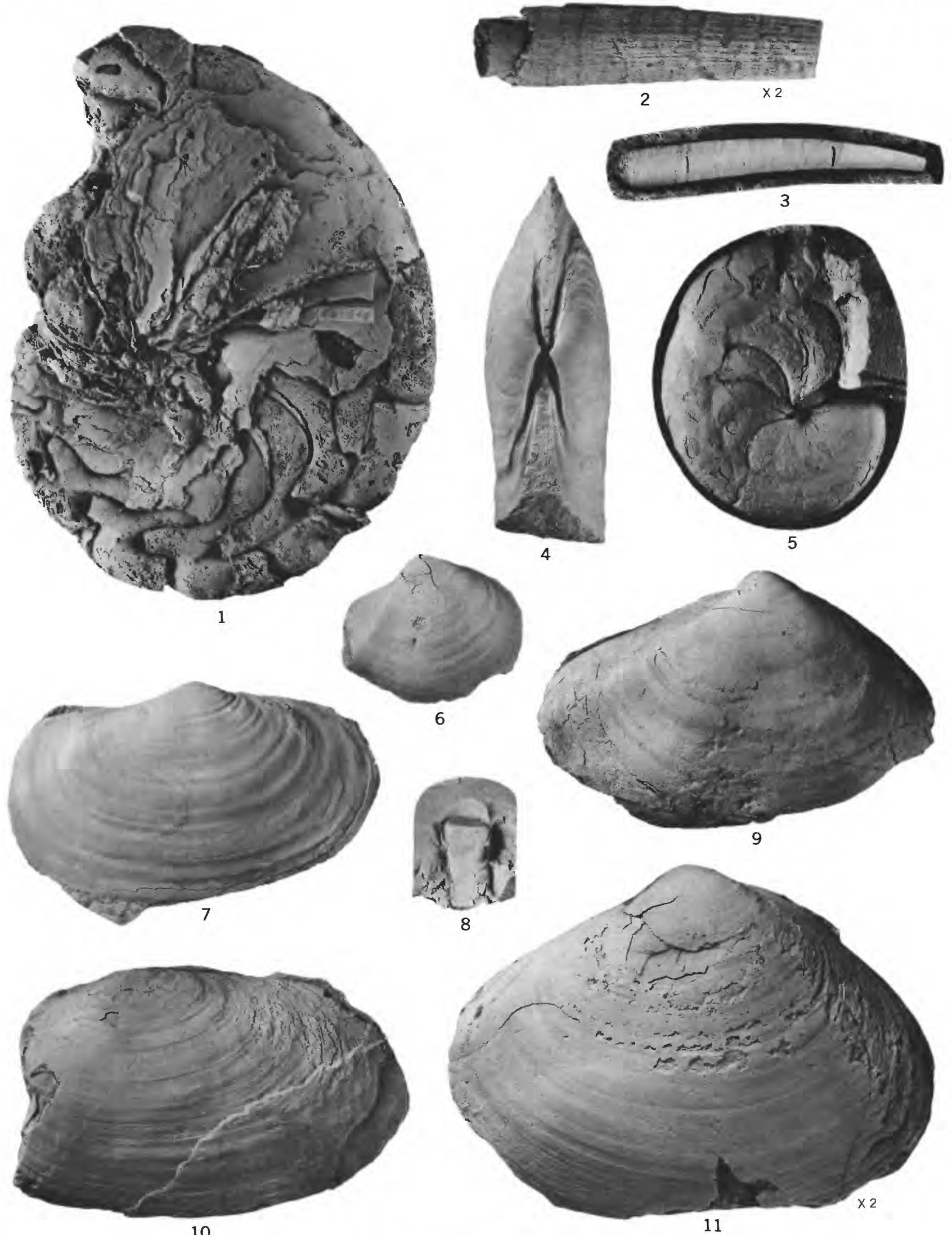


\section{PLATE 32}

Figure 1. Membranipora sp. (p. 88).

Encrusting Calicantharus carlsoni (Anderson and Martin). Loc. 52. USNM 563341. 2, 3. Starfish fragments (p. 89).

2. Loc. 5. USNM 563342.

3. Loc. 43. USNM 563343.

4. Cellepora sp. (p. 88).

Encrusting an unidentified gastropod. Loc. 187. USNM 563344.

5. Terebratulina? sp. (p. 89).

Height $19 \mathrm{~mm}$ (incomplete), width $14 \mathrm{~mm}$ (incomplete). Loc. 79. USNM 563345.

6, 7, 9, 13, 15. Terebratalia? sp. (p. 89).

6, 7. Height $12 \mathrm{~mm}$ (incomplete), width $11 \mathrm{~mm}$ (incomplete). Loc. 139 . USNM 563346.

9, 13. Height $9 \mathrm{~mm}$ (incomplete), width $8 \mathrm{~mm}$ (incomplete). Loc. 134. USNM 563347.

15. Height $26 \mathrm{~mm}$ (incomplete), width $22 \mathrm{~mm}$ (incomplete). Loc. $81 \mathrm{~b}$. USNM 563617.

8. Galerites? oregonensis Dana (p. 89).

Syntype. Loc. 1a. USNM 561547.

10-12. Freileia astoriana (Dall) (p. 89).

Holotype. Loc. 1a. USNM 3487.

14. Stephanocyathus diadema (Pourtalès) (p. 88).

Maximum preserved diameter $52 \mathrm{~mm}$ (incomplete). Loc. 1a. USNM 3575.

16. Unidentified ophiuroid? (p. 89). Loc. 1a. USNM 3683. 


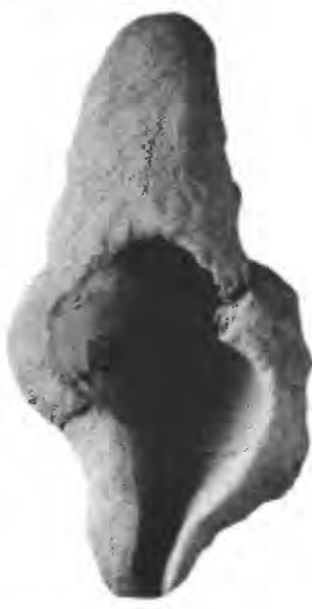

1
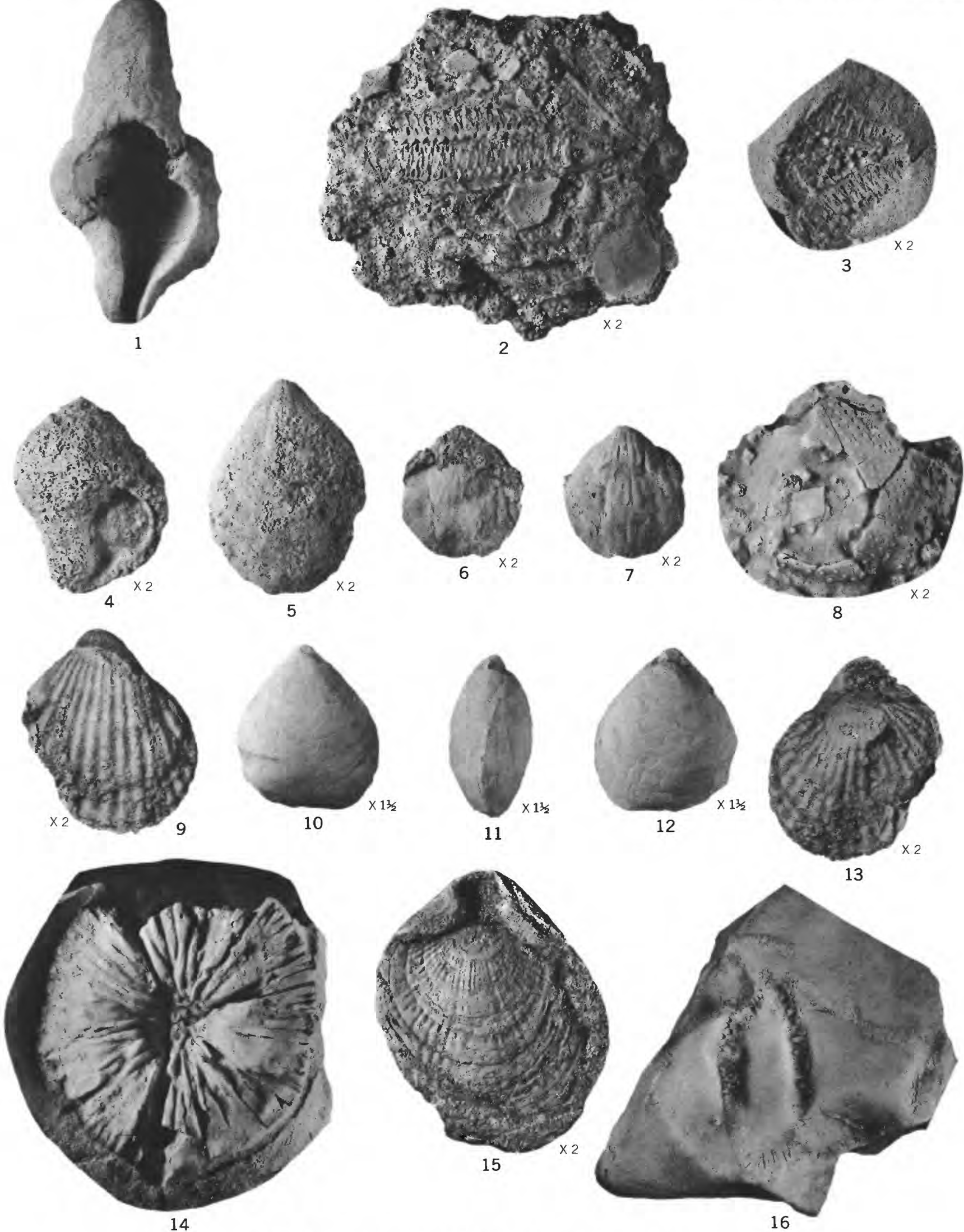

BRYOZOA, BRACHIOPODS, CORAL, AND ECHINOIDS

U. S. GOVERNMENT PRINTING OFFICE: $19630 \div 648-524$ 
